\title{
Prestatie-onderzoek naar Nederlandse overheidsbedrijven : case-studies naar de Staatsmijnen, de NV Nederlandse Spoorwegen en de Nederlandse Centrale Organisatie voor toegepast- natuurwetenschappelijk onderzoek
}

Citation for published version (APA):

Jansen, R. W. J. (1993). Prestatie-onderzoek naar Nederlandse overheidsbedrijven : case-studies naar de Staatsmijnen, de NV Nederlandse Spoorwegen en de Nederlandse Centrale Organisatie voor toegepast-natuurwetenschappelijk onderzoek. [Doctoral Thesis, Maastricht University]. Rijksuniversiteit Limburg. https://doi.org/10.26481/dis.19930617rj

Document status and date:

Published: 01/01/1993

DOI:

10.26481/dis.19930617rj

Document Version:

Publisher's PDF, also known as Version of record

Please check the document version of this publication:

- A submitted manuscript is the version of the article upon submission and before peer-review. There can be important differences between the submitted version and the official published version of record. People interested in the research are advised to contact the author for the final version of the publication, or visit the DOI to the publisher's website.

- The final author version and the galley proof are versions of the publication after peer review.

- The final published version features the final layout of the paper including the volume, issue and page numbers.

Link to publication

\footnotetext{
General rights rights.

- You may freely distribute the URL identifying the publication in the public portal. please follow below link for the End User Agreement:

www.umlib.nl/taverne-license

Take down policy

If you believe that this document breaches copyright please contact us at:

repository@maastrichtuniversity.nl

providing details and we will investigate your claim.
}

Copyright and moral rights for the publications made accessible in the public portal are retained by the authors and/or other copyright owners and it is a condition of accessing publications that users recognise and abide by the legal requirements associated with these

- Users may download and print one copy of any publication from the public portal for the purpose of private study or research.

- You may not further distribute the material or use it for any profit-making activity or commercial gain

If the publication is distributed under the terms of Article $25 \mathrm{fa}$ of the Dutch Copyright Act, indicated by the "Taverne" license above,

Download date: 26 Apr. 2023 


\section{PRESTATIE-ONDERZOEK NAAR NEDERLANDSE OVERHEIDSBEDRIJVEN}

Case-studies naar de staatsmijnen, de NV Nederlandse spoorwegen en de Nederlandse Centrale organisatie voor toegepast-naturwetenschappelijk onderzoek. 


\title{
PRESTATIE-ONDERZOEK NAAR NEDERLANDSE OVERHEIDSBEDRIJVEN
}

\author{
Case-studies naar de Btantsmijnen, de NV Nederlandae \\ Spoorwegen en de Nederlandse Centrale organisatie voor \\ toegepast-natuurwetenschappelijk onderzoek.
}

PROEFSCHRIFT

ter verkrijging van de graad van doctor aan de Rijksuniversiteit Limburg te Maastricht,

op gezag van de Rector Magnificus, Prof. mr. M.J. Cohen, volgens het besluit van het college van Dekanen, in het openbaar te verdedigen op donderdag, 17 juni 1993 om 14.00 uur

door

Robert Willem Jacob Jansen geboren te Nijmegen in 1960 


$\begin{array}{ll}\text { Promotor : } & \text { Prof. dr. J.G. Backhaus } \\ \text { Co-promotor : } & \text { Dr. G. Meijer }\end{array}$

Beoordelingscommissie: Prof. A. Beek ra (voorzitter)

Prof. dr. W. Albeda

Prof. dr. P.B. Boorsma (Univ. Twente)

Prof. dr. C.J. Dort

\section{CIP-Gegevens Koninklijke Bibliotheek, Den Haag}

Jansen, Robert Willem Jacob

Prestatie-onderzoek naar Nederlandse overheidsbedrijven: case-studies naar de Staatsmijnen, de NV Nederlandse Spoonwegen en de Nederlandse Centrale Organisatie voor toegepast-natuurwetenschappelijk onderzoek/' Robert Willem Jacob Jansen. (S.I.:s.n.)

Proefschrift Masstricht. - Met lit. opg. - Met samenvatting in het Engels.

ISBN 90-9005968-7

NUGI 681

Trefiw.: overbeidsbedrijven; Nederland, onderzoek.

Copyright 1993, R.W.J. Jansen, Hoofddorp

Omslagontwerp: E. Swart

Druk: Nautilus, Leiden

Alle rechten voorbehouden. Niets uit deze uitgave mag worden vervezlvoudigd, opgeslagen in een geautornatiseerd gegevenshestand of openbaar gemaakt, in enige vorm of op enige wijze, hetzij elektronisch, mechanisch, door fotokopieenn, opnamen of enige andere manier, zonder voorafigaande schriftelijke toestemming van de uitgever.

No part of this book may be produced in any form, by print, photoprint, microfilm or any other means without the prior written permission of the publisher. 


\section{Inhoud}

Voorwoord

Hoofdstuk 1 Inleiding en probleemstelling

Bijlage 1.1 Fiscale vrijstelling overheidsbedrijven in 194817

Hoofdstuk 2 De prestatio-analyse van overheidsbedrijven

2.1 Inleiding

2.2 Beleidsevaluatie en prestatie-analyse

2.2.1 De kwantitatieve prestatie-analyse

2.2.2 De kwalitatieve prestatie-analyse

2.3.1 Toezicht op het aankoopbeleid en de prestaties van produktiefactoren

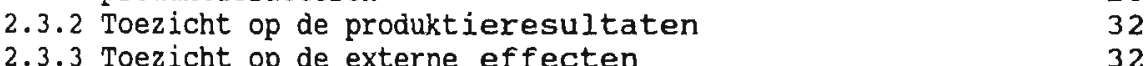

$\begin{array}{ll}2.3 .3 \text { Toezicht op de externe effecten } & 32 \\ 2.3 .4 \text { Toezicht op het produktieproces } & 34\end{array}$

2.3.5 Toezicht op de samenstelling en de omvang van het team van producenten

2.3.6 Aanspraak op de winst

2.4 Het vaststellen van de kenbaar gemaakte doeleinden 38

2.4.1 De kosten van de kenbar gemaakte doeleinden $\quad 42$

2.5 Een scenario voor privatisering $\quad 46$

2.6 Verklaring van de prestaties en de reacties van principalen

2.6.1 Benoemingen

2.6.2 Expliciete beleidswijzigingen

2.6.3 Impliciete beleidswijzigingen

2.6.4 Ritueel gedrag

2.6.5 Voortzetting van niet ter discussie staande beleidsactiviteiten 
3.2 structuuranalyse 54

3.3 Analyse van de kenbaar gemakte doeleinden 62

3.3.1 Kenbaar gemaakte doeleinden 63

3.3.2 Uit de structuuranalyse afgeleide doeleinden 66

3.3.3 Vergelijking van de met beide analyses gevonden
doeleinden

3.4 Beleidsvrijheid 67

3.4.1 Gasdistributie $\quad 75$

3.4 .2 Subsidies 79

3.4.3 Bezitsvorming 81

3.4.4 Het recht op de mijnen en de belastingen 90

3.4 .5 onderzoek en ontwikkeling 93

3.5 Privatisering 95

3.5.1 Verklaring van de prestaties door het overheidsbedrijf en de reacties van de principalen 97

3.5.2 Benoemingen 97

3.5.3 Voortzetting niet ter discussie staande
activiteiten

Bijlage 3.1 DSM als houdstermatschappij in $1958 \quad 100$

Bijlage 3.2 Data prestatie-onderzoek mijnbouw 101

Bijlage 3.3 Tarief gaslevering aan gemeenten in $1936 \quad 102$

Bijlage 3.4 Onderzoek Staatsmijnen 103

Organogram 3.1 Toezicht op de Staatsmijnen in Limburg 104

Organogram 3.2 Externe begroting Staatsmijnen 105

Organogram 3.3 Bedrijfseconomisch verslag en rapport 106

\section{Hoofdstuk 4 De NV Nederlandse spoorwegen}

4.1 Inleiding

$\begin{array}{ll}4.2 \text { Structuranalyse } & 107\end{array}$

4.3 Analyse van de kenbaar gemaakte doeleinden 121

4.3.1 Kenbaar gemaakte doeleinden en documentenanalyse 121

4.3.2 Uit de structuuranalyse afgeleide doeleinden 123

4.3.3 Vergelijking van de met beide analyses gevonden
doeleinden

4.4 Beleidsvrijheid 124

4.4.1 Werkgelegenheid 129 
4.4.2 Arbeidsvoorwaarden $\quad 134$

$\begin{array}{ll}4.4 .3 \text { Verborgen subsidiëring } & 134\end{array}$

4.4.4 Aankopen 138

4.4.5 Beheersing overheidsfinanciën 142

$\begin{array}{ll}4.5 \text { Kostenverdeling } & 142\end{array}$

4.6 Garantiewet en financiële sanering 145

$\begin{array}{lr}4.7 \text { Privatisering } & 147\end{array}$

4.8 Prestaties overheidsbedrijf en reacties principalen 148

$\begin{array}{ll}4.8 .1 \text { Benoemingen } & 148\end{array}$

4.8.2 Niet ter discussie staande beleidsactiviteiten 151

Bijlage 4.1 Investeringen en afschrijvingen 155

Bijlage 4.2 Prestatie-analyse 155

Bijlage 4.3 Exploitatie-coëfficiënten en toegekende
pensioenen over de periode 1950-1965

Bijlage 4.4 Spoorwegpensioenfonds 158

Bijlage 4.5 Publiciteits- en advertentiekosten 160

$\begin{array}{ll}\text { Bijlage } 4.6 \text { Garanties } & 161\end{array}$

\section{Hoofdstuk 5 De Nederlandse Centrale organisatie TNO}

5.1 Inleiding

5.2 Structuuranalyse

5.3 Analyse van de kenbaar gemaakte doeleinden 172

5.3.1 Kenbaar gemaakte doeleinden en documentenanalyse $\quad 174$

5.3.2 Uit de structuuranalyse afgeleide doeleinden 176

5.3.3 Vergelijking van de met beide analyses gevonden
doeleinden

$\begin{array}{lr}5.4 \text { Beleidsvrijheid } & 176\end{array}$

5.4.1 Inhalen achterstand op het gebied van toegepastnatuurwetenschappelijk onderzoek

5.4.2 Subsidiebeleid

5.4.3 Beheersing van de overheidsuitgaven

5.5 Privatisering

5.6 Prestaties overheidsbedrijf en reacties principalen 188

5.6.1 Benoemingen

5.6.2 Expliciete beleidswijziging 189

Bijlage 5.1 Groei rijkssubsidie TNO 1950 tot en met 1970190

Bijlage 5.2 Investeringsgroei TNO en Staatsmijnen 1953 tot en met 1966

Bijlage 5.3 Groei bouwkosten en kapitaalsubsidie 192 
Hoofdstuk 6 samenvatting on aabevelingen

6.1 Inleiding 193

6.2 Ondoorzichtigheid en prestatie-analyse 193

$\begin{array}{ll}6.3 \text { Structuuranalyse } & 197\end{array}$

6.4 Analyse van de kenbaar gemakte doeleinden 210

6.5 Kosten van de kenbaar gemakte doeleinden 211

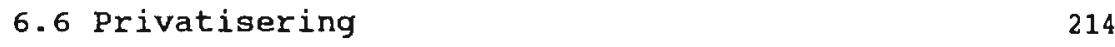

6.7 De verklaring van de prestaties en de reacties
van de ministers

$\begin{array}{ll}6.8 \text { Beleidsadvisering } & 218\end{array}$

$\begin{array}{ll}\text { Noten } & 221\end{array}$

Geraadpleegde archieven 278

$\begin{array}{ll}\text { Gedrukte stukken } & 280\end{array}$

Literatuur $\quad 282$

$\begin{array}{ll}\text { Bummary } & 291\end{array}$

Curriculun vitae 301 


\section{Voorwoord}

De internationale economische en politicologische literatuur over overheidsbedrijven is omvangrijk. Theorievorming over overheidsbedrijven geniet tegenwoordig vooral belangstelling in de leer der openbare financiën, vanwege het overheidsbeleid gericht op privatisering en de uitvoering van de Europese regelgeving. De ontwikkeling van de theorie heeft zich de laatste jaren vooral geconcentreerd op het verrichten van kwantitatieve prestatie-analyses. Tot op heden heeft uitgebreid empirisch onderzoek naar het gedrag en de prestaties van Nederlandse overheidsbedrijven niet plaatsgevonden. $U$. Rosenthal en $A$. Reinders noemen als oorzaken van deze lacune in Nederland de onoverzichtelijkheid van de publieke sector van het bedrijfsleven en het ontbreken van een consistent overheidsbeleid met betrekking tot overheidsbedrijven.'

Kenmerkend voor de Nederlandse publieke sector van het bedrijfsleven is de terughoudendheid van de betrokken ministeries en directies van overheidsbedrijven bij het verstrekken van informatie. De NV Nederlandse spoorwegen stelt dat het archief van de Raad van Commissarissen "bedrijfsgeheim" is. Ervaringen met onderzoek in het verleden hebben ertoe geleid dat er bij hen minder behoefte bestaat aan hernieuwd onderzoek. Bovendien zou de rol van de Raad van Commissarissen in de relatie met de overheid schromelijk worden overschat. ${ }^{2}$

Het archief over de Nederlandse Centrale organisatie voor toegepast-natuurwetenschappelijk onderzoek (TNO) bij het Ministerie van onderwijs en wetenschappen is niet toegankelijk, omdat de dossiers voor een groot deel uit geheime of vertrouwelijke stukken bestaan. Niet geheime/vertrouwelijke stukken zijn hiermee tevens gerubriceerd. Informatie over het overheidsbeleid ten aanzien van TNO is echter steeds in openbare documenten aan de statenGeneraal bekend gemaakt. ${ }^{3}$

Deze dissertatie kwam tot stand in het kader van het VFonderzoekprogramma "Keuze en Verantwoording" en heeft tot doel de belangstellende lezer te informeren over de politiekeeconomie van het Nederlandse overheidsbedrijf. Ter verkrijging van de benodigde informatie heb ik onderzoek verricht bij het Ministerie van Economische Zaken, het Ministerie van Financiën, het Ministerie van Verkeer en waterstaat, de NV Nederlandse staatsmijnen, de NV Nederlandse spoorwegen, het Koördinatie-orgaan Spoorwegvakorganisaties, het Sociaal Historisch Centrum voor Limburg en het Algemeen Rijksarchief.

De afgelopen vier jaar hebben archiefmedewerkers van de bovengenoemde departementen, bedrijven en instellingen mij met veel inzet geassisteerd bij het archiefonderzoek. Ik ben hen daarvoor zéér erkentelijk. Daarnaast bedank ik Prof. dr. J.G. Backhaus en dr. G. Meijer voor hun commentaar en positieve begeleiding. Tevens bedank ik dr. J. van den Noort voor zijn commentaar op hoofdstuk 4 en de interessante gedachtenwisseling over het onderwerp. 
Mijn ouders en silvia ben ik véél dank verschuldigd voor de aanmoediging en steun tijdens het onderzoek en het schrijven van deze dissertatie. 


\title{
Hoofdstuk 1
}

\section{Inleiding en probleemstelling}

Nederlandse kabinetten hebben voor de realisatie van hun beleidsdoeleinden de keuze uit diverse instrumenten en dragen daarvoor de verantwoording. Het overheidsbedrijf is één van de beleidsinstrumenten. Verantwoording betreft het stelsel van verantwoording over de aanwending van publieke middelen, waarbij rechtmatigheid en doelmatigheid toetsingscriteria zijn. In dit stelsel van verantwoording legt de minister verantwoording af aan de volksvertegenwoordiging. De overdracht van financiële informatie vormt de kern van het stelsel van ministeriële verantwoording over het gedrag van overheidsbedrijven.

Van een overheidsbedrijf wordt in deze studie gesproken als is voldaan aan het naar de Duitse econoom J. Popitz genoemde criterium. ${ }^{4}$ Popitz formuleerde zijn economisch criterium bij de afbakening van het overheidsbedrijf van andere organisaties op gemeente niveau. Zijn criterium luidt:

\begin{abstract}
"Wirtschaftliche Unternehmungen der Gemeinden, für deren Betrieb die nachfolgenden vorschriften gelten, sind solche Veranstaltungen der Gemeinden, die gegen Entgelt Leistungen zur Verfügung stellen, die ihrer Art nach auch durch Privatunternehmer mit der Absicht der Gewinnerzielung in den allgemeinen verkehr gebracht $\mathrm{zu}$ werden pflegen"."
\end{abstract}

Dit criterium houdt in dat de goederen en diensten van een overheidsbedrijf ook door particuliere ondernemers kunnen worden geleverd. Overheidsbedrijven kunnen verschillende vormen van rechtspersoonlijkheid aannemen. Voorbeelden hiervan zijn de naamloze vennootschap, de stichting en het zelfstandig bestuursorgaan. Het begrip overheidsbedrijf $\mathrm{zal}$ op grond van bovengenoemd criterium nader worden gedefinieerd in hoofdstuk 2 .

Het belang en de bestaansredenen van overheidsbedrijven in de Westeuropese economieën variëren. De activiteiten van overheidsbedrijven beinvloeden de mededingingsverhoudingen. Het is om deze reden dat in het Verdrag van de Europese Economische Gemeenschap van 1957 wordt getracht vrije mededinging te verenigen met het algemene economische belang van de lidstaten. De mededingingsregels zijn van toepassing op overheidsbedrijven voor zover de an deze bedrijven toevertrouwde bijzondere taak niet wordt verhinderd. ${ }^{6}$ De Commissie van de Europese Gemeenschap heeft de opdracht toezicht te houden op naleving hiervan en de bevoegdheid tot het uitvaardigen van richtlijnen en beschikkingen. Als eerste tak van overheidsbedrijven onderwierp de Europese Economische Gemeenschap de nationale spoorwegondernemingen aan nadere regulering. Het ontbreken van definities van het algemene economische belang en de taak van het overheidsbedrijf in het Verdrag van de Europese Economische Gemeenschap biedt de lidstaten tot op heden ruime mogelijkheden om financiële steun 
te verlenen an hun overheidsbedrijven. De lidstaten verstrekken financiële steun aan hun overheidsbedrijven in de vorm van leningen, subsidies, garanties en fiscale voordelen.

Het Centre Européen de l' Entreprise Publique (CEEP) behartigt de belangen van overheidsbedrijven bij de Commissie van de Europese Gemeenschap. Het CEEP stelt dat overheidsbedrijven moeten handelen onder omstandigheden van mededinging, maar soms in opdracht van hun overheid resultaten moeten realiseren, die verschillen van die van particuliere ondernemingen. Deze opdracht zou volgens het CEEP moeten worden gecompenseerd. Om overheidsbedrijven te laten participeren in de internationale concurrentie, streeft deze belangenorganisatie naar: (a) een vergroting van de autonomie voor de directie van overheidsbedrijven, (b) een besef van de exploitatiekosten en een verhoging van de produktiviteit, (c) een verbetering van de sociale verhoudingen en nauwere banden met universiteiten en (d) het oprichten van gemengde ondernemingen. In 1990 ontstond ten gevolge van de beleidsontwikkelingen in de Europese Gemeenschap tussen de Europese commissie en het CEEP een meningsverschil over de overheidssteun. ${ }^{7}$

Een jaar later stelde Duitsland voor een wijziging aan te brengen in het Verdrag van de Europese Economische Gemeenschap, die de lidstaten verplichtte hun overheidsbedrijven te privatiseren. Frankrijk verzette zich tegen dit voorstel uit vrees voor een machtsconcentratie bij de Europese Commissie. Deze stelde zich namelijk op het standpunt dat de lidstaten geen financiële steun meer zouden verstrekken aan overheidsbedrijven, tenzij door hen kon worden aangetoond dat particuliere investeerders ook zo zouden hebben gehandeld. De Europese Commissie achtte de volgende vormen van subsidiëring onaanvaardbaar: a. de aanvaarding van een rendement op investeringen van overheidsbedrijven beneden het rendement op de markt, b. het verstrekien van impliciete garanties voor leningen, c. het uitbreiden van het aandelenkapitaal, als particuliere ondernemers dit niet zouden doen, en $d$. het afzien van dividenduitkeringen. ${ }^{9}$ Bedrijven met een jaarlijkse omzet van 250 miljoen ecu's en een overheidsdeelneming van minstens $51 \%$ werden verplicht hun jaarverslagen ter controle naar de Europese commissie te zenden. ${ }^{10}$

Frankrijk en Italië verzetten zich tegen de besluiten van de Europese Commissie, omdat zij vrezen hun controle over het overheidsbedrijf als beleidsinstrument te verliezen." De economische en de politicologische literatuur geven een duidelijk beeld van de rol van overheidsbedrijven in de Franse en Italiaanse economie. ${ }^{12}$ Het verzet van deze lidstaten wordt hierdoor inzichtelijk. De wetenschappelijke literatuur over Nederlandse overheidsbedrijven heeft een bescheiden omvang.

Het leveren van een bijdrage aan de Nederlandse literatuur over overheidsbedrijven vormt één van de redenen voor het verrichten van onderzoek vanuit het perspectief van de leer der openbare financiën. Een verdere ontwikkeling van de Nederlandse literatuur over dit onderwerp kan bovendien een bijdrage leveren aan de onderbouwing van het Nederlandse beleid ten aanzien van overheidsbedrijven op nationaal en 
Europees niveau. De leer der openbare financiën bestudeert de ontvangsten en de uitgaven van de overheid vanuit een analytische, een institutionele en een beleidsmatige optiek.

Deze optieken maken van de leer der openbare financiën een op de praktijk gerichte wetenschap. In de loop van de tijd hebben zich in de leer der openbare financiën twee visies op de staat ontwikkeld, namelijk die van de staat als fiscale staat en die van de staat als ondernemer.

De visie van de fiscale staat stelt dat de belastingen en de uitgaven kunnen worden aangewend voor het bereiken van politieke en economische doeleinden. De visie van de staat als ondernemer heeft als uitgangspunt de publieke eigendomsrechten. De staat bezit overheidsbedrijven om inkomsten te verwerven en beleidsdoeleinden te verwezenlijken. zij kan optreden als financier of als aandeelhouder van het overheidsbedrijf. De Nederlandse overheid trad in beide rollen op. Uit geraadpleegde documenten blijkt, dat de rol van de staat als financier ook wel werd aangeduid met "de staat als geldschieter". Kenmerkend voor deze rol was dat de overheid niet over voldoende financiële middelen beschikte om in de overheidsbedrijven te investeren. Voor het verstrekken van kapitaal aan het overheidsbedrijf moest de overheid een beroep doen op de kapitaalmarkt. Hierdoor ontstond een vlottende schuld, die naderhand kon worden geconsolideerd. Een andere methode van financieren was de toekenning van de resterende middelen op de gewone dienst van de rijksbegroting aan de overheidsbedrijven. Aanwending van de middelen op de gewone dienst van de rijksbegroting had tot gevolg dat deze niet konden worden aangewend voor de amortisatie van schuld, waarvoor deze volgens een gangbare opvatting zouden moeten dienen. De rol van de staat als aandeelhouder houdt in dat het overheidsbedrijf zoveel mogelijk wordt bestuurd als een particuliere onderneming. De overheid zal pas besluiten tot het aantrekken van vreemd vermogen als de bedrijfsoverschotten rente en aflossing garanderen. In de rol van financier wil de staat zijn financiële positie vaststellen voor het geval dat het overheidsbedrijf niet wordt geëxploiteerd. De rente-oprenterekening biedt een instrument om deze kosten te bepalen. Vanuit het perspectief van de staat als aandeelhouder moet deze berekening buiten de bedrijfsadministratie blijven. Het overheidsbedrijf verliest anders zijn commercieel karakter. ${ }^{13}$

In Nederland en Nederlands-Indië kwam de publieke sector van het bedrijfsleven rond 1900 tot ontwikkeling. De overheidsbedrijven in Nederlands-Indië vervulden een fiscale rol voor het koloniale bestuur. Tegenvaliende bedrijfsresultaten konden zelfs het evenwicht op de begroting voor Nederlands-Indië verstoren. ${ }^{14}$ om inzicht te verwerven in de betekenis van staatsbedrijven voor de overheidsfinanciën drongen de staten-Generaal reeds in een vroeg stadium aan op de invoering van een commerciële boekhouding voor de staatsbedrijven. Voor een juiste beoordeling van de bedrijfsresultaten door de staten-Generaal mochten geen categorieën van uitgaven in de financiële verslaggeving ontbreken. Drie problemen moesten bij de beoordeling van de bedrijfsresultaten in beschouwing worden genomen, namelijk de pensioenlasten, de belastingen en de kosten van het toezicht 
door het departement, een eventueel daartoe ingesteld toezichthoudend orgaan en de Algemene Rekenkamer. 's In 1912 aanvaardden de staten-Generaal de Bedrijvenwet, die het mogelijk maakte de bedrijfsadministratie op commerciële basis in te richten. De verwachting bestond in deze jaren dat de publieke sector van het bedrijfsleven zich zou uitbreiden. De reden hiervoor was de gedachte dat de toeneming van de directe en indirecte belastingen de economische ontwikkeling kon beperken. Voor de rijksoverheid bestond er geen andere oplossing dan met staatsbedrijven inkomsten te verwerven. ${ }^{16}$

De verdere groei van de Nederlandse publieke sector van het bedrijfsleven vond plaats in de schaduw van een debat over winstneming door overheidsbedrijven en socialisatie van het bedrijfsleven. Aan de tot op heden actuele discussie over winstneming participeerden onder andere de liberalen $D$. Bos en M.W.F. Treub en de sociaal-democraten F.M. Wibaut en B. van den Tempel. $\mathrm{Zij}$ verschilden onderling echter van mening over de wenselijkheid en de mate van winstneming door overheidsbedrijven. De liberalen bepleitten de overdracht van natuurlijke monopolies aan overheidsbedrijven, teneinde de consument te beschermen tegen monopolistische prijzen. De sociaal-democraat wibaut wilde de winsten uit de staatsmonopolies niet slechts aanwenden om de rente op de staatsschuld en de aflossing van oorlogsleningen te financieren, maar ook voor sociale uitgaven. ${ }^{17}$ Het debat over socialisatie duurde voort tot enige jaren na de Tweede wereldoorlog en had een overwegend ideologische inhoud. J.A. Veraart vertolkte toen het katholieke standpunt in het debat. Het was volgens hem wenselijk bepaalde overheidsbedrijven te exploiteren, maar een algehele nationalisatie wees hij af. Hij bepleitte de oprichting van een publiekrechtelijke bedrijfsorganisatie als alternatief voor de socialisatie van het bedrijfsleven. ${ }^{18}$ Uiteindelijk aanvaardde ook een meerderheid van de sociaal-democraten de publiekrechtelijke bedrijfsorganisatie. ${ }^{19}$

De visie van de stat als ondernemer heeft zijn oorsprong in de Kameralistiek. Het overheidsbedrijf had primair tot taak de vorst inkomsten te verschaffen. In Duitsland en oostenrijk bestond na de Eerste Wereldoorlog uit vrees voor een fiscale crisis enige tijd belangstelling voor de staat als ondernemer. De Oostenrijkse econoom $R$. Goldscheid verrichtte historisch onderzoek naar de inkomsten van de overheid en concludeerde in zijn boek "staatskapitalismus oder staatssozialismus" dat de belastingopbrengsten de inkomsten uit het staatseigendom als belangrijkste bron van inkomsten hadden vervangen. Het probleem voor de overheid was dat $z i j$ het functioneren van de economie moest waarborgen, terwijl zij voor haar belastingen hiervan afhankelijk was. Om aan haar financieringsbehoefte te voldoen, moest de overheid in toenemende mate overgaan tot schuldfinanciering. In plaats van de particuliere sector te exploiteren, werd de overheid gedomineerd door de crediteuren. Goldscheid stelde als oplossing voor het particuliere eigendom te doen overgaan naar de overheid door het toepassen van een heffing op kapitaal, die voldoende hoog was om een publieke sector van het bedrijfsleven te vestigen ("Repropriierung des staates"). De inkomsten van de publieke sector van het 
bedrijfsleven zouden kunnen worden aangewend om de staatsschuld af te lossen en de kosten van het sociale vraagstuk te financieren. ${ }^{20}$

De Sociaal-Democratische Arbeiders Partij verwierp in haar Socialisatie-rapport van 1920 met twee argumenten Goldscheids voorstel van een heffing op kapitaal. Ten eerste leidden heffingen tot deelname in ondernemingen, waarbij de samenleving geen uitgesproken belang had. De aandelen zouden afkomstig kunnen zijn van onrendabele ondernemingen. Ten tweede zou aandelenbezit alleen van belang zijn, wanneer het een middel was om invloed uit te oefenen op het beheer van ondernemingen. Een meerderheidsbelang betekende immers geen doorslaggevende invloed op de leiding van een onderneming. Deze invloed werd volgens de opstellers van het rapport steeds vaker in de statuten tot een privilege van de eigenaren van preferente aandelen gemakt. Wettelijk kon dit privilege worden doorbroken, maar dan bleef het gevaar bestaan dat invloed werd verkregen in willekeurig bijeengebrachte ondernemingen. De heffing op kapitaal zou aan betekenis kunnen winnen door het te koppelen aan het uitwisselen van aandelen, zodat de gewenste ondernemingen konden worden bijeengebracht. ${ }^{21}$ Een omkering van de doorslaggevende invloed van de eigenaren van preferente aandelen is het in GrootBrittannië toegepaste "gouden aandeel" in het geprivatiseerde bedrijf. Het bezit van een "gouden aandeel" biedt de overheid de mogelijkheid een doorslaggevende stem uit te brengen over specifieke beleidsaangelegenheden, zoals bijvoorbeeld een overname. Het risico van overname verdwijnt voor de directie van het geprivatiseerde bedrijf en leidt mogelijk tot een verlies aan efficiëntie. De Britse regering heeft onder andere een "gouden aandeel" in Enterprise Oil (1984) en British Telecom (1984). ${ }^{22}$ In 1920 kenden de Nederlandse sociaaldemocraten deze constructie nog niet.

De Algemene Rekenkamer vermeldde in haar verslag over 1946 dat er vanaf 1930 in Nederland een tendens bestond om financiële middelen van de overheid te beheren met organisaties, die beschikten over rechtspersoonlijkheid, voornamelijk stichtingen. Het gevolg was het ontstaan van een interpretatie dat de Comptabiliteitswet van 1927 niet langer van toepassing was op deze organisaties. Het uiteindelijke resultaat van deze ontwikkeling was dat het verbreken van de eenheid van het beheer van rijksmiddelen en goederen niet kon worden tegengegaan. Hieruit vloeiden handelingen, die in strijd waren met de geldende regels voor financieel beheer, en een minder juist inzicht in de begroting voort. Een voorbeeld hiervan was de overdracht van wetenschappelijke rijksinstellingen aan de Nederlandse Centrale organisatie voor toegepast-natuurwetenschappelijk onderzoek (TNO). ${ }^{23}$

Het overheidsbedrijf in de vorm van een naamloze vennootschap genoot de belangstelling van de rijksoverheid. Begrotingen van de naamloze vennootschappen, die geheel of gedeeltelijk met overheidsmiddelen opereerden, kwamen niet aan de orde in de staten-Generaal. De richtlijnen voor de bedrijfsvoering werden veelal niet bepaald door de bedrijfseconomische overwegingen, mar door de politieke motieven van het an het bewind zijnde kabinet. ${ }^{24}$ De Minister 
van Financiën Lieftinck (Partij van de Arbeid, PvdA) vertegenwoordigde in 1951 de zienswijze dat een regeling voor toezicht, waarbij de mogelijkheid zou bestaan het ondernemingsbeleid in het openbaar ter sprake te brengen, niet aanvaardbaar was. De staten-Generaal noch de Algemene Rekenkamer dienden zich te mengen in dit beleid. Wilden de staten-Generaal echter toch interveniëren, dan moest de naamloze vennootschap de status van een staatsbedrijf aannemen. De Staten-Generaal waren niet bevoegd de Algemene Rekenkamer meer rechten te delegeren, dan die zij zelf konden uitoefenen. ${ }^{25}$

De geringe mogelijkheden tot financieel toezicht op Nederlandse overheidsbedrijven hadden tot gevolg dat een gedeelte van de overheid een "onzichtbaar" karakter kreeg, met als resultat dat $z i j$, die beschikten over de publieke eigendomsrechten, een bepaalde mate aan beleidsvrijheid verwierven. De onzichtbare kosten en baten van de beleidsvrijheid konden worden afgewenteld, respectievelijk verdeeld over bepaalde delen van de samenleving. ${ }^{26}$ Nederlandse staatsbedrijven verstrekten in het kader van hun beleid subsidies aan instellingen, waarin $z i j$ geen direct belang hadden. Hun subsidiebeleid was gedeeltelijk onzichtbaar, omdat uit de begrotingen niet kon worden opgemaakt aan welke instellingen subsidies waren verstrekt. Hierdoor was het onmogelijk de subsidies in de hoofdstukken van de rijksbegroting in verband te brengen met de subsidies van de staatsbedrijven. In 1949 was Minister Lieftinck van mening dat deze bedrijven in hun subsidiebeleid rekening moesten houden met de positie van 's Rijks financiën. Hij bepleitte een nominatieve opgave van de gesubsidieerde instellingen in de memorie van toelichting bij de begroting van het staatsbedrijf, teneinde de staten-Generaal meer inzicht te bieden. ${ }^{27}$

Vanaf 1966 publiceerde de Algemene Rekenkamer in haar verslagen een overzicht met enkele bedrijfseconomische gegevens van overheidsbedrijven. Voor 1966 publiceerde zij slechts in de verslagen over 1950 en 1960 overzichten. De Comptabiliteitswet van 1976 beëindigde met artikel 80 het ontbreken van toezicht door de Algemene Rekenkamer op naamloze vennootschappen.

De Nederlandse publieke sector van het bedrijfsleven groeide uit tot een belangrijke werkgever en vormde een beleggingsmogelijkheid voor institutionele beleggers. Het aandeel van de werkgelegenheid bij staatsbedrijven als de staatsmijnen en de PTT in de totale werkgelegenheid bij de rijksoverheid bedroeg voor 1950, 1955, 1960, 1965 en 1970 respectievelijk $44,68,47,98,45,28,43,88$ en $31,6 \%{ }^{28}$. Keyser en windle schatten het aandeel van de werkgelegenheid bij overheidsbedrijven in de totale Nederlandse werkgelegenheid met inbegrip van de werkgelegenheid bij de PTT (exclusief rijksambtenaren) op 6,6 procent in $1970 .{ }^{29}$

Uit tabel 1.1 blijkt dat de beleggingen van institutionele beleggers in Nederlandse overheidsbedrijven slechts 3 procent zijn van de totale beleggingen. De belangrijkste beleggers blijken de pensioenfondsen te zijn, die belang hebben bij risicoloze beleggingen. Institutionele beleggers kunnen geen 
fondsen beleggen in staatsbedrijven. Deze bedrijven verkrijgen hun kapitaal van de rijksoverheid op grond van artikel 6 van de Bedrijvenwet van 1928.

Tabel 1.1 Institutionele beleggingen in overheidsbedrijven

\begin{tabular}{|c|c|c|c|c|c|c|}
\hline & 1961 & 8 & 1962 & 8 & 1963 & 8 \\
\hline & $\operatorname{mln} g l d$ & & mln $\mathrm{glc}$ & & mln gld & \\
\hline Sociale fondsen & 273 & 22.5 & 279 & 19.4 & 279 & 17.5 \\
\hline Pensioenfondsen & 375 & 30.9 & 409 & 28.5 & 435 & 27.3 \\
\hline Levensverzekeringen & 238 & 19.6 & 254 & 17.7 & 280 & 17.6 \\
\hline Girodiensten & 26 & 2.1 & 50 & 3.5 & 98 & 6.1 \\
\hline Rijkspostspaarbank & 26 & 2.1 & 99 & 6.9 & 159 & 10.0 \\
\hline Algemene spaarbanken & 93 & 7.6 & 131 & 9.1 & 119 & 7.5 \\
\hline Kredietinstellingen (1) & 172 & 14.2 & 194 & 13.5 & 213 & 13.4 \\
\hline $\begin{array}{l}\text { Spaar-bouwkassen en } \\
\text { begrafenisfondsen }\end{array}$ & 10 & 0.8 & 11 & 0.7 & 9 & 0.5 \\
\hline Totaal & 1213 & 100 & 1435 & 100 & 1592 & 100 \\
\hline \multicolumn{7}{|l|}{ Beleggingen: } \\
\hline langlopend & 1199 & 98.8 & 1415 & 98.6 & 1559 & 98.0 \\
\hline kortlopend & 14 & 1.2 & 20 & 1.3 & 33 & 2.0 \\
\hline Totale beleggingen & 39571 & & 44153 & & 49348 & \\
\hline Overheidsbedrijven & & 3.1 & & 3.2 & & 3.2 \\
\hline
\end{tabular}

Opmerkingen: (1) Landbouwkredietinstellingen

Bron: CBS, Maandstatistiek Financiewezen, jaargang 12 , no. 8 , 1964 , en jaargang 13, no. 8, 1965.

Uit tabel 1.2 blijkt dat overheidsbedrijven in de vorm van een naamloze vennootschap (deelnemingen) als bron van inkomsten voor de rijksoverheid weinig betekenis hadden. 
Tabe1 1.2 overheidsbedrijven in nv-vorm

\begin{tabular}{lccccc}
\hline \multicolumn{3}{c}{$\begin{array}{l}\text { Overheidsbedrijven } \\
\text { Jinst }\end{array}$} & verlies & Dividend & $\begin{array}{l}\text { Overheids- } \\
\text { inkomsten (1) }\end{array}$ \\
\hline \multicolumn{5}{c}{ aantal } \\
1959 & 19 & 7 & 60.5 & 9224 & 0,6 \\
1965 & 19 & 7 & 36.1 & 18136 & 0,2 \\
1966 & 16 & 6 & 51.5 & 19780 & 0,3 \\
1967 & 19 & 6 & 105.8 & 22932 & 0,5 \\
1968 & 20 & 9 & 120.4 & 25025 & 0,5 \\
1969 & 18 & 11 & 173.2 & 28650 & 0,6 \\
1970 & 17 & 14 & 201.7 & 32542 & 0,6
\end{tabular}

Opmerking: (1) De overheidsinkomsten (exclusief opbrengst van staatsleningen) bestaan uit de gewone en buitengewone inkomsten van de rijksoverheid. Deze inkomsten zijn de som van de opbrengst van de belastingen en de overige inkomsten.

Bron: Algemene Rekenkamer, Verslagen over 1960 tot en met 1972; CBS, Negentig jaren statistiek in tijdreeksen, 1989, p. 167.

ondanks het belang van de publieke sector van het bedrijfsleven voor de werkgelegenheid heeft het in Nederland ontbroken aan een algemeen beleid voor overheidsbedrijven. Een algemeen beleid voor overheidsbedrijven zou mogelijk zijn met een afzonderlijk departement of directoraat-generaal voor overheidsbedrijven. De verkokering van het toezicht op overheidsbedrijven betekende niet dat er geen algemene beleidsopvattingen bestonden bij politici en beleidsambtenaren. Dit blijkt uit:

1. Belastingheffing

Van 1914 tot en met 1940 kende de fiscale politiek vrijstellingen toe aan overheidsbedrijven. Op aandrang van de Duitse autoriteiten kwam hier tijdens de bezetting van Nederland een einde aan. Het fiscale regime tijdens de bezetting stelde de belastingheffing afhankelijk van de vorm van uitoefening van het overheidsbedrijf. Na de bevrijding kwam er in afwachting van een herziening van de wettelijke regeling een voorlopige administratieve voorziening. ${ }^{30}$ In 1949 liet Minister van Financiën Lieftinck zich over deze problematiek adviseren door de Adviescomissie voor fiscale aangelegenheden onder voorzitterschap van mr. P.J. Oud. Deze commissie attendeerde de minister erop, dat de noodzaak van de belastingplicht voor overheidsbedrijven werd ingegeven door de toename van het aantal van deze bedrijven. De groei van het aantal overheidsbedrijven leidde voor de rijksoverheid tot een derving van inkomsten, die nodig waren voor een sluitende begroting. ${ }^{31}$ Bijlage 1.1 geeft een overzicht van de fiscale vrijstelling voor overheidsbedrijven in 1948. Het zou tot 1956 duren voordat een definitieve regeling van de 
vennootschapsbelasting voor overheidsbedrijven tot stand kwam.

De wet belastingheffing overheidsbedrijven van 1956 beëindigde de fiscale vrijstelling van overheidsbedrijven, met uitzondering van die van het staatsbedrijf der Posterijen, Telegrafie en Telefonie (PTT) en de energiebedrijven. Een meerderheid in de staten-Generaal achtte de argumenten voor vrijstelling aanvaardbaar. Een van de argumenten behelsde dat het bepalen van het belastingobject, de winst, op grote technische moeilijkheden stuitte (bijvoorbeeld de splitsing in vreemd en eigen vermogen, de aftrekbaarheid van concessiegelden, de retributies en onkostendeclaraties door het algemene bestuursapparaat). ${ }^{32}$ In 1964 ontstond ten gevolge van de parlementaire discussie over de vennootschapsbelasting op het Ministerie van Financiën de vraag of deze vrijsteliing moest worden gehandhaafd. Een dergelijk besluit had immers voor de gemeenten gevolgen voor de middelen van de gewone dienst. Beëindiging zou een bedrag in de orde van 100 miljoen per jaar kunnen opleveren. De directie Rijksbegroting wees de thesaurier-generaal erop dat het kabinet Drees III in 1956 het standpunt innam dat overheidsbedrijven alleen in de belastingheffing moesten worden betrokken, indien $\mathrm{zij}$ concurreerden met particuliere ondernemingen.

Tussen het directoraat-generaal Fiscale zaken en de Generale-Thesaurie bestond in de jaren ' 60 een meningsverschil over de heffing van vennootschapsbelasting bij overheidsbedrijven. De Generale-Thesaurie was van mening dat kapitaalgebruik door overheidsbedrijven op dezelfde wijze moest worden belast als bij particuliere bedrijven. Het directoraat-generaal Fiscale Zaken vreesde voor een aantasting van de fiscale basis van de indirecte belastingen." Uitbreiding van de basis van de vennootschapsbelasting resulteerde via de doorberekening in de tarieven immers in een soort verhoging van indirecte belastingen. De heffing van vennootschapsbelasting vergrootte structureel de inkomsten van het Rijk en makte het onder andere mogelijk de kosten verbonden aan de bouwproduktie beter op te vangen. ${ }^{34}$

Het heffen van belastingen van overheidsbedrijven kan worden beschouwd als een "vestzak-broekzak" benadering. Een hoge winst bij overheidsbedrijven werd echter politiek minder aanvaardbaar geacht dan het ontvangen van een bedrag aan vennootschapsbelasting. ${ }^{35}$ De fiscale regeling had tot doel het creëren van gelijke mededingingsvoorwaarden tussen particuliere bedrijven en overheidsbedrijven, het verlagen van winsten bij overheidsbedrijven en het beëindigen van de liquiditeitsvoorsprong. Het beëindigen van fiscale vrijstellingen voor overheidsbedrijven wordt in de literatuur beschouwd als een voltooiing van de ontwikkeling naar een belastingstaat. ${ }^{36}$ De wet op de vennootschapsbelasting van 1969 integreerde de belastingheffing bij overheidsbedrijven met die bij particuliere ondernemingen.

\section{Tantièmes}

In 1948 vroeg Minister van Financiën Lieftinck aan de vrijstelling van de vennootschapsbelasting voor 
overheidsbedrijven geen beperkingen of voorwaarden moesten worden gesteld aan de tantièmes en salarissen. ${ }^{37}$ De fiscale vrijstelling kon immers ten goede komen aan de tantièmisten, hetgeen hij als ongewenst beschouwde. Dit zou kunnen worden voorkomen met de bepaling de winst te verdelen op een wijze, waarbij werd verondersteld dat de vrijstelling niet bestond. overheidsbedrijven konden deze benadering echter ontwijken met het toekennen van hogere salarissen. Hij beschouwde het verbinden van de goedkeuring van salarissen als voorwaarde voor fiscale vrijstelling als een omslachtige controle. ${ }^{38}$ De leden van de commissie meenden dat de vaststelling van de bezoldiging van de directies en commissarissen van overheidsbedrijven tot de aangelegenheden van de toezichthoudende publiekrechtelijke lichamen behoorde. De rijksoverheid mocht hier niet interveniëren. Wettelijke maatregelen waren slechts noodzakelijk als de fiscale vrijstelling op grond van de bestaande arbeidscontracten tot hogere tantiezmes zou leiden, dan bij de aanvankelijk bestaande verhoudingen waren bedoeld. ${ }^{39}$

\section{Afschrijuingen}

De Bedrijvenwet van achtereenvolgens 1912 en 1928 hadden tot doel een commerciële bedrijfsvoering van staatsbedrijven te bevorderen. De keuze van de methode van afschrijven was van invloed op de tariefstelling en de tekorten bij overheidsbedrijven. De Bedrijvenwet van 1928 bepaalde dat het opstellen van voorschriften over de afschrijuingen was voorbehouden aan de verantwoordelijke Minister en de Minister van Financiën. Hierdoor ontstond de mogelijkheid de afschrijvingen aan te passen aan de omstandigheden van elk staatsbedrijf en aan te wenden als instrument in het kader van de structuur- en conjunctuurpolitiek. Beleidsambtenaren beschouwden aanvankelijk afschrijvingen tegen vervangingswaarde als strijdig met de intentie van de Bedrijvenwet. $z i j$ waren voorstander van afschrijvingen op basis van historische kosten. De lasten moesten worden gedragen door hen, die van de aanwending van de kapitaalgoederen profiteerden. ${ }^{40}$ In 1948 werd door de Ministeries van Financiën, Binnenlandse Zaken, Economische Zaken en Verkeer en Waterstaat een commissie ad hoc onder voorzitterschap van dr. A. Mey ingesteld voor de aanpassing van het afschrijvingsbeleid van staatsbedrijven aan de gewijzigde waarde- en prijsverhoudingen teneinde desinvesteringen te voorkomen. De voorzitter was voorstander van annuiteiten-afschrijving met toepassing van indexcijfers. De ambtenaren van de vakdepartementen identificeerden $z$ ich echter met de staatsbedrijven, die bezwaren hadden tegen de binding van hun beleid aan een onmodifieerbaar systeem van afschrijvingen. De voorzitter attendeerde deze ambtenaren erop dat $z i j$ hun ministers vertegenwoordigden en zich moesten verplaatsen in het algemeen kabinetsbeleid. ${ }^{41}$ In 1955 aanvaardde Minister van Financiën Van de Kieft (PvdA) dat staatsbedrijuen hun activa afschreven tegen vervangingswaarde. ${ }^{42}$ 
overheidsbedrijven behoorden kostendekkend, dan wel rendabel te zijn. Tariefwijzingen dienden aan te sluiten bij de prijspolitiek en te worden gemeld bij het Ministerie van Economische zaken. Verhogingen van overheidstarieven konden deel uitmaken van bestedingsbeperkende matregelen. ${ }^{43}$

\section{Ondernemingsraden}

De wet op de ondernemingsraden van 1950 bood de overheid de mogelijkheid om overheidsbedrijven ontheffing te verlenen voor het instellen van ondernemingsraden. Het beleid was er echter op gericht hiervan geen gebruik te maken, als daarvoor geen reden was. Aangezien de ondernemingsraden geen wezenlijk medebeslissingsrecht hadden, moest als reden voor deze uitzonderingsmogelijkheid worden beschouwd dat voor overheidsbedrijven reeds op de een of andere wijze in een personeelsvertegenwoordiging was of kon worden voorzien. ${ }^{44}$

\section{Rentabiliteit}

De rentabiliteit van overheidsbedrijven bleek een punt van discussie te vormen in het kabinet-Drees IV. In de miljoenennota voor 1957 van het demissionaire kabinet-Drees III werd gesteld dat $z$ ich een vorm van prijssubsidie voordeed, indien overheidsbedrijven hun diensten tegen te lage tarieven aanboden. Aan overheidsbedrijven, warvan de diensten in beginsel niet voor subsidie in aanmerking behoorden te komen, diende de eis te worden gesteld dat de tarieven de reële kosten compenseerden. $\mathrm{zij}$ konden als rendabel worden aangeduid, indien de investeringen hetzelfde rendement opleverden als particuliere investeringen. Aan deze norm voldeden $z i j$ echter niet altijd. ${ }^{45}$ In de ministerraad bestond hierover in december 1956 reeds een ander inzicht. Voor Minister-President Drees ging de gedachte van een zelfde gemiddelde rentabiliteitspercentage voor overheidsbedrijven en particuliere bedrijven te ver. $\mathrm{zij}$ konden immers tot taak hebben te zorgen voor goedkope voorzieningen ten behoeve van de bevolking. Wel moesten volgens Minister-President Drees overheidsbedrijven rente over investeringen opbrengen. Minister van Financiën Hofstra (PvdA) kon $z$ ich niet geheel met de betreffende passage in de miljoenennota verenigen 40 en deelde tijdens de algemene $f$ inanciële beschouwingen mee dat de tarieven van overheidsbedrijven werden onderzocht. Mocht uit het onderzoek blijken dat de rentabiliteit van bepaalde bedrijven onvoldoende was, dan konden volgens hem maatregelen ter verhoging van de rentabiliteit niet uitblijven. ${ }^{47}$

\section{Vermogen}

Overheidsbedrijven maken deel uit van het vermogen van de Nederlandse rijksoverheid. Uit de staatsbalans blijkt de netto-vermogenspositie van de overheid. De nettovermogenspositie is gelijk aan de som van het saldo op de staatsbalans en de post "reserve waardeverandering". Aan de 
zijde van de activa beïnvloeden overheidsbedrijven de nettovermogenspositie met een verandering van de post "staatsbedrijven en deelnemingen" en aan de zijde van de passiva met de post "reserve waardeverandering". 48

Privatisering van overheidsbedrijven heeft een verandering van de samenstelling van de netto-vermogenspositie van het Rijk tot gevolg. De rijksoverheid kan de inkomsten aanwenden voor aflossing van staatsschuld en betaling van rente op staatsschuld. Een overheidsbedrijf zou niet in aanmerking mogen komen voor privatisering als de contante waarde van de netto-opbrengsten hoger is dan de contante waarde van de verminderde rentelast en het verlies aan waardestijging.

Tabel 1.3 toont de uit de staatsbalans blijkende ontwikkeling van de intrinsieke waarde van de staatsbedrijven en deelnemingen als percentage van de totale activa.

Tabel 1.3 Staatsbalans: staatsbedrijven en deelnemingen

\begin{tabular}{lrll}
\hline Jaar & $\begin{array}{l}\text { Staatsbedrijven } \\
\text { en deelnemingen }\end{array}$ & $\begin{array}{l}\text { Totale } \\
\text { activa }\end{array}$ & \\
\hline \multicolumn{4}{c}{ mln gld } \\
1950 & 3555 & 21921 & 16,2 \\
1955 & 4165 & 24125 & 17,3 \\
1960 & 5980 & 31876 & 18,8 \\
1965 & 7300 & 46790 & 15,6 \\
1970 & 11115 & 77319 & 14,3 \\
\hline
\end{tabular}

opmerking: Voor 1950, 1955 en 1960 zijn de totale activa gelijk aan het verschil tussen het balanstotaal en het saldo.

Bron: Miljoenennota's, Staatsbalans 1950, 1955, 1960, 1965 en 1970 .

Uit tabel 1.3 blijkt dat de intrinsieke waarde van de staatsbedrijven en overheidsdeelnemingen als percentage van de totale activa daalde over de periode 1950 tot en met 1970 .

Het kabinet-De Quay verzocht in 1960 een wijziging in de rijksbegroting voor het dienstjaar 1960 aan te brengen. Een van de redenen betrof de invoeging van de post deelneming in de uitbreiding van het aandelenkapitaal van de NV Hoogovens en Staalfabrieken. Voor de Vaste commissie voor Financiën vormde dit aanleiding on bij Minister van Financiën J. Zijlstra (AR) te informeren naar de grondslagen van het beleid gericht op het bezit van en de deelneming in vennootschappen. Hij antwoordde dat het kabinet het standpunt deelde dat het principieel niet wenselijk was dat de staat zich steeds dieper in het bedrijfsleven begaf. Verder onderscheidde hij voor de opbrengsten van het afstoten van staatsvermogen twee mogelijkheden. Ten eerste vloeiden de opbrengsten definitief in de staatskas. De overheid diende de opbrengst niet aan te wenden voor een verhoging van de overheidsuitgaven, maar te gebruiken voor een vermindering van het beroep op de kapitaalmarkt. Ten tweede zouden de opbrengsten kunnen worden 
gebruikt voor nieuwe in het algemene belang noodzakelijke deelnemingen of uitbreiding van bestaande deelnemingen. Hij sloot de afstoting van deelnemingen ten behoeve van de bezitsvorming niet uit. De verkoop van de deelnemingen zou het bezit in de vorm van kleine effectencoupures voor werknemers kunnen bevorderen. ${ }^{49}$

Het uitoefenen van bestuurlijk toezicht op het overheidsbedrijf makt deel uit van het stelsel van verantwoording over de aanwending van de publieke middelen. Het stelsel van toezicht op de prestaties van Nederlandse overheidsbedrijven bestaat uit drie lagen, namelijk de minister(s), het departement en het toezichthoudende orgaan.

Voor het toezicht op het overheidsbedrijf hebben de controlerende instanties financiële informatie van de directie van het overheidsbedrijf nodig. De problematiek van de principaal-agent relatie doet zich hier voor tussen de minister en de directie.

De relatie tussen minister en directie kan bij het overheidsbedrijf verschillende vormen aannemen. De minister(s) en de andere controlerende instanties streven naar het bereiken van de wettelijke en statutaire doeleinden. Het is echter niet uitgesloten dat de minister(s), naast een voldoende realisatie van de wettelijke en statutaire doeleinden, streeft (streven) naar een mate van vrijheid om andere doeleinden te verwezenlijken. Directies van overheidsbedrijven kunnen als reactie op de ministeriële beleidsvrijheid streven naar autonomie. Beleidsvrijheid tast de voor de directie belangrijke bedrijfsresultaten aan. De relaties tussen principalen en agenten kenmerken $\mathrm{zich}$ bij overheidsbedrijven door een mate van conflict en onduidelijkheid. De aanwezigheid van een vorm van prestatiebeloning neemt in deze relatie een belangrijke plaats in. Een prestatie-beloningsstelsel biedt de controlerende organen en de directie de mogelijkheid de doeleinden kenbaar te maken en de commerciële prestaties van het bedrijf te beinvloeden.

De spanningen tussen principalen en agenten deden $z i c h$ ook bij Nederlandse overheidsbedrijven voor. In 1954 bestond binnen het kabinet-Drees III de opvatting dat de overheid meer invloed kon uitoefenen op particuliere bedrijven dan op staatsbedrijven. In tegenstelling tot het particuliere bedrijf was het staatsbedrijf een eigen orgaan, waartegen zelden scherp kon worden opgetreden. ${ }^{50}$ Verder schreef $J$. Goudriaan in 1961 dat de Minister van Financiën zijlstra de klacht uitte dat het kabinet minder invloed had op overheidsbedrijven dan op particuliere bedrijven. ${ }^{\text {s1 }}$ Er bestaan voor de oplossing van het conflict tussen controlerende organen en de directie van het overheidsbedrijf twee mogelijkheden, namelijk centralisatie van de publieke eigendomsrechten of overdracht aan het particuliere bedrijfsleven.

In parlementaire democratieën kunnen overheidsbedrijven trachten de kosten van hun beleidsactiviteiten af te wentelen op de begroting en het toezicht door de wetgevende macht bemoeilijken. Het is om deze reden dat nader onderzoek moet worden verricht naar de verdeling en de aanwending van de 
eigendomsrechten in overheidsbedrijven. Dit onderzoek concentreert zich op drie overheidsbedrijven, namelijk: de Staatsmijnen, de NV Nederlandse Spoorwegen en de Nederlandse Centrale organisatie voor toegepast-natuurwetenschappelijk onderzoek. Bovendien ligt aan de keuze van deze bedrijven de overweging ten grondslag dat zij in de primaire, secundaire en tertiaire sector van de Nederlandse economie werkzaam zijn.

Het onderzoek beperkt $z$ ich om praktische en juridische redenen tot de periode tussen het jaar van oprichting en het jaar 1970. Het archief van de Raad van Commissarissen van NV Nederlandse spoorwegen is bedrijfsgeheim. ${ }^{52}$ Het huishoudelijk reglement voor de Raad van commissarissen bepaalt dat haar notulen geheim zijn, behalve voor de minister en voorzover de raad niet anders beslist voor de hoofddirectie en de directieraad. ${ }^{53}$ De Concernarchieven van de NV Staatsmijnen met archiefmateriaal vanaf 1970 dragen een geheim karakter. ${ }^{\text {s4 }}$ De andere archieven zijn slechts toegankelijk tot en met het jaar 1969. Voor meer inzicht in de principaal-agent relatie tussen minister en directie c.q. bestuur van een overheidsbedrijf zouden de notulen en bijlagen van de ministerraad en de Raad voor Economische Aangelegenheden informatie kunnen bevatten. Voor dit archief gelden de aanwijzingen van de ministerraad van 23 februari 1973. De ministerraad bepaalde daar de termijn waarbinnen de notulen niet voor raadpleging toegankelijk zijn op 20 jaar. Van deze termijn kan met machtiging van de ministerraad slechts worden afgeweken ten behoeve van de uitvoering van een regeringsopdracht. ${ }^{55}$

De probleemstelling van dit onderzoek luidt derhalve:

Welke andere doeleinden maakten de politieke eigenaren van de Staatsmijnen, de NV Nederlandse Spoorwegen en de Nederlandse Centrale organisatie voor toegepast-natuurwetenschappelijk onderzoek, naast een voldoende realisatie van de wettelijke en statutaire doeleinden, kenbaar vanaf hun oprichting tot en met 1970 ?

In dit onderzoek wordt getracht de probleemstelling te beantwoorden door het verrichten van case-studies naar de genoemde overheidsbedrijven. Deze bedrijven hebben de afgelopen jaren ook de belangstelling genoten van de StatenGeneraal. De wet van 19 december 1985 hield een herstructurering in van de Nederlandse Centrale organisatie TNO. Zij regelde de financiering en gaf de organisatie als doelstelling ertoe bij te dragen dat op toepassing gericht technisch- en natuurwetenschappelijk onderzoek en daarmede te verbinden sociaal-wetenschappelijk en ander op toepassing gericht onderzoek op doelmatige wijze dienstbaar wordt gemaakt aan het algemene belang en de daarbinnen te onderscheiden deelbelangen. 56

In 1988 verleenden de Staten-Generaal het kabinet-Lubbers I I toestemming om de aandelen in de NV Nederlandse Staatsmijnen te verkopen. De Partij van de Arbeid betreurde de privatisering van de NV Nederlandse Staatsmijnen, omdat de rijksoverheid door de verkoop van de aandelen een financieel nadeel zou kunnen lijden. Aflossing van een deel van de staatsschuld met de opbrengst van de privatisering betekende 
dat hierover geen rente meer hoefde te worden betaald. Het lid van de PvdA-fractie in de Tweede Kamer der staten-Generaal $M$. wöltgens betwijfelde of dit voordeel opwoog tegen het verlies aan dividend en waardestijging van het concern. ${ }^{57}$ De overheid heeft in 1992 een belang van 31,3 procent in het bedrijf en beschikt over het recht twee commissarissen en drie van de vijf bestuurders van de stichting Prioriteitsaandelen DSM te benoemen. De Stichting Prioriteitsaandelen biedt de Minister van Economische Zaken het recht voorstellen tot wijziging van de statuten of tot ontbinding van de vennootschap goed te keuren en de reservering van de winst vast te stellen. ${ }^{58}$

De NV Nederlandse Spoorwegen vormde met rapporten als "Rail 21" (1988) en "Rail 21 Cargo" (1990) een uitgesproken voorbeeld van beleidsinitiatieven met budgettaire consequenties voor de rijksoverheid. De directie van de NV Nederlandse Spoorwegen drong bij de rijksoverheid aan op een integraal verkeers- en vervoersbeleid. Een substantiële bijdrage aan de oplossing van de milieu- en congestieproblemen kon slechts worden geleverd als op tijd de juiste beleidsbeslissingen werden genomen. $\mathrm{zij}$ achtte het uitgesloten dat de voorgestelde projecten uit de exploitatieresultaten of de eigen middelen konden worden gefinancierd. De rijksoverheid zou bereid moeten zijn de financiële middelen ter beschikking te stellen, omdat de versterking van de railfunctie een nationaal belang was. ${ }^{9}$

De aanwendingsmogelijkheden en de fiscale rol van overheidsbedrijven komen aan de orde in de Nederlandse economische literatuur. Economen als C.A. Verrijn Stuart, B. van den Tempel, M.J.H. Smeets en C. Goedhart bespraken de fiscale rol van het overheidsbedrijf in hun werk. ${ }^{60}$

Verrijn stuart schreef dat staten zich aanvankelijk economisch in stand hielden met de inkomsten uit domeinen en de opbrengsten van allerlei eigen bedrijven, zoals bijvoorbeeld: post, telegrafie, telefonie, spoorwegen, mijnen, monopolies. Later verkregen $z i j$ hun inkomsten overwegend uit gedwongen heffingen. ${ }^{61}$ Van den Tempel behandelde onder andere de fiscale rol van de staatsmijnen. De rijksoverheid zou uit de stichting van de staatsmijnen een grotere winst verwerven, dan zij bij particuliere exploitatie als haar aandeel zou ontvangen. ${ }^{62}$ Smeets vermeldde dat de overheid inkomsten genoot uit ondernemingen in de vorm van uitkeringen ten bedrage van het voordelig saldo, dividenden op aandelen, gedeelten van de overwinst of het exploitatiesaldo. Hij categoriseerde de overheidsbedrijven naar marktvorm. ${ }^{63}$ Goedhart besteedde bij de behandeling van de inkomsten uit overheidsbedrijven bovendien nog uitvoerig aandacht aan de prijsstelling vanuit welvaartstheoretisch perspectief. ${ }^{64}$

Het verwerven van kennis over het succes en falen van bedrijfsactiviteiten met behulp van case-studies kan bijdragen aan een herwaardering van de betekenis van het overheidsbedrijf. De herwaardering van de fiscale rol van het overheidsbedrijf kan echter alleen plaatsvinden, als is onderzocht welke factoren van invloed zijn op de kenbaar gemakte doeleinden en de prestaties van het overheidsbedrijf. De wetenschappelijke beleidsadvisering voor overheidsbedrijven kan een bijdrage leveren aan de herwardering van de fiscale 
rol van het overheidsbedrijf. Deze beleidsadvisering veronderstelt een empirische theorie over overheidsbedrijven. ${ }^{65}$

De case-studies leiden tot het vaststellen van de doeleinden van de politieke eigenaren. Hun doeleinden blijken uit een analyse van de verdeling en de aanwending van de eigendomsrechten, een analyse van (beleids)documenten en jaarverslagen en een analyse van de wisselwerking tussen de verklaring van de onderneming over de eigen prestaties en hun reacties daarop. Het onderzoek naar overheidsbedrijven beweegt zich op het terrein war politiek en economie interageren en kan daarom worden beschouwd als een bijdrage aan de economische theorie van de politieke besluitvorming (in de Engelse literatuur bekend als "Public Choice") en de wetenschappelijke beleidsadvisering.

Deze studie ter beantwoording van de probleemstelling sluit aan bij het tot dusver uitgevoerde kwantitatieve onderzoek naar de prestaties van overheidsbedrijven. In de navolgende hoofdstukken worden achtereenvolgens behandeld het onderzoek naar de prestaties van overheidsbedrijven en de case-studies over de Nederlandse Staatsmijnen, de NV Nederlandse Spoorwegen en de Nederlandse Centrale organisatie voor toegepastnatuurwetenschappelijk onderzoek (TNO). De case-studies bevatten een analyse van de structuur en van de kenbaar gemaakte doeleinden. Afgesloten wordt met een samenvatting en conclusie. 


Soort bedrijf vennootschaps vermogens- Ondernemingsbelasting
belasting bedrijfs- Bedrijfs-

\begin{tabular}{|c|c|c|c|c|}
\hline Landbouwbedrijven & $\mathrm{v}$ & $\mathrm{v}$ & $\mathrm{v}$ & $\mathbf{v}$ \\
\hline $\begin{array}{l}\text { Staatsbedrijf PTT } \\
\text { Spaarbankinstel- }\end{array}$ & $\mathrm{v}$ & $\mathrm{v}$ & $\mathrm{v}$ & $v$ (2) \\
\hline lingen (3) & $\mathrm{b}$ & $\mathbf{v}$ & b & b \\
\hline staatsloterij & $\mathrm{v}$ & $\mathbf{v}$ & $\mathbf{v}$ & $\mathbf{v}$ \\
\hline Staatsbosbeheer & $\mathrm{v}$ & $\mathbf{v}$ & $\mathrm{v}$ & $\mathbf{v}$ \\
\hline $\begin{array}{l}\text { Trambedrijven } \\
\text { Elektriciteits- }\end{array}$ & $\mathrm{b}$ & $\mathbf{v}$ & b & b (4) \\
\hline bedrijven & $\mathrm{b}$ & $\mathrm{v}$ & b & $\mathbf{b}$ \\
\hline $\begin{array}{l}\text { Gasbedrijven } \\
\text { Waterleiding- }\end{array}$ & $\mathrm{b}$ & v & b & b \\
\hline bedrijven & b & $\mathbf{v}$ & $\mathbf{b}$ & b \\
\hline Warmtebedrijven & $b$ & $\mathbf{v}$ & b & b \\
\hline Kredietbedrijven & $b$ & b & b & $\mathrm{b}$ \\
\hline Havenbedrijven & $b$ & $\mathrm{v}$ & b & b \\
\hline staatsmijnbedrijf & $b$ & $\mathrm{v}$ & b & $\mathrm{b}$ \\
\hline Veerbedrijven & $b$ & $\mathrm{v}$ & b & $\mathrm{b}$ \\
\hline Grotbedrijf & b & $\mathrm{v}$ & b & b \\
\hline Marktbedrijven & $\mathrm{b}$ & $\mathbf{v}$ & b & b \\
\hline Woningbedrijven & $\mathrm{b}$ & $\mathrm{v}$ & b & $\mathrm{b}$ \\
\hline $\begin{array}{l}\text { Grondbedrijven } \\
\text { ontsettingsbe- }\end{array}$ & $\mathrm{b}$ & $\mathrm{v}$ & b & b \\
\hline $\begin{array}{l}\text { Ontsmettingsbe- } \\
\text { drijven }\end{array}$ & $\mathrm{b}$ & $\mathrm{v}$ & b & b \\
\hline $\begin{array}{l}\text { NV Nederlandsche } \\
\text { Bank }\end{array}$ & $\mathrm{v}$ & $\mathrm{v}$ & v & $\mathrm{v}$ \\
\hline NV Nederlandse & & & & \\
\hline Spoorwegen & $\mathrm{v}$ & $\mathrm{v}$ & $\mathrm{v}$ & $\mathrm{v}$ \\
\hline $\begin{array}{l}\text { Andere nv's met } \\
\text { publiekrechtelijke } \\
\text { aandeelhouders }\end{array}$ & $\mathrm{b}$ & $\mathrm{v}$ & $v$ & $v$ \\
\hline
\end{tabular}

Opmerkingen: b-belastingplichtig en v-vrijstelling

(1) Tot 1-1-1947.

(2) Inclusief Rijkspostspaarbank, Postcheque- en Girodienst.

(3) Zie art. 9, sub 2, Vennootschapsbelasting, welke bepaling krachtens dienstvoorschrift analoog is toegepast voor de Vermogensbelasting II.

(4) Behalve die van de NV Nederlandse Spoorwegen.

Bron: Minister P. Lieftinck, Brief aan mr. P.J. Oud, voorzitter van de adviescommissie voor fiscale aangelegenheden, no. 227,'s-Gravenhage, 4 februari 1948 , p. 2; bron: Archief Ministerie van Financiën, dossier: Wetsontwerp Belastingheffing van overheidsbedrijven, 1954-1975. 


\section{Hoofdstuk 2}

\section{De prestatie-analyse van overbeidsbedrijven}

\subsection{Inleiding}

Nationale overheden toonden in de jaren veertig en vijftig geringe belangstelling voor de analyse van de prestaties van overheidsbedrijven. De redenen voor de geringe belangstelling waren onder andere de slechte bedrijfseconomische resultaten, de mogelijke bedreiging van bepaalde economische belangen (onder andere technologische ontwikkeling), en de problematiek van "verantwoording" versus "autonomie". ${ }^{66} \mathrm{De}$ aanhoudende slechte prestaties van veel overheidsbedrijven, de inefficiënte dienstverlening door de overheid en privatisering verklaren de huidige wetenschappelijke aandacht voor de analyse van de prestaties van en de theorievorming over overheidsbedrijven.

overheidsorganisaties behoren in aanmerking te komen voor een prestatie-analyse, als $z i j$ voldoen aan het reeds in het vorige hoofdstuk genoemde economische criterium van Popitz. Op grond van dit criterium kunnen overheidsbedrijven worden gedefinieerd als organisaties, in het bezit van of onder controle van publiekrechtelijke lichamen, waarvan de goederen en diensten ook door naar winst strevende particuliere ondernemingen tegen een vergoeding kunnen worden geleverd. Uit de definitie blijkt dat de eis om winst te realiseren, ontbreekt bij overheidsbedrijven. zij moeten echter wel voor dit fiscale doel geschikt zijn. Zo kunnen bijvoorbeeld staatsloterijen met behulp van het criterium van popitz worden geclassificeerd als overheidsbedrijven, omdat hun activiteiten ook kunnen worden uitgevoerd door naar winst strevende particuliere ondernemingen. ${ }^{67}$

De Belgische economen P. Pestieau, S. Perelman en $H$. Tulkens leverden een interessante bijdrage aan de theorievorming over overheidsbedrijven. $\mathrm{Zij}$ ontwikkelden een kwantitatieve prestatie-analyse en namen daarbij de doeleinden van het overheidsbedrijf over van de algemeen economische politiek. Hun onderzoek beperkt zich hoofdzakelijk tot het bepalen van efficiëntie als doelstelling. vanuit het perspectief van de economische theorie van de politieke besluitvorming ("public choice") kan daartegen te berde worden gebracht dut de doeleinden van het overheidsbedrijf blijken uit de verdeling en de aanwending van de publieke eigendomsrechten.

Een kwalitatieve prestatie-analyse breidt de kwantitatieve prestatie-analyse uit. Deze analyse tracht de kenbare doeleinden af te leiden uit het gedrag van de principalen, die beschikken over de publieke eigendomsrechten, en uit de bestudering van documenten. De kwalitatieve analyse bestaat uit het verrichten van case-studies en omvat drie fasen. De eerste fase betreft een analyse van de verdeling van de publieke eigendomsrechten in het overheidsbedrijf en wordt in het vervolg aangeduid als structuranalyse. De tweede fase bestaat uit het vaststellen van de kenbaar gemakte doeleinden 
met een documentenanalyse. De statutaire en/of wettelijke doeleinden worden daarbij beschouwd als een nevenvoorwaarde. In de derde fase worden de resultaten uit beide vorige fasen in verband gebracht met de rechtvaardiging van de prestaties door de bestuurders van het overheidsbedrijf en de reacties van de principalen hierop.

In dit hoofdstuk komen achtereenvolgens de kwantitatieve en de kwalitatieve prestatie-analyse aan de orde. Het vormt het theoretische kader voor de navolgende drie hoofdstukken met case-studies.

\subsection{Beleidsevaluatio en prestatie-analyse}

In Nederland besteden onderzoekers, actief op het terrein van wetenschappelijke beleidsevaluatie en de ontwikkeling van de beleidstheorie, aandacht aan de toepassing van combinaties van kwantitatieve en kwalitatieve evaluatiemethoden voor de bereiking van beleidsdoeleinden. Voor verschillende onderdelen van het onderzoek kunnen diverse methoden worden toegepast. Het is echter ook mogelijk te trachten een onderzoeksvraag te beantwoorden met een kwantitatieve en een kwalitatieve methode. Men duidt deze benadering ook wel aan met triangulatie. ${ }^{68}$

Het verschil tussen het in dit onderzoek toegepaste prestatie-onderzoek en de wetenschappelijke beleidsevaluatie is dat de laatst genoemde éen specifieke beleidsactiviteit evalueert. De prestatie-analyse achterhaalt meerdere beleidsactiviteiten en tracht deze te beoordelen.

\subsubsection{De kwantitatieve prestatie-analyse.}

De bovengenoemde Belgische economen verrichten kwantitatieve prestatie-analyses met de intentie de realisatie te meten van doeleinden afgeleid uit de algemeen economische politiek. ${ }^{69}$ $\mathrm{Zij}$ hanteren voor het meten van de prestaties parametrische en non-parametrische econometrische technieken. In dit proefschrift komt slechts één van de parametrische technieken aan de orde, namelijk de techniek van de kleinste kwadraten en de verschuiving van de regressielijn (in de Engelse literatuur staat deze techniek bekend als "displaced ordinary least squares", afgekort: DoLS).

De kwantitatieve prestatie-analyse vindt zijn oorsprong in het werk van M.J. Farrel. Hij introduceerde in 1957 een methode om efficiëntie te bepalen aan de hand van een uit warnemingsresultaten afgeleide empirische produktiefunctie. ${ }^{70}$ Sindsdien bestaan er verschillende varianten om de technische efficiëntie te bepalen. De techniek van de kleinste kwadraten leidt eerst uit de beschikbare data een produktiefunctie van het type Cobb-Douglas af. Vervolgens wordt een omhullende curve van produktiemogelijkheden geconstrueerd door de constante in de produktiefunctie te verhogen. De constante wordt verhoogd met de hoogste restterm, zodat tenminste één warneming zich bevindt op de produktiemogelijkhedencurve." De maximale restterm stamt af van het meest efficiënte overheidsbedrijf en is gelijk aan het verschil tussen de waargenomen en de voorspelde waarde van de produktie. 
De methode van efficiëntie-meting makt gebruik van een reeks vergelijkbare gegevens afkomstig van een verzameling overheidsbedrijven. Voor de analyse kan ook gebruik worden gemaakt van tijdreeksdata. Het probleem doet zich dan echter voor dat de gevolgen van technologische veranderingen of schaalfactoren en de consequenties van variërende technische inefficiëntie moeten worden gecontroleerd. ${ }^{72}$ Vaak neemt een overheidsbedrijf een monopoliepositie in, waardoor het niet mogelijk is over te gaan tot een vergelijking. Dit probleem kan worden opgelost met een intertemporele analyse van de bedrijfsprestaties. Een andere oplossing biedt het verrichten van international vergelijkend onderzoek.

Tulkens onderscheidt in het kwantitatieve prestatieonderzoek de volgende fasen: a. het expliciet specificeren van de aan het overheidsbedrijf toegekende doeleinden, b. het geven van een rechtvaardiging voor de geselecteerde doeleinden, $c$. het operationaliseren van doeleinden in waarneembare en meetbare indicatoren en $\mathrm{d}$. het ontwerpen van methoden om de geobserveerde waarden van de indicatoren te vergelijken met de waarden van de volledige realisatie van gelijke doeleinden. Elke fase brengt specifieke werkzaamheden met zich mee, waarvoor de bestaande literatuur slechts gedeeltelijk een uitkomst biedt. Hij wijst erop dat met name het ontwikkelen van indicatoren voor de doeleinden de nodige methodologische problemen met zich zal meebrengen. ook hij beperkt $\mathrm{zich}$ tot het meten van technische efficiëntie. ${ }^{73}$

Een vergelijkende prestatie-analyse behoort volgens Pestieau vooraf te gaan aan een besluit tot privatisering. Hij onderscheidt voor $\mathrm{zijn}$ prestatie-onderzoek vier categorieën doeleinden, namelijk efficiëntie, rechtvaardigheid, financieel evenwicht en macro-economische doeleinden. ${ }^{74}$

Efficiëntie betreft de aanwending en de allocatie van de produktiefactoren. Aan efficiëntie kunnen twee aspecten worden onderscheiden, namelijk technische en allocatieve efficiëntie. Technische efficiëntie behelst de transformatie van de produktiefactoren in consumptiegoederen. Allocatieve efficiëntie betreft de keuze van de prijzen van de produktiefactoren en de consumptiegoederen teneinde de winst te maximaliseren. Beide aspecten van efficiëntie hangen met elkaar samen. Aan de hand van figuur 2.1 illustreert Pestieau dit met een bedrijf dat één soort produktiefactor aanwendt om consumptiegoederen te produceren. ${ }^{75}$ 


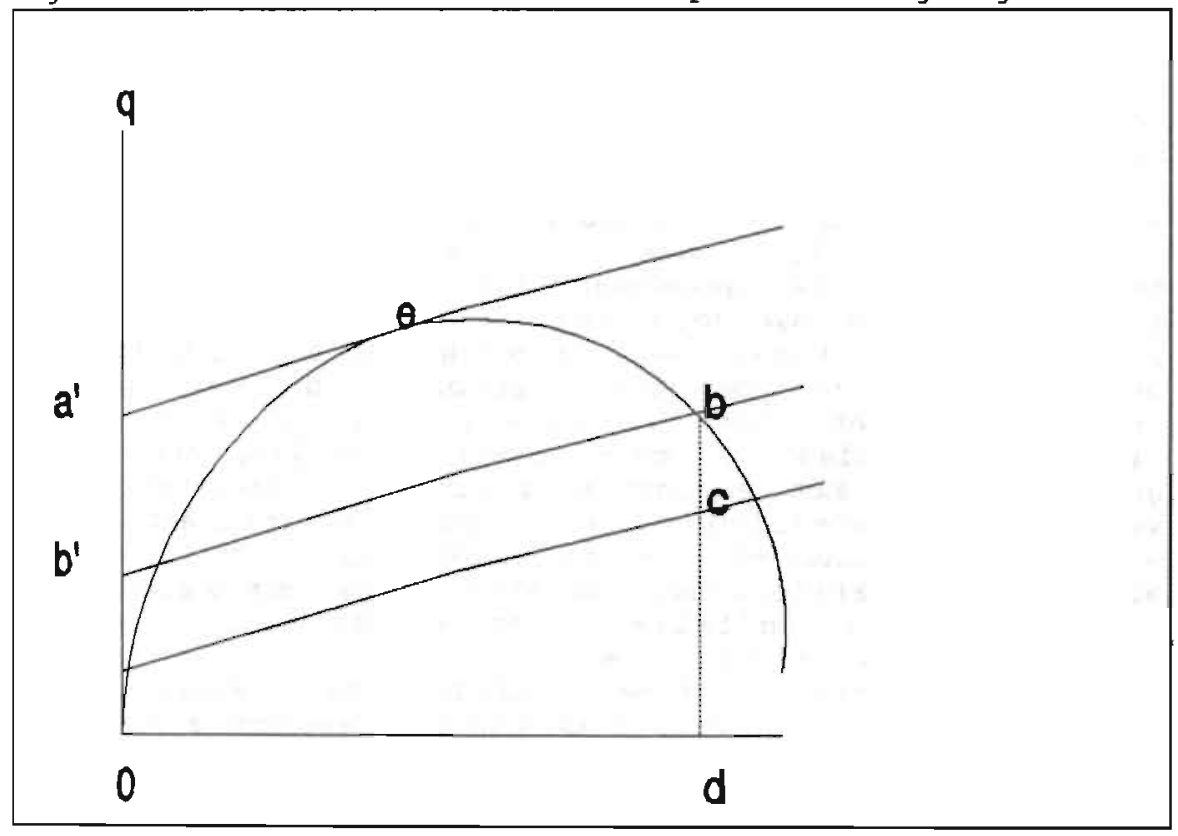

opmerking: De rechte lijnen zijn de zogenaamde isowinstlijnen. De vergelijking van de functie $Q=f\left(p_{1}\right.$, $\left.\mathrm{p}_{2}, \mathrm{~L}, \mathrm{w}^{*}\right)$ heeft de volgende structuur:

$$
Q=\frac{W^{\prime}}{-}+\frac{p_{2}}{p_{1}}+L
$$

Q. : het aantal eenheden consumptiegoederen.

W. : de constante winst.

$\mathrm{L} \quad$ : het aantal eenheden arbeid.

$\mathrm{p}_{1} \quad$ : de prijs van het consumptiegoed.

$p_{2} \quad$ : het loon.

De produktiemogelijkhedencurve in de bovenstaande figuur 2.1 omhult de combinaties van de produktiefactor arbeid en de consumptiegoederen. Punt B blijkt technisch efficiënter te zijn dan punt c. Immers in punt $B$ vervaardigt het overheidsbedrijf meer produkten bij dezelfde hoeveelheid arbeid. De ratio $C D / B D$ meet de mate van technische efficiëntie. De mate van allocatieve inefficiëntie wordt gemeten met de ratio $O B^{\prime} / O A^{\prime}$. Allocatieve efficiëntie wordt niet noodzakelijkerwijs in punt $B$ gerealiseerd. Ter bepaling hiervan dienen de relatieve prijzen bekend te zijn van de consumptiegoederen en de produktiefactor. Vervolgens moet worden gekeken naar het punt dat zowel technisch efficiënt is en de maximale winst verwezenlijkt. De nauwkeurigheid van de omhullende curve is afhankelijk van de omvang van de 
steekproef, de specificatie van de onderzochte relatie, de variabelen en de geldigheid van de toegepaste statistische methode. In figuur 2.1 geven de parallelle iso-winstlijnen de relatieve prijzen weer. In punt E raakt de iso-winstlijn $A^{\prime}$ de technisch meest efficiënte combinatie van produktiefactoren en consumptiegoederen. ${ }^{76}$ De prijzen geven de bereidheid weer voor een additionele hoeveelheid eindprodukt te betalen of een extra hoeveelheid arbeidsinspanning te leveren.

Als doelstelling heeft rechtvaardigheid bij pestieau betrekking op de gevolgen van het werkgelegenheids- en prijsbeleid van overheidsbedrijven op de verdeling van het reële inkomen. Financieel evenwicht zou eigenlijk deel uit moeten maken van de macro-economische doelstellingen. De behandeling van het financiële evenwicht vindt echter afzonderlijk plaats, omdat overheidsbedrijven vaak worden geconfronteerd met exploitatietekorten. Het probleem hierbij vormt de vaststelling of het tekort het resultaat is van slecht management of van te hoge vaste kosten. De macroeconomische doelstellingen omvatten volgens hem problemen als werkloosheid, inflatie, onevenwichtigheden op de betalingsbalans en stagnatie. ${ }^{n}$

Pestieau stelt dat deze multi-doeleinden benadering enkele problemen bevat. Ten eerste kunnen de bovengenoemde doeleinden niet zonder conflict worden gerealiseerd. In het bijzonder bestaan er spanningen tussen allocatieve efficiëntie en de non-allocatieve doeleinden. Om een algehele prestatie te garanderen, moet er een evenwicht tussen beide categorieën van doeleinden worden gerealiseerd. De doelstelling van technische efficiëntie belemmert daarentegen niet de realisatie van de andere doeleinden. Ten tweede kunnen afwegingen tussen allocatieve en non-allocatieve doeleinden gevolgen hebben voor het toezicht op overheidsbedrijven. Een bedrijf kan inefficiënt zijn, omdat het non-allocatieve doeleinden of eigen doeleinden nastreeft. Deze twee oorzaken van inefficiëntie vormen vaak de basis voor de argumentatie tot privatisering of deregulering. Ten derde bestaat het probleem van de prestatie-evaluatie, dat wil zeggen het meten van de mate van realisatie van de genoemde doeleinden. Hij schetst de constructie van een multi-criteria variabele. Theoretisch zou voor iedere doelsteliing een indicator moeten worden ontworpen. De multi-criteria variabele bestaat uit een samenvoeging van de afzonderlijke indicatoren. Pestieau acht de ontwikkeling van een dergelijke variabele gegeven de huidige stand van zaken in de economische wetenschappen en de moeilijke beschikbaarheid van gegevens niet reëel. Het is mogelijk de efficiëntie te meten, terwijl de bepaling van de andere doeleinden slechts ad hoc kan geschieden. ${ }^{78}$

J.G. Backhaus plaatst bij het kwantitatieve prestatieonderzoek een aantal kanttekeningen ${ }^{79}$ :

Ten eerste kent de kwantitatieve prestatie-analyse algemeen economische doeleinden toe an overheidsbedrijven. Alle overheidsbedrijven zouden dezelfde doeleinden nastreven. De overheid bestaat echter uit diverse organisaties, die in verschillende mate uiteenlopende doeleinden realiseren. Arbeidsverdeling tussen overheidsbedrijven is dan ook niet 
uitgesloten. Het overheidsbedrijf stelt een kabinet in staat te interveniëren op de markt en resultaten te boeken, die anders niet kunnen worden behaald. Gegeven de diversiteit aan overheidsbedrijven is het vrijwel uitgesloten algemeen economische doeleinden toe te kennen, zeker niet a priori. voor elk overheidsbedrijf moeten de doeleinden steeds weer empirisch worden vastgesteld.

Ten tweede is efficiëntie bijna nooit een beleidsdoelstelling van een overheidsbedrijf. Het is niet waarschijnlijk een overheidsbedrijf an te treffen met een produktiefunctie identiek aan die van een particuliere onderneming. Efficiëntie vormt een voorwaarde voor de realisatie van beleidsdoeleinden. Kabinetten kunnen overheidsbedrijven tot op zekere hoogte hanteren om doeleinden op korte termijn te realiseren, waarvan sommige geen onderwerp van publiek debat zijn. Verwezenlijkt een overheidsbedrijf zijn wettelijke en statutaire doeleinden op een politiek aanvaardbaar niveau, dan kan over de beleidsvrijheid worden beschikt voor het realiseren van korte termijn doeleinden. Een overheidsbedrijf wordt "efficiënt bestuurd" als de mogelijkheden tot beleidsvrijheid efficiënt worden aangewend. De efficiëntie van een overheidsbedrijf kan worden geformuleerd in paretiaanse $\mathrm{z}$ in: geen enkele doelstelling kan worden gerealiseerd zonder éen of meer (expliciete of impliciete) doeleinden te schaden. De beoordeling van de prestaties van zo'n bedrijf geschiedt in termen van de realisatie van deze doeleinden, gegeven de te vervullen statutaire en wettelijke restricties.

Ten derde geven de prestatie-indicatoren niet de bedoelingen om een overheidsbedrijf te beheren weer. In beginsel kan elk kabinet een overheidsbedrijf als een particuliere onderneming besturen. Dit beginsel kent echter zijn uitzonderingen. Kabinetten verwerven slechts tot de volgende verkiezingen het recht te beschikken over het overheidsbedrijf. Als een kabinet meerdere termijnen aanblijft dan behoort het verdwijnen van de verschillen tussen het particuliere en het overheidsbedrijf tot de mogelijkheden en kan de produktiefunctie zonder veel moeilijkheden worden bepaald. Overheidsbedrijven gericht op het maximeren van winst als inkomstenbron zijn het meest geschikt voor de kwantitatieve prestatie-analyse.

Enige uitzonderingen daargelaten streven kabinetten zelden naar het verminderen van de verschillen tussen het particuliere en het overheidsbedrijf. Deze keuze onthult een voorkeur. Beleidsvrijheid bij overheidsbedrijven is belangrijker dan het alternatief van het verwerven van inkomsten. De gederfde inkomsten vormen een aanwijzing voor de beoordeling van de prestaties van een overheidsbedrijf.

Ten vierde moet privatisering worden gezien als bijzondere vorm van ondernemerschap door de overheid. De kwantitatieve prestatie-analyse kan het verschijnsel privatisering niet verklaren. Privatisering wordt in de praktijk niet voorafgegaan door een kwantitatieve prestatie-analyse. De kwalitatieve prestatie-analyse biedt daarentegen een verklaring voor de privatisering van overheidsbedrijven. 
Vanuit dit perspectief beschikt het kabinet niet over de gehele verzameling van eigendomsrechten in het overheidsbedrijf. Het kan slechts tijdens zijn kabinetsperiode beschikken over het recht het bedrijf aan te wenden (usus fructus). In een twee-partijenstelsel vindt na een verkiezingsnederlaag de overdracht plaats van het overheidsbedrijf aan de politieke tegenstander. Er bestaat slechts één manier om dit te voorkomen, namelijk privatisering. De verkoop van een overheidsbedrijf leidt ertoe dat het kabinet de beschikking krijgt over de toekomstige inkomsten.

Ten vijfde vormen de prestaties van een overheidsbedrijf niet de matstaf voor de prestaties van een ander overheidsbedrijf. overheidsbedrijven zijn immers economische beleidsinstrumenten, waarvan de doelstellingenfuncties slechts kunnen worden vastgesteld na een analyse van de verdeling van de publieke eigendomsrechten en de kenbaar gemakte doeleinden van de politieke eigenaren. Een prestatie-analyse is niet mogelijk zonder een theorie, die de politieke prestaties van deze ondernemingen verklaart. Prestatie-criteria zijn niet af te leiden uit het debat binnen de economische wetenschappen of uit de observatie van particuliere ondernemingen in dezelfde bedrijfstak. De veelvoud aan doeleinden leidt tot het derven van inkomsten. Het verlies aan inkomsten voor de overheid verklaart het belang van prestatie-analyses. Deze analyses hebben slechts betekenis als zij zijn gebaseerd op een reële theorie van het publieke ondernemerschap. Een dergelijke theorie vormt de voorwaarde voor de afleiding van prestatiecriteria ten behoeve van de prestatie-analyse.

De bovenstaande kanttekeningen bij de kwantitatieve prestatieanalyse hebben geleid tot de ontwikkeling van een kwalitatieve prestatie-analyse van het overheidsbedrijf, die de doeleinden afleidt uit de verdeling van de publieke eigendomsrechten en uit een analyse van documenten.

\subsubsection{De kwalitatieve prestatie-analyse}

De kwalitatieve prestatie-analyse sluit aan bij de economische theorie van de eigendomsrechten van A. Alchian en H. Demsetz. Een onderneming kenmerkt $z$ ich volgens hen door de produktie in teamverband en de centrale positie van één belanghebbende bij de contractering van de produktiefactoren.

De bestaansreden van een onderneming is de produktie in teamverband, waarbij aan twee noodzakelijke voorwarden moet zijn voldaan. Ten eerste moet de produktie van het team groter zijn dan de som van de produktieresultaten van de afzonderlijke produktiefactoren. De bepaling van de marginale produktiviteit voor de beloning van de produktiefactoren brengt echter kosten met $z$ ich mee. De moeilijkheid om de marginale produktiviteit vast te stellen, kan leden van het team stimuleren $\mathrm{zich}$ minder in te zetten. Ten tweede is het onder dergelijke omstandigheden efficiënter de marginale produktiviteit te bepalen door het gedrag van de afzonderlijke produktiefactoren te observeren en te specificeren. De 
belanghebbende bij alle contracten oefent toezicht uit op de produktiefactoren en baseert zijn motivatie op het recht aanspraak te mogen maken op de winst. ${ }^{80}$ De principaal verkrijgt het recht:

(a) toezicht uit te oefenen op de produktiefactoren en de produktieresultaten,

(b) de samenstelling van het team van producenten te bepalen,

(c) om betrokken te zijn bij alle contracten over de produktiefactoren,

(d) aanspraak te maken op de winst, en

(e) tot overdracht van de eigendomsrechten. ${ }^{81}$

Alchian en Demsetz duiden een principaal met deze verzameling van rechten aan als klassiek kapitalistische ondernemer, indien aan de twee bovengenoemde voorwaarden is voldaan. Deze ondernemer is tegelijkertijd eigenaar en werkgever. ${ }^{82}$ De verdeling van de verzameling van rechten leidt tot het ontstaan van verschillende soorten van ondernemingen. Politieke voorwaarden kunnen de keuze van het type van economische organisatie beperken. Beëindiging van het particuliere recht te beschikken over de produktierniddelen verandert de klassiek kapitalistische onderneming in een socialistische onderneming. ${ }^{8}$

De klassiek kapitalistische ondernemer verloor in de loop van deze eeuw terrein aan andere vormen van economische organisatie, zoals de naamloze vennootschap, het staatsbedrijf, het overheidsbedrijf in nv-vorm, de besloten vennootschap en het ministerie. De verdeling van de eigendomsrechten in het overheidsbedrijf verschilt van de verdeling van de eigendomsrechten in de andere vormen van economische organisatie. Het Nederlandse overheidsbedrijf kan de vorm aannemen van een staatsbedrijf (de staatsmijnen), een naamloze vennootschap (de NV Nederlandse Spoorwegen), een stichting (de Nederlandse Herstructureringsmaatschappij) of een zelfstandige bestuursorganisatie (de Nederlandse Centrale organisatie voor toegepast-natuurwetenschappelijk onderzoek).

Het verschil tussen publieke en particuliere eigendomsrechten betreft de hoogte van de kosten, verbonden aan de overdracht van deze rechten. De kiezer-belastingbetaler kan de samenstelling van het vermogen van de overheid niet wijzigen. Hij kan slechts tegen kosten van constitutie veranderen. De overdracht van de publieke eigendomsrechten vindt slechts plaats bij kabinetswisselingen of bij de verdeling ervan over de politieke partijen, overeenkomstig de verkiezingsuitslagen. overheidsbedrijven ondervinden geen bedreiging van vijandelijke overnemingen door particuliere ondernemingen. De kosten, verbonden aan de overdracht van de publieke eigendomsrechten en de afwezigheid van het gevaar van overnames, beïnloeden de mate van technische en allocatieve efficiëntie van overheidsbedrijven. De gevolgen van de hoge kosten verbonden aan de overdracht van de publieke eigendomsrechten en de afwezigheid van de dreiging van overnames zijn dat: 
(1) de belastingbetaler zijn kennis niet ter beschikking stelt voor het besturen van het overheidsbedrijf,

(2) de mogelijkheid niet bestaat om de contante waarde van toekomstige baten (of verliezen) tot uitdrukking te brengen,

(3) de publieke eigendomsrechten minder duidelijk zijn dan de particuliere eigendomsrechten, en

(4) de markt geen reden heeft om toezicht en druk uit te oefenen op de directie van het overheidsbedrijf om efficiënter te functioneren. ${ }^{84}$

De interpretatie dat er voor de particuliere markt geen reden bestaat toezicht en druk uit te oefenen op het overheidsbedrijf behoeft enige nuancering. Ten eerste oefenen institutionele beleggers toezicht uit op de financiële kengetallen als een overheidsbedrijf over toestemming beschikt om een beroep te doen op de kapitaalmarkt. Zij kunnen van het desbetreffende overheidsbedrijf zekerheid eisen over het nakomen van financiële verplichtingen. Een dergelijke situatie lag ten grondslag aan de aanvaarding van de wet tot het tijdelijk verlenen van financiële steun aan de NV Nederlandse Spoorwegen van 1968. Ten tweede bieden corporatieve organisaties op bedrijfstakniveau werknemers- en werkgeversorganisaties de mogelijkheid tot het uitoefenen van markttoezicht op overheidsbedrijven. Het toezicht wordt mogelijk gemaakt door de verplichting informatie te verstrekken over de economische gang van zaken. Daarnaast beschikt de overheid via de participatie van het overheidsbedrijf in een corporatieve organisatie over een instrument om invloed uit te oefenen op particuliere ondernemingen en werknemersorganisaties. Een voorbeeld van zo'n corporatieve organisatie is de zogenaamde Mijnindustrieraad (afgekort: MIR), die functioneerde van 1945 tot en met 1976. De directie van de Staatsmijnen deelde in 1957 mee dat zijn vertegenwoordigers in deze organisatie handelden als representanten van de Gezamenlijke steenkolenmijnen in Limburg (GSL), een belangenorganisatie van de Iimburgse mijnbouwondernemingen. ${ }^{55}$ Deze mededeling staat op gespannen voet met het beginsel van loyaliteit aan het beleid van de minister, dat ten grondslag ligt aan de benoeming van directieleden van overheidsbedrijven (zie voor een nadere behandeling van loyaliteit aan het beleid paragraaf 6.1 van dit hoofdstuk). De mijnbouwondernemingen waren verplicht informatie te verstrekken over de economische gang van zaken. De betrokken werknemersorganisaties en bedrijven droegen bij in de kosten van de corporatieve organisatie. 


\section{3 structuuranalyge}

De benadering van Alchian en Demsetz biedt de gelegenheid een analyse te verrichten van de structuur van het overheidsbedrijf. De analyse van de verdeling van de publieke eigendomsrechten over de betrokkenen makkt het mogelijk doeleinden vast te stellen. De structuuranalyse bestaat uit de volgende vragen:

(1) Wie houdt toezicht op het aankoopbeleid en de prestaties van de produktiefactoren?

(2) Wie houdt toezicht op de produktieresultaten en de externaliteiten?

(3) Wie houdt toezicht op het produktieproces?

(4) Wie houdt toezicht op de samenstelling en de omvang van het team van producenten? ${ }^{86}$

(5) Wie makt aanspraak op de winst?

De structuuranalyse benadrukt het toezicht op het overheidsbedrijf op diverse niveaus. Toezicht en beheersing van het bedrijf brengen transactiekosten met zich mee. Voor een volksvertegenwoordiging kunnen de kosten voor het verwerven van informatie over de activiteiten van overheidsbedrijven de baten, verbonden aan de verworven informatie, overschrijden. Een methode om de kosten verbonden aan het toezicht op en de beheersing van overheidsbedrijven te reduceren, is een rekenkamer de bevoegdheid te verlenen toezicht uit te oefenen op de rechtmatigheid en de doelmatigheid van de activiteiten. De inspanning van het toezicht op het produktieproces van het overheidsbedrijf kan dan elders worden aangewend. De klassiek kapitalistische ondernemer draagt deze kosten zelf. De kosten van het toezicht op het overheidsbedrijf zijn gespreid over de begrotingen van de betrokken ambtelijke organisaties. Het feit dat de Nederlandse overheid de kosten van het toezicht en de beheersing voor haar rekening nam, betekende nog geen politieke aanvaarding daarvan. Minister van Financiën Lieftinck zag 2 ich in 1948 geplaatst voor het vraagstuk van de beheerskosten. Hij verzocht de Adviescommissie voor fiscale aangelegenheden om advies over de vraag of openbare lichamen een bijdrage in de algemene beheerskosten in rekening konden brengen. Tot de beheerskosten behoorden onder andere de salarissen van de betrokken wethouders, gedeputeerden en ambtenaren. Deze commissie adviseerde de algemene kosten in rekening te brengen aan het overheidsbedrijf, voor zover dat wettelijk was geregeld. ${ }^{87}$

De beantwoording van bovengenoemde vragen leidt tot de identificatie van verschillende categorieën agenten, zoals kabinetten, ministers, leden van de Staten-Generaal, Álgemene Rekenkamer, directies en vakorganisaties. $\mathrm{zij}$ die beschikken over de publieke eigendomsrechten in het overheidsbedrijf, worden aangeduid als politieke eigenaren. Deze zijn in staat het economische besluitvormingsproces te beinvloeden, met andere woorden achter de identificatie van de politieke eigenaren schuilt een uitgebreide hoeveelheid economische theorie. $\mathrm{zij}$ biedt de mogelijkheid het beleid van de politieke 
eigenaren met betrekking tot overheidsbedrijven te evalueren.

\subsubsection{Toezicht op het aankoopbeleid en de prestaties van de produktiefactoren.}

De begroting en de fiscale wetgeving behoorden tot de instrumenten van de principalen om toezicht en invloed uit te oefenen op het aankoopbeleid van overheidsbedrijven. Het ontbreken van een uniforme wettelijke regeling over de vaststelling van de begrotingen van overheidsbedrijven concentreerde het toezicht op het aankoopbeleid bij verschillende principalen. De staten-Generaal stelden de begroting van het staatsbedrijf vast en de betrokken ministers droegen de politieke verantwoordelijkheid voor de uitvoering ervan. Bij de NV Nederlandse Spoorwegen beschikte de Raad van Commissarissen over het recht de begroting vast te stellen. De Minister van Financiën en de vakministers hadden niet het recht om de exploitatie- en kapitaalbegroting bij de Nederlandse Centrale organisatie voor toegepastnatuurwetenschappelijk onderzoek vast te stellen.

overheidsbedrijven intervenieerden met hun aankoopbeleid in de markt. De Comptabiliteitswet van 1927 bevatte de bepaling dat alle niet in eigen beheer uit te voeren werken van meer dan 2500 gulden in aanmerking kwamen voor openbare aanbesteding. ${ }^{8}$ De plaatsing van de opdracht vond plaats bij de inschrijver met het laagste bod. Het aankoopbeleid van staatsbedrijven stimuleerde op deze manier de mededinging. De ministeriële instructies voor staatsbedrijven bevatten een soortgelijke bepaling. Elk staatsbedrijf beschikte ter implementatie van de ministeriële instructie over zijn eigen stelsel van machtigingen voor aankopen. Regeringen hebben er belang bij dat overheidsbedrijven hun orders plaatsen bij de nationale toeleveringsbedrijven, in plaats van het materiaal in het buitenland aan te kopen of zelf te produceren. ${ }^{89}$ Dit laatste staat bekend als verticale integratie en komt later in deze paragraaf aan de orde. De redenen voor aanbesteding bij nationale toeleveringsbedrijven zijn bijvoorbeeld het behoud van de werkgelegenheid, het bevorderen van inkomensherverdeling, het stimuleren van innovatie en het verminderen van de afhankelijkheid van het buitenland. De methoden ter beinvloeding van het aankoopbeleid bestaan onder andere uit met redenen omklede verzoeken om een ministeriële machtiging voor het plaatsen van een order in het buitenland en uit a ankopverplichtingen bij nationale toeleveringsbedrijven.

De marktrelatie tussen het overheidsbedrijf en het toeleveringsbedrijf kan de vorm aannemen van een bilateraal monopolie. Het overheidsbedrijf treedt in deze relatie op als enige vrager (in de economische literatuur aangeduid als monopsonist). Beide ondernemingen onderhandelen over de prijs en de hoeveelheid investeringsgoederen. Westeuropese spoorwegondernemingen plaatsen hun orders hoofdzakelijk bij de nationale wagonindustrie. In Nederland benaderde de relatie tussen de NV Nederlandse Spoorwegen en de fabriek WerkspoorUtrecht het bilaterale monopolie.

Duidelijkheid over het recht toezicht uit te oefenen op de 
aankoop van materieel door het overheidsbedrijf voorkomt belangenconflicten op ministerieel niveau over de financiële compensatie van het prijsverschil met het buitenland en autonoom optreden van de directie van overheidsbedrijven. De mate van ministerieel toezicht bepaalt de vrijheid van de directie van het overheidsbedrijf om een buitenlandse prijsbreker aan te wenden met de bedoeling de prijsvorming van nationale toeleveringsbedrijven te beinvloeden. Figuur 2.2 toont een grafische variant van het bilaterale onderhandelingsproces tussen het overheidsbedrijf en het toeleveringsbedrijf, zoals deze wordt beschreven en geilliustreerd door R. Rees. ${ }^{90}$

Figuur 2.2 Bilateraal monopolie

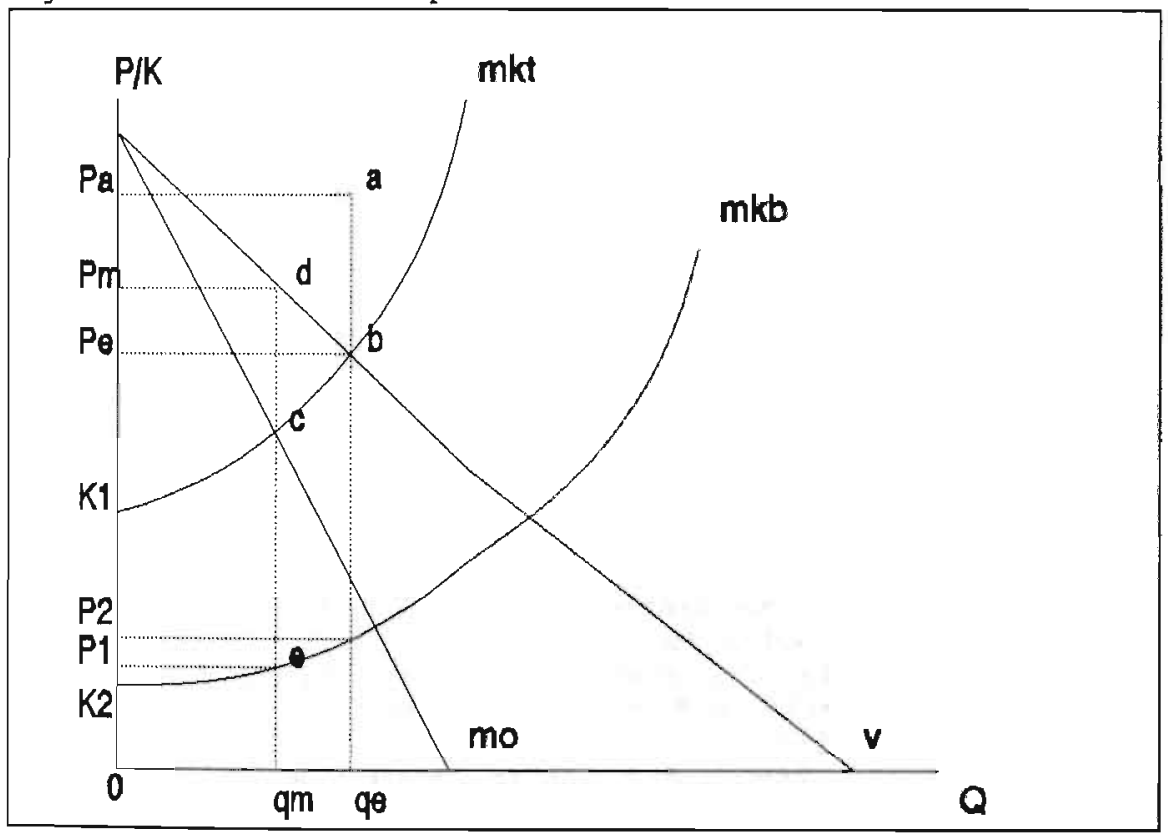

opmerkingen: mkt : marginale kostencurve toeleveringsbedrijf mkb : marginale kostencurve buitenland

$\mathrm{v}$ : vraagcurve overheidsbedrijf

mo : marginale opbrengsten

q : investeringsgoed

$k$ : kosten

p : prijs

Uit de bovenstaande figuur 2.2 blijkt dat er sprake is van een efficiënt produktieniveau bij de produktie van hoeveelheid $q_{0}$ tegen de prijs $P_{c}$. De marginale sociale baten, weergegeven door de vraagcurve $v_{\text {, }}$ zijn hier gelijk aan de marginale kosten van het binnenlandse toeleveringsbedrijf. Bij een openbare aanbesteding zal de directie van het overheidsbedrijf in het kader van haar investeringsplan de geplande hoeveelheid $q_{\text {e }}$ aankopen bij het buitenlandse toeleveringsbedrijf tegen prijs 
$P_{2}$. In het geval van een aankoopverplichting bij het binnenlandse toeleveringsbedrijf resulteert uit de gelijkheid van de marginale kosten en de marginale opbrengsten de winstmaximaliserende prijs $P_{m}$. Het overheidsbedrijf prefereert uit overwegingen van onderhandelingsstrategie de prijs Pe. De prijs $P_{c}$ wordt de marginale opbrengst voor het binnenlandse toeleveringsbedrijf. De maximalisatie van de winst vindt plaats in punt $b$ tegen hoeveelheid $q_{c}$. Bij een prijs lager dan $\mathrm{Pe}$ lijdt het binnenlandse toeleveringsbedrijf bij de produktie van de hoeveelheid ge verlies. Dit is in strijd met het doel van een aankoopverplichting, namelijk de continuiteit van het toeleveringsbedrijf te waarborgen.

Bij prijs $P_{c}$ en hoeveelheid $q_{c}$ kan volgens Rees het monopolistische toeleveringsbedrijf van mening zijn dat het een lagere winst realiseert, dan het eigenlijk zou moeten behalen. Hij veronderstelt dat het overheidsbedrijf om deze reden de hoeveelheid $q_{c}$ wil aankopen en onderhandelen over de prijs. Het toeleveringsbedrijf zou nu zijn winstdoelstelling kunnen behalen door een prijs hoger dan $P_{\varepsilon}$ na te streven. Het toeleveringsbedrijf zou bijvoorbeeld de prijs $P_{\text {, kunnen }}$ realiseren in het onderhandelingsproces. Onder deze omstandigheden is het voor het overheidsbedrijf verstandig

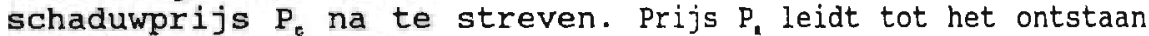
van een tekort en brengt een inkomensoverdracht met zich mee van de overheid naar het toeleveringsbedrijf. ${ }^{91}$

Het prijsverschil tussen het binnenlandse toeleveringsbedrijf en het buitenlandse bedrijf vormt een bedrijfsvreende last voor het overheidsbedrijf. Besluit een kabinet tot compensatie van een bedrijfsvreemde last ten laste van de begroting, dan is $\mathrm{q}_{m}\left(\mathrm{P}_{\mathrm{m}}-\mathrm{P}_{1}\right)$ het te compenseren bedrag bij een monopolistische prijsstelling. Uitgaande van schaduwprijs $P_{e}$ en de daarbij behorende hoeveelheid $Q_{e}$ bedraagt de te vergoeden bedrijfsvreemde last $g_{e}\left(P_{c}-P_{2}\right)$. De uiteindelijk te compenseren last resulteert uit een onderhandelingsproces tussen het kabinet, het overheidsbedrijf en het binnenlandse toeleveringsbedrijf.

De plaatsing van orders voor investeringsgoederen bij de duurclere nationale toeleveringsbedrijven leidt tot een daling van de rentabiliteit (winstderving) van het overheidsbedrijf, ten gevolge van een opwaartse verschuiving van de gemiddelde totale kostencurve. De toename van de kosten voor het overheidsbedrijf hebben volgens V.V. Ramanadham tot gevolg dat: a. de prijzen toenemen, b. de prijzen toenemen, maar de lonen dalen, $c$. de prijzen en de lonen constant blijven, maar de dividenden dalen, $d$. de prijzen, lonen en dividenden niet veranderen, maar de winstinhouding, vermindert, en $d$. de overheid bijdraagt aan het exploitatietekort door het prijsverschil met het buitenland te vergoeden als bedrijfsvreemde last. Op lange termijn kunnen de kosten leiden tot een hogere prijs van de eindprodukten van het overheidsbedrijf. De prijselasticiteit van het eindprodukt bepaalt hoeveel de vraag zal dalen en in welke mate de groei van de onderneming zal worden belemmerd. Consumenten, werknemers en de overheid als investeerder verwerven minder baten. De vraag of het hier om een aanvaardbare opoffering van 
baten gaat ten behoeve van de toeleveringsindustrie, zou volgens Ramanadham deel uit moeten maken van de beleidsoverwegingen. ${ }^{92}$

Een oplossing voor de problemen bij een bilateraal monopolie biedt volgens A. Koutsoyiannis de verticale integratie van het toeleveringsbedrijf in het monopsonistische bedrijf. ${ }^{93}$ voorwaarde voor integratie vormt overeenstemming over de waarde van het toeleveringsbedrijf. Bij de directie van de NV Nederlandse Spoorwegen ging de voorkeur uit naar een integratie in de vorm van een "skeleton-unit" met een beperkte seriebouw (zie voor een verdere behandeling van dit onderwerp ook hoofdstuk 4 paragraaf 4.4$).{ }^{94}$ Besluit het overheidsbedrijf tot verticale integratie dan komt de prijs $p^{e}$ tot stand met hoeveelheid $q_{c}$. Blijft verticale integratie uit, dan ontstaat er een welvaartsverlies. Bij een keuze voor de prijsstelling van het monopolistische toeleveringsbedrijf bestaat het nettowelvaartsverlies uit de bestanddelen bcd en $P_{1} K_{1} c e$. Het laatste bestanddeel is het verschil tussen de compensatie voor de bedrijfsvreemde kosten ten laste van de overheidsbegroting $\left(P_{1} P_{m} d e\right)$ en de overwinst van het toeleveringsbedrijf $\left(K_{1} P_{m} d c\right)$.

De aanbesteding resulteert uit een besluit om de produktiecapaciteit in stand te houden of uit te breiden. De uitbreiding van de capaciteit bij een gegeven vraag tracht een produktie van het overheidsbedrijf tegen de laagste kosten te realiseren. Het besluit tot investeren en de bezetting van de capaciteit dienen op elkaar te zijn afgestemd. De vraag is een functie van de prijs. De capaciteit en de bezettingsgraad ervan moeten in dat geval eveneens worden afgestemd op de prijs. C.B. Blankart stelt dat bij deze afstemming de marginale kosten op de korte en op de lange termijn een uitkomst bieden. De korte termijn marginale kosten (kmk) ontstaan als bij een gegeven produktiecapaciteit in een periode de produktie met één eenheid wordt uitgebreid. De marginale kosten op lange termijn (lmk) betreffen de (periode) investerings- en bedrijfskosten bij een uitbreiding van de capaciteit teneinde de produktie met één extra eenheid te laten toenemen. Blankart wijst erop dat de marginale kostenregel zowel een richtlijn bevat voor de prijzen als een richtlijn voor de investeringen. De richtlijn voor de prijzen betreft een prijsstelling gelijk aan de marginale kosten op korte termijn. De investeringsrichtlijn behelst de gelijkheid van de marginale kosten op de korte en de lange termijn. De uitbreiding van de produktiecapaciteit vindt doorgang, totdat de kosten hiervan gelijk zijn aan de kosten van de bezetting van de capaciteit om een extra-eenheid produkt te vervaardigen. Dit punt is het snijpunt van de marginale kosten op de korte termijn en de marginale kosten op de lange termijn. Er bestaan echter veel van deze snijpunten. De te produceren hoeveelheid is daarmee nog niet bepaald. Van een optimale situatie is sprake als de marginale capaciteits- en bezettingskosten gelijk zijn aan de prijs. ${ }^{95}$

Fiscale wetgeving beïnloedt de liquiditeitspositie van overheidsbedrijven en remt ongebreidelde investeringen af. ${ }^{96}$ Fiscale vrijstelling betekent het prijsgeven van de mogelijkheden tot toezicht en beinvloeding van de aankopen. Het leidt tot een liquiditeitsvoorsprong, die 
uitbreidingsinvesteringen stimuleert. De particuliere ondernemingen kunnen zich dergelijke investeringen niet permitteren. De uitbreidingsinvesteringen ten gevolge van de vrijstelling kunnen het conjuncturbeleid van een kabinet doorkruisen.

\subsubsection{Toezicht op de produktieresultaten.}

De beloning moet gerelateerd zijn aan de produktieve prestaties. Beloningsstructuren zijn volgens simon slechts effectief als de individuele bijdrage aan de produktie effectief kan worden vastgesteld. Als de indicatoren niet de juiste variabelen meten of niet in staat zijn de individuele bijdragen te meten, dan zijn de beloningssystemen inefficiënt en zelfs contra-produktief. ${ }^{97}$ Het meten van onjuiste produktievariabelen of de manipulatie ervan brengt het gevaar met $z i c h$ mee van aanhoudende exploitatietekorten bij een overheidsbedrijf. Daarnaast is het ook niet uitgesloten dat sommige werknemers trachten te profiteren van de grotere arbeidsinspanning van de andere werknemers.

\subsubsection{Toezicht op de externe effecten.}

Externe effecten vormen de bijkomstige gevolgen van de produktie van goederen en diensten. Deze hebben een positief of negatief effect voor derden, producenten en /of consumenten. Externe effecten zijn van technische of financielle aard. Technische externe effecten ten gevolge van de produktie van een consumptiegoed beïnvloeden de produktie of consumptie door derden. Met andere woorden deze externe effecten maken deel uit van de produktie- of nutsfunctie. Financielle externe effecten vloeien voort uit de verandering van de vraag- en aanbodverhoudingen. Een duidelijke scheiding van technische en financiële externe effecten blijkt in de praktijk niet altijd mogelijk. ${ }^{48}$

De beheersing van externe effecten vormt één van de bestaansredenen van overheidsbedrijven, zelfs als er sprake is van een gering bedrijfseconomisch rendement. Het geringe rendement duidt dan niet op het bestaan van technische inefficiëntie of hogere kosten, mar op positieve externe effecten. 99 voor de beheersing van de negatieve gevolgen van de produktie door overheidsbedrijven bestaan drie methoden, namelijk de verrekening in de kostprijzen, de heffing van een pigoviaanse belasting en de verhandeling van het externe effect met behulp van de eigendomsrechten. ${ }^{100}$ subsidies aan overheidsbedrijven vormen een instrument om de positieve externe effecten, verbonden aan de produktie, te bevorderen. overheidsbedrijven zijn bijvoorbeeld betrokken bij externaliteiten, zoals de vernietiging van milieukapitaal, milieuverontreiniging, economische groei, extra-investeringen in de infrastructuur, verspreiding van wetenschappelijke kennis, en beinvloeding van de rentevoet op de kapitaalmarkt.

Het milieubeleid van de overheid heeft tot taak maatregelen te nemen om de milieuverontreiniging te reduceren en de allocatie van produktiefactoren te verbeteren. De prijzen dienen daartoe de relatieve scharste van de milieugoederen 
weer te geven. Een kabinet ziet zich voor een dilemma geplaatst als het beschikt over de publieke eigendomsrechten in een overheidsbedrijf. Voorbeelden van overheidsbedrijven betrokken bij milieuverontreiniging zijn elektriciteitsbedrijven en luchtvaartmaatschappijen. Een dergelijk bedrijf kan een machtspositie innemen tegenover het kabinet en weigeren milieubepalingen na te leven. Aharoni vermeldt het verzet van het canadese elektriciteitsbedrijf ontario Hydro tegen het toezicht op luchtverontreining teneinde het ontstaan van zure regen te verminderen. ${ }^{101}$ In de extractieve sector draagt een overheidsbedrijf mede de verantwoording voor de vernietiging van milieukapitaal en milieuverontreiniging. De bodem maakt deel uit van het milieukapitaal en bevat een uitputbare voorraad delfstoffen. De bodem is in dit geval een duurzaam produktiemiddel, waarop moet worden afgeschreven. ${ }^{102}$ Het achterwege laten van afschrijvingen op de bodem als produktiemiddel bij een overheidsbedrijf in de extractieve sector leidt tot een vertekening van de presentatie van de winstcijfers.

Overheidsbedrijven in de extractieve- en de vervoerssector vertonen vaak een hoog kapitaalcoëfficiënt. Deze coëfficiënt is het quotiënt van de totale kapitaalinzet en de totale produktie, gemeten als waardebedragen. ${ }^{103}$ De afschrijvingen compenseren een vermindering van de technische capaciteit of een waardedaling van het vermogen. Kapitaalgoederen met een lange levensduur bieden de mogelijkheid afschrijvingsgelden aan te wenden voor een uitbreiding van de capaciteit. De voorwaarden daarvoor zijn de behoefte aan een uitbreiding van de capaciteit en de technische deelbaarheid van de kapitaalgoederen. Bij sommige overheidsbedrijven (bijv. elektriciteitsbedrijven) bestaat niet altijd de mogelijkheid de uitbreiding van de capaciteit te financieren uit de afschrijuingen. De reden is dat de installatie niet is op te splitsen in kleinere eenheden. Hebben de afschrijvingen het niveau van de noodzakelijke vervangingsinvesteringen bereikt, dan vindt de beëindiging van het proces van de uitbreiding van de capaciteit plaats. ${ }^{104}$ In de economische literatuur staat dit verschijnsel bekend als het groei-effect van Domar en Eisner. 145

In het overheidsbedrijf vindt een kabinet een instrument voor het realiseren van doeleinden in het kader van het technologie- en innovatiebeleid. De verspreiding van de resultaten van wetenschappelijk onderzoek vormt een positief extern effect. Particuliere ondernemingen optimaliseren de omvang van hun onderzoek en ontwikkeling om deze reden niet. De externaliteiten hebben tot gevolg dat een onderneming slechts een deel van de baten van zijn onderzoek verwerft, dat. overeenkomt met zijn marktaandeel. ${ }^{10}$ overheidsbedrijven kunnen daarentegen door hun marktpositie of financiële relatie met de overheid een optimale omvang van onderzoek en ontwikkeling realiseren voor het bedrijf, de bedrijfstak of de samenleving. $\quad W$. Niopek onderscheidt vier patronen van innovatiegedrag bij overheidsbedrijven, namelijk innovatie belemmerende, innovatie bevorderende, innovatie sturende en innovatie leidende overheidsbedrijven. ${ }^{107}$ Naast het toezicht en de invloed van belangengroepen, zijn de motivatie van het 
personeel, de organisatiestructuur en de marktpositie van belang. Het innovatief vermogen van een overheidsbedrijf is volgens Niopek afhankelijk van het aandeel van het eigen vermogen in het totale vermogen. Een uitbreiding van het eigen vermogen vergroot de financiële speelruimte tegenover de verantwoordelijke ministeries en de kapitaalmarkt, maar bevordert tevens een op middellange en lange termijn doeleinden gerichte innovatieve strategie. slechts met voorwaardelijke financiering kan de verantwoordelijke minister de innovatie bevorderen en sturen. Onvoorwaardelijke financiering ter compensatie van exploitatietekorten stellen de directie van het overheidsbedrijf in staat te beslissen over de allocatie van de financiële middelen en stimuleert geen kostenbewustzijn. De omvang van het ter beschikking gestelde eigen vermogen en de goedkeuringsprocedures bij een beroep op de kapitaalmarkt garanderen een greep op de besluitvorming over innovatie. ${ }^{108}$

op de kapitaalmarkt verkeren overheidsbedrijven in een gunstiger positie dan particuliere ondernemingen. zij beschikken over impliciete of expliciete overheidsgaranties. Het feit dat de overheid garant staat, maakt overheidsbedrijven aantrekkelijk voor de aanbieders van kapitaal. In een situatie van hoogconjunctuur veroorzaakt een overheidsbedrijf met een beroep op de kapitaalmarkt een stijging van de rentevoet en mogelijk inflatie. De consequentie hiervan is dat de investeringen van particuliere ondernemingen dalen, omdat zij tegen een hogere rentevoet moeten lenen (in de Engelse literatuur staat dit bekend als "crowding out"). Een limiet op de omvang van de externe financiering van het overheidsbedrijf biedt de mogelijkheid om deze externaliteit(en) te beheersen. In een periode van laagconjunctuur daarentegen belemmert het beroep op de kapitaalmarkt de particuliere ondernemingen niet, maar draagt het bij aan het herstel van de investeringen. De Britse overheid introduceerde deze techniek in $1978 .^{109}$

\subsubsection{Toezicht op het produktieproces.}

Overheidsbedrijven kunnen de vorm aannemen van een bureaucratie. Dit betekent dat het bedrijf beschikt over hiërarchische verhoudingen en een functionele organisatie. De bureaucratische organisatievorm verstrekt de principalen en de directie de benodigde informatie om toezicht uit te oefenen op het produktieproces. De verkregen informatie stelt de directie van het overheidsbedrijf in staat het produktieproces te beïnvloeden met een straf- en beloningsstelsel.

\subsubsection{Toezicht op de samenstelling en de omvang van het team van producenten.}

Het recht om toezicht uit te oefenen op de samenstelling en de omvang van het team van producenten kan zijn geconcentreerd bij de verantwoordelijke minister of voor bepaalde categorieën werknemers worden gedelegeerd aan de directie van het overheidsbedrijf. Delegatie van het toezicht op de samenstelling en de omvang van het team van producenten aan de 
directie van het overheidsbedrijf dient ter vermijding van conflicten in de sfeer van de arbeidsverhoudingen. De werknemers vormen immers een electoraal potentieel. ${ }^{110}$

Verborgen werkloosheid blijkt een kenmerk te zijn van overheidsbedrijven in ontwikkelde en ontwikkelingslanden. De houders van het recht toezicht uit te oefenen op de samenstelling en de omvang van het personeel in landen met een hoge werkloosheid zijn betrokken bij de verdeling van baten. Ramanadham noemt als voorbeelden van verborgen werkloosheid de British Steel Corporation en British Rail.111 De verborgen werkloosheid op hogere besluitvormingsniveaus kan nauw verweven zijn met de aanstelling in een vast dienstverband als een beloning voor bewezen diensten aan politieke partijen of kabinetten. Kabinetswisselingen hebben onder deze omstandigheden een uitbreiding van het. personeelsbestand of een aanvulling van het natuurlijke verloop tot gevolg. op de hogere besluitvormingsniveaus van overheidsbedrijven komen dan meer managers voor dan bij andere bedrijven in dezelfde bedrijfstak. ${ }^{112}$ De personeelslasten van het overheidsbedrijf zullen stijgen. Alchian wijst erop dat directies van overheidsbedrijven (potentiële) winst omzetten in hogere kostenactiviteiten om redenen van patronage of selectief personeelsbeleid, waarbij etnische, levensbeschouwelijke of politieke criteria een rol spelen. ${ }^{113}$

Het verschil in salariëring tussen particuliere ondernemingen en overheidsbedrijven kan leiden tot de selectie van minder gekwalificeerd personeel bij overheidsbedrijven ("adverse selection"). De Britse politicus H. Morrison trachtte dit probleem te ondervangen door te bepleiten dat het personeel van overheidsbedrijven hogere salarissen ontving dan de ambtenaren. 114

Onderzoek naar het personeelsbeleid en de hiermee verbonden bedrijfscultuur bij Nederlandse overheidsbedrijven ontbreekt. De Jonge (hoofddirecteur Personeelszaken PTT) schrijft in generaliserende en schematiserende $z$ in over de bedrijfscultuur van de PTT als overheidsbedrijf. Volgens hem kenmerkt de bedrijfscultuur van dit bedrijf $\mathrm{zich}$ door een grote tolerantie tegenover niet optimaal functionerende medewerkers. De Jonge wijst erop dat teveel tolerantie reorganisaties en vernieuwingen bemoeilijkt. ${ }^{115}$

De samenstelling van het personeel kan verder worden beinvloed door het bestaan van pensioen- en wachtgeldregelingen. Het bestaan van vervroegde en invaliditeitspensioenen kan een stimulans vormen voor directies en werknemers van overheidsbedrijven om het pensioen eerder in werking te laten treden. $\mathrm{zij}$ verschillen daarbij waarschijnlijk niet van particuliere ondernemingen, terwijl ook de redenen identiek kunnen zijn. Tot de redenen om dergelijke pensioenen eerder in werking te laten treden behoren onder andere rationalisering en elektrificatie.

\subsubsection{Aanspraak op de winst.}

Het recht om aanspraak te maken op de winst berust in de klassiek kapitalistische onderneming bij de ondernemer. Bij de socialistische onderneming kan winstdeling ten behoeve van de 
werknemers door het politieke bestuur zijn opgelegd. Een winstdelingsregeling voor het gehele personeel betekent dat er voor de werknemers geen reden meer bestaat tot dienstontduiking (in het Engels aangeduid als "shirking"). De winstdelingsregeling stimuleert de motivatie van werknemers om hun taken efficiënt uit te voeren. Voor het management bestaat er onder dergelijke omstandigheden aanleiding tot dienstontduiking, omdat zij de winst moeten delen met de werknemers. De kosten van dienstontduiking door het management kunnen de baten van de grotere inspanning van het personeel overschrijden. Een stelsel van toezicht op het management wordt dan noodzakelijk. Een voorbeeld hiervan zijn de vroegere Yoegoslavische arbeiderscomités, die beschikten over de bevoegdheid om het management te ontslaan. 116

Het overheidsbedrijf in de gemengde economie neemt wat betreft het recht om aanspraak te mogen maken op de winst een positie in tussen beide bovengenoemde vormen van onderneming. $\mathrm{Bij}$ het ontbreken van een winstdelingsregeling vindt aanspraak op de winst plaats met de conversie van winst in kostenverhogende activiteiten (bijvoorbeeld: subsidies en spaarregelingen). De (vennootschaps)belasting en het afschrijvingsbeleid beïnvloeden de hoogte van de winst bij het overheidsbedrijf. De rentelast ten gevolge van financiering met vreemd vermogen reduceert de omvang van de winst, waarop aanspraken kunnen worden gemakt met vergoedingsregelingen voor het personeel. 117 Artikel 5 van de Bedrijvenwet van 1928 kent de Minister van Financiën het recht toe aanspraak te maken op een uitkering ten bedrage van het voordelig saldo van het staatsbedrijf. ${ }^{11 k}$ Teneinde te voorkomen dat deze voordelige saldi naar het Rijk stromen, kunnen deze saldi eveneens tot op zekere hoogte worden omgezet in kosten.

Het recht aanspraak te maken op de winst met een dividenden een tantième-regeling bij overheidsbedrijven kan achtereenvolgens zijn vastgelegd in de statuten of de arbeidscontracten. 119 De regeling van het recht om aanspraak te maken op de winst beinvloedt de arbeidsprestaties en de stijl van de bedrijfsvoering. Aan het begin van deze eeuw bestond reeds in de economische literatuur onenigheid over de vraag of directies en commissarissen van overheidsbedrijven recht hebben op tantièmes. $H$. Aumund was er voorstander van om leidende beambten een deel van de winst toe te kennen en de ontwikkeling van hun inkomen niet naar boven te beperken. ${ }^{120}$ Een tantième-regeling voor het hogere kader kan tot gevolg hebben dat het overheidsbedrijf wordt geleid met het doel inkomsten voor de overheid te verwerven. Het hogere kader heeft immers belang gekregen bij het verwerven van maximale winst. Het is niet uitgesloten dat in het geval van een winstdelingsregeling het uitblijven van winsten een nadelige invloed heeft op de arbeidsprestaties. ${ }^{121}$

Als alternatief voor winstdelingsregelingen kunnen regelingen functioneren, die de salariëring koppelen aan de omzet. Empirisch onderzoek naar de relaties tussen salariëring, omzet en winst bij overheidsbedrijven ontbreekt (een verklaring hiervoor kan zijn de moeilijkheid om informatie te verkrijgen over de bezoldiging van het hogere kader). ${ }^{122}$ Ramanadham constateert dat overheidsbedrijven een 
restrictief inkomensbeleid voeren voor het hogere kader in tegenstelling tot voor het lagere kader. Bij geringe nettoinkomsten is het onwaarschijnlijk dat aan het personeel bonussen worden uitgekeerd. De arbeidsmotivatie van het personeel kan dan worden gestimuleerd door een uitkering administratief te boeken als kostenpost. ${ }^{123}$ Een illustratie hiervan is een premiespaarregeling bij een verliesgevend overheidsbedrijf. Het personeel stort een deel van het (netto)loon op een tijdelijk geblokkeerde spaarrekening en de directie keert een spaarpremie uit als aan de voorwaarden is voldaan. De spaarpremie kan echter niet uit de winst worden gefinancierd. Een ander voorbeeld hiervan betreft de gepremieerde spaarregeling van de NV Nederlandse spoorwegen. De directie verantwoordde de spaarregeling voor het eerst onder de rubriek overige sociale kosten in de exploitatiebegroting voor 1968. Deze spaarregeling maakte geen deel uit van het Reglement dienstvoorwaarden en de collectieve arbeidsovereenkomst. ${ }^{124}$

Vrijstelling van bijvoorbeeld dividend- en tantièmebelasting voor het leidinggevend personeel van overheidsbedrijven verhoogt de arbeidsmotivatie. Deze fiscale faciliteit is een onzichtbare overdracht van baten van de rijksoverheid naar het leidinggevend personeel. Om het gedrag van overheidsbedrijven te kunnen voorspellen moet de aandacht worden gevestigd op de beloningsstimuli bij de diverse organisatievormen van overheidsbedrijven. ${ }^{125}$ Nederlandse overheidsbedrijven, die concurreerden met particuliere ondernemingen, waren tot 1956 vrijgesteld van de vennootschapsbelasting.

De beperking van de tantièmes en de beheersing van de lonen (bijvoorbeeld een geleide loonpolitiek) leiden ertoe dat de directie (en het personeel) gaat streven naar autonomie om haar eigen doeleinden te realiseren. Het streven naar autonomie vindt plaats met winstconversie en kan in het geval van een ondoorzichtige financiële administratie worden benaderd met een evaluatiecriterium. Dit laatste komt aan de orde in paragraaf 2.4.1.

Directies van overheidsbedrijven trachten met het creëren van stille en geheime reserves aanspraken op de winst van de kant van belangenorganisaties, zoals vakbonden, te vermijden. Stille reserves vormen reserves waarvan het bestaan blijkt uit de gepubliceerde balans, maar de omvang echter niet. Deze reserves ontstaan uit de versnelde afschrijving van duurzame produktiemiddelen. Geheime reserves daarentegen $z i j n$ niet vast te stellen aan de hand van de gepubliceerde balans. Deze reserves zijn het resultat van een te lage waardering van de vaste activa of gaan schuil achter een te hoge presentatie van het vreemd vermogen. ${ }^{126}$ Artikel 9 lid 1 van de Bedrijvenwet van 1928 staat de interpretatie toe dat staatsbedrijven stille reserves, ontstaan uit afschrijvingen, mogen beleggen. Dit artikel bepaalt dat afschrijvingen op bezittingen worden uitgekeerd aan het Rijk als aflossing van het beschikbaar gestelde kapitaal. De overheid kan een combinatie van rentedragend en rentevrij kapitaal ter beschikking stellen. Het rentedragend kapitaal dwingt de directie van een staatsbedrijf tot aflossing. In de praktijk bestaat er voor 
staatsbedrijven geen aanleiding om over te gaan tot de aflossing van het rentevrije kapitaal, maar een reden tot belegging van deze middelen. De staatsmijnen beschikten over rentedragend en rentevrij kapitaal, hetgeen dit bedrijf de mogelijkheid bood stille reserves te beleggen. Waren de stille reserves voldoende hoog, dan kon dit staatsbedrijf besluiten over te gaan tot een ruimere uitkeringspolitiek, gepaard met een verlaging van de afschrijuingen. ${ }^{127}$

\subsection{Het vastgtellen van de kenbaar gemaxte doeleinden.}

Bij het verrichten van een kwantitatieve prestatie-analyse ontlenen economen als Perelman en Pestieau hun doeleinden aan de algemeen economische politiek. Zij werken deze doeleinden niet nader uit en beperken zich tot het meten van technische efficiëntie. Politiek-economische bijdragen aan het onderzoek naar het gedrag en de doeleinden van overheidsbedrijven leveren Aharoni, Haririan en Ramanadham. $\mathrm{Zij}$ vermelden dat de ruimte voor overheidsbedrijven om eigen doeleinden na te streven, kosten tot gevolg heeft.

Aharoni beschouwt het overheidsbedrijf niet alleen als een contract tussen de produktiefactoren, maar ook als een coalitie tussen ambtenaren, directie, politici en vakorganisaties. De doeleinden resulteren uit een machtsstrijd tussen de belanghebbenden over de bedriffsvoering en vormen onafhankelijke variabelen. De machtsmiddelen dienen om deze redenen te worden geanalyseerd. Volgens hem besteden managers van overheidsbedrijven meer tijd aan de beheersing van de omgeving, dan de managers van particuliere ondernemingen. De resultaten van het machtsconflict - de keuze van doeleinden kunnen worden voorspeld met de contingentie-theorie. De omgevingsvariabelen verklaren in deze theorie de prestaties van het bedrijf. Deze doeleinden zijn zelden identiek aan de formele doeleinden. De kenbare doeleinden blijken uit het gedrag van het overheidsbedrijf. ${ }^{128}$

Aharoni besteedt aandacht aan de prestaties van overheidsbedrijven en definieert efficiëntie in termen van realisatie van doeleinden. Zonder meetbare doeleinden is het meten van prestaties niet mogelijk. Zijn doeleinden geformuleerd in statische termen, dan leidt de realisatie tot leereffecten, herhaling en specialisatie. Dergelijke doeleinden verhinderen innovaties en aanpassing aan veranderende marktomstandigheden. Effectiviteit bij het overheidsbedrijf houdt in dat alle actoren zich inzetten voor de verwezenlijking van de doeleinden. De evaluatie van de effectiviteit kan op drie manieren plaatsvinden. De methode van de instroom van produktiefactoren stelt dat het bedrijf effectiever wordt als het meer middelen uit de omgeving kan verkrijgen. Er bestaat een duidelijk verband tussen de produktiefactoren en de produktie. Een andere methode ter bepaling van de effectiviteit legt de nadruk op de belanghebbenden. Effectiviteit wordt gemeten aan de hand van de mate van behoeftebevrediging van de belanghebbenden. De afwezigheid van kritiek is een indicator voor effectiviteit. De laatste methode beschouwt effectiviteit als een functie van de interne spanningen in het overheidsbedrijf. Hier ligt de 
nadruk op het proces binnen de organisatie en de mate van communicatie tussen de bedrijfsonderdelen. De verschillen tussen deze methoden zijn volgens hem aanzienlijk. Als een overheidsbedrijf effectief is bij één methode betekent dat nog geen effectiviteit bij de andere methoden. ${ }^{129}$

De marktvorm belinvloedt volgens Aharoni de prestaties en de mate van overheidsbemoeienis met het overheidsbedrijf. Kabinetten doen eerder een beroep op het overheidsbedrijf als de kosten verbonden aan uiteenlopende doeleinden kunnen worden verborgen of kruiselings gesubsidieerd. Rendabele bedrijfsactiviteiten financieren dan de niet-commerciële doeleinden. De mate van mededinging bepaalt uiteindelijk of kruiselingse subsidiëring tot de mogelijkheden behoort. De transparantie van de markt maakt een vergelijking tussen overheidsbedrijf en particuliere ondernemingen mogelijk en beperkt de mogelijkheden voor het kabinet niet-commerciële doeleinden kruiselings te subsidiëren. ${ }^{130}$

Haririan introduceert een raamwerk voor de evaluatie van efficiëntie, investeringen, financiering en prijsbeleid van overheidsbedrijven in gemengde economieën. Hij concludeert dat de doeleinden van overheidsbedrijven complex, verwarrend, vaag, tegenstrijdig en zelfs niet exact meetbaar zifn. Hij onderscheidt twee categorieën doeleinden. De eerste categorie bestaat uit micro-economische (efficiëntie) doeleinden, die worden gemeten met financiële ratio's. De tweede categorie betreft de macro-economische doeleinden, die meestal niet worden gemeten of niet meetbaar zijn. Voor de evaluatie van de realisatie van doeleinden heeft Haririan een zogenaand Doeleinden-Realisatie Model ontwikkeld. ${ }^{131}$ De sociale doeleinden veroorzaken kosten en tasten de financiele levensvatbaarheid van het overheidsbedrijf aan. De compensatie van deze kosten door de overheid dient te zijn gebaseerd op de doctrine van de bedrijfsvreemde lasten (in het Engels "doctrine of improper burdens"), hetgeen betekent dat de overheid zich contractueel verplicht de kosten van de nietcommerciële doeleinden te subsidiëren. De vergelijking van exante en ex-post subsidies zou dan moeten fungeren als instrument voor de evaluatie van de prestaties. De ongelijkheid tussen beide subsidies betekent nog niet dat er sprake is van ineffectiviteit. Deze ongelijkheid kan het resultaat $z i j n$ van externe factoren. ${ }^{132}$

Een andere manier voor het meten van prestaties is gebaseerd op de mate van effectiviteit om ex-ante doeleinden te verwezenlijken. De diversiteit aan doeleinden maakt het noodzakelijk rangnummers (R) en een wegingscoëfficiënten toe te passen. De factor $m$ geeft de negatieve gevolgen van de tegenstrijdige doeleinden weer. 
De formule van deze benadering luidt:

$$
\mathrm{DE}=E \frac{\mathrm{R}_{\mathrm{i}} \mathrm{W}_{\mathrm{i}}^{*}}{\mathrm{R}_{\mathrm{i}} \mathrm{W}_{\mathrm{i}}}-\mathrm{m}=\frac{\mathrm{Z}^{\cdot}}{\mathrm{Z}}
$$

Z

$\mathrm{Z}^{*}$

m

$R_{i} W_{i}$

$R_{i} W^{*}$

DE

: de ex ante combinatie van wegingscoëfficiënt en rangorde,

: de ex post combinatie van wegingscoëfficiënt en rangorde,

: de factor voor de negatieve invloed voor conflicterende doeleinden,

: de ex ante gewogen realisatie van diverse doeleinden,

: de ex post gewogen realisatie van diverse doeleinden, en

: de mate van effectiviteit.

Nadert de ratio voor de mate van effectiviteit de waarde één, dan neemt de effectiviteit toe. Het initiële niveau van de verwachtingen is immers accuraat. Overschrijdt de mate van effectiviteit de waarde één, dan zijn de initiële verwachtingen van het overheidsbedrijf te laag ingeschat. ${ }^{133}$ Haririan geeft echter niet aan hoe de wegingscoëfficiënten en de rangorden voor de diverse doeleinden worden bepald.

Ramanadham benadert het verschijnsel overheidsbedrijf analytisch, maar neemt voorbeelden op in zijn argumentatie. $\mathrm{Hij}$ onderscheidt officiële en niet-commerciële doeleinden. De laatst genoemde doeleinden vinden vaak hun oorsprong buiten het overheidsbedrijf. De directie internaliseert soms met haar besluitvorming deze niet-commerciële doeleinden. Zij neemt dit besluit op aandrang of beoordeelt de niet-commerciële doelstelling zelf als waardevol. Ramanadham onderscheidt twee soorten niet-commerciële doeleinden, namelijk economische en niet-economische doeleinden. Tot de economische doeleinden rekent hij de zogenaamde macro-economische doeleinden, zoals: economische groei, betalingsbalansevenwicht en technologische ontwikkeling. De niet-economische doeleinden omvatten onder andere veiligheid, milieu, medezeggenschap, financiële verantwoording, politieke en persoonlijke belangen. ${ }^{134}$

Besluit een overheid tot het nastreven van niet-commerciële doeleinden met overheidsbedrijven, dan dient zij volgens Ramanadham ${ }^{135}$ :

1. de doeleinden te formuleren in voor de directie te begrijpen termen,

2. de financiële gevolgen voor de onderneming te quantificeren,

3. de meest geschikte modaliteiten voor de financiering van de gevolgen te formuleren, en

4. het institutionele karakter van de onderneming als autonome vorm van organisatie in stand te houden.

De voordelen van de autonome vorm van het overheidsbedrijf zijn maximaal als de niet-commerciële doeleinden vooraf op basis van wederzijdse overeenstemming tot stand komen en 
worden gecompenseerd. Deze doeleinden mogen niet op een informele of versluierde wijze kenbaar worden gemaakt. De ervaring leert volgens Ramanadham dat overheden in zowel ontwikkelde als ontwikkelingslanden deze doeleinden op informele wijze kenbaar maken aan de directies van overheidsbedrijven. De financiële implicaties van de nietcommerciële doeleinden, noch de alternatieve kosten van de vermindering van de netto-opbrengsten zijn tot op heden geëvalueerd. ${ }^{136}$

Ramanadham onderscheidt vier niveaus voor de evaluatie van de prestaties, namelijk de directie, de onderneming, de samenleving en de voordelen in vergelijking met de andere beleidsinstrumenten. Op het niveau van de directie richt de evaluatie zich op de bedrijfsresultaten, waarbij wordt getracht externe invloeden te beheersen. Bij de evaluatie op het niveau van de onderneming ligt de nadruk op de totaliteit van de bedrijfsresultaten, warbij de invloed van externe factoren wordt onderzocht. Een bijzonder aspect van de analyse op dit niveau is de invloed van toezichthoudende overheidsinstanties. De evaluatie op het niveau van de samenleving richt zich op de maatschappelijke waardering van de geleverde prestaties. De vergelijking met andere beleidsinstrumenten betreft de vraag of het overheidsbedrijf een efficiënter instrument is voor het behalen van de gewenste resultaten. 137

De kwalitatieve prestatie-analyse onderscheidt zich van de benadering van de drie bovengenoemde auteurs en de kwantitatieve prestatie-analyse, doordat het de beschikking over beleidsvrijheid tracht te analyseren met behulp van (beleids)documenten. De tweede fase van de kwalitatieve prestatie-analyse bestaat uit de verzameling en de analyse van de kenbaar gemaakte doeleinden. Deze analyse bevestigt of weerlegt de met de structuuranalyse gevonden doeleinden en bestaat uit de navolgende procedure:

1. Het verzamelen en definiëren van de kenbaar gemaakte doeleinden in documenten en verklaringen van de bij het overheidsbedrijf betrokken principalen.

2. Het verzamelen en definiëren van de doeleinden, die zijn gevonden in niet-officiële documenten.

3. Het vergelijken van de doeleinden uit de bovengenoemde procedures.

4. Het samenstellen van een lijst met doeleinden, die als volgt wordt onderverdeeld:

a. Doeleinden gevonden met de analyse van de kenbaar gemaakte prestaties.

b. Doeleinden gevonden met de structuuranalyse.

c. Doeleinden gevonden met beide analyses.

onduidelijk geformuleerde wettelijke en statutaire doeleinden voor overheidsbedrijven bevorderen het streven naar een mate van vrijheid om eigen beleidsdoeleinden te verwezelijken. De 
kwalitatieve prestatie-analyse stelt deze doeleinden vast. De kosten van de beleidsvrijheid blijken uit de gederfde winst, in het Engels aangeduid als "public enterprise rent". De gederfde winsten zijn echter geen indicatie voor de realisatie van eigen doeleinden.

\subsubsection{De kosten van de kenbaar gemaakte doeleinden.}

Inzicht in het bestaan van de kenbaar gemaakte doeleinden biedt een criterium voor de kosten van de beleidsvrijheid en de welvaartstheoretische analyse van de rendementsverschillen. Voor het vaststellen van de alternatieve sociale kosten, verbonden aan de vrijheid om eigen doeleinden na te streven, is een criterium nodig. Een overheidsbedrijf. vormt een investering. Een criterium voor overheidsinvesteringen vormt het rendement van eeuwigdurende staatsleningen. Het rendement van de overheidsinvestering dient minimaal gelijk te zijn aan het rendement van eeuwigdurende staatsleningen. De benodigde financiële middelen zouden immers ook kunnen worden aangewend voor de aflossing van de staatsleningen en de vermindering van de rentelast. De kosten van de beleidsvrijheid bestaan uit het verschil tussen het rendement van de overheidsinvestering en het rendement van de eeuwigdurende staatsleningen over de desbetreffende investering. Het verschil vormt de gederfde winst. Het eigen vermogen van het overheidsbedrijf geeft de omvang van de overheidsinvestering weer. De mogelijkheid bestaat dat de rentabiliteit van het overheidsbedrijf het rendement op eeuwigdurende staatsleningen overtreft. In dit geval vervult het overheidsbedrijf een fiscale rol.

overheidsbedrijven maken voor de bepaling van de rentabiliteit gebruik van de conventies in de externe verslaggeving. De beheersingsstructuur, resulterend uit de verdeling van de publieke eigendomsrechten, beïnvloedt de rapportage van de verlies- en winstcijfers. Het recht aanspraak te maken op de winst in de vorm van tantièmes stimuleert de directie tot minimalisatie van de kosten en correcte externe verslaggeving. Bij de interpretatie van de rentabiliteit van het overheidsbedrijf mogen de volgende punten niet buiten beschouwing blijven:

1. Kapitalisatie

De kapitalisatie van het overheidsbedrijf betekent de bepaling van de grootte en de samenstelling van het eigen vermogen. Het betreft in het bijzonder de verhouding tussen het geplaatste nominale aandelenkapitaal en het totale eigen vermogen. Kapitalisatie kan zijn gebaseerd op de intrinsieke waarde van de inbreng of op de rendementswaarde. ${ }^{138}$

Een overheidsbedrijf kan onder- of overgekapitaliseerd zijn. Onderkapitalisatie houdt in dat de intrinsieke waarde van het aandelenkapitaal groter is dan de nominale waarde. Wordt uitgegegaan van de rendementswaarde, dan is er sprake van onderkapitalisatie als de rendementswaarde van het eigen vermogen de nominale waarde van het aandelenkapitaal overschrijdt. In deze situatie keert het bedrijf een verhoudingsgewijs te hoog dividendpercentage uit. Een 
verklaring voor onderkapitalisatie is dat de overheid reeds de lasten en tekorten van het overheidsbedrijf vergoedt. $\mathrm{zij}$ kan de middelen voor een uitbreiding van het aandelenkapitaal niet meer opbrengen. ${ }^{139}$

overkapitalisatie treedt op als de intrinsieke waarde van het aandelenkapitaal lager is dan de nominale waarde ervan.

Bij overkapitalisatie is de rendementswaarde van het eigen vermogen lager dan het nominale aandelenkapitaal. De directie van het overheidsbedrijf beschikt nu over meer kapitaal dan zij rendabel kan investeren. De rentabiliteit van het bedrijf komt door de overkapitalisatie onder druk te staan. overkapitalisatie ontstaat als resultaat van kapitaalsubsidies, lage rente op verstrekt kapitaal, uitstel van de betaling van verschuldigde interest en niet aan de staat uitgekeerde dividenden. ${ }^{140}$

\section{Presentatie van verlies- en winstcijfers}

De verantwoordelijke ministers en de directie hebben belang bij de presentatie van de verlies- en winstcijfers. Politieke eigenaren hebben om electorale overwegingen belang bij de presentatie van het winstcijfer. De tantième-regeling voor de directie kan consequenties hebben voor de keuze van een methode van afschrijven. Daarnaast vereist de interpretatie van de rentabiliteit van een overheidsbedrijf voorzichtigheid, omdat de resultaten van de deelbedrijven en bepaalde investeringen onbekend zijn. ${ }^{141}$

\section{Belang bij het bedrijfsresultaat}

Tantième-regelingen bij overheidsbedrijven hebben tot gevolg dat directies belang krijgen bij het bedrijfsresultaat. Om zoveel mogelijk inkomsten uit tantièmes te verwerven, zullen zij hun investeringen uitbreiden. Dit kan leiden tot onjuiste en te omvangrijke investeringen, die mogelijk de rentabiliteit aantasten.

De Duitse Deskundigenraad voor de economie hanteert een soortgelijk criterium voor de identificatie van te privatiseren overheidsbedrijven. $\mathrm{zij}$ weegt de rente op staatsschuld af tegen de creditrente en de afdracht van winst. Blankart beschouwt dit criterium als de kern van een theorie over het financiële management van de overheid. Hij behandelt deze theorie met een vergelijking van de rente op staatsleningen en de rente op particuliere leningen. De rente op staatsleningen is altijd lager dan die op particuliere leningen. De overheid realiseert hierdoor altijd een hoger netto-rendement dan particuliere ondernemers. De veronderstelling dat de staat niet failliet kan gaan, verklaart de lagere rente. De financiering van de rente kan desnoods uit de belastingopbrengsten geschieden. De crediteuren van de overheid staan aan een zeer gering risico bloot. Zij hoeven geen risico-premie te overwegen. De kosten verbonden aan het risico van overheidsinvesteringen zijn laag, omdat deze kunnen worden afgewenteld op de belastingbetaler. 
Het bestaan van impliciete of expliciete garanties voor het overheidsbedrijf houdt een rendement in gelijk aan de rente op de staatsschuld, zonder daarnaast nog een risico-premie te vergoeden.

Deze theorie over het financiële management van de overheid leidt tot een afwijzing van de minimale overheid. Een consequente toepassing van deze theorie houdt in dat de publieke sector van het bedrijfsleven zou moeten worden uitgebreid als het rendement van de overheidsinvestering het rendement op eeuwigdurende staatsleningen overschrijdt. De theorie van het financiële management houdt geen rekening met de doeleinden van de politieke eigenaren. ${ }^{142}$ Hun doeleinden waarborgen het voortbestaan van het overheidsbedrijf als het rendement lager is dan het rendement van de eeuwigdurende staatsleningen.

Aan het voortbestaan van het overheidsbedrijf liggen verdelingspolitieke overwegingen ten grondslag. Het overheidsbedrijf vormt een instrument om (extra-)budgettaire financiële voordelen toe te kennen, waaraan politieke besluitvormers om politieke redenen geen ruchtbaarheid willen geven. Een voorbeeld hiervan was de toekenning van subsidies aan kerkgenootschappen en patronaten door de staatsmijnen. Hier ontstond de vraag of dit in strijd was met de grondwettelijke scheiding van stat en kerk. Fiscale vrijstellingen aan overheidsbedrijven hebben eveneens verdelingspolitieke gevolgen, als de directie besluit de hieruit voortvloeiende baten door te geven.

Figuur 2.3 geeft een analyse van de rendementsverschillen als gevolg van het bestaan van kenbaar gemaakte doeleinden. Deze verschillen blijken uit de ligging van de potentiële en de geobserveerde marginale en gemiddelde kostencurves op korte termijn. De ligging wordt bepaald door de verschillen in onder andere: loonkosten, prijzen van de grondstoffen, onderhoudskosten en afschrijvingen. De ligging van de geobserveerde kostencurves toont aan dat het overheidsbedrijf niet streeft naar de minimalisatie van de kosten, maar naar de realisatie van kenbaar gemakte doeleinden. De optimale bezetting van de beschikbare capaciteit ligt bij de snijpunten van de marginale kostencurves met de desbetreffende gemiddelde kostencurves. Op deze punten vindt de produktie plaats tegen de laagste kosten. De prijsstelling met de potentiële kostencurves benadert het rendement van de eeuwigdurende staatsleningen.

Uit het bestaan van een verzameling van geobserveerde en potentiële kostencurves op korte termijn kunnen theoretisch gesproken de bijbehorende kostencurves op lange termijn worden afgeleid. Het verloop van de gemiddelde totale kostencurves kan dan leiden tot verkeerde conclusies over de optimale schaal en de rentabiliteit van het overheidsbedrijf. 
Figuur 2.3 Welvaartsverliezen bij een monopolistisch overheidsbedrijf

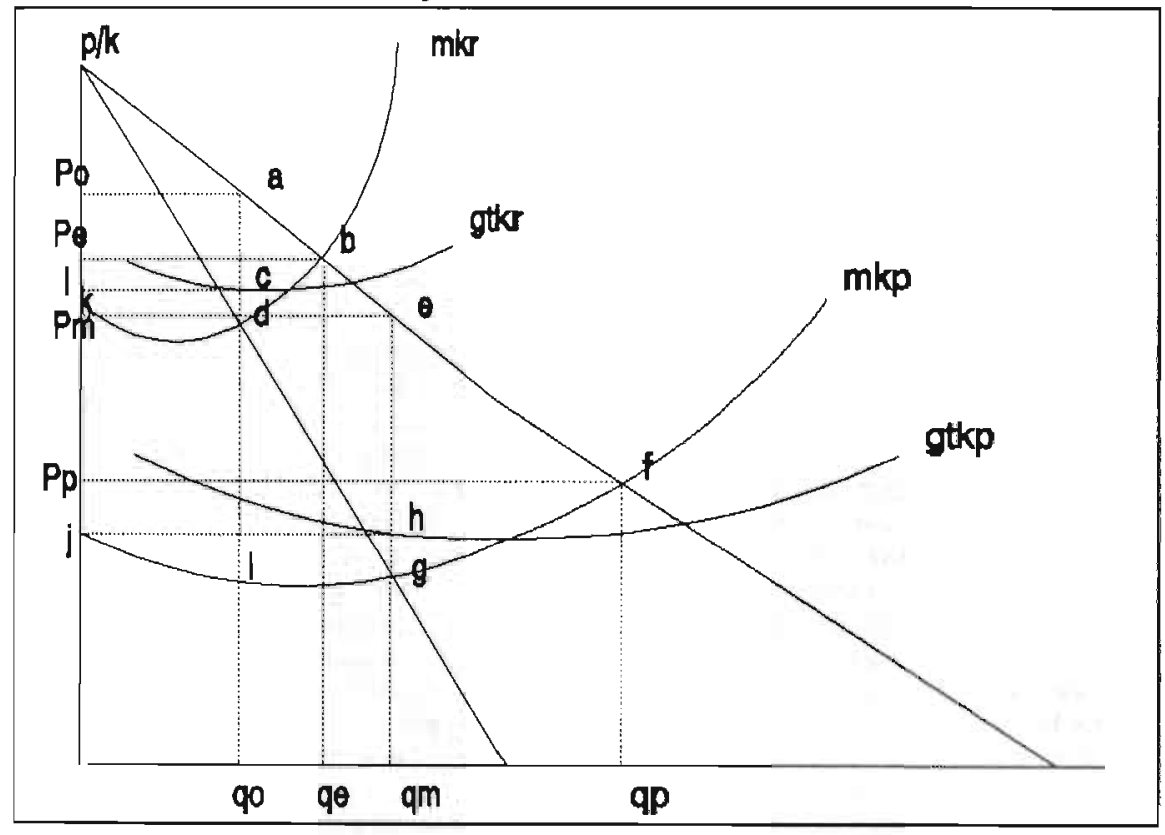

Opmerkingen: mkr - geobserveerde marginale kosten,
gtkr - geobserveerde gemiddelde totale kosten,
mkp - potentiële marginale kosten, en
gtkp - potentiële gemiddelde totale kosten.

De sociaal optimale produktie ontstaat bij omvang qp. Hier zijn de prijs Pp en de potentiële marginale kosten gelijk. Uitgaande van de geobserveerde marginale kosten is de orvang van de werkelijk sociaal optimale produktie qe. Streeft het overheidsbedrijf naar de maximalisatie van zijn winst, dan is de werkelijke produktie gelijk aan qo en bedraagt de prijs Po. Slaagt het overheidsbedrijf erin de potentiële marginale kosten te realiseren, dan vindt maximalisatie van de potentiële winst plaats bij een produktie van de omvang qm en een prijs $\mathrm{Pm}$.

De maximale winst bij de produktie qo bedraagt Poacl en Pmehj bij de omvang gm. Bij de produktie qo bedraagt het welvaartsverlies abd, terwijl het werkelijke verlies wordt weergegeven door afi. De voortbrengerspremie ${ }^{143}$ stijgt met dijk, maar met een netto verlies van bdfi. ${ }^{144}$ Beloningsstimuli voor het personeel en de directie stimuleren tot een efficiënter produktie, hetgeen leidt tot een verschuiving van de geobserveerde kostenlijnen in de richting van de potentiële kostenlijnen. ${ }^{145}$ Een welvaartseffect, dat niet uit figuur 2.3 blijkt, vormt het derven van vennootschapsbelasting door de nationale overheid ten gevolge van het verschil tussen de geobserveerde en de potentiële rentabiliteit. 


\subsection{Een acenario voor privatisering.}

Het begrip privatisering betekent de overdracht van een verzameling eigendomsrechten in een overheidsbedrijf aan de particuliere sector, met andere woorden: denationalisering. De overdracht van deze eigendomsrechten beëindigt de vrijheid voor politieke eigenaren om eigen doeleinden na te streven. Privatisering beinvloedt de arbeidsmotivatie en bevordert de bedrijfsprestaties. ${ }^{146}$

In de jaren vijftig en zestig brachten Nederlandse politici privatisering in verband met bezitsvorming en -spreiding. De bezitsvorming heeft uiteindelijk gestalte gekregen in de vorm van winstdeling en spaarregelingen. Tegenwoordig zijn de motieven voor privatisering: betere bestuurlijke beheersing, versterking van de marktsector, vergroting van de effectiviteit van voorzieningen en budgettaire besparingen. ${ }^{147}$

Een scenario voor privatisering bestaat uit de volgende fasen: (1) de toetsing aan een selectiecriterium, (2) de waardebepaling van het desbetreffende overheidsbedrijf, en (3) de verkoop. Twee selectiecriteria voor privatisering kunnen worden onderscheiden, namelijk de contante waarde van de netto-geaggregeerde baten voor de consument en het rendement op eeuwigdurende staatsleningen. M. Beesley en S. Littlechild benaderen privatisering vanuit het perspectief van de kostenbaten analyse en hanteren als selectiecriterium een positieve contante waarde van de geaggregeerde netto baten voor de consument. Deze netto baten vloeien enerzijds direct voort uit de besparingen ten gevolge van een prijsverlaging voor consumptiegoederen en anderzijds indirect uit de lagere belastingen ten gevolge van de vermindering van subsidies. Bedrijven met de hoogste contante waarde van de geaggregeerde netto baten voor de consument komen in aanmerking voor privatisering. Zij bepalen deze waarde aan de hand van de omzet, het eigen vermogen, de reorganisaties met personele consequenties en de mate van concurrentie. ${ }^{148}$

Beesley en Littlechild leggen met het selectiecriterium van de contante waarde van de geaggregeerde netto baten geen koppeling met de overheidsfinanciën. Een alternatief selectiecriterium vormt het rendement op eeuwigdurende staatsleningen. Overheidsbedrijven, met een rentabiliteit lager dan het rendement van eeuwigdurende staatsleningen, worden geselecteerd voor privatisering. De overheid weegt dan bij de besluitvorming over privatisering de verminderde rentelasten op staatsschuld af tegen de gederfde inkomsten uit het geprivatiseerde bedrijf.

De waarde van het overheidsbedrijf is gelijk aan de som van de intrinsieke waarde van de vaste activa en de rentabiliteitswaarde. Dit bedrag wordt verminderd met de contante waarde van de kosten. De intrinsieke waarde betreft het verschil tussen enerzijds de actuele waarde van de activa en anderzijds de voorzieningen en verplichtingen. De rentabiliteitswaarde omvat de gekapitaliseerde waarde van de bestaande en toekomstige winstgevendheid van het overheidsbedrijf. De kapitalisatie vindt plaats tegen de rentabiliteit van én of meer representatieve bedrijven in de bedrijfstak. ${ }^{149}$ Tot de contante waarde van de kosten behoren 
onder andere de kosten van de aandelenuitgifte, de compensatiekosten voor de pensioenfondsen, de kosten voor toekomstig onderhoud en de kosten voor de reiniging van het milieu. 150

$\mathrm{Na}$ de bepaling van de waarde vindt de introductie van de aandelen rechtstreeks plaats op de beurs of na inschrijving. Bij inschrijving bestaan twee methoden. Ten eerste kunnen belangstellenden inschrijven tegen een vaste prijs. Ten tweede bestaat de mogelijkheid van het tender-systeem. De inschrijvers geven aan hoeveel aandelen zij willen kopen en tegen welke prijs. Een beursintroductie is niet altijd wenselijk. Dan bestaat de mogelijkheid de aandelen te plaatsen of te verkopen aan één investeerder of een groep van investeerders. De reden hiervoor is dat de overheid de aanwezige externe effecten in de overname-prijs kan doorberekenen. Het betreft hier efficiënter management, synergievoordelen en toegang tot een bepaalde markt of technologie. 151

Koersstijgingen bij de verkoop van overheidsdeelnemingen leiden tot de beschuldiging dat de aandelen tegen te lage prijzen werden verkocht. In Groot-Brittannië ontkenden volgens Veljanovski woordvoerders van de overheid dat het doel van privatisering de maximalisatie van overheidsinkomsten inhield en dat er sprake was van onderwaardering van de aandelen. ${ }^{152}$ In 1960 deed zich in Nederland een dergelijke situatie voor bij de verkoop van aandelen/certificaten Hoogovens. De intrinsieke warde van de aandelen/certicaten kon volgens de media hoger worden berekend dan de verkoopprijs van 743 procent in de periode 25 februari tot en met 16 maart. De aandelen fluctueerden later in dat jaar tussen de 800 en 900 procent. Voor de Vaste Commissie voor Financièn vormde dit aanleiding vragen te stellen aan Minister van Financiën Zijlstra. De leden vroegen in het bijzonder naar de bezitsspreiding. Enkele leden berekenden een financieel nadeel voor de Nederlandse overheid van 16,6 miljoen gulden. Minister Zijlstra lichtte toe dat de intrinsieke waarde geen bepalende betekenis had voor het besluit tot verkoop. De verkoop moest worden gezien in het kader van het beleid van roulatie in deelnemingen. De overheid diende speculatieve overwegingen buiten beschouwing te laten. Het was volgens hem onmogelijk om bij deze transactie over te gaan tot specifieke bezitsspreidende matregelen. ${ }^{153}$

C. Shapiro en R.D. Willig introduceren het informatieprobleem tussen politieke elgenaar en onderneming in de discussie over privatisering. Regulering van geprivatiseerde ondernemingen biedt volgens hen de mogelijkheid dezelfae doeleinden te realiseren als met overheidsbedrijven. Het veroorzaakt echter wel informatiekosten voor de besluitvormer. De geprivatiseerde onderneming beschikt immers over de noodzakelijke particuliere informatie over de kosten en baten van haar activiteiten. Het informatie-probleem vormt een drempel voor de politieke besluitvormer om naast de officiële beleidsdoeleinden eigen doeleinden na te streven. is 


\subsection{Verklaring van de prestaties en de reacties van principalen.}

Uit de wisselwerking tussen de verklaring van de bedrijfsprestaties door de bestuurders van het overheidsbedrijf en de reacties van de principalen hierop, valt het relatieve gewicht van de verschillende doeleinden af te leiden. De navolgende analyse richt zich om deze reden op de benoemingen, de expliciete en impliciete beleidswijzigingen, het rituele gedrag en de continuering van niet ter discussie staande activiteiten.

\subsubsection{Benoemingen}

Uit de international politiek-economische literatuur over overheidsbedrijven blijkt dat kabinetten de directies en de leden van de toezichthoudende organen benoemen en herbenoemen. $2 i j$ kunnen deze bevoegdheid ook delegeren aan de betrokken ministers. De departementale ambtenaren dienen hen bij deze besluitvorming van advies. Morrison vertrouwt erop dat de traditie van correctheid van de Britse ambtenarij borg staat voor een eerlijke benoeming van kandidaten. ${ }^{155}$ Het bestaan van verschillende achtergronden bij departementale ambtenaren en leden van de directie en de toezichthoudende organen brengt wederzijdse spanningen met $z$ ich mee.

Benoemingen weerspiegelen de nationale of lokale politieke verhoudingen. Voorbeelden hiervan zijn oostenrijk en Italië. De zetelverdeling in de oostenrijkse volksvertegenwoordiging bepaalt het aantal per partij te benoemen leden in toezichthoudende lichamen (dit stelsel staat bekend onder de aanduiding "Proporz"). In het Italiaanse stelsel geven de verkiezingsuitslagen de doorslag in welk overheidsbedrijf een politieke partij het recht verwerft om bestuurders te benoemen ("lottizzazione"). ${ }^{156}$ over de politieke aspecten van benoemingen bij Nederlandse overheidsbedrijven is weinig bekend. De case-studies kunnen hier enige duidelijkheid in brengen.

De achtergronden van de directieleden en de leden van de toezichthoudende lichamen variëren. zij zijn afkomstig uit het bedrijfsleven of de politiek. Hun achtergrond beinvloedt de prestaties van het overheidsbedrijf. Bestuurders en directieleden met een achtergrond in het bedrijfsleven leiden het overheidsbedrijf als een commerciële onderneming. Bestuurders met een ambtelijke of politieke achtergrond oriënteren zich daarentegen op de overheidsdienst of het kabinetsbeleid. ${ }^{157}$ Loyaliteit aan het kabinetsbeleid houdt in dat het overheidsbedrijf de kenbaar gemaakte doeleinden zal nastreven. Het betekent niet altijd dat de kandidaat geschikt is om een overheidsbedrijf te leiden. Ambtenaren maken bezwaren tegen een benoeming, als zij vermoeden dat de kandidaat zal streven naar een maximalisatie van zijn begroting ten behoeve van persoonlijke doeleinden of sectorale belangen.

stabiliteit van het lidmaatschap van toezichthoudende lichamen en de Raad van Commissarissen is van belang. De leden worden geacht toe te zien op de besluitvorming, adviezen te 
verstrekken, de bedrijfsresultaten te beschouwen, de continulteit van het bedrijf te bewaken en ontvankelijk te zijn voor het kabinetsbeleid. Om voor een benoeming in aanmerking te komen moet een kandidaat beschikken over bekendheid met het bedrijf, de bedrijfstak en de externe relaties. Over de benoemingen in toezichthoudende lichamen, Raden van Commissarissen bestaat weinig informatie. De casestudies kunnen hier mogelijk een nader inzicht bieden.

De benoeming van loyale externe kandidaten kan spanningen veroorzaken op directieniveau. ${ }^{158}$ Een voorbeeld van dergelijke spanningen heeft $z$ ich voorgedaan rond de benoeming door het kabinet-colijn IV van de sociaal-democraat prof. dr. ir. J. Goudriaan (voorheen als onderdirecteur werkzaam bij de NV Philips) tot president-directeur bij de NV Nederlandse Spoorwegen in 1938. Goudriaan streefde naar een hechte binding met de Minister van Waterstaat. ${ }^{159}$

De vermeende inefficiëntie van overheidsbedrijven en de verwevenheid met de politiek bevorderen de opvatting dat directies van overheidsbedrijven incompetent zijn. K.D. Walters en R.J. Monsen bestrijden aan de hand van profielschetsen van E. Mattei (ENI), P. Dreyfus (Renault) en D. Ezra (National Coal Board), dat directies in de publieke sector van het bedrijfsleven incompetent zijn. De succesvolle directieleden onderhouden een pragmatische en effectieve relatie met de overheid met het doel financiële steun en autonomie te verwerven. Geen van hen treedt op als zou hij de leiding hebben over een particuliere onderneming. Walters en Monsen wijzen erop dat directieleden een onderscheid moeten maken tussen belangenbehartiging ten behoeve van het overheidsbedrijf bij het kabinet en kritiek op het kabinetsbeleid. Zij die dit onderscheid niet wisten te maken, verloren hun positie. ${ }^{160}$

\subsubsection{Expliciete beleidswijzigingen}

De principalen kunnen uit ontevredenheid over de prestaties besluiten on de beschikbare beleidsvrijheid in een overheidsbedrijf te beëindigen. $\mathrm{zij}$ kunnen dan in een ander overheidsbedrijf weer beleidsvrijheid creëren.

\subsubsection{Impliciete beleidswijzigingen}

Impliciete beleidswijzigingen kunnen worden vastgesteld met de analyse van statistische discontinuiteiten in tijdreeksen. De discontinuïteiten duiden op een beleidswijziging.

\subsubsection{Ritueel gedrag}

Ritueel gedrag betreft het verschil tussen de presentatie van het beleid en de beleidsuitvoering. De introductie van planningsmethoden, zoals "management by objectives" en "planning progamming and budgetting systems" bevordert soms het ontstaan van ritueel gedrag in het openbaar bestuur. De planningsmethoden leiden onder andere tot de publikatie van informatie over ambtelijk falen en een herverdeling van de financiële middelen van de overheid. Dit verklaart het 
politieke en ambtelijke verzet tegen planningsmethoden. Worden de planningsmethoden onder druk ingevoerd, dan blijft slechts een uitwijkstrategie over, namelijk ritueel gedrag. Voor de vorm wordt het beleid uitgevoerd, maar inhoudelijk handelen de verantwoordelijken overeenkomstig de traditionele gedragspatronen. ${ }^{161}$

Over de toepassing van planning bij overheidsbedrijven in gemengde economieën is in de literatuur weinig bekend. Een overheidsbedrijf vertoont in deze optiek ritueel gedrag als het de indruk wekt het beleid uit te voeren met nieuwe methoden, maar in werkelijkheid het traditionele gedragspatroon voortzet. Van ritueel gedrag bij een overheidsbedrijf is in dit onderzoek reeds sprake als de presentatie of verantwoording van het beleid verschilt van de uitvoering.

\subsection{5 voortzetting van niet ter discussie staande beleidsactiviteiten.}

Met de analyse van de financiële administratie kunnen de niet ter discussie staande beleidsactiviteiten worden achterhaald. Tot deze activiteiten behoren bij overheidsbedrijven bijvoorbeeld het reclame- en het garantiebeleid.

\section{a. Reclame}

Het reclamebeleid biedt overheidsbedrijven, zoals spoorwegmaatschappijen en telecommunicatiebedrijven, de mogelijkheid hun cliëntèle te bereiken. Overheidsbedrijven kunnen hun marketing concentreren op de meritorische aspecten van het consumptiegoed of de dienstverlening. Het overheidsbedrijf beinvloedt dan de preferenties en de vraag van de consumenten. ${ }^{162}$

Reclame en publiciteit vormen een belangrijk aspect op markten, waar overheidsbedrijven geen hinder ondervinden van comparatieve nadelen bij de produktie. Het betreft hier homogene markten. Het overheidsbedrijf beschikt dan over goede mogelijkheden de markt te betreden en de welvaart van de consumenten te verbeteren met informatieve reclame en lage prijzen. Op heterogene markten concurreren overheidsbedrijven met particuliere ondernemingen door consumptiegoederen en diensten te leveren van een bepaalde kwaliteit en de prijzen te benadrukken. Overheidsbedrijven kunnen $z i c h$ hierbij richten op de lagere inkomensgroepen. De rol van het overheidsbedrijf is in deze context het resultaat van, een door de particuliere ondernemingen toegepaste premie ten gevolge van excessieve reclame. Het bedrijf dient goodwill te verkrijgen met reclame en een consistente kwaliteit van het geleverde produkt. Het overheidsbedrijf zou zich kunnen ontwikkelen tot een marktleider en de prestaties van alle betrokken ondernemingen kunnen bevorderen. ${ }^{16}$

Prijs- en reclamebeleid zijn complementaire of substitueerbare instrumenten voor de maximalisatie van de omzet. Van complementariteit is sprake als reclame de enige effectieve methode vormt voor het bevorderen van een hoog geprijsd consumptiegoed. Substitueerbaarheid houdt in de 
realisatie van een gegeven omzet met een prijsverlaging bij een vast bedrag aan reclamekosten of de realisatie van een gegeven omzet bij een gegeven prijs en een verhoging van de reclamekosten. ${ }^{164}$

De vraag rijst hoe voor overheidsbedrijven het verband tussen prijsbesluiten en de kosten voor reclame moet worden vastgesteld. Empirische studies naar particuliere ondernemingen relateren de reclamekosten aan de maximalisatie van de winst. Overheidsbedrijven functioneren soms in een politieke cultuur die het streven naar maximalisatie van de winst minder wenselijk acht. Deze bedrijven hebben echter belang bij een uitbreiding van de omzet. Een hogere onzet onder omstandigheden van een natuurlijk monopolie leidt tot een volledige benutting van de schaalvoordelen. Reclame maakt het mogelijk de prijs dichter bij de marginale kosten te stellen, zonder de noodzaak tot subsidiëring. ${ }^{165}$

Reclame en publiciteit vormen voor kabinetten en directies van overheidsbedrijven het instrument om het electoraat via de bedrijfsprestaties te beinvloeden. De presentatie van goede prestaties is van cruciaal belang. Ministers trachten hiermee hun herverkiezing te verzekeren en de directies van overheidsbedrijven trachten op deze manier het verwerven van overheidsfondsen ter financiering van het bedrijf veilig te stellen. Bij overheidsbedrijven bestaat om deze redenen de tendens on meer aandacht te besteden aan reclame en publiciteit dan bij particuliere ondernemingen het geval is. Aangezien slechte prestaties altijd een mogelijkheid zijn, moet het reclamebeleid op lange termijn zich richten op het creëren van een veelvoud van doeleinden teneinde het bedrijf in een gunstig daglicht te plaatsen ${ }^{106}$.

\section{b. Garanties}

Garanties maken deel uit van de beleidsinstrumenten van de overheid en hebben een extra-budgettair karakter. zij verschijnen op de begroting als de verplichting tot het nakomen van de garantie $z i c h$ voordoet. Nederlandse overheidsgaranties hebben hun grondslag in ministeriële wetten en besluiten, die financiële voorrechten meebrengen voor bepaalde organisaties en belangengroepen. voorbeelden zijn onder andere de Garantieregeling inrichtingen voor gezondheidszorg van 1958 en de wettelijke machtiging tot het verstrekken van garanties aan de Nederlandse Overzeese Financieringsmaatschappij van 1959. ${ }^{167}$ Overheidsgaranties bieden overheidsbedrijven de mogelijkheid kapitaal te verkrijgen op de kapitaalmarkt tegen een gunstige rentevoet. ${ }^{168}$ In 1986 vaardigde Minister van Financiën H.O.C.R. Ruding (CDA) een circulaire uit, warin hij bepaalde dat geldmarktleningen niet voor overheidsgaranties in aanmerking kwamen. Hij makte echter een uitzondering voor geldmarktleningen ten behoeve van de NV Nederlandse Spoorwegen en enkele andere organisaties. ${ }^{169}$

De garanties van niet-financiële overheidsbedrijven en hun dochterondernemingen vormen een alternatief voor overheidsgaranties. Nederlandse overheidsbedrijven waren niet verplicht hun garanties in de jaarverslagen te publiceren. Zij 
verborgen hun garanties in de balansposten of vermeldden deze afzonderlijk. De liquiditeitspositie vormt een maatstaf om vast te stellen of het overheidsbedrijf de garantieverplichtingen kan nakomen. De liquiditeitspositie is het verschil tussen de vorderingen en de schulden op korte termijn.

Garanties van overheidsbedrijven leiden tot het ontstaan van een getrapt stelsel van toezicht op ondernemingen en belangengroepen. $\mathrm{zij}$ hebben het karakter van indirecte subsidies, die risico-nemende activiteiten bevorderen. Het is efficiënt voor een kabinet overheidsbedrijven garanties te laten toekennen, omdat de kosten van het toezicht voor deze bedrijven lager zijn dan voor de overheid. Ambtenaren beschikken niet altijd over de gespecialiseerde (commerciële) kennis om toezicht uit te oefenen op de activiteiten van de betrokken ondernemingen. Het gevaar bestaat dat meer garanties worden gevraagd dan strikt noodzakelijk. ${ }^{170}$ Directieleden van overheidsbedrijven oefenen in het kader van het garantiebeleid toezicht uit door het bekleden van functies in de directies van dochterondernemingen en in de Raden van Commissarissen van particuliere ondernemingen. Directies van overheidsbedrijven hebben in tegenstelling tot ambtenaren belang bij een systeem van toezicht op garanties, omdat riskante activiteiten van naar financiële privileges strevende belangengroepen de liquiditeitspositie van het overheidsbedrijf kunnen schaden. Een liquiditeitstekort heeft gevolgen voor het prijsbeleid van het overheidsbedrijf of voor de fiscale lasten van de belastingbetaler. 


\section{Hoofdstuk 3}

\section{De staatsmijnen}

\subsection{Inleiding}

De in het vorige hoofdstuk ontwikkelde kwalitatieve prestatieanalyse biedt het kader voor het onderzoek naar de in 1902 opgerichte staatsmijnen. De analyse gat achtereenvolgens in op de structuur, de doeleinden, de beleidsvrijheid, de benoemingen, de impliciete en expliciete beleidswijzigingen en de continuering van de niet ter discussie staande activiteiten.

De Staten-Generaal aanvaardden in 1928 de wet tot aanwijzing van de staatsmijnen als staatsbedrijf. In 1967 veranderde de rechtsvorm van de staatsmijnen in een naamloze vennootschap. Het bedrijf ontwikkelde zich in de onderzochte periode tot een multi-sectorele houdstermaatschappij met dochterondernemingen in het buitenland (zie bijlage 3.1). De afzonderlijke bedrijven waren actief in de koolwinning, de briketproduktie, de cokesproduktie, de gasdistributie en de chemie (in het bijzonder de stikstofbinding en de produktie van caprolactam en polyetheen). Het bedrijf participeerde verder in kolenhandelsmaatschappijen, verkooporganisaties en transportmaatschappijen. Kruiselingse subsidies en onderlinge leveranties kenmerkten dit overheidsbedrijf.

Ministeriële instructies regelden de relaties tussen de verantwoordelijke minister en de directie van de staatsmijnen. Deze instructies zijn, in tegenstelling tot de organisatieregelingen van de andere staatsbedrijven, nooit gepubliceerd. ${ }^{11}$ De staatsmijnen beschikten lange tijd over een grote mate van zelfstandigheid binnen de rijksoverheid. Na de Tweede Wereldoorlog beperkten de Ministers van Economische Zaken G.W.M. Huysmans (RKSP) en J.R.M. van den Brink (KVP) deze zelfstandigheid. ${ }^{172}$

De Staten-General droegen de formele verantwoordelijkheid voor het functioneren van de staatsmijnen. Tijdens de mondelinge behandeling van de begroting van de staatsmijnen voor het dienstjaar 1949 in de Eerste Kamer der statenGeneraal uitte het kamerlid G. Vixseboxe (CHU) de klacht dat de leden van de staten-Generaal geen duidelijk inzicht kregen in het rendement en de efficiëntie van de verschillende bedrijfsonderdelen van dit staatsbedrijf. Hij drong aan op een door een onafhankelijk orgaan opgesteld bedrijfseconomisch rapport. De directie van de Staatsmijnen verwierp zijn kritiek en hield vast aan de eenheid van het gehele staatsmijncomplex, ook bij de verantwoording over het gevoerde beleid. ${ }^{173}$

In tegenstelling tot de markt voor chemische produkten werd de Nederlandse kolenmarkt gekenmerkt door prijsregulering. De overheidsregulering begon in 1916 met het Koninklijk Besluit tot instelling van de Rijkskolendistributie, die onder leiding kwam te staan van de directeur-voorzitter van de Staatsmijnen. ${ }^{174}$ In 1949 richtte het kabinet Drees-Van Schaik het Brandstoffenegalisatiefond (BEF) op met als doel prijsverlagende subsidies toe te kennen aan geimporteerde 
kolen. Om de verkoop van Nederlandse en geïmorteerde kolen tegen dezelfde prijzen mogelijk te maken, introduceerde de overheid een stelsel van mengprijzen. De mijnondernemingen droegen het verschil tussen de mengprijs en de opbrengstprijs af aan het Fonds. Na een overgangsperiode voor het BEF beschikte de Europese Gemeenschap voor Kolen en Staal (EGKS) vanaf 1955 over de bevoegdheid de Nederlandse kolenprijzen te bepalen. ${ }^{175}$

\section{2 structuranalyse}

De structuuranalyse van de staatsmijnen betreft een analyse van de verdeling van de publieke eigendomsrechten. De nadruk ligt daarbij op het recht om toezicht uit te oefenen op de aankopen, de prestaties van de produktiefactoren, de samenstelling van het team van producenten en het recht aanspraak te mogen maken op de winst. De bijgevoegde organogrammen 3.1 tot en met 3.3 geven een schematisch overzicht van het stelsel van verantwoording en toezicht bij de staatsmijnen.

a. Toezicht op de aankopen en de prestaties van de produktiefactoren.

Vanaf de oprichting beschikten de staatsmijnen over een uitzonderingsmogelijkheid op de regel van de openbare aanbesteding van werken en leveranties. De verklaring hiervoor was dat de mijnbouw een deskundigheid vereiste, die bij openbare inschrijving moeilijk zou zijn vast te stellen. De Comptabiliteitswet van 1927 verplichtte de rijksoverheid tot openbare aanbesteding van alle, niet in eigen beheer uit te voeren werkzaamheden en leveranties. In 1929 verzocht de directie aan Minister van Waterstaat H.W. van der vegte (AR) een Koninklijk Besluit uit te vaardigen, dat de voortzetting van de bestaande praktijk toestond. ${ }^{176}$

De ministeriële instructie van 1937 machtigde de minister om toezicht uit te oefenen over de aankoop van produktiefactoren. Dit resulteerde in het ontstaan van een procedureel stelsel van externe en interne machtigingen. De procedure voor het verkrijgen van een externe machtiging hield in dat de directie vóor de aanvang van elk dienstjaar aan de minister een werkplan ter goedkeuring aanbood van de in dat jaar aan te leggen en/of uit te breiden werken met bijvoeging van een kostenraming. Alvorens over te gaan tot machtiging, verzocht de minister de Mijnraad om een advies. Hij bepaalde welke projecten in het werkplan niet mochten worden uitgevoerd zonder een bijzondere ministeriële machtiging. ${ }^{177}$ In dit stelsel van externe machtiging moesten aanvragen tot een bijzondere ministerielle machtiging voor bestellingen in het buitenland met redenen omkleed aan de minister te worden voorgelegd. ${ }^{178}$

Het stelsel van interne machtiging regelde de toestemmingsprocedures voor de realisatie van investeringen binnen het bedrijf. Het stelsel van interne machtiging had tot doel om bij een verder doorgevoerde delegatie van bevoegdheden de eenheid van het totale beleid te handhaven. ${ }^{179}$ 
Veranderingen in de procedure voor het verkrijgen van externe machtiging leidden tot wijzigingen in procedures voor interne machtiging. Het was echter niet geoorloofd een werk uiteen te laten vallen in afzonderlijke bestellingen, zodat de verplichting tot het vragen van een machtiging of het achteraf kennis geven kon worden ontdoken. ${ }^{180}$ Het stelsel van interne machtiging functioneerde niet zonder problemen. Het kwam voor dat aan de directie voorgelegde investeringsplannen in een zo ver gevorderd stadium van voorbereiding verkeerden, dat de beslissing in feite reeds was genomen. ${ }^{181}$

In 1955 leidde en verandering in de ministeriële instructie van 1937 tot een aanpassing van het stelsel van externe machtigingen en goedkeuringen. De directie verwierf hierdoor grotere bevoegdheden voor de afdoening van aanlegwerken ${ }^{182}$. Tot de werken behoorden: a. de uitbreiding van gebouwen en apparatuur, b. de verbetering en modernisering, en $c$. het onderhoud. De categorieën $a$ en $b$ makten deel uit van de zogenaamde Aanlegwerken ( $A$-werken) en werden op de kapitaalrekening geboekt. De categorie c ressorteerde onder de zogenaamde B-werken. In 1960 verdeelde het stelsel van interne machtigingen uit 1955 de kosten voor de Aanleg- en B-werken over de volgende categorieën:

A. projecten van honderdduizend gulden of meer,

B. projecten van vijftig- tot honderdduizend gulden, en

C. projecten tot vijftigduizend gulden.

De goedkeuringsprocedure bestond uit drie delen:

Deel I : regelde de machtiging tot aanpak van een werk. Dit deel machtigde de aanvrager tot het treffen van alle voorbereidende werkzaamheden, voorafgaande aan de realisatie en gaf principielle toestemming voor plaatsing op het "Werkplan Aanleg".

Deel II : diende voor het verkrijgen van een machtiging om over te gaan tot realisatie van een reeds in deel I goedgekeurd werk.

Deel III : bevatte de machtiging tot opdracht van het werk of een gedeelte hiervan aan een bepaalde inschrijver. ${ }^{183}$

Projecten onder A behoefden de goedkeuring van de hoofddirectie in alle delen. Voor de projecten onder $B$ was slechts toestemming van de chefs bedrijfseconomische afdeling en de chef inkoop vereist bij deel I. Voor deel. II was de procedure identiek aan die van de tot $A$ behorende werken. Deze functionarissen besloten eveneens bij deel III, als de opdracht aan de laagste inschrijver werd verleend. In andere gevallen besliste de hoofddirectie. Voor categorie $c$ verstrekte de chef van het desbetreffende bedrijf voor alle delen de toesteming voor rechtstreeks ten behoeve van de produktie uit te voeren werken tot een bedrag van tienduizend gulden. Tot vijftigduizend gulden berustte de bevoegdheid bij de bedrijfsdirecteuren, de chef bedrijfseconomische afdeling 
en de chef inkoop. Voor de niet rechtstreeks met de produktie verband houdende werken van bijzondere aard was voor deel II toestemming van de hoofddirectie nodig. ${ }^{184}$

Voor kapitaalwerken was de hoofddirectie gehouden aan een door de staten-Generaal goedgekeurd begrotingsbedrag en een door de Minister van Economische Zaken aanvaard werkplan met een specificatie van de werken. Projecten lager dan honderdduizend gulden mochten vrij aan het werkplan worden toegevoegd, voorzover deze het goedgekeurde totale bedrag niet overschreden. ${ }^{185}$

Na afloop van het dienstjaar stelde de directie ten behoeve van de minister een toelichtende nota op over de realisatie van het werkplan. De directie droeg er zorg voor, dat alle bestellingen en aanbestedingen werden geplaatst bij, respectievelijk gegund aan de laagste inschrijver. Was dit niet mogelijk in gevallen van meer dan honderdduizend gulden dan moest dit met opgaaf van redenen worden gemeld aan de minister. ${ }^{186}$

$\mathrm{Na}$ de verzelfstandiging in 1967 oefenden de Raad van Commissarissen en de Vergadering van Aandeelhouders toezicht uit op de aankoop van de produktiefactoren. De hoofddirectie stelde jaarlijks een investerings- en een financieringsplan op, die moesten worden goedgekeurd door de Raad van Commissarissen. De plannen werden vervolgens ter goedkeuring aan de Algemene Vergadering van Aandeelhouders voorgelegd. Niet in het goedgekeurde investeringsplan opgenomen investeringen van boven de honderdduizend gulden moesten worden goedgekeurd door de Raad van Commissarissen. ${ }^{187}$

Ter illustratie van het aantal verstrekte opdrachten boven de tienduizend gulden geeft het kolommendiagram in figuur 3.1 de Aanleg- en B-werken (de zogenaamde niet-onderhoudswerken). Het diagram onderscheidt opdrachten die niet werden toegekend aan de laagste inschrijver (categorie I), opdrachten, die niet in concurrentie tot stand zijn gekomen (categorie II), en meerwerkopdrachten op lopende bestellingen (categorie III). 


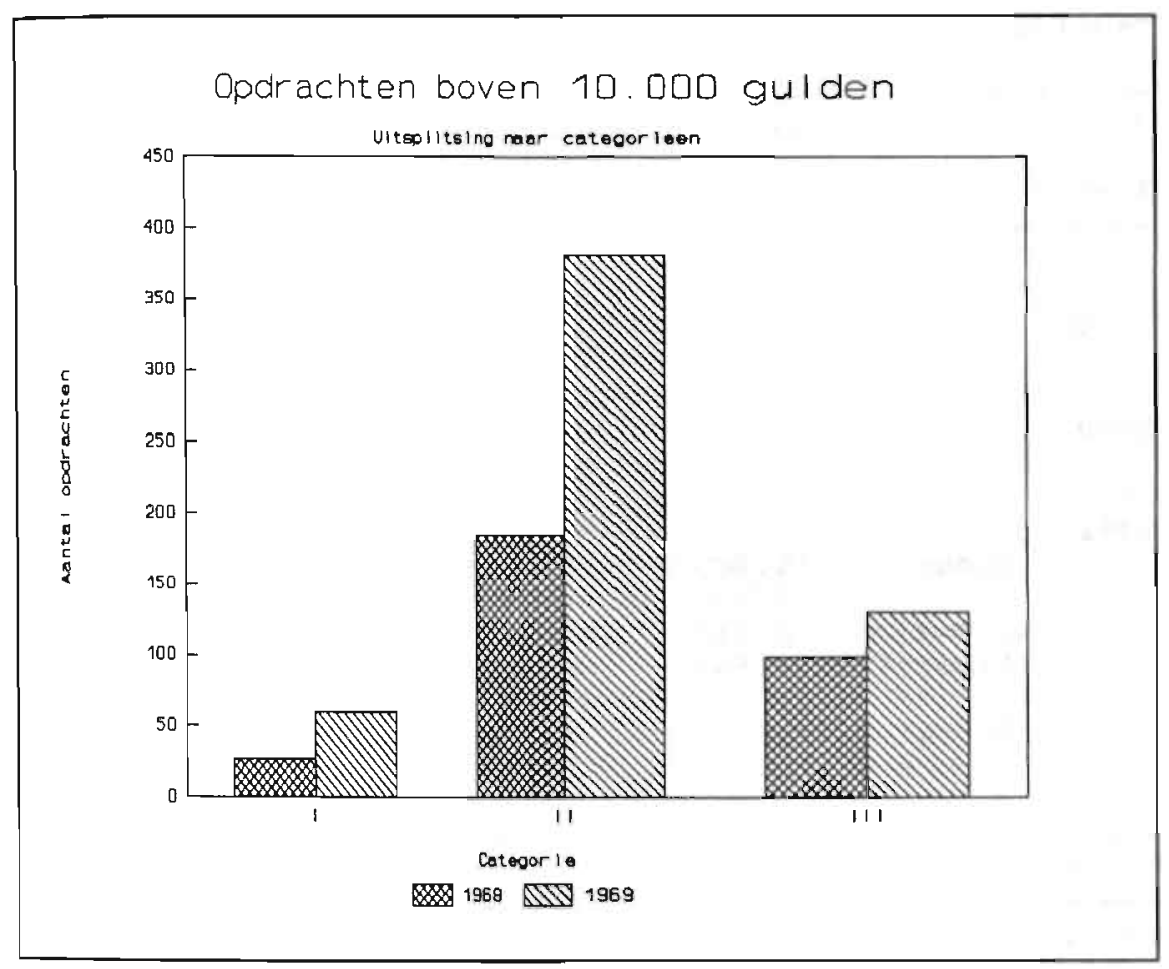

Figuur 3.1

Het aandeel van de jaarlijkse investeringen, dat leidde tot aankopen bij buitenlandse industrieën, varieerde. Daarnaast hadden de investeringen indirect via Nederlandse ondernemingen aankopen en bestellingen in het buitenland tot gevolg. De navolgende tabel 3.1 geeft de ontwikkeling van de importquote van de staatsmijnen over de periode 1959 tot en met 1964 weer. 
Tabel 3.1 Staatsmijnen: importquote van de totale bestellingen over de periode 1959 tot en met 1964.

\begin{tabular}{|c|c|c|c|c|c|}
\hline \multirow[t]{2}{*}{ Jaar } & & $\begin{array}{l}\text { Machine } \\
\text { Mijnen }\end{array}$ & $\begin{array}{l}\text { en installaties } \\
\text { Chem. bedrijven }\end{array}$ & Totaal & \multirow[t]{2}{*}{$\begin{array}{l}\text { Import } \\
\text { quote }\end{array}$} \\
\hline & & & x $1000 \mathrm{gld}$ & & \\
\hline 1959 & $\begin{array}{l}\text { Totaal } \\
\text { Import }\end{array}$ & $\begin{array}{r}20.750 \\
5.400\end{array}$ & $\begin{array}{r}22.400 \\
7.500\end{array}$ & $\begin{array}{l}43.150 \\
12.900\end{array}$ & 30 \\
\hline 1960 & $\begin{array}{l}\text { Totaal } \\
\text { Import }\end{array}$ & $\begin{array}{r}23.801 \\
3.850\end{array}$ & $\begin{array}{r}48.851 \\
8.150\end{array}$ & $\begin{array}{l}72.652 \\
12.000\end{array}$ & 17 \\
\hline 1961 & $\begin{array}{l}\text { Totaal } \\
\text { Import }\end{array}$ & $\begin{array}{r}25.641 \\
4.900\end{array}$ & $\begin{array}{l}53.333 \\
12.900\end{array}$ & $\begin{array}{l}78.974 \\
17.800\end{array}$ & 23 \\
\hline 1962 & $\begin{array}{l}\text { Totaal } \\
\text { Import }\end{array}$ & $\begin{array}{r}28.830 \\
2.543\end{array}$ & $\begin{array}{r}43.450 \\
9.800\end{array}$ & $\begin{array}{l}72.280 \\
12.343\end{array}$ & 17 \\
\hline 1963 & $\begin{array}{l}\text { Totaal } \\
\text { Import }\end{array}$ & $\begin{array}{r}23.791 \\
2.250\end{array}$ & $\begin{array}{r}53.462 \\
6.950\end{array}$ & $\begin{array}{r}77.253 \\
9.200\end{array}$ & 12 \\
\hline 1964 & $\begin{array}{l}\text { Totaal } \\
\text { Import }\end{array}$ & $\begin{array}{l}7.000 \\
1.900\end{array}$ & $\begin{array}{l}92.500 \\
41.000\end{array}$ & $\begin{array}{l}99.500 \\
42.900\end{array}$ & 43 \\
\hline
\end{tabular}

Bron: Staatsmijnen, Enige national-economische consequenties van het investeringsprogramma van de Staatsmijnen, 12 februari 1965; Concern Archief DSM, Comptabele en financiële aangelegenheden, 1960-1969, inv. nr. 38 .

Uit tabel 3.1 blijkt het stijgende aandeel van de import van de chemische bedrijven van de staatsmijnen. Geraamd werd dat de totale importquote ten gevolge van het werkplan 1965 53\% zou bedragen van de totale investeringen van de Staatsmijnen. ${ }^{188}$

De ontwikkeling van de bovenstaande statistische gegevens kan niet los worden gezien van de politieke en ambtelijke discussie over de rechtsvorm van de staatsmijnen. Verandering van rechtsvorm heeft immers gevolgen voor de inhoud van het recht om toezicht te mogen uitoefenen op de aankopen en de prestaties van de produktiefactoren.

bl. Toezicht op de produktieresultaten.

Vanaf 1920 werd een begin gemaakt met de wetenschappelijke bedrijfsvoering. organisatorisch werd het ondergrondse bedrijf gesplitst in een staf- en en uitvoeringsinstantie. De planning van steenwerk, afbouw en voorbereiding was aanvankelijk onbekend of geschiedde primitief. De hoofdopzichter gaf aanwijzingen voor de aanpak van de werkzaamheden en bepaalde welke stukken voor verkenning in aanmerking kwamen. Na de jaren twintig werd in toenemende mate plaats ingeruimd voor het planbureau. De werkzaamheden vonden 
plaats na voorbereiding en overleg tussen staf en uitvoeringsinstantie. De afzonderlijke mijnbedrijven stelden een vijfjarenplan op voor de ontginning, de ontsluiting, de voorbereiding en de afbouw, met daaraan toegevoegd een kolenvoorraadplan. ${ }^{189}$

De (hoofd)directie vermeldde ramingen van de produktie van kolen en chemische produkten in de voor de staten-Generaal bestemde begroting.

b2. Toezicht op de externe effecten.

De staatsmijnen veroorzaakten verschillende negatieve en positieve externe effecten, zoals bijvoorbeeld milieuverontreiniging en regionale economische ontwikkeling.

Vanaf 1923 industrialiseerde het bedrijf, maar niet zonder gevolgen voor het milieu. ${ }^{190}$ De staatsmijnen loosden op basis van een vergunning van de Gedeputeerde staten van Limburg afvalwater in de Ur. ${ }^{191}$ In de jaren zestig ontstond bij de staatsmijnen voor het eerst aandacht voor milieuinvesteringen ter bestrijding van water- en luchtverontreiniging. De directie vermeldde de milieuvoorzieningen in het werk- en investeringsplan voor 1960. De Minister van Economische Zaken beinvloedde met zijn besluitvorming over het investerings- en werkplan de aanpak van de milieuverontreiniging. De Mijnraad, belast met het toezicht op de staatsmijnen, adviseerde aan de Minister van Economische Zaken de milieuvoorzieningen voortaan aan te duiden als een zogenaamd "sterproject". Een dergelijk project moest dan voor nadere goedkeuring aan de minister worden voorgelegd. ${ }^{192}$

De aanleg van een mijn leidt tot externe effecten voor de regionale economische ontwikkeling. Om deze ontwikkeling mogelijk te maken zijn investeringen in de economische en sociale infrastructuur noodzakelijk. De vraag rijst wie de kosten voor de aanpassing van de infrastructuur buiten de mijnzetel draagt. In 1952 nam het kabinet Drees $I$ het besluit tot de aanleg van de staatsmijn Beatrix voor de exploitatie van het vlodropveld. Het kabinet uitte bij het besluit over de aanleg van de staatsmijn Beatrix de wens de nationale energievoorziening zoveel mogelijk te baseren op de eigen hulpbronnen. De aanleg van de staatsmijn Beatrix bracht infrastructurele aanpassingen met $z$ ich mee voor de Roergemeenten. ${ }^{193}$ Het project staatsmijn Beatrix mocht volgens de directie van de Staatsmijnen niet op dezelfde wijze worden beoordeeld als de andere bedrijfsinvesteringen. De directie schatte de totale investeringskosten in de statismijn Beatrix op 375 miljoen gulden over de periode 1957-1967. ${ }^{194}$ 2ij ging er bij deze schatting van uit dat de overheid de kosten van de infrastructuur buiten de mijnzetel ten laste bracht van de rijksbegroting. De ministerraad had immers in 1952 besloten de investeringskosten voor de sociale en economische infrastructuur buiten de mijnzetel ten laste van de rijksbegroting te brengen. Over de financiering van deze kosten bestond geen duidelijkheid. Een nota van de directie Mijnwezen uit 1959 vermeldt dat de Raad voor de Ruimtelijke ordening, een onderdeel van de ministerraad, besloot deze kosten ten laste te brengen van de Staatsmijnen. ${ }^{14 s}$ De 
staatsmijn Beatrix werd uiteindelijk niet in exploitatie genomen, hetgeen betekende dat een positief extern effect voor de regionale economische ontwikkeling uitbleef. In 1962 werden de schachten geconserveerd. Voor de Roergemeenten had deze afloop financiële consequenties, omdat $z i j$ bij de voorbereiding van de economische ontsluiting hadden nagelaten de vestiging van andere industrieën te stimuleren. ${ }^{196}$

\section{c. Toezicht op het produktieproces.}

De directie stelt onder goedkeuring van de minister de diensten werkvoorschriften op voor beambten en werklieden. ${ }^{197}$

Het toezicht op het produktieproces in de mijnbouw wordt gekenmerkt door een hiërarchie. Verder wordt toezicht op de produktieresultaten mogelijk gemaakt door het gebruik van een systeem van merit-rating en prestatiepremies. Deze premies zouden moeten leiden tot produktiviteitsverbetering en kostenverlaging. Merit-rating vereist controle en coördinatie van beoordelaars. ${ }^{198}$

d. Toezicht op de omvang en de samenstelling van het team van producenten.

Het Koninklijk besluit van 1902 kende aan de Kroon de bevoegdheid toe om personeel op basis van een jaarwedde in dienst te nemen en te ontslaan. De directeur-generaal van de dienst der staatsmijnen stelde personeel op dag-, week- en maandloon aan. ${ }^{199}$ Het Koninklijk besluit van 1907 wijzigde het besluit van 1902. De Kroon verkreeg het recht vaste en tijdelijke ambtenaren op een jaarwedde van twaalfhonderd gulden en hoger aan te stellen en te ontslaan. Tijdelijke ambtenaren, beambten en werklieden werden toen door de directie in dienst genomen en ontslagen. De functie van directeur-generaal verdween. ${ }^{200}$ Een nieuwe regeling van het personeelsbeleid kwam in 1913 tot stand. Voortaan kwam het personeel in dienst op basis van een arbeidsovereenkomst. De minister besliste over de aanstelling van de beambten en de directie besloot over de aanstelling van de werklieden. De Kroon benoemde, schorste en ontsloeg de (hoofd)directie of gaf daartoe machtiging aan de verantwoordelijke minister. ${ }^{201}$

Aan het begin van de jaren vijftig bepaalde elk bedrijf, elke dienst of zelfstandige afdeling mede de samenstelling van het personeel. Daartoe stelden $z i j$ een prognose op van het aantal in het komende jaar noodzakelijk geachte functies voor loongerechtigden. De prognoses werden opgenomen in het personeelsplan. Dit plan bepalde, na goedkeuring door de directie, de maximumbezetting aan werknemers. ${ }^{20}$

Het Buitengewoon besluit arbeidsverhoudingen van 1945 was niet van toepassing op de werknemers bij een publiekrechtelijk lichaam. Dit betekende voor de directie van de staatsmijnen dat $z i j$ in het geval van personeelsvermindering geen toestemming nodig had van de directeur van het Gewestelijk Arbeidsbureau. ${ }^{203}$ Vanaf 1967 beschikte de Raad van Commissarissen over het recht de dienstbetrekking van een aanmerkelijk aantal werknemers van een door de vennootschap gedreven onderneming of zelfstandig ondernemingsonderdeel te 
beëindigen. ${ }^{204}$

f. Aanspraak op de winst.

Het recht on aanspraak te maken op de winst moet worden onderscheiden van de winstbestemming.

De staat beschikte over het recht aanspraak te maken op de winst van de staatsmijnen. De (hoofd)directie deed jaarlijks een voorstel over de winstbestemming aan de Minister van Economische zaken toekomen. De winstbestemming omvatte de vennootschapsbelasting, het dividend, de uitkering aan het personeel, de voorziening bijzondere doeleinden en de algemene reserve. De Minister van Economische Zaken besloot over de winstbesteming, na overleg met de Minister van Financiën. Deze minister maakte de hoogte van het uit te keren dividend kenbaar. ${ }^{205}$

Vanaf de oprichting van de staatsmijnen vormden de salariëring en de regeling van de tantièmes voor de directie een belangrijk onderwerp van discussie tussen de verantwoordelijke minister en de Mijnraad. Deze laatste maakte in 1911 bezwaren tegen de uitkering yan tantièmes aan de directieleden, omdat $2 i j$ vreesde voor een conflict tussen het eigen belang en het zakelijke belang. ${ }^{200}$ De directie van de Staatsmijnen vestigde in 1918 en 1919 de aandacht van de Ministers van Landbouw, Handel en Nijverheid op de wenselijkheid een tantième-regeling in te stellen. ${ }^{\circ}$ De directie verkreeg het recht aanspraak te maken op een van de bedrijfsresultaten afhankelijke gratificatie als aanvulling op het salaris, zonder dat hiervoor een regeling bestond. ${ }^{208}$

De ambtenaren werkzaam bij de staatsmijnen vielen niet onder het Bezoldigingsbesluit rijksambtenaren van 1934. Van 1936 tot en met 1940 ontving de directie een vast salaris van veertienduizend gulden, een gratificatie van tienduizend gulden (direct uit te keren aan het einde van het boekjaar) en een premie afhankelijk van het bedrijfsresultaat. Voor de premie werd de formule gehanteerd dat per duizend gulden salaris $1,9375 / 100$ \& van de gemaakte winst tot een maximum van 87,5 van het salaris werd uitgekeerd. Onder winst werd verstaan het bruto-overschot verminderd met de rente van de obligatielening en een bedrag van 5,7 miljoen gulden aan af schrijvingen. ${ }^{200}$

In 1964 bepaalde de Minister van Economische Zaken dat voor elk procent boven de vijf procent dividend over 125 miljoen gulden een premie van vijfduizend gulden werd uitgekeerd an elk directielid. Het uit te keren bedrag mocht maximaal vijftigduizend gulden bedragen. De uitkering van de premie vond plaats nadat de Minister van Economische Zaken de balans en de verlies- en winstrekening had goedgekeurd. ${ }^{210}$ De vakorganisaties maakten voor de werknemers eveneens aanspraken op de winst in de vorm van winstdeling en spaarregelingen.

De winst, blijkend uit de door de Algemene vergadering van Aandeelhouders vastgestelde winst- en verliesrekening, stond vanaf 1967 ter beschikking van de Algemene Vergadering van Aandeelhouders. ${ }^{21}$ De statuten vermeldden geen regeling over de uitkering van tantièmes en winsten aan de hoofddirectie. De Algemene Vergadering van Aandeelhouders stelde de bezoldiging 
en de andere arbeidsvoorwaarden van de leden van de hoofddirectie vast. De Raad van Commissarissen diende daartoe een voorstel in. ${ }^{212}$ Een commissie bestaande uit Gedelegeerd Commissarissen en de vice-voorzitter formuleerde in 1967 de arbeidsvoorwaarden. Deze bestonden uit een verhoging van het vaste salaris met 40 procent en een aanpassing van de tantième-regeling aan het tot 300 miljoen verhoogde aandelenkapitaal. De commissieleden motiveerden de wenselijkheid van de salarisverhoging met de ontwikkeling van het algemene prijsniveau en het salarisniveau van vergelijkbare functionarissen in andere Nederlandse ondernemingen. De Raad van Commissarissen aanvaardde het voorstel van de commissie. ${ }^{213}$

De Minister van Economische Zaken was statutair bevoegd de Commissarissen een jaarlijkse vergoeding toe te kennen. Minister J.A. Bakker (AR) had er in 1967 geen bezwaar tegen als de verschuldigde commissarissenbelasting voor rekening van de onderneming kwam. ${ }^{214}$ De Gedelegeerd Commissarissen droegen hun inkomsten af aan het ministerie. 215

Vanaf 1950 was de verlening van subsidies door de staatsmijnen gebonden aan een in de externe begroting opgenomen post, die niet mocht worden overschreden zonder ministeriële machtiging. ${ }^{210}$ Tijdens de behandeling van de begroting van de staatsmijnen in 1952 verzochten de leden van de begrotingscommissie van de Tweede Kamer der Staten-Generaal Minister van Economische Zaken Zijlstra om informatie over de toegekende subsidies. Hij legde een lijst van door de staatsmijnen gesubsidieerde instellingen ter inzage op de Griffie van de Tweede Kamer der Staten-Generaal. ${ }^{217}$

\subsection{Analyse van de kenbaar gemaakte doeleinden}

De analyse van de kenbaar gemaakte doeleinden van de politieke eigenaren en de directie van de staatsmijnen bevat de verzameling en definiëring van de doeleinden gevonden in financiële verslagen, beleidsdocumenten en kamerstukken. Alvorens tot deze analyse over te gaan, volgen eerst een behandeling van de doeleinden die ten grondslag liggen aan de oprichting van de staatsmijnen en een behandeling van de statutaire doeleinden.

De memorie van toelichting bij de Wet betreffende exploitatie van staatswege van de steenkolenmijnen in Limburg (1901) vermeldde als redenen voor de overheidsexploitatie: 1. de zekerheid dat de in Nederland gewonnen steenkool ten goede kwam aan de Nederlandse behoeften, 2. het verwerven van inkomsten voor de schatkist, 3. het onvoldoende benut worden van de particuliere concessies, terwijl de buitenlandse invloed te groot was, 4 . staatsexploitatie was in het belang van de consument, die hierdoor minder afhankelijk werd van buitenlandse leveranciers (bijvoorbeeld: het kolensyndicaat van Rijnland-Westfalen), en 5 . in tegenstelling tot de particuliere ontginning kon de overheid gelijke tred houden met de mogelijkheid van voorziening in Nederlandse arbeidskrachten. 218

Tot 1967 werden de betrokken ministers en directieleden van de staatsmijnen bij de beschikking over hun beleidsvrijheid 
respectievelijk autonomie geconfronteerd met de ministeriële instructie. De in 1937 geformuleerde doelstelling als nevenvoorwaarde voor beleidsvrijheid luidde dat de directie er zorg voor zou dragen het beheer van de staatsmijnen zoveel mogelijk te voeren in overeenstemming met de gestie van een particulier grootbedrijf. In 1960 werd "het beheer te voeren" vervangen door "te besturen", hetgeen een ruimer begrip was. ${ }^{219}$ Onderkend werd dat de hoofddirectie van de staatsmijnen wel eens uitspraken wilde doen, waarmee zij als "ondernemer" het belang van het bedrijf of de bedrijfstak wilde dienen. Het doel dat daarmee werd nagestreefd, hoefde echter niet overeen te stemmen met het door de minister of het kabinet gevoerde beleid. Het wekte de indruk dat het kabinet de beslissingsbevoegdheid uit handen had gegeven aan de directie van de staatsmijnen. 20

De verandering van rechtsvorm in 1967 had tot gevolg dat de doelstelling in de ministeriële instructie als nevenvoorwaarde werd vervangen door statutaire doeleinden, namelijk:

a. het werkzaam zijn op het terrein van de mijnbouw, in het bijzonder de steenkolenmijnbouw, de handel en het transport;

b. het oprichten, verwerven en financieren van, het deelnemen in en het voeren van de directie over andere ondernemingen; en

c. het streven naar een welvaartspolitiek op lange termijn en naar een maximal nuttige werkgelegenheid. ${ }^{221}$

De Commissie Kapitaalpositie staatsmijnen besefte dat in de relatie tussen de rijksoverheid en dit staatsbedrijf de vrijheid voor de directie om een eigen beleid te voeren van cruciaal belang was. De commissie concludeerde dat de Staatsmijnen moesten beschikken over een grote mate van vrijheid voor de dagelijkse leiding en de algemene gang van zaken teneinde de door de rijksoverheid kenbaar gemaakte plannen op doeltreffende wijze te verwezenlijken. Volgens deze commissie beschikte de directie in 1949 over de nodige vrijheid om de opdrachten van de overheid te implementeren. 22

\subsubsection{Kenbaar gemaakte doeloinden.}

het kabinet maakte de navolgende doeleinden kenbaar:

a. Investeringen, welke bijdragen tot een directe produktieverhoging dienen voortgang te vinden, waarbij het afschrijvingsbestanddeel in de kostprijs van het produkt relatief gering is, tenzij het een schaarse grondstof betreft (1952). ${ }^{22 .}$

b. Investeringen, welke in belangrijke mate bijdragen tot de rationalisatie van de produktie, dienen voortgang te vinden. 
c. Investeringen van niet direct produktief karakter en niet strikt noodzakelijk onderdeel van de investeringen ad 1 en 2 , dienen zoveel mogelijk achterwege te blijven of te worden gesteld (1953). ${ }^{224}$

De kenbaar gemaakte doeleinden van de directie van het staatsbedrijf $z i j n$ respectievelijk:

d. Reeds lang houdt ons de vraag bezig op welke wijze het gasdebiet in het bestaande verzorgingsgebied zou kunnen worden uitgebreid (1936). ${ }^{225}$

e. Voorts worden teneinde de levensduur van de mijnen te verlengen in toenemende mate dunne en onzuivere kolenlagen in de exploitatie betrokken hetgeen steeds hogere kosten meebrengt (1953)..$^{226}$

f. Het sociale beleid der staatsmijnen wordt gevoerd volgens het subsidiariteitsbeginsel. Dit leidt ertoe dat men zich bij voorkeur beperkt tot het stimuleren en activeren van het particulier initiatief en dat men tot het zelf ter hand nemen van sociale activiteiten en het zelf oprichten van sociale instellingen slechts overgaat in die gevallen, waarin het particulier initiatief tekort schiet en dan nog met de vooropgezette bedoeling tot overdracht aan de daarvoor aangewezen particuliere instantie over te gaan, zodra dit verantwoord geacht wordt (1954).227

g. Het bevorderen van sociale voorzieningen, die niet tot het werkterrein van de staatsmijnen behoren, doch in het belang van het personeel worden geacht.

Het uit een oogpunt van arbeidsklimaat, arbeidsrust en de gebondenheid aan de streek bevorderen van het totstandkomen van een goed geoutilleerde maatschappelijke entourage (1954). ${ }^{228}$

h. Weliswaar is vanaf het begin het streven der staatsmijnen erop gericht geweest in deze particulier initiatief te stimuleren, maar een bewust beleid van distanciëring op het gebied van "periferie"-activiteiten kan eerst worden gevolgd naarmate de sociaal-economische structuur der mijnstreek zich heeft aangepast aan de industriële ontwikkeling (1958). ${ }^{229}$

i. Op het gebied van de arbeidsvoorwaarden is ons beleid gericht op een gestage, harmonische ontwikkeling (1955).230

j. Het streven is erop gericht de concurrentie met andere energiebronnen te kunnen doorstaan (gaspolitiek) (1957). 
$k$. Het beleid blijft er dan ook op gericht de organen van de publiekrechtelijke bedrijfsorganisatie in de mijnindustrie tot verdere ontplooing te brengen (1957). .231

1. Evenals de eigenbouwregeling is de spaarregeling bij de staatsmijnen in het leven geroepen om de vorming van persoonlijk bezit door het personeel te stimuleren (1957). . $32^{23}$

m. Mede in het kader van het streven naar behoud van werkgelegenheid is de netto-produktie van steenkolen voor 1960 gesteld op 7.500 .000 ton $(1960) .{ }^{233}$

n. De research, die ten behoeve van de mijnbedrijven wordt verricht door het Centraal proefstation, is in toenemende mate gericht op de ontwikkeling van technische apparatuur en hulpmiddelen ten behoeve van de mechanisatie in de ondergrondse en bovengrondse bedrijuen (1961).

Het speurwerk, gericht op de verbetering van de bestaande chemische produkten en de ontwikkeling van nieuwe werkwijzen, nam in het afgelopen jaar in omvang toe (1961).

De research op het gebied van kunstmeststoffen had vooral betrekking op de bereiding van produkten, welker eigenschappen en samenstelling tegemoet komen aan de zich wijzigende omstandigheden in de landbouw (1961).234

o. De uitkomsten van eigen researchwerk en de in eigen bedrijven verkregen ervaring en kennis vormen voor verdere uitbreidingen een hechte grondslag, maar, zoals uit het voorgaande blijkt, zal het daarnaast veelal nodig zijn aanvullende kennis en kunde voor een verantwoorde verwezenlijking van anderen te verwerven (1961)..$^{235}$

p. De Staatsmijnen hebben in de afgelopen periode nog meer dan voorheen het accent van hun activiteiten gelegd op een expansie van de chemische sector van het bedrijf in zuid-Limburg en op een uitbreiding van hun belangen ook buiten de landsgrenzen (1962). ${ }^{236}$

q. Een belangrijk gedeelte van de research-activiteiten was gericht op het onderzoek naar en het tot ontwikkeling brengen van nieuwe produkten (1962). ${ }^{237}$

r. De staatsmijnen streven naar een versteviging van hun positie ter verzekering van de economische stabiliteit van het gehele concern (1962). ${ }^{238}$ 
s. Ten einde de weerstandskracht van de onderneming te versterken is een dotatie aan de reserves en voorzieningen geraamd van 15 miljoen en is de dividenduitkering aan het Rijk p.m. opgenomen (1964). ${ }^{239}$

$t$. In het geval van de staatsmijnen wordt deze wenselijkheid echter nog onderstreept door de noodzaak om - zeker in de eerstkomende jaren - een 20 groot mogelijke groei van werkgelegenheid en rentabiliteit op dit gebied na te streven, gelet op de bijzondere moeilijkheden, waarvoor de onderneming zich ten aanzien van deze beide punten in andere bedrijfssectoren gesteld ziet $(1965) .240$

u. Staatsmijnen hebben zich in het afgelopen jaar ingezet voor het op gang brengen van de noodzakelijke structuurwijziging in het industriële patroon van zuidLimburg $(1966) .241$

v. DSM ging voort ook buiten het eigen ondernemingsverband de werkgelegenheid in Limburg te bevorderen (1968). . $^{242}$

w. Het voornaamste doel van de reorganisatiemaatregelen en het kritisch bezien van personeelsbezettingen in de chemie is dan ook gericht op een zuiniger beleid en niet in de eerste plaats op het afvloeien van personeel $(1969) \cdot 243$

$x$. Het beleid van DSM blijft gericht op minimalisering van de te betalen vennootschapsbelasting (1969). ${ }^{244}$

\subsubsection{Uit de structuranalyse afgeleide doeleinden.}

De structuuranalyse maakt het mogelijk de doeleinden, verbonden aan de verdeling van de publieke eigendomsrechten, vast te stelien.

De navolgende doeleinden kunnen worden afgeleid uit het recht toezicht te mogen uitoefenen op de aankopen:

1. het verstrekken van opdrachten aan de nationale industrie (deze doelstelling gold tot 1955),

2. het bevorderen van de concurrentie (deze doelstelling was van toepassing tot 1967) en

3. het verstrekken van opdrachten aan bepaalde industrieën (deze doelstelling zou kunnen worden afgeleid uit de toename van het aantal niet in concurrentie verstrekte opdrachten).

Uit het recht toezicht uit te oefenen op het produktieproces kan worden afgeleid:

1. de bevordering van de produktiviteit. 
Het toekennen van het recht aanspraak te maken op een deel van de winst had tot doel:

1. de bevordering van de efficiëntie en

2. het garanderen van de continuïteit van het bedrijf

\subsubsection{Vergelijking van de met beide analyses gevonden doeleinden.}

Uit de vergelijking van de doeleinden, gevonden met beide methoden, blijkt dat er geen gemeenschappelijke doeleinden zijn. Het ontbreken van gemeenschappelijke doeleinden bevestigt dat de directie van de staatsmijnen beschikt over een mate van zelfstandigheid, met andere woorden: autonomie. Deze autonomie blijkt uit de sociale doeleinden $f, g, h, k$ en 1.

\subsection{Beleidsvrijheid}

Naast de staatsmijnen waren vier particuliere ondernemingen betrokken bij de steenkolenmijnbouw, namelijk de NV oranjeNassau Mijnen, de NV Laura en Vereniging, de NV willem en Sophie en de NV Domaniale Mijn. Zij vormden een homogeen oligopolie, met als kenmerken: de produktie van homogene goederen, het bestaan van hoge toetredingsbelemmeringen en door de overheid gereguleerde prijzen (BEF en EGKS). Een homogeen oligopolie met deze kenmerken biedt de directie van een overheidsbedrijf een mate van vrijheid om eigen beleidsdoeleinden na te streven, omdat de kosten van markttoetreding de concurrentie door nieuwe particuliere ondernemingen belemmeren. De premie- en tantièmeregelingen voor de directie van de Staatsmijnen verminderden het streven naar autonomie en bevorderden een commercieel beleid. Tabel 3.2 toont de ontwikkeling van de marktpositie van de staatsmijnen over de periode 1950 tot en met 1970 .

Tabel 3.2 Marktpositie Staatsmijnen in Nederland

\begin{tabular}{ccccccc}
\hline \multicolumn{5}{c}{ Netto kolenproduktie in mln ton } & & $\begin{array}{c}\text { Eigen } \\
\text { verbruik }\end{array}$ \\
Jaar & Nederland & Afzet & Staatsmijnen & Afzet & & \\
\hline 1950 & 12,2 & 6,9 & $7,7(63,1 \%)(1)$ & 3,5 & $(50,7 \%)$ & 4,2 \\
1955 & 11,9 & 5,1 & $7,5(63,0 \%)$ & 2,3 & $(45,1 \%)$ & 4,8 \\
1960 & 12,5 & 4,3 & $7,7(61,6 \%)$ & 1,8 & $(41,9 \%)$ & 5,0 \\
1965 & 11,4 & 3,6 & $6,7(58,8 \%)$ & 1,4 & $(38,8 \%)$ & 4,1 \\
1970 & 4,3 & 1,2 & $1,7(39,5 \%)$ & 0,4 & $(33,3 \%)$ & 0,8 \\
\hline
\end{tabular}

opmerking: (1) Percentage netto-kolenproduktie staatsmijnen van de totale Nederlandse Steenkolenproduktie.

Bron: Staatsmijnen, Bedrijfseconomisch Verslag 1952, 1954 en 1955; Verslag van de Gezamenlijke Steenkolenmijnen, 1960,1965 en 1970. 
De oligopolistische marktvorm makt het mogelijk om met de kwantitatieve prestatie-analyse de technische efficiëntie van de staatsmijnen en de particuliere mijnen te bepalen en te vergelijken. Het bestaan van een premieregeling voor de directie van dit staatsbedrijf doet vermoeden dat er geen significant verschil in technische efficiëntie bestaat met de particuliere mijnbouwondernemingen.

om de vergelijking van de omhullende produktiemogelijkhedencurve c.q. -lijn te bepalen, moet eerst de vergelijking voor de regressiecurve van de mijnbouwondernemingen worden afgeleid. Hiervoor wordt een logaritmische vergelijking gebruikt met als afhankelijke variabele de netto-gemiddelde steenkoolproduktie per effectieve ondergrondse werknemer:

$$
\operatorname{Ln} Y=b_{0}+b_{1} X_{1}+b_{2} \operatorname{Ln} X_{2}+b_{3} \operatorname{Ln} X_{3}+b_{4} X_{4}+b_{5} D_{i}+e .
$$

$Y \quad: Q / L$ Netto-gemiddelde steenkoolproduktie in tonnen

per effectieve ondergrondse werknemer.

$b_{0}:$ Constante.

$X_{1}: Q_{m} / Q$ Procentueel aandeel van de mechanische steenkoolwinning in de netto-produktie van steenkool per onderneming.

$\mathrm{x}_{2} \quad$ : $\quad$ Eigen verbruik elektriciteit in Kwh $\mathrm{x} 1000$.

$X_{3}: Q / N$ Gemiddelde omvang per mijn gemeten in nettogemiddelde steenkoolproduktie.

$\mathrm{X}_{4} \quad$ : $\quad$ Netto-gemiddelde laagdikte in centimeters.

$D_{1}$ : Dummy-variabele: 1: overheidsbedrijf, en

e : : storingsterm.

De gegevens over de mate van mechanisatie zijn ontleend aan het onderzoek van J.M.G. Pieters naar de lonen en bedrijfsresultaten bij de Nederlandse mijnbouwondernemingen. $245 \mathrm{Zij} z i j n$ slechts in beperkte mate beschikbaar: Staatsmijnen (1951 tot en met 1965), Laura en Vereniging ( 1952 tot en met 1965), Oranje Nassau (1951 en 1952, 1960 tot en met 1965), en Willem-Sophia (1954 tot en met 1959). Voor de gegevens wordt verwezen naar de bijlage 3.2.

De parameters in de navolgende vergelijking zijn statistisch significant en geven de vergelijking de navolgende structuur:

$$
\begin{aligned}
& \operatorname{LnY}=-1,345-0,0013 X_{1}+0,168 \operatorname{Ln} X_{2}+0,387 \operatorname{LnX} X_{3}-0,003 X_{4}-0,919 D_{1} \\
& \begin{array}{llllll}
(-1,634) & (2,842) & (4,424) & (5,214) & (2,271) & (7,95)
\end{array} \\
& R_{y .1234 i}=0,93121 \text {. }
\end{aligned}
$$

onder de vergelijking staan tussen haakjes de t-waarden.

Uit de dummy-variabele blijkt het bestaan van een significant verschil tussen de technische efficiëntie van de staatsmijnen en de particuliere ondernemingen. De negatieve richting van de dummy-variabele betekent dat de voorspelde netto-kolenproduktie voor dit overheidsbedrijf steeds met minus 0,919 moet worden gecorrigeerd. 
De vergelijking van de omhullende produktie-mogelijkhedenlijn wordt gevonden door de vergelijking van de regressielijn te verhogen met de maximale restterm, in dit geval 0,1359. De vergelijking van de omhullende lijn luidt:

$\operatorname{LnY}=-1,2091-0,0013 X_{1}+0,168 \operatorname{Ln} X_{2}+0,387 \operatorname{Ln} X_{3}-0,003 X_{4}-0,919 D_{i}$

Tabel 3.3 geeft de ontwikkeling weer van de technische efficiëntie van de verschillende mijnbouwondernemingen.

Tabel 3.3 Efficiëntie bij mijnbouwondernemingen

\begin{tabular}{lcccc}
\hline Jaar & staatsmijnen & $\begin{array}{l}\text { Laura en } \\
\text { Vereniging }\end{array}$ & $\begin{array}{c}\text { Oranje } \\
\text { Nassau }\end{array}$ & $\begin{array}{c}\text { Willem en } \\
\text { Sophie }\end{array}$ \\
\hline 1951 & 0,9838 & - & 0,9870 & - \\
1952 & 0,9742 & 0,9850 & 0,9882 & - \\
1953 & 0,9756 & 0,9855 & - & - \\
1954 & 0,9730 & 0,9827 & - & 0,9770 \\
1955 & 0,9726 & 0,9727 & - & 0,9828 \\
1956 & 0,9708 & 1,0000 & - & 0,9763 \\
1957 & 0,9597 & 0,9673 & - & 0,9717 \\
1958 & 0,9674 & 0,9623 & - & 0,9786 \\
1959 & 0,9762 & 0,9671 & - & 0,9810 \\
1960 & 0,9846 & 0,9859 & 0,9821 & - \\
1961 & 0,9897 & 0,9859 & 0,9845 & - \\
1962 & 0,9784 & 0,9772 & 0,9670 & - \\
1963 & 0,9862 & 0,9723 & 0,9713 & - \\
1964 & 0,9853 & 0,9729 & 0,9693 & - \\
1965 & 0,9923 & 0,9723 & 0,9765 & - \\
\hline
\end{tabular}

Uit de cijfers van tabel 3.3 blijkt dat in 1952 de particuliere mijnbouwonderneming oranje-Nassau beschikte over een hogere mate van technische efficiëntie dan de Laura en Vereniging en de staatsmijnen. In 1955 en over de periode van 1957 tot en met 1959 realiseerde de mijnbouwonderneming willem en Sophie de hoogste mate van technische efficiëntie, terwijl de Staatsmijnen dit bereikten in de periode van 1961 tot en met 1965 .

Een verklaring voor de lagere technische efficiëntie van de staatsmijnen over de periode 1951 tot en met 1960 wordt aangetroffen in een nota uit 1952 van Minister van Economische Zaken Zijlstra, gericht aan de Tweede Kamer der statenGeneraal. Hierin lichtte hij toe dat de voortzetting van de afbouwpolitiek van na de bevrijding niet meer mogelijk was. Voortzetting van dit beleid was economisch niet verantwoord gelet op de levensduur van de mijnen. Te snel zou moeten worden overgegaan tot de exploitatie van dieper gelegen lagen, waarbij de niet ontgonnen lagen op geringere diepte verloren zouden gaan. Om deze reden begonnen de staatsmijnen in 1952 in versterkte mate met de exploitatie van minder goede lagen. De afbouw van de minder goede lagen ging gepaard met een lagere netto-produktie. Deze zou volgens Minister Zijlstra samengaan met een kostprijs boven die van 1951 en $1952 .{ }^{240}$

De exploitatie van minder goede lagen verminderde de 
rentabiliteit van de steenkoolexploitatie door de staatsmijnen en leidde mogelijk tot winstderving. Dit laatste kan echter niet worden vastgesteld aan de hand van de bedrijfseconomische- en de jaarverslagen. Uit deze verslagen valt niet af te leiden welk gedeelte van het eigen vermogen werd aangewend voor de mijnbouw.

Reeds in de beginjaren stond de rentabiliteit van de staatsmijnen ter discussie in de staten-Generaal. Naast de balans publiceerden de staatsmijnen tot en met 1931 een zogenaamde rente-op-rente berekening, die aansloot bij de benadering van de "staat als geldschieter". De rente-op-rente berekening vond plaats over het door de overheid verstrekte kapitaal. De directie was niet verplicht de rente onder de uitgaven van het staatsbedrijf te brengen, als de geinvesteerde hoeveelheid kapitaal maar kon worden vastgesteld. Het winstsaldo werd in mindering gebracht op de rente. De vermindering werd één jaar vertraagd doorgevoerd nadat het winstsaldo in 's Rijksschatkist was gestort. Het winstsaldo over 1914 werd bijvoorbeeld in mindering gebracht op de renteberekening tot en met $1915 .{ }^{247}$ De rente op de alternatieve aanwendingen van het verstrekte kapitaal kan worden beschouwd als de alternatieve kosten van de mijnexploitatie door de Nederlandse stat. In tabel 3.4 wordt de gederfde winst met een rente-op-rente berekening bepaald door de winst in mindering te brengen op de rente van hetzelfde jaar.

Tabel 3.4 Gederfde winst in guldens als matstaf voor beleidsvrijheid.

\begin{tabular}{lccrc}
\hline Jaar & Winst & $\begin{array}{l}\text { Totale } \\
\text { rente }\end{array}$ & $\begin{array}{l}\text { Gederfde } \\
\text { winst (1) }\end{array}$ & $\begin{array}{l}\text { Rente } \\
\text { percentage }\end{array}$ \\
\hline 1910 & 111.091 & 228.021 & -116.929 & 3,5 \\
1915 & 1.000 .000 & 695.012 & 304.987 & 3,5 \\
1920 & 3.900 .000 & 3.324 .855 & 575.144 & 5,0 \\
1925 & 0 & 4.069 .512 & -4.069 .512 & 5,0 \\
1930 & 3.854 .809 & 4.239 .000 & -384.191 & 4,5 \\
\hline
\end{tabular}

Opmerkingen: De gederfde winst is het verschil tussen de winst en de totale rente, als matstaf voor de alternatieve kosten.

Bron: Staatsmijnen, Bijlage F, Jaarverslag over 1931.

De Bedrijuenwet van 1912 was niet van toepassing op de Staatsmijnen als tak van dienst. In 1913 vroeg Minister van Financiën M.J.C.M. Kolkman aan Minister van Landbouw, Nijverheid en Handel A.S. Talma of het niet wenselijk zou zijn de staatsmijnen aan te wijzen als staatsbedrijf in het kader van de Bedrijvenwet. De Minister van Landbouw, Nijverheid en Handel bleek echter tegen de toepassing van de Bedrijvenwet te zijn, omdat deze was gebaseerd op het standpunt dat staatsbedrijven 3,5 of $3,75 \%$ rente moesten realiseren, voordat van winst kon worden gesproken. Er zou sprake zijn van verlies als de rentabiliteit van de investeringen lager was dan de 
genoemde percentages. Van dit standpunt kon volgens Minister Kolkman niet worden afgeweken. ${ }^{248}$

Tabel 3.5 vergelijkt de rentabiliteit van het eigen vermogen met het rendement op eeuwigdurende staatsleningen over de periode 1960 tot en met 1970 .

Tabel 3.5 Vergelijking rentabiliteit en rendement eeuwigdurende staatsleningen, 1960-1970.

\begin{tabular}{|c|c|c|c|c|c|c|}
\hline Jaar & \multicolumn{2}{|c|}{$\begin{array}{l}\text { Eigen Winst } \\
\text { vermogen (1) }\end{array}$} & 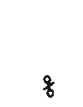 & \multicolumn{2}{|c|}{$\begin{array}{l}\text { Rendement } \\
\text { staatsleningen }\end{array}$} & $\begin{array}{l}\text { Verschil } \\
(1)-(2)\end{array}$ \\
\hline \multicolumn{4}{|c|}{$\operatorname{mln} g l d$} & \multicolumn{3}{|c|}{ mln gld } \\
\hline 1960 & 504 & 77 & 15,2 & 4,4 & 22,2 & 54,8 \\
\hline 1961 & 534 & 53 & 9,9 & 4,2 & 22,4 & 30,6 \\
\hline 1962 & 552 & 30 & 5,4 & 4,4 & 24,3 & 5,7 \\
\hline 1963 & 558 & 53 & 9,5 & 4,4 & 24,5 & 28,5 \\
\hline 1964 & 589 & 54 & 9,2 & 4,8 & 28,3 & 25,7 \\
\hline 1965 & 554 & 71 & 13,1 & 5,2 & 28,3 & 42,3 \\
\hline 1966 & 699 & 52 & 7,4 & 5,8 & 40,5 & 11,5 \\
\hline 1967 & 754 & 60 & 8,0 & 5,7 & 43,0 & 17,0 \\
\hline 1968 & 801 & 88 & 11,0 & 6,2 & 49,7 & 38,3 \\
\hline 1969 & 835 & 109 & 13,1 & 7,0 & 58,7 & 50,5 \\
\hline 1970 & 878 & 81 & 9,2 & 7,1 & 62,3 & 18,7 \\
\hline
\end{tabular}

Opmerkingen: De winst bestaat uit het verschil tussen het exploitatiesaldo (inclusief restitutie vennootschapsbelasting) en de vennootschapsbelasting.

Bron: Staatsmijnen, Jaarverslag over 1960 en Jaarverslag over 1970; CBS, Negentig jaren statistiek in tijdreeksen, 1989 , p. 146.

Uit tabel 3.5 kan worden geconcludeerd dat de staatsmijnen geen winst derfden, maar een fiscale rol vervulden voor de rijksoverheid. Het vaststellen van beleidsvrijheid is echter afhankelijk van de gekozen benadering. De Centrale Accountantsdienst van het Ministerie van Financiën bepaalde het netto-rendement van de staatsmijnen met behulp van de vervangingswaarde van de vaste activa. Voor informatie over de waarde van de vaste activa was deze dienst afhankelijk van de staatsmijnen. Het netto-rendement kan worden vergeleken met dat van andere staatsbedrijven en met het rendement van eeuwigdurende staatsleningen. Het netto-rendement van de staatsmijnen bestond uit de verhouding tussen enerzijds het dividend en de rente over de obligatielening van 50 miljoen gulden en anderzijds de vervangingswaarde van het geinvesteerd vermogen. In 1955 bedroeg de vervangingswaarde van de duurzame activa 1410 miljoen gulden, het dividend en de obligatierente bedroegen respectievelijk 13,75 en 0,94 miljoen gulden. ${ }^{249}$ Het netto-rendement was 1,04 procent, terwijl het rendement van eeuwigdurende staatsleningen 3,19 procent bedroeg. Het nettorendement van de staatsmijnen was in 19592 procent, terwijl 
dat van de PTT 4 procent opleverde. ${ }^{250}$ Het rendement van de eeuwigdurende staatsleningen bedroeg toen 4,27 procent. Het verschil tussen het rendement, berekend op basis van de vervangingswaarde, en het rendement op eeuwigdurende staatsleningen vormt een indicatie voor het bestaan van beleidsvrijheid. In 1960 kon de Centrale Accountantsdienst, ondanks de verbeterde balansopstelling, geen volledig beeld krijgen van de rentabiliteit en de vermogenspositie van de staatsmijnen, omdat de vaste activa niet volgens het stelsel van vervangingswaarde waren gewaardeerd. ${ }^{251}$

Bij de evaluatie van de resultaten van de Staatsmijnen om het bestaan van winstderving vast te stellen mogen de prijsvorming, het bestaan van stille en geheime reserves, en de toepassing van kruiselingse subsidiëring niet buiten beschouwing worden gelaten.

Artikel 10 van de ministeriële instructie van 1937 machtigde de directie zelf de prijzen vast te stellen. De instructie van 1960 bevatte geen artikel over de prijsvorming meer, mar deze machtiging kon uit de interpretatie van de artikelen worden afgeleid. Prijsconcurrentie tussen de Nederlandse mijnbouwondernemingen kwam vrijwel niet voor. Het zou de posities van deze bedrijven schaden en het sociaaleconomische klimat van zuid-Limburg aantasten. De bedrijven stemden hun prijzen onderling af in de Commissie Kolenprijzen en de commerciële Commissie van de Gezamenlijke steenkolenmijnen in Limburg (GSL). Zij hielden daarbij rekening met het beleid van prijsstabilisatie van verschillende kabinetten. ${ }^{252}$

$\mathrm{Na}$ een overgangsperiode verloor de Nederlandse overheid in 1955 de bevoegdheid in te grijpen in het prijsbeleid van de mijnbouwondernemingen aan de Europese Gemeenschap voor Kolen en staal. Zij stelde vanaf dat moment de maximum kolenprijzen (loco-mijn) voor de Nederlandse mijnbouwondernemingen vast. ${ }^{253}$ In 1955 was de loco-mijnprijs hoger dan de Nederlandse kostprijs met als gevolg dat volgens het lid van de Eerste Kamer der staten-Generaal Vixseboxse de Nederlandse mijnen een extra-winst realiseerden. Volgens hem was nu een nauwgezette controle op de directie van de staatsmijnen meer dan voorheen vereist. 254

In de jaarrekeningen van de staatsmijnen schuilden stille en geheime reserves, die het beeld van de rentabiliteit en de reële vermogenspositie vertekenden. Deze reserves ontstonden door afschrijvingen op vaste activa, reservering op de deelneming in andere ondernemingen en de balanswaardering van materialen en grondstoffen. Aan de vorming van deze reserves liggen verschillende overwegingen ten grondslag, zoals de beheersing van de gevolgen van extra-afschrijvingen en het matigen van de eisen van de vakbeweging.

De beheersing van de gevolgen van de extra-afschrijvingen met geheime reserves kwam op ministerieel niveau aan de orde in 1948 bij de beleidsvoorbereiding van een bijzondere reserve voor afschrijvingen. In dat jaar schreef Minister van Financiën Lieftinck aan Minister van Economische Zaken Van den Brink dat de schokken van de extra-afschrijvingen op de aanlegkosten van de cokesfabrieken en de chemische bedrijven mede konden worden opgevangen met de zeer aanzienlijke geheime 
reserves van het bedrijf. ${ }^{255}$

Tijdens een voordracht in 1949 vertelde directeur A.C.J. Rottier aan de leden van de ondernemingsraad dat de gezonde financiële positie van de staatsmijnen te danken was aan de lage waardering van de vaste activa. De werknemers zouden te zijner tijd profiteren van de gevormde stille reserves. ${ }^{2 s 6}$ Herwaardering van te laag gewaardeerde vaste activa leidde tot de bekendmaking van de stille reserves. De problematiek van de afschrijvingen en de herwaardering was jarenlang een gespreksonderwerp tussen de staatsmijnen, het Ministerie van Economische zaken en het Ministerie van Financiën. De Staatsmijnen achtten het, tijdens een overleg in 1956 met beide ministeries, niet wenselijk over te gaan tot een herwaardering van de vaste activa. De herwaardering mobiliseerde de stille reserves en stimuleerde de vakbeweging eisen te stellen met betrekking tot de arbeidsvoorwaarden. De betrokken ambtenaren van het Ministerie van Financiën stelden dat een herwaardering de sociale eisen van de vakbeweging zou matigen. Uit de herkapitalisatie zou blijken dat de rentabiliteit van de Staatsmijnen gering was, waardoor de eisen van de vakbeweging zouden worden getemperd. ${ }^{257}$

De Nederlandse Katholieke Mijnwerkers Bond (NKMB) evalueerde de jaarrekeningen en de begrotingen van de staatsmijnen. De beoordeling van de post "Afschrijvingen" in de begroting voor 1964 leverde problemen op, vanwege het ontbreken van nadere informatie over de vervangingswaarde en de levensduur van de vaste activa. De hoogte van de afschrijvingen tegen vervangingswaarde werd vergeleken met de vervangingswaarde van de nog niet afgeschreven vaste activa. ${ }^{258} \mathrm{Te}$ hoge afschrijvingen leidden tot het ontstaan van stille reserves en hadden consequenties voor de resultatenrekening. De afschrijvingen beinvloedden de winstbestemming en de winstdeling.

De directie van de staatsmijnen makkte na de Tweede Wereldoorlog gebruik van kruiselingse subsidies: de positieve exploitatiesaldi compenseerden de negatieve exploitatiesaldi. Tabel 3.6 toont de ontwikkeling van de kruiselingse subsidies bij de staatsmijnen. 
Tabel 3.6 kruiselingse subsidies staatsmijnen (in mln gld)

\begin{tabular}{lrcrrc}
\hline & & Briket & \multicolumn{3}{c}{ Gasdistributie } \\
Jaar & Kolen & Synthraciet & Cokes & NAM & Stikstof \\
\hline 1951 & 6,8 & 1,1 & 25,7 & $-0,8$ & 24,2 \\
1952 & $-2,1$ & 1,0 & 29,3 & $-0,7$ & 29,2 \\
1953 & 26,1 & 2,0 & 5,4 & $-1,0$ & 27,9 \\
1954 & 36,9 & 0,8 & $-1,8$ & $-0,2$ & 29,2 \\
1955 & 19,5 & 0,7 & 5,3 & 0,8 & 37,1 \\
1956 & 2,4 & 1,5 & 34,3 & $-0,1$ & 25,9 \\
1957 & $-5,0$ & 1,1 & 27,3 & 0,7 & 37,3 \\
1958 & 11,6 & $-0,1$ & 6,6 & 0,7 & 31,6 \\
1959 & 8,7 & 0,2 & 9,1 & 0,5 & 37,3 \\
1960 & 8,0 & 1,0 & 15,3 & 0,7 & 41,5 \\
1961 & 13,3 & 0,3 & 10,9 & 0,6 & 33,8 \\
1962 & $-33,5$ & 2,4 & $-8,2$ & $(1)$ & 28,1 \\
1963 & $-25,4$ & 3,7 & 3,0 & $-4,7$ & $(2)$ \\
1964 & $-33,2$ & 3,9 & 4,7 & $-5,3$ & 31,2 \\
1965 & $-31,6$ & 0,6 & 11,3 & $-4,0$ & 40,4 \\
\end{tabular}

Vervolg

Exploitatie

Jaar Energie Chemie Woningen overigen saldo

\begin{tabular}{|c|c|c|c|c|c|}
\hline 1951 & $-2,1$ & & $-2,5$ & 1,4 & 47,3 \\
\hline 1952 & $-1,6$ & & $-3,0$ & $-0,5$ & 46,6 \\
\hline 1953 & 3,5 & & (3) & $-0,2$ & 57,2 \\
\hline 1954 & 2,6 & & - & $-1,7$ & 60,6 \\
\hline 1955 & $-0,5$ & & $-2,8$ & 1,6 & 57,5 \\
\hline 1956 & $-0,5$ & & $-2,9$ & 1,6 & 59,3 \\
\hline 1957 & 1,5 & & $-3,2$ & 1,4 & 38,6 \\
\hline 1958 & 1,2 & 7,3 & - & $-2,5$ & 55,9 \\
\hline 1959 & 3,2 & 13,3 & $-1,8$ & 1,4 & 68,5 \\
\hline 1960 & 6,3 & 18,7 & $-1,1$ & 1,2 & 93,5 \\
\hline 1961 & 1,8 & 13,8 & $-1,3$ & 1,1 & 70,9 \\
\hline 1962 & 2,9 & 21,6 & $-1,4$ & 2,1 & 17,1 \\
\hline 1963 & 2,4 & 23,3 & $-0,4$ & 3,4 & 37,0 \\
\hline 1964 & 0,3 & 37,7 & 0,3 & (4) & 53,9 \\
\hline 1965 & $-2,3$ & 36,6 & 0,05 & - & 61,6 \\
\hline
\end{tabular}

Opmerkingen: (1) Het cijfer voor de cokes in 1962 bevat tevens het cijfer voor de gasdistributie.

(2) Vanaf 1963 cijfers van de NAM.

(3) De cijfers van 1953, 1954 en 1958 worden niet gegeven.

(4) Voor 1964 en 1965 wordt de categorie overigen niet gegeven.

Bron: Staatsmijnen, Bedrijfseconomische Verslagen, 1952 tot en met 1966 .

De exploitatiesaldi van de cokes-producerende en de chemische bedrijven compenseerden de verliezen van de mijnbouw, de 
gasdistributie en de woningexploitatie. De chemische bedrijven waren afhankelijk van de grondstoffen van het mijnbedrijf. De vanaf 1962 optredende verliezen in de kolensector vormden voor de directie reden zich meer te concentreren op de chemische sector. ${ }^{259}$

\subsubsection{Gasdistributie}

De directie van de Staatsmijnen leverde vanaf het einde van de jaren ' 20 cokesovengas aan gemeenten en industrieën in Limburg en Noord-Brabant. Belangstelling bestond in het bijzonder voor het industrialiserende Eindhoven. Aanvankelijk lag het vanwege de kosten niet in de bedoeling om zelf de benodigde leidingen aan te leggen en te exploiteren. De technologische ontwikkelingen op het terrein van het transport over lange afstanden maakten de aanleg en de exploitatie echter rendabel voor de staatsmijnen. ${ }^{260}$ De gasprijs van de staatsmijnen was lager dan de kostprijs van de gemeentelijke gasfabrieken en stelde bedrijven in staat tot modernisering en verbetering van hun produkten over te gaan. ${ }^{261}$ De directie van de staatsmijnen prefereerde met elke gemeente afzonderlijk een contract over de gasprijs af te sluiten. ${ }^{262}$ De gastarieven waren na 1927 contractueel gekoppeld aan een kolenclausule. In 1936 hield deze clausule in dat elke stijging of daling van de middenprijs met één gulden leidde tot een stijging of daling van de gasprijs met 0,1 cent per $m_{3}$ of een evenredig gedeelte daarvan per $\mathrm{m}^{3}$. De middenprijs bedroeg tien gulden en als minimum prijs gold acht gulden. 263

De crisisjaren hadden vanwege het gedaalde welvaartspeil en de lage prijzen van petroleum een vermindering van het gasverbruik tot gevolg. Voor de directie van de staatsmijnen was het in deze jaren belangrijk om het niveau van haar gasafzet te behouden en zelfs uit te breiden. In 1936 benaderden de gemeenten de directie van de staatsmijnen or de kolenclausule aan te passen aan de daling van de kolenprijzen. De directie van de staatsmijnen kon $z$ ich hierin vinden en kende een tijdelijke verlaging toe aan de gemeenten. $\mathrm{Zij}$ verbond hieraan de voorwaarde dat de verlaging van het tarief ten goede kwam aan de verbruikers. Voor een definitieve regeling was een machtiging van de Minister van Waterstaat nodig. ${ }^{204}$ De directie attendeerde de Minister O.C.A. van Lidth de Jeude (Lib.) erop dat de prijsverlagingen de belangen van de onderneming bevorderden. Het verhinderde een verdere daling van het huishoudelijk gasverbruik door de slechtere levensomstandigheden en stimuleerde het gasgebruik voor industriële doeleinden. De Staatsmijnen stelden de minister voor de kolenbasisprijs te verlagen van 8 gulden naar 6 gulden per ton, hetgeen overeenkwam met een verlaging van de gasprijs met 0,2 cent per $\mathrm{m}^{3}$ (De kolenprijs bedroeg 4,68 gulden per ton). De tariefherziening betekende een winstderving van 75000 gulden voor de staatsmijnen, wanneer het verbruik niet zou toenemen. 265

De Mijnraad deelde de directie van de staatsmijnen mee dat zij het prijsgeven van de helft van de netto-winst niet gemotiveerd achtte. De gasprijzen voor de gemeenten waren reeds laag en deze geringe verlaging leidde nauwelijks tot een 
uitbreiding van het gasdebiet. De gemeenten zouden de prijsverlaging zeker aan hun afnemers toestaan zonder een noodzakelijke verlaging van de engros-prijs. De Mijnraad keurde de introductie van een voorlopige regeling met een tijdelijke verlaging van de gasprijzen voorafgaand aan een ministeriële machtiging dan ook af. 260

De directie van de staatsmijnen besloot zich tegen de kritiek van de Mijnraad te verweren met een nadere toelichting op het tariefbeleid voor de gemeenten. De tarieven voor gasleveranties aan de gemeenten kenmerkten zich volgens de directie door onvolkomenheden, die de toename van het gasverbruik onder de crisisomstandigheden belemmerden. De leverantie van gas aan gemeenten vond plaats volgens een stelsel van prijsschalen, die onderlinge verschillen vertoonden in verband met het tijdstip van het totstandkomen van de overeenkomsten, de te verwachten afname aan een bepaald leidinggedeelte en de afstand tussen de gemeente en de staatsmijn. De berekening van het tarief volgens deze prijsschalen bood grotere gemeenten het voordeel van een lagere gemiddelde gasprijs. De directie van de staatsmijnen achtte dat aanvaardbaar, omdat de kostprijs van gas in het geval van produktie door de grotere gemeenten ook lager zou zijn (zie bijlage 3.3). Verder ging zij ervan uit dat de baten uit de vergroting van de gasafzet ten gevolge van voorgestelde tariefwijzigingen opwoog tegen de winstderving bij een constante afzet. ${ }^{267}$ 


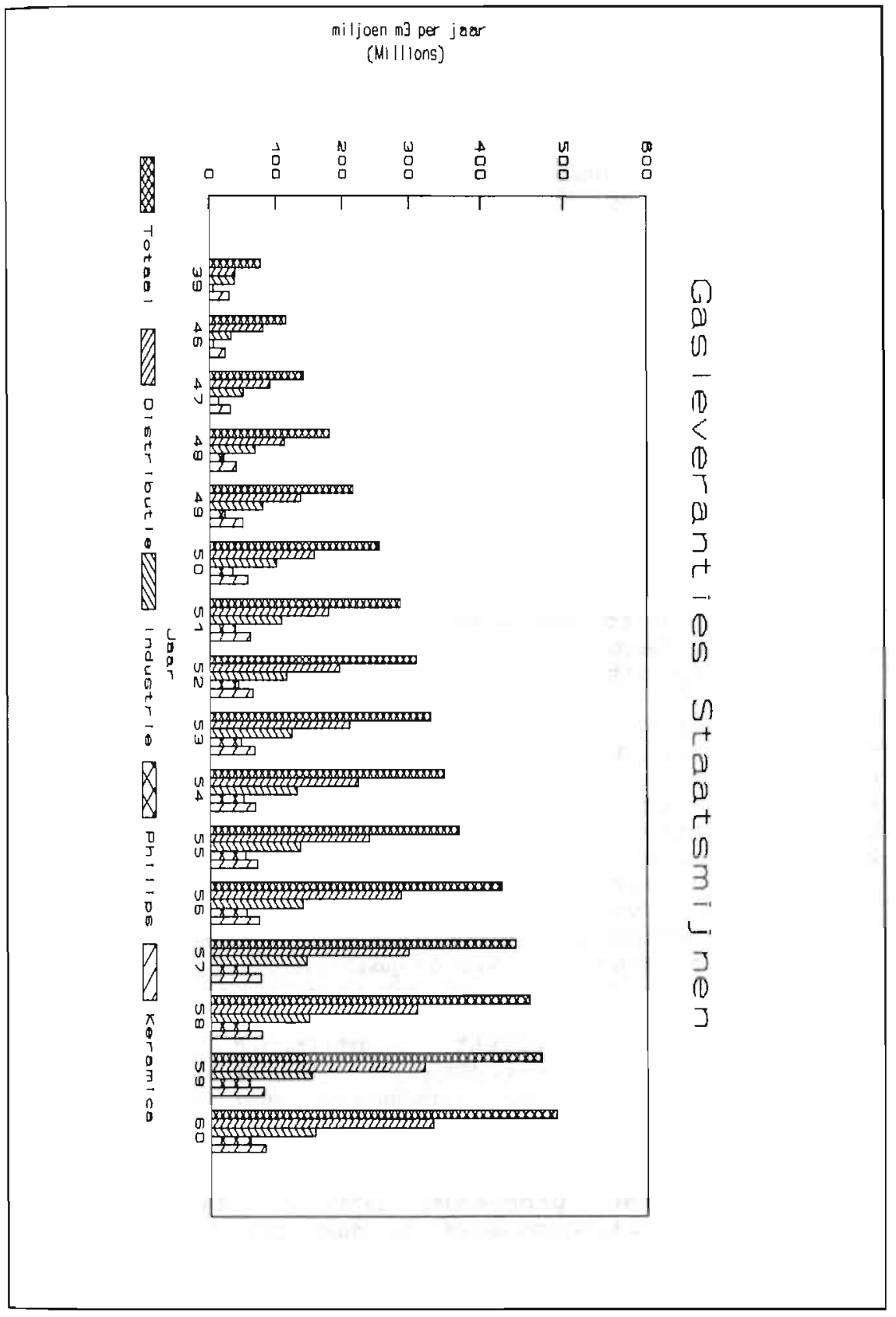

Figuur 3.2
Bron:
statsmijnen, Raming gasafgifte door gasdistributiebedrijf, nr 1262, Gasdistributie bedrijf 1950-1969, inv. nr. 29.


Figuur 3.2 toont het verloop en de verdeling van de gasleveranties van de Staatsmijnen over de periode 1939, 1946 tot en met 1960 .

Met het doel om een meer uniforme regeling van de gasprijzen te realiseren, vaardigde het kabinet-Beel I in 1946 de Prijzenbeschikking Gas 1947 uit. Deze bepaalde dat de gasprijzen niet meer dan 3,5 cent hoger mochten zijn dan de prijzen, die op 31 december 1939 van kracht waren. De gasproducerende bedrijven hadden het recht de tarieven en kolenclausules uit de bestaande contracten toe te passen. De distributiebedrijven daarentegen mochten de gasprijzen met niet meer dan 3,5 cent boven het niveau van 1939 verhogen. ${ }^{268}$ Een jaar later stegen de kolenprijzen met vijf gulden. De producerende industrieën mochten deze stijging niet doorberekenen in hun produkten. De elektriciteitsbedrijven hadden toestemming om de verhoging van de kolenprijzen door te berekenen aan de industriële verbruiker, maar niet aan de huishoudelijke verbruikers. Dat de verhoging van de kolenprijzen voor de gasbedrijven leidde tot een stijging van de gasprijzen was echter niet de bedoeling. Uitgangspunt was blijkbaar dat de gasbedrijven hoofdzakelijk gas leverden aan huishoudens. Gegeven het feit dat de Staatsmijnen 45 procent van hun gasproduktie aan de industrie leverden (en naar verwachting 60 tot 65 procent in de nabije toekomst), bestond er voor het Gasdistributiebedrijf een rechtvaardiging on net als de elektriciteitsbedrijven de gasprijzen voor de industrie te verhogen. ${ }^{269}$

Vanaf 1952 pasten de staatsmijnen een nieuw standaardcontract toe. Het bedrijf stelde de prijs van cokesovengas vast op basis van de kostprijs van uit kolenvergassing verkregen gas. De zogenaamde kolenclausule bewerkstelligde dat de kolenprijzen doorwerkten in de kostprijs van het cokesovengas. De directie van de Staatsmijnen vermeldde in haar bedrijfseconomisch verslag over 1953 dat een volledige doorwerking echter niet plaatsvond, omdat in overleg met de rijksoverheid was besloten tot een geleidelijke aanpassing van de gasprijzen. ${ }^{270}$

over de leverantie van cokesovengas was omzetbelasting verschuldigd. In 1960 moest het Gasdistributiebedrijf van de staatsmijnen 5 procent omzetbelasting afdragen. De concurrerende oliemaatschappijen (BPM/SHELL) waren 1,25 procent omzetbelasting verschuldigd over het door hen geproduceerde propaangas. De verschillende heffingspercentages van de omzetbelasting over diverse soorten gas leidden tot een verstoring van de mededingingsverhoudingen. Ten gevolge van de concurrentie van propaangas zagen de staatsmijnen zich genoodzaakt prijsconcessies te doen aan de gemeentelijke distributiebedrijven. De staatsmijnen streefden ernaar de verstoring van de mededingingsverhoudingen ongedaan te maken met een verzoek aan het Ministerie van Financiën om de heffing van de omzetbelasting uitsluitend te doen plaatsvinden bij het Gasdistributiebedrijf, onder toepassing van artikel 14 van het Uitvoeringsbesluit omzetbelasting van 1954. Het Gasdistributiebedrijf zou dan 5 procent omzetbelasting voldoen over 25 procent van de omzet, terwijl heffing van omzetbelasting bij gemeentelijke distributiebedrijven volledig 
achterwege kon blijven. De staatssecretaris van Financiën H.W. van den Berge accepteerde dat met ingang van 1 januari 1960 voor gasleveringen aan industrieën een omzetbelasting was verschuldigd van 1,25 procent van de omzet ( $5 \%$ van 25\%). Hij kende vrijstelling toe voor leveringen an gemeentelijke distributiebedrijven. ${ }^{271}$

De ervaring met de produktie en distributie van gas leidde ertoe dat sedert 1963 het staatsbedrijf der staatsmijnen in samenwerking met de Nederlandse Aardolie Maatschappij (NAM) het Groningse aardgas exploiteerde. Voor dat doel richtten $2 i j$ een maatschap op. De maatschap verkocht het gas aan de NV Nederlandse Gasunie, waarin de rijksoverheid (10\%), de Staatsmijnen (40\%), de Shell (25\%) en de Esso (25\%) participeerden. De directie van de staatsmijnen bracht het Gasdistributiebedrijf onder in de NV Gasunie. Na de wijziging van de rechtsvorm vond een verdeling van de winst na belasting tussen de rijksoverheid en het bedrijf plaats op basis van een staffel. De staatsmijnen makten het aandeel van de rijksoverheid rechtstreeks over met een bijzondere uitkering. De uitbreiding van de afzet van aardgas leidde tot een inkrimping van de produktie van cokesovengas. ${ }^{272}$

\subsection{2 subsidies}

Sinds 1909 verstrekten de staatsmijnen op een voor de statenGeneraal onbekende wijze subsidies. Dit leidde tot debatten tussen sociaal-democraten en confessionelen. In 1914 diende het lid van de Tweede Kamer der Staten-Generaal J.W. Albarda (SDAP) een amendement in op hoofdstuk $X$ van de begroting in om de subsidiëring van kerkgenootschappen door de staatsmijnen te beëindigen. zijn motie werd met een ruime meerderheid verworpen. ${ }^{273}$ Vanaf 1917 vermeldden de memories van toelichting de subsidiebedragen. De bedrijfsrekeningen verantwoordden de subsidies van sociale aard als algemene kosten, sociale lasten en sociale voorzieningen.

In 1932 presenteerden de leden van Tweede Kamer der statenGeneraal W. Drop (SDAP) en A. van der Heide (SDAP) een nota over het blijvende karakter van de subsidies aan kerkgenootschappen. Zij achtten deze subsidies in strijd met het uitgangspunt van artikel 172 van de Grondwet. Gezien de historie van de "Scheiding van Kerk en staat" moest volgens hen de overheid zich onthouden van financiële steun aan kerkgenootschappen buiten de uitvoering van artikel 172 van de Grondwet. ${ }^{274}$ Minister van waterstaat P.J. Reymer (RKSP) zei ter verdediging dat de in de nota ontwikkelde bezwaren tegen de subsidies ten onrechte in verband werden gebracht met artikel 172 van de Grondwet. De staatsmijnen verstrekten volgens hem in navolging van de particuliere bedrijven subsidies en dat verschilde van de taak van de staat als overheid. Zelfs al zou voor het staatsbedrijf dezelfde maatstaf worden gehanteerd als voor de overheid, dan nog viel niet in te zien, dat tegenstanders deze subsidies konden bestrijden met een beroep op artikel 172 van de Grondwet. ${ }^{279}$

De directie van de staatsmijnen baseerde haar subsidiebeleid op het zogenaamde "subsidiariteitsbeginsel". Dit beginsel hield in dat het bedrije $\mathrm{zich}$ beperkte tot het 
stimuleren en activeren van het particuliere initiatief. subsidies fungeerden als het beste instrument ter activering en stimulering hiervan. Bleef particulier initiatief achterwege, dan werd overgegaan tot sociale activiteiten en het oprichten van sociale instellingen. ${ }^{276}$ Aan het toekennen van subsidies lag verder de overweging ten grondslag dat afstoting van bepalde activiteiten tot kostenbesparingen zou leiden in de sfeer van de sociale lasten bij de Staatsmijnen. 27

Vanaf 1950 beperkte een in de externe begroting opgenomen post het verlenen van subsidies. Overschrijding van de hoogte van deze post was slechts toegestaan na een ministeriële machtiging. De omschakeling van sociale activiteiten naar het verlenen van subsidies aan derden plaatste het bedrijf voor het probleem van de verplichte budgettaire verantwoording. De vervanging van de kosten voor sociale activiteiten door nieuwe subsidies beperkte de speelruimte voor de traditionele subsidies. 278 In 1958 werd de begrote subsidielimiet van 650.000 gulden ontoereikend geacht. Het standpunt van het kabinet over de betaling van de ontwikkelingskosten van de staatsmijn Beatrix impliceerde een uitbreiding van het subsidiegebied. Verder gebood de voortzetting van het beleid van distantiëring een verhoging van de subsidielimiet. ${ }^{279} \mathrm{De}$ staatsmijnen verstrekten de subsidies direct of indirect via het Fonds voor Sociale Instellingen en de Gezamenlijke Mijnen. ${ }^{2 \times 0}$ De subsidie aan het Fonds voor Sociale Instellingen bedroeg de helft van de aan het personeel opgelegde boetes. Dit bedrag werd op de begroting verantwoord. ${ }^{31}$ verschuiving van subsidies uit overwegingen van takverdeling tussen de staatsmijnen en het Fonds was niet uitgesloten. ${ }^{2 \times 2}$

De directie van de staatsmijnen stelde voor de afdeling Maatschappelijk Werk de volgende criteria op ter beoordeling van een subsidie-aanvraag:

a. een aanwijsbaar belang voor de personeelsleden,

b. een aanwijsbaar belang voor de mijnstreek,

c. het ontstaan van de sociale behoefte door de staatsmijnen,

d. de deelname van het overige bedrijfsleven,

e. de urgentie,

f. de verzwarende omstandigheden, waaronder het

werk moest geschieden, zoals politieke onrust, asociaal

gedrag, armoedige bevolking en veel vreemdelingen, en

g. een goede organisatorische en financiële opzet. ${ }^{283}$

De Gezamenlijke Mijnen in Limburg (GSL) oordeelden in 1952 dat de subsidiebedragen voor externe voorzieningen in het belang van het personeel (bijvoorbeeld: muziekkorpsen en ontspanningsoorden) hoog waren. De subsidies stonden in een ongunstige verhouding tot de beschikbare subsidies voor verschiliende matschappelijke doeleinden. ${ }^{2 \times 4}$

In 2 ijn rapport over de begroting van de staatsmijnen voor 1956 ten behoeve van de fractie van de Katholieke volkspartij stelde fractielid $\mathrm{J}$. Maenen dat onder artikel 2 van de afdeling "Lasten der Exploitatie" slechts een bescheiden bedrag was geraamd voor subsidie aan kerkgenootschappen en de stichting Uitbreiding en Instandhouding van Kerken en 
Patronaten. Gezien de snelle uitbreiding van de bevolking was het volgens hem noodzakelijk om deze posten aan de gewijzigde omstandigheden aan te passen. ${ }^{285}$ Het kabinet-Drees III nam in 1958 een afwijzende houding aan tegen het subsidiëren van kerkgenootschappen, maar de staatsmijnen meenden te zijner tijd zelf te kunnen beslissen of zij voldoende aanleiding konden vinden om dergelijke subsidies alsnog te verlenen. ${ }^{286}$

De begroting van de Staatsmijnen voor het dienstjaar 1962 vermeldde een verhoging van het voor subsidies bestemde bedrag vanwege het ontstaan van nieuwe vormen van maatschappelijke zorg, de toenemende behoefte aan gemeenschappelijke voorzieningen en de groeiende aandacht voor bepaalde groeperingen, zoals jeugdigen en bejaarden. In de ondernemingsraad werd gewezen op het bestaan van de onjuist geachte tendens dat instellingen de staatsmijnen benaderden voor subsidies, maar zich een vrije brandstofkeuze wilden voorbehouden. ${ }^{2 \times 7}$

De NV Nederlandse Staatsmijnen beëindigde in 1967 de subsidiëring van kerkgenootschappen, maar continueerde de subsidiëring van de godsdienstige verzorging. ${ }^{288}$

\subsubsection{Bezitsvorming}

Bezitsvorming ontwikkelde zich in de jaren vijftig en zestig tot een van de belangrijke politieke onderwerpen. Duidelijke ideeën over bezitsvorming en aanvaarde begrippen ontbraken in de Nederlandse politiek. De directie van de staatsmijnen oordeelde in 1952 een voorzichtig standpunt in te moeten nemen over bezitsvorming. Zij had als directie van een staatsbedrijf rekening te houden met het standpunt van het kabinet. De handelwijze van het bedrijf zou van invloed zijn op andere Nederlandse ondernemingen en de mogelijkheid bestond dat de particuliere mijnbouwondernemingen zich verplicht voelden het beleid van de staatsmijnen te volgen. ${ }^{289}$

De vakorganisaties (Algemene Nederlandse Bedrijfsbond Mijnindustrie, Protestants-Christelijke Mijnwerkersbond, Nederlandse Katholieke Mijnwerkersbond, Katholieke Vereniging van Mijnbeambten en de Katholieke Federatie) waren nauw betrokken bij de politiek van bezitsvorming. Het dagelijks bestuur van de Katholieke Federatie had op 2 mei 1961 een Commissie Bezitsvorming ingesteld om te komen tot een plan voor bezitsvorming door het personeel van de Limburgse mijnindustrie. Deze commissie kwam tot de slotsom dat een ondernemingsbijdrage de bezitsvorming zou moeten bevorderen. De ondernemingsbijdrage behoorde tot de exploitatiekosten van de onderneming. $Z i j$ beschouwde de bijdrage als een gedeelte van het loon of het salaris, dat in een andere vorm aan het personeel ten goede kwam. ${ }^{29 l}$

\subsection{3.a Bezitsvorming: sparregeling}

Volgens de directie was de uitvoering van het beleid gericht op bezitsvorming niet halbaar met behulp van uit de winst afkomstige dotaties. De verklaring hiervoor was dat de continuiteit van de dotaties onder geen voorwaarde in het vooruitzicht kon worden gesteld. $\mathrm{Zij}$ was van mening dat een 
eenmalige bijdrage van de onderneming het doel van persoonlijke bezitsvorming niet realiseerde. In 1953 verkeerde de directie in een impasse over de vraag welke werknemers konden participeren in het te ontwikkelen stelsel van bezitsvorming. ${ }^{291}$ om hieruit te geraken kwam het volgende compromisvoorstel tot stand:

(1) het instellen van een sparregeling met een rentevergoeding, hoger dan de normale, met een mogelijkheid tot deelneming, warvan niemand principieel was uitgesloten,

(2) de verdeling van de jubileumgave 1952 en mogelijke toekomstige dotaties uit de winst onder de deelnemers aan de spaarregeling, desnoods onafhankelijk van het gespaarde bedrag (de kosten van de rentevergoeding kwamen ten laste van de exploitatierekening), en

(3) de vervreemding van de woningen van de Staatsmijnen, indien hiertoe werd besloten, bij voorkeur aan spaarders. ${ }^{292}$

Dit compromis gaf de richting aan voor het in de navolgende jaren ontwikkelde stelsel van bezitsvorming bij de Staatsmijnen.

De directie ontwierp een spaarregeling, ondat met de eenmalige bijdrage het doel van bezitsvorming niet kon worden bereikt. In 1954 legde $z i j$ deze regeling voor aan de Minister van Economische zaken zijlstra. De regeling hield in dat de onderneming aan elk gestort spaarbedrag voor eenmaal een premie van 20 procent toevoegde. Het gevormde bezit zou uitsluitend kunnen worden aangewend voor de oude dag, de financiering van een eigen huis, een aanvullende pensioens- of levensverzekering, studiedoeleinden en eventueel nader vast te stellen erkende bestedingsdoeleinden. Een college, de zogenaamde spaarraad, werd belast met het toezicht op de uitvoering van de spaarregeling. De spaarraad besliste over de deblokkering van de gespaarde bedragen. ${ }^{293}$ Deze raad verleende altijd toestemming aan de deelnemers om te beschikken over de zelf gespaarde gelden. ${ }^{294}$

In september 1953 verleenden de Staten-General de directie van de staatsmijnen toestemming om de begroting voor het dienstjaar 1952 te wijzigen. In het kader van het 50-jarig jubileum mochten de staatsmijnen 1 miljoen gulden bestemmen voor bezitsvorming. De ondernemingsraad zou richtlijnen voor de aanwending van het bedrag vaststellen, zodat alle personeelsleden boven de 25 jaar hiervan konden profiteren. Het persoonlijke aandeel in dit bedrag zou worden gestort op een voorlopig voor twee jaar geblokkeerde rekening bij een bankinstelling en vormde de eerste inleg voor deelname aan een te ontwerpen spaarregeling. ${ }^{295}$ Uit dit zogenaamde jubileum miljoen van 1952 ontving elk personeelslid een uitkering van 32 gulden. Het resterende gedeelte zou worden aangewend voor het betalen van de verschuldigde belasting en ter uitkering van extra spaarpremies in het kader van de spaarregeling. Na twee jaar zou de spaarraad vaststellen welke personeelsleden 
verder hadden gespaard. Voor hen zou deze inleg van 32 gulden deel uitmaken van het gespaarde bedrag. De directie stelde voor dat de Spaarraad een besluit zou nemen over de eerste inleg van diegenen, die niet verder hadden gespaard. Het bedrag kon worden gedeblokkeerd ten behoeve van de betrokkenen of ten behoeve van het bedrijf. Dit laatste achtten Minister van Economische Zaken J. Zijlstra en zijn ambtgenoten van Sociale zaken en volksgezondheid en Publiekrechtelijke Bedrijfsorganisatie minder juist. De jubileumuitkering diende in elk geval aan het personeel ten goede te komen. ${ }^{296}$

In april 1954 stelde de directie Binnenlands Geldwezen van het Ministerie van Financiën dat er na een blokkering van twee jaar, geen verschil mocht worden gemaakt tussen de inleg en andere gelden op de bijzondere spaarrekening. $\mathrm{zij}$ verwierp de gedachte om het aandeel in de jubileumgave van personeelsleden, die niet verder hadden gespaard, niet uit te keren. De jubileumgave was een cadeau en de publiciteit voor bezitsvorming zou worden ondermijnd, als dit niet onaantastbaar bleek te zijn. Bovendien was het aan twijfel onderhevig of de bezitsvormingsgedachte zou worden bevorderd door de regeling dat het behoud van reeds toegekende toeslagen afhankelijk zou worden gesteld van de besteding, die de rechthebbenden aan hun gelden wilden geven. ${ }^{297}$ Daarnaast bestond het gevaar dat deze regeling ontaardde in een verkapte loonsverhoging. De directie van het Binnenlands Geldwezen concludeerde dat het haar niet juist voor kwam dat de staatsmijnen overgingen tot de beoogde spaarregeling. $\mathrm{Zij}$ stelde voor de jubileumbonus te storten bij spaarbanken met de bedoeling een snelle besteding van extra gelden te voorkomen. De spaarbanken konden op deze wijze nieuwe cliënten winnen en mogelijk behouden. ${ }^{298}$

In juni 1954 kwam de directie van de staatsmijnen tegemoet aan de kritiek van Minister Zijlstra met een regeling over de verdeling van de jubileumgave. De personeelsleden konden vrij beschikken over hun op een geblokkeerde rekening gestorte aandeel vanaf 1 juli 1956. Voor deze datum kon alleen worden gedeblokkeerd voor erkende bestedingsdoeleinden.

De spaarregeling van de staatsmijnen trad in werking op 1 juli 1954 .

Aan de spaarregeling waren voor de staatsmijnen kosten verbonden, namelijk de kosten van de spaarpremie, administratieve kosten en overige kosten. De administratieve kosten betroffen kosten, verbonden aan het overmaken van de inleg en de premie op de geblokkeerde rekening, en de deblokkering van spaartegoeden. De overige kosten hadden betrekking op onder andere voorlichting en werkzaamheden van de Spaarraad. Deblokkering met het verlies van de spaarpremie voor de spaarder betekende geen kostenvermindering voor de Staatsmijnen. De teruggevloeide premies kwamen ten goede aan de overige spaarders. ${ }^{299}$

Uit tabel 3.7 blijkt dat vanaf 1954 de kosten van de spaarpremie ongeveer negentig procent van de totale kosten uitmaakten. ${ }^{300}$ 
Tabel 3.7 Kosten Spaarregeling

\begin{tabular}{|c|c|c|c|c|c|c|}
\hline \multirow{2}{*}{ Jaar } & \multirow[b]{2}{*}{ Premie } & \multicolumn{2}{|c|}{ Administratieve kosten } & \multicolumn{2}{|r|}{ Overige } & \multirow[b]{2}{*}{ Totaal } \\
\hline & & Deblokkering & Sparen & & kosten & \\
\hline & & \multicolumn{4}{|c|}{$\times 1000 \mathrm{gld}$} & \\
\hline 1954 & 300 & 5.2 & 17.5 & & 10.0 & 332.7 \\
\hline 1955 & 765 & 16.1 & 34.6 & & 25.0 & 840.7 \\
\hline 1956 & 992 & 33.2 & 39.5 & & 30.0 & 1094.7 \\
\hline 1957 & 1144 & 54.9 & 43.0 & & 33.0 & 1274.9 \\
\hline 1958 & 1265 & & 104.0 & (1) & 34.0 & 1403.0 \\
\hline 1959 & 1407 & & 122.0 & (2) & 31.0 & 1560.0 \\
\hline
\end{tabular}

Opmerkingen: (1) Totale administratieve kosten

(2) Totale administratieve kosten

Uit: Staatsmijnen, Overzicht kosten van de spaarregeling 1954 in 1959, p. 3; bron: Concern Archief DSM, Sociale Zorg en Maatschappelijk Werk, 1960-1969, inv. nr. 16.

Intussen discussieerden de bestuurders van de vakorganisaties over het feit dat de laagstbetaalde personeelsleden (bijvoorbeeld: "de bovengronders") niet altijd bij machte waren te participeren in de spaarregeling. De Protestantschristelijke Vereniging van Mijnbeambten en de Algemene Nederlandse Bedrijfsbond Mijnindustrie bepleitten een verdeling van de winstmiljoenen, die in gelijke mate ten goede kwam aan alle personeelsleden. De storting op een geblokkeerde rekening gaf de spaarregeling een onvrijwillig karakter. De Nederlandse Katholieke Mijnwerkersbond (NKMB) en de Algemene Bond van Werkers waren voorstander van een verdeling over de spaarders. ${ }^{301}$

Minister van Economische Zaken J. Zijlstra stemde slechts in met de besteding van het derde winstmiljoen over het dienstjaar 1954, als dat bedrag ten goede kwam aan het gehele personeel en niet uitsluitend aan de deelnemers aan de spaarregeling. De meerderheid van de ondernemingsraad van de Staatsmijnen gaf de voorkeur aan een zekere binding met de spaarregeling. Een minderheid deelde deze mening niet en gaf er de voorkeur aan het gehele bedrag ten goede te doen komen aan alle personeelsleden. ${ }^{302}$

De directie van de Staatsmijnen besloot in 1957 om net als in de voorgaande jaren één miljoen gulden extra ter beschikking van het personeel te stellen in de vorm van een uitkering van 1,25 dag verlofloon. Het personeel ontving een spaarpremie van veertig procent over de uitkering, indien dit. bedrag werd gespaard. Voor de Katholieke Federatie vormde dit besluit aanleiding om de Gezamenlijke Steenkolenmijnen in Limburg te verzoeken een deel van de bedrijfsresultaten van de particuliere mijnbouwondernemingen op een overeenkomstige wijze te verdelen. De reactie van de Gezamenlijke steenkolenmijnen in Limburg luidde dat de particuliere mijnen geen vrijheid konden vinden over te gaan tot de uitkering van de door de federatie bedoelde gelden. Het gedrag van de Katholieke Federatie leidde wel tot protesten van de kant van 
de Algemene Nederlandse Bedrijfsbond Mijnindustrie. Deze bond beschouwde de verdeling van het miljoen bij de staatsmijnen als onrechtvaardig. Het bezwaar betrof de ongelijke uitwerking van de premie van veertig procent over de verschillende inkomenscategorieën. Uit een brief van het bestuur van de NKMB aan de ondernemingsraad van de staatsmijnen blijkt dat deze bond de kritiek van de bedrijfsbond hoog op nam. ${ }^{303}$

De Katholieke Federatie wendde zich in 1958 tot de staatsmijnen en de andere mijnbouwondernemingen, nadat $z i j$ had vernomen dat de loonstop niet van toepassing was op de regelingen van bezitssparen en systemen van winstdeling. De federatie was van oordeel dat de verbetering van de spaarregeling zou bijdragen tot de bedrijfsvrede, die werd bedreigd als gevolg van het achterwege blijven van de goedkeuring door het kabinet van de verordeningen van de Mijnindustrieraad. De federatie deed de volgende voorstellen:

1. het maximaal te sparen bedrag werd verhoogd tot ten hoogste 8 procent van elk maandsalaris of loon,

2. het geheel of gedeeltelijk sparen van extra-uitkeringen werd gehandhaafd c.q. mogelijk gemaakt,

3. de spaarpremie werd verhoogd en gedifferentieerd, zodanig dat de mijnonderneming een spaarpremie op de rekening van de deelnemer stortte tot:

(a) 40 procent van de bijdragen die werden gespaard van het jaarlijkse inkomen of inkomensdeel tot en met 6000 gulden,

(b) 30 procent van de bedragen die werden gespaard van het jaarlijkse inkomensdeel tussen de 6000 en 12000 gulden en

(c) 25 procent van de bedragen die werden gespaard van het jaarlijkse inkomensdeel dat boven de 12000 gulden ligt.

4. de deeinemer die zijn spaargelden aanwendde voor de bouw of het doen bouwen van een woning zou onder nader te stellen voorwaarden van de mijnonderneming een extrauitkering ineens dan wel een over 10 jaren af te schrijven renteloos voorschot ten bedrage van 15 procent van de netto-stichtingskosten met een maximum van 4000 gulden ontvangen, en

5. na de eerste 5 jaar van deelname aan de spaarregeling kon het over de eerste 3 jaren gespaarde bedrag met behoud van spaarpremie ineens worden opgenomen. ${ }^{304}$

Directeur van de staatsmijnen Rottier antwoordde namens de Gezamenlijke Steenkolenmijnen in Limburg geen gevolg te kunnen geven aan de voorstellen. De reden was dat naar het oordeel van de Gezamenlijke Steenkolenmijnen in Limburg de grenzen aan het gesubsidieerde sparen en het percentage van de spaarpremies zodanig waren vastgesteld, dat de stimulans tot het vormen van bezit voldoende krachtig was. ${ }^{305}$

De spaarregeling voor volwassenen verschilde per mijnonderneming. Het Besluit premiespaarregelingen en 
winstdelingsregelingen van 1962 had tot gevolg dat de spaarregeling 1954 werd aangewezen als een premiespaarregeling in de betekenis van dit besluit. De staatsmijnen wijzigden de regeling op een aantal punten. ${ }^{306}$ Bij het bestuur van de NKMB bestond het besef dat de voordelen van de aanpassing van de spaarregeling voor volwassenen aan het besluit in het algemeen niet opwogen tegen de nadelen. Voor de participanten aan spaarregeling 1954 betekende dit een beperking van de mogelijkheden tot deblokkering. ${ }^{307}$ De Mijnindustrieraad verklaarde in 1964 de spaarregeling 1954 van de Staatsmijnen vanaf 1 juli 1955 van toepassing op het personeel van het bedrijfschap voor de steenkolenmijnindustrie.

Deelname aan de spaarregeling was vrijwillig. Vooral de directie gaf in het kader van de bezitsvorming de voorkeur aan het bevorderen. van het spaargedrag. De participatiegraad varieerde van 55 procent van het personeel in het eerste spaarjaar tot 79 procent in 1970. Procentueel makkten meer beambten dan arbeiders gebruik van de spaarregeling. Het bleek dat een aantal personeelsleden $z$ ich niet kon permitteren deel te nemen aan de spaarregeling, hetgeen een mate van inkomensongelijkheid tot gevolg had. Ook beschouwden arbeiders participatie in de spaarregeling als een indicatie voor de directie, dat loonsverhoging voorlopig niet nodig was. ${ }^{308}$

De beheerder van de Nederlandse Steenkolenmijnen Ch. Groothoff introduceerde de spaarregeling voor personeelsleden beneden de leeftijd van 25 jaar op 12 maart $1948 .{ }^{309}$ Voor de uitvoering zou de Mijnindustrieraad een vijf leden tellend spaarcollege benoemen. De statsmijnen, de particuliere mijnbouwondernemingen en de erkende beambtenorganisaties benoemden elk één lid van dit college. De erkende vakorganisaties wezen twee leden aan. Had de spaarder voldaan aan de voorwaarden, dan stortte de betrokken mijnonderneming een spaarpremie van tien procent over het totaal van het gespaarde bedrag en de gekweekte rente. ${ }^{310}$

In 1956 streefde de Nederlandse Katholieke Mijnwerkersbond naar een wijziging van het premiepercentage, omdat een verhoging van de premie de aanmoediging tot deelname aan de spaarregeling voor jeugdigen zou bevorderen. ${ }^{311}$ De NKMB stelde voor om de extra-premie voor personeelsleden onder de 25 jaar (15 procent) op gelijke hoogte te brengen met de premie in het kader van de spaarregeling voor de oudere mijnwerkers $(20$ procent.). ${ }^{312}$ Het dagelijks bestuur van de Mijnindustrieraad besloot op 10 maart 1956 de NKMB mede te delen, dat zij een wijziging van het premiepercentage niet wenselijk achtte. ${ }^{3 / 3}$

Tabel 3.8 toont het gebruik van de spaarregeling voor jeugdigen bij de staatsmijnen. 
Tabel 3.8 spaarregeling jeugdigen bij staatsmijnen

\begin{tabular}{|c|c|c|c|c|}
\hline Jaar & $\begin{array}{l}\text { Aantal } \\
\text { deelnemers }\end{array}$ & $\begin{array}{c}\text { Participatie } \\
\left(\frac{8}{8}\right)\end{array}$ & $\begin{array}{l}\text { Eind- } \\
\text { saldo }\end{array}$ & $\begin{array}{l}\text { Uitgekeerde } \\
\text { spaarpremie }\end{array}$ \\
\hline & & & $\times 1000$ & gld \\
\hline 1948 & 1366 & 27,0 & & \\
\hline 1950 & 2741 & 43,0 & 203,6 & \\
\hline 1951 & 3533 & 47,0 & 736,0 & \\
\hline 1952 & 5014 & 54,0 & 1061,4 & \\
\hline 1953 & 5373 & 58,0 & 1408,1 & 98,1 \\
\hline 1954 & 6196 & 65,0 & 1827,8 & 154,3 \\
\hline 1955 & 6284 & 71,0 & 2229,7 & 157,6 \\
\hline 1956 & 6450 & 71,0 & 2667,7 & 295,1 \\
\hline 1957 & 6353 & 68,0 & 3064,5 & 405,0 \\
\hline 1958 & 7100 & 73,0 & 3540,2 & 535,4 \\
\hline 1959 & 6678 & 81,0 & 3953,0 & 686,4 \\
\hline 1960 & 2283 & 91,0 & 4146,5 & 187,7 \\
\hline 1961 & 1941 & 90,4 & 3962,8 & 211,8 \\
\hline 1962 & 1590 & 85,8 & 3956,1 & 208,6 \\
\hline 1963 & 1274 & 88,3 & 3771,7 & 235,8 \\
\hline 1965 & 3186 & 75,2 & 3758,5 & 176,7 \\
\hline 1966 & 2579 & 77,2 & 3493,1 & 226,2 \\
\hline 1967 & 2047 & 76,9 & 3240,5 & 223,1 \\
\hline
\end{tabular}

Bron: Spaarregeling Jeugdigen, De Gezamenlijke Steenkolenmijnen in Limburg, Afd. Statistiek; uit: Nederlandse Katholieke Mijnwerkersbond, Sociaal Historisch Centrum, Maastricht, EAN 581, H. 16.3.

Uiteindelijk werd de jeugdspaarregeling in 1959 aangepast aan de Jeugdspaarwet. Personeelsleden, die participeerden in de Jeugdspaarwet, ontvingen over het gespaarde bedrag in plaats van de aanvankelijke premie van 15 procent een premie van 20 procent. Voor zover het gespaarde bedrag niet hoger was dan 200 gulden per jaar, vloeide de helft van deze premie voort uit de Jeugdspaarwet. De andere helft, benevens de premie van 20 procent van het gespaarde boven de 200 gulden per jaar, kwam ten laste van het bedrijf..$^{314}$

\subsection{3.b Bezitsvorming: woningbouwregelingen}

De directie van de staatsmijnen stimuleerde de bezitsvorming van het personeel ook met de woningbouwregelingen van 1952, 1954 en 1960. De bouwregeling uit 1954 stelde personeelsleden in staat een renteloos voorschot te verkrijgen van 30 procent van de netto-bouwkosten van een eigen woning, tot een maximum van 12000 gulden. Zij vermeldde deze voorschotten in artikel 15 van afdeling II van de bedrijfsbegroting. Deze voorschotten zouden binnen 10 jaar moeten worden afgelost. De directie schold jaarlijks de aflossingen kwijt bij een doorlopend dienstverband en verantwoordde dit in de bedrijfsrekeningen onder de post sociale lasten. De regeling was geldig tot en met 1956, maar was in 1959 nog niet afgewikkeld. In 1957 ging de directie over tot een versnelde afboeking van het restant 
van de voorschotten. De staten-Generaal zouden deze handelwijze stilzwijgend hebben aanvaard. ${ }^{315}$

op grond van de eigenbouwregelingen van 1952 en 1954 konden 2795 personeelsleden eind 1959 beschikken over een eigen woning. ${ }^{316}$ ongeveer 650 personeelsleden participeerden in de eigenbouwregeling van $1960^{317}$. Aan 600 personeelsleden werd in 1964 een renteloos voorschot verstrekt ten behoeve van de aankoop of de bouw van een woning. ${ }^{318}$

\subsection{3.c Bezitsvorming: wingtdeling}

De directie van de staatsmijnen had de goedkeuring van de Minister van Economische Zaken nodig voor de bestemming van de winst. Na advies van de Mijnraad hechtte de minister al dan niet zijn goedkeuring aan het voorstel tot winstbesteming. Winstdelingsregelingen moesten voldoen aan de door het college van Rijksbemiddelaars gestelde voorwaarden. Tabel 3.9 geeft de winstbestemming weer bij de staatsmijnen. In de tabel zijn niet opgenomen de posten "voorziening voor bijzondere afloopen rationalisatiekosten" en "overige reserves".

Tabel 3.9 Winstbestemming (in mln gld)

\begin{tabular}{|c|c|c|c|c|c|c|}
\hline Jaar & $\begin{array}{c}\text { Belasting } \\
\text { (1) }\end{array}$ & Dividend & Personeel & $\begin{array}{l}\text { Bijz. } \\
\text { Research }\end{array}$ & $\begin{array}{l}\text { Soc. cult. } \\
\text { doeleinden }\end{array}$ & Totaal \\
\hline 1951 & 35,0 & 8,00 & & & & 47,50 \\
\hline 1952 & 33,0 & 8,00 & & & & 46,60 \\
\hline 1953 & 42,0 & 9,00 & 1,0 & & & 57,20 \\
\hline 1954 & 42,0 & 12,50 & 1,0 & & & 60,60 \\
\hline 1955 & 33,0 & 13,75 & 1,0 & & & 57,50 \\
\hline 1956 & 34,0 & 13,75 & 1,0 & & & 59,30 \\
\hline 1957 & 31,0 & 13,75 & 1,0 & & & 58,55 \\
\hline 1958 & 26,0 & 12,50 & 1,0 & & & 55,90 \\
\hline 1959 & 24,0 & 16,30 & 1,5 & & & 68,50 \\
\hline 1960 & 34,6 & 25,00 & 10,0 & 10,0 & 3,0 & 111,40 \\
\hline 1961 & 20,4 & 20,00 & 9,0 & & & 73,50 \\
\hline 1962 & & 10,00 & 3,0 & & & 30,00 \\
\hline 1963 & & 12,50 & 4,5 & & & 53,20 \\
\hline 1964 & & 15,00 & 6,0 & & & 53,90 \\
\hline 1965 & & 17,50 & 7,0 & & & 70,80 \\
\hline 1966 & & 17,50 & 5,8 & & & 52,20 \\
\hline 1967 & & 24,00 & 5,0 & & & 60,00 \\
\hline 1968 & & 30,00 & 5,8 & & & 87,60 \\
\hline 1969 & & 36,00 & 5,0 & & & 109,20 \\
\hline 1970 & & 30,00 & 5,0 & & & 80,90 \\
\hline
\end{tabular}

Opmerking: (1) Restitutie vennootschapsbelasting.

Bron: Staatsmijnen, Enige notities met betrekking tot het verband tussen de winst en uitkeringen aan personeel, 28 februari 1964, p. 3; Concern Archief DSM, Comptabele en Financiële Aangelegenheden 1960-1969, inv. nr. 91. Ministerie Van Economische Zaken, Dir. Mijnwezen, Bestemming van de winst over 1965, 20 april 1966. DSM, Jaarverslagen over 1968, 1969 en 1970. 
Het exploitatieresultaat over 1960 gaf de directie de beschikking over 3 miljoen gulden voor sociale bestemmingen. Deze winstbesteming stond los van het bestaande subsidiebeleid van het bedrijf en het was niet de bedoeling hiermee de regelmatig verstrekte subsidies uit te breiden. ${ }^{314}$ Bij de beoordeling van de bestemmingsmogelijkheden prevaleerden projecten gericht op het welzijn van de gehele bevolking van de mijnstreek, in het bijzonder projecten ten behoeve van de personeelsleden. De voorkeur ging uit naar een bestemming voor recreatiedoeleinden. ${ }^{320}$ De directie overwoog het geld te besteden aan het Recreatieschap Brunssummerheide (1 miljoen), een 15 -tal projecten tot verbetering van het leefklimat ( 1 miljoen) en de Schouwburg te Heerlen ( $1 / 4$ miljoen). De Minister van Economische Zaken J.W. de Pous (CHU) wilde gekend worden in de bestemming van de gereserveerde 3 miljoen. Hij was van oordeel dat bij de projecten tot verbetering van het leefklimaat ook protestants-christelijke en neutrale groepen moesten worden betrokken. ${ }^{321}$

De rol van de Minister van Economische Zaken blijkt ook uit het feit dat zijn goedkeuring was vereist voor het voorstel om 10 miljoen gulden uit de winst van 1960 te bestemmen voor het personeel. Het voorstel viel volgens de directie binnen de aanwijzingen van de door de loonpolitiek geopende mogelijkheden. ${ }^{322}$ Als voorwaarde stelde Minister De Pous dat ook uit de resultaten over 1961 een soortgelijke uitkering moest worden gedaan. Voor 1961 werd een bedrag van 9 miljoen gulden voorgesteld. ${ }^{323}$ over de vorm van de voorgestelde uitkering pleegde de directie overleg met de ondernemingsraad. De directie streefde ernaar dat een gedeelte van het beschikbare bedrag ter beschikking kwam van de spaarregeling. ${ }^{324}$

Op 2 mei 1961 installeerde de Katholieke Federatie de Commissie winstdelingregeling met de opdracht onderzoek te verrichten naar de eisen waaraan een winstdelingsregeling moest voldoen. Op de vraag of de laagstbetaalden voor een hogere uitkering in aanmerking kwamen, meende deze commissie ontkennend te moeten antwoorden. Als reden gaven $z i j$ dat een hogere winstuitkering voor de laagstbetaalden consequenties zou meebrengen voor het gehele beloningssysteem. De commissie verwees naar de verdeling van het jaarlijkse winstmiljoen bij de staatsmijnen. Het dividend diende de hoogte van de winstuitkering te bepalen. Hierdoor zouden misverstanden en moeilijkheden omtrent het vaststellen van de hoogte van de winst kunnen worden voorkomen. Winstdeling kon ook in de vorm van aandelencertificaten en obligaties. $\mathrm{zij}$ adviseerde aangaande deze vorm van winstdeling een politiek besluit over de rechtsvorm van de staatsmijnen af te wachten. ${ }^{325}$

In het zelfde jaar verzocht de Katholieke Federatie schriftelijk aan de Mijnindustrieraad een verordening over winstdeling vast te stellen. Het dagelijks bestuur van de Mijnindustrieraad deelde echter mee dat de Gemeenschappelijke Steenkolenmijnen in Limburg op deze problematiek studeerden. Een verplichting tot het instellen van een winstdelingsregeling voor het personeel behoorde juridisch niet tot de mogelijkheden. ${ }^{3 / 6}$ Het wetboek van Koophandel makte het onmogelijk om met een verordening van de 
Mijnindustrieraad een winstdelingsregeling voor de gehele bedrijfstak vast te stellen. Uitsluitend de aandeelhouders van de naamloze vennootschap konden statutair een winstdelingsregeling introduceren.

In 1964 benaderde de Katholieke Federatie het dagelijks bestuur van de Mijnindustrieraad met het verzoek om de besprekingen over de winstdeling te hervatten. ${ }^{327}$ De federatie deed een beroep op de hoofddirectie van de staatsmijnen om een gunstig besluit van de Mijnindustrieraad over een verordening op de winstdeling voor het personeel van de Nederlandse steenkolenmijnen te bevorderen. ${ }^{328}$ De Werkgroep Winstdeling van de staatsmijnen schreef in haar notitie voor de directie dat de Mijnindustrieraad niet behoorde over te gaan tot het vaststellen van een dergelijke verordening. Winstdeling was een aangelegenheid voor de afzonderlijke ondernemingen. Verder wees de werkgroep erop dat de wijziging van de status van de staatsmijnen tot gevolg had dat een winstdelingsregeling niet kon worden opgesteld. Na de wijziging van de rechtsvorm zouden enkele jaren van aanpassing moeten verstrijken, gedurende welke het niet mogelijk zou zijn om anders dan van jaar tot jaar een uitkering uit de winst vast te stellen. ${ }^{329}$ De winstuitkeringen in de mijnbouw waren afhankelijk van de bedrijfsresultaten. De staatsmijnen pasten zich aan bij de lagere uitkering van de particuliere mijnen.

Tijdens de bijeenkomst van het dagelijks bestuur van de Mijnindustrieraad op 3 maart 1964 stelde A. Hennekens, secretaris van de Katholieke Federatie, dat de lagere winstuitkering in 1963 bij de staatsmijnen het gevolg was van druk van de kant van de particuliere mijnen. De voorzitter van deze federatie F.S. Dohmen informeerde of in 1964 de winstdelingsregelingen zouden verschillen tussen de staatsmijnen en de particuliere mijnen. Hoofddirecteur A. Hellemans van de staatsmijnen vermeldde dat het totaal van de bedrijfsuitkomsten in aanmerking was genomen. F.M.J. Jansen, eveneens lid van de hoofddirectie van de staatsmijnen, attendeerde de aanwezigen op het feit dat de uitkomsten van de koolwinningsbedrijven ongunstig waren. ${ }^{330}$

\subsubsection{Het recht op de mijnen en de belastingen}

De Franse mijnwet van 1810 en het Keizerlijk Decreet van 1811 regelden het recht op de mijnen. Dit was een vergoeding aan de staat voor een concessie tot exploitatie van mineralen. De winst werd belast met opcenten. De staatsexploitatiewet van 1901 vrijwaarde de staatsmijnen hiervan. ${ }^{331}$ Het kabinet-Ruys de Beerenbrouck I beëindigue met behulp van de Wet op het recht op de mijnen van 1920 deze situatie met de bedoeling de extra-uitgaven van de mijngemeenten ten gevolge van de mijnindustrie te compenseren. Deze wet verhinderde dat de externe kosten (politie, openbaar bestuur, riolering), veroorzaakt door de mijnindustrie, via de inkomstenbelasting en de personele belasting werden verhaald bij de minder draagkrachtige bevolking van de mijnstreek. Het recht voor steenkolen werd gesteld op 25 cent per ton. Hiervan kwam 50 procent toe aan de rijksoverheid, de provincies en gemeenten ontvingen respectievelijk 10 en 40 procent. ${ }^{332}$ Financiële 
moeilijkheden in de mijnindustrie leidden in 1925 tot een schorsing van het recht op de mijnen. Het Rijk stelde de provincies en de gemeenten schadeloos.

In 1929 trad een nieuwe wet op het recht op de mijnen in werking. Het recht op steenkool werd gesteld op 10 cent per ton en kwam uitsluitend ten goede aan de gemeenten. ${ }^{333}$

In de jaren vijftig was de financiële relatie tussen de gemeenten en de rijksoverheid gewijzigd. Het stelsel van rijksuitkeringen beëindigde de ratio voor het recht op de mijnen. De aanwezigheid van de mijnindustrie begunstigde de mijngemeenten. Andere argumenten on het recht op de mijnen af te schaffen waren:

1. de discriminatie van de mijnbouwondernemingen ten opzichte van de andere industrieën,

2. het heffen van een dubbele belasting bij de mijnondernemingen, en

3. de onverenigbaarheid met het oprichtingsverdrag van de Europese Gemeenschap voor Kolen en Staal van 1952.334

Het recht op de mijnen was bij de bepaling van de belastbare winst voor de vennootschapsbelasting aftrekbaar als onkosten. Het stelsel van de vennootschapsbelasting stond niet toe dat het recht op de mijnen op het te betalen bedrag aan vennootschapsbelasting in mindering werd gebracht.

In 1950 werd de ondernemingsbelasting beëindigd en het tarief van de vennootschapsbelasting verhoogd. De Gezamenlijke Steenkolenmijnen in Limburg (GSL) hadden in het verleden actie gevoerd bij de rijksoverheid om de de ondernemingsbelasting te compenseren met het recht op de mijnen. De staatsmijnen bestudeerden of het, gezien de problematiek van de ongelijke druk van omzetbelasting op kolen en olie, aanbeveling verdiende actie te ondernemen tegen het recht op de mijnen. De olie-industrie betaalde immers concessiegelden in tegenstelling tot de staatsmijnen. Een poging het recht op de mijnen af te schaffen vestigde de aandacht van de olieindustrie op het argument dat de hogere omzetbelastingdruk werd gecompenseerd door het voordeel dat geen concessiegeld hoefde te worden afgedragen. ${ }^{335}$

Bij Wet van 12 juli 1961 verviel per 1 januari 1960 de tweede titel van de wet van 26 maart 1920 tot heffing van een recht op de mijnen. ${ }^{336}$

De bepalingen van de wet op de dividend- en tantièmebelasting van 1917 waren niet van toepassing op de winsten van de Staatsmijnen. Hierdoor derfden de gemeenten inkomsten in de vorm van opcenten op een rijksbelasting. De directie van de staatsmijnen wenste geen fiscaal bevoorrechte positie in te nemen ten opzichte van de particuliere mijnbouwondernemingen. In 1939 adviseerde de Mijnraad, met instemming van de directie van de Staatsmijnen, de Minister van Financiën J.A. de Wilde (AR) de vrijstelling van de dividend- en tantièmebelasting voor dit staatsbedrijf te beëindigen. De Minister stelde zich op het standpunt dat het er niet toe deed hoe het geld in de staatskas kwam (een winstuitkering met of zonder dividendbelasting). Hij liet hier echter de 48 opcenten die 
aan de gemeenten toekwamen buiten beschouwing. Uit overwegingen van billijkheid moesten de gemeenten op dezelfde wijze profiteren van de staatsmijnen als van de particuliere mijnen.

De afwijzende houding van Minister De wilde kan mogelijk worden verklaard door het verzoek van de directie van de staatsmijnen on een wijziging aan te brengen in de wet op de dividend- en tantièmebelasting. Mocht een wijziging op bezwaren stuiten, dan stelde de directie voor om in de begroting van de staatsmijnen naast de winstuitkering een uitkering op te nemen gelijk aan het bedrag aan dividend- en tantièmebelasting. Van deze uitkering zouden 48 opcenten ten goede komen aan de gemeenten. ${ }^{337}$

Minister van Financiën D.J. de Geer schreef aan Minister van Verkeer en waterstaat J.W. Albarda dat er geen sprake was van bevoorrechting van de staatsmijnen. Uit de analoge toepassing van de wet op de dividend- en tantièmebelasting resulteerde voor de staat een nadeel als gevolg van de uitkering aan de gemeenten. Deze uitkering zou in totaal ongeveer 87.000 gulden bedragen. De helft hiervan zou ten goede komen van noodlijdende gemeenten en dus strekken ter vermindering van de overheidssteun aan die gemeenten. De andere helft zou ten goede komen van gemeenten, die geen bijzondere steun behoefden. Deze financiële middelen stroomden naar plaatsen, waar daaraan geen dringende behoefte bestond. Minister De Geer verklaarde hiermee accoord te gaan, als de Minister van verkeer en Waterstaat deze vorm van uitkering prefereerde. Hij gaf er de voorkeur aan het bedrag, boven het aan de staat uit te keren dividend, te verantwoorden als een verhoging van de winstuitkering. De middelen hiervoor moesten worden verkregen door minder extra- afschrijving of door minder toe te voegen aan de reserves. ${ }^{338}$

Vanaf 1939 inde de rijksoverheid winstbelasting. De staatsmijnen waren niet aan winstbelasting onderworpen, maar betaalden deze voor 1939 en 1940 vrijwillig. De heffing bedroeg in 1939 tien procent en vijftien opcenten en in 1940 tien procent en tweehonderdvijftien opcenten. Voor 1940 stelde de directie het vrijwillig te betalen bedrag vast op 15,4 miljoen gulden en het aan het Rijk uit te keren bedrag stelde zij op 4,6 miljoen gulden.

De staatsmijnen genoten verder wettelijke vrijstelling van de vermogensbelasting voor de bedrijven van openbare lichamen, die werd geheven van 1941 tot en met 1946. De directie betaalde ook deze belasting vrijwillig. De ondernemingsbelasting van 1941, verschuldigd over het vermogen en de winst, werd gewoon betaald. De rijksoverheid inde de belasting over vermogen voor het laatst in 1947 en die over winst voor het laatst in $1949 .{ }^{339}$

De particuliere mijnondernemingen verkregen van de rijksoverheid een belastingvrije vergoeding overeenkomstig artikel 5 van het Buitengewoon mijnbesluit van 26 april 1945. De directie van de staatsmijnen meende dat er sprake was van een gunstiger regeling voor de particuliere mijnen dan voor hen. Zij meende aanspraak te mogen maken op een identieke fiscale behandeling. Dit hield in dat de staatsmijnen bij de opstelling van de fiscale balans en de verlies- en winstreke- 
ning moesten worden behandeld alsof $z i j$ vergoeding verkregen overeenkomstig mijnbesluit. ${ }^{340}$ op analoge wijze een het Buitengewoon

\subsubsection{Onderzoek en Ontwikkeling}

Na 1945 daalde de kolenproduktie van de Nederlandse mijnen als gevolg van het afnemend aantal werknemers en de overschakeling op aardgas. De geleidelijke sluiting van de mijnen kwan op de agenda's van enkele kabinetten en de hoofddirectie van de staatsmijnen voor. In dit kader moet dan ook het doel van de directie om de staatsmijnen te veranderen in een chemisch bedrijf worden beschouwd. ${ }^{34}$ onderzoek en ontwikkeling waren van belang voor de omschakeling van een mijnbouwonderneming naar een chemisch bedrijf.

Het onderzoek bij de Staatsmijnen had inmiddels vanaf 1929 drie stadia doorlopen. Het eerste stadium van het service onderzoek begon in 1929. Het tweede stadium van het pionierend toegepast onderzoek startte in 1937 en het derde stadium betrof het fundamenteel industrieel onderzoek vanaf het begin van de jaren veertig. ${ }^{342}$ Het toenemende belang van de research noopte tot management van de ontwikkelde kennis. Management van kennis zou naast het beschermen met octrooien, een beheersing van de verspreiding van wetenschappelijke kennis als nevenresultaat inhouden. Wetenschappelijke kennis mocht niet zonder tegenprestatie ten goede komen van derden. ${ }^{343}$

Het beleid met betrekking tot wetenschappelijke en technische adviezen kwam in de jaren vijftig door de veranderde omstandigheden voor wijziging in aanmerking. Het slechts doorberekenen van de directe kosten, zonder dat deze in enige verhouding stonden tot de waarde van het advies werd afgewezen. Het was gebruikelijk dat aan het te garanderen rendement ten gevolge van de toepassing van vergaarde kennis een boete, respectievelijk een premie werd verbonden voor elk procent beneden of boven het gegarandeerde rendement. Het bezwaar hiertegen was dat bedrijven premies inden en kennis verkregen, terwijl de staatsmijnen de lasten van het onderzoek voor hun rekening namen. ${ }^{344}$

De staatsmijnen gingen aan het begin van de jaren zestig over tot de planning van hun bedrijfsactiviteiten. De planning van het onderzoek en de verdeling van de beschikbare financiële middelen over de verschillende onderzoekstaken makkten daar deel van uit. Het werd wenselijk geacht de research-inspanning te laten toenemen met de groei van de omzet van de chemische bedrijven. De belangsteliing voor pionierend onderzoek nam toe en ging gepaard met een aanzienlijke mate van vrijheid voor de onderzoekers. De kosten voor dit type van onderzoek stegen van 1968 naar 1969 van 3,6 miljoen gulden naar 6,2 miljoen gulden bij totale onderzoekskosten van respectievelijk 39,2 en 40,7 miljoen gulden. De staatsmijnen ontwikkelden een capaciteit om onderzoek in opdracht van derden uit te voeren. Voorbeelden van onderzoek in opdracht waren bijvoorbeeld het "hydranonproces", het "hyamproces" en het "solutieproces" voor de produktie van polyetheen. ${ }^{345}$

Uit de verhouding tussen investeringen in nieuwe processen 
en researchkosten voor nieuwe processen bij de staatsmijnen blijkt dat onderzoek in toenemende mate leidde tot investeringen. De resultaten van onderzoek en ontwikkeling hadden echter vertraagd investeringen tot gevolg. Tabel 3.10 toont de verhouding tussen de kosten voor onderzoek en de hieruit resulterende vertraagde investeringen.

Tabel 3.10 Researchkosten en investeringen in nieuwe processen.

\begin{tabular}{|c|c|c|c|c|}
\hline Jaar & $\begin{array}{l}\text { Saldo researchkosten } \\
\text { nieuwe processen (a) }\end{array}$ & $\begin{array}{l}\text { Investeringen in } \\
\text { nieuwe processen (b) }\end{array}$ & $(b):(a)$ & \\
\hline \multicolumn{5}{|c|}{ mln gld } \\
\hline 1957 & 10,0 & - & - & \\
\hline 1958 & 8,6 & - & - & \\
\hline 1959 & 8,2 & - & - & \\
\hline 1960 & 10,8 & 0,8 & 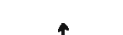 & 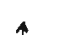 \\
\hline 1961 & 14,2 & 10,5 & 1,1 & \\
\hline 1962 & 18,4 & 17,3 & $d$ & 1,3 \\
\hline 1963 & 17,6 & 21,2 & & 1 \\
\hline 1964 & 20,6 & 17,3 & & \\
\hline 1965 & 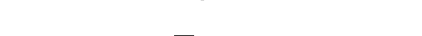 & 35,7 & $\uparrow$ & 2,8 \\
\hline 1966 & - & 54,7 & 3,2 & \\
\hline 1967 & - & 91,8 & $\downarrow$ & \\
\hline Totaal & 108,4 & 249,3 & & \\
\hline
\end{tabular}

Bron: staatsmijnen, ondernemingsraad, bijlage bij notulen van 305e vergadering, 12 februari 1969, p. 3; bron: Concern Archief DSM, Organen van overleg en bedrijfsrechtspraak, 1950-1969, inv. $\mathrm{nr} .89 \mathrm{c}$.

De loon- en salarisontwikkeling bepaalde voor een belangrijk deel de kosten voor het onderzoek bij de staatsmijnen. Na een correctie voor de invloed van deze factor bleef een reële groei van de onderzoeksactiviteiten van gemiddeld zes procent over voor de periode 1960 tot en met 1966. Voor de periode 1966 tot en met 1970 trachtte de directie een gemiddeld groeipercentage van drie procent te verwezenlijken. De realisatie van het laatst genoemde percentage was afhankelijk van de ontwikkeling van de loonkosten. Men voerde een voorzichtig personeelsbeleid om te voorkomen dat de geraamde reële groei van de onderzoeksactiviteiten een te grote stijging van de bruto-researchkosten met zich mee zou brengen. ${ }^{346}$ De licentie- en octrooikosten zijn een indicatie voor de resultaten van het wetenschappelijk onderzoek. De correlatie-coëfficiënt tussen enerzijds de loon- en salariskosten en anderzijds de licentie- en octrooikosten was $r^{2}=0,67$ voor de periode 1952 tot en met 1966 . 
De regressievergelijking luidt:

$$
\begin{aligned}
Y= & 0,02 X+76.8 \\
& (5,168)(1.610)
\end{aligned}
$$

Y: de licentie- en octrooikosten, en

$X$ : de loon- en salariskosten.

onder de vergelijking staan tussen haakjes de $t$-waarden. Voor de cijfers ter bepaling van de bovengenoemde correlatiecoëfficiënt en regressievergelijking wordt verwezen naar bijlage 3.4. Tabel 3.11 toont voor 1966 de verhouding tussen de uitgaven voor onderzoek en de omzet van een aantal chemische bedrijven.

\begin{tabular}{|c|c|c|c|}
\hline onderneming & Omzet (1) & $\begin{array}{l}\text { Uitgaven } \\
\text { onderzoek (2) }\end{array}$ & $\underset{\substack{8 \\
\text { (2) }}}{(2)}$ \\
\hline & $\mathrm{mln}$ gld & $\mathrm{mln} g l d$ & \\
\hline Aku & 2.800 & 100 & 3,6 \\
\hline Basf & 4.250 & 170 & 4,0 \\
\hline Bayer & 5.300 & 185 (Bayer AG) & 3,5 \\
\hline Ciba & 1.750 & 160 & 9,2 \\
\hline Dow & 4.250 & 255 & 6,0 \\
\hline Du Pont & 11.400 & 550 & 4,8 \\
\hline Esso-chemicals & 2.676 & 327 & 12,0 \\
\hline Hoechst & 5.250 & 225 & 4,2 \\
\hline ICI & 8.850 & 325 & 3,7 \\
\hline Merck & 1.505 & 144 & 9,6 \\
\hline DSM 1966 & 442 & 35.8 & 8,1 \\
\hline DSM 1967 & 505 & 38.7 & 7,7 \\
\hline DSM 1968 & 597 & 39.1 & 6,5 \\
\hline
\end{tabular}

Tabel 3.11 Uitgaven voor onderzoek in 1966

Bron: Staatsmijnen, ondernemingsraad, Bijlage bij notulen van $305 \mathrm{e}$ vergadering, 12 februari $1969, p$. 1 i bron: Concern Archief DSM, Organen van overleg en bedrijfsrechtspraak, 1950-1969, inv. nr. $89 \mathrm{c}$.

Uit de bovenstaande cijfers blijkt dat de staatsmijnen een vierde plaats innam op de ranglijst. De vergelijking van deze cijfers moet met voorbehoud geschieden, omdat niet bekend is op welke soorten van onderzoek $z i j$ betrekking hebben.

\subsection{Privatigering}

Het politieke debat over de wenselijkheid van staatsbedrijven en bezitsvorming vormde na de Tweede Wereldoorlog aanleiding om nader aandacht te besteden aan het vraagstuk van de status van de Staatsmijnen. In 1955 beschouwde de CHU afgevaardigde in de Eerste Kamer der Staten-Generaal Vixseboxse het verstrekken van matschappelijk aandelenkapitaal als een manier om de bezitsvorming te bevorden, zonder afbreuk te doen 
aan de zeggenschap van de staat. Zijn collega Hellema (AR) deelde deze mening. ${ }^{37}$ De politieke belangstelling voor bezitsspreiding door denationalisatie vormde voor de hoofddirectie van de staatsmijnen reden het vraagstuk van de rechtspersoonlijkheid, vooruitlopend op de politieke ontwikkelingen, te regelen. De houding van de hoofddirectie tegenover de ideologie van de bezitsvorming was onverschillig. ${ }^{348}$ Binnen de staatsmijnen werd bezitsvorming door denationalisatie, dit wilde zeggen verspreiding van aandelen van overheidsbedrijven, gezien als een omvorming van reeds bestaand bezit. Denationalisatie betekende de afstoting van financiële overheidsdeelneming. Het gevaar bestond dat bij het falen van de denationalisatie of door de politieke ontwikkelingen concentratie van de aandelen plaatsvond bij een relatief kleine groep. Ondanks de bezwaren en problemen, verbonden aan bezitsvorming, betekende dit echter niet dat spreiding van aandelen onder alle omstandigheden zou moeten worden uitgesloten. Om bij spreiding van aandelen bezitstransformatie (belegging door spaarders) te vermijden en bezit te vermeerderen, zou de mogelijkheid moeten worden bestudeerd van een regeling die de intekenaars een extrakorting op de koers verstrekte. Bijvoorbeeld een korting afhankelijk van de hoogte van het inkomen en van de gezinsgrootte. 349

In 1964 was de vermogensaanwasdeling een belangrijk politiek onderwerp. Vermogensaanwasdeling betekende het delen in de toeneming van het ondernemingsvermogen door werknemers in de vorm van vermogenstitels. In het voorlopig verslag over het Wetsontwerp over omzetting van het staatsbedrijf der staatsmijnen in een naamloze vennootschap, stelden enkele leden van de staten-Generaal aan het kabinet-Marijnen voor om particuliere aandeelhouders te betrekken bij de nieuwe vennootschap. Daarnaast verzochten zij aan het kabinet na te gaan of de werknemers onder gunstiger voorwaarden, dan die golden voor de overige particulieren, aandelen zouden kunnen verwerven. ${ }^{350}$ De hoofddirectie van de staatsmijnen stelde Minister van Economische Zaken J.E. Andriessen (CHU) voor hierop te reageren met de mededeling dat een eventuele privatisering van de staatsmijnen, al dan niet gekoppeld aan het streven van bezitsvorming bij de eigen werknemers, slechts op eigen merites aan de orde kon worden gesteld. Privatisering van de staatsmijnen moest worden beschouwd in samenhang met een eventuele privatisering van overheidsdeelname in het algemeen. ${ }^{31}$

Het wetsontwerp tot statuswijziging bevatte geen bepalingen over vermogensaanwasdeling bij de staatsmijnen. De Werkgroep Winstdeling van de staatsmijnen wees de hoofddirectie op de mogelijkheid, dat in de staten-General bij de behandeling van de financieringsstructuur al dan niet direct een verband zou worden gelegd met de vermogensaanwasdeling. De werkgroep adviseerde hiertegen geen bezwaren te maken als de statenGeneraal opnieuw zouden aandringen om werknemers toe te laten als aandeelhouders. ${ }^{352}$ De Wet van 23 juni 1966 veranderde het staatsbedrijf in een naamloze vennootschap per 1 januari 1967. Deze wet machtigde de Minister van Economische Zaken om voor 300 miljoen gulden te participeren in een matschappelijk 
kapitaal van 500 miljoen gulden. ${ }^{353}$

\subsection{1 verklaring van de prestaties door het overheidsbedriff en de reacties principalen}

Het gewicht van de doeleinden van de staatsmijnen kan worden afgeleid uit een analyse van de wisselwerking tussen de verklaring van het bedrijf en de (uitblijvende) reacties van de principalen.

\subsubsection{Benoemingen}

De Staten-Generaal, de vakbeweging en de media hadden de benoeming van de directieleden en de samenstelling van de directie van staatsmijnen altijd nauwlettend gevolgd. De belangstelling hiervoor was gebaseerd op de vraag of het politieke benoemingen behelsde en of de matschappelijke verhoudingen tot uitdrukking kwamen. In de jaren twintig uitte Monseigneur H.A. Poels, een voorstander van de emancipatie van het rooms-katholieke volksdeel, de klacht dat de directie van de staatsmijnen slechts bestond uit protestanten. Het lid van de Eerste Kamer der Staten-Generaal G.F. Lindemeijer (SDAP) beschouwde dit als een poging de leiding van het bedrijf in handen te krijgen en de belangrijkste functies te bezetten. Toepassing van de verkiezingsuitslagen zou volgens Lindemeijer voor de staatsbedrijven consequenties hebben, die zelfs de katholieke politici en media niet wensten. ${ }^{354}$

In 1940 hanteerde Minister van Economische zaken Steenberghe als uitgangspunt dat geen benoeming tot 1 id van de directie bij de staatsmijnen kon plaatsvinden, als daartegen bij de directie bezwaar bestond. De minister verzocht de directie voorstellen te doen en consulteerde de Mijnraad. ${ }^{355}$

De directie van de Staatsmijnen werd in 1949 met twee leden uitgebreid, terwijl één vacature werd opgevuld. De drie kandidaten kwamen voort uit het eigen personeel. Het was een uitbreiding op het sociaal-economisch beleidsterrein, die inging tegen de verwachtingen van de technische beambten. Zij hadden de verwachting gekoesterd dat een uitbreiding van de directie aan de technische kant zou plaatsvinden. ${ }^{356}$

In 1953 waren drie van de vijf directeuren van de staatsmijnen rooms-katholiek. Zij bekleedden de zogenaamde "sleutelposities" in de sociale en de economische sector en in de nevenbedrijven. De technische en commerciële functies werden waargenomen door niet-katholieken. De directie bestond uit Wemmers (directeur-voorzitter), Van Aken (rk), Jansen (rk), Rottier (rk) en Hellemans. ${ }^{357}$ Het Koninklijk Besluit van 1959 bepaalde dat de directie van de staatsmijnen voortaan zou worden aangeduid met de term "hoofddirectie". Rekening houdend met de situatie in 1959 verwachtte de Katholieke Federatie dat de topleiding van de staatsmijnen in 1965 zou zijn samengesteld uit 5 katholieken en 3 niet-katholieken. Deze verhouding zou volgens deze federatie ook in de toekomst blijven gehandhaafd. ${ }^{338}$ De verwachting van de Katholieke Federatie kwam niet uit. In 1965 bestond de hoofddirectie uit: A.C.J. Rottier (president-directeur), J.S.A.J.M. van Aken, F.M.J. Jansen, A. Hellemans en W.E. van Os. 
De Minister van Economische Zaken beschikte over het recht de leden van de hoofddirectie toesteming te verlenen om nevenfuncties te vervullen. De hoofddirectie volgde de gedragslijn om geen commissariaten te aanvaarden. Op deze algemene regel werden in de loop van de tijd uitzonderingen gemakkt. De inkomsten uit commissariaten vormden een aanvulling op de beloning, omdat deze in vergelijking met particuliere ondernemingen laag was.

De inkomsten uit commissariaten in dochterondernemingen en vennootschappen waarin de staatsmijnen deelnamen, werden gestort in de kas van dit staatsbedrijf. Voor comissariaten op grond van een persoonlijke relatie, met name familievennootschappen, kwamen de inkomsten toe an de betrokkene. De inkomsten uit alle andere commissariaten kwamen ten bate van de gehele hoofddirectie, met dien verstande dat de betrokken directeur een dubbel aandeel ontving. De verdeling van de inkomsten uit commissariaten verhinderde spanningen ten gevolge van inkomensverschillen. ${ }^{359}$

De statutaire regeling van het instituut van de Gedelegeerd Commissarissen stond hoog op de agenda van de commissie Rechtsvorm staatsmijnen. De ambtelijke vertegenwoordigers in deze commissie waren er voorstander van on de door de overheid aan te wijzen commissarissen de status van Gedelegeerd Commissaris toe te kennen. De ambtelijke vertegenwoordigers hadden hier aanvankelijk van afgezien. Het gevolg hiervan was dat bij een laag aandelenkapitaal en een hoog dividendpercentage, een groter winstaandeel in de vorm van tantièmes toekwam aan de directie en de commissarissen. Voor de aandeelhouder bestonden er weinig mogelijkheden om hiertegen op te treden. President-directeur Rottier argumenteerde in de Commissie Rechtsvorm Staatsmijnen dat het niet noodzakelijk was een sterke band met de overheid uitdrukkelijk in de statuten vast te leggen. ${ }^{360}$ op het Ministerie van Economische Zaken overwogen de betrokken ambtenaren de staatsmijnen voor de keuze te stellen 350 miljoen gulden aandelenkapitaal te aanvaarden of in te stemmen met 300 miljoen gulden aandelenkapitaal, gecombineerd met de aanwijzing van Gedelegeerd Commissarissen door de betrokken ministers. Binnen de Commissie Rechtsvorm staatsmijnen was de groep Staatsmijnen-Mijnraad voorstander van een aandelenkapitaal van 300 miljoen gulden, hetgeen werd gemotiveerd met het te realiseren dividendpercentage. ${ }^{361}$

De statuten van 1967 gaven de Algemene Vergadering van Aandeelhouders de bevoegdheid om ten hoogste drie Gedelegeerd commissarissen te benoemen, die tot taak hadden een intensief toezicht op de hoofddirectie uit te oefenen. De voorzitter van het College van Gedelegeerden was voorzitter van de Raad van Commissarissen, indien deze door de Algemene Vergadering van Aandeelhouders tot. gedelegeerde was benoemd. ${ }^{302}$ De Gedelegeerd Commissaris W.C.L. van der Grinten (Mijnraad, KVP) bekleedde het voorzitterschap van de Raad van Commissarissen van 1967 tot en met 1985. De andere Gedelegeerd Commissarissen waren w.A. van de Garde (Ministerie van Economische Zaken) en J.C.W.M. Huijsmans (Ministerie van Financiën). Aan de benoeming van de leden van de Raad van Commissarissen lagen levensbeschouwelijke en sociale (werknemer, werkgever, 
algemeen en departement) overwegingen ten grondslag, die een matschappelijk afspiegeling in de raad mogelijk maakte.

Tegelijk met de oprichting van de staatsmijnen in 1902 werd de reeds eerder genoemde Mijnraad ingesteld. De Minister benoemde de leden van de Mijnraad. De samenstelling van de Mijnraad diende een afspiegeling te vormen van de geestelijke en politieke stromingen in Nederland. In 1948 achtte de Mijnraad het om deze reden wenselijk voorlopig tenminste één lid uit socialistische kring te accepteren. ${ }^{363}$ voorzitter van de Mijnraad waren achtereenvolgens: C.H.A. van den Wijck (1902-1908), C. Lely (Unie van Liberalen, 1908-1913), W.H. Nolens (RKSP, 1913-1931), J.R.H. van Schaik (RKSP, 1932-1933), Ch. J.M. Ruys de Beerenbrouck (RKSP, 1933-1936), P.J.M. Aalberse (RKSP, 1937-1945), L.F.H. Regout (KVP, 1945-1957) en W.C.L. van der Grinten (KVP, 1957-1967).

\subsection{3 voortzetting niet ter discussie stande activiteiten}

\subsection{3.a. Garantiebeleid}

Het Wetboek van Koophandel bevatte geen richtlijnen voor de publikatie van garanties. Het garantiebeleid van de directie van de staatsmijnen kan worden beschouwd als een voortzetting van beleid, dat niet ter discussie staat. $\mathrm{zij}$ vermeldde de aangegane garantieverplichtingen in het bedrijfseconomisch verslag, maar niet in het jaarverslag. De verwachting was dat de garanties voor de dochterondernemingen zouden teruglopen na de ontwikkeling van een zelfstandig kredietpotentieel. De Staatsmijnen gingen garanties aan voor de activiteiten van de Columbia Nitrogen Corporation, de Colombia Nipro Corporation, de Chemische Industrie Rijnmond, de DSM Transport NV en de woningbouw. Het streven om kapitaalbehoefte van dochterondernemingen zoveel mogelijk te financieren met leningen verklaarde het niveau van de garantieverplichtingen. ${ }^{364}$

Na de verzelfstandiging nam het bedrijf de garanties van de rijksoverheid aan de dochterondernemingen over. In 1969 verwachtte de hoofddirectie van de NV staatsmijnen de garantieverplichtingen te moeten nakomen tot een bedrag van 41,3 miljoen gulden. Hiervoor bracht de directie in 1969 en 1970 respectievelijk 20,6 en $20,7 \mathrm{miljoen}$ gulden ten gunste van de balanspost "overige voorzieningen". Het bedrag van 20,7 miljoen kwam ten laste van de voorziening "overige reserves" en van de voorziening "uitgestelde belastingen". ${ }^{365}$

In hoofdstuk 4 wordt in paragraaf 8.2 de groei van de garanties, die zijn verstrekt door de NV Nederlandse Spoorwegen, de NV Nederlandse staatsmijnen en de rijksoverheid, vergeleken. De liquiditeitsposities van beide bedrijven worden geconfronteerd met de garantiebedragen. 
Bijlage 3.1

De NV staatsmijnen als houdstermatschappij in 1968

(niet) geconsolideerde dochterondernemingen

$<50 \% \quad 50-<100 \% \quad 100 \%$

$\begin{array}{lll}12 & 13 & 11\end{array}$

deelnemingen via niet-geconsolideerde dochterondernemingen 5 1 2

Bron: Concern Archief DSM, Comptabele en Financiële Aangelegenheden 1960-1969, inv. nr. 177 (2). 
Bijlage 3.2 Data prestatie-onderzoek mijnbouw.

\begin{tabular}{|c|c|c|c|c|c|c|}
\hline onderneming & $Q / L$ & $Q_{m}(1)$ & Kwh (2) & $Q / N$ & laagdikte (3) & D \\
\hline \multicolumn{6}{|l|}{ Staatsmijnen } & \\
\hline 1951 & 422,4 & 9,0 & 792836 & 1950250 & 115 & 1 \\
\hline 1952 & 393,3 & 12,0 & 858496 & 1880500 & 107 & 1 \\
\hline 1953 & 394,4 & 15,0 & 907892 & 1882750 & 103 & 1 \\
\hline 1954 & 393,0 & 20,0 & 940555 & 1898250 & 100 & 1 \\
\hline 1955 & 392,9 & 26,0 & 960548 & 1869250 & 99 & 1 \\
\hline 1956 & 389,8 & 25,0 & 974777 & 1874750 & 102 & 1 \\
\hline 1957 & 363,8 & 30,0 & 1044147 & 1808000 & 100 & 1 \\
\hline 1958 & 490,9 & 34,0 & 1072844 & 1888750 & 99 & 1 \\
\hline 1959 & 418,3 & 46,0 & 1109027 & 1876500 & 98 & 1 \\
\hline 1960 & 455,7 & 49,0 & 1187767 & 1940000 & 98 & 1 \\
\hline 1961 & 485,8 & 60,0 & 1266153 & 1942250 & 102 & 1 \\
\hline 1962 & 447,0 & 71,0 & 1362795 & 1749500 & 100 & 1 \\
\hline 1963 & 474,0 & 75,0 & 1426140 & 1731000 & 101 & 1 \\
\hline 1964 & 474,0 & 75,0 & 1504944 & 1700250 & 102 & 1 \\
\hline 1965 & 499,5 & 75,0 & 1573818 & 1682000 & 103 & 1 \\
\hline \multicolumn{7}{|c|}{ Laura en Vereniging } \\
\hline 1952 & 462,7 & 50,0 & 47736 & 722500 & 105 & 0 \\
\hline 1953 & 453,7 & 47,0 & 57068 & 683500 & 96 & 0 \\
\hline 1954 & 452,3 & 40,0 & 67151 & 644500 & 100 & 0 \\
\hline 1955 & 424,3 & 45,0 & 64228 & 639000 & 102 & 0 \\
\hline 1956 & 406,1 & 49,0 & 61719 & 625000 & 101 & 0 \\
\hline 1957 & 389,8 & 49,0 & 59961 & 592500 & 98 & 0 \\
\hline 1958 & 391,6 & 50,0 & 59248 & 609000 & 105 & 0 \\
\hline 1959 & 420,0 & 61,0 & 67450 & 638000 & 101 & 0 \\
\hline 1960 & 473,8 & 67,0 & 55900 & 688000 & 100 & 0 \\
\hline 1961 & 477,6 & 76,0 & 53188 & 661500 & 107 & 0 \\
\hline 1962 & 454,7 & 79,0 & 53645 & 634500 & 112 & 0 \\
\hline 1963 & 435,9 & 87,0 & 57591 & 612500 & 106 & 0 \\
\hline 1964 & 439,2 & 78,0 & 60756 & 616000 & 105 & 0 \\
\hline 1965 & 434,0 & 75,0 & 62945 & 603000 & 105 & 0 \\
\hline \multicolumn{7}{|c|}{ Oranje Nassau } \\
\hline 1951 & 475,2 & 13,0 & 79549 & 608250 & 117 & 0 \\
\hline 1952 & 491,3 & 25,0 & 80598 & 663500 & 111 & 0 \\
\hline 1960 & 455,4 & 44,0 & 96767 & 599000 & 92 & 0 \\
\hline 1961 & 506,0 & 68,0 & 101996 & 633500 & 103 & 0 \\
\hline 1962 & 460,3 & 87,0 & 106033 & 586000 & 106 & 0 \\
\hline 1963 & 458,3 & 80,0 & 104951 & 588750 & 100 & 0 \\
\hline 1964 & 459,3 & 79,0 & 106020 & 608250 & 100 & 0 \\
\hline 1965 & 497,9 & 85,0 & 106726 & 635500 & 103 & 0 \\
\hline
\end{tabular}


Bijlage Data prestatie-onderzoek mijnbouw (vervolg).

\begin{tabular}{lcccccc}
\hline \multicolumn{2}{c}{ onderneming $Q / L$} & $Q_{\mathrm{m}}(1)$ & $\mathrm{KWh}(2)$ & $Q / N$ & laagdikte(3) & $D$ \\
\hline Willem en Sophie & & & & & & \\
1954 & 311,8 & 12,0 & 35595 & 377000 & 103 & 0 \\
1955 & 318,4 & 44,0 & 35724 & 376000 & 85 & 0 \\
1956 & 322,1 & 53,0 & 37740 & 382000 & 92 & 0 \\
1957 & 309,2 & 57,0 & 37980 & 381000 & 86 & 0 \\
1958 & 310,6 & 74,0 & 36957 & 382000 & 70 & 0 \\
1959 & 314,1 & 78,0 & 35108 & 387000 & 68 & 0 \\
\hline
\end{tabular}

Opmerking: (1) De cijfers over mechanisatie zijn ontleend aan: J.M.G. Pieters, Lonen en bedrijfsresultaten bij de Nederlandse steenkolenmijnondernemingen in de Gemeenschappelijke Steenkolenmarkt van de EGKS, Proefschrift, Alberts Gulpen b.v., 1981, p. 300 .

(2) Eigen verbruik elektriciteit $\times 1000 \mathrm{Kwh}$.

(3) Netto-laagdikte in centimeters.

Bron: Gezamenlijke steenkolenmijnen in Limburg, Statistieken. Geologie en Mijnbouw, maart/april 1971.

Bijlage 3.3

Tarief gaslevering aan gemeenten 1936

(Prijzen per $\mathrm{m}^{3}$ bij een kolenbasisprijs van 8 gulden en lager)

\begin{tabular}{lllll}
\hline Gemeente & Maastricht & Weert & 's-Bosch & Boxtel \\
& Roermond & & Vught \\
& Eindhoven & & Helmond \\
& Echt & &
\end{tabular}

miljoen $\mathrm{m}^{3} /$ jaar

$\begin{array}{lllll}\text { le } & 2,6 \text { cent } & 2,8 \text { cent } & 3,15 \text { cent } & 3,2 \text { cent } \\ 2 \mathrm{e} & 2,4 & 2,6 & 2,95 & 3,0 \\ 3 \mathrm{e} & 2,2 & 2,4 & 2,75 & 2,8 \\ 4 \mathrm{e} & 2,1 & 2,3 & 2,55 & 2,7 \\ 5 \mathrm{e} & 2,0 & 2,2 & 2,35 & 2,6 \\ 6 \mathrm{e} & 1,9 & 2,1 & 2,15 & 2,5 \\ 7 \mathrm{e} & 1,8 & 2,0 & 2,0 & 2,4 \\ \text { volgende } & 1,7 & 1,9 & 1,9 & 2,3\end{array}$

Uit: Staatsmijnen, Gaslevering aan gemeenten, Heerlen, 2 december 1936, nr. 104726; bron: Concern Archief DSM, Gasdistributiebedrijf tot en met 1939, inv. nr. 188. 
Bijlage 3.4 Onderzoek Staatsmijnen

\begin{tabular}{lcc}
\hline Jaar & $\begin{array}{l}\text { Lonen en } \\
\text { salarissen }\end{array}$ & $\begin{array}{l}\text { Licentie- en } \\
\text { octrooikosten }\end{array}$ \\
& \multicolumn{2}{c}{$\times 1000$ gld } \\
1952 & 2.487 & 138 \\
1953 & 2.739 & 145 \\
1954 & 3.264 & 171 \\
1955 & 3.666 & 174 \\
1956 & 4.159 & 98 \\
1957 & 4.454 & 207 \\
1958 & 7.872 & 209 \\
1959 & 10.527 & 296 \\
1960 & 12.307 & 342 \\
1961 & 13.598 & 303 \\
1962 & 15.026 & 479 \\
1963 & 16.648 & 196 \\
1964 & 18.941 & 259 \\
1965 & 19.695 & 526 \\
1966 & 23.896 & 710 \\
\hline
\end{tabular}

Bron: Staatsmijnen, Bedrijfseconomische Verslagen van 1952 tot en met 1966 . 
organogram 3.1 Toezicht op de staatsmijnen in Limburg

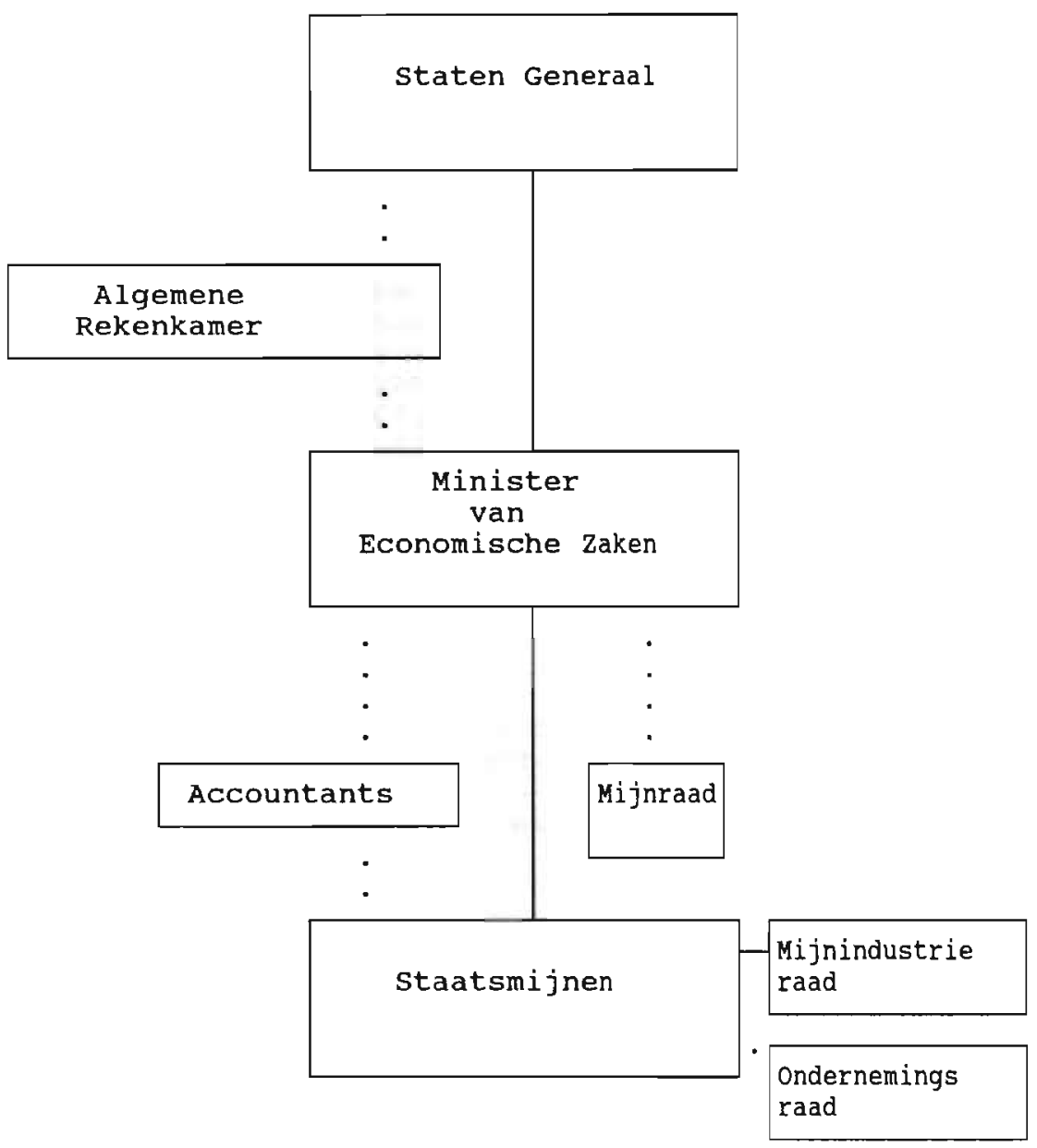


Organogram 3.2 Externe Begroting Staatsmijnen

Verschaffen van gegevens

Samenstelling van begroting ontwerp van wet

Memorie van Toelichting

Bespreking en goedkeuring

Beoordeling en opmerkingen

Beoordeling en goedkeuring

Overleg Hoofddirectie Advies Minister van Economische Zaken

Invoeging rijksbegroting

Vaststelling
Bedrijven en

Algemene diensten

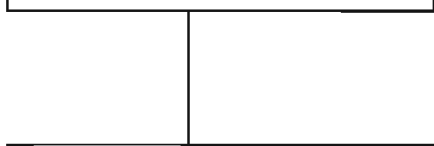

Bedrijfseconomische

Afdeling

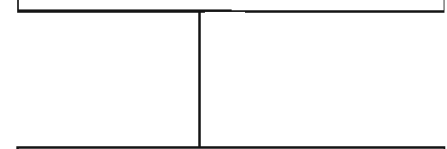

Hoofddirectie

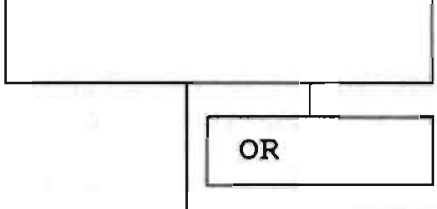

Minister van

Economische Zaken

Mijnraad

Minister van

Financiën

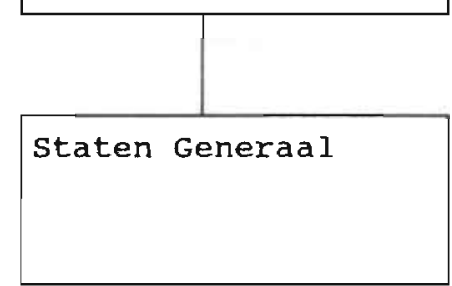


Organogram 3.3 Bedrijfseconomisch Verslag en Rapport

Samenstelling Verslag en Rapport

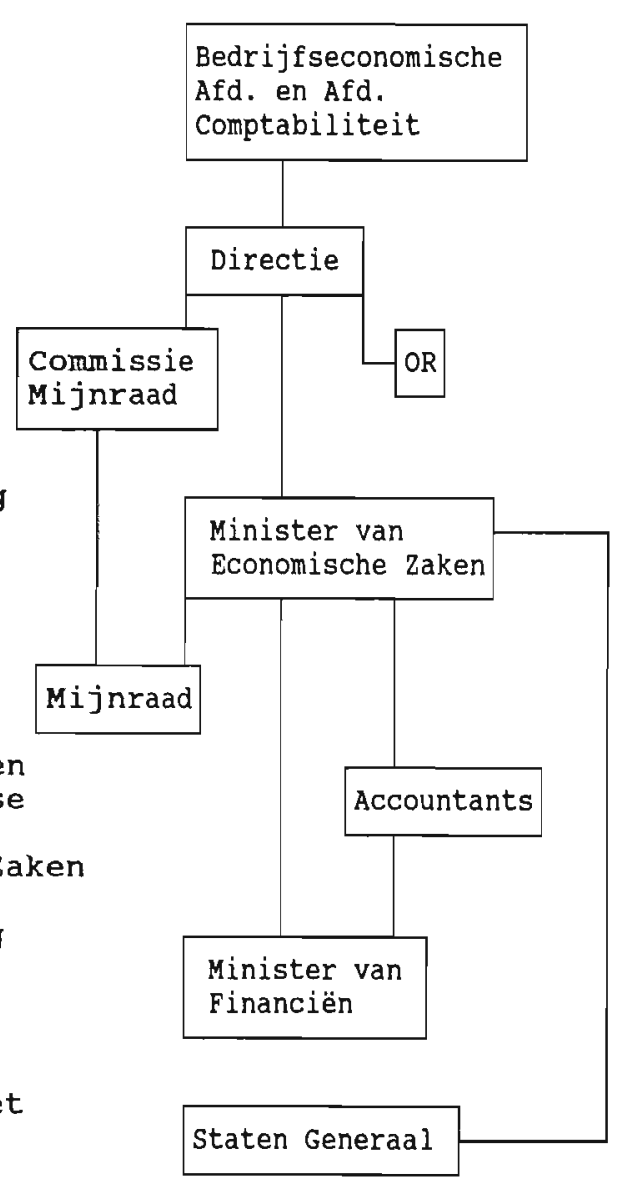

Vertrouwelijke visie in het Rapport

Staten Generaal

Bron: Concern Archief DSM, Organisatie 1950-1969, inv. nr. 1. 


\section{Hoofdstuk 4}

\section{De NV Nederlandse spoorwegen}

\subsection{Inleiding}

Vanaf 1890 baseerde de Nederlandse overheid haar spoorwegbeleid op de beginselen van concurrentie en concentratie. Het beleid had tot doel de ongelijkheid tussen de NV Hollandse IJzeren Spoorweg Maatschappij (1837) en de NV Matschappij tot Exploitatie van Staatsspoorwegen (1863) wat betreft de voorwaarden tot exploitatie en de financiële relatie met de overheid te beëindigen. De duopolistische concurrentie tussen beide ondernemingen tastte het rendement aan en noopte hen in 1916 het kabinet-Cort van der Linden te verzoeken in te stemmen met het aangaan van een belangengemeenschap onder de naam "Nederlandse Spoorwegen". ${ }^{366}$

In 1935 zette Minister van Waterstaat H. Colijn (AR) in de Eerste Kamer der Staten-Generaal de bestanddelen van het verkeersbeleid uiteen. Het was volgens hem niet aanvaardbaar dat het particuliere vervoer de activiteiten van de spoorwegen zou afromen in streken met een grotere verkeersdichtheid. Bovendien zouden met de spoorwegen concurrerende vervoermiddelen door concessies moeten worden gebonden. ${ }^{367} \mathrm{Hij}$ gaf hiermee de aanzet tot een verdere regulering van het Nederlandse verkeer. ${ }^{368}$ De overheid had immers in diverse regelingen al een exploitatie- en vervoerplicht opgelegd. ${ }^{369}$

De aanhoudende financiële problemen van de Nederlandse Spoorwegen leidden in 1937 tot een wettelijke reorganisatie van het bedrijf. De reorganisatie had tot doel het bedrijf financieel te saneren. Daartoe moest de exploitatie van de spoorwegen worden overgedragen aan één vennootschap. De oprichting van de NV Nederlandse Spoorwegen op 2 augustus 1937 betekende de liquidatie van de bedrijven, verenigd in de belangengemeenschap. De rijksoverheid nam een schuldenlast over van 229 miljoen gulden, hetgeen overeenkwam met de achterstand van de afschrijvingen. ${ }^{370}$

$\mathrm{Na}$ de Tweede Wereldoorlog beinvloedden verschillende aangelegenheden de verhoudingen tussen de NV Nederlandse Spoorwegen en de rijksoverheid. Tot deze aangelegenheden behoorde onder andere een regeling voor de bedrijfsvreemde lasten en de ongelijke voorwaarden van concurrentie.

De kwalitatieve prestatie-analyse vormt het kader voor het onderzoek naar de NV Nederlandse spoorwegen. Deze analyse richt zich op de structuur, de kenbaar gemaakte doeleinden, de beleidsvrijheid en de voortzetting van het niet ter discussie staande beleid.

\subsection{8tructuuranalyse}

De structuuranalyse in dit hoofdstuk betreft een analyse van de verdeling van de publieke eigendomsrechten in de NV Nederlandse Spoorwegen over de verantwoordelijke ministers, de Raad van Commissarissen, de directie en de vakverenigingen, vertegenwoordigd in de Personeelsraad (opgericht in 1926). 
De nadruk ligt op het recht om toezicht uit te oefenen op de aankopen, de prestaties van de produktiefactoren, de samenstelling van het team van producenten en het recht om aanspraak te mogen maken op de winst.

De rechtspersoonlijkheid van de NV Nederlandse Spoorwegen beperkte het preventieve toezicht van de staten-Generaal. Het beleid van dit bedrijf onttrok zich hierdoor gedeeltelijk aan het toezicht van de staten-Generaal. ${ }^{372}$ De politieke verantwoordelijkheid voor de NV Nederlandse spoorwegen berustte bij de Minister van Waterstaat, later het Ministerie van verkeer en waterstaat.

a. Toezicht op de aankopen en de prestaties van de produktiefactoren.

De Concessie tot exploitatie van spoor- en tramwegen van 1937 en de statuten van 1937 regelden het toezicht op de aankopen van de NV Nederlandse Spoorwegen.

De concessie kende de Minister van Waterstaat het recht toe preventief toezicht uit te oefenen op de aanschaf van rollend materieel. Het betrof hier de aanschaf van rollend materieel dat naar het oordeel van de Minister van Waterstaat van betekenis was voor de ontwikkeling van het bedrijf of met andere rijksbelangen in aanraking kwam. ${ }^{373}$

De statuten van 1937 machtigden de Raad van Commissarissen toezicht op de aankopen uit te oefenen met de vaststelling van de exploitatie- en kapitaalbegroting. De Raad moest haar goedkeuring hechten aan de aanschaf van rollend materieel, exploitatie-inrichtingen en het aangaan van werken boven een bedrag van 10.000 gulden. ${ }^{374}$ De Statuten van 1964 verstrekten de Raad van commissarissen het recht toezicht uit te oefenen op de aankopen door het jaarlijks vaststellen van een exploitatiebegroting, een investerings- en een financieringsplan. De bovengenoemde regeling voor de aanschaf van rollend materieel, exploitatie-inrichtingen en werken was uit deze statuten verwijderd. ${ }^{375}$

De directie legde jaarlijks aan de Raad van commissarissen een investeringsplan voor, waarin de investeringsuitgaven voor de eerstvolgende drie jaren per object waren begroot. De investeringen hadden grotendeels betrekking op duurzame kapitaalgoederen met lange levertijden (veelal $1 \frac{1}{2}$ à 2 jaar). In 1966 stelde $z i j$ dat de beperking van de goedkeuring van het investeringsplan tot de uitgavenbegroting voor één bepaald jaar de continuiteit in de investeringen direct aantastte. ${ }^{376}$ De investeringsplannen bevatten tevens een onderzoek naar de bedrijfseconomische rendementen van de investeringen.

De concessie en de statuten boden het kabinet en de Raad voor Economische Aangelegenheden de mogelijkheid toezicht uit te oefenen op de aankoop van rollend materieel en de overige investeringen van de NV Nederlandse spoorwegen. In 1949 nodigde de Raad voor Economische Aangelegenheden alvorens haar goedkeuring te hechten aan het investeringsprogramma president-directeur F.Q. den Hollander uit om een nadere toelichting te geven. ${ }^{3 / 7}$

Over de periode 1942 tot 1956 genoot de NV Nederlandse spoorwegen vrijstelling van de vennootschapsbelasting. ${ }^{378}$ In 
1948 schreef Minister van Financiën $P$. Lieftinck aan de Adviescommissie voor fiscale aangelegenheden dat fiscale vrijstelling voor overheidsbedrijven niet alleen gevolgen had voor de concurrentie, mar ook de reserves begunstigde. Verwijzend naar de NV Nederlandse Spoorwegen, vestigde hij de aandacht op het feit dat deze reserves enerzijds de uitbreidingsinvesteringen bevoordeelden, in tegenstelling tot die van de concurrerende vormen van vervoer, en anderzijds de conjunctuurpolitiek doorkruisten. ${ }^{379}$ Enkele leden van deze commissie verdedigden de vrijstelling met het argument dat de NV Nederlandse Spoorwegen de kosten van de weg voor haar rekening nam, in tegenstelling tot de andere vormen van vervoer. Bovendien was volgens hen het bedrijf reeds voor de Tweede Wereldoorlog, in het belang van de toeleveringsbedrijven, ertoe overgegaan de aankopen aan te passen aan de conjuncturele omstandigheden. ${ }^{380}$

De terughoudendheid van de Minister van verkeer en Waterstaat ten aanzien van de investeringspolitiek van de NV Nederlandse Spoorwegen vormde een onderwerp van gesprek in de staten-Generaal. De leden van de Tweede Kamer der statenGeneraal C. van der Zaal (AR) en H. Gortzak (CPN) bepleitten in 1956 een ruimer inzicht in de investeringspolitiek van dit bedrijf. Zij stelden de vraag of door te ruime afschrijvingen de gepubliceerde winst niet een te ongunstig beeld gaf van het rendement. Minister J. Algera antwoordde dat de afschrijvingspolitiek van het bedrijf erop was gericht de continuiteit van het bedrijf te garanderen. De directie diende naar een matige beloning van het in het bedrijf werkzame kapitaal te streven. Op grond van deze doeleinden bepaalde de directie de afschrijvingen. ${ }^{381} \mathrm{Hij}$ achtte het uit overwegingingen van mededinging onjuist om de NV Nederlandse Spoorwegen meer gegevens over de afschrijvingen en investeringen te laten verstrekken. ${ }^{382}$ verscheidene leden van de Eerste Kamer der Staten-Generaal verzochten de minister een naar onderdelen gesplitst overzicht van de bruto- en nettoinvesteringen te publiceren. Gegevens over de investeringen in de infrastructuur waren belangrijk voor een beoordeling van de onderlinge verhouding en ontwikkeling van de infrastructuur bij het weg- en spoorverkeer. In zijn memorie van antwoord verklaarde de minister dat de publikatie van de gevraagde gegevens het streven naar gelijke concurrentievoorwaarden voor de verschillende vervoertakken schade berokkende. Uiteindelijk deed hij de toezegging om met de directie van de NV Nederlandse Spoorwegen overleg te plegen over de publikatie van investeringen in de infrastructuur. De directie was bereid de bruto-investeringen in de infrastructuur te publiceren.

In 1958 attendeerde het directoraat-generaal van het verkeer Minister Algera op de mogelijke gevolgen van deze publikatie. Het zou aanleiding kunnen zijn om een volledig inzicht in de investeringen en afschrijvingen te eisen. Daarnaast wees het erop dat de directie van de NV Nederlandse Spoorwegen na 1950 meer investeerde dan uit de jaarverslagen bleek. De Raad van Commissarissen en de Algemene Vergadering van Aandeelhouders hadden daartoe toestemming verleend. ${ }^{383}$

Een voorbeeld van het feit dat de NV Nederlandse Spoorwegen meer investeerde dan uit de jaarverslagen bleek, was de post 
"instandhouding bovenbouw". De bovenbouwactiva (met een levensduur van ongeveer 25 jaar) moesten eigenlijk worden geactiveerd en afgeschreven. De financiële administratie vermeldde de bovenbouwactiva als exploitatiekosten onder de post "instandhouding bovenbouw". De consequentie was dat de post "afschrijvingen" in de gepubliceerde verlies- en winstrekening van 1951 ten opzichte van 1950 en voorgaande jaren lager was. De post "exploitatiekosten" was daarentegen hoger op deze rekening na 1950. In 1956 bedroegen de investeringsuitgaven voor de instandhouding bovenbouw 39 miljoen gulden. Voor het opheffen van gelijkvloerse kruisingen werd 3 miljoen gulden uitgegeven. ${ }^{384}$ op basis van de boven beschreven methode kan tabel 4.1 worden samengesteld.

Tabel 4.1 Investeringen en afschrijvingen (in mln gld).

\begin{tabular}{|c|c|c|c|c|c|}
\hline Jaar & Bovenbouw & Kruisingen & Bruto & Afschrijvingen & Netto \\
\hline 1954 & 33 & 4 & $165(202)$ & $59(96)$ & 106 \\
\hline 1955 & 37 & 4 & $231(272)$ & $67(108)$ & 164 \\
\hline 1956 & 37 & 4 & $243(284)$ & $73(114)$ & 170 \\
\hline
\end{tabular}

Opmerking:(1) Tussen haakjes staan de gecorrigeerde cijfers met uitgaven voor de instandhouding bovenbouw en het opheffen van de gelijkvloerse kruisingen.

bron: Accountantskantoor Moret \& De Jong, Jaarrekening NV Nederlandse Spoorwegen 1954, 1955 en 1957.

NV Nederlandse Spoorwegen, Exploitatiebegrotingen over 1956,1957 en 1958.

De directoraat-generaal van het Verkeer wees erop dat de publikatie van alle gegevens de leden van de staten-General aanleiding zou geven tot kritiek op het niveau van de infrastructurele afschrijvingen, de tarieven en het rendement van de onderneming. Het slechts de nadruk leggen op de afschrijvingen was volgens het directoraat énzijdig. De tarieven maakten afschrijuingen mogelijk en stelden de $\mathrm{NV}$ Nederlandse spoorwegen in staat ingehouden winst te investeren, met als neveneffect dat geen beroep op de kapitaalmarkt hoefde te worden gedaan. Het verdiende zorgvuldige overweging of aan een verzoek van de statenGeneraal om meer gegevens te publiceren, tegemoet moest worden gekomen. Dit moest zolang mogelijk worden tegengehouden. ${ }^{385}$

De navolgende figuur 4.1 toont het verloop van de indices van de netto-investeringen en de afschrijvingen over de periode 1955 tot en met 1970 . 
Invester ingsbeleid Ned. Spoorwegen

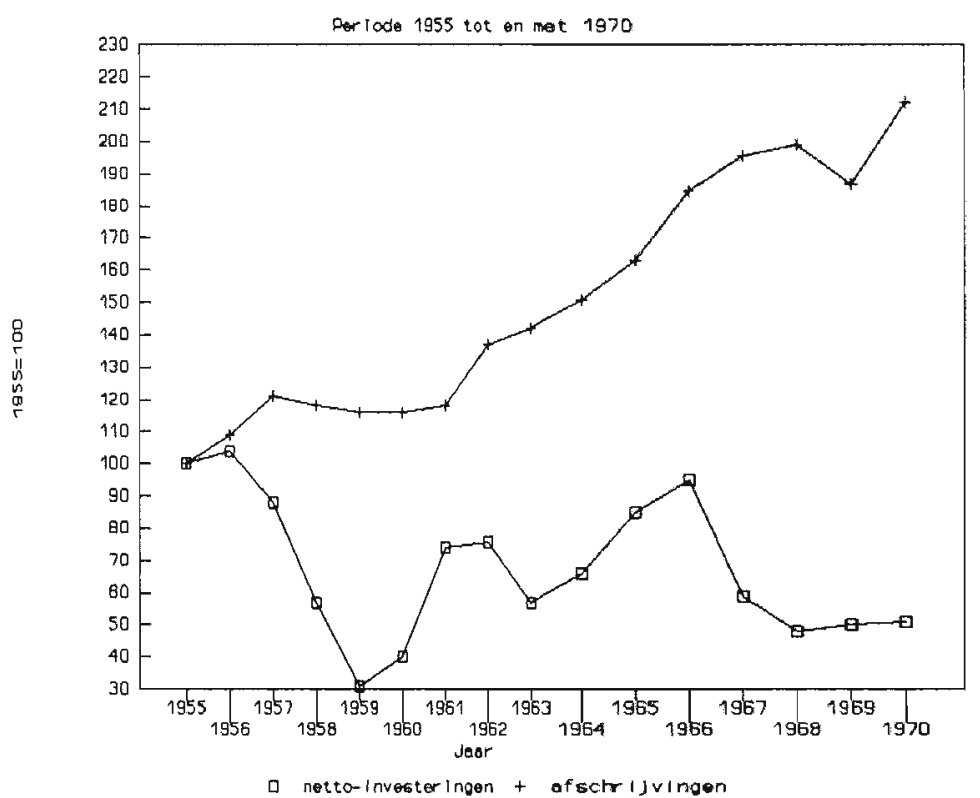

Figuur 4.1

Uit de figuur 4.1 blijkt dat de ontwikkeling van de nettoinvesteringen achterbleven bij het verloop van de afschrijvingen (voor de cijfers wordt verwezen naar bijlage 4.1). Een verklaring voor het lage investeringsniveau over de periode 1968 tot en met 1970 vormt het in de Garantiewet gestelde middelenplafond. Het investeringsniveau van de NV Nederlandse spoorwegen leidde tot een vermindering van het aantal orders voor de toeleveringsbedrijven, in het bijzonder de wagonindustrie. ${ }^{386}$

b1. Toezicht op de produktieresultaten.

Voor het vaststellen van de produktieresultaten van een spoorwegonderneming als de NV Nederlandse spoorwegen kunnen verscheidene, matstaven worden onderscheiden, bijvoorbeeld: trein- en eenheidskilometers, toegevoegde waarde, treinvertragingen en bedrijfseconomische kengetallen. De matstaven voor het produktieresultaat $z i j n$ nauw verbonden met de wensen van de politieke eigenaren bij de uitoefening van hun recht toezicht uit te oefenen op het produktieresultaat.

De produktieresultaten zijn mede bepalend voor de beloning van het personeel. Het Algemene reglement voor de dienst op de spoorwegen (ARD) van 1875 kende in 1903 de Minister van Verkeer en waterstaat het recht toe te beslissen over de lonen 
en arbeidsvoorwaarden bij de NV Nederlandse Spoorwegen. Deze werden neergelegd in het Reglement dienstvoorwaarden (RDV), dat periodiek werd herzien. Het reglement was met betrekking tot de lonen en arbeidsvoorwaarden inhoudelijk identiek aan een collectieve arbeidsovereenkomst. De geleide loonpolitiek van 1945 tot en met 1963 hield voor het resultaat van loonbesprekingen bij de NV Nederlandse Spoorwegen een dubbele goedkeuringsprocedure in. De directie onderhandelde met de Personeelsraad over de lonen en presenteerde het onderhandelingsresultaat aan de Minister van verkeer en Waterstaat en aan het college van Rijksbemiddelaars. De minister en het college waren overeengekomen hun besluiten op dezelfde datum te doen uitgaan, gelijke bewoordingen te gebruiken en naar elkaar te verwijzen. De minister volgde het algemene loonbeleid van het college van Rijksbemiddelaars. ${ }^{387}$

Het college van Rijksbemiddelaars en de stichting van de Arbeid drongen vanaf de jaren '50 aan op een stelsel van individuele prestatiebeloning, bekend onder de naam "meritrating", bij de NV Nederlandse spoorwegen. Tijdens een hoorzitting in 1958 van de stichting van de Arbeid over de herziening van het Reglement dienstvoorwaarden van 1956 kwam de vraag aan de orde waarom het bedrijf niet een stelsel van merit-rating introduceerde. Directeur F.Q. den Hollander meldde dat de grootte van het bedrijf en de geografische spreiding dit verhinderden. De NV Nederlandse Spoorwegen kenmerkte zich door werkzaamheden in teamverband. Beloning van individuele prestaties schaadde de werkzaamheden in teamverband. ${ }^{388}$

De geleide loonpolitiek stond het vanaf 1959 toe de lonen te koppelen aan de produktiviteit in de bedrijfstak. De directie en de Personeelsraad raakten bij besprekingen over de wijziging van het Reglement dienstvoorwaarden van 1956 in discussie over de prestatiebeloning. De Personeelsraad was voorstander van prestatiebeloning mits deze voldeed aan de voorwaarde dat de prestaties werden vastgesteld aan de hand van objectief meetbare normen. Deze raad verwierp de koppeling van persoonsbeoordelingen aan een prestatiebeloning voor lagere personeelsgroeperingen. ${ }^{389}$

In 1962 stelde de directie de Minister van verkeer en waterstaat H.A. Korthals (VVD) in kennis overeenstemming te hebben bereikt met de personeelsraad over voorstellen tot wijziging van het Reglement dienstvoorwaarden van 1956. 2ij kwamen overeen dat voor het openbaar vervoerbedrijf NV Nederlandse Spoorwegen de produktiviteitsgegevens als criterium voor loonsverhoging niet zonder meer van toepassing kunnen zijn. Toepassing van de produktiviteit als maatstaf voor een wijziging van het Reglement dienstvoorwaarden zou nadelige gevolgen hebben voor het personeel en zou de onderneming belemmeren in de uitoefening van haar taak. ongunstige arbeidsvoorwaarden zouden de dienstverlening beperken. De directie en de Personeelsraad beschouwden beiden de produktiviteit op basis van geproduceerde treinkilometers als een minder aanvechtbaar gegeven dan op basis van toegevoegde waarde. ${ }^{390}$ De treinkilometers zouden de prestaties van het personeel het duidelijkst naar voren doen komen. ${ }^{391}$

De directie van de NV Nederlandse spoorwegen presenteerde 
aan de Minister van Verkeer en Waterstaat tabel 4.2 over het verloop van de prestatie-matstaven treinkilometers en brutotoegevoegde waarde.

Tabel 4.2 Produktiviteit bij de NV Nederlandse Spoorwegen over de periode 1949 tot en met $1960 \quad(1953=100)$.

\begin{tabular}{|c|c|c|c|c|}
\hline Jaar & $\begin{array}{l}\text { Index } \\
\text { (1) }\end{array}$ & $\begin{array}{l}\text { produktiviteit } \\
\text { (2) }\end{array}$ & $\begin{array}{l}\text { Berekende } t \\
\text { (3) }\end{array}$ & $\begin{array}{c}\text { trend } \\
\text { (4) }\end{array}$ \\
\hline 1949 & 68 & 86 & 74 & 86 \\
\hline 1950 & 77 & 86 & 80 & 90 \\
\hline 1951 & 83 & 95 & 85 & 94 \\
\hline 1952 & 94 & 96 & 91 & 98 \\
\hline 1953 & 100 & 100 & 96 & 102 \\
\hline 1954 & 107 & 108 & 101 & 106 \\
\hline 1955 & 110 & 116 & 107 & 110 \\
\hline 1956 & 113 & 122 & 112 & 114 \\
\hline 1957 & 120 & 121 & 117 & 118 \\
\hline 1958 & 123 & 116 & 123 & 123 \\
\hline 1959 & 123 & 121 & 128 & 127 \\
\hline 1960 & 129 & 132 & 133 & 131 \\
\hline
\end{tabular}

opmerkingen: (1) Quotiënt index treinkilometers en index effectief personeel.

(2) Quotiënt index toegevoegde waarde en index effectief personeel.

(3) Trend arbeidsproduktiviteit in treinkilometers.

(4) Trend arbeidsproduktiviteit in toegevoegde waarde.

Bron: Ministerie van Verkeer en Waterstaat, nr. A-3/014259, 20 juli 1962, doss. 283/6, class. nr. 25.08.17.

Uit tabel 4.2 blijkt dat de bepaling van de produktiviteit op grond van treinkilometers leidde tot een trend met een jaarlijkse toename van 5,2 procent ten opzichte van de gemiddelde produktiviteit in deze periode. Werd rekening gehouden met de vereiste matiging, dan was een produktiviteit van 4,4 procent beschikbaar. Werd uitgegaan van de toegevoegde waarde, dan was het resultaat een trend met een jaarlijkse toename van 3,8 procent ten opzichte van het gemiddelde van de periode. Rekening houdend met het matigingsbeleid was dat een toename van 3,4 procent. ${ }^{392}$ De keuze uit de matstaven voor produktiviteit beinvloedde de toename van de beloning.

Het Ministerie van Verkeer en Waterstaat intervenieerde sinds 1964 niet meer in het loonbeleid van de spoorwegen. De voor het bedrijfsleven toetsende organen bleven daarentegen wel bevoegd. In 1964 trad de eerste collectieve arbeidsovereenkomst in werking. ${ }^{393}$ In het kader van de collectieve arbeidsovereenkomst van 1965 startte op 1 april 1965 de Regeling algemene prestatiebeloning voor de duur van drie jaar. Op basis van kwantitatieve en kwalitatieve factoren zou de gezamenlijke prestatie worden beloond met een percentage variërend van 5 procent tot 15 procent boven de 
cao-lonen. ${ }^{394}$ verleende het personeel zijn medewerking, dan behoorde een prestatiebeloning van 12 procent tot de mogelijkheden. ${ }^{395}$ De prestatiebeloning was gebaseerd op een waardering in punten van de geleverde prestaties. Het totale aantal punten werd omgerekend in premiepercentages op het maandsalaris. Het toezicht op de Regeling algemene prestatiebeloning berustte bij een begeleidingscommissie, bestaande uit drie vertegenwoordigers van de NV Nederlandse spoorwegen en drie vertegenwoordigers van de Personeelsraad. De commissie had onder andere tot taak de resultaten van deze regeling maandelijks vast te stellen. ${ }^{3 \%}$

De toepassing van het stelsel van algemene prestatiebeloning werd in 1968 verlengd tot en met 1 april 1970. Ten gevolge van de verminderde vervoersomvang en de verminderde personeelsbezetting stelde de begeleidingscommissie toen een aantal technische veranderingen voor. De directie en de vakorganisaties in de Personeelsraad aanvaardden de voorgestelde veranderingen. De kwalitatieve factor energieverbruik kwam te vervallen. ${ }^{397}$ De vakorganisaties, vertegenwoordigd in de Personeelsraad, wilden ook in 1970 doorgaan met de algemene prestatiebeloning. Zij wilden dat de extra-inspanning van het personeel tot uitdrukking kwam in de resultaten van het systeem van algemene prestatiebeloning. De normen moesten zodanig worden aangepast dat het niveau van de uitkomsten toenam. Tijdens de cao/rdv onderhandelingen konden de delegatie van NV Nederlandse spoorwegen en de delegatie van de werknemers geen overeenstemming bereiken. Het overleg werd uiteindelijk voortgezet tussen de hoofddirectie en de vakorganisaties met als resultaat overeenstemming om de overeenkomst te verlengen tot 1 januari 1971. De maximal toe te kennen prestatiebeloning werd vastgesteld op 17 procent. ${ }^{398}$

Leden van de staten-Generaal gebruikten hun vragenrecht naar de treinvertraging en de dienstregeling. De dienst Exploitatie van de NV Nederlandse Spoorwegen hield daarvan een registratie bij. De vertraging werd vastgesteld als een percentage van de op tijd rijdende treinen. Dit percentage vormde de indicator van de kwaliteit van de reizigers- en goederentreindienst van de Regeling algemene prestatiebeloning.

om de staten-Generaal de gelegenheid te bieden inzicht te verwerven in de resultaten van de NV Nederlandse Spoorwegen deed Minister $H$. Vos (PvdA) in 1948 de toezegging opdracht te zullen geven tot het ontwikkelen van een verdeling van de kosten bij de NV Nederlandse Spoorwegen. Vanaf dat jaar werd jaarlijks een verdeling van de kosten ter vertrouwelijke kennisgeving aan de leden van de staten-Generaal voorgelegd. De verdeling onderscheidde algemene kosten van het vervoer en kosten van het reizigers- en het goederenvervoer. De algemene kosten bestonden uit kosten die geen directe samenhang vertoonden met het reizigers- of goederenvervoer. Het verschil tussen de toegerekende kosten en opbrengsten moest worden geplaatst tegenover de algemene kosten. ${ }^{399}$ 
b2. Toezicht op de externe effecten.

Spoorwegmaatschappijen veroorzaken negatieve en positieve externe effecten. Het beroep op de kapitaalmarkt door een spoorwegonderneming of door de overheid ten behoeve van deze onderneming vormt een negatief extern effect, als er een stijging van de rentevoet optreedt. De Minister van Financiën en de Minister van Verkeer en Waterstaat oefenen toezicht uit op de kapitaalmarktactiviteiten van de NV Nederlandse spoorwegen. zij zijn hiervoor uiteindelijk politieke verantwoording schuldig aan de Staten-Generaal.

De investeringen van de NV Nederlandse Spoorwegen leidden tot een beroep op de kapitaalmarkt als de afschrijvingen lager waren dan de investeringen. De NV Nederlandse Spoorwegen kon met vreemd vermogen financieren door de uitgifte van obligaties en het aangaan van onderhandse leningen. Zij was daarbij niet gebonden aan het rentegamma. ${ }^{400}$

$\mathrm{Na}$ de Tweede Wereldoorlog heerste er een periode van kapitaalschaarste in Nederland. In 1951 antwoordden Minister van Verkeer en Waterstaat H.H. Wemmers en Minister van Financiën P. Lieftinck aan de Tweede Kamer der Staten-Generaal dat de kapitaalvoorziening van de NV Nederlandse Spoorwegen ter financiering van het investeringsprogramma 1948-1952 (1139 miljoen gulden) het algemene financiële beleid van het kabinet zou doorkruisen. De kapitaalvoorziening van het bedrijf moest passen in het beleid. Beide ministers deelden de opvatting dat de doorkruising van het algemene financiële beleid kon worden voorkomen met het verschuiven van werken naar latere jaren. ${ }^{401}$

De Spoorwegpensioenwet van 1925 makkte het mogelijk om de negatieve gevolgen van het beroep van de NV Nederlandse Spoorwegen op de kapitaalmarkt te verminderen. Deze wet machtigde de directie om het bestuur uit te oefenen over het Spoorwegpensioenfonds. De wet bood de mogelijkheid om onder garantie van de rijksoverheid de financiële middelen van dit fonds in deposito te geven aan de onderneming. De Ministers van Financiën en Waterstaat bepaalden het rentepercentage voor het deposito. ${ }^{402}$ Het deposito, uitgedrukt als percentage van het balanstotaal, daalde in de loop van de tijd van 29,3 procent in 1938 naar 1,8 procent in 1950.

De Raad van Commissarissen beschikte, met behulp van het recht om goedkeuring te verlenen aan de exploitatiebegroting, over de mogelijkheid toezicht uit te oefenen op de positieve externe effecten verbonden aan wetenschappelijk onderzoek. De begrote uitgaven voor onderzoek waren over de onderzochte periode slechts gering. Deze uitgaven maakten onderdeel uit van de post "Accountants-, adviseurs- en researchkosten". De investeringen van het bedrijf in rollend materieel leidden tot innovatieve activiteiten bij de toeleveranciers.

De verantwoordelijke minister stelde de tarieven en de dienstregeling vast voor de $\mathrm{NV}$ Nederlandse Spoorwegen. Hij verwierf hierdoor de mogelijkheid mede inhoud te geven aan de regionale economische ontwikkeling. 
c. Toezicht op het produktieproces.

De NV Nederlandse Spoorwegen beschikte over een straf- en prestatieloonstelsel. Het Reglement dienstvoorwaarden regelde het stelsel van disciplinaire straffen en onderscheidde materiële en immateriële straffen. Met name de hoofdstationchefs en de lijnchefs waren bevoegd tot het opleggen van straffen. Hiertegen kon beroep worden aangetekend. ${ }^{403}$

\section{d. Toezicht op de samenstelling van het team van producenten.}

De Staten-Generaal, het Ministerie van Verkeer en Waterstaat, de directie en de Personeelsraad oefenden toezicht uit op de samenstelling van het team van producenten.

De staten-General oefenden toezicht uit op de samenstelling van het team van producenten tijdens de behandeling van de begroting van het verantwoordelijke ministerie. De Concessie van 1937 bepaalde dat de beambten van de onderneming de Nederlandse nationaliteit moesten hebben, tenzij de verantwoordelijke minister zijn toesteming verleende om van deze bepaling af te wijken. ${ }^{404}$

De directie en de Personeelsraad overlegden over het voor de onderneming te voeren personeelsbeleid. De vakorganisaties, vertegenwoordigd in deze raad, schuwden het daarnaast niet om ministers te benaderen om het personeelsbeleid aan te wenden als instrument ter vermindering van de werkloosheid. In 1938 benaderde de Personeelsraad de Minister van Sociale Zaken C.P.M. Romme (RKSP) met het verzoek het spoorwegbedrijf te betrekken in een onderzoek naar de mogelijkheden de werkloosheid te verminderen met arbeidsregelingen. Tijdens de behandeling van de rijksbegroting voor het dienstjaar 1939 in de Eerste Kamer der Staten-Generaal vertelde Minister van Waterstaat A.M. van Buuren dat $z i j$ dit verzoek hadden afgewezen. De afwijzing werd gemotiveerd met het argument dat de spoorwegen $z i c h$ in een concurrentiepositie bevonden. 415

Het overleg tussen de directie en de Personeelsraad kon het beleid ten aanzien van bepaalde bevolkingsgroepen tot onderwerp hebben, zoals bijvoorbeeld de oud-ambtenaren van de Nederlands-Indische Spoorwegen en dienstplichtigen. De directie verzocht de Personeelsraad in 1951 om medewerking te verlenen bij de aanstelling van 10 of hoogstens 15 oudambtenaren van de Nederlands-Indische Spoorwegen (NIS) . Aanstelling was volgens de directie verantwoord omdat het personeel jaarlijks met ongeveer 2000 personeelsleden afnam, maar ook moreel verplicht. De Personeelsraad koesterde geen bezwaren, maar eiste dat: 1 . het in de eerste plaats om personen ging, die in moeilijke financiële omstandigheden verkeerden, 2. ambtenaren, die een pensioen genoten of elders reeds een betrekking hadden, niet in aanmerking kwamen en 3 . betrokkenen moesten voldoen aan alle eisen, die werden gesteld voor de te bekleden functie. Het Bureau van de Personeelsraad verzocht de chef Algemene Dienst toe te zien op de naleving van de gestelde eisen.40 Een jaar later kwamen de chef Algemene Dienst en de Personeelsraad overeen dat aan wegens dienstplicht afgewezen sollicitanten, na vervulling van hun 
dienstplicht, voorrang moest worden verleend boven eventuele andere sollicitanten. De opzet hiervan was de nadelige gevolgen van de verplichte militaire dienst voor deze personen zo gering mogelijk te maken. ${ }^{40}$

Vanaf 1948 beschouwde het college van Rijksbemiddelaars het bestaan van een wetenschappelijk werkclassificatiesysteem als een voorwaarde voor het inwilligen van een verzoek tot een speciale behandeling van loonaangelegenheden. De overheid stimuleerde een landelijk uniform systeem van werkclassificatie, de zogenaamde genormaliseerde methode. ${ }^{401}$ Het College van Rijksbemiddelaars adviseerde de Minister van verkeer en Energie in 1948 om in overweging te nemen de voorstellen tot wijziging van het Reglement van dienstvoorwaarden van 1946 niet te aanvaarden. Het college drong aan op de toepassing van een werkclassificatie, waarbij het beter mogelijk was om de loonvoorstellen voor groepen spoorwegpersoneel te beoordelen. ${ }^{409}$ De NV Nederlandse spoorwegen ontwikkelde een eigen methode van werkclassificatie, waarbij het personeel naar de aard en de zwarte van de werkzaamheden in taakgroepen werd ingedeeld. 410 De indeling van het personeel vormde de basis voor de vergelijking van de arbeidsvoorwaarden met andere bedrijfstakken. Het Ministerie van verkeer en waterstaat beschouwde deze werkclassificatie als een bron van verwarring en onrust. Het bevorderde de overtuiging bij het personeel, dat $z i j$ in vergelijking met het bedrijfsleven ongelijk werden behandeld. 411

De financiële omstandigheden van het bedrijf makten het in 1968 noodzakelijk bezuinigingen in de personele sfeer te overwegen. De staf van het bedrijf presenteerde via de directeur-general van het verkeer enkele bezuinigingsmogelijkheden aan staatssecretaris M.J. Keijzer (VVD). Een van de mogelijkheden tot bezuiniging behelsde de vermindering van het aantal academici, werkzaam in het Hoofdgebouw te utrecht. Het aantal academici in dienst van de NV Nederlandse Spoorwegen was in de loop van de jaren gestegen. Een deel van hen hield zich volgens deze informatie bezig met werkzaamheden in commissies, waruit weinig concrete resultaten voortkwamen met betrekking tot de kwaliteit en kwantiteit van de vervoersdiensten van het bedrijf.412 De navolgende tabel 4.3 geeft een overzicht van de volgens de staf van de NV Nederlandse Spoorwegen nodige en aanwezige academici. 
Tabel 4.3 Academici in dienst van de NV Nederlandse Spoorwegen

Academici in 1968:

onderdeel

Nodig Aanwezig

Directie Administratie
Algemene Verdediging
Exploitatie
Elektriciteit
en Seinwezen
Economische Zaken
Financiële Dienst
Interne Controle
Inkoop en Magazijnen
Materieel en Magazijnen
Personeelszaken
Secretariaat
Spoorwegrecherche
Vervoer
Weg en Werken

Totaal

$\begin{array}{rr}5 & 8 \\ 7 & 14 \\ 12 & 19 \\ 13 & 23 \\ 2 & 7 \\ 0 & 0 \\ 1 & 1 \\ 13 & 24 \\ 12 & 30 \\ 13 & 24 \\ 0 & 0 \\ 13 & 26 \\ 28 & 49 \\ --- & --- \\ 119 & 225\end{array}$

Bron :

\begin{abstract}
Ministerie van Verkeer en Waterstaat, Directoraatgeneraal van het Verkeer, Bijlage bij Nota inzake mogelijke bezuinigingen bij de Nederlandse Spoorwegen, maart 1968 , p. 2 ; Ministerie van Verkeer en waterstaat, doss. $\mathrm{nr}$. $26430 / \mathrm{n}$, class. nr. 25.07.352.
\end{abstract}

De vermindering van het aantal academici in het Hoofdgebouw van de Nederlandse Spoorwegen met honderd personen à 35 duizend gulden en 30 procent overheadkosten zou een bezuiniging opleveren van 4,5 miljoen gulden per jaar. ${ }^{413}$

Aan bevorderingen lag het anciënniteitsbeginsel ten grondslag. Dit beginsel leidde ertoe dat directieleden en chefs van dienst moeilijk onafhankelijk konden optreden ten aanzien van de vroegere "eigen" dienst of afdeling. Een manager van het type Prof. dr. J. Goudriaan zou volgens deze informatie aan de staatssecretaris hierin verandering moeten brengen. ${ }^{414}$

De NV Nederlandse Spoorwegen vermeldde in haar exploitatiebegrotingen een categorie centraal betaald personeel met een geheim salaris. Het bedrijf verantwoordde deze categorie personeel onder de rubriek algemene kosten. Dit personeel was over de gehele organisatie verspreid. Uit de exploitatiebegroting blijkt echter niet om wat voor soort personeel het hier gaat. Tabel 4.4 verstrekt een overzicht van het personeel met geheim salaris. 
Tabel 4.4 Aantal personeelsleden met geheim salaris

\begin{tabular}{lcc}
\hline Jaar & Personeel & Bedrag \\
\hline & & $\times 1000$ gld \\
& & 18.909 \\
1965 & 662 & 22.746 \\
1966 & 674 & 28.160 \\
1967 & 704 & 30.215 \\
1968 & 702 & 29.610 \\
1969 & 623 & 33.953 \\
1970 & 658 & \\
\hline
\end{tabular}

Bron: NV Nederlandse Spoorwegen, Exploitatiebegrotingen, 1965 tot en met 1970 .

e. Aanspraak op de winst.

De statuten tot oprichting van de NV Nederlandse Spoorwegen van 1937 regelden het recht aanspraak te maken op de winst.

Tot 1956 werkte de vrijstelling van de vennootschapsbelasting voor de NV Nederlandse Spoorwegen in het voordeel van de hoogte van de winst.

De statuten van 1937 kenden aan de Raad van Commissarissen het recht toe de hoogte van de afschrijvingen te bepalen, voordat werd overgegaan tot een verdeling van de winst. Voor de vorming van een reserve ter compensatie van verliezen werd tien procent van de winst op de goedgekeurde verlies- en winstrekening afgezonderd. Het resterende deel van de winst kwam toe aan het Spoorwegpensioenfonds indien dit fonds kampte met een tekort op de balans. Was hiervan geen sprake dan had de onderneming recht op de winst voor de vorming van een reserve, totdat deze het niveau van vijftig procent van het aandelenkapitaal had bereikt. Voldeed het bedrijf aan deze voorwaarde dan had de rijksoverheid als aandeelhouder het recht om aanspraak te maken op de winst in de vorm van een dividend. Het recht om aanspraak te maken op een dividend verviel vijf jaar na betaalbaarstelling. ${ }^{415}$

De wijzigingen van 1943 en 1964 veranderden de bestemming van de winst. De wijziging van de statuten in 1943 hield een verandering in voor de vorming van een reserve tot dekking van het verlies. De Algemene Vergadering van Aandeelhouders mocht de winst voortaan geheel of gedeeltelijk aanwenden voor de reserve en de compensatie van het tekort op de balans van het Spoorwegpensioenfonds. Het resterende deel $\mathrm{kwam}$ ten goede aan de rijksoverheid. ${ }^{416}$ De wijziging van 1964 machtigde de Algemene Vergadering van Aandeelhouders orn de verlies- en winstrekening vast te stellen en de besteming van de winst te bepalen. .17

De statuten van 1964 kenden aan de Raad van Commissarissen de bevoegdheid toe een jaarwedde (inclusief een algemene prestatiebeloning) vast te stellen voor de (hoofd)directie van de NV Nederlandse Spoorwegen. Bepalingen over een tantièmeregeling voor de (hoofd)directie en een winstdelingsregeling voor het personeel ontbraken.

De geleide loonpolitiek bemoeilijkte de introductie van 
winstdelingsregelingen. De gedifferentieerde loonpolitiek bracht hierin vanaf 1959 verandering. Het college van Rijksbemiddelaars creëerde in 1961 de mogelijkheid tot het toekennen van een uitkering uit de bedrijfsresultaten aan het personeel voor een periode van twee jaar. De vakverenigingen in de Personeelsraad beschouwden deze regeling als een mogelijkheid tot bezitsvorming door het personeel. In 1962 wilde de Personeelsraad deze regeling continueren en aan de orde stellen tijdens de onderhandelingen over de herzieningen van het Reglement dienstvoorwaarden van 1956. 2ij was, gezien de liquiditeitspositie van het bedrijf, bereid om medewerking te verlenen aan een regeling om het uit te keren bedrag tijdelijk in de onderneming te houden. De NV Nederlandse Spoorwegen verplichtte $z i c h$ dan echter rente te vergoeden over dit werknemersaandeel. ${ }^{18}$ Twee jaar later tijdens het paritair overleg wees de directie van de NV Nederlandse Spoorwegen de Personeelsraad op de positie van het bedrijf, die over het vraagstuk van de bezitsvorming een bijzondere problematiek zou oproepen. ${ }^{419}$ Het vraagstuk van de bezitsvorming verdween bij de NV Nederlandse spoorwegen in tegenstelling tot de staatsmijnen naar de achtergrond.

Het streven naar het verwerven van een fiscaal voordeel met gevolgen voor de winstpositie slaagde niet altijd. Tijdens de voorbereiding van het Wetsontwerp inzake belastingheffing van overheidsbedrijven stelde Minister van Verkeer en Waterstaat J. Algera voor de NV Nederlandse Spoorwegen vrij te stellen van de vennootschapsbelasting, zolang de voorwaarden tot mededinging ten opzichte van het particuliere vervoer niet gelijk waren. De staatssecretaris van Financiën W.H. van den Berge verwierp dit voorstel, omdat vrijstelling voor het concurrerende spoorwegbedrijf in strijd was met de aan het wetsontwerp ten grondslag liggende gedachte. Hij achtte het onjuist de belastingheffing te hanteren als een instrument om ongelijke voorwaarden van mededinging zonder een fiscale oorzaak te corrigeren. Hij liet deze bewindsman weten dat de Minister van Financiën Van de kieft en hij bereid waren deze nieuwe last voor de onderneming in de eerstkomende jaren zoveel mogelijk te beperken, als het bedrijf werd onderworpen aan de vennootschapsbelasting. ${ }^{420}$ Tijdens de behandeling van het Wetsontwerp inzake de belastingheffing van overheidsbedrijven in 1956 stelde het lid van de Tweede Kamer der Staten-Generaal H.J.Hofstra (PvdA) dat het beleid ten aanzien van het vervoer een eenheid behoorde te $z i j n .{ }^{421}$ Het mocht niet zo zijn dat de ene minister de positie van vrije mededinging ondermijnde, en de andere minister en stalssecretaris beweerden dat die vrije concurrentiepositie wel aanwezig was. Het kabinet had een inbreuk gemaakt op de positie van de NV Nederlandse Spoorwegen, waardoor de redenering van de Minister van Financiën geen stand meer hield. Hofstra was bereid de belastbaarheid van het bedrijf te aanvaarden als de andere delen van het beleid werden aangepast aan het standpunt van Financiën. De NV Nederlandse Spoorwegen behoorde zich in een vrije concurrentiepositie te bevinden en mocht niet bij andere ondernemingen worden achtergesteld. ${ }^{42}$ De Wet belastingheffing van overheidsbedrijven van 1956 beëindigde de fiscale voordelen van de NV Nederlandse 
Spoorwegen en haar dochterondernemingen.

De bevoegdheid van de Raad van Commissarissen jaarlijks de exploitatiebegroting vast te stellen, betekende dat zij toezicht uitoefende op de hoogte van de subsidies en contributies. De directie stelde een zogenaamde "lijst van subsidies" samen, die ter inzage lag bij het secretariaat. Het totale bedrag aan subsidies en contributies werd in de exploitatiebegroting verantwoord onder de rubriek "diversen".

\subsection{Analyse van de kenbaar gemaakte doeleinden}

De analyse van de doeleinden, kenbaar gemaakt door de verantwoordelijke ministers en de directie van de NV Nederlandse Spoorwegen, bestaat uit de verzameling en de definiëring van doeleinden, gevonden in financiële verslagen, beleidsdocumenten en kamerstukken. Aan deze analyse gaat een behandeling vooraf van de statutaire doeleinden als nevenvoorwaarden.

De statuten van 1937 gaven de onderneming de opdracht de navolgende doeleinden na te streven:

a. het aanleggen en exploiteren van spoor- en tramwegen,

b. het uitoefenen van het transportbedrijf, anders dan per spoor, en van andere bedrijven, evengenoemd transportbedrijf of de aanleg en de exploitatie van spoor- en tramwegen betreffende, alsmede alle andere daden van koophandel, die met een en ander in de ruimste zin verband houden, en

c. het exploiteren van, het oprichten van of het deelnemen aan ondernemingen, welke aan het onder $a$. omschreven doel bevorderlijk kunnen zijn. ${ }^{423}$

De statuten van 1964 bevatten slechts een kleine wijziging. Doelstelling $c$. vermeldde exploitatie van, oprichting van en deelneming aan ondernemingen, die eveneens aan doelstelling b. bijdroegen.

De directie stelde gezamenlijk het algemene beleid vast. De directeuren implementeerden afzonderlijk voor hun ressort het beleid. ${ }^{424}$

\subsubsection{Kenbaar gemaakte doeleinden en documentenanalyse.}

Het kabinet maakte de volgende doeleinden kenbaar:

a. In het onlangs plaatsgevonden hebbend overleg met de NSdirectie is er nog eens met nadruk op gewezen, dat de NS dient te streven naar de maximalisatie van de opbrengsten (1969). ${ }^{425}$ 
De directie vermeldde de navolgende doeleinden:

b. Wij streven er daarom krachtig naar, met de medewerking van de regering en met $z$ o groot mogelijke inschakeling van de Nederlandse industrie, de moeilijkheden bij de wederopbouw van het spoorwegapparaat te boven te komen (1946). ${ }^{426}$

c. Het belangrijkste middel om de ongunstige financiële toestand van NS te wijzigen, bestaat in de bewerkstelliging van een rechtvaardige doorbelasting van de kosten der infrastructuur voor weg- en watervervoer.

d. Het beleid is erop gericht deze vermindering van personeel ook voor de jaren $1967 / 1970$ met kracht voort te zetten (1967).427

e. Het huidige arbeidsterrein van het NS-concern kan worden beschouwd als het resultat van een bescheiden, doch bewust nagestreefd diversificatiebeleid in het verleden (1967). . $28^{28}$

f. Het beleid, dat aan de samenstelling van het investeringsplan IPK "Y" ten grondslag is gelegd, is voor wat het reizigersvervoer betreft primair gericht op het op een verantwoorde wijze in stand houden van het bedrijf en doen slagen van spoorslag ${ }^{\prime} 70$.

g. Het beleid van het goederenvervoer is onveranderd gericht op het realiseren van rendabele investeringen $(1969) \cdot{ }^{429}$

h. Bij de investeringen ten behoeve van het goederenvervoer staat het leveren van een bijdrage in de verbetering van het bedrijfsresultaat voorop, terwijl voorts het zeker stellen van een NS-aandeel in toekomstige ontwikkelingen nagestreefd wordt.

i. Het streven naar een sociaal verantwoord beleid ten aanzien van het werkklimat en de huisvesting van het personeel is geaccentueerd door het opnemen van post 3204 ad $2,0 \mathrm{miljoen}(1970)$, , $^{430}$

j. Het investeringsplan IPK "A" is gebaseerd op de voornaamste doelstellingen van het investeringsbeleid, te weten het verhogen van de kwaliteit van het vervoer en het op verantwoorde wijze in stand houden van het spoorwegbedrijf (1970). ${ }^{431}$

k. NS streeft naar een railnet binnen het bereik van zoveel mogelijk potentiële reizigers en naar een aan hoge eisen van frequentie en snelheid beantwoordende dienstregeling $(1970) \cdot 432$ 
1. In het kader van het streven naar een optimale benutting van het NS-grondbezit heeft NS boven het te bouwen station Den Haag Centraal een kantoorgebouw van elf lagen geprojecteerd (1970)..$^{43}$

m. Hoewel wij ernaar streven onze dienstregeling jaarlijks te verbeteren, moeten wij ons daarbij richten op de belangen van de grootste groepen reizigers, waarbij niets steeds is te vermijden, dat incidenteel een minder gunstige oplossing gekozen moet worden voor bepaalde stations of bepaalde kleine groepen reizigers (1970).434

\subsubsection{0it de structuranalyse afgeleide doeleinden.}

De structuuranalyse maakt het mogelijk de doeleinden verbonden aan de verzameling van publieke eigendomsrechten vast te stellen.

De doeleinden, afgeleid uit het recht om toezicht uit te oefenen op de aankopen en de prestaties van de produktiefactoren, zijn:

1. het streven naar continuïteit van de investeringen,

2 . het verwezenlijken van gelijke voorwaarden van mededinging in de vervoersector,

3. het realiseren van een gering rendement en

4 . het streven naar conjuncturele stabiliteit.

Uit het recht om toezicht uit te oefenen op de produktieresultaten kan de navolgende doelstelling worden afgeleid:

1. het streven de lonen te laten toenemen met de ontwikkeling van de produktiviteit.

Het recht om toezicht uit te oefenen op de externaliteiten heeft betrekking op:

1. het beheersen van de hoogte van de rentevoet op de kapitaalmarkt.

De doeleinden verbonden aan het recht toezicht uit te oefenen op de samenstelling van het team van producenten zijn:

1. het bieden van werkgelegenheid aan groeperingen, getroffen door een sociaal nadeel, en

2. de vermindering van het personeelsbestand.

Het verwerven van het recht aanspraak te mogen maken op een gedeelte van de winst heeft tot doel:

1. het handhaven van de continuiteit van de onderneming, en

2. het compenseren van de tekorten van het spoorwegpensioenfonds teneinde de pensioenen veilig te stellen. 


\subsection{3 vergelijking van de met beide analyses gevonden doeleinden.}

Het uitoefenen van toezicht op de samenstelling van het team van producenten met de intentie de omvang van het personeel te verminderen, wordt bevestigd met de kenbaar gemaakte doelstelling dat het beleid erop is gericht de vermindering van personeel ook voor de jaren 1967/1970 met kracht voort te zetten. ${ }^{435}$

\section{4 Beleidsvrijheid}

De mate van technische efficiëntie van de Europese spoorwegondernemingen kan worden vastgesteld met de eerder besproken methode van de kleinste kwadraten. Toepassing van deze methode op 14 Europese spoorwegondernemingen over de periode 1961 tot en met 1970 leidt tot een produktiefunctie van het Cobb-Douglas type:

$$
\text { In } Y=\begin{gathered}
0,50 \text { in } X_{1}+\begin{array}{c}
0,46 \text { in } X_{2}+67,15 \text { ln } X_{3}-555,85 \text { (1) } \\
(5,547) \\
(6,048)
\end{array}(3,727) \\
(-3,734)
\end{gathered}
$$

$R_{\text {. } .123}=0,9673$

De afhankelijke variabele (Y) bestaat uit de eenheidskilometers, die de som vormen van de ton- en reizigerskilometers. De onafhankelijke variabelen zijn achtereenvolgens het personeel $\left(X_{1}\right)$, het materieel bestaande uit wagons en rijtuigen $\left(X_{2}\right)$ en de tijd $\left(X_{3}\right)$. De laatste variabele is geintroduceerd ter verwijdering van de trend in de data. De $t$-waarden staan tussen haakjes vermeld onder de vergelijking. De hoogste restterm is 0,6649 . De vergelijking gecorrigeerd met de hoogste restterm luidt:

In $x=0,50$ ln $X_{1}+0,46$ in $x_{2}+67,15 \ln x_{3}-555,19$ (2)

De mate van technische efficiëntie voor de betrokken spoorwegondernemingen over de periode 1961 tot en met 1970 wordt weergegeven in tabel 4.5. 
Tabel 4.5 Efficiëntie spoorwegondernemingen in 1965 en 1970.

\begin{tabular}{|c|c|c|c|c|c|}
\hline Land & Onderneming & $\begin{array}{l}\text { Techn. } \\
1965\end{array}$ & $\begin{array}{c}\text { efficiëntie } \\
1970\end{array}$ & $\begin{array}{l}\text { Expl. } \\
1965\end{array}$ & $\begin{array}{c}\text { coëfficient } \\
1970\end{array}$ \\
\hline België & SNCB & 0,9366 & 0,9414 & 95,1 & 100,0 \\
\hline Denemarken & DSB & 0,9268 & 0,9242 & 102,1 & 131,7 \\
\hline Finland & VR & 0,9280 & 0,9415 & 119,3 & 123,6 \\
\hline Frankrijk & SNCF & 0,9649 & 0,9708 & 107,5 & 100,0 \\
\hline G. Brittannië & $\mathrm{BR}$ & 0,8929 & 0,9099 & 113,8 & 91,8 \\
\hline Italië & FS & 0,9466 & 0,9492 & 127,4 & 149,3 \\
\hline Luxemburg & CFL & 0,8702 & 0,8696 & 96,6 & 100,4 \\
\hline Nederland & NS & 0,9873 & 0,9821 & 101,3 & 115,4 \\
\hline Noorwegen & NSB & 0,9132 & 0,9202 & 134,5 & 130,8 \\
\hline oostenrijk & $\ddot{O B B}$ & 0,9374 & 0,9353 & 135,9 & 117,7 \\
\hline Portugal & $\mathrm{CP}$ & 0,8926 & 0,8951 & 80,5 & 103,9 \\
\hline Spanje & RENFE & 0,9323 & 0,9516 & 108,3 & 120,4 \\
\hline Zweden & SJ & 0,9607 & 0,9698 & 94,5 & 97,2 \\
\hline Zwitserland & CFF & 0,9637 & 0,9590 & 92,7 & 99,8 \\
\hline Gemiddeld & & 0,9324 & 0,9371 & & \\
\hline
\end{tabular}

opmerking: De exploitatiecoëfficiënt geeft de verhouding weer tussen de totale kosten en opbrengsten, vermenigvuldigd met 100 .

Bron: Union Internationale des Chemins de Fer, Statistique Internationale des Chemins de Fer, 1961 tot en met 1970.

Uit tabel 4.5 blijkt dat de NV Nederlandse Spoorwegen in 1965 en 1970 wordt gekenmerkt door de hoogste mate van technische efficiëntie, gevolgd door de Franse spoorwegen (Voor de gegevens wordt verwezen naar bijlage 4.2 ). De hoge mate van technische efficiëntie bij de NV Nederlandse Spoorwegen gaat gepaard met een exploitatietekort, zoals blijkt uit de exploitatiecoëfficiënten. Hieruit blijkt dat de technische efficiëntie slechts is gericht op de verwezenlijking van de statutaire doeleinden, namelijk de exploitatie van spoorwegen en het uitoefenen van het transportbedrijf. zijn deze doeleinden op aanvaardbare wijze voldaan, dan beschikken de principalen over de vrijheid dit bedrijf aan te wenden voor de realisatie van andere beleidsdoeleinden. De gederfde winsten vormen dan een indicatie voor het bestaan van beleidsvrijheid. In het uiterste geval kan het overheidsbedrijf te kampen krijgen met geaccumuleerde verliezen.

De Raad van Commissarissen beheerste en beinvloedde met de aanvaarding van de exploitatiebegroting de gederfde winsten als matstaf van beleidsvrijheid of autonomie. verder blijkt de aanvaarding van beleidsvrijheid uit de opvatting van de directeur-general van het verkeer in 1956 dat de NV Nederlandse Spoorwegen een commercieel beleid moest voeren om een rentepercentage over het overheidskapitaal te realiseren. Het algemeen belang reduceerde echter het rentepercentage. Hij achtte een matig rentepercentage dan cok aanvaardbaar, omdat 
de onderneming dit belang niet buiten beschouwing mocht laten. Bovendien meende $\mathrm{hij}$ dat het rendement niet boven een matig rentepercentage behoefde uit te gaan, aangezien het niet tot de taak van de overheid behoorde financiële middelen te verwerven (leningen, belastingen) teneinde een maximale winst te realiseren. ${ }^{436}$

Bij het vaststellen van de rentabiliteit en de gederfde winst bij overheidsbedrijven moet rekening worden gehouden met de kapitalisatie van het eigen vermogen, met andere woorden de omvang en samenstelling van het eigen vermogen. overheidsbedrijven kunnen onder- of overgekapitaliseerd zijn. onderkapitalisatie betekent dat het aandeel van het gestorte nominale aandelenkapitaal in het eigen vermogen is afgenomen. De rentabiliteit van het aandelenvermogen is hierdoor toegenomen. Overkapitalisatie houdt in dat het overheidsbedrijf over meer aandelenvermogen beschikt dan het rendabel kan aanwenden. De rentabiliteit van het aandelenkapitaal daalt in dat geval. Het behoort tot de taken van een rekenkamer om de wetgevende macht en het kabinet te wijzen op de ontwikkelingen in de kapitalisatie van het eigen vermogen. 437

Minister van Financiën Hofstra vestigde tijdens de behandeling van de tarieven van dit bedrijf in de vergadering van de ministerraad van 28 januari 1957 de aandacht op de onderkapitalisatie. De kapitaalwaarde bedroeg 1800 miljoen, terwijl op de balans hiervoor een bedrag van 300 miljoen aan aandelenkapitaal stond. Particuliere ondernemingen hadden volgens de minister hun kapital wegens geldontwaarding rechtgetrokken in tegenstelling tot de spoorwegen. ${ }^{438}$ De minister beseft hier echter niet dat kabinetten soms onderkapitalisatie laten voortduren, omdat het overheidsbedrijf reeds beschikt over fiscale faciliteiten en andere financiële tegemoetkomingen, zoals de compensatie van de bezettingsschade en de bijdragen in het tekort van het Spoorwegpensioenfonds. De gerealiseerde winst, behaald met een kapitaalwaarde van $1800 \mathrm{miljoen,} \mathrm{uitgedrukt} \mathrm{als} \mathrm{een} \mathrm{percentage}$ van een aandelenkapitaal van 300 miljoen geeft een te hoge rentabiliteit. Tabel 4.6 bepaalt de gederfde winst als maatstaf voor beleidsvrijheid op basis van het nominale aandelenkapitaal. 
Tabel 4.6 Gederfde winst in miljoenen guldens, berekend op basis van het aandelenkapitaal van $1950 \mathrm{t} / \mathrm{m} 1970$.

\begin{tabular}{|c|c|c|c|c|c|}
\hline Jaar & $\begin{array}{l}\text { Verlies } \\
\text { of winst }\end{array}$ & $\begin{array}{l}\text { Aandelen- } \\
\text { kapitaal }\end{array}$ & $\begin{array}{l}\text { Rentabi- } \\
\text { liteit \& }\end{array}$ & $\begin{array}{l}\text { Rendement } \\
\text { eeuwigdurende } \\
\text { staatsschuld }\end{array}$ & $\begin{array}{l}\text { Gederfde } \\
\text { winst }\end{array}$ \\
\hline 1950 & $+1,4$ & 10,0 & 14,0 & 3,12 & 1,09 \\
\hline 1955 & $+10,6$ & 300,0 & 3,5 & 3,19 & 1,03 \\
\hline 1960 & $+12,6$ & 300,0 & 4,2 & 4,38 & $-0,54$ \\
\hline 1965 & $-21,4$ & 300,0 & $-7,1$ & 5,19 & $-15,57$ \\
\hline 1966 & $-79,1$ & 300,0 & $-26,4$ & 5,86 & $-17,58$ \\
\hline 1967 & $-94,0$ & 300,0 & $-31,3$ & 5,67 & $-17,01$ \\
\hline 1968 & $-80,3$ & 300,0 & $-26,8$ & 6,19 & $-18,57$ \\
\hline 1969 & $-80,3$ & 300,0 & $-26,8$ & 7,02 & $-21,06$ \\
\hline 1970 & $-141,8$ & 300,0 & $-47,3$ & 7,06 & $-21,18$ \\
\hline
\end{tabular}

Bron: Jaarverslagen Nederlandse Spoorwegen, 1950, 1955, 1960,1965 tot en met 1970.

Uit de bovenstaande tabel 4.6 blijkt voor de jaren 1965 tot en met 1970 een toename van de gederfde winsten op de overheidsinvesteringen. Tabel 4.7 toont de ontwikkeling van de gederfde winst, die is berekend op basis van het eigen vermogen.

Tabel 4.7 Gederfde winst, berekend op basis van het eigen vermogen.

\begin{tabular}{lccl}
\hline Jaar & Eigen vermogen & Rentabiliteit & $\begin{array}{l}\text { Gederfde } \\
\text { winst }\end{array}$ \\
\hline & mln gld & f & mln gld \\
1950 & 125,4 & 1,1 & - \\
1955 & 478,2 & 2,2 & - \\
1960 & 964,7 & 1,3 & $-2,7$ \\
1965 & $1.087,9$ & $-2,0$ & $-56,5$ \\
1966 & $1.126,0$ & $-7,0$ & $-66,0$ \\
1967 & 1.164 .9 & $-8,1$ & $-66,0$ \\
1968 & $1.207,2$ & $-6,6$ & $-74,7$ \\
1969 & $1.248,3$ & $-6,4$ & $-87,6$ \\
1970 & $1.297,9$ & $-10,9$ & $-91,6$ \\
\hline
\end{tabular}

Bron: NV Nederlandse Spoorwegen, Jaarverslagen over 1950, $1955,1960,1965$ tot en met 1970 .

De balansen van de NV Nederlandse spoorwegen lieten een accumulatie van verliezen zien. Tabel 4.8 geeft de ontwikkeling weer van de geaccumuleerde verliezen over de periode 1965 tot en met 1970. 
Tabel 4.8 Geaccumuleerde verliezen van 1965 tot en met 1970

\begin{tabular}{lcccc}
\hline Jaar & $\begin{array}{c}\text { Geac. verlies } \\
\text { min gld }\end{array}$ & $\begin{array}{l}\text { als } \\
\text { EV (1) }\end{array}$ & $\begin{array}{l}\text { V (2) } \\
\text { min gld }\end{array}$ & $\begin{array}{c}\text { Werkelijk } \\
\text { EV/VV (3) }\end{array}$ \\
\hline 1965 & 38,5 & 3,54 & 627,8 & 167,16 \\
1966 & 117,5 & 10,43 & 751,8 & 134,14 \\
1967 & 211,5 & 18,16 & 818,9 & 116,42 \\
1968 & 291,8 & 24,17 & 856,4 & 106,89 \\
1969 & 372,1 & 29,80 & 907,2 & 96,58 \\
1970 & 513,9 & 39,59 & 1030,7 & 76,06 \\
\hline
\end{tabular}

opmerkingen: (1) EV : Eigen vermogen.

(2) VV : Vreemd vermogen.

(3) Werkelijk eigen vermogen is het verschil tussen het eigen vermogen en het geaccumuleerde verlies.

Bron: NV Nederlandse Spoorwegen, Jaarverslagen 1966 tot en met 1970 .

Uit tabel 4.8 blijkt een aantasting van de vermogenspositie, hetgeen het verkrijgen van vreemd vermogen bemoeilijkt. In 1966 stelden de directie en de Raad van commissarissen in een memorandum, gericht aan de Minister van verkeer en waterstaat en van Financiën, dat naast gelijke concurrentievoorwaarden de vergoeding van de bedrijfsvreemde lasten bijdroegen aan de oplossing van de financiële problemen. ${ }^{439}$ Het begrip bedrijfsvreemde lasten is voor interpretatie vatbaar. Het zijn de kosten, die niet voortvloeien uit de oorspronkelijke bestaansredenen van het overheidsbedrijf. 40

over het begrip bedrijfsvreemde last bestond in het overleg over de sanering van de NV Nederlandse spoorwegen geen duidelijkheid. Dit leidde tot spanningen tussen de bewindslieden en de NV Nederlandse Spoorwegen. De NV Nederlandse spoorwegen beschouwde veiligheid een bedrijfsvreemde last. In 1965, tijdens overleg met de Ministers J.G. Suurhoff (PvdA) en A. Vondeling (PvdA), beschouwde president-directeur J. Lohmann de automatische treinbeinvloeding (ATB) als een bedrijfsvreemde last. Minister Suurhoff sprak dit tegen, omdat de spoorwegen zorg moesten dragen voor de veiligheid van hun passagiers. De automatische treinbeinvloeding werd door de rijksoverheid van de onderneming geëist op basis van het Algemeen reglement voor de dienst op de spoorwegen. De directie ervoer de ATB als een zware last. Volgens de directie moest de overheid de consequenties van deze beveiliging dragen bij het uitblijven van rentabiliteit. De staatssecretaris van verkeer en waterstaat S.A. Posthumus (PvdA) stelde dat de overheid de automatische treinbeinvloeding niet had geëist, want er waren immers goedkopere alternatieven. ${ }^{41}$ De voorkeur van de rijksoverheid ging uit naar het zogenaamde Indusi-systeem, dat goedkoper was dan het door de spoorwegen gewenste systeem van de Amerikaanse General Railway signal Company. Uiteindelijk stemde de rijksoverheid in met het door de NV Nederlandse Spoorwegen gewenste systeem van automatische beinvloeding. ${ }^{42}$ 
De directie wilde vóor 1971 alle hoofdlijnen voorzien van ATB. ${ }^{443}$

De Raad van de Europese Gemeenschap aanvaardde in 1969 een verordening over de compensatie van de kosten van openbare dienstverplichtingen. De lidstaten hadden tot 1 januari 1972 de tijd over te gaan tot compensatie. ${ }^{44}$ Het was duidelijk dat deze verordening overheidsbedrijven in de vervoerssector stimuleerde tot het verkrijgen van compensaties. Artikel 12 van deze verordening bepaalde dat de compensatie van de kosten van de openbare dienstverplichtingen een calculatorische rente over het in het reizigersvervoer geinvesteerde eigen vermogen moest bevatten. De calculatorische rente bracht het economische offer van het vermogensbeslag tot uitdrukking. vergoeding van de calculatorische rente over de vervangingswaarde van het geinvesteerde vermogen zou een verliesgevende in een winstgevende positie kunnen veranderen. De vervangingswaarde was gekozen om een normaal rendement voor de aandeelhouder mogelijk te maken. De rente over het eigen kapital kon in mindering worden gebracht op de calculatorische rente. In de Raad van de Europese Gemeenschap was echter afgesproken deze aftrek niet toe te passen. ${ }^{45}$ Het niet vergoeden van de calculatorische rente betekende slechts uitstel, omdat later het exploitatietekort diende te worden gecompenseerd. Zou de vergoeding leiden tot winst, dan zou deze naar de aandeelhouder terugvloeien. De ambtenaren op het Ministerie van verkeer en waterstaat waren de opvatting toegedaan dat de vergoeding niet tot buitensporige bestedingen door de spoorwegen zou leiden, omdat $z i j$ was bedoeld om de zelfstandigheid en de economische zelfdiscipline te verzekeren. Was in dit verband controle nodig, dan behoorde deze uit te gaan van de Raad van Commissarissen. ${ }^{446}$

De verordening vermeldde niet het percentage van de calculatorische rente. Dat zou volgens de betrokken ambtenaren zes procent bedragen, berekend over het eigen vermogen gewaardeerd tegen vervangingswaarde. Dit vermogen werd geschat op 2 miljard gulden. Minister van Financiën H.J. Witteveen (VVD) had met ontsteltenis van dit percentage kennis genomen. Het was Minister van Verkeer en waterstaat J.A. Bakker (AR) evenmin bekend dat uit deze verordening een winstpositie voor de NV Nederlandse Spoorwegen zou kunnen voortvloeien. Op basis van deze bepaling zou de $\mathrm{NV}$ Nederlandse Spoorwegen 100 miljoen gulden teveel ontvangen. ${ }^{447}$ Nodig was een methode warbij de vergoeding het verlies niet overschreed. Een van de mogelijkheden om de hoge uitkering te vermijden, opperde Staatssecretaris M.J. Keyzer, was het omzetten van de naamloze vennootschap in een staatsbedrijf. Minister van Financiën witteveen (VVD) en zijn ambtenaren (waaronder de Gedelegeerd Commissaris) prefereerden de liquidatiewaarde in plaats van de vervangingswaarde. Tot 1972 bestond er volgens de minister de mogelijkheid alternatieven te bestuderen, zoals het busvervoer. ${ }^{448}$

\subsubsection{Werkgelegenheid}

De directie van de NV Nederlandse Spoorwegen voerde een beleid van personeelsvermindering. $\mathrm{Zij}$ beschikte over een aantal 
instrumenten om deze vermindering te bewerkstelligen, zoals het vervroegde en invaliditeitspensioen, de toepassing van de wachtgeldregeling en de personeelsstop.

Het beleid van de NV Nederlandse Spoorwegen was erop gericht om jaarlijks tot en met 1970 het personeel met gemiddeld 500 personen te verminderen. Arbeidsbesparende investeringen (rationalisatie, automatisering, elektrificatie) verkregen daarbij zoveel mogelijk voorrang, ofschoon deze beperkingen ondervonden door het geaccumuleerde verlies. 49 In november 1967 kwam de directie terug op het streefgetal van 500 personen. Als mogelijkheden tot herplaatsing ontbraken, dan zou de toepassing van de wachtgeldregeling onvermijdelijk $z i j n$. Het verslag van de Personeelsraad over 1968 vermeldde de noodzaak tot overleg tussen bedrijfsleiding en Personeelsraad teneinde matregelen te nemen om overtolligheid te voorkomen. Was overtolligheid niet te vermijden, dan moest worden vastgesteld hoe de wachtgeldregeling zou worden toegepast. 450

Tabel 4.9 vertoont het verloop van het personeel aangesteld onder het Reglement dienstvoorwaarden en het totale personeel.

Tabel 4.9 Personeelsreductie 1960 tot en met 1970

\begin{tabular}{|c|c|c|c|c|}
\hline Jaar & $\begin{array}{l}\text { Personeel } \\
\text { RDV }\end{array}$ & Reductie & $\begin{array}{l}\text { Personeel } \\
\text { totaal }\end{array}$ & Reductie \\
\hline 1960 & 28909 & -1141 & 31139 & -953 \\
\hline 1961 & 28078 & -831 & 30428 & -711 \\
\hline 1962 & 28794 & 716 & 30352 & -76 \\
\hline 1963 & 28428 & $-\quad 366$ & 29645 & -707 \\
\hline 1964 & 28054 & 374 & 29183 & -462 \\
\hline 1965 & 27700 & $-\quad 354$ & 28740 & -443 \\
\hline 1966 & 26600 & -1100 & 27826 & -914 \\
\hline 1967 & 26600 & 0 & 26710 & 1116 \\
\hline 1968 & 25810 & -790 & 26482 & -228 \\
\hline 1969 & 25912 & 102 & 26036 & -446 \\
\hline 1970 & 27342 & 1430 & 27610 & 1574 \\
\hline Gemiddeld & & $-\quad 246$ & & -407 \\
\hline \multicolumn{5}{|l|}{ Gemiddeld } \\
\hline$t / m \quad 67$ & & -431 & & -394 \\
\hline $67 \mathrm{t} / \mathrm{m} 70$ & & $+\quad 185$ & & -54 \\
\hline
\end{tabular}

Bron: J.A. Faber (red.), Het spoor, Meulenhoff Informatief, Amsterdam, 1989, p. 379.

Uit de bovenstaande cijfers blijkt dat een gemiddelde reductie met 500 werknemers per jaar niet werd gerealiseerd. Het personeel, met arbeidsvoorwaarden opgenomen in het Reglement dienstvoorwaarden, steeg over de periode 1967 tot en met 1970 met gemiddeld 185. Het totale aantal personeelsleden daalde met gemiddeld 54 .

De Spoorwegpensioenwet bevatte vanaf 1939 de mogelijkheid tot vervroegd pensioen voor ontslagen personeel boven de 60 
jaar. Na de Tweede Wereldoorlog verleende de directie ook vervroegd pensioen als een personeelslid daar op gegronde redenen om verzocht. Het aantal personeelsleden dat van deze mogelijkheid gebruik maakte, was gering. Van 1948 tot en met 1961 bestond het streven zoveel mogelijk personeelsleden tussen de 60- en 65-jarige leeftijd te laten afvloeien, zelfs zonder instemming van de betrokkenen. ${ }^{451}$ Het kolommendiagram in figuur 4.2 geeft de ontwikkeling weer van de toekenning van het vervroegde en het invaliditeitspensioen.

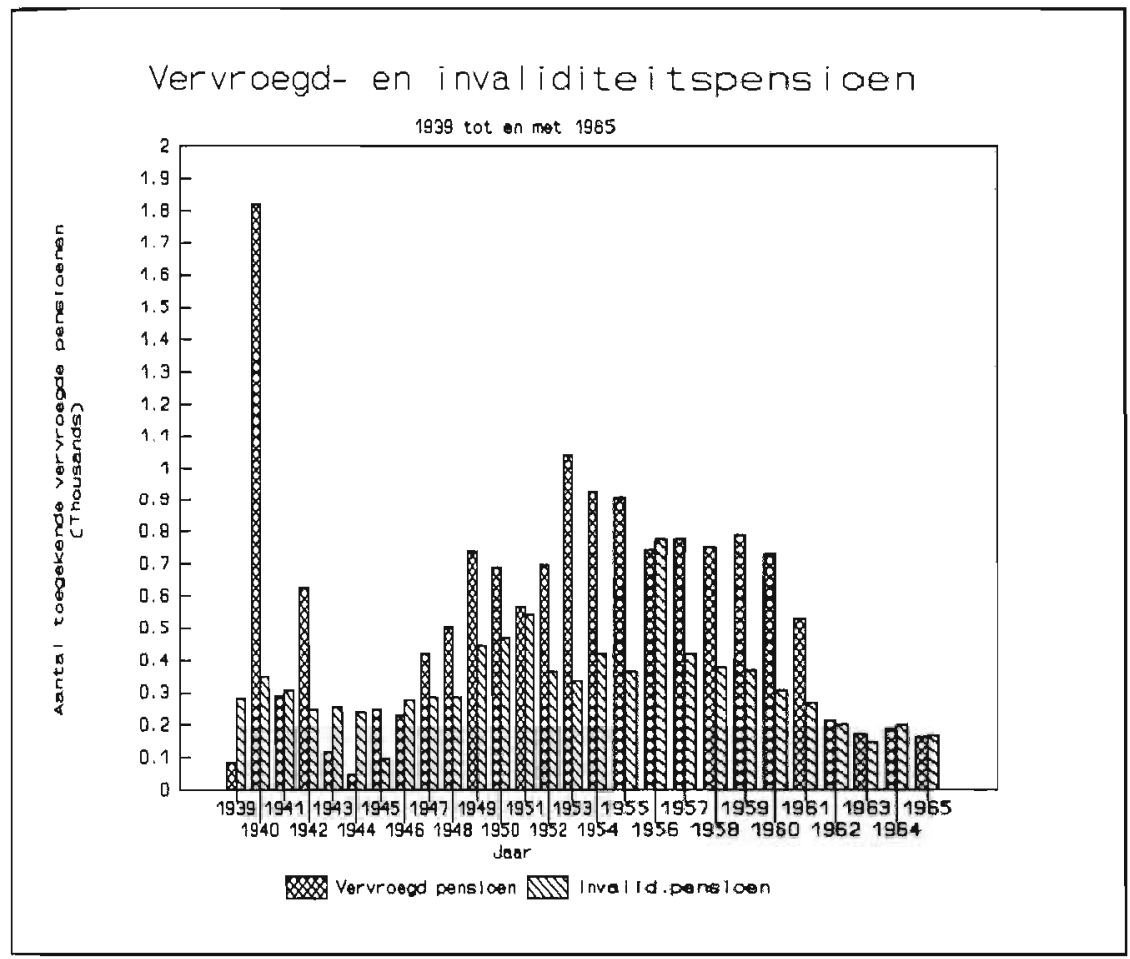

Figuur 4.2

Over de periode 1960 tot en met 1965 kende de directie van de NV Nederlandse Spoorwegen aan gemiddeld 323 personeelsleden een vervroegd pensioen en aan 215 personeelsleden een

invaliditeitspensioen toe. Dit resultaat sloot aan bij het tot november 1967 door de NV Nederlandse Spoorwegen gevoerde beleid ter vermindering van het personeel. Het beleid gericht op de vermindering van personeel met behulp van vervroegd en invaliditeitspensioen blijkt onder andere verband te houden met de door de NV Nederlandse Spoorwegen gehanteerde exploitatiecoëfficiënt (Voor de gegevens wordt verwezen naar bijlage 4.3$)$. 
Tabel 4.10 Relatie tussen variabele) (onafhankelijke tot en met 1965 .

\begin{tabular}{lrrrrr}
\hline $\begin{array}{l}\text { Soort van } \\
\text { pensioen }\end{array}$ & r2 & parameter & t-waarde & sig. $t$ & $\begin{array}{l}\text { Durbin- } \\
\text { Watson }\end{array}$ \\
\hline $\begin{array}{l}\text { Vervroegd } \\
\text { Constante }\end{array}$ & 0,59 & $-18,90$ & $-4,482$ & 0,0005 & 1,097 \\
& & 90,12 & 4,817 & 0,0003 & \\
Invaliditeit & 0,42 & $-10,90$ & $-3,207$ & 0,0063 & 2,047 \\
Constante & & 54,17 & 3,590 & 0,0030 & \\
Totaal & 0,58 & $-15,69$ & $-4,380$ & 0,0006 & 1,417 \\
Constante & & 76,35 & 4,806 & 0,0003 & \\
\hline
\end{tabular}

opmerkingen: Gegevens uit bijlage 4.3 zijn omgerekend in natuurlijke logaritmen.

De bovenstaande tabel 4.10 staat de conclusie toe dat een stijging van de exploitatiecoëfficiënt met $1 \frac{8}{8}$ gepaard ging met een daling van het totale aantal toegekende vervroegde pensioenen en invaliditeitspensioenen met 15,7\%. Met andere woorden een daling van de exploitatiecoëfficiënt diende samen te gaan met een stijging van het total aan vervroegde en invaliditeitspensioenen. Arbeidsbesparende investeringen vormden daartoe een bijdrage.

De NV Nederlandse spoorwegen droeg in tegenstelling tot het bedrijfsleven de lasten van werkloosheid, die werden vermeld in de verlies- en winstrekening. De rijksoverheid droeg de lasten van werkloosheid voor het particuliere bedrijfsleven. ${ }^{452}$ Het Reglement dienstvoorwaarden regelde de toekenning van wachtgeld. Beëindiging van de aanstelling door de spoorwegen wegens overtolligheid gaf recht aanspraak te maken op wachtgeld, mits er geen aanspraak bestond op een wettelijke werkloosheidsuitkering of een pensioen. Het wachtgeld werd toegekend voor een periode van 3 maanden. De uitkeringsduur werd verlengd tot het bereiken van het 65 ste levensjaar, als op de ontslagdatum de som van de diensttijd (minimaal 10 jaar) en de leeftijd 60 jaar of hoger was. ${ }^{453}$ De Personeelsraad vermeldde in zijn verslag over 1968 dat de wachtgeldregeling in de voorgaande dertig jaren niet actueel was. Er was namelijk geen sprake van ontslag wegens overtolligheid. ${ }^{454}$

De NV Nederlandse Spoorwegen had gebruik gemaakt van de in de Werkloosheidswet geboden mogelijkheid om de bestaande publiekrechtelijke regelingen te handhaven, indien deze gunstiger waren dan die van de betrokken wet. Dit betekende dat het bedrijf sinds 1950 een eigen risico aanvaardde en het personeel geen premie in het werkloosheidsfonds hoefde te storten. De rijksoverheid was niet verplicht stortingen in het fonds te verrichten. De NV Nederlandse spoorwegen vormde in de jaren 1950 tot en met 1965 voor dit doel een eigen risicoreserve. Eind 1965 bedroeg deze 4,8 miljoen gulden. De uitkeringen in die jaren waren gering. De beëindiging van de 
mogelijkheid tot vervroegd pensioen door de Spoorwegpensioenwet van 1966 leidde tot de omzetting van het reservefonds voor wachtgelden in een "reserve voor vervroegd ouderdomspensioen". Het gevolg hiervan was dat er geen fonds meer bestond voor de uitkering van wachtgelden. ${ }^{455}$ Volgens de directeur-generaal van het Verkeer betekende dit echter niet dat de wachtgelden voor personeel jonger dan 60 jaar in beginsel niet ten laste zouden komen van het bedrijf. De NV Nederlandse Spoorwegen had immers in 1950 een eigen risico aanvaard. Voor het bedrijf ontstond de vraag of zij deze uitkeringen ook moest betalen, als zij de uitkeringen uit de Werkloosheidswet overschreden. De directie beschouwde de overschrijding als strijdig met de Europese harmonisatiebeschikking van 13 mei 1965. Tabel 4.11 toont de wachtgeldkosten per man en de extra last voor de NV Nederlandse spoorwegen voor personeel met de geboortejaren 1903, 1905 en 1910.

Tabel 4.11 Kosten wachtgeld per man en extra-last NV Nederlandse Spoorwegen ten opzichte van het bedrijfsleven (in guldens).

\begin{tabular}{|c|c|c|c|c|c|c|}
\hline (1) & (2) & (3) & $\begin{array}{l}\text { Uitkering } \\
\text { (4) }\end{array}$ & $\begin{array}{l}\text { Werkloos } \\
\text { (5) }\end{array}$ & $\begin{array}{l}\text { sheidswet } \\
(6)\end{array}$ & $\begin{array}{r}(808) \\
(7)\end{array}$ \\
\hline 1903 & 0,5 & 6.996 & 1.702 & 1.395 & 1.395 & 3.889 \\
\hline 1905 & 2,5 & 31.698 & 1.842 & 2.073 & 2.073 & 27.783 \\
\hline 1910 & 7,5 & 88.024 & 1.842 & 2.073 & 2.073 & 84.109 \\
\hline
\end{tabular}

Opmerkingen:(1) Geboortejaar en gemiddelde geboortedatum is 1 juli. In het jaar, waarin de 65-jarige leeftijd wordt bereikt, is de gemiddelde duur van het wachtgeld 7 maanden.

(2) Gemiddelde duur in jaren.

(3) Totaal wachtgeld.

(4) 8 weken wachtgeld gefinancierd door het bedrijfsleven.

(5) 18 weken werkloosheidsuitkering: financiering uit premie bedrijfsleven.

(6) 18 weken werkloosheidsuitkering: financiering uit premie overheid.

(7) Last voor Nederlandse Spoorwegen uitgaande boven het bedrijfsleven betreft het verschil tussen kolom 3 en de som van de kolommen 4 en 5.

Bron: Overzicht kosten wachtgeld per man, Ministerie van Verkeer en Waterstaat, Directoraat-generaal van het Verkeer, doss. nr. $26430 / \mathrm{k}-4$, class. nr. 25.07.352.

In 1968 verzocht de NV Nederlandse Spoorwegen de Minister van Sociale Zaken B. Roolvink (AR) de normalisatie-uitkeringen ten laste van het Rijk uit te breiden met de extra-kosten ten gevolge van de wachtgeldregeling, voorzover deze last groter was dan die van andere vervoersondernemingen, die vielen onder 
de algemene wettelijke regelingen (de Werkloosheidswet, de Wet werkloosheidsvoorziening de Algemene Bijstandswet). De wachtgeldregeling van de Nederlandse Spoorwegen was gunstiger dan de wettelijke regelingen voor het bedrijfsleven.456 Minister van Sociale zaken Roolvink wees dit verzoek af en stelde dat het treffen van voorzieningen in plaats van en uitgaande boven de wettelijke voorzieningen - mede ter voorkoming van een ongewenste precedentwerking - niet ten laste van de begroting van zijn departement kon worden gebracht. ${ }^{457}$

\subsubsection{Arbeidsvoorwarden}

De vakorganisaties, vertegenwoordigd in de Personeelsraad, streefden naar het verwerven van gunstige arbeidsvoorwaarden tijdens hun besprekingen met de directie over de herziening van het Reglement dienstvoorwaarden en vanaf 1964 bij de CAOonderhandelingen.

In 1948 attendeerde het college van Rijksbemiddelaars de Minister van Verkeer en Energie erop dat het personeel van de NV Nederlandse Spoorwegen in vergelijking met bijvoorbeeld de werknemers in de metaalnijverheid een aantal sociale voordelen genoot, namelijk: betere pensioenvoorziening, doorbetaling van het volledige loon bij ziekte, geen premie ziektewet en ziekenfonds, langere vakanties en vakantiebijslag van een weekloon, vrij vervoer voor het gezin bij vakantiereizen, betere regeling van de kinderbijslag, gratificaties, recht op wachtgeld bij ontslag wegens dienstinkrimping en een regeling voor nabestaanden. ${ }^{45}$ De exploitatiebegroting vermeldde de kosten voor deze sociale voorzieningen in het kader van het RDV, de CAO en de wet. De verworven arbeidsvoorwaarden zijn kostenverhogend voor het bedrijf en dragen bij aan het ontstaan van een gederfde winst als maatstaf voor beleidsvrijheid.

\subsubsection{Verborgen subsidiöring}

In de Europese Gemeenschap rechtvaardigden het Ministerie van Verkeer en Waterstaat en de NV Nederlandse Spoorwegen de subsidiëring van de pensioenlasten van de NV Nederlandse spoorwegen met de mededeling dat de regeling van de spoorwegpensioenen nooit op de gunstige overheidsregeling zou zijn afgestemd, als zij daartoe niet waren gedwongen. De overheid had deze regeling na de spoorwegstaking van 1903 in het algemeen belang opgelegd aan het spoorwegbedrijf. ${ }^{459}$ De Spoorwegpensioenwet van 1925 compenseerde het uit 1903 daterende wettelijke stakingsverbod voor personeel in dienst van de spoorwegen. Deze wet belastte de directie van de NV Nederlandse Spoorwegen met het bestuur over het spoorwegpensioenfonds. In $1967 \mathrm{kwam}$ in deze situatie verandering met het instellen van een fondsdirectie en een Raad van Toezicht. De Raad bestond uit vertegenwoordigers van de NV Nederlandse Spoorwegen en vertegenwoordigers uit de vakbeweging. ${ }^{460}$

De tekorten van het spoorwegpensioenfonds, dwongen de desbetreffende kabinetten tot het nemen van wettelijke 
maatregelen:

1. De Wet van 27 mei 1948 regelde de delging van het tekort van het fonds. De staat betaalde gedurende 50 jaar, te rekenen vanaf 1 juli 1940 , jaarlijks een annuiteit ten bedrage van 16.296 .000 gulden. Vanaf 1 juli 1946 werd dit bedrag verhoogd tot 22.483 .174 gulden. 461

2. De Wet van 23 februari 1961 kende gedurende 60 jaar vanaf 1961 een annuiteit van 8,9 miljoen gulden toe. ${ }^{46}$

3. De Wet van 15 februari 1967 bepaalde dat de overheid ter dekking van het wiskundig tekort, dat per 1 januari 1966 aanwezig was, een bijdrage verstrekte in 15 gelijke jaarlijkse termijnen. ${ }^{463}$

Uit tabel 4.12 blijkt dat er een statistisch significant verband bestaat tussen enerzijds de ratio tussen het ongedekte saldo en de contante waarde van de vordering op de Nederlandse overheid (danwel het balanstotaal) en het lopende aantal invaliditeitspensioenen (de gegevens worden vermeld in bijlage 4.4). De bestaande zekerheid van de vordering op de staat der Nederlanden bood de mogelijkheid om het vervroegde en het invaliditeitspensioen te hanteren als instrument ter vermindering van het personeelsbestand.

Tabel 4.12 Ongedekt saldo en invaliditeitspensioen, 1950-1960.

\begin{tabular}{lccrc}
\hline Variabele & $r^{2}$ & Parameter & t-waarde & sig. $t$ \\
\hline Tekort (1) & 0.59 & 29.7 & 3.604 & 0.0057 \\
Constante & & -7.8 & -3.829 & 0.0040 \\
Tekort (2) & 0,40 & 7.4 & 2.443 & 0.0372 \\
Constante & & -2.0 & -2.665 & 0.0258 \\
\hline
\end{tabular}

Opmerkingen: (1) Ratio tussen ongedekt saldo en de contante waarde van de vordering op de staat der Nederlanden ( Wet van 27 mei 1948).

(2) Ratio tussen ongedekt saldo en het balanstotaal.

De Ministers Verdam en Vondeling verwachtten geen aantasting van de financiële basis van het Spoorwegpensioenfonds bij de handhaving van het vervroegde ouderdomspensioen voor het spoorwegpersoneel. Zij waren niet beducht voor gevaren, warvan de ernst onbekend was. De financiële gevolgen waren aan de hand van de ervaring opgedaan met de huidige regeling bij benadering te ramen. Uit die raming bleek echter dat de voortzetting van het vervroegde pensioen een betrekkelijk kostbare zaak was. Te verwachten was namelijk dat met handhaving jaarlijks een bedrag gemoeid was dat overeenkwam met ongeveer 1 procent van de NS-loonsom. De kosten waren, gezien de loonhoogte in 1966, te warderen op bijna 4 miljoen gulden per jaar. ${ }^{404}$

Na 1945 hielden opeenvolgende kabinetten zich bezig met de 
financiële reorganisatie van de pensioenfondsen en de pensioenwetgeving. De overheidsbijdragen en de aan de pensioenfondsen af te dragen premies waren politiek omstreden onderwerpen. De Tweede Kamer Commissie van Rapporteurs over het Wetsontwerp tot dekking van het tekort van het Spoorwegpensioenfonds stelde in 1948 de vraag of de exploitatieoverschotten van de NV Nederlandse Spoorwegen niet konden worden aangewend om de tekorten van het Spoorwegpensioenfonds te compenseren. Volgens de Ministers Lieftinck en vos was dit niet mogelijk, omdat daarmee de afschrijvingen moesten worden gecompenseerd. ${ }^{465}$ Tijdens de vergadering van de Raad voor Economische Aangelegenheden op 11 januari 1950 vestigde Minister zonder portefeuille L. Götzen (sympathiserend met de AR) de aandacht op het feit dat het spoorwegbedrijf niet "selfsupporting" was en informeerde naar de mogelijkheid om de bijdragen aan het spoorwegpensioenfonds te beëindigen. ${ }^{466}$

Tijdens het kabinet Drees-II besloot Minister van Financiën Van de Kieft het spoorwegpensioenfonds financieel te saneren. Voor de NV Nederlandse spoorwegen betekende dit een stijging van het bijdragepercentage van 16,1 naar 20 procent. De directie koesterde aanvankelijk geen bezwaren tegen deze verhoging en sprak zich uit voor een 50-50 verdeling tussen bedrijf en personeel. In 1957 wilde zijn opvolger Minister Hofstra slechts de toekomstige tekorten compenseren en eventuele tekorten aan backservice ten gevolge van loonronden financieren met een verhoging van de bijdrage. De vergoeding van de backservice was in deze optiek een indirecte subsidie. Het voornemen van de minister hield in dat het bijdragepercentage voor de NV Nederlandse Spoorwegen zou kunnen stijgen tot boven de 20 procent. ${ }^{467}$ Voor de directie vormde dit aanleiding om terug te komen op de aanvaarding van een verhoging tot 20 procent. De verhoging had gevolgen voor de tariefsteliing. De directie beschouwde de extra-last als een bedrijfsvreemde last en verwees naar de pensioenlasten van de vervoersondernemingen aangesloten bij de Pensioenstichting Transport. De meeste dochterondernemingen van het bedrijf waren reeds aangesloten bij dit fonds. $\mathrm{Zij}$ verzocht de Minister van Binnenlandse zaken een wijziging in het wetsontwerp aan te brengen. ${ }^{46 \%}$

Tabel 4.13 geeft een verdeling van het premiepercentage dat door de werkgever en de werknemers moet worden betaald aan respectievelijk het Algemeen Burgerlijk Pensioenfonds en het Spoorwegpensioenfonds. Een verhoging van het premiepercentage van de werknemer betekende een loonsvermindering en een poging de lasten te verschuiven. 
Tabel 4.13 Verdeling pensioenpremies in 1957.

\begin{tabular}{lccc}
\hline Fonds & Premie & Werkgever & Werknemer \\
\hline ABP & 16,1 & 8,6 & 7,5 \\
SPF & 16,1 & 7,6 & 8,5 \\
\hline
\end{tabular}

opmerking: Premie berekend over pensioengrondslag.

Bron: Ministerie van Verkeer en Waterstaat, Wetsontwerp sanering Spoorwegpensioenfonds, augustus 1957, p. 1 ; doss. $\mathrm{nr} .898 / \mathrm{AI}$, class. nr. 25.08.743.

In 1957 was het Ministerie van Binnenlandse Zaken bereid de 50-50 verdeling te aanvaarden, als het-Spoorwegpensioenfonds en het Algemeen Burgerlijk Pensioenfonds gescheiden zouden blijven. Bij een samenvoeging van beide fondsen kon het bijdrageverhal niet meer verschillend worden geregeld. In juli 1957 bepleitte de vertegenwoordiger van de NV Nederlandse Spoorwegen in de Staatscommissie voor de Pensioenwetgeving, onder voorzitterschap van Prof. dr. G.A. van Poelje, een fusie van beide fondsen. ${ }^{469}$

In 1959 stelden Minister van Financiën H.J. Hofstra en Minister van Binnenlandse Zaken A.A.M. Struycken (KVP) geen redenen te zien om de tekorten in het Algemeen Burgerlijk Pensioenfonds uitsluitend ten laste van de staat te laten komen. De kosten van de pensioenvoorziening behoorden tot de apparaatkosten van de overheidsdiensten. Alleen op deze grondslag zou het mogelijk zijn een juist inzicht te verwerven in de exploitatie-uitkomsten van overheidsbedrijven. ${ }^{470}$ Het Tweede Kamerlid J. Smallenbroek (AR) bekritiseerde op 9 november 1960 de regeling van de spoorwegpensioenen in het Wetsontwerp over maatregelen in verband met de financiële positie van het Algemeen Burgerlijk Pensioenfonds en van het Spoorwegpensioenfonds. De premie werd volgens hem niet gesteld op een percentage, waardoor in de toekomst nieuwe tekorten werden voorkomen. Het ontstaan van tekorten werd bewust aanvaard, omdat aan de NV Nederlandse spoorwegen geen lasten mochten worden opgelegd, welke uitgingen boven die van de particuliere sector. Smallenbroek achtte het een bedenkelijke aangelegenheid dat de NV Nederlandse Spoorwegen, vanwege de bijzondere concurrentiepositie ten opzichte van de andere vervoerstakken een uitzonderingspositie zou genieten. Volgens hem handelden de verantwoordelijke ministers in strijd met het uitgangspunt dat de kosten van de pensioenvoorziening behoorden tot de apparaatkosten. Hij was van mening dat deze problematiek moest worden opgelost en karakteriseerde de overheidsbijdrage als een versluierde "subsidie".471 Zijn collega G. Ritmeester (VVD) stelde dat bij een verhoogde pensioenbijdrage de concurrentie nog wel was vol te houden. De NV Nederlandse Spoorwegen keerde immers dividenden uit van 3 procent en de dochtermaatschappijen boekten winsten van gemiddeld 10 à 12 procent. ${ }^{472}$

Tijdens de parlementaire behandeling van de nieuwe regeling van de spoorwegpensioenen in 1966 wezen de Minister van Financiën Vondeling (PvdA) en de Minister van Binnenlandse 
Zaken Verdam (AR) een fusie af. Volgens hen leverde de fusie geen administratief voordeel op en bestond het gevaar van een afwenteling van de tekorten van het spoorwegpensioenfonds naar het Algemeen Burgerlijk Pensioenfonds. ${ }^{473}$

De NV Nederlandse Spoorwegen betaalde een lagere premie, dan nodig was om de pensioenen van de spoorwegambtenaren veilig te stellen. De bijdrage van de NV Nederlandse spoorwegen was zodanig vastgesteld dat $z i j$ niet werd benadeeld ten opzichte van de andere vervoersondernemingen. Ten behoeve van de welvaartsvastheid bracht het Ministerie van Binnenlandse zaken het in dit fonds te storten bedrag ten laste van de begroting. ${ }^{474}$ De wettelijke bijdragen van de rijksoverheid aan het spoorwegpensioenfonds hadden consequenties voor de inkomensverdeling. Het betekende ten eerste een herverdeling van de belastingopbrengsten naar de werknemers van de NV Nederlandse Spoorwegen en ten tweede een verlaging van de tarieven in het reizigers- en goederenvervoer.

Tabel 4.14 Het verloop van de lasten van het Spoorwegpensioenfonds en de belastingdruk per stemgerechtigde (in guldens).

\begin{tabular}{lcrrr}
\hline Jaar & $\begin{array}{l}\text { Lasten } \\
\text { spf }\end{array}$ & $\begin{array}{c}\text { Index } \\
1971=100\end{array}$ & $\begin{array}{l}\text { Belasting } \\
\text { druk }\end{array}$ & $\begin{array}{c}\text { Index } \\
1971=100\end{array}$ \\
\hline 1946 & 3,09 & 21,2 & 352,35 & 14,6 \\
1948 & 4,13 & 28,3 & 415,53 & 17,3 \\
1952 & 3,88 & 26,6 & 630,76 & 26,2 \\
1956 & 3,67 & 25,2 & 706,12 & 29,4 \\
1959 & 3,56 & 24,4 & 733,20 & 30,5 \\
1963 & 4,65 & 31,9 & 978,81 & 40,7 \\
1967 & 7,09 & 48,6 & 1565,40 & 65,1 \\
1971 & 14,58 & 100,0 & 2403,77 & 100,0 \\
\hline
\end{tabular}

Bron: CBS, Negentig jaren statistiek in tijdreeksen, 1989. Ministerie van Binnenlandse Zaken, Begrotingen van de desbetreffende jaren.

Uit tabel 4.14 kan worden geconstateerd dat de ontwikkeling van de lasten ten behoeve van het spoorwegpensioenfonds achter blijven bij het verloop van de belastingdruk.

\subsubsection{Aankopen}

In verschillende lidstaten van de Europese Gemeenschap maakten de aankopen van spoorwegondernemingen deel uit van een protectionistisch beleid. De orders voor spoorwegmaterieel kwamen ten gunste van de nationale wagonindustrieën. De directie van NV Nederlandse Spoorwegen was nauw betrokken bij de sanering van de Nederlandse wagonindustrie. Het bedrijf begunstigde met zijn orders voor reizigersmaterieel de nationale industrie, die echter duurder was dan de buitenlandse. Het bedrijf Werkspoor bleef uiteindelijk over als de enige Nederlandse onderneming, gespecialiseerd in de produktie van spoorwegmaterieel. Het bedrijf fuseerde in 1954 
met de Koninklijke Machinefabriek Gebroeders stork en Co. in de Verenigde Machine Fabrieken VMF/Werkspoor. De NV Nederlandse Spoorwegen betrok lange tijd haar materieel van de fabriek Werkspoor-Utrecht. ${ }^{475}$

De NV Nederlandse Spoorwegen betaalde bij Werkspoor-Utrecht hogere prijzen dan bij buitenlandse leveranciers. De aankoop van spoorwegmaterieel had consequenties voor het bedrijfsresultaat van de NV Nederlandse Spoorwegen. over de periode 1959 tot en met 1965 makten de leveranties aan de spoorwegen gemiddeld 79,3 procent van de omzet van Werkspoor uit. Het bedrijf werd hierdoor in hoge mate afhankelijk van de spoorwegen. Het prijsverschil vond zijn oorzaak in de loonexplosie van de jaren 1964 tot en met $1966 .^{476}$ Tabel 4.15 toont het verloop van de orders bij Werkspoor-Utrecht.

Tabel 4.15 orders van de NV Nederlandse Spoorwegen bij Werkspoor-Utrecht.

\begin{tabular}{llccc}
\hline & $\begin{array}{l}\text { Rijtuigen: } \\
\text { Afgeleverd en } \\
\text { nog te leveren }\end{array}$ & $\begin{array}{l}\text { Geplande } \\
\text { orders }\end{array}$ & $\begin{array}{l}\text { Goederenwagens } \\
\text { Afgeleverd en } \\
\text { nog te leveren }\end{array}$ & $\begin{array}{l}\text { Geplande } \\
\text { orders }\end{array}$ \\
\hline 1963 & 54 & & 357 & \\
1964 & 80 & & 479 & \\
1965 & 60 & & 458 & \\
1966 & 69 & & 121 & \\
1967 & 30 & & & 100 \\
1968 & 16 & 72 & & pm \\
1969 & & 48 & & pm \\
1970 & & 20 & & pm \\
1971 & & 20 & & \\
1972 & & & & \\
\hline
\end{tabular}

Bron: Ministerie van Verkeer en Waterstat, Bestellingen door de Nederlandse Spoorwegen van rollend materieel bij Werkspoor-Utrecht, 2 mei 1967, nr. $\mathrm{V}-1$, p.1; Ministerie van verkeer en waterstaat, doss. $26430 \mathrm{~F}$ deel I, class. nr. 25.07.352.

De Raad van Comissarissen van de NV Nederlandse Spoorwegen besloot in 1966, in afwachting van een overheidsregeling voor de financiële positie van het bedrijf, de investeringen in rollend materieel (investeringsplan 1967 tot en met 1969) uit te stellen. Dit besluit bedreigde de werkgelegenheid voor ongeveer 1150 geschoolde arbeidskrachten bij het bedrijf Werkspoor-Utrecht. ${ }^{4 \pi}$ Tot de andere oorzaken van de problemen bij Werkspoor-Utrecht behoorden de rationalisatie en het teruglopend vervoer bij de NV Nederlandse Spoorwegen. ${ }^{478}$ De VMF wilde orders, alsmede garanties voor orders, van de overheid.

De directle van de spoorwegen had in 1967 in het kader van Plan $W 2$ ook een offerte in het buitenland aangevraagd. Dit dwong Werkspoor tot het verlagen van zijn offerte met 20 procent. De NV Nederlandse spoorwegen oefende hiermede druk uit op het prijsbeleid van Werkspoor. ${ }^{479}$ Als prijsdrukker voor reizigersmaterieel functioneerde het Westduitse bedrijf 
Talbot, dat echter geen orders ontving. 480

Het aankoopbeleid moest volgens de directie van de $\mathrm{NV}$ Nederlandse spoorwegen gericht zijn op het bedrijfsbelang. Dit betekende de aanbesteding bij ondernemingen met de laagste prijzen, gegeven de kwaliteit van het materieel. Het Ministerie van Economische Zaken en de directie van Werkspoor verzetten zich tegen deze opvatting. In het kader van het economisch beleid van de overheid was de bereidheid aanwezig te accepteren, dat de NV Nederlandse Spoorwegen haar orders plaatste bij Werkspoor-Utrecht. ${ }^{481}$

Het Ministerie van Economische Zaken poogde in 1968 te bewerksteliigen dat de NV Nederlandse Spoorwegen een order van 31 treinstellen plaatste bij Werkspoor. De directeur-generaal van het verkeer informeerde zijn secretaris-generaal dat plaatsing van de order bij dit bedrijf als nadelig voor de spoorwegenwerd beschouwd. Hij vroeg zich af of het Ministerie van Economische Zaken bereid was het financiële nadeel te compenseren. De betrokken ambtenaar attendeerde de secretarisgeneraal erop dat het verlenen van een machtiging tot het plaatsen van een deel of de gehele order bij Werkspoor ertoe kon leiden dat het prijsverschil in de toekomst via de overname van de bedrijfsvreemde lasten ten laste van zijn departement kwam. Het kon echter niet de bedoeling zijn dat het Ministerie van Verkeer en Waterstaat geruisloos de subsidiëring van Werkspoor op haar begroting bracht. ${ }^{482}$ De secretaris-generaal van verkeer en waterstaat was van mening dat de rijksoverheid, respectievelijk de leden van de Raad van Commissarissen, de directie van de spoorwegen niet stimuleerde tot goed koopmansgedrag als zij het bedrijf dwongen zich hogere uitgaven te getroosten ten behoeve van de Nederlandse industrie.4k3 Het Ministerie van Economische Zaken bekritiseerde de NV Nederlandse spoorwegen over de continuiteit van het plaatsen van orders. Het bedrijf motiveerde de vertragingen bij het plaatsen van de orders met technische, budgettaire en prijsoverwegingen. Het was in het belang van het Ministerie van Verkeer en Waterstaat en de NV Nederlandse spoorwegen zorg te dragen voor de continuiteit van de orders, omdat bij het wegvallen van werkspoor als leverancier afhankelijkheid van het buitenland ontstond. Een feit dat in de rekening kon worden teruggevonden. ${ }^{44}$

Een aankoopverplichting bij Werkspoor voor de NV Nederlandse spoorwegen behoorde tot de beleidsmogelijkheden. De NV Nederlandse Spoorwegen wilde dat bij een dergelijke verplichting het kabinet het verschil tussen de prijs van Werkspoor en de buitenlandse prijs compenseerde. ${ }^{4 S}$ Het bedrijf moest een zuinig beleid voeren vanwege zijn financiële positie. Het Ministerie van Verkeer en Waterstaat kon de NV Nederlandse spoorwegen niet verplichten regelmatig bepaalde orders te plaatsen bij Werkspoor, ongeacht de vraag of de prijzen van dit bedrijf concurrerend waren. Het Ministerie van Economische zaken trachtte het Ministerie van verkeer en waterstaat ertoe te bewegen het prijsverschil met het buitenland te compenseren. Dit ministerie hanteerde hiertegen het argument dat de NV Nederlandse Spoorwegen niet was aangewezen op Werkspoor. Voor het Ministerie van Verkeer en Waterstaat bestond er dan ook geen aanleiding om een bedrag 
voor compensatie in haar begroting op te nemen. ${ }^{486}$

De Raad van Bestuur van VMF vestigde in november 1969 de aandacht van de Minister van Economische Zaken $L$. de Block (KVP) op het feit dat de produktie van rollend materieel slechts zou kunnen worden gecontinueerd als een garantie kon worden verkregen voor een jaarlijks niveau van bestellingen van 70 rijtuigbakken voor een periode van 5 jaar. De personeelsbezetting van Werkspoor-utrecht was te hoog en de produktiviteit te laag. Een reorganisatie was slechts mogelijk, indien er een oplossing bestond voor de problemen. De Staatssecretaris van Verkeer en Waterstaat M.J. Keijzer (VVD) deelde op 7 januari 1970 mee de gevraagde garantie niet te kunnen verstrekken. De Raad van Bestuur van VMF had besloten de produktie van rollend materieel te beëindigen, indien de gevraagde garanties niet werden verleend. 48 ?

De NV Nederlandse Spoorwegen beschouwde het wegvalien van de produktie van rollend materieel in Nederland als een ernstig nadeel. In februari 1970 achtten de directies van de VMF en de NV Nederlandse spoorwegen in principe een overeenstemming mogelijk, waarbij de VMF haar activiteiten op het gebied van de produktie van rollend materieel overdroeg aan de spoorwegen. Feitelijk betekende dit de oprichting van een dochteronderneming door de NV Nederlandse spoorwegen. Zes honderd personeelsleden van Werkspoor-Utrecht zouden hier emplooi vinden. De kosten van de transactie bedroegen 24 miljoen gulden. De NV Nederlandse Spoorwegen zou de helft voor haar rekening nemen. De overheid zou de andere helft bijdragen. ${ }^{488}$ In mei 1970 schreef de secretaris-generaal van Verkeer en Waterstaat in zijn notitie voor de staatssecretar is M.J. Keijzer dat de hoofddirectie van de NV Nederlandse Spoorwegen belang had bij een Nederlandse wagonindustrie. $2 i j$ stelde zich een "skeleton-unit" voor van ongeveer 400 personeelsleden, die een beperkte seriebouw maakte en geen ontwikkelingswerk verrichtte. De produktie zou beneden de behoefte van de spoorwegen liggen. Een afzonderlijk probleem vormde de waardebepaling van de overdracht. ${ }^{489}$

Staatssecretaris Keijzer peilde nog in mei 1970 wat de reactie zou zijn van de directie en de Raad van Commissarissen, als hij aan de Tweede Kamer der statenGeneraal eventueel mededeelde dat er geen bezwaar bestond de komende vijf jaar machtiging te verlenen tot het bestellen van 60 bakken. De hoofddirectie van de spoorwegen beschouwde dit als een inkoopverplichting, die in strijd was met het inkoopbeleid. In het binnen- en buitenland aangevraagde offerten fungeerden als uitgangspunt van het inkoopbeleid. Het bedrijf, met de gunstigste combinatie van prijs, kwaliteit en overige leveringsvoorwaarden verwierf de opdracht. Bij geringe verschillen ging de voorkeur uit naar de Nederlandse industrie. De Raad van Commissarissen, die uiteindelijk de machtigingen verstrekte, sloot zich aan bij dit standpunt van de directie. ${ }^{491}$

Het kabinet-De Jong nam in juli 1970 het standpunt in dat er geen bestaansgrond meer was voor een Nederlandse wagonfabriek. De vakorganisaties en de ondernemingsraad ontvingen de mededeling dat de afdeling Rollend Materieel van Werkspoor-Utrecht in 1971 na de voltooiing van de spoorweg- 
order V7 materieel werd opgeheven. De hoofddirectie van de NV Nederlandse spoorwegen had in besprekingen met de VMF te kennen gegeven een verhoudingsgewijs groot aantal vacatures aan oud-werknemers van Werkspoor aan te kunnen bieden. Het was echter geen groepsgewijze overname van het personeel van Werkspoor. Bij aanneming en selectie golden de normale eisen. De hoofddirectie betrachtte slechts soepelheid ten aanzien van de leeftijdsgrenzen. ${ }^{491}$

\subsubsection{Beheersing overheidsfinanciön}

In 1966 besloot het kabinet-Cals tot temporisering van de investeringen vanwege de moeilijke positie van de overheidsfinanciën. Om deze matregel te realiseren, moest deze eveneens worden uitgevoerd door de overheidsbedrijven. Het Ministerie van verkeer en waterstaat verzocht de NV Nederlandse spoorwegen en haar dochterondernemingen om alle investeringen, welke niet voortvloeiden uit reeds gesloten overeenkomsten, tot 1 oktober 1966 op te schorten. ${ }^{42}$

\subsection{Kostenverdeling}

De kosten van het reizigers- en goederenvervoer van een spoorwegonderneming kunnen worden verdeeld op basis van gelijkwaardig kostendragerschap (integrale kosten) of op grond hoofdkostendragerschap (differentiële kostencalculatie). Beide methoden van kostenverdeling maakten deel uit van een geschil tussen de NV Nederlandse Spoorwegen en de ambtenaren van het Ministerie van verkeer en waterstaat. In 1973 leidde dat zelfs tot een verzoek van de Raad van state om een prejudiciële beslissing van het Europese Hof van Justitie. ${ }^{493}$ Aan dit geschil ging een ontwikkeling van de kostenadministratie vooraf.

Vanaf 1947 stelde de directie een kostensplitsing op ten behoeve van de staten-Generaal. De direct aanwijsbare kosten werden geplaatst tegenover de afzonderlijke opbrengsten van het reizigers- en goederenvervoer. Het verschil tussen beiden vormde het bruto-overschot, dat de niet direct met het goederen- en reizigersvervoer samenhangende kosten moest compenseren. Het beleid van kostencalculatie had als uitgangspunt dat zolang uit het goederen- en reizigersvervoer gezamenlijk een positief resultat voor het bedrijf voortvloeide, een verdergaande verbijzondering van de "algemene kosten van vervoer" niet noodzakelijk werd geacht. ${ }^{44}$ Uit tabel 4.16 blijkt dat de opbrengsten de toegerekende kosten overschreden. 
Tabel 4.16 Kostensplitsing reizigers- en goederenvervoer in miljoenen guldens

\begin{tabular}{lll}
\hline Jaar opbrengsten kosten & $\begin{array}{l}\text { Toegerekende Bruto } \\
\text { overschot }\end{array}$ & $\begin{array}{l}\text { Bruto-overschot als } \\
\text { \& van de opbrengst }\end{array}$ \\
\hline
\end{tabular}

Reizigersvervoer

$\begin{array}{lllll}1947 & 205,1 & 115,7 & 89.3 & 43,5 \\ 1950 & 190,0 & 129,4 & 60,6 & 31,9 \\ 1955 & 259,2 & 190,3 & 68,9 & 26,6 \\ 1960 & 291,1 & 205,7 & 85,4 & 29,3 \\ 1965 & 369,8 & 288,0 & 81,8 & 22,1\end{array}$

Goederenvervoer

$\begin{array}{rrrrr}1947 & 78,4 & 76,1 & 2,3 & 2,9 \\ 1950 & 123,3 & 101,0 & 22,3 & 18,1 \\ 1955 & 192,8 & 146,3 & 46,5 & 24,1 \\ 1960 & 222,8 & 167,2 & 55,6 & 25,0 \\ 1965 & 306,9 & 241,1 & 65,8 & 21,4\end{array}$

Opmerkingen:(1) Vórr 1947 stelde de NV Nederlandse Spoorwegen geen kostenverdelingen op.

Bron: Kostenverdeling van de NV Nederlandse Spoorwegen over de jaren 1947, 1950, 1955, 1960 en 1965; in: Ministerie van Verkeer en waterstaat, doss. nr. 9501 , class. $\mathrm{nr} .25 .07 .352 .18$.

Uit tabel 4.17 blijkt dat het totale bruto-overschot van het goederen- en reizigersvervoer van de NV Nederlandse Spoorwegen in 1965 niet meer in staat was de algemene kosten te dekken. Daarnaast blijkt uit de cijfers dat het aandeel van het reizigersvervoer in de algemene kosten afnam. In hetzelfde jaar namen de Raad van Commissarissen en de directie over deze problematiek contact op met het kabinet.

Tabel 4.17 Dekking algemene kosten.

\begin{tabular}{rrrrrr}
\hline $\begin{array}{l}\text { Jaar Total Bruto- Algemene } \\
\text { Overschot }\end{array}$ & \multicolumn{2}{c}{$\begin{array}{l}\text { Dekkingspercentage: } \\
\text { Kosten }\end{array}$} & Total & Reizigers & Goederen \\
\hline \multicolumn{7}{c}{ mln gld } \\
1947 & 91,6 & 61,1 & 149,9 & 146,1 & 3,8 \\
1950 & 82,9 & 66,2 & 125,2 & 91,5 & 33,7 \\
1955 & 115,4 & 102,8 & 112,2 & 67,0 & 45,2 \\
1960 & 141,0 & 122,1 & 115,5 & 69,9 & 45,5 \\
1965 & 147,6 & 160,0 & 92,3 & 51,1 & 41,1 \\
\hline
\end{tabular}

Bron: Kostenverdeling van de NV Nederlandse Spoorwegen over de jaren 1947, 1950, 1955, 1960 en 1965; in: Ministerie van verkeer en Waterstaat, doss. $\mathrm{nr}$. 9501, class. nr. 25.07.352.18. 
In 1966 kreeg de directie van de NV Nederlandse Spoorwegen van het Ministerie van Verkeer en waterstaat de opdracht het resultaat van de onderneming te splitsen in: 1. een resultaat op het reizigersvervoer, 2. een resultat op het goederenvervoer, 3 . een resultaat op de overige activiteiten, en 4. een in het jaarresultaat begrepen kostencategorie voor de financiering van het gecumuleerde verlies. De NV Nederlandse Spoorwegen presenteerde in 1967 het rapport "Kostensplitsing Reizigers-Goederen 1967", waarin bij de toerekening van de kosten, die niet specifiek als reizigersof goederenkosten konden worden beschouwd, werd uitgegaan van gelijkwaardigheid van beide soorten van dienstverlening. ${ }^{495} \mathrm{De}$ splitsing had betrekking op het resultaat, zoals dat uit de verlies- en winstrekening van het bedrijf bleek. Het rapport vestigde er de aandacht op dat het, gezien ook het matschappelijke belang, mogelijk was geweest een splitsing op te stelien, waarbij het reizigersvervoer fungeerde als hoofdkostendrager. Het gevolg hiervan was dat de resultaten van het goederenvervoer gunstiger zouden worden en die van het reizigersvervoer ongunstiger. De mogelijkheid om het reizigersvervoer als hoofdkostendrager aan te merken, werd door het bedrijf niet losgelaten. ${ }^{40}$ De kostensplitsing in tabel 4.18 is gebaseerd op het reeds genoemde rapport.

Tabel 4.18 Kostenverdeling in miljoenen guldens op basis van gelijkwaardig kostendragerschap van 1967 tot en met 1969 .

\begin{tabular}{lll}
\hline Jaar $\begin{array}{l}\text { Reizigers- } \\
\text { vervoer }\end{array}$ & $\begin{array}{l}\text { Goederenen- } \\
\text { vervoer }\end{array}$ & Rente \\
\hline
\end{tabular}

kosten opbrengsten kosten opbrengsten

$\begin{array}{lllllll}1967 & 440,0 & 405,7 & 335,4 & 283,8 & -10,7 & -94,0 \\ 1968 & 467,0 & 444,3 & 340,2 & 296,0 & -16,6 & -80,3 \\ 1969 & 478,9 & 453,9 & 360,6 & 324,2 & -22,2 & -80,3\end{array}$

Bron: NV Nederlandse Spoorwegen, Kostensplitsingen over 1967, 1968 en 1969; in: Ministerie van Verkeer en Waterstaat, doss. nr. 9501, class. nr. 25.07.352.18.

Opmerkelijk is dat het aandeel van de rentefinanciering in het totale negatieve resultaat toenam van 11,4 procent in 1967 tot 27,6 procent in 1969 .

op international niveau verdedigde de Nederlandse overheid de toepassing van integrale calculatiemethoden. De reden hiervoor was dat de verschillende vervoersactiviteiten op gelijke voet moesten worden behandeld. De calculatie, waarbij het reizigersvervoer als hoofdkostendrager werd beschouwd, was in strijd met het international gevoerde beleid. Deze methode van calculatie zou de Nederlandse positie in het internationale overleg op het gebied van de kosten van de weg onhoudbaar maken. De samengevoegde (capaciteits) kosten moesten dan bij alle vervoerstakken uit de algemene middelen van de overheid worden gedekt. Het meest fundamentele bezwaar tegen het beschouwen van het reizigersvervoer als hoofdkostendrager 
was echter, dat Nederland steeds had verdedigd dat vervoer een commerciële activiteit was. overheidsinterventie behoorde tot de uitzonderingen. ${ }^{49}$

In 1969 liet de directie staatssecretaris Keijzer weten voorstander te zijn van het reizigersvervoer als hoofdkostendrager. Het reizigersvervoer was volgens de directie onrendabel en binnen afzienbare tijd niet rendabel te maken. $\mathrm{Zij}$ beschouwde het goederenvervoer als een additionele activiteit, waarvan het resultaat ten goede kwam aan het bedrijf. ${ }^{498}$ Met de integrale kostentoerekening voor het goederenvervoer was in 1968 een verlies van 44,2 miljoen gulden vastgesteld. Hierin was tevens opgenomen de bijdrage van 27,5 miljoen gulden voor het medegebruik van de voor het reizigersvervoer noodzakelijke capaciteit. Het verlies in het goederenvervoer bedroeg dus in feite 16,7 miljoen gulden. Daartegen zou actie moeten worden ondernomen. Voortzetting van de kostensplitsing op basis van gelijkwaardigheid voor het bedrijfsbeleid zou sociaal-economische en politieke consequenties hebben. ${ }^{499}$

In 1970 benaderde de NV Nederlandse Spoorwegen de staatssecretaris van verkeer en Waterstaat keijzer met het verzoek tot opheffing van alle openbare dienstverplichtingen in het goederen- en reizigersvervoer op grond van de EEG verordening 1191/69. Het geschil dat hieruit voortvloeide, leidde ertoe, dat de Hoge Raad in haar verzoek om een prejudiciële beslissing van het Europese Hof van Justitie tevens de vraag stelde of bij handhaving van de exploitatieen vervoerplicht van het personenvervoer, bij gelijktijdige opheffing van deze verplichtingen voor het goederenvervoer, de vaststelling van compensatie op basis van gelijkwaardigheid strookte met de uitleg van artikel 10 van de EEG verordening $\mathrm{nr}$. 1191/69. De NV Nederlandse spoorwegen meende dat het reizigersvervoer was te beschouwen als hoofdkostendrager. De gemeenschappelijke kosten moesten in de relevante periode noodzakelijkerwijze worden gemaakt en toegerekend aan het reizigersvervoer. Het Ministerie van verkeer en waterstaat was hiermee oneens en wilde slechts overgaan tot compensatie op basis van gelijkwaardigheid. Als alle kosten van de infrastructuur zouden worden toegerekend aan het reizigersvervoer, dan zou het goederenvervoer tegen "uitzonderlijk lage prijzen" plaatsvinden. Het reizigersvervoer als hoofdkostendrager verstoorde dan de mededingingsverhoudingen. ${ }^{500}$

\subsection{Garantiewet en financiële sanering}

De financiële positie van de NV Nederlandse spoorwegen verslechterde vanaf het begin van de jaren zestig. In 1965 verzochten de directie en de Raad van commissarissen het kabinet-cals matregelen te treffen om het financiële evenwicht te herstellen en aanwijzingen te geven over de investeringen. ${ }^{501}$

Het beroep van het bedrijf op het kabinet werd beantwoord. In 1967 wezen de verantwoordelijke bewindslieden in hun memorie van toelichting over het verlenen van tijdelijke financiële steun aan de NV Nederlandse Spoorwegen erop, dat de 
kostenstijging en het teruglopende vervoersvolume de financiële positie van het bedrijf verslechterden. De solvabiliteit en de continuiteit van de onderneming dreigden in gevaar te komen. Maatregelen waren noodzakelijk. ${ }^{502}$ Institutionele beleggers eisten meer zekerheid over de nakoming van de financiële verplichtingen in de komende jaren. Zekerheid zou slechts kunnen worden verkregen met van rijkswege toegekende garanties voor de aflossingen en de rentebetalingen. De Garantiewet van 1968 machtigde de Ministers van verkeer en waterstaat en Financiën namens de staat tot 31 december 1970 garanties te stellen ter verzekering van de betaling van rente en aflossing op door de NV Nederlandse Spoorwegen aan te gane geldleningen tot een bedrag van ten hoogste 315 miljoen gulden. Deze wet machtigde de bewindslieden voorwaarden te verbinden aan de garanties. De directie van de NV Nederlandse spoorwegen had politieke goedkeuring nodig voor het sluiten van leningen, investeringen, deelnemingen en andere vormen van kapitaalverstrekking boven de 250 duizend gulden. ${ }^{503}$ De NV Nederlandse spoorwegen benutte deze mogelijkheid ten volle. .04 $^{0}$ De Garantiewet hield echter geen financiële sanering in. Sanering was slechts mogelijk met behulp van voorzieningen, zoals de vergoeding van de bedrijfsvreemde lasten en het creëren van identieke voorwaarden van mededinging. ${ }^{505}$ In de Tweede Kamer der staten-Generaal bestond onduidelijkheid over de betekenis van balanssanering bij de NV Nederlandse spoorwegen. Staatssecretaris Keijzer (VVD) verduidelijkte dat hij met de balanssanering de cumulatie van schulden ten gevolge van de financiering van schulden wilde beëindigen. 500 De directie van de spoorwegen raamde het geaccumuleerde verlies per 31 december 1969 op 403 miljoen gulden. De sanering van de balans zou volgens de directie met ingang van 1 januari 1970 op de volgende wijzen kunnen plaatsvinden:

a. De staat der Nederlanden zou een bedrag aan langlopende leningen moeten overnemen, dat gelijk was aan het geaccumuleerde verlies in de balans. Hiervoor zouden ten eerste in aanmerking komen de in het kader van de Garantiewet gesloten, respectievelijk nog te sluiten, leningen tot een bedrag van 315 miljoen. Ter verwezenlijking van het bedrag van 403 miljoen gulden zou een aantal leningen tot een bedrag van 88 miljoen gulden, opgenomen tijdens de verliesperiode, moeten worden toegevoegd.

b. Het vervangen van het geaccumuleerde verliessaldo op de balans door het creëren van een vordering op de rijksoverheid tot een gelijk bedrag. Een aflossingsschema op annuïteitenbasis werd afgewezen, omdat de onderneming geen annuiteitenleningen had afgesloten. Bovendien zou de uitkering van annulteiten door de overheid liquiditeitsproblemen voor het bedrijf veroorzaken. ${ }^{507}$ 
In het jaarverslag over 1970 liet de directie weten ook voor 1971 een staatsgarantie te willen. ${ }^{506}$

De NV Nederlandse Spoorwegen zou volgens de directeurgeneraal van het Verkeer vanaf 1970 theoretisch een sluitende rekening kunnen realiseren, als:

1. de omvang van de bedrijfsvreemde lasten voor 1970 - en volgende jaren - op een zodanig bedrag werd vastgesteld, dat het verlies van het personenvervoer daarmee zou kunnen worden gedekt;

2. voor het verlies van het goederenvervoer een financiële overgangsregeling werd getroffen voor het verlies over 1970 en volgende jaren;

3. een sanering van de balans tot stand werd gebracht, zodat de NV Nederlandse Spoorwegen vanaf 1970 niet langer werd geconfronteerd met de rente- en aflossingslasten, voortvloeiende uit de aangegane leningen ter financiering van de per ultimo 1969 geaccumuleerde verliezen. ${ }^{500}$

\subsection{Privatisering}

De privatisering van de NV Nederlandse spoorwegen kan twee vormen aannemen, namelijk de verhandeling van de publieke eigendomsrechten of de tijdelijke overdracht van de publieke eigendomsrechten.

Voor de verhandeling van de publieke eigendomsrechten in de NV Nederlandse spoorwegen moet de waarde van het bedrijf worden vastgesteld. Deze waarde is gelijk aan de som van de intrinsieke waarde van de vaste activa en de rentabiliteitswaarde. Voor de prognose van de rentabiliteitswaarde moeten een periode en een rentepercentage voor kapitalisatie worden vastgesteld. Daarnaast moet bij de bepaling van de rentabiliteitswaarde rekening worden gehouden met de ontwikkeling van de tarieven onder de gegeven marktomstandigheden. De intrinsieke waarde van de vaste activa en de rentabiliteitswaarde staan in een nader vast te stellen verhouding. ${ }^{510}$ Het behoort tot de mogelijkheden om het goederenvervoer te privatiseren. De rentabiliteitswaarde van het goederenvervoer wordt beinvloed door de wijze van kostentoerekening. Deze waarde van het goederenvervoer is bij gelijk kostendragerschap lager dan bij het reizigersvervoer als hoofdkostendrager.

De tijdelijke overdracht van de publieke eigendomsrechten betreft het verlenen van concessies. Vuchelen en Van Impe onderscheiden twee methoden van concessieverlening. De eerste mogelijkheid betreft volgens hen het verlenen van de concessie aan het bedrijf dat de minste subsidies vraagt. Het bedrijf draagt de verantwoordelijkheid voor de infrastructuur en het rollend materieel. De tweede mogelijkheid bestaat uit het verhuren van de basisinfrastructuur aan particuliere ondernemingen. De overheid blijft dan de lasten van de infrastructuur dragen. 


\subsection{Prestaties overheidsbedrijf en reacties principalen}

\subsubsection{Benoemingen}

De Algemene Vergadering van Aandeelhouders beschikte over het recht alle zestien leden van de Raad van Commissarissen te benoemen. 512 De Raad wees drie leden aan als Gedelegeerd Commissaris om met de directie overleg te plegen over algemene aangelegenheden en het beheer van de vennootschap. De aanwijzing van de Gedelegeerden had de goedkeuring nodig van de Ministers van Verkeer en Waterstat en Financiën. ${ }^{513}$

Bij de behandeling van de begroting van het Verkeersfonds voor 1938 constateerden enige leden van de Tweede Kamer der Staten-Generaal een éénzijdige samenstelling van de Raad van Commissarissen. Bovendien waren niet alle posities opgevuld. van de twaalf benoemde commissarissen was er slechts één sociaal-democraat. Deze kamerleden drongen er bij de Minister van Waterstaat J.A.M. van Buuren (RKSP) op aan een einde te maken aan de verwaarlozing van de belangen van de arbeidersklasse. Enkele kamerleden wilden één of meer leden van de Personeelsraad tot commissaris te benoemen. ${ }^{514}$ Het kabinet $\mathrm{zag}$ geen aanleiding de Raad van commissarissen uit te breiden tot het in de statuten genoemde maximum. De eenzijdige samenstelling van de Raad kon bezwaarlijk worden toegegeven. Vanaf 1921 werd volgens Minister van Buuren geen evenredige representatie van politieke partijen nagestreefd en dit kwam ook niet overeen met de taak van de Raad. ${ }^{515}$ Hij verwoordde het standpunt van het kabinet dat het principieel geen aanbeveling verdiende om leden van de Personeelsraad tot commissaris te benoemen. ${ }^{516}$

Tabel 4.19 Politieke en bestuurlijke samenstelling Raad van Commissarissen (1)

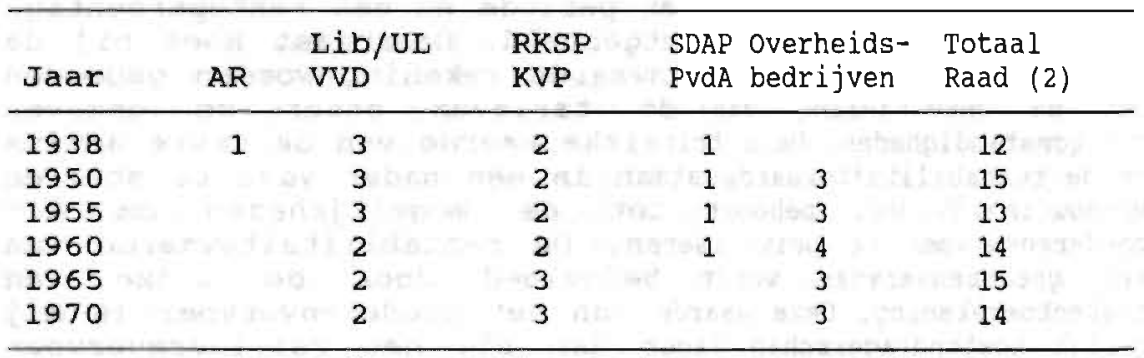

opmerkingen: (1) vertegenwoordigers van vakorganisaties zijn ondergebracht bij de geestverwante politieke partijen,

(2) totale aantal leden Raad van Commissarissen.

Bron: P.J. oud, Het jongste verleden, deel VI, Van Gorcum \& Comp. NV, Assen, 2e druk, 1968; Compendium voor politiek en samenleving in Nederland, Bohn, Stafleu, Van Loghum, april 1991; F. van Egmond, Wie is wie in Nederland, 19841988, Pragma Nederland, 's-Gravenhage. 
Benoemingen bieden een mogelijkheid om conflicten tussen overheidsorganisaties op te lossen. Tussen de NV Nederlandse spoorwegen en de staatsmijnen bestond een probleem over "het eigen vervoer" van de Staatsmijnen. In 1945 benoemde de Minister van Verkeer en Energie Th. van Schaik (KVP) dr. ir. Ch. Th. Groothof, tot directeur bij de staatsmijnen, op voorstel van de NV Nederlandse Spoorwegen tot commissaris. ${ }^{517}$

Het Ministerie van Binnenlandse Zaken toonde belangstelling voor een commissariaat bij de NV Nederlandse spoorwegen. Het ministerie kon zich daarbij beroepen op commissariaten bij de Staatsspoorwegen en de Hollandsche spoorwegmaatschappij. Zou dit ministerie een commissariaat verwerven, dan zou dat consequenties kunnen hebben voor de onderneming. De directie van de NV Nederlandse Spoorwegen was voorstander van de integratie van de pensioenwetgeving. De directeur-generaal voor het verkeer wees de directie erop dat het aandringen op integratie bij het Ministerie van Binnenlandse Zaken zou leiden tot belangstelling voor een commissariaat. Een Minister van Binnenlandse Zaken zou dan interesse kunnen krijgen voor de aanzuivering van het tekort van het spoorwegpensioenfonds uit de winst van het spoorbedrijf en voor de bedrijfsvoering. ${ }^{518}$

Het beheer van de vennootschap was krachtens de statuten van 1937 opgedragen aan een tweehoofdige directie, die werd benoemd door de Algemene Vergadering van Aandeelhouders. De Raad van Commissarissen had het recht om éen of meer personen voor benoeming aan te bevelen. In 1938 benoemde het kabinetcolijn IV de sociaal-democraat prof. dr. J. Goudriaan (werkzaam bij Philips van 1928 tot en met 1938) tot directielid. Het kabinet verstrekte hem de opdracht het tekort terug te dringen, het bedrijf te moderniseren en het populair te maken bij het reizigerspubliek. zijn beleid bracht hem in conflict met de gevestigde belangen in de organisatie. De arbeidsvoorwaarden van de NV Nederlandse spoorwegen waren beter dan die van het particuliere bedrijfsleven, hetgeen niet verdedigbaar was bij de bestaande exploitatietekorten. Hij was voorstander van een koppeling van de arbeidsvoorwaarden aan de bedrijfsresultaten. $\mathrm{zijn}$ voorstellen om een aantal voorrechten af te schaffen vonden naar zijn zeggen geen ernstige bestrijding van de Personeelsraad. ${ }^{519}$ Goudriaan wist te bewerkstelligen dat de Raad van Commissarissen en de Minister van Waterstaat instemden met een uitbreiding van de directie naar drie leden, inclusief de functie van president-directeur. $\mathrm{Hij}$ bestemde de functie van president-directeur voor zichzelf. De externe recrutering leidde tot een machtsconflict tussen Goudriaan en een coalitie van Raad van commissarissen, departementale ambtenaren en spoorwegbeambten, die uiteindelijk resulteerde in zijn vrijwillig ontslag op 1 juni 1945.520

In hetzelfde jaar deelde de Minister van Verkeer en Energie Th. S. van Schaik aan de voorzitter van de Raad van Commissarissen $\mathrm{mr}$. G. van der Meulen mee dat het hem gewenst voorkwam de lijnen te bepalen voor de opvolging van de zittende directie. Het kon nuttig zijn de aanvulling van de directieplaatsen niet uitsluitend plaats te doen vinden met personeel uit de onderneming. Ten minste een van de 
directieleden moest afkomstig zijn van buiten de NV Nederlandse Spoorwegen. Hij droeg ir. F.Q. den Hollander (technicus, ervaring met de Indische staatsspoorwegen en directeur-generaal van het directoraat-generaal van het verkeer) voor aan de Raad van Commissarissen. Zijn voorkeur voor de samenstelling van de directie ging uit naar een combinatie van een bedrijfsman, een technicus en een econoom. Hij wilde echter in geen geval de discussie in de Raad beïnvloeden. ${ }^{521}$ De Gedelegeerd Commissarissen verenigden zich met de ministeriële richtlijnen. Verder achtten zij een uitbreiding van de directie naar drie leden nodig. Gelijktijdig met de benoeming van Den Hollander was het volgens hen wenselijk uit het ambtenarenkorps van de NV Nederlandse spoorwegen twee hoofdambtenaren tot directeur te benoemen. ${ }^{522}$ De Raad van Commissarissen sloot zich in 1946 bij dit standpunt aan. ${ }^{523}$ De leiding van de onderneming kwam, overeenkomstig de wijziging van de statuten in 1946, te berusten bij een directie bestaande uit een presidentdirecteur en ten hoogste drie directeuren. Den Hollander werd in 1947 benoemd tot president-directeur. In 1970 veranderde de statutaire aanduiding "directie" in "hoofddirectie", die voortaan bestond uit vier leden. De hoofddirectie kon, na machtiging van de Raad van Commissarissen, aan de diensthoofden de titel "directeur" toekennen. In dat jaar bestond de hoofddirectie slechts uit twee leden. ${ }^{524}$

Tabel 4.20 Samenstelling Raad van Commissarissen in 1970.

\begin{tabular}{|c|c|}
\hline Commissaris & Organisatie \\
\hline $\begin{array}{l}\text { 1. Dr. ir. Th.P. Tromp (1) } \\
\text { 2. Dr. J.R.M. van den Brink (2) } \\
\text { 3. Dr. M.W. Holtrop (3) } \\
\text { 4. Drs. A.A. van Ameringen } \\
\text { 5. Drs. G. Brouwers } \\
\text { 6. Drs. Th. Coppes } \\
\text { 7. Mr. J.C.W.M. Huijsmans } \\
\text { 8. Dr. W.T. Kroese } \\
\text { 9. Ir. J. Lohmann } \\
\text { 10. Mr. V.G.M. Marijnen } \\
\text { 11. G.R. Meijer } \\
\text { 12. Dr. A.C.J. Rottier } \\
\text { 13. Ir. L.P. Ruys } \\
\text { 14. C.J.G.J. Vinkesteyn } \\
\text { 15. } \\
\text { 16. }\end{array}$ & $\begin{array}{l}\text { Philips } \\
\text { RvB Amro-bank } \\
\text { Oud Pres. Ned. bank } \\
\text { Economisch adviseur } \\
\text { Secr. gen. min. v. EZ } \\
\text { Directie Volkskrant } \\
\text { Secr. gen. min. v. Financiën } \\
\text { Directie Nijverdal-ten Cate } \\
\text { Oud Pres. dir. NS } \\
\text { Voorzitter Rijnmond } \\
\text { Oud Ged. Prov. Groningen } \\
\text { Oud Pres. dir. DSM } \\
\text { Voorzitter RvB NSU } \\
\text { Secr. gen. min. v. V en W }\end{array}$ \\
\hline
\end{tabular}

Opmerkingen: (1) voorzitter.

(2) ondervoorzitter.

(3) secretaris.

Bron: Nederlandse Spoorwegen, Kroniek, februari 1977, p. 26.

In 1970 waren twee commissariszetels vacant. De participatie van een oud-president van de NV Nederlandse Bank en een lid van de Raad van Bestuur van de Amro-bank moet worden gezien in 
verband met het beroep van het bedrijf op de kapitaalmarkt.

\subsubsection{Niet ter discussie staande beleidsactiviteiten}

Twee beleidsactiviteiten van de NV Nederlandse Spoorwegen, die niet ter discussie stonden, behelsden het reclame- en garantiebeleid.

De dienstverlening van de NV Nederlandse spoorwegen kan een meritorisch karakter hebben. Toezicht op de uitgaven aan reclame biedt de mogelijkheid het meritorische karakter te benadrukken. Reclame kan worden gericht op bepaalde doelgroepen, zoals bijvoorbeeld de lagere inkomensgroepen en de ouderen. Tijdens een overleg over de financiële positie van het bedrijf tussen de verantwoordelijke ministers en een delegatie van de NV Nederlandse Spoorwegen in 1965 vond Minister van Financiën vondeling de reclame van de NV Nederlandse Spoorwegen niet agressief genoeg. Hij wees op het voorbeeld van de Scandinavische spoorwegondernemingen en meende dat het bedrijf er goed aan deed het publiek te attenderen op de voordelen van het reizen per spoor bij verschillende weersomstandigheden. ${ }^{525}$

De Raad van Commissarissen machtigde met de exploitatiebegrotingen de directie tot het verrichten van complementaire of substitueerbare uitgaven voor publiciteitsen advertentiedoeleinden. De exploitatiebegrotingen waren incrementeel van aard, hetgeen inhield dat de uitgaven van het voorgaande jaar als basis fungeerden voor het berekenen van de begroting. Uit de gegevens van bijlage 4.5 blijkt dat de uitgaven aan publiciteit en advertenties vanaf 1964 binnen de begrote bedragen bleven. Het feit dat de werkelijke kosten de geraamde kosten niet overschreden, bevestigde de mening van Minister Vondeling. De geboden mogelijkheden om de uitgaven aan te wenden binnen de grenzen van de beleidsvrijheid werden niet volledig benut.

Tabel 4.21 geeft de mate van verband weer tussen enerzijds de definitieve publiciteitskosten $\left(x_{1}\right)$, de definitieve advertentiekosten $\left(X_{2}\right)$ en de som van beide kosten $\left(X_{3}\right)$ en anderzijds de totale opbrengsten uit het reizigersvervoer $\left(Y_{1}\right)$, de totale opbrengst van het goederenvervoer $\left(Y_{2}\right)$ en de som van beiden $\left(Y_{3}\right)$ over de periode 1956 tot en 1968 .

Tabel 4.21 Verband advertentie- en reclamekosten met totale opbrengsten reizigers- en goederenvervoer.

\begin{tabular}{clll}
\hline Variabele & \multicolumn{1}{c}{$\mathrm{Y}_{1}$} & \multicolumn{1}{c}{$\mathrm{Y}_{2}$} & \multicolumn{1}{c}{$\mathrm{Y}_{3}$} \\
\hline $\mathrm{X}_{1}$ & $0,8423 * \star$ & $0,9424 * \star$ & $0,9087 * \star$ \\
$\mathrm{X}_{2}$ & $0,0317(\mathrm{n})$ & 0,1921 & 0,0725 \\
$\mathrm{X}_{3}$ & $0,6879 *$ & $0,8499 * *$ & $0,7798 * \star$ \\
\hline
\end{tabular}

Opmerkingen: 1. Significantieniveau: $\star-0,01 ; \star \star-0,001$.

2. (n): negatief.

Uit de bovenstaande tabel blijkt een statistisch significant verband tussen de publiciteitskosten en de totale opbrengsten 
over de periode 1956 tot en met 1968. Voor de gegevens wordt verwezen naar bijlage 4.5.

De statuten van de NV Nederlandse Spoorwegen bevatten geen bepalingen over het toekennen van garanties. De NV Staatsmijnen bepaalde daarentegen in de statuten van 1967 dat de hoofddirectie de goedkeuring van de Raad van Commissarissen nodig had voor het stellen van borgtochten en garanties boven een bedrag van honderdduizend gulden. ${ }^{526}$ Het jaarverslag van de NV Nederlandse Spoorwegen vermeldde de gegeven garanties als een afzonderlijke post onder het balanstotal. Een nadere toelichting ontbrak in het verslag. Het rapport van de externe accountant vermeldde slechts de bedrijven waaraan garanties werden gegeven en posten als "diverse garantiereserves", "reserve huurgaranties" en "reserve overige verstrekte garanties" zonder nadere toelichting.

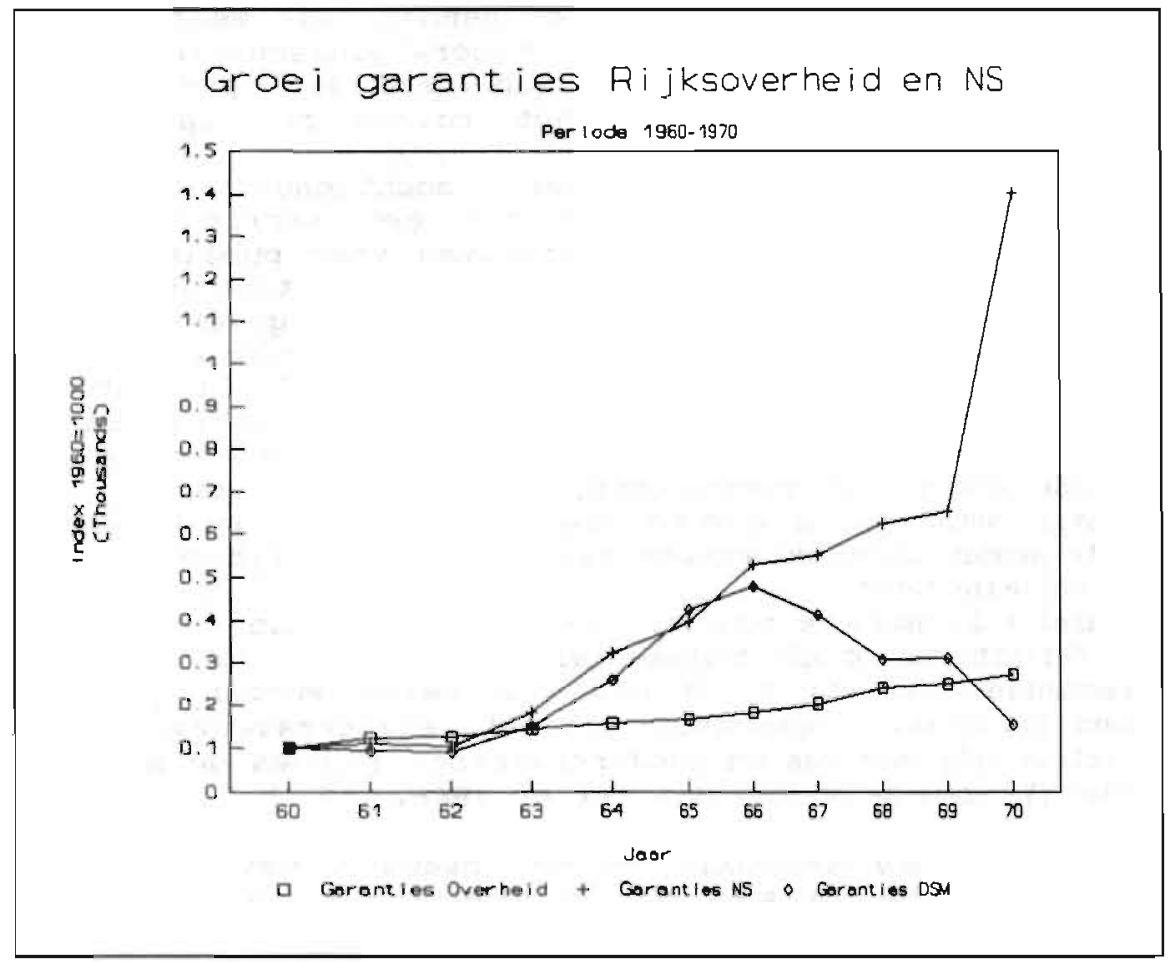

Figuur 4.3

De bovenstaande figuur 4.3 vergelijkt de groei van de garanties gegeven door de rijksoverheid, de staatsmijnen en de NV Nederlandse Spoorwegen. Hieruit blijkt dat de garanties van de Nederlandse Staatsmijnen na 1966 afnamen in tegenstelling tot die van de overheid en de NV Nederlandse Spoorwegen. Na 1969 vertoonden de garanties van de NV Nederlandse Spoorwegen een sterke stijging.

De NV Nederlandse Spoorwegen kende garanties toe aan 
woningbouwverenigingen, de Vereniging Pensioen Risico, de Interfrigo, de Compagnie des Wagons Iits, de Container Terminal Amsterdam en de Europe Container Terminus. De garantiereserves van de NV Nederlandse spoorwegen varieerden per jaar rond de 2 miljoen gulden in de periode 1960 tot en met 1970. In het geval dat een beroep werd gedaan op de verstrekte garanties waren de bovengenoemde reserves onvoldoende. Het is om deze reden dat de liquiditeitspositie van de NV Nederlandse Spoorwegen in de twee onderstaande kolommendiagramen wordt vergeleken met die van de staatsmijnen. De liquiditeitspositie betreft het verschil tussen de vorderingen en de schulden op korte termijn. Deze positie vormt een indicatie voor de mogelijkheid om de garanties te kunnen nakomen.

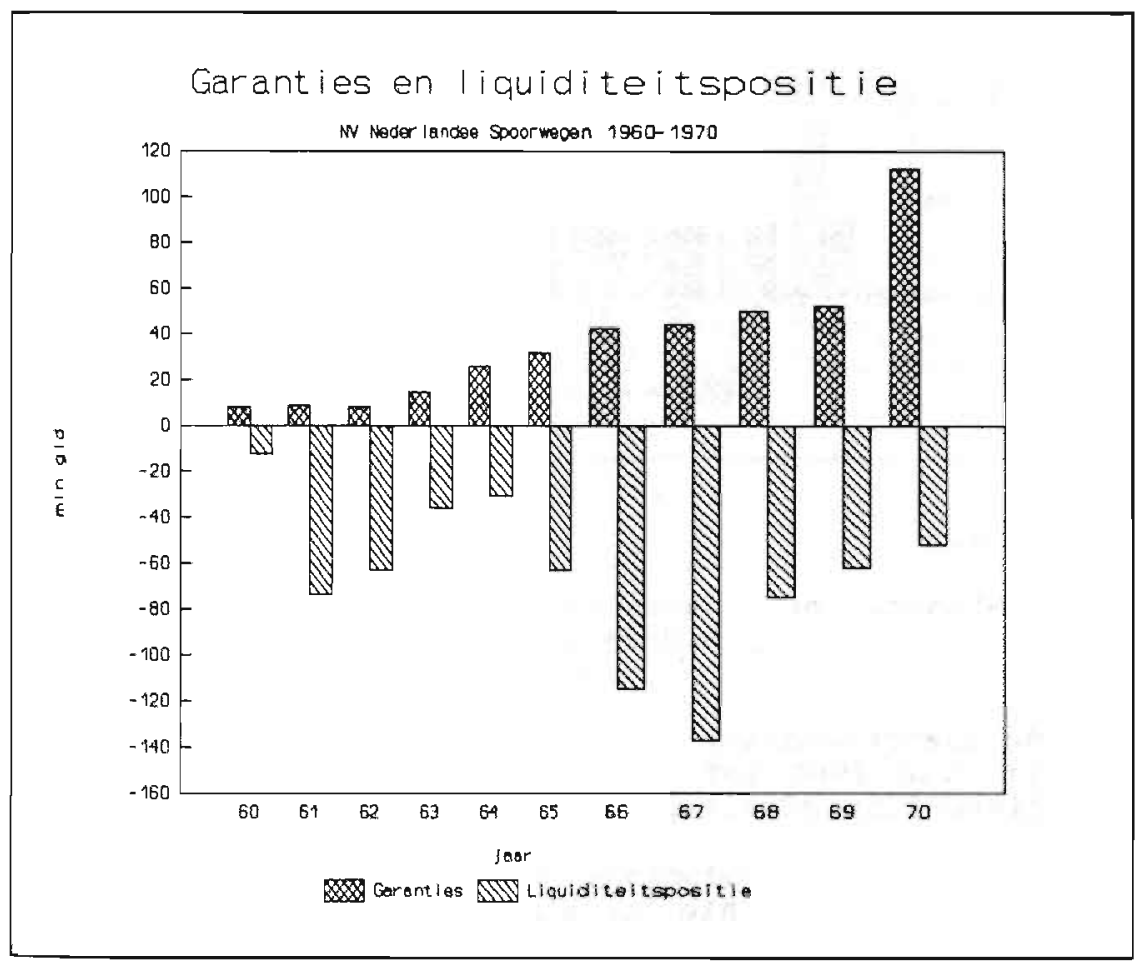

Figuur 4.4

Bron: NV Nederlandse Spoorwegen, Jaarverslagen 1960 tot en met 1970 . 


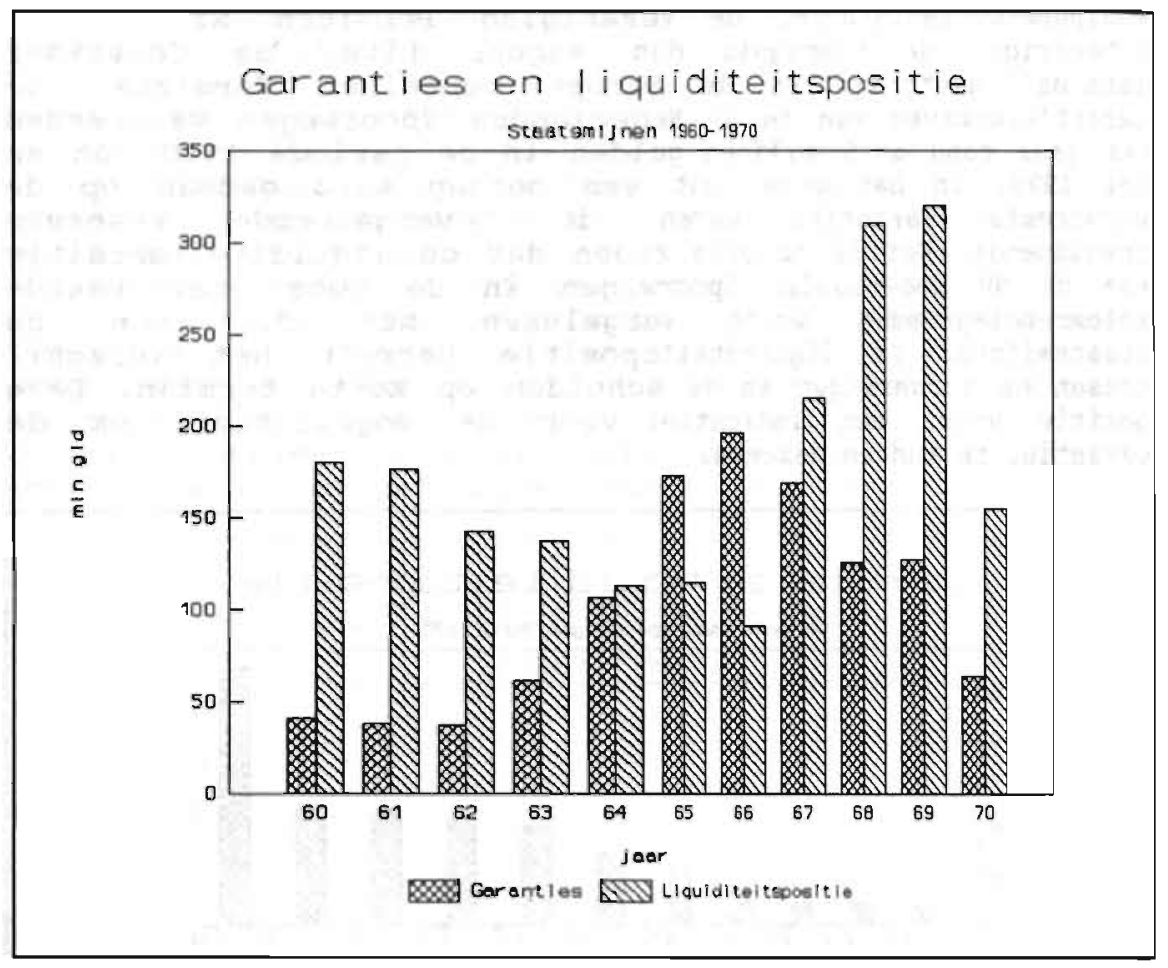

Figuur 4.5

Bron: Staatsmijnen, Jaarverslagen 1960 tot en met 1970. Staatsmijnen, Bedrijfseconomische Verslagen 1960 tot en met 1970 .

Uit de jaarrekeningen van de NV Nederlandse Spoorwegen over de periode van 1960 tot en met 1970 blijkt het bestaan van een negatieve liquiditeitspositie. Dit hield in dat het bedrijf op korte termijn niet bij machte was zijn garanties na te komen, als daartoe een noodzaak ontstond. Het staatsbedrijf der staatsmijnen bleek hiertoe niet in staat in 1965 en 1966 (voor de gegevens wordt verwezen naar bijlage 4.6). 
Bijlage 4.1 Investeringen en afschrijvingen in miljoenen guldens

\begin{tabular}{lrlrll}
\hline Jaar & \multicolumn{1}{c}{ Netto-investeringen (1) } & Afschrijvingen $(2)$ & $(1):(2)$ \\
\hline 1954 & 106 & $(65)$ & $59(88)$ & 1,80 \\
1955 & 164 & $(100)$ & $67(100)$ & 2,45 \\
1956 & 170 & $(104)$ & $73(109)$ & 2,33 \\
1957 & 145 & $(88)$ & $81(121)$ & 1,79 \\
1958 & 94 & $(57)$ & $79(118)$ & 1,19 \\
1959 & 51 & $(31)$ & $78(116)$ & 0,65 \\
1960 & 66 & $(40)$ & $78(116)$ & 0,85 \\
1961 & 122 & $(74)$ & $79(118)$ & 1,54 \\
1962 & 124 & $(76)$ & $92(137)$ & 1,35 \\
1963 & 93 & $(57)$ & $95(142)$ & 0,98 \\
1964 & 109 & $(66)$ & $101(151)$ & 1,08 \\
1965 & 140 & $(85)$ & $109(163)$ & 1,28 \\
1966 & 155 & $(95)$ & $124(185)$ & 1,25 \\
1967 & 97 & $(59)$ & $131(195)$ & 0,74 \\
1968 & 78 & $(48)$ & $133(199)$ & 0,59 \\
1969 & 82 & $(50)$ & $125(187)$ & 0,66 \\
1970 & 84 & $(51)$ & $142(212)$ & 0,60 \\
\hline
\end{tabular}

Bron: Accountantskantoor Moret \& De Jong, Jaarrekeningen NV Nederlandse Spoorwegen, 1954, 1957, 1959, 1963, 1965 en 1970, in: Archief Vaște Commissie verkeer en Waterstaat.

Bijlage 4.2 Prestatie-analyse

Eenheidskilometers (x 1000)

\begin{tabular}{lcccccccc}
\hline & BR & CFF & CFL & CP & DSB & FS & NS & NSB \\
\hline 1961 & 62657 & 11711 & 843 & 2723 & 4561 & 43675 & 11382 & 3336 \\
1962 & 58153 & 12270 & 830 & 2763 & 4671 & 40259 & 11580 & 3356 \\
1963 & 58543 & 12812 & 836 & 2920 & 4756 & 45269 & 12004 & 3475 \\
1964 & 58152 & 13387 & 860 & 3020 & 4732 & 42588 & 11739 & 3586 \\
1965 & 55344 & 13045 & 806 & 3163 & 4798 & 41859 & 11236 & 3759 \\
1966 & 53938 & 13244 & 749 & 3186 & 4795 & 43461 & 10875 & 3851 \\
1967 & 51364 & 13211 & 774 & 3337 & 4796 & 45002 & 10646 & 4001 \\
1968 & 52729 & 13526 & 841 & 3424 & 4619 & 46051 & 10629 & 4131 \\
1969 & 52699 & 14198 & 926 & 3502 & 4643 & 47216 & 10935 & 4164 \\
1970 & 54959 & 14747 & 967 & 3502 & 5074 & 50526 & 11543 & 4293 \\
\hline
\end{tabular}


Vervolg Eenheidskilometers (x1000).

\begin{tabular}{rcccrrl}
\hline & ÖBB & SJ & RENFE & SNCB & SNCF & VR \\
\hline 1961 & 14153 & 15143 & 12854 & 14563 & 92443 & 7322 \\
1962 & 14157 & 15286 & 14541 & 14589 & 96930 & 7267 \\
1963 & 14699 & 15794 & 16271 & 14933 & 99762 & 6881 \\
1964 & 14719 & 16296 & 19318 & 15050 & 106442 & 6901 \\
1965 & 14589 & 17830 & 20262 & 14826 & 102840 & 7233 \\
1966 & 14645 & 18554 & 20403 & 14078 & 102457 & 7741 \\
1967 & 13845 & 17216 & 21000 & 13808 & 101279 & 7749 \\
1968 & 13656 & 17475 & 20060 & 13624 & 98828 & 7828 \\
1969 & 15018 & 18579 & 21246 & 14990 & 105993 & 8180 \\
1970 & 16149 & 20747 & 22634 & 15443 & 110882 & 8426 \\
\hline
\end{tabular}

Personeel.

\begin{tabular}{lcccccccc}
\hline \multicolumn{1}{c}{ BR } & CFF & CFL & CP & DSB & FS & NS & NSB \\
\hline 1961 & 500434 & 40509 & 5134 & 30426 & 27847 & 166364 & 30351 & 24044 \\
1962 & 475222 & 41071 & 5088 & 31641 & 28270 & 168783 & 30219 & 23626 \\
1963 & 439551 & 41590 & 5040 & 31522 & 28014 & 190507 & 29227 & 23637 \\
1964 & 399005 & 43417 & 5003 & 29321 & 27961 & 219779 & 28694 & 23208 \\
1965 & 359263 & 42234 & 4911 & 27733 & 27466 & 209804 & 28456 & 22161 \\
1966 & 338951 & 42558 & 4870 & 27742 & 26850 & 206893 & 27893 & 21450 \\
1967 & 318092 & 42018 & 4760 & 27750 & 26302 & 197826 & 27146 & 21184 \\
1968 & 317478 & 41689 & 4625 & 25894 & 25478 & 189977 & 25953 & 20837 \\
1969 & 283172 & 41651 & 4518 & 26002 & 24724 & 197506 & 25497 & 20435 \\
1970 & 247259 & 41530 & 4419 & 25559 & 24014 & 215237 & 26766 & 19803 \\
\hline
\end{tabular}

Vervolg Personeel

\begin{tabular}{lccrccc}
\hline & ÖBB & SJ & RENFE & SNCB & SNCF & VR \\
\hline 1961 & 77718 & 62022 & 129429 & 66918 & 349755 & 35427 \\
1962 & 77307 & 60889 & 127407 & 65073 & 348489 & 35959 \\
1963 & 76875 & 59188 & 123545 & 63392 & 356413 & 36079 \\
1964 & 82289 & 56905 & 118708 & 62012 & 393161 & 35415 \\
1965 & 80720 & 54664 & 112740 & 60509 & 359263 & 34931 \\
1966 & 79131 & 52942 & 108498 & 58948 & 348919 & 34894 \\
1967 & 78423 & 51775 & 107922 & 57234 & 336718 & 33604 \\
1968 & 77662 & 50277 & 101973 & 56214 & 323125 & 32116 \\
1969 & 75522 & 48484 & 94327 & 55554 & 312649 & 30068 \\
1970 & 75351 & 45316 & 85096 & 56685 & 302989 & 27690 \\
\hline
\end{tabular}


Materieel (Wagons en rijtuigen in goede staat).

\begin{tabular}{rcrrrrrrr}
\hline & BR & CFF & CFL & CP & DSB & FS & NS & NSB \\
\hline 1961 & 920869 & 31877 & 3575 & 10219 & 13495 & 123168 & 22808 & 12401 \\
1962 & 902128 & 32622 & 3429 & 10102 & 13057 & 118871 & 23283 & 12214 \\
1963 & 763683 & 33373 & 3347 & 9887 & 12816 & 120914 & 23760 & 11610 \\
1964 & 656019 & 34729 & 3299 & 9750 & 12666 & 125963 & 23308 & 11617 \\
1965 & 600786 & 34757 & 3436 & 9604 & 12617 & 127951 & 23135 & 11747 \\
1966 & 548498 & 35390 & 3584 & 9463 & 12333 & 128693 & 23076 & 11634 \\
1967 & 483764 & 35972 & 3575 & 9733 & 12207 & 133368 & 22634 & 11671 \\
1968 & 482861 & 35975 & 3733 & 9511 & 12244 & 127787 & 21268 & 11390 \\
1969 & 407598 & 35758 & 3643 & 10126 & 12252 & 123379 & 19535 & 11018 \\
1970 & 379569 & 35835 & 4191 & 9369 & 12063 & 122585 & 19682 & 10747 \\
\hline
\end{tabular}

Vervolg Materieel

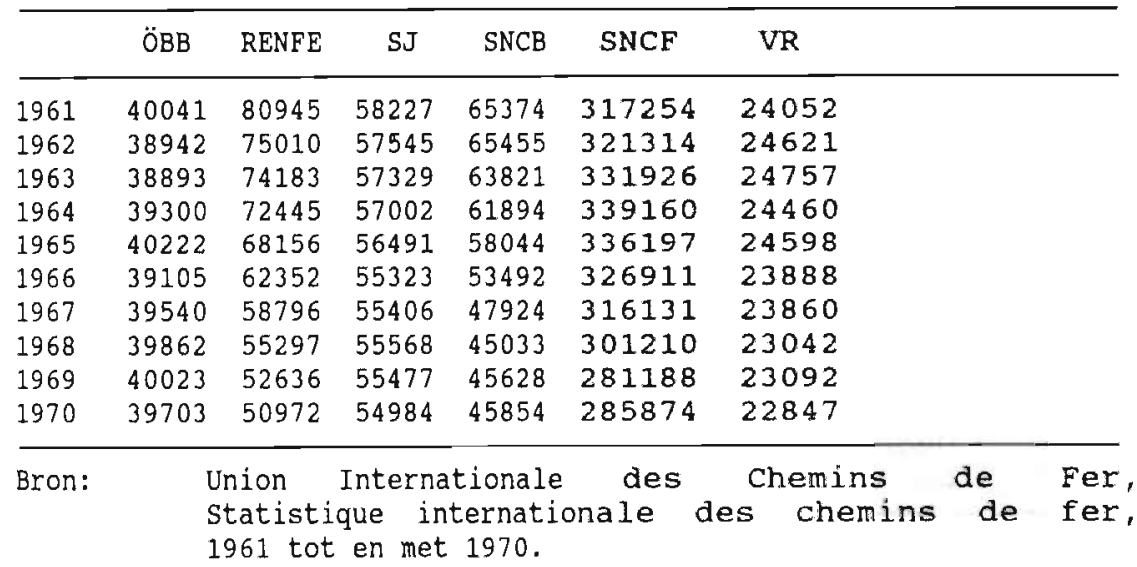


Bijlage 4.3 Exploitatiecoëfficiënten en toegekende pensioenen over de periode 1950 tot en met 1965.

\begin{tabular}{lcccc}
\hline Jaar & $\begin{array}{l}\text { Exploitatie- } \\
\text { coëfficiënt }\end{array}$ & $\begin{array}{l}\text { Vervroegd } \\
\text { pensioen }\end{array}$ & $\begin{array}{l}\text { Invaliditeits } \\
\text { pensioen }\end{array}$ & $\begin{array}{l}\text { Totaal } \\
\text { pensioen }\end{array}$ \\
\hline 1950 & 80,56 & 687 & 469 & 1156 \\
1951 & 85,03 & 567 & 543 & 1110 \\
1952 & 83,42 & 697 & 366 & 1063 \\
1953 & 82,81 & 1042 & 336 & 1378 \\
1954 & 84,98 & 928 & 418 & 1346 \\
1955 & 83,20 & 906 & 365 & 1271 \\
1956 & 83,10 & 745 & 778 & 1523 \\
1957 & 82,59 & 777 & 418 & 1195 \\
1958 & 83,49 & 749 & 380 & 1167 \\
1959 & 82,60 & 791 & 368 & 1159 \\
1960 & 83,12 & 731 & 305 & 1036 \\
1961 & 86,02 & 527 & 271 & 798 \\
1962 & 89,08 & 212 & 201 & 413 \\
1963 & 84,91 & 173 & 145 & 318 \\
1964 & 86,75 & 188 & 201 & 389 \\
1965 & 88,22 & 165 & 166 & 331 \\
\hline
\end{tabular}

Bron: NV Nederlandse Spoorwegen, Balans en Verlies- en Winstrekening, Utrecht, 1967 ; uit: Ministerie van Verkeer en Waterstaat, doss. nr. 6526 A 6, class. nr. 25.07.51.

Bijlage 4.4 Spoorwegpensioenfonds: ongedekt saldo, vorderingen en balanstotaal, 1950-1965.

\begin{tabular}{lccc}
\hline Jaar & $\begin{array}{l}\text { Ongedekt } \\
\text { saldo }\end{array}$ & vorderingen & $\begin{array}{l}\text { Balans } \\
\text { totaal }\end{array}$ \\
\hline & & & \\
1950 & 74.2 & 449.0 & 745.2 \\
1951 & 74.1 & 444.0 & 831.4 \\
1952 & 76.8 & 438.9 & 843.4 \\
1953 & 79.5 & 433.5 & 860.8 \\
1954 & 82.0 & 427.9 & 870.6 \\
1955 & 227.6 & 422.1 & 1012.9 \\
1956 & 220.0 & 416.1 & 1034.1 \\
1957 & 297.8 & 409.8 & 1113.5 \\
1958 & 307.8 & 403.3 & 1109.9 \\
1959 & 318.3 & 396.5 & 1122.9 \\
1960 & 329.7 & 389.4 & 1134.2 \\
1961 & 91.9 & 602.9 & 1121.1 \\
1962 & 95.0 & 594.1 & 1135.2 \\
1963 & 98.1 & 584.9 & 1148.9 \\
1964 & 101.5 & 575.4 & 1169.0 \\
1965 & 104.9 & 565.6 & 1191.1 \\
\hline
\end{tabular}

Bron: Spoorwegpensioenfonds, Utrecht, Jaarverslagen 1950 tot en met 1965. 
Bijlage 4.4 vervolg

\begin{tabular}{cccc}
\hline Jaar & Invaliditeitsratio (1) & $\begin{array}{l}\text { ongedekt } \\
\text { saldo (2) }\end{array}$ & $\begin{array}{l}\text { Ongedekt } \\
\text { saldo (3) }\end{array}$ \\
\hline 1950 & 0.26 & -0.16 & -0.10 \\
1951 & 0.26 & -0.17 & -0.09 \\
1952 & 0.25 & -0.18 & -0.09 \\
1953 & 0.25 & -0.19 & -0.09 \\
1954 & 0.25 & -0.19 & -0.09 \\
1955 & 0.24 & -0.52 & -0.10 \\
1956 & 0.25 & -0.55 & -0.22 \\
1957 & 0.25 & -0.73 & -0.22 \\
1958 & 0.24 & -0.76 & -0.27 \\
1959 & 0.24 & -0.80 & -0.28 \\
1960 & 0.24 & -0.85 & -0.29 \\
1961 & 0.23 & -0.15 & -0.08 \\
1962 & 0.23 & -0.16 & -0.08 \\
1963 & 0.22 & -0.17 & -0.08 \\
1964 & 0.22 & -0.18 & -0.08 \\
1965 & 0.22 & -0.19 & -0.08 \\
\hline
\end{tabular}

opmerkingen: (1) Invaliditeitsratio is de verhouding tussen het totale aantal invaliditeitspensioenen en het totale aantal lopende pensioenen.

(2) De ratio ongedekt tekort is de verhouding tussen het saldo ongedekt tekort en de contante waarde van de vordering op de staat der Nederlanden (Wet 27 mei 1948 en wet 23 februari 1961).

(3) De ratio ongedekt saldo is hier de verhouding tussen het saldo ongedekt tekort en het balanstotaal.

4. Bij de bepaling van de ratio ongedekt tekort is steeds uitgegaan van de laatste balansen van het Spoorwegpensioenfonds. 
Bijlage 4.5 Publiciteits- en advertentiekosten x1000 gld.

\begin{tabular}{lrrrrrr}
\hline & \multicolumn{3}{c}{ Publiciteitskosten: } & \multicolumn{3}{c}{ Advertentiekosten } \\
Jaar & $(1)$ & $(2)$ & $(3)$ & $(4)$ & $(5)$ & $(6)$ \\
\hline 1956 & 433 & 527 & -94 & 408 & 375 & 33 \\
1957 & 534 & 673 & -139 & 406 & 324 & 82 \\
1958 & 436 & 510 & -74 & 327 & 192 & 135 \\
1959 & 460 & 445 & 15 & 248 & 249 & $-r$ \\
1960 & 630 & 703 & -73 & 247 & 344 & -99 \\
1961 & 1.050 & 926 & 124 & 307 & 648 & -341 \\
1962 & 1.599 & 1.303 & 296 & 916 & 635 & -281 \\
1963 & 1.260 & 1.481 & -221 & 672 & 416 & -256 \\
1964 & 1.900 & 1.629 & 271 & 641 & 635 & 6 \\
1965 & 1.961 & 1.521 & 440 & 747 & 690 & 57 \\
1966 & 1.909 & 1.435 & 474 & 709 & 441 & 268 \\
1967 & 1.875 & 1.395 & 480 & 668 & 162 & 506 \\
1968 & 1.735 & 1.617 & 118 & 414 & 125 & 289 \\
\hline
\end{tabular}

Bijlage 4.5 opbrengsten reizigers- en goederenvervoer in miljoenen guldens (vervolg).

\begin{tabular}{lccc}
\hline \multicolumn{3}{c}{ opbrengsten vervoer } \\
Jaar & Reizigers & Goederen & Totaal \\
\hline 1956 & 231,4 & 197,4 & 428,8 \\
1957 & 242,7 & 203,9 & 446,6 \\
1958 & 243,3 & 193,0 & 436,3 \\
1959 & 242,4 & 198,1 & 440,5 \\
1960 & 250,7 & 205,7 & 456,4 \\
1961 & 258,1 & 204,4 & 462,5 \\
1962 & 259,3 & 221,2 & 480,5 \\
1963 & 275,7 & 259,8 & 538,5 \\
1964 & 300,7 & 274,5 & 575,2 \\
1965 & 323,2 & 284,2 & 607,4 \\
1966 & 339,4 & 268,2 & 607,6 \\
1967 & 338,3 & 261,5 & 599,8 \\
1968 & 344,3 & 275,2 & 619,5 \\
\hline
\end{tabular}

Opmerkingen: (1) Begrote publiciteitskosten.

(2) Definitieve publiciteitskosten.

(3) Verschil.

(4) Begrote advertentiekosten.

(5) Definitieve advertentiekosten.

(6) Verschil.

Bron: NV Nederlandse Spoorwegen, Exploitatiebegrotingen, 1958 tot en met 1968. 
Bijlage 4.6 Garanties miljoenen guldens.

\begin{tabular}{|c|c|c|c|c|c|c|}
\hline \multirow[b]{2}{*}{ Jaar } & \multicolumn{2}{|c|}{ Rijksoverheid } & \multicolumn{2}{|c|}{$\begin{array}{l}\text { NV Nederlandse } \\
\text { Spoorwegen }\end{array}$} & \multicolumn{2}{|l|}{ DSM } \\
\hline & Garanties & Index (1) & Garanties & Index & Garanties & Index \\
\hline 1960 & 4066 & 100 & 8.0 & 100 & 40.9 & 100 \\
\hline 1961 & 5096 & 125 & 8.7 & 109 & 38.5 & 94 \\
\hline 1962 & 5216 & 128 & 8.5 & 106 & 37.5 & 92 \\
\hline 1963 & 5920 & 145 & 14.6 & 182 & 62.0 & 151 \\
\hline 1964 & 6423 & 158 & 25.9 & 324 & 106.7 & 261 \\
\hline 1965 & 6877 & 169 & 31.6 & 395 & 173.0 & 423 \\
\hline 1966 & 7430 & 183 & 42.3 & 529 & 196.1 & 479 \\
\hline 1967 & 8311 & 204 & 44.2 & 552 & 169.0 & 413 \\
\hline 1968 & 9813 & 241 & 50.0 & 625 & 125.7 & 307 \\
\hline 1969 & 10258 & 252 & 52.1 & 651 & 127.3 & 311 \\
\hline 1970 & 11005 & 271 & 112.3 & 1404 & 63.7 & 156 \\
\hline
\end{tabular}

Bijlage 4.6 Liquiditeitsposities in miljoenen guldens (vervolg).

\begin{tabular}{llr}
\hline Jaar & $\begin{array}{l}\text { NV Nederlandse } \\
\text { Spoorwegen }\end{array}$ & DSM \\
\hline 1960 & $-12,3$ & 180,6 \\
1961 & $-73,2$ & 176,7 \\
1962 & $-63,2$ & 142,6 \\
1963 & $-35,9$ & 137,6 \\
1964 & $-30,5$ & 113,4 \\
1965 & $-62,9$ & 114,7 \\
1966 & $-115,0$ & 91,6 \\
1967 & $-137,4$ & 215,8 \\
1968 & $-74,6$ & 310,7 \\
1969 & $-61,7$ & 320,0 \\
1970 & $-51,5$ & 155,0 \\
\hline
\end{tabular}

Opmerkingen: (1) $1960=100$.

Bron : 1. NV Nederlandse Spoorwegen, Jaarverslagen 1960 tot en met 1970 .

2. NV Nederlandse Staatsmijnen, Bedrijfseconomische Verslagen, 1960 tot en met 1970 .

3. Staatsbalans, Miljoenennota's, 1960 tot en met 1970. 


\section{Hoofdstuk 5}

\section{De Nederlandse Centrale Organisatie TNO}

\subsection{Inleiding}

De kwalitatieve prestatie-analyse biedt het raamwerk voor de case-studie over de Nederlandse Centrale organisatie voor toegepast-natuurwetenschappelijk onderzoek (afgekort: TNO). De analyse richt zich achtereenvolgens op de structuur, de doeleinden, de beleidsvrijheid, de benoemingen en de voortzetting van niet ter discussie staande beleidsactiviteiten van deze organisatie.

Rond de eeuwwisseling leidden technologische vernieuwingen en internationale economische verhoudingen tot de institutionalisering van het natuurwetenschappelijk onderzoek in Europa en de Verenigde staten van Amerika. De organisaties voor natuurwetenschappelijk onderzoek makten deel uit van particuliere ondernemingen en de overheid. Samenwerkingsverbanden tussen het bedrijfsleven en de overheid kwamen eveneens tot ontwikkeling. In 1923 belastte het kabinet-Ruys de Beerenbrouck II de comissie-Went met de opdracht te onderzoeken op welke wijze het toegepast natuurwetenschappelijk onderzoek in Nederland gestalte kon worden gegeven. De commissie stelde $z$ ich ten doel een vorm van overheidsoptreden uit te werken, waarbij de voordelen van het particuliere onderzoek werden overgenomen en de eraan verbonden nadelen vermeden. ${ }^{527}$ Haar rapport legde de basis voor de latere Nederlandse Centrale organisatie voor toegepast-natuurwetenschappelijk onderzoek. De voorgestelde organisatie zou van de overheid financiële steun ontvangen in de vorm van een subsidie, die werd beheerd door een Uitvoerend comite, waarvan de leden door een speciaal bijeen te roepen College zouden worden voorgedragen. De vertegenwoordigers van de overheid zouden als buitengewone leden in het Uitvoerend comité participeren. Een comptabele en administratieve dienst ondersteunde het vitvoerend Comité, terwijl een Adviserende commissie dit comité van advies zou dienen. Subcommissies uit de Adviserende Commissie behartigden speciale belangen. De onderzoekers en het overige personeel van de laboratoria kwamen niet meer in dienst van de overheid, maar in dienst van de nieuw op te richten organisatie. De verworven rechten van de betrokken ambtenaren werden gewaarborgd. ${ }^{528}$

De verspreiding van de overheidsuitgaven aan natuurwetenschappelijk onderzoek over diverse hoofdstukken van de rijksbegroting bemoeilijkte het wetenschapsbeleid. Met de instelling van de Raad van Advies voor het Wetenschapsbeleid in 1966 en de introductie van het zogenaamde "wetenschapsbudget" bij de begroting van het Ministerie van onderwijs, Kunsten en Wetenschappen begon het Nederlandse wetenschapsbeleid pas vorm aan te nemen. Het wetenschapsbudget integreerde de voor wetenschappelijk onderzoek bestemde uitgaven in de rijksbegroting. De uitgaven van de overheid voor onderzoek en ontwikkeling waren hoofdzakelijk bestemd voor de financiering of de subsidiëring van onderzoek, 
verricht in organisaties die beschikten over een mate van autonoom beleid. ${ }^{529}$

De Nederlandse Centrale Organisatie voor toegepastnatuurwetenschappelijk onderzoek bestond uit een centrale organisatie (1932), een Nijverheidsorganisatie (1934), een Landbouworganisatie (1943), een Rijksverdedigingsorganisatie (1946), een Gezondheidsorganisatie (1949), en een voedingsorganisatie (1964). Elke organisatie omvatte een aantal instituten met een eigen bestuur. De voorzitter van de Raad van Toezicht van TNO Prof. ir. Th. Quené wees in 1986 op het bestaan van het internationale verschijnsel van de oprichting van steeds nieuwe wetenschappelijke instituten en het voortbestaan van de oude instituten. De gevolgen waren veroudering en verstarring van wetenschappelijke instituten. In Duitsland werden deze gevolgen aangeduid met de term "die Forschungsruine". ${ }^{530}$

De cijfers in tabel 5.1 tonen aan dat het aanceel van de overheid en het bedrijfsleven in de totale uitgaven aan wetenschap elkaar over periode 1964 tot en met 1969 naderden. ${ }^{31}$

Tabel 5.1 Rijksuitgaven en uitgaven van het bedrijfsleven (uit eigen middelen) voor wetenschapsbeoefening.

(in miljoenen guldens)

\begin{tabular}{lrrrrrrr}
\hline & 1959 & 1964 & 1965 & 1966 & 1967 & 1968 & 1969 \\
\hline Ondernemingen & 376 & 661 & 765 & 851 & 935 & 1022 & 1116 \\
Rijksoverheid & 164 & 479 & 577 & 726 & 798 & 923 & 1019 \\
\hline
\end{tabular}

Bron: Wetenschapsbudget 1969, overzicht van alle op de rijksbegroting uitgetrokken gelden bestemd voor wetenschappelijk onderzoek.

Het organiseren van het toegepast natuurwetenschappelijk onderzoek als economisch beleidsinstrument speelde zich af rond het vraagstuk van de financiering. Particuliere organisaties voor natuurwetenschappelijk onderzoek beschouwden de financiële steun van de overheid als een verstoring van de voorwaarden tot gelijke mededinging. De orde van Nederlandse Raadgevende Ingenieurs en de Vereniging van Raadgevende Scheikundigen hadden daartegen bezwaren. 4 ? De Nederlandse Centrale Organisatie voor toegepast-natuurwetenschappelijk onderzoek werd beschuldigd van machtsmisbruik in de betekenis van artikel 86 van het Verdrag van Rome uit 1957.93

\section{2 structuuranalyse}

De verdeling van de publieke eigendomsrechten in de Nederlandse Centrale organisatie Two wordt nader onderzocht met de structuuranalyse. Hierbij ligt de nadruk op het recht om toezicht uit te oefenen op de aankopen, de prestaties van de produktiefactoren, de samenstelling van het team van producenten en het recht om aanspraak te mogen maken op het 
residu.

De Nederlandse Centrale organisatie had de status van een zelfstandig bestuursorgaan. Deze zelfstandige positie van de Nederlandse Centrale organisatie TNO had zijn weerslag op de relatie tussen principa(a)l(en) en agent(en). De StatenGeneraal konden het kabinet slechts verantwoordelijk stellen voor de aan TNO gestelde randvoorwaarden, maar niet voor het feitelijk functioneren van deze organisatie. ${ }^{534}$

Het bestuur van de Centrale organisatie bestond uit de voorzitters van de Bijzondere organisaties en de op voordracht van de betrokken ministers door de kroon benoemde gewone en tijdelijke leden. De groep gewone leden bestond enerzijds voor de helft uit deskundigen op natuurwetenschappelijk gebied en anderzijds uit economische deskundigen. Tot tijdelijke leden konden worden benoemd deskundigen op natuurwetenschappelijk of economisch gebied. Daarnaast benoemde de kroon op voordracht van de betrokken ministers ambtenaren tot gedelegeerde. De ministeriële gedelegeerden hadden toegang tot de vergaderingen van het bestuur. $\mathrm{Zij}$ beschikten over het recht van veto bij de bestemming van de verstrekte overheidssubsidie. De gedelegeerde van de Minister van Financiën was de thesauriergeneraal. De verantwoordelijke minister, waronder de gedelegeerde ressorteerde, besliste uiteindelijk over de uitvoering van een besluit, nadat de Centrale organisatie was gehoord. ${ }^{535}$ De overheidssubsidie bestond uit een exploitatieen een kapitaalsubsidie. De exploitatiesubsidie bestond uit het verschil tussen de begrote inkomsten en uitgaven. De groei van de subsidie makte deel uit van een onderhandelingsproces tussen de Nederlandse Centrale organisatie TNo en het Ministerie van Financiën over het toe te passen stelsel van subsidiëring.

\subsubsection{Toezicht op de aankopen en de prestaties van de produktiefactoren.}

Formeel hield het bestuur van de centrale organisatie met de jaarlijkse begroting van de inkomsten en uitgaven toezicht op de aankopen. De besturen van de Bijzondere organisaties overlegden daartoe een begroting en een werkplan aan het bestuur van de centrale organisatie. ${ }^{536}$ De gedelegeerden beschikten slechts over het recht om zich te verzetten tegen de bestemming van de overheidssubsidie. Het bestuur van de centrale organisatie behield hierdoor, afhankelijk van de opbrengsten, de mogelijkheid de aankopen te beheersen. De Wet tot regeling van het toegepast-natuurwetenschappelijk onderzoek van 30 oktober 1930 verstrekte de Algemene Rekenkamer niet de bevoegaheid om toezicht uit te oefenen op de administratieve organisatie en de besteding van de toegekende overheidssubsidies.

Toen in 1941 drie wetenschappelijke overheidsinstellingen aan de Nederlandse Centrale Organisatie TNO werden overgedragen, had dit tot gevolg dat een onderdeel van de rijksoverheid aan het toezicht van de Algemene Rekenkamer werd onttrokken. De secretaris-generaal van het Departement van opvoeding, Wetenschap en Cultuurbescherming had geen behoefte aan controle op de Nederlandse centrale organisatie TNo door 
de Algemene Rekenkamer. Het departement controleerde de organisatie voldoende. De Algemene Rekenkamer stelde dat deze controle zich geheel afspeelde in de administratie en dat haar toezicht door een regeling van interne controle niet kon worden uitgeschakeld. ${ }^{537}$ Aan dit geschil kwam in 1955 een einde. ${ }^{538}$

Minister van Financiën Lieftinck stelde zich in 1950 op het standpunt dat een subsidie aan de Nederlandse Centrale organisatie TNO niet zou worden toegekend op grond van een advies afkomstig van een externe deskundige. De besteding van een vooraf vastgesteld bedrag zou aan de organisatie worden overgelaten. ${ }^{539}$ Het Ministerie van Financiën achtte het wenselijk inzicht te verwerven in de besteding van de aan deze organisatie toegekende subsidie, met andere woorden inzicht in het door het dagelijks bestuur van TNO gevoerde beleid. ${ }^{540}$ De controle op de besteding van de door het Rijk aan TNO toe te kennen subsidie lag bij de directie Financieringen en coördinatie oorlogsschade van het Ministerie van Financiën. ${ }^{541}$

De afdeling Inspectie Rijksfinanciën verzette $\mathrm{zich}$ in 1956 tegen het subsidievoorstel van de plaatsvervangendgedelegeerde van het Ministerie van Financièn. Het voorstel hield een verhoging in van de subsidie voor 1956 met 700 duizend gulden ten behoeve van reservevorming en een toename van het accres tot 14 procent per jaar (cumulatief). De Inspectie duidde de bestaande subsidieregeling met een accres van 10 procent aan als vrijgevig. De regeling kenmerkte zich door het ontbreken van preventief toezicht op de besteding van de financiële middelen en een gematigd repressief toezicht (verplichting tot verslaglegging). Het bestuur van TNO wist bij dit stelsel van subsidiëring van tevoren waar het aan toe was en beschikte hierdoor onder andere over vrijheid in materieelbeheer. De bewegingsvrijheid hield de verplichting in om met de toegekende subsidie uit te komen. ${ }^{542} \mathrm{De}$ plaatsvervangend-gedelegeerde van de Minister van Financiën wilde de positie van de financieel verantwoordelijke personen bij deze organisatie versterken met het introduceren van bestemmingsreserves. Deze reserves waren eenvoudiger te verdedigen tegen de materiële eisen van de directeuren. ${ }^{543}$ Het verzet van de afdeling Inspectie Rijksfinanciën concentreerde zich met name op de conjunctuurreserves. Overheidsorganisaties zouden met deze reserves conjunctuurpolitiek kunnen bedrijven, hetgeen echter aan de rijksoverheid diende te zijn voorbehouden. ${ }^{544}$

Tijdens de beleidsvoorbereiding voor de periode 1958 tot en met 1960 stelde de plaatsvervangend gedelegeerde van de Minister van Financiën voor dat de subsidie zou moeten worden bepaald door de waarde, die de overheid hechtte aan de door de Nederlandse centrale organisatie TNO geleverde prestatie in relatie tot de andere staatstaken. Het Ministerie van Financiën beschikte niet over deskundigen, die het wetenschappelijke programma konden beoordelen. Beoordeling van het wetenschappelijke programma bood de mogelijkheid de noodzakelijke aankoop van produktiefactoren te beoordelen.

Inschakeling van externe deskundigen leidde tot problemen en vormde een ingreep in de zelfstandigheid van de organisatie TNO. 545 
Voor onderzoek en ontwikkeling vormden de duurzame activa een belangrijk kapitaalgoed. Tot de duurzame activa behoorden gebouwen, apparaturen, instrumenten en inventarissen. Deze activa kwamen ten laste van de kapitaalbegroting, hetgeen echter niet vanzelfsprekend was. De minister stond voor de keuze tussen het systeem "het Rijk bouwde voor TNO" en het systeem "TNO bouwde zelf". Het voordeel van bouwen door het Rijk was dat controle mogelijk was op de investeringsactiviteiten van TNO. ${ }^{546}$ Tot aanbesteding kon worden overgegaan nadat de minister het programma van eisen voor de nieuwbouw had goedgekeurd en de nodige fondsen op de kapitaalbegroting beschikbaar kwamen. Het bestuur van de Nederlandse Centrale Organisatie TNO gaf er de voorkeur aan zelf te bouwen. In 1966 aanvaardde het dagelijks bestuur een richtlijn over de nieuwbouw, aanbouw en verbouw van TNOgebouwen ten laste van de kapitaaldienst. ${ }^{547}$

\subsubsection{Toezicht op de wetenschappelijke resultaten.}

Gedurende de jaren dertig beschuldigde het dagelijks bestuur van TNO de rijksoverheid ervan onvoldoende onderzoeksfondsen ter beschikking te stellen. In 1938 verweerde de Minister van Economische Zaken M.P.L. Steenberghe (RKSP) zich hiertegen. $\mathrm{Hij}$ attendeerde er in zijn nota op dat de gedelegeerden van de verantwoordelijke ministers de financiële wensen van deze organisatie met weinig overtuiging en ambitie ondersteunden. Als reden daarvoor noemde hij de beperkte resultaten van de organisatie. ${ }^{548}$

Het eindprodukt van toegepast-natuurwetenschappelijk onderzoek was een octrooi op een uitvinding. Het wetenschappelijke personeel verplichtte $z i c h$ het eigendom van de uitvinding over te dragen aan de organisatie. ${ }^{549}$ onderzoek van TNO leidde volgens de directie Financieringen en coördinatie oorlogsschade van het Ministerie van Financiën tot octrooieerbare uitvindingen, maar niet tot produkt- en procesinnovatie. Het bezit aan octrooien werd slechts van belang als het bedrijfsleven overging tot het toepassen van de geoctrooieerde vinding. Een voorbeeld van het uitblijven van belangstelling voor een door TNO ontwikkeld procédé was de produktie van kunstmatige babyvoeding. ${ }^{550}$ Tabel 5.2 geeft een overzicht van de aangevraagde, verleende en ingetrokken octrooien over de periode 1950 tot en met 1964 . 
Tabel 5.2 Octrooien Nederlandse Centrale Organisatie TNO, 1950-1964.

\begin{tabular}{rrrrrrrrrrr}
\hline & \multicolumn{3}{c}{ Aanvragen } & \multicolumn{3}{c}{ Verleend } & \multicolumn{3}{c}{ Ingetrokken } & \multicolumn{2}{c}{ In behandeling } \\
Jaar & $(1)$ & $(2)$ & $(3)$ & $(4)$ & $(5)$ & $(6)$ & $(7)$ & $(8)$ & $(9)$ & $(10)$ \\
\hline 1950 & - & - & 178 & - & - & - & - & - & 350 & - \\
1951 & - & - & 163 & - & - & 67 & - & - & 374 & - \\
1952 & 33 & 121 & 154 & 9 & 58 & 67 & 10 & 34 & 375 & 113 \\
1953 & 30 & 145 & 175 & 13 & 73 & 86 & 13 & 37 & 418 & 157 \\
1954 & 17 & 217 & 234 & 13 & 118 & 131 & 8 & 26 & 457 & 228 \\
1955 & 37 & 147 & 184 & 16 & 77 & 93 & 11 & 56 & 508 & 233 \\
1956 & 29 & 116 & 145 & 8 & 104 & 112 & 17 & 86 & 474 & 180 \\
1957 & 49 & 90 & 139 & 12 & 94 & 106 & 13 & 64 & 435 & 189 \\
1958 & - & - & - & - & - & - & - & - & - & - \\
1959 & - & - & - & - & - & - & - & - & - & - \\
1960 & 37 & 144 & 181 & 23 & 89 & 112 & 11 & 59 & 448 & 209 \\
1961 & 31 & 140 & 171 & 24 & 73 & 97 & 12 & 29 & 482 & - \\
1962 & 40 & 87 & 127 & 21 & 71 & 92 & 8 & 32 & 542 & - \\
1963 & 30 & 122 & 152 & 13 & 89 & 102 & 12 & 23 & 557 & - \\
1964 & 22 & 89 & 111 & 15 & 100 & 115 & 8 & 35 & 507 & - \\
\hline
\end{tabular}

Opmerkingen: (1) Aanvragen in Nederland.

(2) Aanvragen in buitenland.

(3) Totaal aanvragen.

(4) Verleend in Nederland.

(5) Verleend in buitenland.

(6) Totaal verleend.

(7) Ingetrokken in Nederland.

(8) Ingetrokken in buitenland.

(9) Aanvragen in behandeling.

(10) Aanvragen in behandeling van derden.

Bron: Organisatie TNO, Octrooiafdeling TNO, Verslagen over de jaren 1950 tot en met 1964.

Uit tabel 5.2 blijkt dat over de periode 1950 tot en met 1964 meer octrooien werden aangevraagd dan ingetrokken. Aan de aanvraag en intrekking van octrooien lag de afweging ten grondslag tussen het economische belang van de uitvinding en de kosten, verbonden aan het in bescherming nemen of het continueren van het octrooi. ${ }^{551}$ In 1957 was voor ongeveer zestig procent van het octrooibezit een exploitatieovereenkomst afgesloten, respectievelijk het recht op octrooi aan derden overgedragen. 552

In 1967 vormden de groei van de subsidie en het schaarser worden van de ter beschikking staande financiële middelen aanleiding voor de gedelegeerde van de Minister van Financiën om bij de voorzitter van de Centrale organisatie TNo aan te dringen op een evaluatie van de resultaten van de TNOinstituten. Prestatiemeting door vergelijking van de kosten en de opbrengsten was volgens de gedelegeerde voor de TNOinstituten in bijna alle gevallen niet mogelijk. Hij stelde voor andere matstaven toe te passen, zoals bijvoorbeeld de verhouding tussen het bedrag aan verkregen opdrachten en de totale uitgaven, of de verhouding tussen uitgaven (dan wel het 
aantal personeelsleden) en het aantal en de kwaliteit van de door een instituut gedane vindingen, alsmede de mate van toepassing van TNO-vindingen in het bedrijfsleven. ${ }^{553}$ De resultaten van de toepassing van de eerste matstaf voor de periode 1960 tot en met $1970 \mathrm{zijn}$ weergegeven in tabel 5.3.

Tabel 5.3 Prestaties van TNO over de periode 1960 tot en met 1970 .

\begin{tabular}{|c|c|c|c|}
\hline $\begin{array}{l}\text { Opdrachten: } \\
\text { Jaar }\end{array}$ & derden & overheid & intern \\
\hline 1960 & 0,1964 & 0,0502 & 0,0645 \\
\hline 1961 & 0,1968 & 0,0429 & 0,0664 \\
\hline 1962 & 0,2116 & 0,0356 & 0,0540 \\
\hline 1963 & 0,2004 & 0,0313 & 0,0499 \\
\hline 1964 & 0,1691 & 0,0339 & 0,0391 \\
\hline 1965 & 0,1670 & 0,0270 & 0,0400 \\
\hline 1966 & 0,1713 & 0,0353 & 0,0397 \\
\hline 1967 & 0,1714 & 0,0401 & 0,0415 \\
\hline 1968 & 0,1565 & 0,0764 & 0,0434 \\
\hline 1969 & 0,1514 & 0,0682 & 0,0425 \\
\hline 1970 & 0,1479 & 0,0808 & 0,0414 \\
\hline
\end{tabular}

Opmerking: De prestaties zijn het quotiënt van de opdrachten enerzijds en de som van de kosten van de werkzaamheden en de verstrekte subsidies anderzijds.

Bron: TNO, Verslagen, algemeen gedeelte, 1961 tot en met 1971.

Uit tabel 5.3 blijkt dat de overheidsopdrachten, uitgedrukt in de totale kosten van de Nederlandse Centrale organisatie TNO, daalden over de periode 1960 tot en met 1965, en vervolgens toenamen. De opdrachten van derden stegen van 1960 tot en met 1962 en daalden daarna. De interne opdrachten als percentage van de totale kosten verminderden van zes naar vier procent.

Het bestuur van de Nederlandse Centrale organisatie voor toegepast-natuurwetenschappelijk onderzoek constateerde in het subsidievoorstel voor 1970 dat er national en internationaal behoefte bestond aan "prestatiemeting", of ruimer geformuleerd aan "project-evaluatie", "programma-analyse" en "appraisal". Prestatiemeting was echter niet mogelijk zonder uitbreiding van de staf. Het subsidievoorstel hield met deze ontwikkeling rekening door een bescheiden uitbreiding van de staf van de $\mathrm{N}$ ijverheidsorganisatie. ${ }^{5 s \mathrm{~s}}$

\subsubsection{Toezicht op de externe effecten.}

De Nederlandse Centrale Organisatie TNO verrichtte vrij onderzoek en onderzoek in opdracht van de industrie. onderzoeksopdrachten konden leiden tot additionele resultaten buiten het onderzoeksproject, die niet uitsluitend aan de opdrachtgever hoefden te worden overgedragen. Wilde de Nederlandse Centrale organisatie TNO deze resultaten beschermen met een octrooi, dan zou $z i j$ in de kosten moeten 
hebben bijgedragen. ${ }^{555}$ Toepassing van kennis verkregen uit ander onderzoek bracht $\mathrm{zij}$ in rekening aan de opdrachtgever.

\subsubsection{Toezicht op de omvang en de samenstelling van het personeel.}

Voor het overleg over het accres van de overheidssubsidie was het voor de betrokken ambtenaren belangrijk kennis te nemen van de personeelsomvang en -kosten.

De schaarste aan onderzoekers bemoeilijkte de werkzaamheden van de Bijzondere organisaties van TNO. Een uitbreiding van de financiële steun kon op korte termijn niet tot betere resultaten leiden, als de groei van het aantal bekwame researchwerkers en de daarbij behorende uitbreiding van de beschikbare werkruimten uitbleven. Beide laatst genoemde factoren werkten vertragend op de verdere ontwikkeling van de Bijzondere organisaties, ook al zou deze door het ter beschikking staan van ruim toevloeiende middelen mogelijk worden gemaakt. De geboden beginsalarissen voor fysici en chemici in de industrie noopten tot het steeds verder verhogen van de beloningen van bekwame onderzoekers om deze te behouden, dan wel om deze aan te trekken. ${ }^{556}$ Een onderverdeling van het personeel in academici, middelbare technici en hulpkrachten kon aan het begin van de jaren 150 niet worden verstrekt. Wilde een dergelijke onderverdeling enig nut hebben, dan moest deze verder worden gespecificeerd vanwege de verscheidenheid aan personeelscategorieën. Voor de drie categorieën zou een verhouding van $2: 3: 3$ in vele gevallen opgaan. 5.57

In 1965 constateerde de directie Financieringen en coördinatie oorlogschade van het Ministerie van Financiën in haar nota, gericht aan Minister $A$. Vondeling, dat personeelscijfers nooit konden worden gevonden in de officiële subsidievoorstellen. Deze directie beschouwde de door TNO verstrekte personeelscijfers over 1964 tot en met 1966 als "een duistere geschiedenis". Volgens de begroting voor 1965 zou het personeel met 133 personen $z$ ijn uitgebreid, achteraf bleek dat het personeelsbestand met 300 personen werd uitgebreid. 358 
Tabel 5.4 Personeel

\begin{tabular}{lccccc}
\hline & \multicolumn{2}{c}{$\begin{array}{c}\text { Centrale } \\
\text { Organisatie } \\
\text { Jaar }\end{array}$} & Academici & \multicolumn{4}{c}{ Total } & \\
& & & & \\
1962 & 89 & 396 & 498 & 2291 & 3274 \\
1963 & 95 & 444 & 539 & 2438 & 3516 \\
1964 & 98 & 462 & 565 & 2580 & 3705 \\
1965 & 119 & 511 & 580 & 2602 & 3812 \\
1966 & 117 & 540 & 622 & 2855 & 4134 \\
1967 & 125 & 541 & 608 & 2914 & 4188 \\
1968 & 129 & 556 & 617 & 2986 & 4288 \\
1969 & 135 & 576 & 662 & 3125 & 4498 \\
1970 & 148 & 628 & 697 & 3227 & 4700 \\
\hline
\end{tabular}

Opmerkingen: Academici en overigen werkzaam bij andere TNOorganisaties dan de Centrale organisatie.

Bron: Verslagen over de periode 1962 tot en met 1970

De loonontwikkelingen bij het bedrijfsleven en de rijksoverheid contrasteerden met die van de organisatie TNO. De hogere salariëring in het bedrijfsleven had een toenemend personeelsverloop tot gevolg. In 1956 was het dagelijks bestuur van de Centrale organisatie zich ervan bewust dat de salariëring niet gelijk kon zijn aan die van het particuliere bedrijfsleven. De salariëring mocht niet achterblijven bij die van de ambtenaren (de regeling van de pensioenen, het wachtgeld en de invaliditeitsregeling waren bij TNO ongunstiger dan bij de rijksoverheid). ${ }^{559}$ Tabel 5.5 vergelijkt de ontwikkeling van de gemiddelde salarissen bij de Bijzondere organisaties van TNO met die van de researchdiensten van de staatsmijnen. 
Tabel 5.5 Gemiddeld salaris inclusief sociale lasten. (in duizenden guldens)

\begin{tabular}{lcccc}
\hline organisatie & 1954 & 1955 & 1956 & 1957 \\
\hline $\begin{array}{l}\text { Centrale organisatie } \\
\text { Nijverheidsorganisatie }\end{array}$ & 5.368 & 5.821 & 6.575 & 7.297 \\
$\begin{array}{l}\text { Voedingsorganisatie } \\
\text { Rijksverdedigingsorganisatie }\end{array}$ & 5.817 & 5.853 & 6.528 & 7.146 \\
Gezondheidsorganisatie & 5.108 & 5.264 & 6.405 & 6.504 \\
Gemiddeld (1) & 5.302 & 5.794 & 6.513 & 7.128 \\
& $(100)$ & $(109)$ & $(123)$ & $(134)$ \\
& 8.470 & 8.851 & 9.915 & 11.034 \\
Staatsmijnen & $(100)$ & $(104)$ & $(117)$ & $(130)$ \\
(researchdiensten) & & & &
\end{tabular}

Opmerkingen: (1) Gemiddelde salarissen exclusief landbouw.

Bron: TNo, Voorstel inzake het rijkssubsidie voor 1959, p. 7 i Staatsmijnen, Bijlagen bij Bedrijfseconomische Verslagen, 1954, 1955, 1956 en 1957; Staatsmijnen, Groeiprognose Centraal Laboratorium 1960-1970, bijlage $V, 31$ maart 1961 ; in: Concern Archief DSM, Organisatie 1950-1959, inv. nr. 268.

Uit tabel 5.5 blijkt dat de gemiddelde salarissen (inclusief sociale lasten) bij de researchdiensten van de staatsmijnen hoger waren, maar minder snel toenamen, dan de gemiddelde salarissen bij de Bijzondere organisaties van TNO.

\subsubsection{Aanspraak op de winst.}

De Nederlandse Centrale Organisatie voor toegepastnatuurwetenschappelijk onderzoek streefde niet naar de realisatie van winst. Dit betekende echter niet dat positieve bedrijfsresultaten waren uitgesloten. Een recht om aanspraak te maken op de winst in de vorm winstdelingsregelingen ontbrak. De arbeidsverhoudingen bij de Nederlandse Centrale Organisatie voor toegepast-natuurwetenschappelijk onderzoek kenmerkten zich door buiten-contractuele arbeidsverhoudingen. ${ }^{560}$

Het recht om de hoogte van de vergoeding van de voorzitter van de Centrale organisatie vast te stellen, berustte bij de Minister van onderwijs, Kunsten en Wetenschappen. Het bestuur van de Centrale organisatie beschikte over het recht om de hoogte van de vergoeding van de voorzitter van een Bijzondere organisatie al dan niet goed te keuren. ${ }^{561}$ Het Ministerie van Financiën intervenieerde niet in de salarispolitiek van TNO, ondanks het bestaan van een uit 1951 daterende circulaire die gesubsidieerde instellingen verplichtte geen personeel in dienst te nemen, dan nadat overleg had plaats gevonden met de Ministers van Binnenlandse Zaken en Financiën over salaris, toelagen en emolumenten. De overeengekomen salariëring bij de benoeming van een voorzitter had tot consequentie dat andere 
voorzitters en directeuren van TNO-instituten zouden trachten hun salarisniveau op te trekken. De betrokken ambtenaren op het Ministerie van Financiën wisten niet in hoeverre de gedelegeerden van de betrokken ministers in de besturen van de Centrale organisatie en de Bijzondere organisaties invloed hadden uitgeoefend op het salarisbeleid van TNO. Ingrijpen in de salarissen kon het ministerie niet, tenzij dit betrekking had op de subsidie. ${ }^{562}$

In 1962 bracht een commissie, bestaande uit bestuursleden onder voorzitterschap van dr. M.W. Holtrop, advies uit over een richtlijn voor het toekennen van een vergoeding aan de voorzitters van de TNO-organisaties. De voorgestelde richtlijn hield in dat de vergoeding gelijk gesteld werd aan het salaris van een hoogleraar, vermeerderd met dertig procent. Aan het genoemde percentage lag onder andere de overweging ten grondslag dat het de voorzitters van de Centrale organisatie en de Bijzondere oxganisaties niet was toegestaan op te treden als adviseur van het bedrijfsleven. Het salaris bevatte de huurcompensatie, maar niet de compensatie voor de AOW. De vergoeding was niet onderhevig aan periodieke verhogingen en loonronden. ${ }^{563}$ De voorgestelde richtlijn werd overgenomen en door de ambtenaren van het Ministerie van Financiën toegepast bij de evaluatie van de salariëring. De voorzitter van de Nijverheidsorganisatie nam, wat betreft de salariëring, een uitzonderingspositie in. Het salaris van de voorzitter van de Centrale organisatie, vermeerderd met een toeslag, fungeerde als richtijin. Het dagelijks bestuur van de centrale organisatie beëindigde deze uitzonderingpositie in $1965.564 \mathrm{De}$ salarissen van de TNO-directeuren waren afhankelijk van de salarissen van de voorzitters en in overeenstemming met het hiërarchiebeginsel lager (voorschrift rapport-Holtrop). De ambtenaren van het Ministerie van Financiën slaagden er niet in de regeling van de salarissen van de TNO-directeuren te achterhalen. $\mathrm{zij}$ achtten nader overleg over de vaststelling van de directiesalarissen dan ook wenselijk. ${ }^{565}$

\subsection{Analyse van de kenbaar gemaakte doeleinden}

De analyse van de kenbaar gemakte doeleinden van de Nederlandse Centrale organisatie voor toegepast natuurwetenschappelijk onderzoek bestaat uit het verzamelen en definiëren van de doeleinden, gevonden in beleidsdocumenten en andere officiële documenten. Aan deze analyse gaat en beschouwing vooraf van de wettelijke doeleinden. De vervulling van deze doeleinden vormt de voorwaarde voor de vrijheid eigen doeleinden na te streven, met andere woorden beleidsvrijheid.

Artikel 1 van de Wet van 30 oktober 1930 tot regeling van het toegepast-natuurwetenschappelijk onderzoek vermeldde als na te streven wettelijke doelstelling:

Er is een centrale organisatie voor toegepastnatuurwetenschappelijk onderzoek, die tot taak heeft te bevorderen, dat dit onderzoek op de doelmatigste wijze dienstbaar gemaakt wordt aan het algemeen belang. ${ }^{566}$

De memorie van toelichting van 1929 bij het wetsontwerp stelde 
artikel 1 zelfs niet aan de orde. Het wetsontwerp bevatte volgens de memorie van toelichting een regeling die beoogde belanghebbende groepen te stimuleren tot wetenschappelijke en financiële medewerking aan het toegepast natuurwetenschappelijk onderzoek. Het was de bedoeling een zo hoog mogelijk rendement te verzekeren voor de ter beschikking gestelde financiële middelen. ${ }^{567}$

Minister van Algemene zaken $H$. Colijn bemoeide zich persoonlijk met het onderwerp van toegepastnatuurwetenschappelijk onderzoek. Hij concludeerde in 1938, na een onderhoud met de ambtelijke gedelegeerden, bij de ministeriële bespreking over dit onderwerp dat de Wet van 30 oktober 1930 niet had geleid tot de beoogde samenwerking tussen overheid en samenleving. De samenwerking zou worden verbeterd als het dagelijks bestuur tijdig voor de aanvang van zijn vergaderingen een agenda stuurde naar de betrokken departementen. ${ }^{568}$ In 1939 beschouwde Minister Colijn centralisatie en coördinatie als de hoofdtaken van de Nederlandse Centrale organisatie TNO. Verwijzend naar de artikelen 2 en 15 van de Wet van 30 oktober 1930 vatte Minister Colijn deze taken samen met de volgende punten:

1. het geven van advies aan de regering,

2. de coördinatie van overheids- en particuliere activiteiten

op het gebied van toegepast-natuurwetenschappeIijk

onderzoek,

3. het onderzoek,

4. de voorlichting aan het bedrijfsleven, en

5. bijstand, waar deze door de regering in het belang van TNO wordt gevraagd. ${ }^{569}$

De ministerraad formuleerde in 1939 het beginsel van deze wet als "het streven op het terrein van "research" naar samenwerking tussen overheid en matschappij". Het bestuur van de Nederlandse Centrale organisatie kon zich met deze formulering verenigen. Dit beginsel was echter volgens het bestuur niet duidelijk genoeg omschreven. Zij zou het beginsel als volgt willen weergeven:

"het streven - voor zover mogelijk - naar overdracht van de rechtstreekse bemoeienis der overheid met research aan de matschappij en naar beperking der overheidstaak tot indirecte bemoeienis, bestaande uit stelselmatige aanmoediging en krachtige steun". 570

Verschil van mening bleef bestaan over de overdracht van het beheer van rijksonderzoeksinstituten. Het bestuur en het dagelijks bestuur deelden het oordeel dat naar de bedoeling van de wet overdracht van beheer regel werd.

De onduidelijke wetgeving en de memorie van toelichting boden de mogelijkheid tot beleidsvrijheid. 


\subsubsection{Kenbaar gemaaxte doeleinden en documentenanalyse.}

Het kabinet maakte de volgende doeleinden kenbaar:

a. Het is voor de ontplooiing van de Gezondheidsorganisatie noodzakelijk, dat haar budget in een sneller tempo wordt verhoogd dan dat voor de andere organisaties TNO (1951). . $^{571}$

b. Om financiële steun van de zijde van het bedrijfsleven te bevorderen achten de ministers het verantwoord van overheidswege extra geldmiddelen aan de organisatie TNO te verstrekken indien deze organisatie van het bedrijfsleven grotere vrijwillige bijdragen geniet, respectievelijk in toenemende mate collectieve opdrachten verkrijgt (1953)..$^{572}$

c. De financiële vooruitzichten van het Rijk acht de minister zodanig, dat naar een uiterste beperking moet worden gestreefd, hetgeen hem noopt het bestuur te verzoeken met deze omstandigheid rekening te houden $(1959) .573$

d. In Nederland vormt de research evenals in de Verenigde staten een middel bij het bepalen van het beleid en de uitvoering daarvan. Het beleid is evenwel niet in de eerste plaats op de verdediging gericht, doch op verhoging van het nationale produkt (1959). ${ }^{574}$

e. Bestuurlijk moet men TNO dan ook geheel anders zien dan een bedrijf. Dit neemt in het geheel niet weg, dat het een voortdurende zorg is om de effectiviteit van het onderzoek op te voeren waar dat maar mogelijk is.

f. Het beleid van de Minister van Financiën is erop gericht om matregelen op het gebied van personele voorzieningen voor gesubsidieerde instellingen als TNO zoveel mogelijk gelijk te doen zijn aan die, welke bij het Rijk worden getroffen (1968)..$^{575}$

g. In april 1969 deelde de Minister van Financiën mede, dat in het kader van de matregelen, genomen om de verstoring van het evenwicht in de ontwikkeling van de nationale economie te beteugelen, de kapitaalbegroting TNO voor het jaar 1969 met 2,5 miljoen is verlaagd (1969).576

De besturen van de organisatie TNO streefden naar de volgende doeleinden:

h. Wij zullen ons met behulp van een doeltreffende organisatie van het TNO, waraan in Nederland grote behoefte bestaat, tegen verdringing door andere landen te weer moeten stellen (1934). 577 
i. Een voortdurende zorg vormden het zo spoedig mogelijk inhalen van de door de oorlog ontstane achterstand, de voorziening in personeel, het op peil brengen van de apparatuur en het vraagstuk van de huisvesting van verschillende instituten.

j. De uitvoering van die taak zal in het bijzonder gericht moeten blijven op het inhalen van de hier te lande bestaande achterstand op tno-gebied en op een verdere ontwikkeling daarvan, zowel in het belang van onze bestaande industrieën als ter bevordering van de verdere industrialisatie, op welk terrein door de regering ook op andere wijze doelbewust steun is of zal worden verleend $(1950) .778$

k. Het staat dan ook onomstotelijk vast, dat ons land op het gebied van het toegepast-natuurwetenschappelijk onderzoek een achterstand heeft in te halen. Ten einde daartoe te kunnen geraken zal voor wat TNo betreft gestreefd moeten worden naar een verdere opvoering van de bijdragen van het Nederlandse bedrijfsleven, terwijl daarnaast van rijkswege zal moeten worden gerekend op een belangrijke verhoging van de rijkssubsidie voor de komende jaren (1955). ${ }^{575}$

1. Het scheppen van voldoende werkruimten, in hoofdzaak door nieuwbouw, omdat de huidige ruimten te klein zijn en geen uitbreidingsmogelijkheid bieden. Geleidelijke concentratie van laboratoria.

Uitbreiding van het aantal onderzoekers met het oog op noodzakelijke intensivering van fundamenteel onderzoek.

Verbetering van het salarispeil en van de ouderdomsvoorzieningen van enkele groepen van werknemers.

Uitbreiding van de TNO-werkzaamheid naar buiten op het gebied van publiciteit en propaganda en matregelen ter bevordering van meer organisatorische eenheid naar binnen.

Verbetering van de verhouding tussen rijksbijdragen en inkomsten van anderen (intensieve acquisitie) (1956). ${ }^{580}$

m. De hier te lande bestaande grote achterstand op het gebied van de kernenergie noopt tot intensivering van het onderzoek (1959). . $^{581}$ 


\subsubsection{Dit de structuuranalyse afgeleide doeleinden.}

De structuuranalyse biedt de mogelijkheid de doeleinden van de houders van de publieke eigendomsrechten vast te stellen. De doeleinden, resulterend uit het recht on toezicht uit te oefenen op de aankopen en de prestaties van de produktiefactoren, behelzen:

1. het behouden van eenheid in het beheer van de financiële middelen van de rijksoverheid,

2. het verwerven van inzicht in de besteding van de subsidie,

3. het versterken van de financiële staf om weerstand te bieden tegen de materiële eisen van de directeuren, en

4. het voorkomen dat overheidsorganisaties conjunctuurpolitiek gaan voeren.

Uit het recht toezicht uit te oefenen op de wetenschappelijke resultaten kunnen worden afgeleid:

1. produkt- en procesinnovatie, en

2. exploitatie van octrooien.

De doeleinden, verbonden aan het recht om toezicht uit te oefenen op de omvang en de samenstelling van het personeel, zijn:

1. de salariëring mocht niet achterblijven bij die van de rijksambtenaren, en

2. de groei van het personeelsbestand.

\subsection{3 vergelijking van de met beide analyses gevonden doeleinden.}

Het verwerven van inzicht in de besteding van de subsidie sluit aan bij de kenbaar gemakte doelstelling: b.

Het voorkomen dat overheidsorganisaties conjunctuurpolitiek gaan voeren blijkt eveneens uit doelstelling: $g$.

Dat de salariëring mocht niet achterblijven bij die van de rijksambtenaren komt overeen met de doeleinden: $f$ en $l$.

De groei van het personeelsbestand wordt bevestigd door doelstelling: 1 .

In de analyse van de kenbaar gemaakte doeleinden wordt drie keer de doelstelling van het inhalen van de wetenschappelijke achterstand op het buitenland genoemd. Deze doelstelling wordt niet terug gevonden in de structuuranalyse.

\subsection{Beleidsvrijheid}

Het vermogen van de Nederlandse Centrale organisatie voor toegepast-natuurwetenschappelijk onderzoek bestond uit 
duurzaam geinvesteerde en overige vermogens (reserves). De ministers, die beschikten over de publieke eigendomsrechten, konden aan dit vermogen geen rechten ontlenen. De Wet van 30 oktober 1930 bevatte geen bepalingen over het overdragen van exploitatieoverschotten aan 's Rijksschatkist, netgeen niet betekende dat de Ministers van Financiën het ontstaan van reserves accepteerden. De Nederlandse Centrale organisatie TNO beschikte echter zonder instemming van de Minister van Financiën over reserves. ${ }^{582}$ De reserveringen vonden niet plaats ten laste van de resultatenrekening. In 1956 erkende Minister van Financiën Van de Kieft met de toekenning van onder andere een extra-subsidie voor het reservefonds het recht voor de organisatie TNO on reserves te vormen. De reserves fungeerden als buffer tegen sociale, bedrijfs- en conjunctuurrisico's en waren onderhevig aan plafonds. ${ }^{383} \mathrm{De}$ mate van autonomie, voortvloeiende uit het recht reserves te vormen, zou het bedrijf moeten stimuleren tot het realiseren van een mate aan rentabiliteit.

Uit tabel 5.6 blijkt dat het rendement van het vermogen van de Nederlandse Centrale organisatie voor toegepastnatuurwetenschappelijk onderzoek over de periode 1960 tot en met 1970 lager was dan het rendement op eeuwigdurende staatsleningen. De gederfde winst als matstaf voor beleidsvrijheid steeg.

Tabel 5.6 Beleidsvrijheid: Nederlandse Centrale Organisatie TNO

\begin{tabular}{lcrrrr}
\hline Jaar & $\begin{array}{c}\text { Vermogen } \\
(1)\end{array}$ & $\begin{array}{l}\text { Overschot/ } \\
\text { Tekort }\end{array}$ & $\begin{array}{l}\text { Rendement } \\
\text { Staatsleningen }\end{array}$ & $\begin{array}{l}\text { Gederfde } \\
\text { winst }\end{array}$ \\
\hline \multicolumn{7}{c}{ × 1000 gld } & x 1000 gld & $\times 1000$ gld \\
1960 & 63.132 & $-852-1,35$ & 4,38 & 2.765 \\
1961 & 77.562 & 222 & 0,29 & 4,20 & 3.035 \\
1962 & 94.580 & 508 & 0,54 & 4,39 & 3.644 \\
1963 & 115.464 & -16 & $-0,01$ & 4,39 & 5.069 \\
1964 & 145.888 & 959 & 0,66 & 4,84 & 7.061 \\
1965 & 181.879 & 693 & 0,38 & 5,19 & 8.746 \\
1966 & 214.612 & 666 & 0,31 & 5,86 & 11.910 \\
1967 & 242.202 & 599 & 0,25 & 5,67 & 13.133 \\
1968 & 273.374 & 1.711 & 0,62 & 6,19 & 15.210 \\
1969 & 285.055 & 655 & 0,35 & 7,02 & 20.011 \\
1970 & 297.967 & 205 & 0,07 & 7,06 & 20.083 \\
\hline
\end{tabular}

Opmerkingen: (1) Het vermogen bestaat hier uit duurzaam geinvesteerd vermogen en overig vermogen (reserves).

Bron: TNO, Jaarverslagen van 1960 tot en met 1970 .

CBS, Negentig jaren statistiek in tijdreeksen, 1989.

De beleidsvrijheid van de organisatie TNO zou kunnen zijn aangewend voor het inhalen van de wetenschappelijke achterstand en de financiering van de salarissen van de bestuurders en de directeuren van de TNO-instituten (buiten 
contractuele arbeidsvoorwaarden).

De Nederlandse Centrale organisatie TNO concurreerde met particuliere onderzoeksbureaus. De Vereniging van Raadgevende Scheikundigen stelde dat de Nederlandse Centrale organisatie de jaarlijkse overheidssubsidies en stimuleringsgelden aanwendde voor commerciële activiteiten. De organisatie behaalde hierdoor volgens hen een ongeoorloofde voorsprong in de mededinging. ${ }^{584}$

\subsubsection{Inhalen achterstand op het gebied van toegepast- natuurwetenschappelijk onderzoek.}

In de jaren dertig wees het bestuur van de Nederlandse Centrale organisatie TNO erop dat het ontstaan van een wetenschappelijke achterstand moest worden voorkomen. Het autarkische beleid in de omringende landen vormde een waarschuwing. Het bestuur achtte een doeltreffende organisatie van het toegepast-natuurwetenschappelijk onderzoek noodzakelijk om weerstand te bieden tegen de internationale concurrentie. ${ }^{585}$

$\mathrm{Na} 1945$ hanteerde het bestuur van de organisatie TNO wederom het argument van het inhalen van de achterstand op het gebied van het toegepast-natuurwetenschappelijk onderzoek. De taak van de Nederlandse Centrale organisatie TNO zou in het bijzonder gericht moeten zijn op het inhalen van de Nederlandse achterstand en op een verdere ontwikkeling van het toegepast-natuurwetenschappelijk onderzoek, zowel in het belang van de Nederlandse industrie als ter bevordering van de mogelijkheden van verdere industrialisatie. ${ }^{586}$ In 1952 schreef Minister-President $w$. Drees dat de Nederlandse wetenschap op sommige terreinen zijn door de Duitse bezetting veroorzaakte achterstand had ingehaald. ${ }^{587}$ De voorzitter van de Nederlandse Centrale organisatie TNO Prof. dr. H.R. Kruyt kon zich in zijn algemeenheid wel aansluiten bij de mening van de MinisterPresident. Hij oordeelde dat, in vergelijking met de verenigde Staten van Amerika, Groot-Brittannië en de Sowjet-Unie, de steun voor het onderzoek van de kant van de Nederlandse overheid en het bedrijfsleven minimal was. Als criterium hanteerde hij de verhouding tussen de overheidsuitgaven aan wetenschappelijk onderzoek en het nationale inkomen. ${ }^{888}$

In 1955 baseerde het bestuur van deze organisatie de achterstand (gewezen werd onder andere op de internationale ontwikkelingen op het terrein van de kernenergie) op een fictieve Nederlandse organisatie, die onder Amerikaans-Britse verhoudingen functioneerde. Tabel 5.7 geeft een fictief Amerikaans-Brits budget weer met een jaarlijk accres van vijf procent. De hoogte van dit fictieve budget werd vastgesteld met behulp van de wisselkoers en een bevolkingsfactor. ${ }^{599}$ 
Tabel 5.7 TNO-budget bij Amerikaans-Britse speurwerkactiviteit in miljoenen guldens.

\begin{tabular}{lllll}
\hline $\begin{array}{l}\text { Fictief budget } \\
\text { Amerikaans/Brits } \\
\text { Jiveau }\end{array}$ & $\begin{array}{l}\text { TNo-budget } \\
\text { aansluitend op } \\
\text { fictief budget }\end{array}$ & $\begin{array}{l}\text { Raming } \\
\text { inkomsten } \\
\text { bedrijven }\end{array}$ & $\begin{array}{l}\text { overheids- } \\
\text { subsidie }\end{array}$ \\
\hline 1954 & 45 & 21 & 6 & 15 \\
1955 & 47,25 & 24 & 7 & 17 \\
1956 & 49,50 & 28 & 8 & 20 \\
1957 & 52 & 32 & 9 & 23 \\
1958 & 54,50 & 36,50 & 10,50 & 26 \\
1959 & 57,50 & 41,50 & 12 & 29,50 \\
1960 & 60,25 & 47 & 13,50 & 33,50 \\
1961 & 63,25 & 53 & 15,50 & 37,50 \\
1962 & 66,50 & 59,50 & 17,50 & 42 \\
1963 & 69,75 & 66 & 19,50 & 46,50 \\
1964 & 73,25 & 73 & 22 & 51 \\
\hline
\end{tabular}

Bron: Enige beschouwingen betreffende de toekomstige ontwikkeling van het speurwerk in Nederland, 13 oktober 1955; in: Ministerie van Financiën, doss. Subsidie 1956, map $I$, doos O.A. 4972, inv. nr. 1.854 .2

Uit tabel 5.7 blijkt dat voor het TNo-budget een accres van ongeveer 13 procent was benodigd om in 10 jaar tijd en Amerikaans-Brits niveau te realiseren. ${ }^{900}$

Het bestuur verklaarde in het "Voorstel inzake het rijkssubsidie voor 1968" dat een centrale plaats voor het toegepast-natuurwetenschappelijk onderzoek alleen mogelijk was als naast het accres van 4,5 procent jaarlijks een extra accres van 3 procent beschikbaar werd gesteld. Op de lange duur mocht niet worden verwacht dat de groei van de TNosubsidie de toename van het totale overheidsbudget zou overtreffen. Het bestuur van de centrale organisatie TNo sprak in het hetzelfde subsidievoorstel de verwachting uit dat het punt, waarop deze snellere groei zou moeten afbuigen, nog niet was bereikt. De afremming van de groei van de organisatie door het limiteren van de subsidie leidde tot overheidsuitgaven voor wetenschappelijk speurwerk langs andere kanalen, zowel in Nederland als via internationale organisaties, omdat het onderzoek toch moest worden uitgevoerd. De financiering van het onderzoek langs andere kanalen had volgens het bestuur ten onrechte zijn oorzaak in de opvatting dat de gegroeide situatie bij de Nederlandse Centrale organisatie als de enige mogelijkheid werd beschouwd. Bovendien werd niet geinformeerd naar mogelijke andere vormen in het kader van deze organisatie. ${ }^{591}$ 


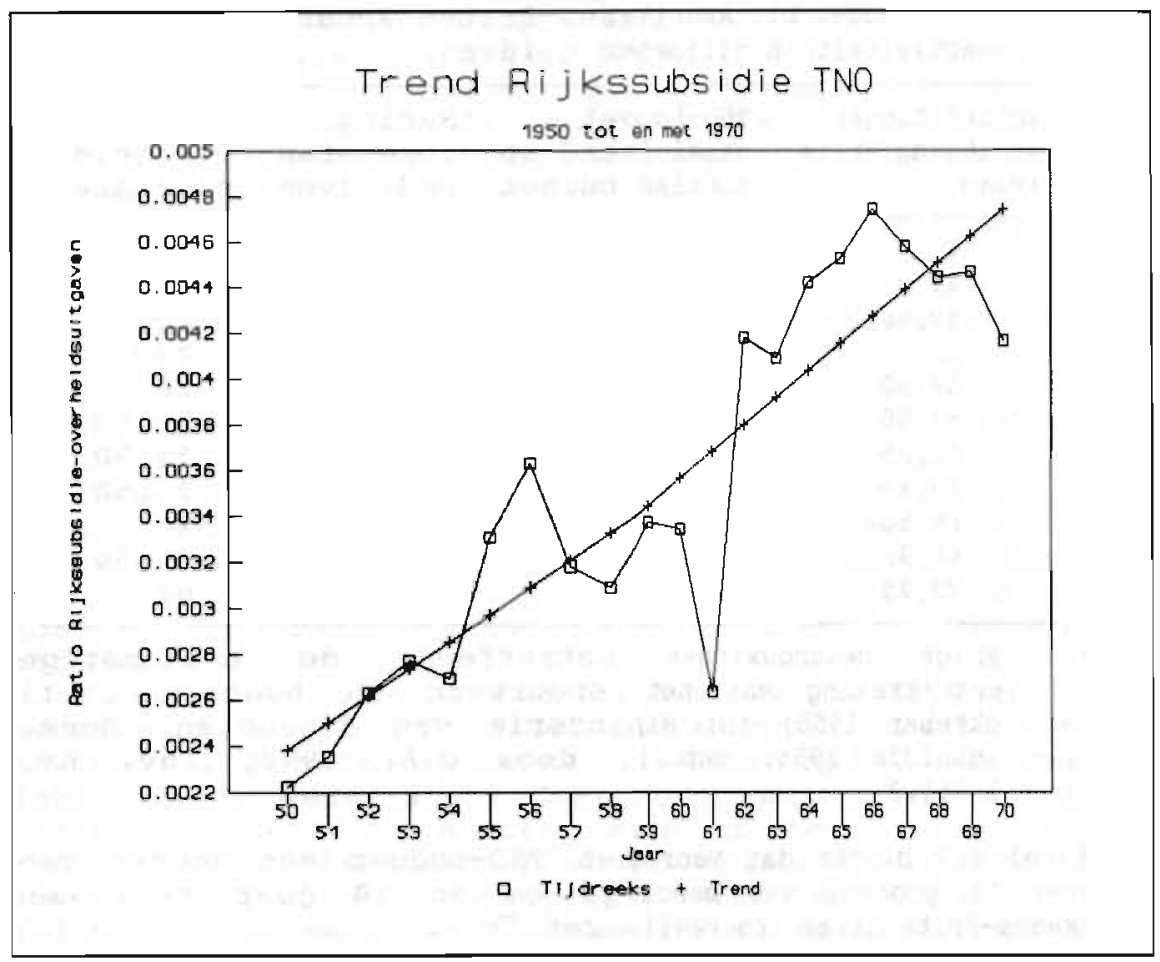

Figuur 5.1

Uit figuur 5.1 blijkt dat het aandeel van de rijkssubsidie in de gewone overheidsuitgaven een stijgende trend vertoonde. De correlatiecoëfficiënt $r$ is 0,8926 voor de periode 1950 tot en met 1970 (voor de gegevens wordt verwezen naar bijlage 5.1). Een afbuiging van de uitgaven voor onderzoek en ontwikkeling heeft consequenties voor de groei van het nationale inkomen en kan een vermindering van de overheidsinkomsten tot gevolg hebben.

Het verwerven van meer bijdragen respectievelijk van meer opdrachten uit het bedrijfsleven zou het mogelijk maken bij de speurwerkinstituten een betere verhouding tussen deze baten en de rijkssubsidie te bereiken. Een te ver doorgevoerde acquisitie ter verhoging van de inkomsten uit opgedragen werk kon echter het vrije speurwerk schaden. Vond het speurwerk in onvoldoende mate plaats, dan leidde dit onherroepelijk tot een achterstand van het niveau van het wetenschappelijk onderzoek. op dit punt moest TNO volgens het "Voorstel inzake rijkssubsidie 1956" vóor zijn, opdat nieuwe wegen zouden worden gevonden, die leidden naar een verdere verhoging van de Nederlandse welvaart. 592

In de toelichting op de kapitaalbegroting voor het jaar 1956 merkte het bestuur op dat de achterstand in het bouwen van laboratoriumruimten zo snel mogelijk moest worden ingehaald, enerzijds om de mogelijkheid te creëren voor het 
uitvoeren van het vereiste onderzoek en anderzijds om de hoogste rentabiliteit van de hieraan te besteden bedragen te realiseren. ${ }^{593}$

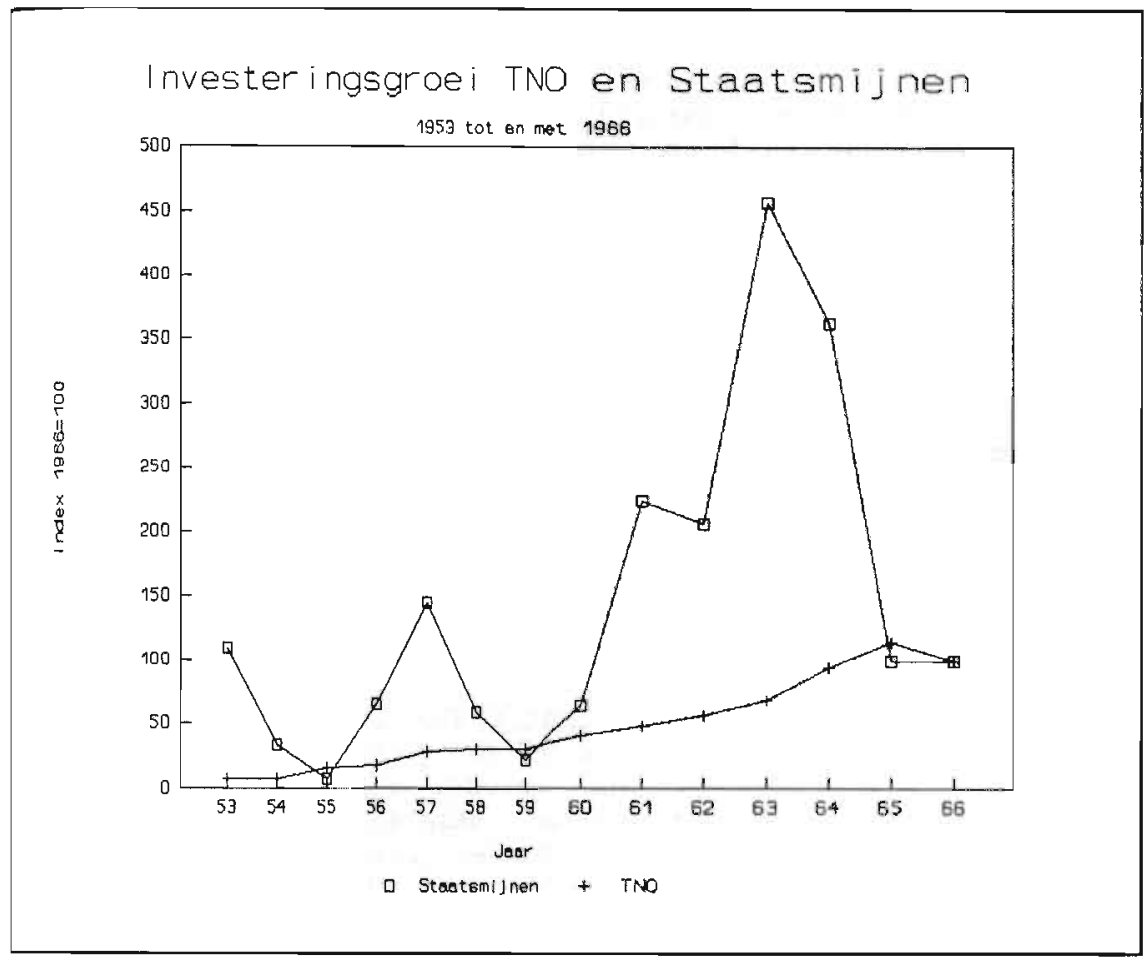

Figuur 5.2

Figuur 5.2 vergelijkt de groei van de investeringen in gebouwen en materialen door de Nederlandse centrale organisatie voor toegepast-natuurwetenschappelijk onderzoek met die van het Centraal Laboratorium van de staatsmijnen (voor de gegevens wordt verwezen naar bijlage 5.2). Ofschoon de investeringen van de organisatie TNo in absolute bedragen hoger zijn dan die van de staatsmijnen, vertonen de indices van de laatste een snellere groei, afgewisseld met dalingen.

\subsubsection{Subsidiebeleid}

De doelstelling van het bestuur van de Nederlandse centrale Organisatie TNO om de Nederlandse achterstand op het terrein van toegepast-natuurwetenschappelijk onderzoek in te halen, leidde tot het streven naar een toename van het accres van de subsidie. De Minister van Financiën bepaalde het niveau van de subsidie. Hij deed daartoe zijn ambtgenoten een voorstel tot verdeling van de toegekende subsidie over de daarvoor in aanmerking komende hoofdstukken van de rijksbegroting. ${ }^{54}$ De ministers beschikten over de bevoegdheid om de financiële 
belangen van hun Bijzondere organisaties te verdedigen, als $z i j$ van mening waren dat deze te weinig subsidie ontvingen. De Minister van onderwijs verantwoordde de totale toegekende rijkssubsidie op de begroting van zijn departement.

De aangevraagde subsidie voor de organisatie TNO berustte op het verschil tussen de begrote lasten en baten van de organisatie. Elk onderdeel (instituut, laboratorium, afdeling) stelde zijn eigen begroting vast. De begrotingen van de Bijzondere organisaties bestonden uit een samenvoeging van de afzonderlijke begrotingen van de onderdelen. De totale begroting van de Nederlandse Centrale organisatie TNo behelsde een bewerking van de afzonderlijke begrotingen van de Bijzondere organisaties. De Bijzondere organisaties waren verplicht de wensen van hun onderdelen onderling af te wegen en in overeenstemring te brengen met de financiële mogelijkheden. Het dagelijks bestuur en het bestuur van de Centrale organisatie herhaalden deze procedure voor de Bijzondere organisaties. ${ }^{595}$

De directie Financieringen en coördinatie oorlogsschade en de directie Rijksbegroting trachtten het accres van de subsidie aan TNO te beheersen in het kader van de door de kabinetten gevoerde begrotingspolitiek. De hoogte van de toegekende subsidie was het resultaat van een bureaupolitiek proces, waaraan de Ministeries en de Nederlandse Centrale organisatie TNO deelnamen.

De groei van de organisatie TNo leidde bij de directie Rijksbegroting tot de vraag of er op den duur nog sprake was van een evenwichtige en gecoördineerde ontwikkeling van verschillende vormen van staatsactiviteit. vergaande decentralisatie zou ertoe kunnen leiden dat verschillende onderzoeksorganisaties hetzelfde aandachtsgebied opeisten. De toename van het aantal organisaties had tot gevolg dat er behoefte ontstond aan niet-specialistische bestuurscoördinatie ter voorkoming van desintegratie en als tegenwicht tegen specialisten. Niet-specialistische bestuurscoördinatie was meer in overeenstemming met de activiteiten van de financiële autoriteiten in het staatsbestel. Het werd van de zijde van de directie Rijksbegroting niet uitgesloten geacht, dat moest worden teruggekomen op de autonomie van de organisatie TNO. Dit betekende een vergroting van de invloed van het Ministerie van Financiën. ${ }^{5 \%}$

Het kolommendiagram in figuur 5.3 geeft de ontwikkeling weer van de aan de Nederlandse Centrale organisatie toegekende rijks- en stimuleringssubsidies over de periode 1950 tot en met 1970 . 


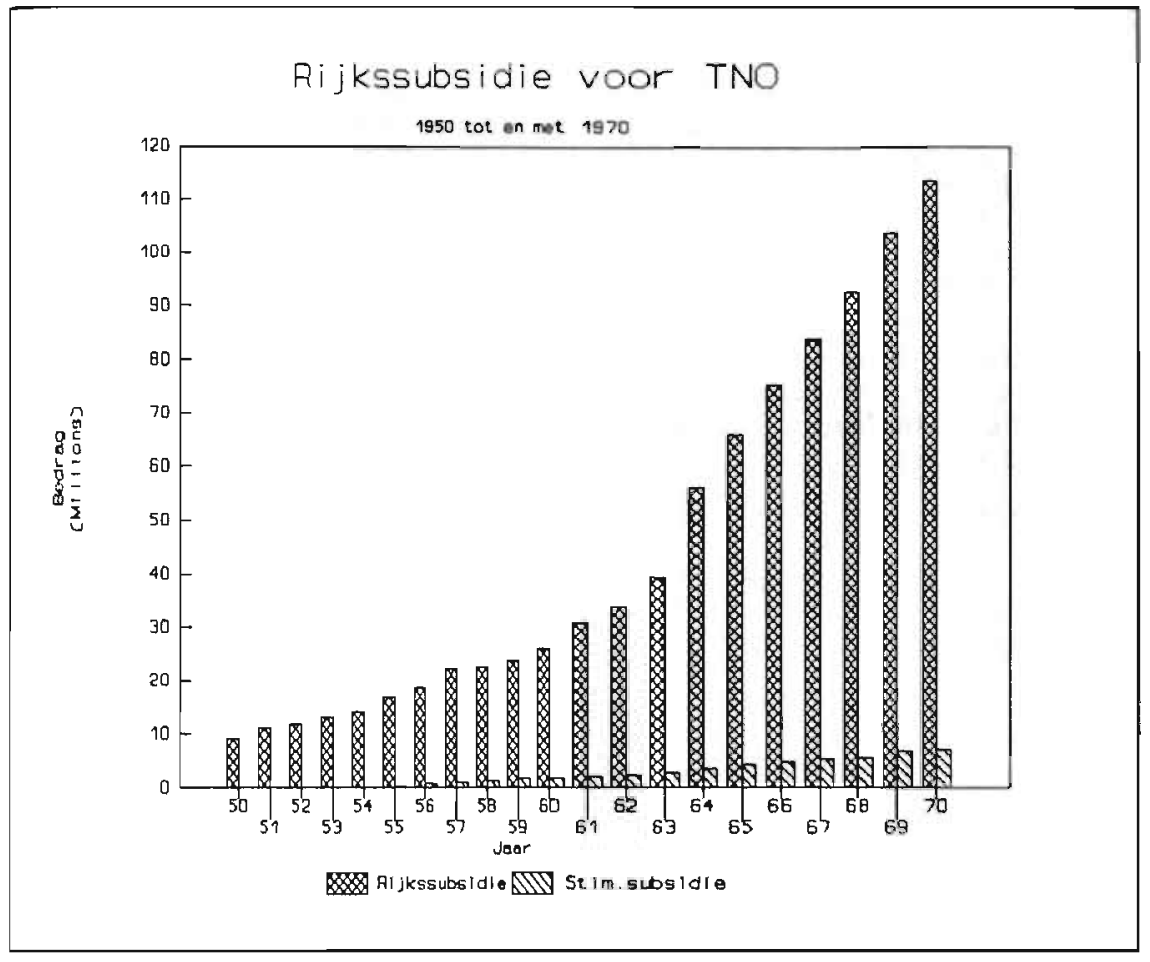

Figuur 5.3

Tot en met 1950 vond er een jaarlijkse vaststelling van de rijkssubsidie plaats. Vanaf 1951 werd een begin gemaakt met de vaststelling van de subsidiebedragen voor een periode van drie jaar. Hierdoor verkreeg de organisatie TNO de vrijheid het beleid voor een reeks van jaren te plannen. De rijkssubsidie bestond nu uit een basisbedrag ter financiering van het onderzoek, waarvoor moeilijk belangstelling van het bedrijfsleven was te verwachten, en een jaarlijkse toeslag afhankelijk van de mate van financiële steun van het bedrijfsleven, de zogenaamde stimuleringssubsidie. Dit bedrag werd gelijk gesteld aan de vrijwillige bijdragen van het bedrijfsleven voor het vrije speurwerkprogramma boven het niveau van 1954. De rijkssubsidie was in 1970 opgebouwd uit een basissubsidie, een stimuleringssubsidie, een subsidie voor international coöperatief speurwerk en een subsidie voor nieuwe huisvesting.

In 1951 bepleitte Minister van Sociale Zaken A.M. Joekes (PvdA) een extra accres voor de Gezondheidsorganisatie bij de Minister van Financiën Lieftinck, waarbij economische en sociale overwegingen een rol speelden. De volksgezondheid leverde een cruciale bijarage aan het economische herstel. Na 1945 verkeerde de Nederlandse gezondheidszorg in een situatie van achterstand, die niet kon worden gecompenseerd met een accres, evenredig aan het toegestane accres van andere 
Bijzondere organisaties. Van economische betekenis waren bijvoorbeeld het onderzoek naar krop, tandcariës, tuberculose en stof. ${ }^{597}$ De Minister van Financiën stemde in met dit verzoek, maar er ontstond een meningsverschil tussen enerzijds de directie Financieringen en Coördinatie oorlogsschade en anderzijds het bestuur van de Centrale organisatie TNo. Naast het accres van 1 miljoen gulden voor de organisatie TNO werd volgens dit bestuur aan de Gezondheidsorganisatie een cumulatief accres toegestaan van resp. 400.0000 (1952), 300.000 (1953), 200.000 (1954) en 100.000 (1955) gulden. De directie Financieringen en Coördinatie Oorlogsschade bestreed dit. De Gezondheidsorganisatie zou dan na vier jaar beschikken over een budget, gelijk aan dat van de andere Bijzondere organisaties.

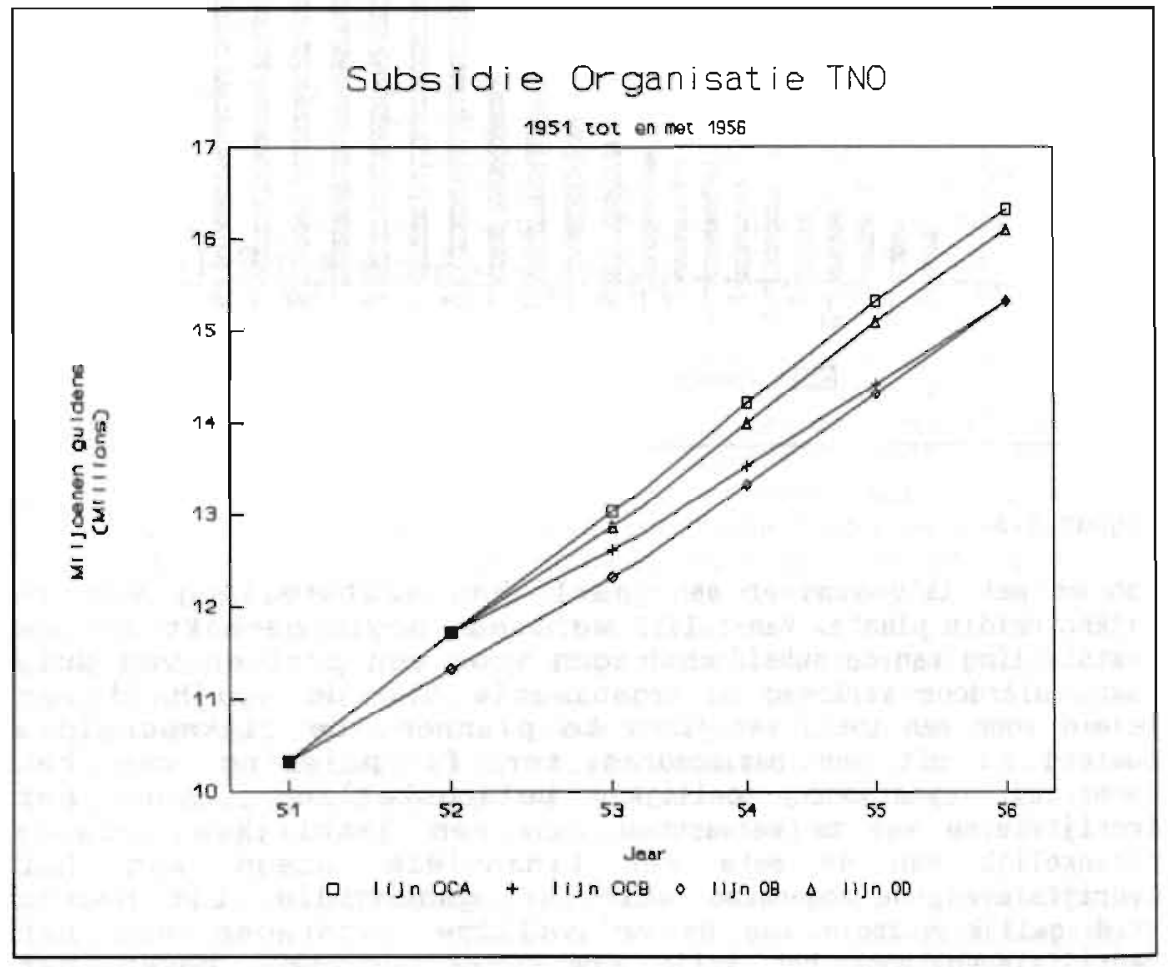

\section{Figuur 5.4}

In figuur 5.4 geeft de lijn $O B$ het verloop van de subsidie aan bij een normaal jaarlijks accres van 1 miljoen gulden. Lijn OCB toont het door het Ministerie van Financiën bedoelde verloop en lijn OCA verloopt volgens de interpretatie van het bestuur van de Centrale organisatie TNo. Een ontwikkeling van de subsidie volgens lijn OCB leidde volgens dit bestuur tot een terugkeer naar de beginsituatie en men verzocht daarom de Minister het traject OCA te volgen. Uit het jaarlijkse accres van 1 miljoen gulden kon de Gezondheidsorganisatie niet tot 
ontwikkeling worden gebracht. Om deze reden stelde de directie Financieringen en coördinatie oorlogsschade een gematigd cumulatief accres voor, namelijk 400.000 (1952), 550.000 $(1953), 675.000(1954), 775.000 \quad(1955)$ en 775.000 gulden (1956). ${ }^{598}$ Het gematigde cumulatieve verloop wordt in figuur 5.4 weergegeven met lijn OD. In 1955 protesteerde Minister van sociale Zaken J.G. Suurhoff (PvdA) tegen het verzoek van de gedelegeerde van het Ministerie van Financiën aan het bestuur van de Centrale organisatie om een uiteenzetting te verkrijgen over de economische en sociale betekenis van door hem aan te wijzen onderzoeken. Bij twijfel over de vraag of de rijkssubsidie kon worden toegekend, moesten de betrokkenen zich voor nadere gewenste inlichtingen wenden tot de Minister van Sociale Zaken. Minister Suurhoff verzette zich tegen de miskenning van zijn gedelegeerde bij de Gezondheidsorganisatie. ${ }^{599}$

De Minister van Onderwijs, Kunsten en Wetenschappen J.M.L. Cals (KVP) wilde de toekenning van de subsidie voor 1955, 1956 en 1957 afhankelijk stellen van een waarborg ten aanzien van de behoefte aan en de redelijke besteding van de toe te zeggen subsidiebedragen. Een dergelijke waarborg kon volgens Minister Cals slechts worden gevonden, wanneer een stelsel werd gevolgd, zoals omschreven in de ontwerp-Hoger onderwijswet (artikel 9 (2) en artikel 24 (4)) ten aanzien van de financiering van rijksuniversiteiten en hogescholen. Minister van Financiën Van de Kieft vreesde dat de Nederlandse Centrale organisatie TNO formele bezwaren zou kunnen maken tegen een dergelijk stelsel, omdat het een en ander niet was geregeld in de TNO-wet van 1930.000 Artikel 24 van de ontwerp-Hoger onderwijswet bepalde dat de Minister van Financiën telkens voor een tijdvak van vier jaren een schema van de uitgaven voor elke universiteit zou vaststellen. Het schema zou aan de staten-Generaal worden overlegd met de bedoeling de rijksbijdrage goed te keuren. Het zou goede diensten kunnen bewijzen voor het opmaken van eventuele begrotingen voor de buitengewone dienst en de wijze van financiering van de benodigde middelen. ${ }^{601}$

De organisatie TNO zag $z i c h$ in de jaren zestig geconfronteerd met een door de algemene loonkostenstijging veroorzaakte verhoging van het prijspeil, een stijging van de materiële lasten en investeringen in apparatuur en een kostenstijging, veroorzaakt door een (beperkte) veroudering van het personeel. Voor zover de kostenstijging niet aan de opdrachtgevers kon worden doorberekend, hetgeen voor het merendeel van de werkzaamheden het geval was, zou tegenover deze stijging een subsidieaccres moeten staan, wilde het niveau van de werkzaamheden gehandhaafd blijven. Dit subsidieaccres werd in de terminologie "rust-accres" genoemd (ongeveer 5,5 procent). ${ }^{602}$

De kapitaalsubsidie stelde de Minister van Financiën in de gelegenheid het bouwbeleid van TNO te beinvloeden. In 1966 verbood de Minister de aanbesteding van bouwkundige werkzaamheden, die ten laste zouden komen van de kapitaaldienst in de periode juni tot en met 1 oktober. ${ }^{6 / 3} \mathrm{Hij}$ reduceerde in 1969 de kapitaalbegroting wNo met 2,5 miljoen gulden teneinde de verstoring van het evenwicht in de 
ontwikkeling van de nationale economie te beteugelen. Het dagelijks bestuur nam deze matregel over en paste de verlaging toe op de nieuwbouw van het TNO Instituut voor Bouwmaterialen en Bouwconstructies. ${ }^{604}$

Figuur 5.5 vergelijkt de ontwikkeling van het indexcijfer voor de kapitaalsubsidie met de ontwikkeling van het globale indexcijfer voor de bouwkosten van woningen. Dit indexcijfer is bij benadering toepasbaar voor de utiliteitsbouw (de gegevens zijn vermeld in bijlage 5.3). De Nederlandse Centrale organisatie TNO streefde naar een verhoging van de kapitaalsubsidie, terwijl het Ministerie van Financiën deze subsidie in de meeste gevallen reduceerde (In 1969 en 1970 verzocht deze organisatie om een bedrag van 24 miljoen gulden, maar zij kreeg deze bedragen niet). ${ }^{.00}$ Het indexcijfer voor de bouwkosten vertoonde een sterkere stijging dan het indexcijfer voor de kapitaalsubsidie over de periode 1952 tot en met 1960, en vervolgens een parallelle ontwikkeling tot en met 1968 (de indexcijfers voor de bouwkosten bevatten in 1969 en 1970 BTW). Het verslag over 1970 vermeldde dat de stijging van de bouwkosten en de ontwikkeling van de kapitaalsubsidie moesten leiden tot een temporisering van de nieuwbouw. ${ }^{606}$

\section{Troei bouwkosten en kapitaalsubsidie}

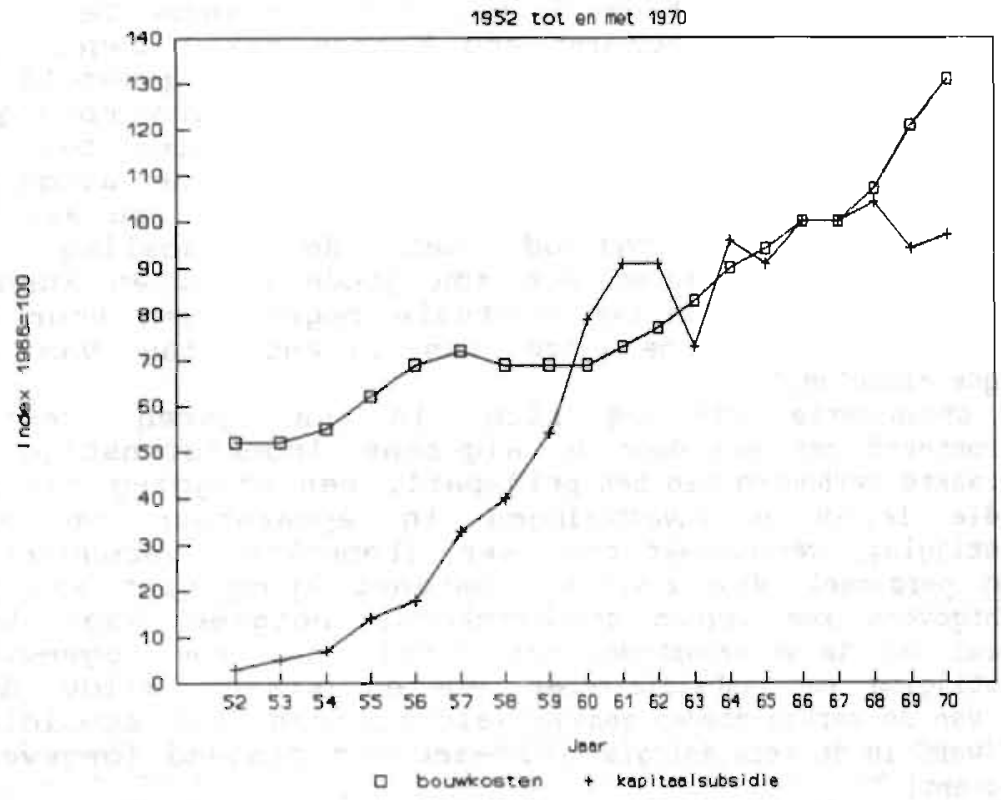

Figuur 5.5

Het Ministerie van Onderwijs en Wetenschappen wilde in 1967 meer inspraak hebben bij de vaststelling van de subsidie voor 
TNO, omdat het belang had bij het werk van deze organisatie. De Ministers van Financiën en Onderwijs kwamen overeen dat voortaan overleg zou worden gepleegd over het groeipercentage van de basissubsidie. ${ }^{607}$ Het Ministerie van Financiën behield daarmee invloed op de andere subsidiecomponenten.

\subsubsection{Beheersing van de overheidsuitgaven.}

Het kabinet-Cals introduceerde in het kader van de beheersing van de overheidsuitgaven en personeelsstop voor de rijksdiensten voor de periode van 1 juni tot en met 31 december 1966, die eveneens met enige wijzigingen van toepassing was op de Nederlandse Centrale organisatie voor toegepast- natuurwetenschappelijk onderzoek.

Het bestuur van de centrale organisatie aanvaardde met enige nuanceringen de personeelsstop, mar achtte het noodzakelijk een uitzondering te maken voor het aanstellen van personeel voor de uitvoering van door derden gefinancierde opdrachten. De Generale Thesaurie stemde namens Minister Vondeling in met deze uitzondering. De Ministerraad wilde tevens vernemen, welke besparingen uit de invoering van de personeelsstop zouden resulteren. Ten gevolge van de getroffen matregel zou naar schatting aan personele kosten inclusief sociale lasten in het tweede halfjaar van 1966 een bedrag van 825 duizend gulden worden bespaard. Hieraan lag de veronderstelling ten grondslag dat geen enkele vacature werd vervuld, ook niet in de sector van de opdrachten. Van het bedrag van 825 duizend gulden had tweederde, ongeveer 550 duizend gulden, betrekking op vrij speurwerk, waarvoor de stop rigoureus van toepassing was. ${ }^{609}$

\subsection{Privatisering}

Artikel 26 van de TNO-wet van 1930 bepaalde dat de ministers de onder hun departement ressorterende diensten, laboratoria en instellingen of gedeelten daarvan overdroegen aan een Bijzondere organisatie. Zij konden tot overdracht besluiten als de betrokken organen daarvoor naar hun oordeel in aanmerking kwamen.

De overdracht van rijkslaboratoria aan de Nederlandse Centrale Organisatie voor toegepast-natuurwetenschappelijk onderzoek kan niet worden beschouwd als een privatisering van een overheidstaak, maar als een bestuurlijke decentralisatie van een overheidstaak. Deze ontwikkeling verstoorde volgens de Algemene Rekenkamer de eenheid van beheer van financiële overheidsmiddelen, waardoor een minder juist inzicht in de rijksbegroting ontstond. ${ }^{610}$

Aan het begin van de jaren vijftig bestond op ambtelijk niveau bij het Ministerie van Financiën de voorkeur om de bijdrage van het Rijk te koppelen aan die van het bedrijfsleven. De voortzetting van de accrespolitiek zou echter deze koppeling beletten voor sectoren waar een particuliere bijdrage mocht worden verwacht, namelijk bij de Nijverheidsorganisatie, de Landbouworganisatie, de Voedingsorganisatie, en de Gezondheidsorganisatie. De Generale Thesaurie achtte een dergelijke koppeling noodzakelijk, omdat 
het geleidelijk aan moeilijker werd het bedrijfsleven te stimuleren een bijdrage te leveren. In 1952 informeerde de Generale Thesaurie Minister Lieftinck dat het noodzakelijk zou $z$ ijn de bestaande TNO-instituten over te dragen aan het bedrijfsleven. De Nederlandse Centrale organisatie TNo diende slechts vraagstukken te bestuderen, als pogingen daartoe door zelfstandige organisaties geen resultaat opleverden. ${ }^{611}$

\subsection{Prestaties overheidsbedrijf en reacties principalen}

\subsubsection{Benoemingen}

De TNO-wet van 30 oktober 1930 regelde de samenstelling van het bestuur. Dit bestuur bestond uit de voorzitters van de Bijzondere organisaties, de gewone en tijdelijke leden. De Kroon benoemde de gewone leden op voordracht van de betrokken ministers. De helft van het aantal gewone leden was deskundig op het terrein van de natuurwetenschappen en de andere helft was deskundig op het gebied van de algemene economische verhoudingen. Voor de eerste categorie deskundigen mocht de afdeling Natuurkunde van de Koninklijke Academie van Wetenschappen een aanbeveling indienen. Voor de economische deskundigen mocht de in 1917 ingestelde Commissie voor de Economische Politiek een aanbeveling doen. In 1934 verving de Economische Raad de eerder genoemde commissie. ${ }^{612}$ Vanaf 1951 werden, voorafgaand aan de benoeming van een economische deskundige, aanbevelingen gevraagd aan de Sociaal Economische Raad. ${ }^{613}$

In 1938 beschouwde Minister van Economische Zaken Steenberghe de samenstelling van de besturen, de bezetting van het dagelijks bestuur en het secretariat als de oorzaken van de departementale problemen met de organisatie TNo. De besturen waren omvangrijk geworden, hetgeen voor een vlotte werkwijze niet bevorderlijk was. De minister beschouwde de aard van de samenstelling van de besturen als problematisch. Het Hoger onderwijs op natuurwetenschappelijk gebied was ruim vertegenwoordigd in de besturen van de organisatie. Hij wees erop dat de uiteenlopende wetenschappelijke visies onder het grote aantal hoogleraren in de organisatie TNO de beantwoording van vragen van toegepast-natuurwetenschappelijke aard schaadden. De overige werkzaamheden van de meeste bestuursleden hadden volgens hem tot gevolg dat veel aangelegenheden aan het dagelijkse bestuur en het secretariaat moesten worden overgelaten. Sinds november 1936 participeerde het lid van de Tweede Kamer der Staten-Generaal en gewoon lid (economisch deskundige) $\mathrm{J}$. Schouten (AR) in de vergaderingen van het dagelijks bestuur van de Centrale organisatie. Minister steenberghe makte hiertegen bezwaar, omdat zijn gedelegeerde geen zitting had in het dagelijks bestuur. De politicus schouten was benoemd op voordracht van de Minister van Handel, Nijverheid en Scheepvaart. De secretaris van de Centrale organisatie, eveneens belast met het secretariaat van de Nijverheidsorganisatie, verwierf ten gevolge van deze dubbelfunctie een machtspositie. ${ }^{614}$

Tabel 5.8 toont de samenstelling van het bestuur van de centrale organisatie en de benoemingen op voordracht van de 
Ministeries van Economische Zaken (EZ), Onderwijs, Kunsten en Wetenschappen (OKW), Defensie (DEF), Binnenlandse Zaken (Biza), Landbouw (L) en Sociale Zaken (SoZa). Uit de tabel blijkt dat het Ministerie van onderwijs en Wetenschappen en het Ministerie van Defensie sterk zijn vertegenwoordigd.

Tabel 5.8 Samenstelling bestuur en aantal gedelegeerden bij de Centrale organisatie.

\begin{tabular}{lcccccccccc}
\hline \multirow{2}{*}{$\begin{array}{c}\text { Dagelijks } \\
\text { Bestuur }\end{array}$} & $\begin{array}{c}\text { Overige } \\
\text { leden }\end{array}$ & $\begin{array}{c}\text { Gedele- } \\
\text { geerden }\end{array}$ & \multicolumn{2}{l}{ Benoemingen: } & OKW & DEF & Biza & L & SoZa \\
\hline 1937 & 2 & 15 & 8 & - & 2 & 2 & 2 & 2 & 2 \\
1950 & 6 & 22 & 13 & 2 & 5 & 4 & 2 & 2 & 2 \\
1955 & 6 & 22 & 12 & 2 & 5 & 5 & 2 & 3 & 2 \\
1960 & 7 & 22 & 12 & 2 & 6 & 4 & 4 & 2 & 2 \\
1965 & 7 & 20 & 3 & 2 & 6 & 5 & 2 & 2 & 2 \\
1970 & 6 & 19 & 3 & 2 & 6 & 4 & 2 & 2 & 2 \\
\hline
\end{tabular}

opmerkingen: Gezamenlijke voordrachten zijn hier buiten beschouwing gelaten.

Kabinetten waren op grond van de TNO-wet van 1930 niet bevoegd de voorzitter van de Centrale organisatie te benoemen. De benoeming van de voorzitter vond plaats door het bestuur, waarin geen overheidsvertegenwoordigers met stemrecht zitting hadden. De Minister van Financièn kon echter zijn bezwaren kenbaar maken en trachten te bevorderen dat een voorzitter werd benoemd met capaciteiten op industrieel en organisatorisch gebied. Ambtenaren van het Ministerie van Financiën makkten van de gelegenheid gebruik hun voorkeuren voor een bepaalde voorzitter kenbaar te maken. ${ }^{615}$

\subsubsection{Expliciete beleidswijziging}

De Minister van Landbouw had zich steeds verzet tegen de overdracht van zijn onderzoeksinstellingen aan TNO, waardoor de eenheid van de drie pijlers van de landbouwpolitiek (onderwijs, onderzoek en voorlichting) werd verbroken.

In 1957 verving de Nationale Raad voor Landbouwkundig onderzoek de Landbouworganisatie TNO. Het bestuur van de Centrale organisatie formuleerde het reglement van de Raad en stelde dat de ervaring had geleerd, dat de bevordering van het landbouwonderzoek niet op bevredigende wijze kon worden toevertrouwd aan een Bijzondere organisatie in de geest van hoofdstuk II van de TNO-wet van 30 oktober $1930 .{ }^{616} \mathrm{De}$ onderzoeksinstituten van deze Bijzondere organisatie werden omgezet in stichtingen en kwamen ten laste van de begroting van het Ministerie van Landbouw. Deze verandering genoot de instemming van de directie Rijksbegroting. ${ }^{617}$ 
Bijlage 5.1 Groei rijkssubsidie TNO 1950 tot en met 1970.

\begin{tabular}{lrrrr}
\hline Jaar & Rijkssubsidie & $\begin{array}{l}\text { Gewone overheids- } \\
\text { uitgaven }\end{array}$ & Ratio & $\begin{array}{l}\text { Voorspelde } \\
\text { ratio }\end{array}$ \\
\hline & mln gld & mln gld & x $10^{-2}$ & $\times 10^{-2}$ \\
1950 & 9,171 & 4125 & 0,2223 & 0,2382 \\
1951 & 11,177 & 4754 & 0,2351 & 0,2500 \\
1952 & 12,215 & 4641 & 0,2631 & 0,2618 \\
1953 & 14,163 & 5117 & 0,2767 & 0,2736 \\
1954 & 15,284 & 5668 & 0,2696 & 0,2854 \\
1955 & 20,464 & 6184 & 0,3309 & 0,2972 \\
1956 & 25,145 & 6925 & 0,3631 & 0,3090 \\
1957 & 23,031 & 7245 & 0,3178 & 0,3208 \\
1958 & 22,436 & 7268 & 0,3086 & 0,3326 \\
1959 & 23,866 & 7047 & 0,3373 & 0,3444 \\
1960 & 26,866 & 8043 & 0,3340 & 0,3562 \\
1961 & 22,700 & 8609 & 0,2636 & 0,3680 \\
1962 & 39,240 & 9398 & 0,4175 & 0,3798 \\
1963 & 44,254 & 10824 & 0,4088 & 0,3916 \\
1964 & 56,057 & 12691 & 0,4417 & 0,4034 \\
1965 & 65,950 & 14580 & 0,4523 & 0,4152 \\
1966 & 76,664 & 16175 & 0,4739 & 0,4270 \\
1967 & 83,742 & 18303 & 0,4575 & 0,4388 \\
1968 & 92,602 & 20852 & 0,4440 & 0,4506 \\
1969 & 103,790 & 23259 & 0,4462 & 0,4624 \\
1970 & 113,657 & 27284 & 0,4165 & 0,4742 \\
\hline
\end{tabular}

Opmerking: De vergelijking voor de voorspelde ratio luidt:

$Y_{t}=0,003562+0,000118 X$.

De waarde van de tijdvariabele $x$ wordt bepald met een berekening van de tijdswaarde in jaren vanaf de oorsprong.

Bron: Organisatie TNO, Verslagen van 1956 tot en met 1970.

CBS, Negentig jaren statistiek in tijareeksen, 18991989, SDU Uitgeverij, 's-Gravenhage, 1989, p. 166. 
Bijlage 5.2 Investeringsgroei TNO en Staatsmijnen 1953 tot en met 1966.

\begin{tabular}{lrrrr}
\hline Jaar & Staatsmijnen & \multicolumn{1}{c}{ Index } & TNO & Index \\
\hline & x1000 gld & $1966=100$ & x1000 gld & $1966=100$ \\
1953 & & & & \\
1954 & 1171 & 108,8 & 2805 & 7,4 \\
1955 & 365 & 33,9 & 2816 & 7,4 \\
1956 & 79 & 7,3 & 6264 & 16,5 \\
1957 & 699 & 65,0 & 7101 & 18,8 \\
1958 & 1557 & 144,7 & 10709 & 28,3 \\
1959 & 637 & 59,2 & 11390 & 30,1 \\
1960 & 238 & 22,1 & 11358 & 30,0 \\
1961 & 685 & 63,7 & 15603 & 41,2 \\
1962 & 2424 & 225,3 & 18249 & 48,2 \\
1963 & 2231 & 207,3 & 21599 & 57,0 \\
1964 & 4934 & 485,5 & 25791 & 68,1 \\
1965 & 3909 & 363,3 & 35461 & 93,7 \\
1966 & 1072 & 99,6 & 43285 & 114,4 \\
\hline
\end{tabular}

Bron: Staatsmijnen, Bedrijfseconomische verslagen van 1953 tot en met 1966 .

Organisatie TNO, Verslagen van 1954 tot en 1966. 
Bijlage 5.3 Groei bouwkosten en kapitaalsubsidie.

\begin{tabular}{lccc}
\hline Jaạ & $\begin{array}{l}\text { Prijsindex } \\
\text { bouwkosten }\end{array}$ & $\begin{array}{l}\text { Kapitaal } \\
\text { subsidie }\end{array}$ & $\begin{array}{l}\text { Index kapitaal } \\
\text { subsidie }\end{array}$ \\
\hline & $1966=100$ & $\times 1000$ gld & $1966=100$ \\
1952 & 52 & 775 & 3 \\
1953 & 52 & 1200 & 5 \\
1954 & 55 & 1500 & 7 \\
1955 & 62 & 3000 & 14 \\
1956 & 69 & 3915 & 18 \\
1957 & 72 & 7248 & 33 \\
1958 & 69 & 8775 & 40 \\
1959 & 69 & 12000 & 54 \\
1960 & 69 & 17400 & 79 \\
1961 & 73 & 20000 & 91 \\
1962 & 77 & 20000 & 91 \\
1963 & 83 & 16000 & 93 \\
1964 & 90 & 21100 & 91 \\
1965 & 94 & 20000 & 100 \\
1966 & 100 & 22000 & 100 \\
1967 & 100 & 22000 & 104 \\
1968 & 107 & 23000 & 94 \\
1969 & 121 & 20600 & 97 \\
1970 & 131 & 21470 & \\
\hline
\end{tabular}

Bron: Organisatie TNO, Verslagen van 1956 tot en met 1970 .

CBS, Negentig jaren statistiek in tijdreeksen, 18991989, SDU Uitgeverij, 's-Gravenhage, 1989, p. 197. 


\section{Hoofdstuk 6}

\section{samenvatting en conclusie}

\subsection{Inleiding}

Dit slothoofdstuk sluit aan bij de theoretische inzichten uit hoofdstuk 2 en bouwt voort op de bevindingen van het prestatie-onderzoek naar de Staatsmijnen, de NV Nederlandse Spoorwegen en de Nederlandse Centrale organisatie voor toegepast-natuurwetenschappelijk onderzoek.

Paragraaf 6.2 bespreekt de ondoorzichtigheid van de Nederlandse publieke sector van het bedrijfsleven en het prestatie-onderzoek. Paragraaf 6.3 behandelt de resultaten van de structuuranalyses van de drie onderzochte overheidsbedrijven. Daarnaast wordt ingegaan op de relevante theorie. De analyse van de kenbaar gemaakte doeleinden komt aan de orde in paragraaf 6.4. De kosten van de kenbaar gemaakte doeleinden en de relatie tot de efficiëntie worden nader besproken in paragraaf 6.5 . In paragraaf 6.6 vindt een behandeling plaats van de mogelijkheden tot privatisering. De verklaring van de prestaties en de reacties van de principalen staan centraal in paragraaf 6.7. Tot slot komt de beleidsadvisering aan de orde in paragraaf 6.8 .

\section{2 ondoorzichtigheid en prestatie-analyse}

De Nederlandse publieke sector van het bedrijfsleven ontstond rond 1900 en kenmerkte zich tot op heden door een zekere mate van ondoorzichtigheid. Aan een systematisch en consistent beleid ten aanzien overheidsbedrijven had het volgens Rosenthal en Reinders in Nederland ontbroken. $\mathrm{zij}$ stelden dat het Nederlandse industriebeleid, anders dan het Franse, niet had getracht specifieke bedrijfstakken te ontwikkelen. Het beleid beperkte $z i c h$ hoofdzakelijk tot het verlenen van steun aan in nood verkerende bedrijfstakken. De beleidsvisie van de Nederlandse overheid op industriebeleid stond verwoord in de Nota inzake de Selectieve Groei. Hierin bleef volgens hen buiten beschouwing de mogelijkheid van een beleid gericht op het opzetten van overheidsbedrijven. Daarnaast stelden $z i j$ dat over het nut of de noodzaak van interdepartementale coördinatie van Nederlandse overheidsbedrijven viel te twisten. Hetzelfde gold voor het idee om een ministerie voor overheidsbedrijven in te stellen onder de Nederlandse verhoudingen. In Nederland waren volgens Rosenthal en Reinders de meest elementaire pogingen om tot onderling overleg en tot uitwisseling van informatie te komen afwezig. 618

Vanaf de jaren dertig bestond er een tendens om de financiële middelen van de rijksoverheid te beheren met organisaties, die beschikten over privaatrechtelijke rechtspersoonlijkheid, in het bijzonder stichtingen. Na 1945 groeide het aantal onder toezicht van de rijksoverheid staande naamloze vennootschappen. De ontwikkeling van de publieke sector van het bedrijfsleven vond plaats in de schaduw van een debat over socialisatie en winstneming door 
overheidsbedrijven.

De begrotingen van de naamloze vennootschappen, waarin de rijksoverheid participeerde, kwamen niet aan de orde in de staten-Generaal. Deze lacune droeg bij tot het voortduren van de ondoorzichtigheid. De staten-Generaal en de Algemene Rekenkamer trachtten inzicht te verkrijgen in het functioneren van overheidsbedrijven. De Algemene Rekenkamer publiceerde vanaf 1966 een overzicht met enkele bedrijfseconomische gegevens van overheidsdeelnemingen. Daarvoor publiceerde $z i j$ slechts in haar verslagen over 1950 en 1960 overzichten. Uit het verslag over 1950 blijkt dat de rijksoverheid in 24 ondernemingen participeerde. zij vermeldde in dit verslag alleen het aandelenkapitaal, het geplaatste kapitaal en de omvang van het rijksaandeel. Deze verslaglegging bevorderde geen beter inzicht in de publieke sector van het bedrijfsleven.

Het eeste lid van artikel 80 van de Comptabiliteitswet van 1976 machtigde de Algemene Rekenkamer om overlegging te vorderen van jaarrekeningen van privatrechtelijke rechtspersonen na tussenkomst van de betrokken minister. Voorwaarde was dat de rijksoverheid voor tenminste de helft deelnam in het kapitaal. Lid vier van dit artikel regelde een door Algemene Rekenkamer in te stellen onderzoek bij een privaatrechtelijke rechtspersoon. Een onderzoek bij een naamloze vennootschap behoorde slechts tot de mogelijkheden, indien alle aandelen in eigendom an de rijksoverheid toebehoorden en een afzonderlijke wettelijke regeling niet in de weg stond. ${ }^{619}$ Artikel 80 kon dus niet worden toegepast op "gouden aandeel" constructies, war de rijksoverheid op grond van een minderheidsbelang bevoegd was over specifieke beleidsaangelegenheden een doorslaggevende stem uit te brengen. In 1988 vond een wettelijke wijziging plaats van artikel 80 . De Algemene Rekenkamer verwierf controle bevoegdheden bij onder andere naamloze vennootschappen, warvan de staat ten minste 5 procent van het geplaatste aandelenkapitaal bezat. Hierbij gold als voorwaarde dat er sprake moest zijn van een belang van 1 miljoen gulden of meer. ${ }^{620}$

De Wet openbaarheid van bestuur van 1978 was niet van toepassing op overheidsbedrijven met een privaatrechtelijke rechtspersoonlijkheid. Tijdens de behandeling van deze wet in de staten-Generaal werden in deze context met name de NV staatsmijnen en de NV Nederlandse spoorwegen genoemd. De nieuwe Wet openbaarheid van bestuur van 1991 bracht in deze situatie geen verandering. Informatie over overheidsbedrijven op verzoek van burgers wordt verstrekt als het bedrijf onder de verantwoordelijkheid van een minister valt. overheidsbedrijven met een privatrechtelijke rechtspersoonlijkheid, die beschikken over een eigen bestuur, functioneren in beginsel onafhankelijk van de minister. $2 i j$ vallen niet onder de verantwoordelijkheid van de minister, tenzij anders is bepaald. ${ }^{621}$

Het Verdrag van de Europese Economische Gemeenschap van 1957 verbood de lidstaten matregelen te nemen, die de mededinging binnen de gemeenschappelijke markt vervalsten of verhinderden. Artikel 90 plaatste overheidsbedrijven onder de 
werking van dit verdrag. Dit artikel verbood de lidstaten matregelen te nemen ten behoeve van overheidsbedrijven in strijd met de regels van het verdrag. Het derde lid van artikel 90 machtigde de Europese Commissie om met richtiijnen of beschikkingen uitvoering te geven aan de bepalingen van dit artikel. In 1980 en 1985 trachtte de Europese Commissie de publieke sector van het bedrijfsleven doorzichtiger te maken met richtlijnen, waarmee $2 i j$ de lidstaten verplichtte opening van zaken te geven over de toekenning en de besteding van openbare middelen. ${ }^{62} \mathrm{Zij}$ introduceerde in 1991 een nieuw rapportagesysteem binnen de bestaande regelgeving, omdat haar beleid niet succesvol was gebleken.623

In de leer der openbare financiën worden twee visies op de staat onderscheiden, namelijk de fiscale staat en de staat als ondernemer. De Nederlandse overheid treedt in beide rollen op. De staat als ondernemer was een belangrijke werkgever binnen de overheid, afgemeten aan het aandeel van de staatsmijnen en de PTT. Keyser en windle schatten het percentage van de werkgelegenheid in deze sector in de totale Nederlandse werkgelegenheid met inbegrip van de werkgelegenheid bij de PTT (exclusief rijksambtenaren) op 6,6 procent in 1970.624 Als bron van inkomsten speelden overheidsbedrijven een bescheiden rol. In 1970 bedroegen de dividenden, uitgekeerd aan de rijksoverheid, slechts 0,6 procent van de totale overheidsinkomsten in 1970.

De ondoorzichtigheid biedt de ministers, die beschikken over de eigendomsrechten in overheidsbedrijven, de gelegenheid om naast de wettelijke en statutaire doeleinden andere doeleinden na te streven. De mogelijkheid om andere doeleinden na te streven, behoort tot de beleidsvrijheid van de betrokken ministers en brengt kosten met zich mee. Deze doeleinden kunnen slechts worden vastgesteld met behulp van case-studies. In dit onderzoek is de keuze gevallen op het verrichten van case-studies naar het staatsbedrijf der staatsmijnen (later: NV Staatsmijnen), de NV Nederlandse spoorwegen en de Nederlandse Centrale organisatie voor toegepastnatuurwetenschappelijk onderzoek. De probleemstelling van dit onderzoek luidde derhalve:

Welke andere doeleinden makten de politieke eigenaren van de Staatsmijnen, de NV Nederlandse Spoorwegen en de Nederlandse Centrale Organisatie voor toegepast-natuurwetenschappelijk onderzoek, naast een voldoende realisatie van de wettelijke en statutaire doeleinden, kenbaar vanaf hun oprichting tot en met 1970 ?

De beleidswetenschap besteedt aandacht aan de toepassing van combinaties van kwantitatieve en kwalitatieve evaluatiemethoden in het doeleindenonderzoek. Voor verschillende onderdelen van een evaluatie-onderzoek kunnen diverse methoden worden toegepast. Het is echter ook mogelijk te trachten één onderzoeksvraag te beantwoorden met een kwantitatieve en een kwalitatieve methode. In de literatuur staat deze benadering bekend als triangulatie.

Het aantal in dit onderzoek bestudeerde overheidsbedrijven is niet representatief voor de Nederlandse publieke sector van 
het bedrijfsleven. Het toepassen van een combinatie van een kwantitatieve en een kwalitatieve prestatie-analyse in casestudies sluit statistische generalisaties over de prestaties van overheidsbedrijven uit. Case-studies maken analytische generalisaties mogelijk, dit wil zeggen het generaliseren van de resultaten van het onderzoek naar een bredere theorie, 625 bijvoorbeeld de theorievorming over agentschappen.

De huidige stand van zaken in de kwantitatieve prestatieanalyse biedt slechts de mogelijkheid algemene uitspraken te doen over de efficiëntie in een bepalde bedrijfstak of over de intertemporele efficiëntie van een overheidsbedrijf.

De kwalitatieve prestatie-analyse leidt tot de verzameling en verwerking van een uitgebreide hoeveelheid informatie, waarover in de economische en de politicologische literatuur nog niet veel is gepubliceerd.

In dit onderzoek vond de beantwoording van de probleemstelling plaats vanuit het perspectief van de economische theorie van de eigendomsrechten en de economische theorie van de politieke besluitvorming. Daartoe werden, voor zover mogelijk, een kwantitatieve en een kwalitatieve prestatie-analyse gecombineerd. De kwantitatieve prestatieanalyse werd toegepast bij de behandeling van de technische efficiëntie in de paragraaf over beleidsvrijheid. De toepassing van beide soorten van analyse in case-studies draagt bij aan de ontwikkeling, de verfijning en de toetsing van de theorievorming over overheidsbedrijven.

Bijdragen aan de ontwikkeling van de kwantitatieve prestatie analyse leverden de Belgische economen Perelman, pestieau en Tulkens. Zij ontleenden de doeleinden van overheidsbedrijven aan de algemeen economische politiek. Hun onderzoek beperkte zich echter tot het vaststellen van de mate van technische efficiëntie. Daartoe bepaalden zij eerst de produktiefunctie van het overheidsbedrijf met behulp van de regressietechniek. Vervolgens leidden $z i j$ met de verkregen resultaten een omhullende curve van de produktiemogelijkheden af. Zij drukten de mate van efficiëntie uit als de ratio tussen de werkelijke produktie en de produktiemogelijkheden, gelegen op de curve. Pestieau sluit de constructie van een multicriteria prestatie-variabele momenteel nog uit. Een dergelijke prestatie-variabele houdt in de operationalisatie en de aggregatie van alle doeleinden. Een van de belemmerende factoren betreft hier de moeilijke beschikbaarheid van gegevens. ${ }^{626}$

De kwalitatieve prestatie-analyse laat zich combineren met de kwantitatieve prestatie-analyse. Zij heeft haar oorsprong in de door Alchian en Demsetz ontwikkelde economische theorie van de eigendomsrechten. ${ }^{62}$ De kwalitatieve prestatie-analyse bestaat uit drie fasen, namelijk een analyse van de structuur, een analyse van de doeleinden en een analyse van de wisselwerking tussen de verklaring die het overheidsbedrijf geeft voor haar prestaties en de reacties van de principalen hierop.

Het verschil tussen het in dit onderzoek toegepaste prestatie-onderzoek en de wetenschappelijke beleidsevaluatie is dat de laatstgenoemde één specifieke beleidsactiviteit evalueert. De prestatie-analyse tracht meerdere 
beleidsactiviteiten te achterhalen en te evalueren. De wetenschappelijke beleidsevaluatie besteedt aandacht aan de rol van de beleidsinstrumenten voor het succes van het beleid.

Dit element moet in de prestatie-analyse van overheidsbedrijven nader worden ontwikkeld. De economische literatuur benadrukt nog teveel de instrumentele rol van het overheidsbedrijf.

\section{3 structuuranalyse}

De structuuranalyse van de drie bestudeerde overheidsbedrijven richtte zich op de verdeling van de publieke eigendomsrechten. Deze analyse behandelde het recht om:

(1) toezicht uit te oefenen op de aankopen en de prestaties van de produktiefactoren,

(2) toezicht uit te oefenen op de produktieresultaten,

(3) toezicht uit te oefenen op de externe effecten,

(4) toezicht uit te oefenen op het produktieproces,

(5) toezicht uit te oefenen op de samenstelling en de omvang van het team van producenten, en

(6) aanspraak te maken op de winst.

Het was niet altijd mogelijk de bovengenoemde vragen theoretisch en empirisch even uitgebreid te beantwoorden. Toch resulteerde uit de beantwoording van deze vragen een bepaald economisch beheersmodel voor overheidsbedrijven. In 1933 ontwikkelde $\mathrm{H}$. Morrison, Minister van verkeer voor de Britse Labour partij van 1929 tot en met 1931, een beheersmodel voor overheidsbedrijven: de "public corporation". Morrison brak met de in de jaren twintig bestaande opvatting binnen de Britse Labour partij dat het kabinet en de vakbeweging samen het overheidsbedrijf zouden moeten besturen. Zijn model bevatte twee elementen, namelijk het toezicht en de financiering. Het overheidsbedrijf mocht niet onderhevig zijn aan druk van politici en belangengroeperingen. $\mathrm{Hij}$ wees om deze reden participatie van werknemers in de besluitvorming van het bedrijf af. Het overheidsbedrijf had tot taak het algemene belang te bevorderen. Morrison gaf geen definitie van het algemene belang. De minister onderhield contact met de directie op basis van goede wil en traditie, maar intervenieerde niet in de dagelijkse bedrijfsvoering. De minister was voor de bedrijfsvoering verantwoording schuldig aan de volksvertegenwoordiging. In de visie van Morrison was het overheidsbedrijf geen kapitalistische onderneming, die streefde naar winst en dividenduitkeringen. Het bedrijf moest zichzelf kunnen financieren (het zogenaamde "sinking fund" beginsel). ${ }^{628}$ De economische literatuur interpreteerde deze vorm van bedrijfsvoering als "break-even"-exploitatie, hetgeen een produktie-omvang inhield warbij de totale opbrengsten gelijk waren aan de totale kosten. Deze omvang van de produktie versterkte de onafhankelijke positie tegenover het kabinet, omdat de financiële administratie werd gescheiden van de overheidsbegroting. ${ }^{629}$ 
(1) Toezicht op de aankopen en de prestaties van de produktiefactoren.

De ministeriële instructie van 1937 voor de directie van de Staatsmijnen kende de Minister van Economische Zaken het recht toe om te beslissen over het aankopen van produktiefactoren. ${ }^{6.30}$ Deze instructie leidde tot het ontstaan van een ingewikkeld stelsel van interne en externe machtigingen. De directie vermeldde de aankoop van produktiefactoren (aanlegwerken) in de kapitaalbegroting, waarover de Minister van Economische Zaken verantwoording schuldig was aan de staten-General.

De Concessie tot exploitatie van spoor- en tramwegen van 1937 verstrekte de Minister van waterstaat het recht om toezicht uit te oefenen op de aanschaf van rollend materieel. ${ }^{631}$ Daarnaast gaven de Statuten van 1937 de Raad van Commissarissen de bevoegdheid om toezicht op de aankopen uit te oefenen met behulp van de vaststelling van de begroting. De Raad van Commissarissen diende haar goedkeuring te hechten aan de aanschaf van rollend materieel, exploitatie-inrichtingen en het aangaan van werken boven een bedrag van tienduizend gulden.632 In de statuten van 1964 kwam deze regeling niet meer voor.

Bij de Nederlandse Centrale organisatie voor toegepast natuurwetenschappelijk onderzoek hield het bestuur van de Centrale organisatie toezicht op de aankopen met de vaststelling van de jaarlijkse begroting van de uitgaven. ${ }^{633}$ De ministeriële gedelegeerden beschikten slechts over het recht om zich te verzetten tegen de besteming van de overheidssubsidie. ${ }^{634}$

(2) Toezicht op de produktieresultaten.

In 1920 begonnen de staatsmijnen met een wetenschappelijke bedrijfsvoering. De directie splitste het ondergrondse bedrijf in een staf- en een uitvoeringsinstantie. Elk mijnbedrijf stelde een vijfjarenplan op voor de ontginning, de ontsluiting, de voorbereiding en de afbouw, met daaraan toegevoegd een kolenvoorraadplan. ${ }^{65}$ De (hoofd)directie vermeldde ramingen van de produktie van kolen en chemische produkten in de voor de staten-Generaal bestemde begroting. Tijdens de behandeling van de begroting maakten leden van de staten-Generaal gebruik van hun recht om vragen te stellen over de produktie.

Voor het vaststellen van de produktieresultaten van de NV Nederlandse spoorwegen kunnen diverse matstaven worden onderscheiden. In 1962 stelde de directie de Minister van Verkeer en Waterstaat ervan in kennis overeenstemming te hebben bereikt met de Personeelsraad over de wijziging van het Reglement dienstvoorwaarden van 1956. $\mathrm{zij}$ kwamen overeen dat voor het openbaar vervoerbedrijf NV Nederlandse Spoorwegen produktiviteitsgegevens als criterium voor loonsverhoging niet zonder meer van toepassing konden zijn. Beiden beschouwden de produktiviteit op basis van geproduceerde treinkilometers als een minder aanvechtbaar gegeven dan produktiviteit op basis van toegevoegde waarde. ${ }^{636}$ De treinkilometers zouden de 
prestaties van het personeel het duidelijkst naar voren doen komen. ${ }^{637}$

In het kader van de collectieve arbeidsovereenkomst van 1965 begon op 1 april van dat jaar de Regeling algemene prestatiebeloning voor de duur van drie jaar. Het toezicht op de Regeling algemene prestatiebeloning berustte bij een begeleidingscomissie, bestaande uit drie vertegenwoordigers van de NV Nederlandse Spoorwegen en drie vertegenwoordigers van de Personeelsraad. De commissie had onder andere tot taak de resultaten van deze regeling maandelijks vast te stellen. ${ }^{638}$ Opvallend was dat in 1962 de directie en de Personeelsraad de voorkeur gaven aan geproduceerde treinkilometers (een a anbodvariabele) als produktiviteitscriterium. Drie jaar later bij de afsluiting van de collectieve arbeidsovereenkomst. wordt echter gebruik gemakt van het aantal reizigerskilometers (een vraagvariabele) als eên van produktiviteitscriteria.

Uit het onderzoek naar de Nederlandse Centrale organisatie voor toegepast-natuurwetenschappelijk onderzoek bleek niet welke functionarissen toezicht uitoefenden op de resultaten van wetenschappelijke produktie.

In 1967 vormden de groei van de subsidie en de financiële problemen van de rijksoverheid aanleiding voor de gedelegeerde van de Minister van Financiën on aan te dringen op een evaluatie van de resultaten van de TNO-instituten bij de voorzitter van de Centrale organisatie TNO. Prestatiemeting door vergelijking van de kosten en de opbrengsten was volgens deze gedelegeerde voor de TNo-instituten in bijna alle gevallen niet mogelijk. Hij stelde onder andere de volgende maatstaven voor: de verhouding tussen het bedrag aan verkregen opdrachten en de totale uitgaven, de verhouding tussen uitgaven en het aantal per instituut gedane uitvindingen, en de mate van toepassing van TNO-uitvindingen in het bedrijfsleven. ${ }^{639}$ Het toezicht op de resultaten van de Nederlandse Centrale organisatie TNO met behulp van prestatiemeting moest in de bestudeerde periode nog tot ontwikkeling worden gebracht.

(3) Toezicht op de externe effecten.

Het toezicht op de externe effecten is verspreid over diverse belanghebbenden, al naar gelang het type van extern effect.

(4) Toezicht op het produktieproces.

De Staatsmijnen en de NV Nederlandse Spoorwegen waxen hiërarchisch gestructureerde ondernemingen. Beide bedrijven kenden een stelsel van boetes om het produktieproces te beheersen. Over het toezicht op het produktieproces bij de organisatie voor toegepast-natuurwetenschappelijk onderzoek kon geen informatie worden gevonden in de verzamelde documenten. 
(5) Toezicht op de samenstelling en de omvang van het team van producenten.

Vanaf 1913 deelden de Kroon en de directie het toezicht op de samenstelling en de omvang van het team van producenten bij de Staatsmijnen. De minister stelde de beambten aan en beëindigde hun dienstbetrekking. De directie nam de werknemers in dienst. ${ }^{640}$ De staten-Generaal oefenden toezicht uit op de samenstelling en de omvang van het team van producenten met het vragen- en budgetrecht. Vanaf 1967 nam de directie al het personeel in dienst. $\mathrm{Zij}$ had de goedkeuring van de Raad van Commissarissen nodig voor het beëindigen van de dienstbetrekking van een aanmerkelijk aantal werknemers. ${ }^{641}$

In het geval van de NV Nederlandse Spoorwegen oefenden de Staten-Generaal, het Ministerie van Verkeer en Waterstaat, de directie en de Personeelsraad toezicht uit op de samenstelling van het team van producenten. De Staten-Generaal konden geen gebruik maken van het budgetrecht, omdat de NV Nederlandse spoorwegen als privaatrechtelijke rechtspersoon niet verplicht was een begroting te overleggen. De leden van de statenGeneraal beschikten slechts over het vragenrecht om toezicht uit te oefenen. De Concessie van 1937 bepaalde dat de beambten van de onderneming de Nederlandse nationaliteit moesten bezitten, tenzij de verantwoordelijke minister zijn instemming verleende om van deze bepaling af te wijken. ${ }^{642}$

Een regeling over het uitoefenen van toezicht op de samenstelling en de omvang van het personeel bij de Nederlandse Centrale organisatie voor toegepast natuurwetenschappelijk onderzoek werd tijdens dit onderzoek niet aangetroffen. Ook hier konden de leden van de statenGeneraal slechts gebruik maken van het recht van vragen. Het recht van het bestuur van de Centrale organisatie om de begroting van de gehele organisatie vast te stellen bood haar de mogelijkheid indirect de omvang van het team van producenten te beinvloeden.

\section{(6) Aanspraak op de winst.}

Het recht om aanspraak te maken op de winst moest worden onderscheiden van de winstbestemming. De minister kon de winst bestemmen voor bepaalde doeleinden. Met het dividendvoorstel kon de directie van een overheidsbedrijf aan de minister kenbaar maken hoe zij over de gang van zaken binnen het bedrijf oordeelde en welke maatregelen zij van hem verwachtte.

De staat beschikte over het recht om aanspraak te maken op de winst van de staatsijijen. De (hoofd)directie deed jaarlijks een voorstel over de winstbestemming aan de minister van Economische Zaken toekomen. De minister besloot over de winstbestemming, na overleg met de Minister van Financiën. De bestemming van de winst omvatte de vennootschapsbelasting, het dividend, de uitkering aan het personeel, de voorziening bijzondere doeleinden en de algemene reserve. ${ }^{643}$

De directie beschikte over het recht om aanspraak te maken op de winst in de vorm van een premie- en tantièmeregeling. De vakorganisaties in de mijnbouw trachtten een recht op de winst te verkrijgen in de vorm van winstdelingen en spaarregelingen. 
Deze aanspraken pasten in het overheidsbeleid gericht op bezitsvorming. $2 i j$ verschilden onderling van mening over de voorwaarden, waarop de dotaties aan de spaarregeling ten goede kwamen aan het personeel. ${ }^{44}$

Tot 1956 beinvloedde de vrijstelling van de vennootschapsbelasting de winst van de NV Nederlandse Spoorwegen. De statuten van 1937, zoals gewijzigd in 1943 en 1964, regelden de winstbesteming. De rijksoverheid had recht op een dividend als de reserves waren aangevuld en het tekort in het Spoorwegpensioenfonds was gecompenseerd. ${ }^{645}$

In 1961 creëerde het college van Rijksbemiddelaars de mogelijkheid tot het toekennen van een uitkering aan het personeel uit de bedrijfsresultaten voor een periode van twee jaar. De vakverenigingen beschouwden deze regeling als een mogelijkheid voor hun leden om bezit te vormen. De Personeelsraad wilde in 1962 deze regeling continueren. $\mathrm{zij}$ was, gegeven de liquiditeitspositie van het bedrijf, bereid medewerking te verlenen aan een regeling om het uit te keren bedrag tijdelijk in de onderneming te houden. ${ }^{646}$

De TNO-Wet van 30 oktober 1930 bevatte geen bepalingen over besluitvorming met betrekking tot winstuitkeringen. Aan het personeel werden ook geen uitkeringen in de vorm van premies of gratificaties gedaan. Uit de bestudeerde documenten is gebleken dat de problematiek van de bezitsvorming niet aan de orde kwam in deze organisatie en ook niet in de relatie tussen het bestuur van de centrale organisatie en het Ministerie van Financiën.

Uit de bovenstaande structuuranalyse blijkt dat de ministers niet intervenieerden in de dagelijkse bedrijfsvoering. In dit opzicht sluit de Nederlandse beheersvorm aan bij het model van Morrison. Beschikt de directie van een overheidsbedrijf over een recht om aanspraak te maken op de winst in de vorm van premies of tantièmes, dan verschilt de beheersvorm met het model van Morrison. De directie van de staatsmijnen beschikte over een dergelijk recht. Het Britse overheidsbedrijt kon volstaan met een "break-even"-produktie.

Het model van Morrison faalde in Groot-Brittanniẻ om twee redenen. Ten eerste bleek het onmogelijk de onafhankelijkheid van het overheidsbedrijf ten opzichte van het kabinet te handhaven. De ministers bemoeiden $z$ ich in toenemende mate met de dagelijkse bedrijfsvoering. Ten tweede beschouwden opeenvolgende kabinetten overheidsbedrijven als instrumenten van het algemeen economische en industriële beleid. of?

De opvatting dat de Nederlandse rijksoverheid meer invloed had op particuliere ondernemingen dan op overheidsbedrijven verklaarde waarschijnlijk mede het ontbreken van een kabinetsbeleid. Hik Hieruit kan worden geinterpreteerd dat kabinetten meer invloed zouden willen hebben op overheidsbedrijven. Ministers slaagden er niet in hun doeleinden kenbaar te maken of werden door hun ervaringen hier niet toe gestimuleerd. Het beleid, gericht op overheidsbedrijven, kreeg hierdoor een ad hoc karakter. De relaties tussen de ministers en de directies danwel de besturen van de onderzochte bedrijuen konden dan ook niet 
altijd gevrijwaard blijven tegen spanningen. Voorbeelden van spanningen waren: het voorstel van de directie van de staatsmijnen aan de Minister van Financiën om een wijziging aan te brengen in de wet op de dividend- en tantièmebelasting van $1917^{649}$, de afwijzende houding van het kabinet-Drees III tegen de subsidiëring van kerkgenootschappen door de staatsmijnen ${ }^{650}$, het vraagstuk of de kosten van de automatische treinbeinvloeding tot de bedrijfsvreemde lasten behoorden 651, en het verzoek van de directie van de NV Nederlandse spoorwegen om alle openbare dienstverplichtingen in het goederen- en reizigersvervoer op basis van EEGverordening $1191 / 69$ op te heffen ${ }^{652}$. Een directie van een overheidsbedrijf kon via de media politieke druk teweegbrengen over beleid, waarover het kabinet nog geen besluit had genomen. Tegenspraak door het kabinet stond gelijk aan het loochenen van zijn beleidsvoorbereiding, terwijl bevestiging naar buiten toe de indruk wekte de beslissingsbevoegdheid uit handen te hebben gegeven. ${ }^{653}$

Het feit dat de structuranalyse niet veel doeleinden oplevert, bevestigt de geringe invloed van de politiek verantwoordelijke ministers en het bestaan van alternatieve beleidsinstrumenten. De beantwoording van de vragen uit de structuuranalyse leidde tot de identificatie van verschillende categorieën belanghebbenden, zoals ministers, leden van de staten-Generaal, Algemene Rekenkamer, Raden van Commissarissen, directies en vakorganisaties. Volgens de economische theorie van de eigendomsrechten kunnen de ministers overheidsbedrijven als beleidsinstrument aanwenden, voorzover $z i j$ beschikken over de publieke eigendomsrechten. De identificatie van de belanghebbenden kan worden verbonden met bepaalde onderdelen van de economische theorie, die in de navolgende punten (1) tot en met (5) nog eens wordt behandeld.

(1) Toezicht op de aankopen en de prestaties van de produktiefactoren.

Het recht om toezicht te houden op de aankopen van overheidsbedrijven heeft aanknopingspunten met de theorie van het bilaterale monopolie bij een protectionistisch overheidsbeleid op bepaalde markten en de toepassing van de marginale kosten bij de besluitvorming over de prijzen en de investeringen.

Protectie van de nationale industrie is in strijd met het Europese recht. De lidstaten oefenen volgens dit recht toezicht uit over de activiteiten van hun overheidsbedrijven. De ondergeschikte positie van het overheidsbedrijf betekent dat de lidstaat verantwoordelijk wordt geacht voor de activiteiten van het overheidsbedrijf. Handelt een overheidsbedrijf in strijd met de verdragsbepalingen op grond van instructies van de nationale autoriteiten, dan wordt de lidstaat geacht te hebben gehandeld. Overheden zouden volgens P.S. Mathijsen de verleiding wel eens niet kunnen weerstaan om hun bedrijven te instrueren over te gaan tot activiteiten, die voor hen zelf verboden zijn. Artikel 30 over kwantitatieve beperkingen zou hiervan een voorbeeld zijn. ${ }^{64}$ Protectionisme heeft $z i c h$ echter toch voorgedaan in de wagonindustrie van de 
lidstaten van de Europese Gemeenschap. Een voorbeeld hiervan zijn de orders van de Deutsche Bundesbahn aan het bedrijf Linke-Hoffman-Busch GmbH, een dochteronderneming van het overheidsbedrijf Salzgitter AG. ${ }^{655}$

Nationale overheden hebben er belang bij dat overheidsbedrijven hun orders plaatsen bij de nationale toeleveringsbedrijven, in plaats van het materieel zelf te produceren of te importeren. De redenen voor aanbesteding bij nationale toeleveringsbedrijven zijn bijvoorbeeld het behoud van de werkgelegenheid, het bevorderen van inkomensherverdeling, het stimuleren van innovatie en het verminderen van de afhankelijkheid van het buitenland. De methoden ter beïnvloeding van het aankoopbeleid bestaan onder andere uit met redenen omklede verzoeken om een ministeriële machtiging voor het plaatsen van een order in het buitenland (het stelsel van externe machtiging bij de staatsmijnen voor 1955) en uit aankoopverplichtingen bij nationale toeleveringsbedrijven (een beleidsoptie in de problematiek over de fabriek Werkspoor-Utrecht).

De marktrelatie tussen het overheidsbedrijf en het toeleveringsbedrijf kan de vorm aannemen van een bilateraal monopolie. Het overheidsbedrijf treedt in deze relatie op als monopsonist. Beide ondernemingen onderhandelen over de prijs en de hoeveelheid investeringsgoederen. In Nederland benaderde de relatie tussen de NV Nederlandse Spoorwegen en de fabriek Werkspoor-utrecht het bilaterale monopolie.

Loyaliteit aan het kabinetsbeleid of in het uiterste geval een aankoopverplichting brengen een prijsverschil tussen het nationale en buitenlandse toeleveringsbedrijf met zich mee. Dit verschil is de bedrijfsvreemde last. Uit de statische analyse van de welvaartseffecten blijkt het bestaan van een maximale en een minimale bedrijfsvreemde last. De plaatsing van een order bij het nationale toeleveringsbedrijf heeft een daling van de rentabiliteit van het overheidsbedrijf tot gevolg. De daling van de rentabiliteit kan door de directie van het overheidsbedrijf worden voorkomen door het buitenlandse bedrijf te gebruiken als prijsbreker tijdens de oriëntatie bij het nationale toeleveringsbedrijf. Bij geringe verschillen ging de voorkeur van de $N V$ Nederlandse Spoorwegen uit naar de Nederlandse wagonindustrie.

Een andere optie biedt de verticale integratie van het toeleveringsbedrijf in het overheidsbedrijf, waarbij in het geval van een verliesgevende produktie gebruik kan worden gemaakt van kruiselingse subsidies. De financiële positie van de NV Nederlandse Spoorwegen sloot deze methode van financieren uit. Het kabinet-De Jong stelde zich op het standpunt dat er geen bestaansgrond meer was voor een Nederlandse wagonindustrie. ${ }^{656}$ De laatste Nederlandse wagonproducent verdween.

Het plaatsen van een order bij een toeleveringsbeclrijf komt voort uit het besluit on de bestaande produktiecapaciteit in stand te houden of uit te breiden. De produktiecapaciteit wordt uitgebreid totdat de marginale kosten op de lange termijn gelijk zijn aan de marginale kosten op de korte termijn en de prijs. In empirisch onderzoek worden de marginale kosten benaderd met het quotiënt van de jaarlijkse 
totale kosten- en volumeverschillen. Het overheidsbedrijf moet op beide tijdstippen de minimale kosten realiseren. Het produktievolume heeft in de jaarverslaggeving meestal betrekking op een langere periode (één jaar), waarin ook de capaciteit wordt veranderd. De empirische benadering houdt dan de vaststelling in van de marginale kosten op lange termijn. ${ }^{657}$ De gebruikte data zijn echter historische kosten in plaats van alternatieve kosten.

Een probleem bij de NV Nederlandse Spoorwegen was de juiste omvang van de investeringen te achterhalen. Het bedrijf activeerde de bovenbouwactiva niet, mar boekte deze als exploitatiekosten onder de post "instandhouding bovenbouw". ${ }^{58}$ Het gevolg hiervan was dat de hoogte van de afschrijvingen onjuist werd weergegeven in de jaarrekening. Deze verslaglegging bemoeilijkt niet alleen het empirisch onderzoek naar de gelijkheid van de prijs en de marginale kosten op korte en op lange termijn, maar doet ook afbreuk aan de betrouwbaarheid van de onderzoeksresultaten. Uit de toepassing van deze benadering op de cijfers, vermeld in de kostensplitsing ten behoeve van de Staten-Generaal, blijkt dat de coëfficiënten voor de benadering van de marginale kosten van het goederen- en reizigersvervoer zelfs negatief kunnen zijn. De toepassing van deze benadering verdient dan ook geen aanbeveling.

ook bij de staatsmijnen en de Nederlandse Centrale organisatie voor toegepast-natuurwetenschappelijk onderzoek wordt geen gebruik gemaakt van de marginale kostenregel bij de besluitvorming over de prijsstelling en de uitbreiding van de capaciteit. Blankart stelt dat het ontbreken van een op marginale kosten gebaseerde kostenadministratie niet direct pleit tegen de toepassing ervan. Deze constatering wijst volgens hem eerder op het bestaan van institutionele gebreken of een afwezige politieke bereidheid om deze benadering aan te wenden. 659

\section{(2) Toezicht op de produktieresultaten.}

De beloning moet gerelateerd zijn aan de produktieve prestaties. Beloningsstructuren zijn volgens Simon slechts effectief als de individuele bijdrage aan de produktie effectief kan worden vastgesteld. Als de indicatoren niet de juiste variabelen meten of niet in staat zijn de individuele bijdragen te meten, dan $z i j n$ de beloningssystemen inefficiënt en zelfs contra-produktief. ${ }^{660}$

In het kader van de collectieve arbeidsovereenkomst van 1965 startte op 1 april 1965 de Regeling algemene prestatiebeloning voor de duur van drie jaar. op basis van kwantitatieve en kwalitatieve factoren zou de gezamenlijke prestatie worden beloond met een percentage, variërend van 5 tot 15 procent boven de cao-lonen. ${ }^{661}$ Verleende het personeel zijn medewerking, dan behoorde een prestatiebeloning van 12 procent tot de mogelijkheden. ${ }^{662}$ De prestatiebeloning was gebaseerd op een waardering in punten van de geleverde prestaties. Het totale aantal punten werd omgerekend in premiepercentages op het maandsalaris. ${ }^{663}$ De toepassing van het stelsel van algemene prestatiebeloning werd in 1968 
verlengd tot en met 1 april 1970.604

De algemene prestatie-beloning bij de NV Nederlandse Spoorwegen voldeed niet aan de voorwaarde dat de individuele bijdragen aan de produktie moeten kunnen worden vastgesteld. Het gevaar was dan ook niet uitgesloten dat sommige werknemers trachtten te profiteren van de grotere inspanning van de andere werknemers.

\section{(3) Toezicht op de externe effecten.}

Externe effecten vormen de bijkomstige gevolgen van de produktie van goederen en diensten. Deze hebben een positief of negatief effect voor derden, producenten en/of consumenten. Externe effecten zijn van technische of financiële aard. Technische externe effecten ten gevolge van de produktie van een consumptiegoed beïnloeden de produktie of consumptie van derden. Met andere woorden deze externe effecten maken deel uit van de produktie- of nutsfunctie. Financiële externe effecten vloeien voort uit de verandering van de vraag- en aanbodverhoudingen. Een duidelijke scheiding van technische en financiële externe effecten blijkt in de praktijk niet altijd mogelijk. ${ }^{665}$

De beheersing van externe effecten behoort tot één van de bestaansredenen van overheidsbedrijven, zelfs als er sprake is van een gering bedrijfseconomisch rendement. Het geringe rendement duidt dan niet op het bestaan van technische inefficiëntie of hogere kosten, maar op positieve externe effecten. 6 . 66

De drie onderzochte ondernemingen brachten externe effecten met zich mee. De activiteiten van de staatsmijnen hadden milieu-effecten. Het was echter niet mogelijk de kosten ervan vast te stellen. De NV Nederlandse Spoorwegen kon met een beroep op de kapitaalmarkt de rentestand beinvloeden. Haar bestuur over het Spoorwegpensioenfonds bood de mogelijkheid te beschikken over kapitaal tegen een door de Ministers van Financiën en Waterstaat vastgesteld percentage. ${ }^{67}$ Een extern effect van het onderzoek in opdracht van derden door de Nederlandse Centrale organisatie voor toegepast natuurwetenschappelijk onderzoek waren de wetenschappelijke nevenresultaten. Had deze organisatie ook bijgedragen in de kosten van het onderzoek, dan kon zij vrij over de nevenresultaten beschikken. ${ }^{068}$

(4) Toezicht op de samenstelling en de omvang van het team van producenten.

Het economische vraagstuk van de samenstelling en de omvang van het team van producenten is nauw verbonden met de problematiek van de benoemingen bij overheidsbedrijven.

In de economische theorie van de eigendomsrechten beschikken ministers in parlementaire democratieën slechts gedurende hun ambtstermijn over de publieke eigendomsrechten in overheidsbedrijven. In een tweepartijenstelsel draagt een regeringspartij na een verkiezingsnederlaag de publieke eigendomsrechten over aan haar opvolger, zoals bijvoorbeeld bij het Britse tweepartijenstelsel. In parlementaire 
democratieèn, waar én partij steeds betrokken is bij het vormen van coalitie-kabinetten met een andere partij, ontstaan er onduidelijkheden over de overdracht en de verdeling van de publieke eigendomsrechten. In Nederland beschikten na 1918 confessioneel-liberale en confessioneel-sociaaldemocratische coalitie-kabinetten over het recht om toezicht uit te oefenen op de samenstelling en de omvang van het team van producenten.

De economische theorie van de eigendomsrechten brengt de beschikking over het recht om toezicht uit te oefenen op de samenstelling en de omvang van het team van producenten in verband met verborgen werkloosheid of overbezetting bij overheidsbedrijven. Kabinetswisselingen in een tweepartijenstelsel leiden tot een uitbreiding van het personeel met een vaste aanstelling of een aanvulling van het natuurlijke personeelsverloop. De aanstellingen vormen een beloning voor in het verleden bewezen politieke diensten aan de regeringspartij. De beloning betekent een veilige inkomensstroom voor de betrokkenen. op de hogere besluitvormingsniveaus van overheidsbedrijven komen dan meer managers voor dan bij andere bedrijven in dezelfde bedrijfstak. ${ }^{669}$

Het Nederlandse parlementaire stelsel staat bekend als een pacificatie-democratie, die zich kenmerkt door een verzuilde politieke cultuur en samenwerking tussen elites. Op grond van deze twee kenmerken ontstaat de verwachting dat de overheidsbedrijven werden verdeeld over de zuilen of dat de beschikking over de publieke eigendomsrechten door de samenwerkende politieke partijen werden gedeeld. Nederlandse overheidsbedrijven kenden het verschijnsel van de beloning in de vorm van vaste kaderaanstellingen niet. Er bestaan indicaties voor het bestaan van overbezetting op de hogere besluitvormingsniveaus en de beloning van politieke diensten met commissariaten of een zetel in toezichthoudende organen voor een overheidsbedrijf.

Uit de reactie van het lid van de Eerste Kamer van de Staten-Generaal Lindemeijer (SDAP) op de herhaaldelijk geuite klacht van Monseigneur Poels blijkt een voorkeur om verkiezingsuitslagen geen rol te laten spelen bij de bezetting van de belangrijkste functies binnen staatsbedrijven. ${ }^{670}$ Er bestaan vrijwel geen cijfers over de sociaal-economische achtergronden van de werknemers op de hogere besluitvormingsniveaus. In 1925 waren bij de staatsmijnen 433 van de 649 beambten Rooms-Katholiek (66 procent). ${ }^{671}$ De Mijnraad moest een afspiegeling vormen van de geestelijke en politieke stromingen in Nederland. In 1948 mocht tenminste één sociaaldemocraat worden benoemd, met andere woorden ook hier was lange tijd geen sprake van een evenredige vertegenwoordiging van belangen. De voorzitters van de Mijnraad waren overwegend afkomstig van de Rooms-Katholieke Staatspartij en later de Katholieke Volkspartij.

Tijdens de behandeling van de begroting van het Verkeersfonds voor 1938 constateerden enige leden van de Tweede Kamer der staten-Generaal bij de NV Nederlandse spoorwegen een eenzijdige samenstelling van de Raad van commissarissen. Daarnaast waren niet alle 16 functies van commissaris bij dit bedrijf opgevuld. Enkele kamerleden wilden 
één of meer leden van de Personeelsraad tot commissaris benoemen. ${ }^{67}$ Het kabinet 2 ag geen aanleiding de Raad van commissarissen uit te breiden tot het in de statuten genoemde maximum. De eenzijdige samenstelling van de Raad kon bezwaarlijk worden toegegeven. Minister Van Buuren (RKSP) verklaarde dat vanaf 1921 kabinetten geen evenredige representatie van politieke partijen nastreefden. Evenredige vertegenwoordiging van politieke partijen kwam ook niet overeen met de taak van de Raad. ${ }^{673}$ In 1969 bestond bij dit bedrijf een overbezetting van 106 academici, die posities Innamen op de hogere besluitvormingsniveaus. De vermindering van dit aantal academici zou een besparing opleveren van 4,5 miljoen gulden per jaar. ${ }^{674}$

De eerder uit de economische theorie van de eigendomsrechten afgeleide verwachting voor de pacificatiedemocratie is naar alle waarschijnlijkheid niet juist. De overheidsbedrijven zijn niet verdeeld over de zuilen en de eigendomsrechten worden niet op een evenredige wijze gedeeld. De eenzijdig samengestelde toezichthoudende lichamen voldeden niet aan het beginsel van Morrison dat uiteenlopende matschappelijke belangen achterwege moesten blijven om het algemene belang te waarborgen.

De samenstelling van het personeel kan verder worden beinvloed door het bestaan van pensioen- en wachtgeldregelingen. Het bestaan van vervroegde en invaliditeitspensioenen kan een stimulans vormen voor directies en werknemers van overheidsbedrijven om het pensioen eerder in werking te laten treden. $\mathrm{zij}$ verschillen daarbij waarschijnlijk niet van particuliere ondernemingen, terwijl ook de redenen identiek kunnen zijn. Tot de redenen om dergelijke pensioenen eerder in werking te laten treden behoren onder andere rationalisering, elektrificatie en besparingen. Maakt de directie van een overheidsbedrijf gebruik van wachtgeldregelingen, vervroegde en invaliditeitspensioneringen, dan kan dat leiden tot besparingen in de betekenis van "rent seeking". De statuten van de NV Nederlandse Spoorwegen uit 1937 en 1943 voorkwamen dit gedrag tot op zekere hoogte met de verplichting de winst aan te wenden voor de compensatie van de verliezen van het Spoorwegpensioenfonds. ${ }^{67 \%}$ De aanhoudende tekorten van dit fonds en de verliezen van de NV Nederlandse Spoorwegen betekenden echter dat de kosten van de vervroegde en invaliditeitspensioenen ten laste kwamen van de belastingbetaler.

Onderzoek naar het personeelsbeleid, de hiermee verbonden bedrijfscultuur van Nederlandse overheidsbedrijven en de politieke voorkeuren bij het personeel ontbreekt.

(5) Aanspraak op de winst.

Het recht aanspraak te maken op de winst berust in de klassiek kapitalistische onderneming bij de ondernemer. Bij de socialistische onderneming kan winstdeling ten behoeve van de werknemers door het politieke bestuur zijn opgelegd. Het overheidsbedrijf in de gemengde economie neemt, wat betreft het recht om aanspraak te mogen maken op de winst, een positie 
in tussen beide bovengenoemde ondernemingsvormen. Het overheidsbedrijf is niet alleen bij verschillende soorten overdrachten uit de winst betrokken, maar tracht ook zijn winsten te beschermen.

Winst bestaat uit het verschil tussen opbrengsten en de historische kosten in plaats van de alternatieve kosten. Het is het resultaat van de produktieve aanwending van de produktiefactoren. Aanspraken op de winst van een overheidsbedrijf door de politiek verantwoordelijke minister, de directie en het personeel nemen de vorm aan van dividenden, tantièmes en premies. Daarnaast kunnen personeelsleden en belangengroepen aanspraken op de winst verwerven zonder daarvoor hun produktiefactoren produktief aan te wenden. Zij hebben hun produktiefactoren onproduktief opgeofferd om een aandeel in de winst te verkrijgen. De gederfde inkomsten ten gevolge van de verspilling van hun produktiefactoren vormen de alternatieve kosten. Dit gedrag staat in de economische theorie van de politieke besluitvorming bekend als "rent seeking" en bestaat vaak uit een ondoorzichtige overdracht van baten uit het overheidsbedrijf naar de betrokkenen. Een voorbeeld van een onderdoorzichtige transfer van baten van de rijksoverheid naar het leidinggevend personeel van overheidsbedrijven was de vooroorlogse vrijstelling van de dividend- en tantièmebelasting. ${ }^{676}$ Een ander voorbeeld van "rent seeking" deed zich voor bij de NV Nederlandse Spoorwegen en had betrekking op het verkrijgen van orders voor de bouw van materieel. Bij geringe prijsverschillen met buitenlandse bedrijven prefereerde de directie van de NV Nederlandse spoorwegen uit loyaliteit aan het kabinetsbeleid haar orders te plaatsen bij de Nederlandse wagonindustrie. Deze industrie verwierf hierdoor extra-baten. De NV Nederlandse Spoorwegen derfde hierdoor inkomsten en winst. De winstderving van overheidsbedrijven staat bekend als "public enterprise rent". 677

Ondernemingen trachten hun bron van extra-baten te beschermen tegen toetreding door concurrerende ondernemingen. Een toeneming van het aantal bedrijven dat van deze baten profiteert, betekent immers een vermindering.

De vermelding van de toekenning van deze baten in de bedrijfsadministratie als kosten verklaart de ondoorzichtigheid van de overdracht. Voorbeelden hiervan waren de subsidies van de Staatsmijnen en de NV Nederlandse Spoorwegen. De staatsmijnen verstrekten subsidies van sociale aard, waaronder subsidies aan kerkgenootschappen en patronaten. De begroting vermeldde de post subsidies zonder nadere specificatie en de bedrijfsrekeningen verantwoordden deze subsidies als algemene kosten, sociale lasten en sociale voorzieningen. De directie van de NV Nederlandse Spoorwegen stelde een zogenaamde "lijst van subsidies" samen, die ter inzage lag bij het secretariaat. zij verantwoordde het totale bedrag aan subsidies en contributies in de exploitatiebegroting onder de rubriek "diversen".

Een ander voorbeeld betreft de gepremieerde spaarregeling van de NV Nederlandse Spoorwegen. De directie verantwoordde de spaarregeling voor het eerst onder de rubriek overige sociale kosten in de exploitatiebegroting voor 1968. ${ }^{678}$ Hoe de NV 
Nederlandse Spoorwegen een spaarpremie wilde financieren, blijkt niet uit de onderzochte documenten. De staatsmijnen financierden de spaarpremie uit de winst. De spaarregelingen pasten in het overheidsbeleid van bezitsvorming en hadden tevens tot doel de arbeidsmotivatie te bevorderen. Het bestaan van dergelijke regelingen makt het voor werknemers interessant kosten noch moeite te sparen om een baan te krijgen bij deze overheidsbedrijven. Een soortgelijk mechanisme kan worden waargenomen op het hoogste besluitvormingsniveau van de Bijzondere TNO-organisaties. De vergoeding bestond hier uit het salaris van een hoogleraar vermeerderd met dertig procent. Aan het genoemde percentage lag onder andere de overweging ten grondslag dat het de voorzitters van de Centrale Organisatie en de Bijzondere organisaties niet was toegestaan op te treden als adviseur van het particuliere bedrijfsleven. Het salaris bevatte de huurcompensatie, maar niet de compensatie voor de AOW. ${ }^{679}$

Een overheidsbedrijf kan zijn winst te hoog of te laag weergeven in zijn externe verslaglegging. De weergave van de winst is afhankelijk van de verdeling van de publieke eigendomsrechten, in het bijzonder de regeling van het recht om aanspraak te maken op de winst. Een te hoge weergave heeft tot doel een gunstig beeld van het bedrijf in de publieke opinie te creëren. Een lage weergave van de winst gaat om defensieve redenen gepaard met stille en geheime reserves. Directies van overheidsbedrijven trachten met het creëren van stille en geheime reserves aanspraken op de winst van de kant van belangenorganisaties, zoals vakbonden, te vermijden. stille reserves vormen reserves waarvan het bestaan blijkt uit de gepubliceerde balans, maar de omvang echter niet. Deze reserves ontstaan uit de versnelde afschrijving van duurzame produktiemiddelen. Geheime reserves daarentegen $z i j n$ niet vast te stellen aan de hand van de gepubliceerde balans. Deze reserves zijn het resultaat van een te lage waardering van de vaste activa of gaan schuil achter een te hoge presentatie van het vreemd vermogen. ${ }^{680}$

In de jaarrekeningen van de staatsmijnen schuilden stille en geheime reserves. Deze reserves waren ontstaan door afschrijvingen op vaste activa, reservering op de deelneming in andere ondernemingen en de balanswaardering van materialen en grondstoffen. Aan de vorming van deze reserves lag onder andere het matigen van de eisen van de vakbeweging ten grondslag. Tijdens een voordracht in 1949 vertelde directeur Rottier aan de leden van de ondernemingsraad dat de gezonde financiële positie van de staatsmijnen te danken was aan de lage waardering van de vaste activa. De werknemers zouden te zijner tijd profiteren van de gevormde stille reserves. ${ }^{681}$ Herwaardering van te laag gewaardeerde vaste activa leidde tot de bekendmaking van de stille reserves. De problematiek van de afschrijuingen en de herwaardering was jarenlang een gespreksonderwerp tussen de Staatsmijnen, het Ministerie van Economische zaken en het Ministerie van Financiën. In 1956 achtte de directie van de staatsmijnen het niet wenselijk over te gaan tot een herwaardering van de vaste activa. De herwaardering mobiliseerde de stille reserves en stimuleerde de vakbeweging eisen te stellen met betrekking tot de 
arbeidsvoorwaarden. De betrokken ambtenaren van het Ministerie van Financiën stelden dat een herwaardering de sociale eisen van de vakbeweging zou matigen. Uit de herkapitalisatie zou blijken dat de rentabiliteit van de staatsmijnen gering was, waardoor de eisen van de vakbeweging zouden worden getemperd. ${ }^{682}$

Het bleek mogelijk om de aanspraken op de winst met bijzondere regelingen bij de Staatsmijnen en de NV Nederlandse spoorwegen te achterhalen. Bij de Nederlandse Centrale organisatie voor toegepast-natuurwetenschappelijk onderzoek konden deze regelingen niet worden achterhaald.

Het Nederlandse overheidsbedrijf verschilde op een punt met het model van Morrison, namelijk het bestaan van bijzondere ondernemingsorganen. J.B. van den Tempel definieerde het bijzondere ondernemingsorgaan als een orgaan, dat naast de directie, beschikte over de bevoegdheid besluiten te nemen of hierover te adviseren. In het bijzondere ondernemingsorgaan participeerden niet alleen vertegenwoordigers van de Minister, maar ook deskundigen en vertegenwoordigers van werknemers en cliënten. ${ }^{683} \mathrm{Bij}$ de Staatsmijnen was de Mijnraad het bijzondere ondernemingslichaam. Bij de NV Nederlandse Spoorwegen betrof het de Personeelsraad en bij de Nederlandse centrale organisatie voor toegepast-natuurwetenschappelijk onderzoek handelde het om de gewone leden, deskundig op economisch en natuurwetenschappelijk gebied. De bijzondere ondernemingsorganen hadden volgens Van den Tempel tot doel verschiliende matschappelijke belangen bij het beheer van het overheidsbedrijf te betrekken. ${ }^{644}$ Morrison beschouwde de aanwezigheid van matschappelijke belangen juist als en bedreiging van het algemene belang. ${ }^{685}$

\subsection{Analyse van de kenbaar gemaakte doeleinden}

Volgens de theorie van de eigendomsrechten maken de politieke eigenaren hun doeleinden kenbaar aan de directie van het overheidsbedrijf. De directie van een overheidsbedrijf kan daarentegen een mate van autonomie ambiëren. De beleidsvrijheid beinvloedt de bedrijfsresultaten en beperkt de mogelijkheden voor de directie van het overheidsbedrijf om eigen doeleinden te bereiken.

De kwalitatieve prestatie-analyse tracht de beschikking over beleidsvrijheid of autonomie te achterhalen met een analyse van een verscheidenheid aan documenten, zoals beleidsnotities, kamerstukken en jaarverslagen. $\mathrm{zij}$ bevestigt of weerlegt de met de structuuranalyse gevonden doeleinden. Wettelijke en statutaire doeleinden van overheidsbedrijven vormen de nevenvoorwaarden voor het streven naar een mate van vrijheid om eigen doeleinden te verwerkelijken.

De analyse van de kenbaar gemaakte doeleinden van de Staatsmijnen, de NV Nederlandse Spoorwegen en de Nederlandse Centrale organisatie voor toegepast-natuurwetenschappelijk onderzoek houdt de verzameling in van doeleinden, aangetroffen in diverse documenten. Deze doeleinden makten deel uit van de beleidsvrijheid van de betrokken ministers of de autonomie van 
de directies c.q. besturen.

Het aantal kenbaar gemaakte doeleinden in de documenten afkomstig van de ministeries en de onderzochte overheidsbedrijven was gering. De doeleinden van de drie onderzochte overheidsbedrijven bevatten geen indicatoren om de effectiviteit vast te stellen. Een tijdsdimensie, waarbinnen doeleinden moesten worden bereikt, ontbrak.

Het feit dat het niet aanvaardbaar was het beleid van overheidsbedrijven in het openbaar ter sprake te brengen, zou juist doen verwachten dat de ministers uitgebreid konden beschikken over beleidsvrijheid. Bovendien reduceerde dit de druk op ministers en directies van overheidsbedrijven om hun doeleinden expliciet te formuleren. Tabel 6.1 geeft een overzicht van de kenbaar gemaakte doeleinden.

Tabel 6.1 Kenbaar gemaakte doeleinden

\begin{tabular}{lccc}
\hline & Staatmijnen & NS & TNO \\
\hline Ministerie & 3 & 1 & 7 \\
Directie/Bestuur & 24 & 12 & 10 \\
Totaal & 27 & 13 & 17 \\
\hline
\end{tabular}

Uit tabel 6.1 blijkt dat de directies c.q. besturen meer doeleinden kenbaar makten dan de betrokken ministers. De directies/besturen van de onderzochte ondernemingen beschikten over een mate van autonomie.

Het geringe aantal kenbaar gemaakte doeleinden brengt met zich mee dat er meer aandacht $z a l$ moeten worden besteed aan niet ter discussie staande activiteiten van deze overheidsbedrijven, teneinde hieruit doeleinden af te leiden.

\subsection{Rosten van de kenbaar gemaakte doeleinden}

Het overheidsbedrijf is een investering voor de lange termijn, waarvan de rentabiliteit op zijn minst gelijk zou moeten zijn aan het rendement van eeuwigdurende statsleningen. Dit rendement is een indicator voor de alternatieve kosten. Een overheidsbedrijf derft winst als het een lagere rentabiliteit heeft dan het rendement op eeuwigdurende staatsleningen. De gederfde winst (in het Engels aangeduid als: public enterprise rent) is een indicator voor beleidsvrijheid van de ministers, danwel autonomie voor de directie en de toezichthoudende (bijzondere) organen. De winstderving is onder andere het resultaat van het streven naar baten, waarbij de produktiefactoren worden verspild (in de Angelsaksische literatuur staat dit streven bekend onder de aanduiding "rent seeking"). Voorbeelden hiervan zijn lonen, sociale voorzieningen en voorrechten boven het niveau van de alternatieve kosten, prijsstelling beneden de marktprijs ten behoeve van bevoorrechte afnemers, en bijdragen aan politieke partijen en charitatieve instellingen. ${ }^{*}$ Behalt een overheidsbedrijf een rentabiliteit hoger dan het rendement van 
de eeuwigdurende staatsleningen, dan vervult deze een fiscale rol.

Tabel 6.2 Gederfde winst in miljoenen guldens.

\begin{tabular}{lccl}
\hline Jaar & Staatsmijnen & $\begin{array}{l}\text { NV Nederlandse } \\
\text { Spoorwegen }\end{array}$ & $\begin{array}{l}\text { Organisatie } \\
\text { TNO }\end{array}$ \\
\hline 1960 & 54,8 & $-29,7$ & $-2,7$ \\
1965 & 42,3 & $-56,5$ & $-8,7$ \\
1966 & 11,5 & $-66,0$ & $-11,9$ \\
1967 & 17,0 & $-66,0$ & $-13,1$ \\
1968 & 38,3 & $-74,7$ & $-15,2$ \\
1969 & 50,5 & $-87,6$ & $-20,0$ \\
1970 & 18,7 & $-91,6$ & $-20,1$ \\
\hline
\end{tabular}

Uit tabel 6.2 kan worden geconcludeerd dat de staatsmijnen geen winsten derfden over de periode 1960, 1965 tot en met 1970. De rentabiliteit van de Staatsmijnen was het resultaat van de bedrijfsresultaten van een aantal deelbedrijven (zie hoofdstuk 3: tabel 3.6). Dit overheidsbedrijf vervulde dus een fiscale rol en voldeed daarmee aan één van de doeleinden, die ten grondslag lagen van zijn oprichting. De positieve en negatieve resultaten van de diverse deelbedrijven compenseerden elkaar en vormden kruiselingse subsidies. De NV Nederlandse Spoorwegen en de Nederlandse Centrale organisatie voor toegepast-natuurwetenschappelijk onderzoek derfden winsten over de periode 1960,1965 tot en met 1970.

De onderzochte overheidsbedrijven opereerden op markten met onvolkomen mededinging. De staatsmijnen functioneerden in een homogeen oligopolie. De NV Nederlandse Spoorwegen beschikte over een monopolie in het reizigersvervoer, maar concurreerde met goederenvervoer over de weg en over het water. Daarnaast concurreerde dit bedrijf met buitenlandse spoorwegondernemingen. De Nederlandse Centrale organisatie voor toegepast-natuurwetenschappelijk onderzoek beschikte over een monopolie.

Een homogeen oligopolistische kolenmarkt, waar een staatsbedrijf en vier particuliere mijnbouwondernemingen naast elkaar functioneerden, was bij uitstek geschikt voor het uitvoeren van een vergelijkende kwantitatieve prestatieanalyse. Het bestaan van een premieregeling voor de directie van de staatsmijnen deed vermoeden dat er geen significant verschil in technische efficiëntie bestond met de particuliere mijnbouwondernemingen. Uit de vergelijkende prestatie-analyse bleek dat in 1952 de efficiëntie van de mijnbouwonderneming oranje-Nassau hoger was dan die van de Laura en Vereniging en de staatsmijnen (voor de cijfers wordt verwezen naar hoofdstuk 3: tabel 3.3). Voor de periode 1957 tot en met 1959 beschikte de onderneming willem en Sophie over de hoogste mate van technische efficiëntie. De Staatsmijnen behalden de hoogste mate van technische efficiëntie in de periode 1961 tot en met 1965.

Een verklaring voor de lagere technische efficiëntie van de staatsmijnen over de periode 1951 tot en met 1960 werd 
aangetroffen in een uit 1952 daterende nota van Minister van Economische Zaken Zijlstra,gericht aan de Tweede Kamer der staten-Generaal. Hierin lichtte hij toe dat de voortzetting van de na de bevrijding gevoerde afbouwpolitiek niet meer tot de mogelijkheden behoorde. Gelet op de levensduur van de mijnen was een voortzetting van deze politiek economisch niet verantwoord. Te snel zou moeten worden overgegaan tot de exploitatie van dieper gelegen lagen, waarbij de niet ontgonnen lagen op geringere diepte verloren zouden gaan. Om deze reden begonnen de staatsmijnen in 1952 in versterkte mate met de exploitatie van minder goede lagen. De afbouw van de minder goede lagen ging gepaard met een lagere nettoproduktie. Deze zou volgens Minister zijlstra samengaan met een kostprijs boven die van 1951 en $1952 .{ }^{687}$

De vergelijkende kwantitatieve prestatie-analyse leidde tot de constatering dat de NV Nederlandse Spoorwegen in 1965 en 1970 beschikte over de hoogste mate van technische efficiëntie, gevolgd door de Franse spoorwegen (voor de gegevens wordt verwezen naar hoofdstuk 4: tabel 4.5). De hoge mate van technische efficiëntie bij de NV Nederlandse Spoorwegen ging gepaard met winstderving. Hieruit bleek dat de technische efficiëntie slechts was gericht op de verwezenlijking van de statutaire doeleinden, namelijk de exploitatie van spoorwegen en het uitoefenen van het transportbedrijf.

Het was niet mogelijk om een kwantitatieve prestatieanalyse te verrichten naar de Nederlandse Centrale organisatie voor toegepast-natuurwetenschappelijk onderzoek, omdat weinig relevante gegevens beschikbaar waren. Het ontbreken van met de organisatie-TNO vergelijkbare organisaties in Nederland betekent dat slechts een intertemporerele prestatie-analyse tot de mogelijkheden behoort, indien er voldoende relevante gegevens beschikbaar zijn. Een andere oplossing is een vergelijkende prestatie-analyse van wetenschappelijke organisaties op internationaal niveau.

Het is niet uitgesloten dat winstderving en een hoge mate van technische inefficiëntie naast elkaar voorkomen in een overheidsbedrijf. De gederfde winsten zijn het resultaat van de vrijheid een beleid te voeren, dat gericht is op positieve externe effecten en collectieve goederen. De produktiefunctie van de externe effecten kan niet worden bepaald. ${ }^{68}$ In en dergelijke situatie kunnen twee maatregelen worden genomen, ten eerste een vermindering van de hoeveelheid produktiefactoren en ten tweede een verlaging van de kosten door de aanspraken op financiële voorrechten te verminderen. ${ }^{689}$

De vermindering van de kosten met een reductie van de produktiefactoren, bijvoorbeeld arbeid, betekent feitelijk een verhoging van de technische efficiëntie. Deze maatregel komt ten goede aan de rentabiliteit van het overheidsbedrijf. Het produktieniveau komt te 1 iggen op de produktiemogelijkhedencurve (hiervoor wordt verwezen naar hoofdstuk 2: figuur 2.1). De verlaging van de kosten kan ook worden bereikt met de beëindiging van de toegekende voorrechten en privileges. Hieruit vloeit een (verhoging van de) overdracht van baten in de vorm van dividenden naar de 
overheid voort.

De staatsmijnen beschikten over een lagere technische efficiëntie, die mede werd verklaard door de afbouwpolitiek. Het bedrijf derfde geen winsten, vanwege de mogelijkheid tot kruiselingse subsidiëring. De NV Nederlandse Spoorwegen beschikte over een hoge mate van technische efficiëntie, in 1965 en 1970 respectievelijk 0,9873 en 0,9821 , maar derfde winsten. De mogelijkheden voor de NV Nederlandse Spoorwegen om de winstderving te verminderen door een verhoging van de technische efficiëntie waren warschijnlijk gering en niet noodzakelijk. De hoge mate van technische efficiëntie duidde op de realisatie van de statutaire doeleinden, namelijk de exploitatie van spoorwegen en het uitoefenen van het transportbedrijf. Het bedrijf kon nu worden aangewend voor de realisatie van andere beleidsdoeleinden, waaraan kosten waren verbonden.

\subsection{Privatisering}

In Nederland was na 1945 het vraagstuk van de privatisering gekoppeld aan de discussie over bezitsvorming en vermogensaanwasdeling. Privatisering betekende in het beleid van bezitsvorming de verspreiding van aandelen van overheidsbedrijven onder de bevolking, in het bijzonder de werknemers. ${ }^{60}$ De overdracht van de publieke eigendomsrechten kon volledig of gedeeltelijk zijn. Het beëindigde de beleidsvrijheid van de ministers en de autonomie van de directie.

Uit de economische literatuur over overheidsbedrijven kan een scenario voor privatisering worden afgeleid, dat bestaat uit de volgende fasen: (1) de toetsing aan een selectiecriterium, (2) de waardebepaling van het overheidsbedrijf, en (3) de verkoop.

Het criterium om overheidsbedrijven in aanmerking te laten komen voor privatisering is het rendement op eeuwigdurende staatsleningen. Slaagt het overheidsbedrijf er niet in dit rendement te behalen dan komt het in aanmerking voor privatisering. Een soortgelijk criterium hanteert de Duitse Deskundigenraad voor de economie voor de identificatie van te privatiseren overheidsbedrijven. ${ }^{691}$ In 1970 zouden de NV Nederlandse Spoorwegen en de Nederlandse Centrale organisatie voor toegepast-natuurwetenschappelijk onderzoek op grond van dit criterium moeten worden geprivatiseerd.

De waarde van het overheidsbedrijf is gelijk aan de som van de intrinsieke waarde van de vaste activa en de rentabiliteitswaarde. Dit bedrag wordt verminderd met de contante waarde van de kosten. De intrinsieke waarde betreft het verschil tussen enerzijds de actuele waarde van de activa en anderzijds de voorzieningen en verplichtingen. De rentabiliteitswaarde omvat de gekapitaliseerde waarde van de bestaande en toekomstige winstgevendheid van het overheidsbedrijf. ${ }^{692}$

op grond van het eerder genoemde privatiseringscriterium kwamen de staatsmijnen als staatsbedrijf en als naamloze vennootschap niet in aanmerking voor privatisering. Het politieke debat over bezitsvorming speelde zich af rond de 
staatsmijnen in de jaren vijftig en zestig. De politieke belangstelling voor bezitsspreiding door denationalisatie vormde voor de hoofddirectie van de staatsmijnen reden het vraagstuk van de rechtspersoonlijkheid vooruitlopend op de politieke ontwikkelingen te regelen. De houding van de hoofddirectie tegenover de ideologie van de bezitsvorming was onverschillig. ${ }^{693}$

De onrendabele NV Nederlandse spoorwegen zou slechts kunnen worden geprivatiseerd, als een belangstellende koper na een zogenaamd proces van management turnaround in de toekomst winst denkt te kunnen realiseren. ${ }^{64}$ Turn-around management houdt een ingrijpend veranderingsproces in om de continuiteit te garanderen van een bedrijf met neergaande bedrijfsresultaten. Zonder veranderingsproces zou het bedrijf ten onder gaan. ${ }^{695}$

De privatisering van de Nederlandse Centrale organisatie voor toegepast-natuurwetenschappelijk onderzoek zou de overdracht van de TNO-instituten aan het particuliere bedrijfsleven inhouden. Deze overdracht zou de rijksoverheid een budgettaire besparing opleveren.

Het beleid van bezitsvorming met behulp van de verspreiding van aandelen van overheidsbedrijven vertoont overeenkomsten met een van de doeleinden van het privatiseringsbeleid van de kabinetten Thatcher. De verspreiding van de aandelen onder kleine beleggers betekent een inkomensoverdracht van de belastingbetaler naar de aandeelhouder. De verkoop van de. aandelen in een overheidsbedrijf beneden de beurskoers betekent immers dat de overheid minder inkomsten verwerft. De. overheid had de belastingdruk met een bedrag gelijk aan de gemiste inkomsten kunnen verminderen. De belastingbetalers subsidiëren als het ware de kleine aandeelhouders. Grote investeerders zijn in eerste instantie uitgesloten van deelname an de uitgifte van de aandelen van overheidsbedrijven. De a andeelhouders kunnen een vermogenswinst realiseren door hun aandelen te verkopen aan de grote investeerders. Een methode voor de overheid on te voorkomen dat de aandelen beneden de beurskoers of rendementswaarde worden verkocht, is de verkoop ervan in tranches. ${ }^{6 \%}$ Veljanovski vermeldt dat het aantal aandeelhouders in Groot-Brittannië aanzienlijk was gestegen, in het bijzonder na de privatisering van British Telecom. In 1986 bezat 17 procent van de Britse bevolking aandelen, dit was een verdubbeling van het individuele aandelenbezit sinds het verkiezingsjaar 1983 . 097 Het Nederlandse bezitvormingsbeleid leidde uiteindelijk niet tot een verspreiding van de aandelen van geprivatiseerde bedrijven onder kleine beleggers. Het aandelenbezit van de Nederlandse rijksoverheid nam zelfs toe (In 1990 bezat de rijksoverheid aandelen in 45 ondernemingen, warvan er 32 winstgevend waren). ${ }^{\circ 88}$ Het huidige privatiseringsbeleid heeft daarentegen tot doel een verbetering van de bestuurlijke beheersing, een versterking van de marktsectoren en het bereiken van budgettaire besparingen. 


\subsection{De verklaring van de prestaties en de reacties van de ministers.}

Het belang van de verschillende doeleinden blijkt uit de analyse van de interactie tussen de verklaring van de prestaties door de organisatie en de reacties van de betrokken ministers hierop. Voor deze analyse moeten worden behandeld: de benoemingen, de expliciete veranderingen in het beleid, de verschuiving van doeleinden tussen instituties, de impliciete beleidsveranderingen, het ritueel gedrag, en de niet besproken maar voortgezette activiteiten.

Loyaliteit aan het kabinetsbeleid is een belangrijke voorwaarde voor benoemingen in de directie van een overheidsbedrijf en de toezichthoudende lichamen. ontvankelijkheid voor dit beleid kan een extern benoemd directielid in conflict brengen met de overige directieleden en de departementale ambtenaren. Een dergelijk conflict heeft zich afgespeeld rondom de benoeming van professor Goudriaan tot president-directeur van de NV Nederlandse Spoorwegen. Het kabinet-colijn IV had hem in 1938 de opdracht gegeven het exploitatietekort te verminderen, het bedrijf populair te maken. en te moderniseren. zijn beleid bracht hem in conflict met de gevestigde belangen in de organisatie. De arbeidsvoorwaarden van de NV Nederlandse Spoorwegen waren beter dan die van het bedrijfsleven, hetgeen volgens hem niet verdedigbaar was bij de bestaande exploitatietekorten. Goudriaan bepleitte een koppeling van de arbeidsvoorwaarden aan de bedrijfsresultaten. Zijn voorstellen om een aantal voorrechten af te schaffen ontmoetten naar zijn zeggen geen ernstige bestrijding van de Personeelsraad. ${ }^{699}$ Een coalitie van Raad van Commissarissen, departementale ambtenaren en spoorwegbeambten leidde tot zijn vrijwillig ontslag in 1945.700

De vermeende inefficiëntie van overheidsbedrijven en de verwevenheid met de politiek bevorderen de opvatting dat directies van overheidsbedrijven incompetent zijn. Walters en Monsen bestrijden aan de hand van profielschetsen dat directies in de publieke sector van het bedrijfsleven incompetent zijn. De succesvolle directieleden onderhouden een pragmatische en effectieve relatie met de overheid met het doel financiële steun en autonomie te verwerven. Geen van hen treedt op als zou hij de leiding hebben over een particuliere onderneming. Deze onderzoekers wijzen erop dat directieleden een onderscheid moeten maken tussen belangenbehartiging ten behoeve van het overheidsbedrijf bij het kabinet en kritiek op het kabinetsbeleid. $\mathrm{Zij}$ die dit onderscheid niet wisten te maken, verloren hun positie. ${ }^{701}$

Ministers kunnen uit ontevredenheid over de prestaties besluiten om de beschikbare beleidsvrijheid in een overheidsbedrijf te beëindigen en in een ander bedrijf de beleidsvrijheid te creëren. Een voorbeeld van een expliciete beleidswijziging was de vervanging van de Landbouworganisatie TNO door de Nationale Raad voor Landbouwkundig onderzoek. De Minister van Landbouw, die zich steeds had verzet tegen de overdracht van zijn onderzoeksinstellingen aan TNo, wilde hiermee de eenheid van de landbouwpolitiek (onderwijs, 
onderzoek en voorlichting) herstellen. ${ }^{702}$

Impliciete beleidswijzigingen kunnen worden vastgesteld met de analyse van statistische discontinuiteiten in tijdreeksen. De discontinuiteiten duiden op een beleidswijziging.

Ritueel gedrag betreft het verschil tussen de presentatie van het beleid en de beleidsuitvoering. Een overheidsbedrijf vertoont in deze optiek ritueel gedrag als het de indruk wekt het beleid uit te voeren met nieuwe methoden, maar in werkelijkheid het traditionele gedragspatroon voortzet. ${ }^{703}$ planning biedt overheidsbedrijven de mogelijkheid tot ritueel gedrag. Over planning bij overheidsbedrijven is in de literatuur weinig bekend.

De bestudering van de uitgaven in de financiële administratie van het overheidsbedrijf maakt het mogelijk de niet ter discussie staande activiteiten te achterhalen. Tot deze activiteiten behoren bijvoorbeeld de uitgaven aan reclame en publiciteit, en de verstrekte garanties. Deze behoren tot het beleidsinstrumentarium van de directie van het overheidsbedrijf.

Het reclamebeleid biedt overheidsbedrijven de mogelijkheid hun cliëntèle te bereiken. zij kunnen hun marketing concentreren op de meritorische aspecten van het consumptiegoed of de dienstverlening. Het overheidsbedrijf beinvloedt dan de preferenties en de vraag van de consumenten. ${ }^{704}$ De dienstverlening van de NV Nederlandse Spoorwegen kan een meritorisch karakter hebben. Toezicht op de uitgaven aan reclame biedt de mogelijkheid het meritorische karakter te benadrukken. De reclame kan worden gericht op bepaalde doelgroepen, zoals bijvoorbeeld de lagere inkomensgroepen en de ouderen. Tijdens een overleg over cle financiële positie van het bedrijf tussen de verantwoordelijke ministers en een delegatie van de NV Nederlandse Spoorwegen in 1965 vond Minister van Financiën Vondeling de reclame van de NV Nederlandse Spoorwegen niet agressief genoeg. Hij wees op het voorbeeld van de Scandinavische spoorwegondernemingen en meende dat het bedrijf er goed aan deed het publiek te attenderen op de voordelen van het reizen per spoor bij verschillende weersomstandigheden. ${ }^{705}$ Uit het onderzoek naar het reclamebeleid van de NV Nederlandse spoorwegen blijkt een significant verband tussen de publiciteitskosten en de omzet, en een significant verband tussen publiciteitskosten en reizigersvervoer ( $z$ ie hoofdstuk 4: tabel 4.21).

Reclame en publiciteit vormen voor kabinetten en directies van overheidsbedrijven het instrument on het electoraat via de bedrijfsprestaties te beinvloeden. De presentatie van goede prestaties is van cruciaal belang. Ministers trachten hiermee hun herverkiezing te verzekeren en de directies van overheidsbedrijven trachten op deze manier het verwerven van overheidsfondsen ter financiering van het bedrijf veilig te stellen. ${ }^{700}$.

Garanties maken deel uit van de beleidsinstrumenten van de overheid en hebben een extra-budgettair karakter. zij verschijnen op de begroting als de verplichting tot het nakomen van de garantie zich voordoet. De garanties van nietfinanciële overheidsbedrijven en hun dochteronderneminingen vormen een alternatief voor overheidsgaranties. Nederlandse 
overheidsbedrijven zijn niet verplicht hun garanties in de jaarverslagen te publiceren. $2 i j$ verbergen hun garanties in de balansposten of vermelden deze afzonderlijk. De Iiquiditeitspositie vormt een maatstaf om vast te stellen of het overheidsbedrijf de garantieverplichtingen kan nakomen. De liquiditeitspositie is het verschil tussen de vorderingen en de schulden op korte termijn.

De directie van de staatsmijnen vermeldde de aangegane garantieverplichtingen in het bedrijfseconomisch verslag, maar niet in het jaarverslag. Het jaarverslag van de NV Nederlandse spoorwegen vermeldde de gegeven garanties als een afzonderlijke post onder het balanstotal. Een nadere toelichting ontbrak in het verslag. De NV Nederlandse Spoorwegen had in de periode 1960 tot en met 1970 een negatieve liquiditeitspositie. Deze positie hield in dat het bedrijf op korte termijn niet bij machte was de verstrekte garanties na te komen, als daartoe de noodzaak ontstond. De staatsmijnen waren wel in staat de garanties na te komen, met uitzondering van 1965 en 1966 (zie hoofdstuk 4: figuren 4.4 en 4.5).

Garanties van overheidsbedrijven leiden tot het ontstaan van een getrapt stelsel van toezicht op ondernemingen en belangengroepen. $\mathrm{Zij}$ hebben het karakter van indirecte subsidies, die risico-nemende activiteiten bevorderen. Het is efficiënt voor een kabinet overheidsbedrijven garanties te laten toekennen, omdat de kosten van het toezicht voor deze bedrijven lager zijn dan voor de overheid. Ambtenaren beschikken niet altijd over de gespecialiseerde (commerciële) kennis om toezicht uit te oefenen op de activiteiten van ondernemingen.

\section{B Beleidsadvigering}

De wetenschappelijke beleidsadvisering voor overheidsbedrijven draagt bij aan de herwaardering van de fiscale rol van het overheidsbedrijf, als zij beschikt over een empirische theorie over overheidsbedrijven. 707 Case-studies, gebaseerd op een combinatie van een kwantitatieve en een kwalitatieve prestatie-analyse, houden een uitgebreide verzameling van gegevens in over de dagelijkse bedrijfsvoering van overheidsbedrijven in gemengde economieën en bevatten inzichten, die de bestaande wetenschappelijke literatuur aanvullen.

De wetenschappelijke beleidsadvisering leidt tot de ontwikkeling van een nieuw economisch beheersmodel voor Nederlandse overheidsbedrijven. In dit beheersmodel staan toezicht en verantwoording centraal, met de bedoeling de winstderving terug te dringen. Uit de case-studies naar de NV Nederlandse Spoorwegen en de Nederlandse Centrale organisatie voor toegepast-natuurwetenschappelijk onderzoek blijkt het bestaan van winstderving. Beide bedrijven bevinden zich op armlengte afstand van de verantwoordelijke ministers en beschikken over bijzondere bedrijfsorganen. De staatsmijnen bevonden zich weliswaar op dezelfde afstand van de minister, maar beschikten over een premie- en tantièmestelsel ter bevordering van de arbeidsmotivatie. 
Een alternatief beheersmodel kan worden ontleend aan Goudriaan. Hij bepleit een gecentraliseerd toezicht op overheidsbedrijven, omdat in het bestaande beheersmodel (Minister-Departement-Raad van Commissarissen) een structurele fout schuilt. De fout betreft het gevaar van een coalitie tussen directie en departement, die onverenigbaar is met de parlementaire democratie. In zijn model oefent de verantwoordelijke minister het voorzitterschap uit van het toezichthoudende orgaan (bij naamloze vennootschappen: de Raad van Commissarissen) en zijn secretaris-generaal is ambtshalve lid en secretaris. Verschillen van inzicht vinden dan hun oplossing in één besluitvormingsorgaan. De minister blijft verantwoording schuldig aan de staten-Generaal over de prestaties van het overheidsbedrijf. ${ }^{708}$ Dit alternatieve beheersmodel breekt met het decentrale model van Morrison.

Het bestaan van een comptabel toezicht, gericht op het vaststellen van de officiële doeleinden en de prestaties van overheidsbedrijven, voorkomt het ontstaan van beleidsvrijheid bij ministers en autonomie bij directies c.q. besturen van overheidsbedrijven. De prestatie-analyse vertoont zekere overeenkomsten met het door Aharoni voorgestelde uitgebreide comptabele toezicht. zijn voorstel van een uitgebreid comptabel toezicht verschilt van het traditionele comptabele toezicht. In het uitgebreide comptabele toezicht ligt de nadruk op de vaststelling van de doeleinden en de kosten, terwijl de traditionele variant nog uitgaat van een financiële administratie overeenkomstig de beginselen van de accounting.

zijn de doeleinden onduidelijk geformuleerd, dan kunnen deze worden vastgesteld uit de besluitvorming van de clirectie van het overheidsbedrijf. De comptabele accountant evalueert de activiteiten en berekent de kosten van alternatieven om de doeleinden te bereiken. Een dergelijk toezicht is niet gebaseerd op objectieve criteria voor de beoordeling van doeleinden. Er bestaan geen regels waaraan doeleinden kunnen worden getoetst en het ontbreekt aan aanvaardbare methoden om op objectieve wijze doeleinden te identificeren. Volgens Aharoni kan de accountant dan ook geen kritiek uitoefenen op de juistheid van de genomen besluiten. De presentatie van zijn bevindingen ondersteunt de wetgevende macht en de directie bij de besluitvorming over de doeleinden en de noodzakelijke activiteiten. ${ }^{709}$

De enige methode om matstaven te ontwikkelen voor de evaluatie van doeleinden is volgens Aharoni de directies te verplichten een opsomming te geven van de na te streven doeleinden en de daarbij aan te wenden beleidsinstrumenten. De zekerheid van een uitgebreide comptabele controle noopt de betrokken overheidsbedrijven $z$ ich te houden aan de kenbaar gemaakte doeleinden. Deze vorm van toezicht maakt een gedetailleerde regulering en overheidsbemoeienis overbodig. De baten van dit toezicht zullen de kosten ruimschoots compenseren. ${ }^{710}$

Centralisatie en uitgebreid comptabel toezicht dragen bij aan het beëindigen van de bestaande ondoorzichtigheid van de publieke sector van het bedrijfsleven. Meer onderzoek naar de verdeling van de eigendomsrechten in overheidsbedrijven kan bijdragen aan de ontwikkeling van een efficiënt beheersmodel 
van overheidsbedrijven. De directies van overheidsbedrijven zouden het belang en de resultaten van toekomstige kwantitatieve en kwalitatieve prestatie-analyses moeten inzien. 


\section{Noten}

1. U. Rosenthal en A. Reinders, Publieke ondernemingen: De schizofrenie van successen en mislukkingen, in: Beleid en Maatschappij, 1981, p. 91.

2. NV Nederlandse Spoorwegen, brief van 17 januari 1990, sct/b.3.3./0182A/N.

3. Ministerie van onderwijs en Wetenschappen, Brief van 12 december 1990, onderwerp Archiefonderzoek, AZ/RA/CAB 89036800.

4. J. Popitz (1884-1945) was Minister van Financiën in Pruisen van 1933 tot en met 1944 .

5. J. Popitz, Der künftige Finanzausgleich zwischen Reich, Ländern und Gemeinden, Verlag von otto Liebmann, Berlin, 1932, p. 49.

6. Voor een juridische uiteenzetting wordt verwezen naar: H.J. de $\mathrm{Ru}$, staatsbedrijven en staatsdeelnemingen, Ars aequi libri, Nijmegen, 1981, pp. 277-303.

7. Europe, Agence internationale d'information pour la presse, Luxembourg-Bruxelles, no. 5166, 6-1-90, p. 15; no. 5369, 14$11-90$, p. 13.

8. Sell by 1992 , Subsidising state-owned firms is incompatible with Europe's internal market, in: The Economist, march 2 nd 1991 , pp. 16-17.

9. The aid plague, in: Survey Business in Europe, The economist, june 8 th 1991, p. 16.

10. EC commission expands power over the state sector, in: The wall street Journal Europe, july 25, 1991.

11. Brittan on the trail of aid to state companies, in: Financial Times, monday november 19, 1990.

12. W. Keyser, R. Windle, Public Enterprise in the EEC, France, part IV, Sijthoff en Noordhoff, Alphen aan den Rijn, 1978; W. Keyser, R. Windle, Public Enterprise in the EEC, Italy, part $V$, sijthoff en Noordhoff, Alphen aan den Rijn, 1978 .

13. Het onderscheid tussen de "staat als geldschieter" on "staat als aandeelhouder" wordt in verscheidene docuntinten aangetroffen. Zie bijvoorbeeld het jaarverslag van de Staatsmijnen over 1908, p. 11. Ook in de notities van de Commissie Kapitaalpositie staatsmijnen komt dit onderscheid voor. Hiervoor wordt verwezen naar: Concern Archief DSM, Comptabele en Financiële Aangelegenheden, 1940-1959, inv. nr. 33. 
14. Staatsmijnbedrijf, Nota over "de organisatie van commerciële staatsbedrijven, in het bijzonder met het oog op het bedrijf van de staatsmijnen in Limburg, 1907, p. 15, bron: Concern Archief DSM, Organisatie tot en met 1939, inv. nr. 7.

15. D. Bos, Het Beheer der Staatsbedrijven, in: Vragen des Tijds, 1908, p. 17; Staatsmijnen, Jaarverslag 1908, Heerlen, pp. $12-13$.

16. H. van Kol, staatsbedrijven en staatsmonopolies, N.V. Boekhandel en Uitgeversmaatschappij "Ontwikkeling", Amsterdam, 1918 , p. 3 .

17. Vereniging voor de staatshuishoudkunde en de statistiek, Pre-advies, 's-Gravenhage, Martinus Nijhoff, 1918, pp. 143$144,154-155,157-158,164,168-169$.

18. Enkele punten uit de inleiding van Prof. Veraart d.d. 25 april 1947 gehouden te Rumpen over socialisatie of bedrijfsorganisatie; bron: Nederlandse Katholieke Mijnwerkersbond, Nationalisatie Algemeen 1945-1955, Sociaal Historisch Centrum, Maastricht, EAN 581, J 1.0.

19. J.P. Windmuller en $C$. de Galan, Arbeidsverhoudingen in Nederland, deel 1 , Uitgeverij Het Spectrum, Utrecht, derde druk 1979, pp. 67-68.

20. R. Goldscheid, Staatskapitalismus oder Staatssozialismus, Anzengruber-Verlag, wien/Leipzig, zweite und dritte verbesserte Auflage, 1917, pp. 11, 15, 23-24.

21. Het Socialisatievraagstuk, Rapport uitgebracht door de Commissie aangewezen uit de SDAP, NV Boekhandel en uitgeversmaatschappij "Ontwikkeling", Amsterdam, 1920, pp. $35-36$.

22. P. Curwen, Public enterprise, Wheatsheaf Books Ltd., Brighton, first published, 1986, pp.216-217. Voortaan geciteerd als: Curwen, 1986. J. Vuchelen en W. van Impe, Privatisering, Standaard Uitgeverij, Antwerpen, 1987, 117-118. Voortaan geciteerd als: Vuchelen en Van Impe, 1987.

23. Algemene Rekenkamer, Verslag over 1946, Zitting 1946-1947, (552), nr. 1, pp. 7-8.

24. Handelingen der Staten-Generaal, Eerste Kamer, 1947-1948, 46 ste Vergadering, 22 juni 1948, $600 \mathrm{~J}$, Vaststelling van de begroting van de staatsmijnen in Limburg voor het dienstjaar 1948 , pp. $637,639$.

25. Ministerie van Verkeer en Waterstaat, Overzicht van de parlementaire behandeling van het vraagstuk van de controle door de Algemene Rekenkamer bij naamloze vennootschappen, waarin de staat in belangrijke mate participeert, 18 september 1963, pp. 5-6; bron: Ministerie van Verkeer en Waterstaat, doss. nr. 60213, class. nr. 25.07.352. 
26. Y. Aharoni, The no-risk society, Chatham House Publishers, New Yersey, 1981, pp. 113-114. Voortaan geciteerd als: Aharoni, 1981.

27. Ministerie van Financiën, Generale Thesaurie, Subsidiëring van Staatsbedrijven, no. 337, 's-Gravenhage, 25 januari 1949; bron: Ministerie van Economische, Archief Directie Mijnwezen, inv. nr. 170.

28. Het cijfer voor 1970 bestaat slechts uit de werkgelegenheid bij de PTT, omdat per 1 januari 1967 de Staatsmijnen werden omgezet in een naamloze vennootschap.

Centraal Bureau voor de Statistiek, Statistisch Zakboek, 1953, p. $28 ; 1956$, p. $35 ; 1961$, p. 43, 1966, p. 45 en 1970, p. 80.

29. W. Keyser en R. Windle, Public enterprise in the EEC, The Netherlands, Sijthoff \& Noordhoff, Alphen aan den Rijn, 1978, p. 67. In het vervolg geciteerd als: Keyser en Windle, 1978.

30. Handelingen Tweede Kamer, Bijlagen, zitting 1954-1955, Belastingheffing van overheidsbedrijven, Memorie van Toelichting, 3816 no. 3, p. 3

31. P.J. Oud, Voorzitter Adviescommissie voor Fiscale Aangelegenheden, Nota inzake belastingheffing van bedrijven van openbare lichamen en van naamloze vennootschappen waarvan de aandelen in handen van openbare lichamen $z i j n$, Rotterdam, juni 1949, p. $1 ;$ bron: Concern Archief DSM, Comptabele en Financiële Aangelegenheden, 1940-1959, inv. nr. 218.

32. Ministerie van Financiën, Afdeling Financiën Publiekrechtelijke Lichamen, Nota Heffing van vennootschapsbelasting van overheidsbedrijven,'s-Gravenhage, 31 december 1964; bron: Ministerie van Financiën, Generale Thesaurie, 1954-1975, dossier Belastingheffing van overheidsbedrijven.

33. Ministerie van Financiën, Nota inzake vennootschapsbelasting bij overheidsbedrijven, nr. 1726/DRbg, 31 december 1964, pp. 1-2; bron: Ministerie van Financiën, Generale-Thesaurie, 1954-1975, dossier Belastingheffing van overheidsbedrijven.

34. Ministerie van Financiën, Nota inzake vennootschapsbelasting bij overheidsbedrijven, 28 januari 1965, pp. 1-3; bron: Ministerie van Financiën, GeneraleThesaurie, 1954-1975, dossier Belastingheffing van overheidsbedrijven.

35. Ministerie van Financiën, Nota inzake vennootschapsbelasting bij overheidsbedrijven, $\mathrm{nr}$. 1726/DRbg, 31 december 1964, p. 8; bron: Ministerie van Financiën, Generale Thesaurie, dossier Belastingheffing van Overheidsbedrijven, 1954-1975. 
36. P. Friedrich en P. Kupsch (Hrsg.), Die Besteuerung Öffentlicher Unternehmen, Nomos-Verlagsgesellschaft, 1981, Baden-Baden, p. 278 .

37. De Adviescommissie voor fiscale aangelegenheden was ingesteld bij de ministeriële beschikking van 11 augustus 1945, no. 14. Het voorzitterschap werd vervuld door P.J. Oud.

38. Minister van Financiën, P. Lieftinck, Brief aan mr. P.J. Oud, Voorzitter Adviescommissie Fiscale Aangelegenheden, Afdeling Directe Belastingen, no. 227, Onderwerp: Belastingheffing van bedrijven van openbare lichamen en van naamloze vennootschappen waarvan de aandelen in handen van openbare lichamen zijn, 's-Gravenhage, 4 februari 1948; bron: Archief Ministerie van Financiën, Generale Thesaurie, 19541975, dossier: Wetsontwerp Belastingheffing van overheidsbedrijven.

39. P.J. Oud, Voorzitter Adviescomissie Fiscale Aangelegenheden, Nota inzake belastingheffing van bedrijven van openbare lichamen en van naamloze vennootschappen waarvan de aandelen in handen van openbare lichamen zijn, Rotterdam, juni 1949, pp. 11-12; bron: Concern Archief DSM, Comptabele en Financiële Aangelegenheden, 1940-1959, inv. nr. 218.

40. N.P. Mol, Bedrijfseconomie voor de collectieve sector, Samsom H.D. Tjeenk Willink, Alphen aan den Rijn, 1986, p. 68.

41. Samenvatting II van de besprekingen omtrent afschrijvingen op de waarde van kapitaalgoederen, gehouden op 20 oktober 1948 door de daartoe ingestelde commissie, p. 2.

Samenvatting III van de besprekingen in de comissie ad hoc voor de aanpassing van het afschrijvingsbeleid van de staatsbedrijven aan de gewijzigde waarde- en prijsverhoudingen, gehouden op 16 november 1948, p. 1 ; bron: Concern Archief DSM, Comptabele en Financiële Aangelegenheden 1940-1959, inv. nr. 28.

42. Ministerie van Financiën, brief aan de minister van Verkeer en Waterstaat, Onderwerp: toepassing vervangingswaarde staatsvissershavenbedrijf, 's-Gravenhage, 22 oktober 1956, p. 1; bron: Ministerie van Financiën, Generale Thesaurie, inv. nr. 1593.

Ministerie van Financiën, Nota Balanswaarde activa Staatsmijnen, 13 februari 1959, p. 1; bron: Ministerie van Financiën, Generale Thesaurie, inv, nr. 1761.

43. Minister van Economische Zaken, Brief inzake tariefverhogingen overheidsbedrijven, Notulen Ministerraad, 19 C, d.d. 26.2.1960; bron: Algemeen Rijksarchief.

44. Uitvoering wet op de ondernemingsraden ten aanzien van overheids- en semi-overheidsondernemingen, Notulen REA d.d. 2 december 1953; bron: Ministerie van Financiën, Generale 
Thesaurie, inv. nr. 1099.

Ministerie van Sociale Zaken en Volksgezondheid, Uitvoering wet op de ondernemingsraden ten aanzien van overheids- en semi-overheidsbedrijven, Nota 1007,1 juli 1953, p. 3; bron: Ministerie van Financiën, Generale Thesaurie, inv. nr. 1099.

45. Nota betreffende de Toestand Van 's Rijks financiën behorende bij de ontwerpbegroting voor 1957, pp. 6-7.

46. Notulen Ministerraad, 10 december 1956, pp. 22-23; bron: Algemeen Rijksarchief.

47. Handelingen Tweede Kamer, Rijksbegroting 1957, Algemene Financiële Beschouwingen, Memorie van Antwoord, no. 2, zitting 1956-1957, 4500, p. 3.

48. F. de Kam, J. de Haan en C. Sterks, De kerfstok van Nederland, Academic Service, Schoonhoven, 1990, pp. 116-125.

49. Handelingen Tweede Kamer, Bijlagen, Nota naar aanleiding van het verslag, nr. 5, zitting 1960-1961, 6003, p.2.

50. Staatsmijnen, Notitie Regeringsopvattingen omtrent staatsbedrijven, LA $3 / 1,21$ juli 1954 ; bron: Concern Archief DSM, Organisatie 1950-1969, inv. nr. 6, map 1.

51. J. Goudriaan, Vriend en vijand, Herinneringen aan de Nederlandse Spoorwegen 1938-1948, Uitgeverij De Bezige Bij, Amsterdam, 1961, p. 274. Voortaan aangeduid als: Goudriaan, 1961.

52. NV, Nederlandse Spoorwegen, brief van 17 januari 1990, sct $/ \mathrm{b} \cdot 3 \cdot 3 \cdot / 0182 \mathrm{~A} / \mathrm{N}$.

53. NV Nederlandse Spoorwegen, Huishoudelijk reglement van de Raad van Commissarissen, 10 september 1975.

54. DSM, Brief, CS/FP 89019, Heerlen, 26 april 1989.

55. Aanwijzingen ten behoeve van archiefbeheerders, in: De Staatscourant, 12 maart 1973, nummer 50 , p. 4 .

56. Wet van 19 december 1985, houdende regeling van de Nederlandse Organisatie voor Toegepast-Natuurwetenschappelijk Onderzoek TNO, Staatsblad 1985, nr. 762.

57. NV DSM, Jaarverslag 1991, p. 53.

H. Wammes, Weerstand tegen beursgang DSM, in: NRC Handelsblad, 7 juli 1988.

58. Groep wil af van invloed staat in DSM, in: NRC Handelsblad 16 april 1992, p. 21. 
59. Rail 21, Sporen naar een nieuwe eeuw, Nederlandse Spoorwegen, Utrecht, oktober 1988.

Rail 21 Cargo: Het Tweede Spoor, Nederlandse Spoorwegen, Utrecht, januari 1990, pp. 2, 25-26.

60. Van den Tempel, Publieke en semi-publieke ondernemingen, N. Samsom n.v., Alphen aan den Rijn, 1935. Voortaan aangehaald als: Van den Tempel, 1935.

C.A. Verrijn stuart, De wetenschap der volkshuishoudkunde en de grondslagen der volkshuishouding, Haarlem, De Erven F. Bohn n.v., vijfde herziene druk 1943. Voortaan aangehaald als: verrijn stuart, 1943.

M.J.H. Smeets, De economische betekenis van belastingen, L.J. Veen's Uitgevers Maatschappij n.v., Amsterdam, tweede druk, 1954. Voortaan aangehaald als: Smeets, 1954.

c. Goedhart, Hoofdlijnen van de leer der openbare financiën, H.E. Stenfert Kroese b.v., Leiden, derde druk, 1975. Voortaan aangehaald als: Goedhart, 1975.

61. Verrijn stuart, 1943, a.w., p. 250.

62. Van den Tempel, 1935, a.w., pp. 36-37.

63. Smeets, 1954, a.w., p. 14 .

64. Goedhart, 1975, a.w., pp. 123-125, 128-136.

65. P. Eichhorn, Anforderungen an eine für die Politikberatung geeignete Theorie öffentlicher Unternehmen, in: $T$. Thiemeyer, Hrsg., Öffentliche Unternehmen und ökonomische Theorie, Nomos, Verlagsgesellschaft, Baden-Baden, 1. Aufl. 1987.

66. V.V. Ramanadham, The economics of public enterprise, Routledge, London, first published 1991, p. 224. Voortaan geciteerd als: Ramanadham, 1991.

67. J. Backhaus, öffentliche Unternehmen, Haag und Herchen Verlag, Frankfurt am Main, 2. durchgesehene und erweiterte Auflage 1980, pp. 88, 102-103, 121 .

68. Zie de bijdragen van $K$. Lulofs en J. Schuddeboom, en J. Bressers en M. Herwijer; in: J. Bressers en A. Hoogerwerf (red.), Beleidsevaluatie, Samsom, H.D. Tjeenk willink, Alphen aan den Rijn, tweede druk 1991, pp. 70-101, 102-121.

69. H. Tulkens, The performance approach in public enterprise economics: an introduction and an example, in: Annals of Public and Co-operative Economy 74, 1986, pp. 429-443. Voortaan geciteerd als: Tulkens, in: Annals of Public and Cooperative Economy, 1986. 
S. Perelman en P. Pestieau, Technical performance in public enterprises, in: European Economic Review 32, 1988, pp. 432441.

P. Pestieau, Measuring the performance of public enterprises, in: Annals of Public and Cooperative Economics, Vol. 60, No. 3, 1989, pp. 293-305. Voortaan geciteerd als: Pestieau, in: Annals of Public and Co-operative Economy, 1989.

P. Pestieau en H. Tulkens, Assessing the performance of public sector activities some recent evidence from the productive efficiency viewpoint, June 1990, pp. 53.

voortaan geciteerd als: Pestieau en Tulkens, 1990.

70. M.J. Farrel, The measurement of productive efficiency, in: The Journal of the Royal statistical Society, Part III, 1957, pp. 253-281.

71. Pestieau en Tulkens, 1990, a.w., p. 9.

72. H. Parris, P. Pestieau en P. Saynor, Public enterprise in Western Europe, Croom Helm, London, 1987, p. 145.

73. Tulkens, in: Annals of Public and Co-operative Economy, 1986, a.w., p. 430-431.

74. Pestieau, in: Annals of Public and Co-operative Economy, 1989, a.w., p. 297.

75. Pestieau, in: Annals of Public and Co-operative Economy, 1989, a.w., p. 297.

76. Pestieau, in: Annals of Public and Co-operative Economy, 1989 , a.w., p. 297.

77. Pestieau, in: Annals of Public and Co-operative Economy, 1989 , a.w., p. 298.

78. Pestieau, in: Annals of Public and Co-operative Economy, 1989 , a.w., p. 298-299.

79. J. G. Backhaus, Assessing the performance of public enterprises: a public choice approach, Rijksuniversiteit Limburg, wp 89-007, 4 april 1989, pp. 4-8. Voortaan aangehaald als: Backhaus, 1989.

80. A. Alchian en H. Demsetz, Production, information costs, and economic organization, in: L. Putterman (ed.), The Economic Nature of The Firm, A Reader, Cambridge University Press, Cambridge, 1988, p. 112. Oorspronkelijk gepubliceerd in: The American Economic Review, 62, 1972, pp. 777-795. Voortaan aangeduid als: Alchian en Demsetz, Production, information costs, and economic organization, in: Putterman, 1988. 
81. Alchian en Demsetz, Production, information costs, and economic organization, in: Putterman, 1988, a.w., pp. 118-119.

82. Alchian en Demsetz, Production, information costs, and economic organization, in: Putterman, 1988, a.w., pp. 118-119.

83. Alchian en Demsetz, Production, information costs, and economic organization, in: Putterman, 1988, a.w., p. 119.

84. D.G. Davies en P.F. Brucato, Property rights and transaction costs: theory and evidence on privately owned and government-owned enterprises, Journal of Institutional and Theoretical Economics, 143 (1987), pp. 11-13.

85. F.A.M. Messing, Geschiedenis van de mijnsluiting in Limburg, Martinus Nijhoff, Leiden, 1988, p. 159. Voortaan geciteerd als: Messing, 1988.

86. Backhaus, 1989, a.w., p. 16.

87. Minister van Financiën P. Lieftinck, Brief aan mr. P.J. oud, Voorzitter Adviescommissie Fiscale Aangelegenheden, afdeling Directe Belastingen, no. 227, onderwerp: Belastingheffing van bedrijven van openbare lichamen en van namloze vennootschappen waarvan de aandelen in handen van openbare lichamen zijn, 's-Gravenhage, 4 februari 1948, p. 3; bron: Archief Ministerie van Financiën, Generale Thesaurie, 1954-1975, dossier: Wetsontwerp belastingheffing van overheidsbedrijven.

88. Comptabiliteitswet 1927, art. 33, Staatsblad 1927, no. 259 .

89. V.V. Ramanadham, Public enterprise and income distribution, Routledge, London and New York, first published, 1988, p. 31. Voortaan aangeduid als: Ramanadham, 1988.

90. R. Rees, Public enterprise economics, Weidenfeld and Nicolson, London, second edition, 1984, p. 137. Voortaan aangehaald als: Rees, 1984 .

91. Rees, 1984, a.w., pp. 137-138.

92. Ramanadham, 1988, a.w., p.33.

93. A. Koutsoyiannis, Modern microeconomics, Macmillan Education Ltd., second edition, 1987, pp. 190-191.

94. Ministerie van Verkeer en waterstaat, Notitie voor de heer staatssecretaris, 's-Gravenhage, 14 mei 1970; bron: Ministerie van Verkeer en Waterstaat, Werkspoor, class. nr. 25.07.352, doss. nr. $26430 \mathrm{~F}$ deel 3.

95. C.B. Blankart, Ökonomie der öffentlichen Unternehmen, Verlag Franz Vahlen, München, 1980, pp. 24-27. Voortaan aangehaald als: Blankart, 1980. 
96. P.J. Oud, Voorzitter Adviescommissie voor Fiscale Aangelegenheden, Nota inzake belastingheffing van bedrijven van openbare lichamen en van namloze vennootschappen waarvan de aandelen in handen van openbare lichamen zijn, Rotterdam, juni 1949; bron: Concern Archief DSM, Comptabele en Financiële Aangelegenheden, 1940-1959, inv. nr. 218.

97. H. Simon, Organizations and markets, 4 february 1989, p. 10. Voortaan aangehaald als: Simon, 1989.

98. Blankart, 1980, a.w., pp. 83-84.

99. A.E. Boardman en A.R. Vining, Ownership and performance in competitive environments: a comparison of the performance of private, mixed, and state-owned enterprises; in: Journal of Law and Economics, vol. XXXII, april 1989, p. 9. In het vervolg aangehaald als: Boardman en Vining; in: Journal of Law and Economics, 1989.

100. Blankart, 1980, a.w., pp. 84-88; Mishan, Cost-benefit analysis, Praeger, New York, 1976, pp. 117-121.

101. Y. Aharoni, The evolution and management of state-owned enterprises, Ballinger Publishing Company, Cambridge, Massachusetts, 1986, pp. 267-268. Voortaan geciteerd als: Aharoni, 1986.

102. R. Slot, Elementaire bedrijfseconomie, stenfert Kroese bv, Leiden/Antwerpen, negende herziene druk, 1983, p. 29. voortaan geciteerd als: Slot, 1983.

103. J.P.J. Frenken, over kapitaalcoëfficiënten, in: Maandschrift economie, jaargang 53, 1989, no. 5, p. 402 .

104.K. Kühne, Der Kapazitätserweiterungseffekt der Abschreibungen (sog. Lohmann-Ruchti-Effekt) in mikro- und makroökonomischer sicht; in: P. Eichhorn en $T$. Thiemeyer (Hrsg.), Finanzierung öffentlicher Unternehmen, Nomos Verlagsgesellschaft, Baden-Baden, 1979, p. 182.

105. R. Eisner, Depreciation allowances, replacement requirements and growth; in: The American Economic Review, vol. XLII, no. 5, 1952, pp. 820-831.

E.D. Domar, Depreciation, replacement and growth; in: The Economic Journal, vol. LXIII, no. 3, 1953, pp. 1-32.

106. W.S. Peirce, Rent and technological change in the extractive industries, paper conference on New Issues in Industrial Economics, june 2, 1988, p. 6 .

107. W. Niopek, Innovationsverhalten öffentlicher Unternehmen, Nomos Verlagsgesellschaft, Baden-Baden, 1. Auflage 1986, pp. 158-167. Voortaan aangehaald als: Niopek, 1986.

108. Niopek, 1986, a.w., pp. 106-110. 
109. Curwen, 1986, a.w., p. 90. M. Haririan, State-owned enterprises in a mixed economy, Westview Press Inc., Boulder, 1989, pp. 48, 53. Voortaan geciteerd als: Haririan, 1989.

110. R.J. Monsen en K.W. Walters, Nationalized companies: a threat to american business, McGraw-Hill Book Company, New York, 1983, pp. 45-47. Voortaan aangeduid als: Monsen en walters, 1983.

111. Ramanadham, 1988, a.w., pp. 17-21.

112. J. Backhaus, Privatisering en nationalisering: een aanzet tot een nieuwe benadering, in: Maandschrift Economie, jaargang 53, 1989, pp. 368-369. Voortaan geciteerd als: Backhaus; in: Maandschrift Economie, 1989.

113. A. Alchian, Corporate management and property rights, in: G. Furubotn en S. Pejovich, The economics of property rights, Ballinger Publishing Company, Cambridge, Massachusets, 1974, p. 147 .

114. H. Morrison, Socialisation and transport, London, Counstable, 1932, p. 165. Voortaan aangeduid als: Morrison, 1932 .

115. H. de Jonge, Een overheidsbedrijf als publieke onderneming: algemeen matschappelijke kanttekeningen, in: Beleid en matschappij, 1981, p. 115.

116. Alchian en Demsetz, Production, information costs, and economic organization, in: Putterman, 1988, a.w., p. 124.

117. Ramanadham, 1991, a.w., p. 108.

118. Artikel 5 (1) (j) en (2)(f), Bedrijvenwet van 1928, Nederlandse Staatswetten, Editie Schuurman \& Jordens, 20, negende druk, Zwolle, 1977.

119. P.J. Oud, Voorzitter Adviescommissie voor Fiscale Aangelegenheden, Nota inzake belastingheffing van bedrijven van openbare lichamen en van naamloze vennootschappen waarvan de aandelen in handen van openbare lichamen zijn, Rotterdam, juni 1949; bron: Concern Archief DSM, Comptabele en Financiële Aangelegenheden, 1940-1959, inv. nr. 218 .

120. H. Aumund, Die Aufgaben der Technik im Dienste der öffentlichen Gemeinwesen; in: Technik und Wirtschaft, 1917, p. 108 .

121. Prof. mr. B.M. Telderstichting, Open ondernemerschap, Martinus Nijhoff, 's-Gravenhage, tweede druk, 1962, p. 292.

122. J.W. McGuire, J.S.Y. Chiu en A.O. Elbing, Executive incomes, sales and profits, in: The American Economic Review, 1962, pp. 753-761. 
123. Ramanadham, 1988, a.w., pp. 14, 21-22.

124. NV Nederlandse Spoorwegen, Exploitatiebegroting 1968, p. $3 a$.

125. D.G. Davies en P.F. Brucato, Property rights and transaction costs: theory and evidence on privately owned and government-owned enterprises, Journal of Institutional and Theoretical Economics, 143 (1987), p. 10.

126. T. Robson, Auditing problems in relation to hidden reserves, in: Maandblad voor accountancy en bedrijfshuishoudkunde, $36 \mathrm{e}$ jaargang, nr. 6, juni 1962, p. 226. Voortaan geciteerd als: Robson; in: Maandblad voor accountancy en bedrijfshuishoudkunde, 1962. Slot, 1983, a.w., p. 159.

127. Voorlichtingsdienst Nederlandse Steenkolenmijnen, Kernpunten uit de regelingen betreffende de wijze van beheer en financiering van de Staatsmijnen in Limburg; in het bijzonder de verhouding hierbij ten opzichte van de overheid, oktober 1948, p. 3; bron: Concern Archief DSM, Comptabele en Financiële Aangelegenheden 1940-1959, inv. nr. 33.

128. Aharoni, 1986, a.w., pp. 132-134.

129. Aharoni, 1986, a.w., pp. 169-171.

130. Aharoni, 1986, a.w., p. 397.

131. Haririan, 1989, a.w., pp. 111-113, 118-119.

132. Haririan, 1989, a.w., pp. 44, 114-115.

133. Haririan, 1989, a.w., pp. 118-119.

134. Ramanadham, 1991, a.w., pp. 72-81.

135. Ramanadham, 1991, a.w., p. 82.

136. Ramanadham, 1991, a.w. pp. 88, 90.

137. Ramanadham, 1991, a.w., pp. 225-228.

138. J.L. Bouma, Leerboek der bedrijfseconomie, deel II, Delwel, Wassenaar, tweede geheel herziene druk, 1988, pp. 285286.

139. P. Eichhorn, Probleme der Eigenfinanzierung bei öffentlichen und gemischtwirtschaftlichen Unternehmen, in: P. Eichhorn, T. Thiemeyer (Hrsg.), Finanzierung öfenticher Unternehmen, Nomos Verlagsgesellschaft, Baden-Baden, 1979, p. 54 .

140. P.K. Porter, G.W. Scully en D.J. Slottje, Industrial policy and the nature of the firm, in: Journal of Institutional and Theoretical Economics, 142, 1, 1986, pp. 89- 
90.

141. Ministerie van Financiën, Nota inzake jaarrekening 1956 Statsmijnen, 26 oktober 1957, A 7/12102, p. 3; bron: Ministerie van Financiën, inv. nr. 1761.

142. C.B. Blankart, Ordnungspolitische Rahmenbedingungen und öffentliche Unternehmertätigkeit: Soll der Staat industrielles Beteiligungskapital halten? in: Th. Thiemeyer (Hrsg.) öffentliche Unternehmen und ökonomische Theorie, Nomos Verlagsgesellschaft, Baden-Baden, 1987, pp. 59-60. Voortaan geciteerd als: Blankart; in: Thiemeyer (Hrsg.), 1987.

143. Verrijn stuart, 1943, a.w., p. 175.

144. Zie ook Boardman en Vining; in: Journal of Law and Economics, 1989, a.w., pp. 8-10.

145. T. Killick, Policy Economics, Heinemann, London, first published 1981, p. 295.

146. C. Veljanovski, selling the state, weidenfeld and Nicolson Ltd, London, 1988, p. 77. Voortaan aangehaald als: veljanovski, 1988 .

147. Handelingen Tweede Kamer, Bijlagen, 1987-1988, 17938, $\mathrm{nr}$. 43 , p. 1 .

148. M. Beesley en S. Littlechild, Privatization: principles, problems and priorities, in: Lloyds Bank Review, july 1983, p. $2,9-11$.

149. Algemene Rekenkamer, Privatisering Staatsvissershavenbedrijf, Tweede Kamer, vergaderjaar 19861987, 17938, nr. 36, p. 7; Ministerie van Financiën, Handboek privatisering, SDU uitgeverij, 's-Gravenhage, 1990, p. 55.

150. Curwen, 1986, a.w., p. 201.

151. Vuchelen en Van Impe, 1987, a.w., pp. 189-191.

152. Veljanovski, 1988, a.w., p. 95.

153. Handelingen Tweede Kamer, Bijlagen, zitting 1960-1961, 6003 , nr. 4 en 5

154. C. Shapiro en R.D. Willig, Economic rationales for the scope of privatization, in: E.N. Suleiman en J. Waterbury (ed.), The political economy of public sector reform, Westview Press, Boulder, 1990, pp. 55-87.

155. Morrison, 1932, a.w., p. 160.

156. Aharoni, 1986, a.w., pp. 288-291; The Economist, A survey of Italy, may 26,1990, p. 4. 
157. Aharoni, 1986, a.w., pp. 290-291.

158. Monsen en Walters, 1983, a.w., p. 37, en Ramanadham, 1991, a.W., p. 357.

159. Goudriaan, 1961, a.w., p. 273. A. van der Zwan, Goudriaan in botsing met NS, Uitgeverij Scriptum, Schiedam, 1991, pp. 234 .

160. Monsen en Walters, 1983, a.w., pp. 57-58, 64 .

161. G.E. Braun, Ziele in öffentlicher Verwaltung und privatem Betrieb, Schriften zur öffentlichen Verwaltung und öfentlichen wirtschaft, Band 76, Nomos Verlagsgesellschaft, Baden-Baden, 1988, pp. 327-328.

162. I. Vogelsang, Public enterprise in monopolistic and oligopolistic industries, Harwood Academic Publishers, Chur, 1990 , p. 44-47. Voortaan geciteerd als: Vogelsang, 1990.

163. Vogelsang, 1990, a.w., p. 44 .

164. Vogelsang, 1990, a.w., p. 45.

165. Vogelsang, 1990, a.w., p. 45.

166. Vogelsang, 1990, a.w., p. 62 .

167. Handelingen Eerste Kamer, deel I, 11 november 1959, zitting 1959-1960, pp.60-64.

168. Aharoni, 1981, a.w., pp. 118-121.

169. Comptabiliteitswet (1976), artikel 5 par. (1) en (2); Circulaire van de Minister van Financiën, no. 386-12107, november 26, 1986 (le aanvulling).

170. Een manier om een ongebreidelde groei van garanties te voorkomen is de introductie van niet-revolverend garantiekapital in de desbetreffende regelingen.

171. Notitie aan de directie, Chef algemeen secretariaat, Heerlen, 8 juni 1959; bron: Concern Archief DSM, Organisatie 1950-1969, inv. nr. 3.

172.Ministerie van Financiën, Generale Thesaurie, Nota wijziging Aanwijzingswet van de Staatsmijnen, 18 januari 1954, nr. 501/DRbg, p. 5; bron: Ministerie van Financiën, Generale Thesaurie, inv. nr. 1549.

173. Handelingen Eerste Kamer, 26ste vergadering, 23 maart 1949, zitting 1948-1949, pp. 343-345.

Minuut, Bedrijfseconomisch rapport statsmijnen, 15575/081.0AZ, 21 juli 1949, p. 4; bron: Concern Archief DSM, Comptabele en Financiële Aangelegenheden 1940-1959, inv. nr. 
174. L. Kreukels, Mijnarbeid: volgzaamheid en strijdbaarheid, Van Gorcum, Assen/Maastricht, 1986, pp. 53-57.

175. Messing, 1988, a.w., pp. 19, 151, 290.

176. Staatsmijnen in Limburg, Brief aan Minister van Waterstaat, 26 februari 1929, pp. 3-4; bron: Concern Archief DSM, organisatie tot en met 1939, inv. nr. 11, map 1.

177. Ministerie van Waterstaat, Ministeriële Instructie, art. 14, 12 april 1937; bron: Concern Archief DSM, Organisatie 1950-1969, inv. nr. 3.

178. Staatsmijnen in Limburg, Richtlijnen inzake het aanvragen van machtiging aan de minister voor de uitvoering van aanlegwerken, nr. 747 A.Z., Heerlen, 14 september 1951, p. 5; bron: Concern Archief DSM, Organisatie 1950-1969, inv. nr. 1.

179. Staatsmijnen in Limburg, Verantwoording van investeringen, Heerlen, 24 november 1966, p. 1, bron: Concern Archief DSM, Comptabele en Financiële Aangelegenheden, inv. $n x .38$.

180. Staatsmijnen in Limburg, Richtlijnen inzake het aanvragen van machtiging aan de minister voor de uitvoering van aanlegwerken, nr. 747 A.Z., Heerlen, 14 september 1951, p. 2; bron: Concern Archief DSM, Organisatie 1950-1969, inv. nr. 1.

181. Staatsmijnen, Notitie inzake een eventuele herziening van de organisatie van de hoogste leiding van de Statsmijnen naar aanleiding van de voorstellen tot structuurwijziging onder de "topchefs" d.d. 14 april 1958 en 17 april 1958 (concept), Heerlen, 21 april 1958, pp. 3-4, bron: Concern Archief DSM, organisatie 1950-1969, inv. nr. 1.

182. Staatsmijnen, wijziging van interne machtigingsregeling, 6 januari 1954, p. 1; bron: Concern Archief DSM, Organisatie 1950-1969, inv. nr. 2 .

183. Staatsmijnen, Goedkeuringsprocedure van uit te voeren werken, Heerlen, 7 september 1960, nr. 2395, p. 1; bron: Concern Archief DSM, Organisatie 1950-1969, inv. nr. 1.

184. Staatsmijnen, Goedkeuringsprocedure van uit te voeren werken, Heerlen, 7 september 1960, $\mathrm{nr} .2395$, pp. 1-2; bron: Concern Archief DSM, Organisatie 1950-1969, inv. nr. 1.

185. Staatsmijnen, Goedkeuringsprocedure van uit te voeren werken, Heerlen, 7 september 1960, nr. 2395, p. 3; bron: Concern Archief DSM, Organisatie 1950-1969, inv. nr. 1.

186. Ministeriële Instructie, Ministerie van Waterstaat, art. 14, 12 april 1937; Ministeriële Instructie, Ministerie van Economische zaken, art. 10, 28 mart 1950; bron: Concern 
Archief DSM, Organisatie 1950-1969, inv. nr. 3 .

187. Statuten NV Nederlandse Staatsmijnen, Art. 10,Bijvoegsel Nederlandse staatscourant, $\mathrm{nr} .613,27$ januari, 1967, $\mathrm{nr} .20$.

188. Staatsmijnen, Enige nationaal-economische consequenties van het investeringsprogramma van de staatsmijnen, 12 februari 1965; Concern Archief DSM, Comptabele en financiële aangelegenheden, 1960-1969, inv. nr. 38 .

189. De organisatie van een mijn, bijlage notulen 65e vergadering ondernemingsraad staatsmijnen, 4 april 1950, pp. 1-2; bron: Concern Archief DSM, Organen van overleg en Bedrijfsrechtspraak, 1950-1959, inv. nr. 89a.

190. DSM, Milieu-Actieplan DSM Limburg BV, 1983, pp. 10-11.

191. Handelingen Tweede Kamer, Bijlagen, zitting 1947-1948, Vaststelling van de begroting van de staatsmijnen in Limburg voor het dienstjaar 1948, Brief van de minister van Economische Zaken 14 april 1948 , no. 6 .

192. Ministerie van Economische Zaken, Directie Mijnwezen, Werkplan Staatsmijnen 1960, nota mw 10/60, pp. 2-3; bron: Ministerie van Economische Zaken, Archief Directie Mijnwezen, Staatsmijnen, inv. nr. 185.

193. Messing, 1988, a.w., pp. 138-143.

194. Staatsmijnen in Limburg, Memorandum: Investeringen en financiering van de Staatsmijnen in de periode 1958-1967; bron: Ministerie van Economische Zaken, Archief Directie Mijnwezen, Staatsmijnen, inv. nr. 185.

195. Ministerie van Economische Zaken, Directie Mijnwezen, Tienjarig investeringsplan van de staatsmijnen, nota MW 10/59, 21 januari 1959, p. 2; bron: Ministerie van Economische zaken, Archief Directie Mijnwezen, Staatsmijnen, inv. nr. 185.

196. Messing, 1988, a.w., pp. 185-188.

197. Besluit van 2 september 1907 tot wijziging van het Koninklijk Besluit van 29 mei 1902 (Staatsblad no. 78) tot inrichting van den dienst der staatsmijnen in Limburg en tot instelling van een Mijnraad, uit: Staatsblad 1907, Art. I (6), no. 246. Voortaan aangehald als: Besluit van 2 september 1907.

198. Notulen ondernemingsraad, 180 e vergadering, 22 april 1958 , p. 4, bron: Concern Archief DSM, Organen van overleg en Bedrijfsrechtspraak 1950-1969, inv. nr. 89b.

199. Art. 4, Besluit van 29 mei 1902 tot inrichting van den dienst der staatsmijnen in Limburg en tot instelling van een Mijnraad, uit: Staatsblad 1902, no. 78 . 
200. Art. I (4), Besluit van 2 september 1907.

201. Koninklijk Besluit van 25 april 1913, in: Staatsblad 1913, nr. 139.

202. Bijlage II, Inleiding van Mr. L.P. van der Weijden over de beloning en de andere arbeidsvoorwaarden der beambten, notulen 84 vergadering $\mathrm{O} . \mathrm{R}$. dd. juli 1951, p. 2; Concern Archief DSM, Organen van overleg en bedrijfsrechtspraak 19501959, inv. nr. 89b.

203. Staatsmijnen, Juridische Afdeling, Faciliteiten, waarop na omzetting van staatsmijnen in een $\mathrm{NV}$ geen beroep meer zal kunnen worden gedaan, 11 december 1961; bron: Concern Archief DSM, Organisatie 1950-1969, inv. nr. 6, map 2.

204. Statuten NV Nederlandse Staatsmijnen, Art. 11 (1)(1), in: Bijvoegsel Nederlandse Staatscourant, $\mathrm{nr} .613,27$ januari 1967, nr. 20.

205. Notulen van de vergadering van de Mijnraad met de directie van de staatsmijnen, gehouden te Heerlen, op donderdag 13 juli 1939, p. 2; bron: Concern Archief DSM, organisatie $t / m$ 1939, inv. nr. 4.

206. Mijnraad, Tantièmes Staatsmijnen, 3 november 1911; bron: Algemeen Rijksarchief, Archief Mijnraad, inv. nr. 50.

207. Afdeling Vervoer en Mijnwezen, Ministerie van Waterstaat, Premieregeling directieleden, 's-Gravenhage, 27 januari 1936; bron: Algemeen Rijksarchief, Archief Mijnraad, inv. nr. 50.

208. Ministerie van Waterstaat, Premieregeling directieleden, no. 481, 's-Gravenhage, 27 januari 1936; bron: Algemeen Rijksarchief, Archief Mijnraad, inv. nr. 50.

209. Ministerie van Waterstaat, Premieregeling directieleden, no. 481, 's-Gravenhage, 27 januari 1936; bron: Algemeen Rijksarchief, Archief Mijnraad, inv. nr. 50 .

Staatsmijnen in Limburg, Brief aan Minister van Waterstaat betreffende salaris-, gratificatie- en premieregeling, Heerlen, 19 februari 1936; bron: Algemeen Rijksarchief, Archief Mijnraad, inv. nr. 50.

210. Het vorige bezoldigingsbesluit was genomen op 8 april 1959.

Besluit houdende bezoldiging hoofddirectie staatsmijnen in Limburg, no. 30, 22 juni 1964; bron: Ministerie van Economische Zaken, Archief Directie Mijnwezen, Bezoldiging hoofddirectie, inv. nr. 159.

211. Statuten NV Nederlandse Staatsmijnen, Art. 25, in: Bijvoegsel Nederlandse staatscourant, nr, 613, 27 januari, $1967, \mathrm{nr} .20$. 
212. Statuten NV Nederlandse Staatsmijnen, Art. 6 (4), in: Bijvoegsel Nederlandse staatscourant, nr. 613, 27 januari 1967, nr. 20.

213. Raad van Commissarissen, notulen $2 \mathrm{e}$ vergadering, Arbeidsvoorwaarden Hoofddirectie, 10 maart 1967, p. 16; bron: Concern Archief DSM.

214. Ministerie van Economische Zaken, brief Vergoeding Commissarissen, 10 maart 1967; bron: Concern Archief DSM, organisatie 1950-1969, inv. nr. 31 .

215. Ministerie van Economische zaken, brief Commissarisbeloning, 22 mei 1968; bron: Concern Archief DSM, organisatie 1950-1969, inv. nr. 31.

216. Staatsmijnen, Subsidiebeleid der staatsmijnen, 23 juli 1958, pp. 2-3; bron: Concern Archief DSM, Sociale Zorg en Matschappelijk Werk, 1950-1959, inv. nr. 191.

217. Handeling Tweede Kamer, Bijlagen, zitting 1952-1953, $2800 \mathrm{~K}$, nr. 5, p. 2 ; nr. 6 , p. 2 .

218. Bedrijven en deelnemingen van de Nederlandse stat en de rechtsvorm van de staatsmijnen, p. 5 ; bron: Concern Archief DSM, Organisatie 1950-1969, inv. nr. 6 map 1.

219. Artikel 10, Instructie, 12 april 1937, La. A. Afdeling Vervoer- en Mijnwezen, Ministerie van waterstaat; Artikel 1 , Instructie, 28 maart 1960, Ministerie van Economische Zaken, bron: Concern Archief DSM, organisatie 1950-1959, inv. nr. 3.

220. Ministerie van Economische Zaken, Directie Mijnwezen, Vaste Commissie/bedrijfseconomisch rapport staatsmijnen, nota MW 225/63, 30 oktober 1963, pp. 1-2; bron: Ministerie van Economische Zaken, Archief Directie Mijnwezen, staatsmijnen, inv. $\mathrm{nr} .384$.

221. Statuten Naamloze Vennootschap staatsmijnen, Art. 2, Heerlen, in: Bijvoegsel Nederlandse staatscourant, 27 januari 1967, nr. 20.

222. Commissie Kapitaalpositie Staatsmijnbedrijf, Nota betreffende de verhouding tussen de overheid en de Staatsmijnen, 16 november 1949, pp. 3-4; bron: Concern Archief DSM, Comptabele en Financiële Aangelegenheden 1940-1959, inv. $\mathrm{nr} .33$.

223. Ministerie van Financiën, Nota suppletoire aanvraag 1952 voor kapitaaluitgaven staatsmijnen, 1 februari 1952, p. 2; bron: Ministerie van Financiën, inv. nr. 1549.

224. Rapport inzake het memorandum betreffende investeringen en kapitaalpositie staatsmijnen over de periode 1953 tot en met 1960, 20 mei 1953, p. 1; bron: Ministerie van Financiën, 
inv. nr. 1549.

225. Staatsmifnen in Limburg, Gaslevering aan gemeenten, $\mathrm{nr}$. 104726, AA/20, Heerlen, 2 december 1936, p. 1; bron: Concern Archief DSM, Gasdistributiebedrijf tot en met 1939, inv. nr. 188 .

226. Vaststelling van de begroting van de staatsmijnen in Limburg voor het dienstjaar 1953, memorie van toelichting, no. 2 , p. 6; bron: Sociaal Historisch Centrum, Begroting van de Staatsmijnen in Limburg, 1953/1959.

227. Subsidiebeleid, 2 oktober 1954, p. 1; bron: Concern Archief DSM, Sociale Zorg en Maatschappelijk Werk, 1950-1959, inv. nr. 191.

228. Subsidiebeleid, 2 oktober 1954, p. 1; bron: Concern Archief DSM, Sociale Zorg en Maatschappelijk Werk, 1950-1959, inv. nr. 191.

229. Staatsmijnen in Limburg, Subsidiebeleid der staatsmijnen, 23 juli 1958, p. 1; bron: Concern Archief DSM, Sociale Zorg en Maatschappelijk Werk, 1950-1959, inv. nr. 191.

230. Staatsmijnen, Jaarvers 3 aq over $1955, p, 21$.

231. Staatsmijnen, Jaarversiag over $1957, p .29$.

232. Staatsijnen, Jaarversiag over $1957, p$, 31.

233. Vastste113ng van de begroting woor het dienstjaar 1960, Menorie van toelichting, nE 2, p. 7 ; bron: sociad Historisch centrum.

234. Jaarverslag Staatsmijnen in Limburg, 1961; $p .36$.

235. Staatsmijnen, De ontwhkeling wan fe statsmijnen in het bijzonder door samenuerking met andete ondernemingen ell docr vestigingen ejders, 1961, p. $5_{*}^{*}$ bron: Ministerie van Economische Zaken, Archief pirectie vijmezen, staatsminen; inv, nr. 378 .

236. Staatsmijnen, Jaarversiag over 1962, p. 10.

237. Jaarverslag staatsmijnen in Limbury, 1962, p. 22.

23a. Staatsmijnen, Jaar wers 39 over $1962, p .10$.

239. Vaststeluing van de begroting wan de staatsulinen in limburg voor het dienstiaze 1964, Menorie van toelichting, $\mathrm{nr}$. 2, p. 3; bron: sociaal isstorisch centrum.

240. Mijnrazd, herplat aanleg 1965 staatsnijnen in himburg, nr. 282, doss, II IWV, $\mathrm{A}$, , 30 decenber $1964, \mathrm{p}, 3$; bron: Ministerie van Economische zaken, Archief directie Mijmezen, Staatsmijnen, inv* $n \times$. 151 . 
241. Staatsmijnen, Jaarverslag over 1966, p. 14.

242. Staatsmijnen, Jaarverslag over 1968, p. 17.

243. Ondernemingsraad, Notulen, $309 \mathrm{e}$ Vergadering, 18 juni 1969 , p. 17; bron: Concern Archief DSM, Organen van overleg en Bedrijfsrechtspraak, 1950-1969, inv. nr. 89c.

244. Hoofdkantoor Interne Accountantsdienst, 9632, 29 december 1969, Samenvatting werkbespreking met de Algemene Rekenkamer op 17 december 1969; bron: Concern Archief DSM, Comptabele en Financiële Aangelegenheden, inv. nr. 185-187.

245. J.M.G. Pieters, Lonen en bedrijfsresultaten bij de Nederlandse steenkolenmijnondernemingen in de Gemeenschappelijke steenkolenmarkt van de EGKS, Proefschrift, Alberts Gulpen B.V., 1981, p. 378. Voortaan geciteerd als: Pieters, 1981.

246. Handelingen Tweede Kamer, zitting 1952-1953, 2800K, nr. 6 , p. 1 .

247. Staatsmijnen, Jaarverslag over 1908, Heerlen, pp. 11-12; Jaarverslag over 1909, p. 10; Jaarverslag over 1923, p. 1 .

248. Ministerie van Financiën, Notitie aan minister van Landbouw, Nijverheid en Handel, no. 90, 's-Gravenhage, 5 mej 1913, pp. 1-2; bron: Concern Archief DSM, Organisatie $t / m$ 1939, inv. nr. 10 .

249. Bijlage B, oriënterende notitie ten behoeve van hr. Jongebreur, Algemene Rekenkamer, Vervangingswaarde en calculatorische afschrijvingen 1955 bij de staatsmijnen in Limburg, B.E.A., 1956, nr. 1259/me; bron: Concern Archief DSM, Comptabele en Financiële Aangelegenheden 1940-1959, inv. nr. 29.

250. Ministerie van Financiën, Nota Jaarrekening 1959, 17 november 1960, no. A 0/16384; bron: Ministerie van Financiën, Generale Thesaurie, inv. nr. 1761.

251. Ministerie van Financiën, Nota Jaarrekening 1959,17 november 1960, no. A 0/16384; bron: Ministerie van Financiën, Generale Thesaurie, inv. nr. 1761.

252. Pieters, 1981, a.w., pp. 96-97, 103.

253. Pieters, 1981, a.w., p. 87.

254. Handelingen Eerste Kamer, Vaststelling begroting Staatsmijnen in Limburg voor het dienstjaar 1955, deel III, zitting 1954-1955, p. 3164 .

255. Ministerie van Financiën, Verliesdekking en bijzondere reserve voor afschrijvingen bij de staatsmijnen, no. 297, 'sGravenhage, 22 juni 1948; bron: Ministerie van Economische 
Zaken, Archief Mijnwezen, Staatsmijnen, inv. nr. 169.

256. Ondernemingsraad, $50 e$ vergadering, notulen van 23 maart 1949, p. 4; Concern Archief DSM, Organen van overleg en Bedrijfsrechtspraak 1940-1949, inv. nr. 97.

257. Verslag van de op 24 februari 1956 op het Departement van Financiën gehouden bespreking inzake het afschrijvingsvraagstuk, Heerlen, 28 februari 1956, p. 3; bron: Concern Archief DSM, Comptabele en Financiële Aangelegenheden 1940-1959, inv. nr. 29.

258. Begroting staatsmijnen 1964, 10 november 1963, pp. 1-4; bron: Nederlandse Katholieke Mijnwerkersbond, SociaalHistorisch Centrum, Maastricht, EAN 581, H. 70.4.

259. Ministerie van Financiën, Nota Gesprek met de Staatsmijnen inzake de investeringen 1963/1964, 4 december 1963, p. 3. Ministerie van Financiën, inv. nr. 1549.

260. Staatsmijnen in Limburg, brief no. 355, afd. Kabinet, 10 februari 1927 ; bron: Concern Archief DSM, Gasdistributiebedrijf tot en met 1939, inv. nr. 5.

261. Staatsmijnen, Brief Gasvoorziening op afstand, 9 december 1936, AA 2/0; bron: Concern Archief DSM, Gasdistributiebedrijf tot en met 1939, inv. nr. 5 .

262. Vereniging van Nederlandse Gemeenten, Gasvoorziening Noord-Brabant, 's-Gravenhage, 14 april 1928; bron: Concern Archief DSM, Gasdistributiebedrijf tot en met 1939, inv. nr. 186 .

staatsmijnen, Brief van 21 april 1928, AA. 2, 26941; bron: Concern Archief DSM, Gasdistributiebedrijf tot en met 1939, inv. nr. 186.

263. 263. Staatsmijnen, wijziging prijzen voor gaslevering aan gemeenten, 30 september 1936 , p. 1 ; bron: Concern Archief DSM, Gasdistributiebedrijf tot en met 1939, inv. nr. 188.

264. 264. Staatsmijnen, wijziging prijzen voor gaslevering aan gemeenten, 30 september 1936, p. $2 ;$ bron: Concern Archief DSM, Gasdistributiebedrijf tot en met 1939, inv. nr. 188.

265. Staatsmijnen, wijziging prijzen voor gaslevering aan gemeenten, 30 september 1936, pp. 2-3; bron: Concern Archief DSM, Gasdistributiebedrijf tot en met 1939, inv. nr. 188 .

266. Mijnraad, Notitie Gaslevering aan gemeenten, no. 292, 'sGravenhage, november 1936, pp. 1-3; bron: Concern Archief DSM, Gasdistributiebedrijf tot en met 1939, inv. nr. 188.

267. Staatsmijnen, Gaslevering aan gemeenten, nr. 104726 , AA/20, Heerlen, 2 december 1936, pp. 1-5; bron: Concern Archief DSM, Gasdistributiebedrijf tot en met 1939, inv. nr. 
188.

268. Vakgroep Gasbedrijven der Bedrijfsgroep Openbare Nutsbedrijven, Mededeling aan heren directeuren van gasbedrijven, 's-Gravenhage, 6 december 1946; bron: Concern Archief DSM, Gasdistributiebedrijf 1940-1949, inv. nr. 489.

269. Staatsmijnen, Kolenprijzen, b 207, Heerlen, 2 juli 1947; bron: Concern Archief DSM, Gasdistributiebedrijf 1940-1949, inv. nr. 489.

270. Staatsmijnen in Limburg, Bedrijfseconomisch Verslag over 1953 , p. 29.

271. Staatsmijnen, Afd. Belastingen, Minuut, Omzetbelasting terzake van leveringen van gas door het Gasdistributiebedrijf, 12 Bel/5, Heerlen 11 januari 1960; bron: Concern Archief DSM, Gasdistributiebedrijf 1950-1969, inv. nr. 184.

Staatsmijnen, Afd. Belastingen, Notitie betreffende de heffing van omzetbelasting door het Gasdistributiebedrijf, Heerlen, 13 juli 1960; bron: Concern Archief DSM, Gasdistributiebedrijf 1950-1969, inv. nr. 184.

272. Staatsmijnen, Jaarverslag 1963, p. 9; Jaarverslag 1966, pp. 13-14.

273. Handelingen Tweede Kamer, 24ste Vergadering, 22 december 1914, Vaststelling van Hoofdstuk $X$ der Staatsbegroting voor 1915, p. 482 .

274. Handelingen Tweede Kamer, Bijlage A, Nota van de heren Drop en Van der Heide, Begroting Staatsmijnen in Limburg voor 1932, 20.4, pp. 31-33.

275. Handelingen Tweede Kamer, Bijlage A, Memorie van toelichting, Begroting Staatsmijnen in Limburg voor 1932, 20.5, pp. 35-37.

276. Staatsmijnen, Subsidiebeleid, 2 oktober 1954, p. 1; bron: Concern Archief DSM, Sociale Zorg en Matschappelijkwerk, 1950-1959, inv. nr. 191.

277. Staatsmijnen, Subsidiebeleid der staatsmijnen, 23 juli 1958, p. 1; bron: Concern Archief DSM, Sociale Zorg en Maatschappelijk Werk, 1950-1959, inv. nr. 191.

278. Staatsmijnen, Subsidiebeleid der staatsmijnen, 23 juli 1958, pp. 2-3; bron: Concern Archief DSM, Sociale Zorg en Maatschappelijk Werk, 1950-1959, inv. nr. 191.

279. Staatsmijnen, Subsidiebeleid der staatsmijnen, 23 juli 1958, p. 5; bron: Concern Archief DSM, Sociale Zorg en Maatschappelijk Werk, 1950-1959, inv. nr. 191. 
280. De subsidies werden in de volgende categorieën ingedeeld: $a$. bijdrage aan het Fonds voor Sociale Instellingen, b. jaarlijkse subsidies aan kerkgenootschappen, $c$. steun bij de stichting, uitbreiding en instandhouding van kerken, patronaten en christelijke tehuizen, d. subsidies aan jeugdorganisaties en jeugdwerk, e. subsidies ten behoeve van instellingen voor maatschappelijke zorg, $f$. subsidies ten behoeve van instellingen voor vorming, onderwijs en ontwikkeling, $g$. subsidies ten behoeve van verenigingen, instellingen werkzaam op cultureel terrein en op het gebied van sport en ontspanning, $h$, bijdrage aan arbeiders- en beambtenhulpkas, i. bijdragen en contributies aan verenigingen, instellingen werkzaam op wetenschappelijk, commercieel, economisch of technisch gebied, en $j$. subsidies aan diverse instellingen.

281. Staatsmijnen, Subsidiebeleid, 2 oktober 1954, p. 3; bron: Concern Archief DSM, Sociale Zorg en Maatschappelijk Werk, 1950-1959, nr. 191 .

282. Staatsmijnen, Nadere toelichting op het voorstel tot verhoging van de post subsidies begroting 1957, 18 april 1956, p. 2; bron: Concern Archief DSM, Sociale Zorg en Maatschappelijk Werk, 1950-1959, inv. nr. 191.

283. Staatsmijnen, Subsidiebeleid, 2 oktober 1954, p. 1-2; bron: Concern Archief DSM, Sociale zorg en Matschappelijkwerk, 1950-1959, inv. nr. 191.

284. Gezamenlijke Mijnen, Voorlopige nota betreffende het subsidiebeleid, Heerlen, 8 februari 1952; bron: Concern Archief DSM, Sociale Zorg en Maatschappelijk Werk 1950-1959, inv. nr. 191.

285. Rapport voor de KVP-fractie, Begroting van de Staatsmijnen in Limburg 1956, p. 3; bron: Nederlandse Katholieke Mijnwerkersbond, Sociaal-Historisch Centrum, Maastricht, EAN 581, K. 70.4.2.

286. Gesprek met mr. Wansink (Econ. Zaken) te 's-Gravenhage op 4 juni 1958; bron: Concern Archief DSM, Organisatie 1950-1969, inv. $\mathrm{nr} .8$.

287. Notulen Ondernemingsraad Staatsmijnen, Sociaal Historisch Centrum, J. 6.22, 1961-1964.

288. Messing, 1988, a.w., p. 93.

289. Staatsmijnen, Korte samenvatting van bespreking over bezitsvorming op 16 januari 1952; Staatsmijnen, Rapport betreffende het bevorderen van de vorming van persoonlijk bezit door personeelsleden der Staatsmijnen, Heerlen, maart 1952 , p. 6; bron: Concern Archief DSM, Sociale zorg en Maatschappelijk Werk, 1950-1959, inv. nr. 28. 
290. Katholieke Federatie, Commissie Bezitsvorming, Verslag van de derde vergadering, 22 februari 1954; bron:Nederlandse Katholieke Mijnwerkersbond, Sociaal-Historisch Centrum, Maastricht, EAN 581, H. 16. 2 .

291. Staatsmijnen, vertrouwelijke notitie van directeur Rottier, Bevordering bezitsvorming, Heerlen, juni 1953, p. 1; bron: Concern Archief DSM, Sociale Zorg en Maatschappelijk Werk, 1950-1959, inv. nr. 28.

292. Staatsmijnen, vertrouwelijke notitie van directeur Rottier, Bevordering bezitsvorming, juni 1953, p. 1; bron: Concern Archief DSM, Sociale Zorg en Maatschappelijk Werk, 1950-1959, inv. nr. 28.

293. De samenstelling van de raad werd in overleg met de ondernemingsraad geregeld. De spaarraad bestond uit tenminste 11 leden en maximaal 13 leden. Drie leden werden aangewezen door de directie. Ten minste 8 leden en ten hoogste 10 leden werden door de vakorganisaties aangewezen in dezelfde getalsverhouding als in de ondernemingsraad. De Nederlandse Katholieke Mijnwerkersbond en de Katholieke Vereniging van Mijnbeambten mochten beiden naar keuze 2 of 3 leden aanwijzen.

Staatsmijnen in Limburg, Samenstelling spaarraad, 15 juli 1954, bron: Nederlandse Katholieke Mijnwerkersbond, SociaalHistorisch Centrum voor Limburg, Maastricht, EAN 581, H. 16.7.

294. Ministerie van Economische Zaken, Nota inzake bezitsvorming personeel staatsmijnen, 1 april 1954, p. 2; bron: Ministerie van Financiën, Plaatsingslijst Generale Thesaurie, inv. nr. 1156.

295. Ministerie van Economische Zaken, Nota inzake bezitsvorming personeel staatsmijnen, 1 april 1954, p. 1; bron: Ministerie van Financiën, Plaatsingslijst Generale Thesaurie, inv. nr. 1156.

296. Ministerie van Economische Zaken, Nota inzake bezitsvorming personeel staatsmijnen, 1 april 1954, p. 2; bron: Ministerie van Financiën, Plaatsingslijst Generale Thesaurie, inv. nr. 1156.

297. Nota Directie Binnenlands Geldwezen, Bezitsvorming personeel staatsmijnen, 8 april 1954; bron: Ministerie van Financiën, Plaatsingslijst Generale Thesaurie, inv. nr. 1156.

298. Nota directie Binnenlands Geldwezen, Bezitsvorming personeel Staatsmijnen, 10 april 1954, p. 2; bron: Ministerie van Financiën, Plaatsingslijst Generale Thesaurie; inv. nr. 1156.

299. Staatsmijnen in Limburg, Regeling betreffende de verdeling van de jubileumgave, overeenkomstig de richtijinen vastgesteld door de ondernemingsraad dd. 30 november 1953, 30 juni 1954; bron: Nederlandse Katholieke Mijnwerkersbond, 
300. Staatsmijnen, overzicht kosten van de spaarregeling-1954 in 1959, p. 3; bron: Concern Archief DSM, Sociale Zorg en Maatschappelijk werk, 1960-1969, inv. nr. 16.

301. Uittreksel uit de notulen van de 150 e vergadering van de ondernemingsraad voor de Staatsmijnen in Limburg, gehouden op 21 december 1955, pp. 1-2; bron: Nederlandse Katholieke Mijnwerkersbond, Sociaal Historisch Centrum, Maastricht, EAN 581 , H. 16.2

302. Uittreksel uit de notulen van de 150 e vergadering van de ondernemingsraad voor de staatsmijnen in Limburg, gehouden op 21 december 1955; bron: Nederlandse Katholieke Mijnwerkersbond, Sociaal-Historisch Centrum, Maastricht, EAN 581, H. 16.2 .

303. Katholieke Federatie in het Mijnbedrijf, Brief aan de Gezamenlijke steenkolenmijnen in Limburg, Heerlen, Extra uitkering, 22 november 1957; bron: Sociaal-Historisch Centrum voor Limburg, Maastricht, EAN H. 16.2.

Gezamenlijke Steenkolenmijnen in Limburg, Brief aan de Katholieke Federatie, Heerlen, 20 december 1957; bron: Sociaal-Historisch Centrum voor Limburg, Maastricht, EAN H. 16.2 .

Algemene Nederlandse Bedrijfsbond Mijnindustrie, Eerlijk zullen wij alles delen, december 1957; bron: SociaalHistorisch Centrum voor Limburg, Maastricht, EAN H. 16.2.

Nederlandse Katholieke Mijnwerkersbond, Brief aan de ondernemingsraad der Staatsmijnen, 28 december 1957; bron: Sociaal-Historisch Centrum voor Limburg, Maastricht, EAN H. 16.2 .

304. Katholieke Federatie, Brief over spaarregeling aan directie staatsmijnen in Limburg, 23 juni 1958; bron: Nederlandse Katholieke Mijnwerkersbond, Sociaal-Historisch Centrum, Maastricht, EAN 581, H. 16.6.

305. Brief aan de Katholieke Federatie in het Mijnbedrijf, Gezamenlijke steenkolenmijnen in Limburg, spaarregeling, $\mathrm{nr}$. 4431, Heerlen, 30 september 1958; bron: Sociaal Historisch centrum, Archief NKMB, H 16.2.

306. Secretariaat, Bedrijfschap voor de Steenkolenmijnindustrie, Notitie inzake sparregeling personeel bedrijfschap, 22 mei 1964; bron: Nederlandse Katholieke Mijnwerkersbond, Sociaal-Historisch Centrum, Maastricht, EAN 581, H. 16.6.

Secretariaat, Bedrijfschap voor de steenkolenmijnindustrie, Notitie inzake spaarregeling personeel bedrijfschap, 27 januari 1966; bron: Nederlandse Katholieke Mijnwerkersbond, Sociaal Historisch Centrum, Mastricht, EAN 581, H. 16.6 
307. Notulen Bondsbestuur NKMB, vergadering 22 april 1964; bron: Sociaal-Historisch Centrum voor Limburg, Maastricht, EAN H. 16.6 .

308. Staatsmijnen, Bezitsvorming bij de staatsmijnen, april 1958, pp. 30-31; bron: DSM, Sociale zorg en Maatschappelijk Werk, 1950-1959, inv, nr. 28.

309. Uitvoeringsbepalingen bij de beschikking van de Beheerder dd. 12 mart 1948 no. 12430, gewijzigd bij beschikking dd. 20 april 1948 no. 12834 betreffende de spaarregeling voor personeelsleden der Nederlandse steenkolenmijnen beneden de leeftijd van 25 jaar; bron: Nederlandse Katholieke Mijnwerkersbond, Sociaal Historisch Centrum, Maastricht, EAN 581 , H. 16.3 .

310. Beheerder van de Nederlandse Steenkolenmijnen, spaarregeling voor personeelsleden der Nederlandse steenkolenmijnen beneden de leeftijd van 25 jaar, 12 maart 1948; bron: Nederlandse Katholieke Mijnwerkersbond, Sociaal Historisch Centrum, Maastricht, EAN 581, H. 16.3.

311. Vergadering Dagelijks Bestuur MIR, 19 januari 1956, bron: Nederlandse Katholieke Mijnwerkersbond, Sociaal Historisch Centrum, Maastricht, EAN 581, H. 16.3.

312. Brief Nederlandse Katholieke Mijnwerkersbond aan Dagelijksbestuur Mijnindustrieraad, 6 januari 1956; bron: Nederlandse Katholieke Mijnwerkersbond, Sociaal Historisch Centrum, Maastricht, EAN 581, H. 16.3.

313. Verslag Vergadering MIR, 10 maart 1956, bron: Nederlandse Katholieke Mijnwerkersbond, Sociaal Historisch Centrum, Maastricht, EAN 581, H. 16.3.

314. Staatsmijnen, Jaarverslag over 1959, p. 24.

315. Algemene Rekenkamer, Jaarrekening van de staatsmijnen in Limburg over 1957, 's-Gravenhage, 6 april 1959, pp. 1-2; bron: Ministerie van Financiën, Generale Thesaurie, inv. nr. 1761.

316. Staatsmijnen, Jaarverslag 1959 , p. 24.

317. Staatsmijnen, Jaarverslag 1960, p. 24.

318. Staatsmijnen, Jaarverslag 1964, pp. 29-30.

319. Staatsmijnen, Centraal Beheer, Nota Winstbestemming, 16 februari 1961, p. 3; bron: Concern Archief DSM, comptabele en Financiële Aangelegenheden 1960-1969, inv. nr. 91.

Staatsmijnen, Minuut Winst en winstbestemming 1960, 190 A.Z./A 15, 16 maart 1961, p. 5; bron: Concern Archief DSM, Comptabele en Financiële Aangelegenheden 1960-1969, inv. nr. 91. 
320. Staatsmijnen, Centraal Beheer, Nota Winstbesteming, 16 februari 1961, pp. 1,4 ; bron: Concern Archief DSM, Comptabele en Financièle Aangelegenheden 1960-1969, inv. nr. 91.

321. Staatsmijnen, verslag van de $45 \mathrm{e}$ bespreking van de hoofddirectie, 16 oktober 1961; bron: Concern Archief DSM, Comptabele en Financiële Aangelegenheden 1960-1969, inv. nr. 91.

322. Staatsmijnen, Winstbesteming 1961, 9 februari 1962, p. 3; bron: Concern Archief DSM, Comptabele en Financiële Aangelegenheden 1960-1969, inv. nr. 91.

323. Staatsmijnen, Nota ten behoeve van de Mijnraad inzake de financiële resultaten en winstverdeling 1961 van de Staatsmijnen in Limburg, 28 februari 1962, p. 6; bron: Concern Archief DSM, Comptabele en Financiële Aangelegenheden 19601969, inv. nx. 91 .

324. Staatsmijnen, Minuut Winst en winstbestemming 1961, 198 A.Z./A 15, 19 maart 1962, p. 5; bron: Concern Archief DSM, Comptabele en Financiële Aangelegenheden 1960-1969, inv. nr. 91.

325. Commissie winstdelingsregeling, Nota winstdelingsregeling, Heerlen, 18 september 1961, pp 2-3; bron: Nederlandse Katholieke Mijnwerkersbond, Sociaal Historisch Centrum, Maastricht, EAN 581, H. 16.2.

326. Notulen Dagelijks Bestuur NKMB, 23 oktober 1962, agenda punt 6 winstdelingsregeling mijnindustrie; bron: Nederlandse Katholieke Mijnwerkersbond, Sociaal-Historisch Centrum voor Limburg, Maastricht, EAN 581, H. 16.2.

327. Katholieke Federatie, Brief aan de Mijnindustrieraad, Verordening winstdeling, Heerlen, 30 januari 1964; bron: Sociaal Historisch Centrum, Archief Nederlandse Katholieke Mijnwerkersbond, EAN 581, H 16.2.

328. Staatsmijnen, Uitkeringen in verband met de winst, Heerlen, 27 februari 1964, p. 1; bron: Concern Archief DSM, Comptabele en Financiële Aangelegenheden 1960-1969, inv. nr. 91 .

329. Staatsmijnen, Werkgroep winstdeling, concept 30 oktober 1964, t.b.v. dir. Huijben en Bogers, p. 1; bron: Concern Archief DSM, Sociale Zorg en Maatschappelijk Werk, 1960-1969, inv. nr. 21 .

330. Notulen Dagelijks Bestuur Mijnindustrieraad, 3 maart 1964, agendapunt 10, Nadere regeling vaststelling uitkeringineens op grond van behaalde bedrijfsresultaten; bron: Nederlandse Katholieke Mijnwerkersbond, Sociaal-Historisch Centrum voor Limburg, Maastricht, EAN 581, H. 16.2. 
331. Handelingen Tweede Kamer, Bijlagen, 1918-1919, Heffing van een recht op de mijnen, Memorie van Toelichting, 533.3, pp. 3-4.

332. Staatsmijnen, Het recht op de mijnen, juli 1955, pp. 1-2; bron: Concern Archief DSM, comptabele en Financiële Aangelegenheden 1940-1959, inv. nr. 207.

333. Staatsmijnen, Het recht op de mijnen, juli 1955, pp. 1-2; bron: Centraal oud Archief DSM, Comptabele en Financiële Aangelegenheden 1940-1959, inv. nr. 207.

334. Staatsmijnen, Het recht op de mijnen, juli 1955, pp. 2024 ; bron: Concern Archief DSM, Comptabele en Financiele Aangelegenheden 1940-1959, inv. nr. 207.

335. Staatsmijnen, Afdeling Belastingen, Recht op de mijnen, Heerlen, 22 juli 1959; bron: Concern Archief DSM, Comptabele en Financiële Aangelegenheden 1940-1959, inv. nr. 207.

336. Wet van 12 juli 1961 houdende vaststelling van de Financiële Verhoudingswet 1960, Art. 27 (3)(b), in: Staatsblad 217,1961, p. 471.

337. Staatsmijnen in Limburg, Brief aan de Minister van Waterstaat, 30 januari 1939, no. 228 , pp. 1-3; bron: Concern Archief DSM, Organisatie, tot en 1939, inv. nr. 4.

338. Ministerie van Financiën, Brief, Belastingplicht Staatsmijnbedrijf, 's-Gravenhage, 1 december 1939; bron: Concern Archief DSM, Comptabele en Financiële Aangelegenheden 1940-1959, inv. nr. 208.

339. Staatsmijnen, Belastingheffing, Afdeling Comptabiliteit, Heerlen 19 december, ongedateerd; bron: Concern Archief DSM, Comptabele en Financiële Aangelegenheden 1940-1959, inv. nr. 217.

340. Staatsmijnen in Limburg, Brief aan minister van Financiën, Fiscale winstberekening voor de staatsmijnen, 31 maart 1949; bron: Concern Archief DSH, Comptabele en Financiële Aangelegenheden 1940-1959, inv. nr. 217.

341. Ministerie van Financiën, Nota Investeringen Staatsmijnen en subsidieproblemen steenkolenmijnen, 19 december 1963 ; bron: Ministerie van Financiën, inv. nr. 1549.

342. Staatsmijnen, Organization, problems and results of the research at staatsmijnen, february 20, 1949, pp. 4-7; bron: Concern Archief DSM, Centraal Laboratorium tot en met 1949, inv. nr. 1.

343. Octrooibureau, Nota aan de directie, Geleen, 13 juli 1950, pp. 1-2; bron: Concern Axchief DSM, organisatie, 19501969, inv. nr. 367. 
344. Octrooibureau, Nota aan de directie, Geleen, 13 juli 1950, pp. 1-2; bron: Concern Archief DSM, Organisatie, 19501969, inv. nr. 367 .

345. Organisatie en onvang van het Centraal Laboratorium, Bijlage bij de notulen van de 305 e o.r.-vergadering, gehouden op 12 februari 1969, pp. 4-5; bron: Concern Archief DSM, organen van Overleg en Bedrijfsrechtspraak, 1950-1969, inv. nr. $89 \mathrm{c}$.

346. Organisatie en omvang van het Centraal Laboratorium, Bijlage bij de notulen van de $305 e$ o.r.-vergadering, gehouden op 12 februari 1969 , p. 4; bron: Concern Archief DSM, Organen van Overleg en Bedrijfsrechtspraak, 1950-1969, inv. nr. 89c.

347. Handelingen Eerste Kamer, Wetsontwerp tot vaststelling van de begroting van de Staatsmijnen in Limburg voor het dienstjaar 1955 (3700K), deel III, zitting 1954-1955, 26ste vergadering, 1 maart 1955, pp. 3163-3165.

348. EFA, Ontwikkeling van de staatsmijnen, 5 april 1960, p. 6; bron: Concern Archief DSM, organisatie 1950-1969, inv. nr. 8 .

349. Notitie met betrekking tot Overheidsbedrijven en bezitsvorming, Heerlen, 22 juli 1960, pp. 6-7, 9; bron: Concern Archief DSM, Organisatie 1950-1969, inv. nr. 6, map 1.

350. Handelingen Tweede Kamer, Bijlagen, Voorlopig verslag, nr. 6, p. 3 .

351. Staatsmijnen, werkgroep winstdeling, 30 oktober 1964 , t.b.v. dir. Huijben en Bogers, p. 3 ; bron: Concern Archief DSM, Sociale Zorg en Maatschappelijk Werk, 1960-1969, inv. nr. 21.

352. Staatsmijnen, werkgroep winstdeling, 30 oktober 1964, t.b.v. dir. Huijben en Bogers, p. 7; bron: Concern Archief DSM, Sociale Zorg en Maatschappelijk Werk, 1960-1969, inv. nr. 21 .

353. Wet van 23 juni 1966, houdende regelen betreffende de omzetting van de tak van Rijksdienst, omvattende de Staatsmijnen in Limburg, in een naamloze vennootschap, Staatsblad 271, 1966, p. 706.

354. Handelingen Eerste Kamer, Vaststelling van de begroting van uitgaven van de Staatsmijnen, 41 ste vergadering, 27 april 1928, pp. 787-788.

355. Mijnraad, Nota betreffende de vervulling van de vacatures in de directie van de Staatsmijnen, 3 januari 1940; bron: Algemeen Rijksarchief, Archief Mijnraad, 1902-1955, inv. nr. 50 . 
356. Rede van dr. ir. M.H.R.J. Plusjé ter gelegenheid van de installatie van drie nieuwe leden van de directie, 4 januari 1949; bron: Concern Archief DSM, Centraal Laboratorium 19401949, inv. nr. 184.

357. De benoemingen bij de staatsmijnen, Gazet van Limburg, 29 december 1952: bron Sociaal Historisch Centrum, Maastricht, EAN 581, Archief Nederlandse Katholieke Mijnwerkersbond, F 70.2 .1$.

358. Katholieke Federatie, T.a.v. het Dagelijks Bestuur, Heerlen, (ondertekend met $P$ ), 16-10-1959; bron: Archief Nederlandse Katholieke Mijnwerkersbond, Sociaal-Historisch Centrum, Maastricht, EAN 581, H. 70.2.

359. Ministerie van Economische Zaken, Directie Mijnwezen, Nota MW 97/59, Commissariaten, 20 juni 1959; bron: Ministerie van Economische Zaken, Archief Directie Mijnwezen, inv. nr. 386.

360. Staatsmijnen, Notitie ten behoeve van President-directeur Rottier, Heerlen, 10 december 1962; bron: Concern Archief DSM, 1950-1969, inv. nr. 6, map 2 .

361. Ministerie van Economische Zaken, Kapitalisatie Staatsmijnen, 19 april 1962, p. 6; bron: Ministerie van Economische Zaken, Archief Directie Mijnwezen, Staatsmijnen, inv. $\mathrm{nr} .148$.

362. Statuten NV Nederlandse Staatsmijnen, Art. 12, Heerlen, in: Bijvoegsel Nederlandse Staatscourant, $\mathrm{nr}$. 613, vrijdag 27 januari 1967, nr. 20.

Art. 15, Reglement voor de Raad van Commissarissen van de NV Nederlandse Staatsmijnen te Heerlen (ex art. 14 der statuten, 29 augustus 1967 ; bron: Concern Archief DSM, Organisatie, 1950-1969, inv. nr. 26.

363. Mijnraad, Uitbreiding Mijnraad, nr. 49778, 21 juni 1948; bron: Algemeen Rijksarchief, Archief Mijnraad, 1902-1955, inv. $\mathrm{nr} .80$,

364. Staatsmijnen, Afd. Financiering, Garantieverplichtingen Staatsmijnen, 19 november 1964, p. 1; bron: Concern Archief DSM, Comptabele en Financiële Aangelegenheden 1960-1969, inv. $\mathrm{nr}, 29$.

365. NV Staatsmijnen, Bedrijfseconomisch Verslag over 1970, Heerlen, p. 9.

366. J.H. Jonckers Nieboer, Geschiedenis der Nederlandsche Spoorwegen 1932-1938, Nijgh \& Van Ditmar NV, Rotterdam, tweede geheel herziene druk, 1938, pp. 185-186, 249-251. In het vervolg geciteerd als: Jonckers Nieboer, 1938.

367. J.H. Jonckers Nieboer, 1938, a.w., p. 305. 
368. Voorbeelden van deze regulering zijn: de Wet autovervoer personen van 1939 (heringevoerd in 1948), de Wet goederenvervoer binnenscheepvaart van 1951 en de Wet autovervoer goederen van 1951 .

369. De Spoorwegwet van 1875, het Algemeen reglement voor de dienst op de spoorwegen van 1933 en de concessie tot exploitatie van spoor- en tramwegen van 1937 regelden de exploitatieplicht. De Spoorwegwet van 1875 en het Algemeen reglement voor het vervoer op de spoorwegen 1928 bevatten de vervoerplicht.

370. Jonckers Nieboer, 1938, a.w., pp. 316-325.

371. De erkende vakorganisaties participeerden in de Personeelsraad: de Katholieke Bond van Vervoerspersoneel (KBV), de Protestants Christelijke Bond van spoor- en Tramwegpersoneel ( $\mathrm{PCB}$ ) en Nederlandse Bond van Vervoerspersoneel (NBV).

372. Handelingen Eerste Kamer, zitting 1947-1948, $600 \mathrm{~J}$ Vaststeliing van de begroting van de begroting van de staatsmijnen in Limburg voor het dienstjaar 1948, 22 juni 1948,637 , vel 172 .

Bijlagen Eerste Kamer, Voorlopig Verslag van de Commissie van Rapporteurs over het ontwerp van wet tot vaststelling van hoofdstuk IXb (Departement van verkeer en Waterstaat) der Rijksbegroting voor het dienstjaar 1949, Zitting 1948-1949, 1000 , no. 62, p. 2 .

373. Concessie NV Nederlandse Spoorwegen, art. 8, Nederlandse staatscourant, 30 december 1937, no. 253.

374. Statuten NV Nederlandse Spoorwegen, art. 12, in: Bijvoegsel tot de Nederlandse staatscourant van maandag 30 augustus 1937 , no. 166.

375. Statuten NV Nederlandse Spoorwegen, art. 12, Bijvoegsel Nederlandse staatscourant, nr. 1786, 12 mei 1964, nr. 90.

376. NV Nederlandse Spoorwegen, Memorandum, Bijlage 2, Utrecht, december 1966, p. 1-2; bron: Ministerie van Verkeer en waterstaat, doss. $\mathrm{nr} .26430 \mathrm{~A}-3$, class. $\mathrm{nr} .25 .07 .352 \mathrm{~ns}$.

377. Notulen Raad voor Economische Aangelegenheden, 2 februari 1949, pp. 3-8; Notulen Raad voor Economische aangelegenheden, 5 mei 1949, p.2; bron: Algemeen Rijksarchief.

378. Besluit op de vennootschapsbelasting, 1942

Vrijstellingsbeschikking Belasting Lichamen, Staatscourant, 10 december 1945 , no. 129. 
379. Minister van Financiën P. Lieftinck, Brief aan mr. P.J. oud, Voorzitter Adviescomissie Fiscale Aangelegenheden, afdeling Directe Belastingen, no. 227, Onderwerp: Belastingheffing van bedrijven van openbare lichamen en van naamloze vennootschappen waarvan de aandelen in handen van openbare lichamen zijn, 's-Gravenhage, 4 februari 1948, p. 6; bron: Archief Ministerie van Financiën, Generale Thesaurie, 1954-1975, dossier: Wetsontwerp belastingheffing van overheidsbedrijven.

380. P.J. Oud, Voorzitter Adviescommissie voor Fiscale Aangelegenheden, Nota inzake belastingheffing van bedrijven van openbare lichamen en van naamloze vennootschappen waarvan de aandelen in handen van openbare lichamen zijn, Rotterdam, juni 1949, pp. 4-6; bron: DSM, Centraal Oud Archief, Comptabele en Financiële Aangelegenheden 1940-1959, inv. nr. 218.

381. Tweede Kamer der Staten-Generaal, Handelingen, Deel III, Zitting 1956-1957, p. 3315.

382. Tweede Kamer der Staten-Generaal, Handelingen, Deel III, Zitting 1956-1957, p. 3366.

383. Ministerie van Verkeer en Waterstaat, DirectoraatGeneraal van het verkeer, Nota betreffende publikatie investeringsgegevens N.S., 10 januari 1958; bron: Ministerie van Verkeer en Waterstaat, Samenstelling Jaarverslagen NS, 1956-1964, doss. nr. 6543/A, class. nr. 25.07 .77$.

384. Ministerie van verkeer en waterstaat, DirectoraatGeneraal van het Verkeer, Nota betreffende publikatie investeringsgegevens N.S., 10 januari 1958; bron: Ministerie van Verkeer en Waterstaat, Samenstelling Jaarverslagen NS, 1956-1964, class. nr. 25.07.77, doss. nr. 6543/A.

385. Ministerie van Verkeer en Waterstaat, DirectoraatGeneraal van het Verkeer, Nota betreffende publikatie investeringsgegevens N.S., 10 januari 1958, pp. 4-5; bron: Ministerie van verkeer en Waterstaat, Samenstelling Jaarverslagen NS, 1956-1964, doss. nr.6543/A, class. nr. 25.07 .77 .

386. Handelingen Tweede Kamer, Bijlagen, Memorie van Antwoord, nr.5, 9218, zitting 1967-1968, p. 3 .

387. Toespraak van de President-Directeur van NS ir. J. Lohmann ter gelegenheid van de installatie van de onafhankelijke commissie ter bestudering van de inkomenspositie van het NS-personeel in vergelijking met die van werknemers in het bedrijfsleven en bij de overheid, gehouden op 17 mei 1965, p. 1; bron: Koördinatie-orgaan Spoorwegvakverenigingen.

Ministerie van Verkeer en Waterstaat, Herziening lonen en arbeidsvoorwaarden spoorwegpersoneel, 5 juli 1956, pp. 1-2; 
bron: Ministerie van Verkeer en Waterstaat, doss. nr. 283/5, class. nr. 25.08.17.

388. Ministerie van Verkeer en waterstaat, Herziening RDV NS 1956, Rapport hoorzitting Stichting van de Arbeid, 23 januari 1958, pp. 3-4; bron: Ministerie van Verkeer en Waterstaat, dossier $283 / 5$, class. nr. 25.08.17.

389. Personeelsraad, Rechtspositie van het personeel, Jaarverslag over 1962, p. 24.

390. Personeelsraad, Rechtspositie van het personeel, De produktiviteit, Jaarverslag over 1962, p. 26.

391. Personeelsraad, Jaarverslag over 1962, p. 26.

392. Personeelsraad, Rechtspositie van het personeel, Jaarverslag over 1962, pp. 27-28.

393. Toespraak van de President-Directeur van NS ir. J. Lohmann ter gelegenheid van de installatie van de onafhankelijke commissie ter bestudering van de inkomenspositie van het NS-personeel in vergelijking met die van werknemers in het bedrijfsleven en bij de overheid, gehouden op 17 mei 1965, pp. 4-5.

394. De kwantitatieve factoren omvatten het aantal reizigerskilometers, het aantal wagenladingen, het aantal zendingen snel- en expresgoed en rijwielen, het aantal afgegeven plaatsbewijzen en de personeelsbezetting. De kwalitatieve factoren behelsden: gebruiksintensiteit van de goederenwagens, energieverbruik, kwaliteit reizigerstreindienst (het percentage op tijd rijdende reizigerstreinen) en kwaliteit goederentreindienst (het percentage op tijd rijdende goederentreinen).

395. Personeelsxaad, Rechtspositie van het personeel, Jaarverslag over 1965, p. 25.

396. Personeelsraad, Rechtspositie van het personeel, Jaarverslag over 1965, pp. 21, 26-27.

397. Bezoldiging, vergoedingen en uitkeringen, Herziening van het algemene prestatiebeloningssysteem, Personeelsraad, Jaarverslag over 1968, pp. 91-92.

398. Personeelsraad, Rechtspositie van het personeel, Jaarverslag over 1970, pp. 24-25.

399. Kostenverdeling der NV Nederlandse Spoorwegen in 1947, p. 1; bron: Ministerie van Verkeer en Waterstaat, doss. 9501, map I, class. nr. 25.07.352.

400. Handelingen Tweede Kamer, Begroting dienstjaar 1958, Memorie van antwoord, zitting 1957-1958 (4900), hoofdstuk IXb, p. 12 . 
401. Handelingen der Staten-Generaal, Bijlagen, 1950-1951, 1751, nr. 4, p. 10; nr. 5, p. 13.

402. Wet betreffende pensioenregeling voor de spoorwegambtenaren en hun weduwen en wezen (Spoorwegpensioenwet), 29 juni 1925, in: staatsblad 1925, no. 294 .

403. Personeelsraad, Jaarverslag, 1956, p. 37.

404. Concessie Nederlandse Spoorwegen, artikel 6, Nederlandse Staatscourant, 30 december 1937 , no. 253.

405. Rijksbegroting voor het dienstjaar 1939, 2, IX, Bijlage A, Handelingen Eerste Kamer, 1938-1939, p. 8.

406. Werving van personeel, Personeelsraad, Jaarverslag over 1951, p. 55.

407. Werving van personeel, Personeelsraad, Jaarverslag over 1952 , p. 28 .

408. J.P. Windmuller en C. de Galan, Arbeidsverhoudingen in Nederland, deel 2, Uitgeverij Het spectrum, Utrecht/Antwerpen, 1979, pp. 63-66. Voortaan geciteerd als: Windmulier en De Galan, 1979.

409. College van Rijksbemiddelaars, wijziging RDV Nederlandse Spoorwegen, 14 januari 1948, pp. 1 en 4; bron: Ministerie van Verkeer en Waterstaat, RDV 1946, doss. nr. 283/2, class. nr. 25.08 .17 .

410. Ministerie van Verkeer en waterstaat, Herziening RDV NS 1956, Rapport hoorzitting Stichting van de Arbeid, 23 januari 1958, pp. 1-2; bron: Ministerie van verkeer en waterstaat, dossier $283 / 5$, class. nr. 25.08.17.

411. Ministerie van Verkeer en Waterstaat, Spoorweglonen, 'sGravenhage, 17 juni 1958; bron: Ministerie van Verkeer en Waterstaat, RDV 1956, doss. nr. 283/5, class. nr. 25.08.17.

412. Ministerie van verkeer en waterstaat, Directoraatgeneraal van het verkeer, Bijlage bij Nota inzake mogelijke bezuinigingen bij de NS, maart 1968, pp. 1-2; Ministerie van Verkeer en Waterstaat, Bedrijfsvoering bij de NS, doss. nr. $26430 / \mathrm{n}$, class. nr. 25.07.352.

413. Ministerie van verkeer en Waterstaat, Directoraatgeneraal van het Verkeer, Bijlage bij Nota inzake mogelijke bezuinigingen bij de NS, maart 1968; Ministerie van verkeer en Waterstaat, Bedrijfsvoering bij de Ns, doss. nr. $26430 / \mathrm{n}$, class. nr. 25.07.352.

414. Ministerie van verkeer en Waterstaat, Directoraatgeneraal van het Verkeer, Bijlage bij Nota inzake mogelijke bezuinigingen bij de NS, maart 1968, pp. 1-2; Ministerie van 
Verkeer en Waterstaat, Bedrijfsvoering bij de NS, doss. nr. $26430 / \mathrm{n}$, class. nr. 25.07.352.

415. Statuten NV Nederlandse Spoorwegen, Artt. 16 en 17, Bijvoegsel Nederlandse Staatscourant, nr. 1206, 30 augustus 1937 , nr. 166.

416. Wijziging statuten NV Nederlandse Spoorwegen, art. II, Bijvoegsel Nederlandse Staatscourant, $\mathrm{nr} .389,13$ juli 1943, nr. 133 .

417. Statuten NV Nederlandse Spoorwegen, art. 15, $\mathrm{nr}$. 1786, Bijvoegsel Nederlandse Staatscourant, 12 mei 1964, nr. 90.

418. Personeelsraad, Jaarverslag over 1962, p. 23.

419. Personeelsraad, Jaarverslag over 1964, p. 28.

420. Ministerie van Financiën, Directie Wetgeving Directe Belastingen, No. 137, Wetsontwerp inzake de belastingheffing van overheidsbedrijven, 's-Gravenhage, 21 september 1954; bron: Ministerie van Financiën, dossier Wetsontwerp belastingheffing van overheidsbedrijven, Generale Thesaurie 1954-1978.

421. Hofstra wees erop dat in het Voorlopig Verslag werd gesteld dat het aanvaarden van de volledige concurrentiepositie van de NV Nederlandse Spoorwegen niet erg in overeenstemming was met de politiek, die op grond van de Wet Autovervoer Goederen ten aanzien van de NV Nederlandse Spoorwegen werd gevoerd.

Hofstra, Handelingen Tweede Kamer, Zitting 1955-1956, 76ste Vergadering, 17 april 1956, pp. 994.

422. Hofstra, Handelingen Tweede Kamer, Zitting 1955-1956, 76 ste Vergadering, 17 april 1956, pp. 994-995.

423. Statuten NV Nederlandse Spoorwegen, Bijvoegsel tot de Nederlandsche staatscourant van maandag 30 augustus 1937, no. 166.

424. Handelingen Tweede Kamer, Zitting 1962-1963, 6900, Rijksbegroting voor het dienstjaar 1963, Hoofdstuk XII, Verkeer en Waterstaat, Memorie van Antwoord, nr. 11, p. 7.

425. Ministerie van Verkeer en Waterstaat, Wet ter gezondmaking van de financiële positie van de NS, 8 oktober 1969 , p. 4; bron: Ministerie van Verkeer en Waterstaat, doss. nr. $26430 / \mathrm{s}$ (deel I), class. nr. 25.07.352/ns.

426. NV Nederlandse Spoorwegen, Jaarverslag over 1946, p. 3.

427. NV Nederlandse Spoorwegen, Efficiency bij NS, sct 1/4721388,6 oktober 1967, p. 1 . 
428. NV Nederlandse Spoorwegen, Diversificatie bij NS, 23 november 1967, p. 1; bron: Ministerie van verkeer en Waterstaat, doss. $\mathrm{nr} .26430 \mathrm{~A}-3$, class. nr. 25.07.352.

429. Investeringsplan IPK "Y", Korte Termijn, januari 1969, no. 45, pp. $2-3$.

430. NV Nederlandse Spoorwegen, Toelichting op het investeringsplan IPK "Z", december 1969, bron: NV, Nederlandse Spoorwegen, seriewerken 35 , doos 96 .

431. NV Nederlandse spoorwegen, Toelichting op het investeringsplan IPK "A", december 1970, p. 1; bron: NV Nederlandse Spoorwegen, seriewerken 35, doos 96 .

432. Prospectus NV Nederlandse Spoorwegen, Lening 1970, p. 3; bron: Ministerie van Verkeer en Waterstaat, doss. nr. $26430 / \mathrm{D} 2$, class. nr. 25.07. $352 \mathrm{~ns}$.

433. Nederlandse Spoorwegen, Bedrijfsinformatie, maart 1970, p. 6 .

434. NV Nederlandse Spoorwegen, Brief van 24 juni 1970, sct/4310-956, p. 1; bron: Ministerie van verkeer en Waterstaat, doss. nr. 1223/a, class. nr. 25.01 .416$.

435. NV Nederlandse Spoorwegen, Efficiency bij NS, sct 1/4721388,6 oktober 1967, p. 1 .

436. Ministerie van Verkeer en waterstaat, Nota $6 \%$ NSpersoneel, 6 juli 1956, p. 1; bron: Ministerie van Verkeer en Waterstaat, RDV 1956, doss. nr. 283/5, class. nr. 25.08.17.

437. G. Püttner, Die Finanzierungsentscheidungen und deren Überwachung; in: P. Eichhorn en T. Thiemeyer (Hrsg.), Finanzierung öffentlicher Unternehmen, Nomos Verlagsgesellschaft, Baden-Baden, 1979, p. 162.

438. Notulen Ministerraad, 28 januari 1957, pp. 7-10, bron: Algemeen Rijksarchief.

439. NV Nederlandse Spoorwegen, Memorandum, Utrecht, december 1966, pp. 1, 10: bron: Ministerie van Verkeer en waterstaat, doss. nr. $26430 \mathrm{~A}-3$, class. nr. 25.07 .0352 .

440. T. Thiemeyer, Die Abgeltung gemeinwirtschaftlicher Lasten als Mittel der Finanzierung öffentlicher Unternehmen, in: $P$. Eichhorn en T. Thiemeyer (Hrsg.), Finanzierung öffentlicher Unternehmen, Nomos Verlagsgesellschaft, Baden-Baden, 1979, p. 132-134.

441. Notulen van de bespreking, gehouden op woensdag 8 december 1965, Ministerie van Binnenlandse Zaken, tussen enerzijds de Ministers Verkeer en Waterstaat en Financiën en anderzijds een delegatie uit het bestuur van de NV Nederlandse spoorwegen; bron: Ministerie van Verkeer en Waterstaat, doss. 
nr. $26430 b$, class. nr. 25.07 .352 .

442. J.A. Faber (red.), Het spoor, 150 jaar spoorwegen in Nederland, Meulenhoff Informatief, Amsterdam, 1989, p. 107.

443. J.W.P.P. van den Noort, Gemengde gevoelens. vijftig jaar in de relatie NS-overheid; in: J.A. Faber, Het Spoor, Meulenhoff Informatief, Amsterdam, 1989.

444. Verordening (EEG) $\mathrm{nr}$. 1191/69 van de raad van 26 juni 1969 betreffende het optreden van de lid-staten ten aanzien van met het begrip openbare dienst verbonden verplichtingen op het gebied van het vervoer per spoor, over de weg en over de binnenwateren; in: Publikatieblad van de Europese Gemeenschappen, nr. L $156 / 1$.

445. Verslag van de bespreking DGV-NS d.d. 18 maart te 'sGravenhage, Sct 1/0101-774, april 1970, p. 6; bron: Ministerie van Verkeer en Waterstaat, doss. $\mathrm{nr}, 26430 / \mathrm{s}$ (deel 2), class. nr. 25.07 .352 .

446. Ministerie van Verkeer en Waterstaat, De spoorwegpolitiek in de EG, 2 juli 1969, p. 2; bron: Ministerie van Verkeer en Waterstaat, doss. nr. 26430/s (deel 1), class. nr. $25.07 .352 / \mathrm{ns}$.

447. Verslag bespreking van 8 juli 1969 betreffende verliessituatie NS; bron: Ministerie van verkeer en waterstaat, doss. nr. $26430 /$ s9 (deel 1), class. nr. 25.07.352.

448. Verslag bespreking van 8 juli 1969 betreffende verliessituatie NS; bron: Ministerie van verkeer en waterstaat, doss. nr. $26430 / \mathrm{s} 9$ (deel 1), class. nr. 25.07.352.

449. NV Nederlandse Spoorwegen, Begrote verlies- en winstrekening $1967 \mathrm{t} / \mathrm{m} 1970$ en raming 1975, utrecht, 17 mei 1967, pp. 4-5; bron: Ministerie van verkeer en waterstaat, doss. nr. $26430 \mathrm{c}$, class. nr. 25.07 .352

450. Personeelsraad, Beëindiging van de dienstbetrekking, Jaarverslag over 1968, p. 31 .

451. Handelingen Tweede Kamer, Bijlagen, Spoorwegpensioenwet, Memorie van antwoord, $\mathrm{nr}$. 7, zitting 1965-1966, 8506, p. 2.

452. J. Goudriaan, De toekomst der Nederlandsche Spoorwegen, in: Economisch-statistische Berichten, 22 maart 1939, p. 228.

453. Wachtgeldregeling, Artikel 81 (1), bron: Ministerie van verkeer en Waterstaat, Directoraat-Generaal van het Verkeer, doss. nr. $26430 / \mathrm{k}-4$, class. 25.07 .352 .

454. Personeelsraad, Beëindiging van de dienstbetrekking, verslag over 1968 , p. 31. 
455. Ministerie van Verkeer en Waterstaat, Directoraat van het Verkeer, Nota inzake normalisatie van wachtgelden van de N.S., 9 oktober 1968, $\mathrm{nr}$. V-1, bron: Ministerie van verkeer en Waterstaat, Directoraat-Generaal van het Verkeer, 1960-1971, doss. $\mathrm{nr} .2640 / \mathrm{k}-4$, class. $\mathrm{nr} .25 .07 .352$.

456. Ministerie van Verkeer en Waterstaat, Directoraat van het Verkeer, Nota inzake normalisatie van wachtgelden van de N.S., 9 oktober 1968, $\mathrm{nr} . \mathrm{V}-1$, bron: Ministerie van Verkeer en Waterstaat, Directoraat-Generaal van het Verkeer, 1960-1971, doss. nr. 2640/k-4, class. nr. 25.07.352.

457. Ministerie van Sociale Zaken en Volksgezondheid, Directorat voor Sociale Voorzieningen, Wachtgeldregeling NV Nederlandse Spoorwegen, no. 52448, 16 mei 1969; bron: Ministerie van Verkeer en Waterstaat, Directoraat-generaal Verkeer, 1960-1971, doss. nr. 26430/k-4, class. nr. 25.07.352.

458. College van Rijksbemiddelaars, Wijziging RDV Nederlandse Spoorwegen, 's-Gravenhage, 14 januari 1948, pp. 1-2; bron: Ministerie van Verkeer en waterstaat, RDV 1946, doss. 283/2, class. nr. 25.08.17.

459. Ministerie van Financiën, Nota Financiering Spoorwegpensioenfonds in de nieuwe spoorwegpensioenwet, 20 augustus 1965, p. 3; bron: Ministerie van Financiën, Spoorwegpensioenfonds 1957-1984, map 80/4442 (1.812.5), doos A 10057.

460. Wet van 29 juni 1925 betreffende pensioenregeling voor de spoorwegambtenaren en hun weduwen en wezen, artt. 5 tot en met 12, Staatsblad nr. 294, 1925.

Wet van 15 februari 1967 houdende nieuwe regeling van de pensioenen van de personeelsleden van de NV Nederlandse Spoorwegen en van hun nabestaanden (Spoorwegpensioenwet), artt. 3, 7 en 9, Staatsblad nr. 138, 1967.

461. Wet van 27 mei 1948, Staatsblad I 217.

462. Wet van 23 februari 1961, houdende matregelen in verband met de financiële positie van het Algemeen Pensioenfonds en van het Spoorwegpensioenfonds, Staatsblad 66, 1961.

463. Wet van 15 februari 1967, staatsblad nr. 138, 1967.

464. Nieuwe regeling van de pensioenen van de personeelsleden van de NV Nederlandse Spoorwegen en hun nabestaanden, (Spoorwegpensioenfonds), Memorie van Antwoord, nr. 7, pp. 1-2.

465. Handelingen Tweede Kamer, Bijlagen, Zitting 1947-1948, 736, Dekking tekort Spoorwegpensioenfonds, Verslag, no. 4.

Handelingen Tweede Kamer, Bijlagen, Zitting 1947-1948, 736, Dekking tekort spoorwegpensioenfonds, Nota naar aanleiding van het verslag, no. 5, p. 2 . 
466. Notulen Raad voor Economische Aangelegenheden, Tariefsverhoging NS, d.d. 11.1.1950, punt 3, pp. 5-6.

467. Ministerie van Verkeer en Waterstaat, Wetsontwerp sanering spoorwegpensioenfonds, augustus 1957, p. 4; bron: Ministerie van verkeer en Waterstaat, doss. nr. 898/AI, class. nr. 25.08.743.

468. NV Nederlandse Spoorwegen, Brief van 8 juni 1957, Sct 1/5831; bron: Ministerie van Verkeer en Waterstaat, doss. nr. $898 / \mathrm{AI}$, class. 25.08.743.

Ministerie van Verkeer en Waterstaat, Nota Wetsontwerp sanering spoorwegpensioenfonds, augustus 1957, p. 5; bron: Ministerie van verkeer en Waterstaat, doss. nr. $891 / \mathrm{I}$, class. $\mathrm{nr} .25 .08 .743$.

Ministerie van Verkeer en Waterstaat, Nota inzake spoorwegpensioenwet, 16 september 1965, p. 1; bron: Ministerie van Verkeer en Waterstaat, doss. nr. 18813, class. nr. 25.08 .743 .1 .

469. Koninklijk Besluit van 22 juni 1949, Statsblad nr. 12, 1949; Ministerie van verkeer en Waterstaat, Sanering pensioenfondsen, 16 juli 1957, p. 5; bron: Ministerie van Verkeer en Waterstaat, doss. 898/AI, class. nr. 25.08.743.

470. Handelingen Tweede Kamer, Bijlagen, Memorie van Toelichting, zitting 1958-1959, 5389, nr. 3, pp. 4-5.

471. Handelingen Tweede Kamer, Deel I, Zitting 1960-1961, 15de vergadering, 9 november 1960 , p. 176.

472. Handelingen Tweede Kamer, Deel I, Zitting 1960-1961, 15de vergadering, 9 november 1960, pp. 177-178.

473. Handelingen Tweede Kamer, Bijlagen, Memorie van Antwoord, Zitting 1965-1966, 8506, nr. 7, p. 1.

474. Ministerie van Verkeer en Waterstaat, DirectoraatGeneraal van het Verkeer, nota inzake normalisatie van wachtgelden van de N.S., 9 oktober 1968, bron: Ministerie van Verkeer en Waterstaat, Directoraat-Generaal van het Verkeer, doss. nr. $2640 / \mathrm{k}-4$, class. nr. 25.07.352.

475. De toekomst van Werkspoor-Utrecht NV, Rapport uitgebracht door de werkgroep "Wagonbouw-Werkspoor", 1968, p. 24; bron: Ministerie van Verkeer en Waterstaat, Werkspoor, doss. nr. 26430 F deel I, class. nr. 25.07.352.

476. Ministerie van Economische Zaken, D.G. voor Industrie en Handel, Dreigende liquidatie afdeling Rollend Materieel van Werkspoor-Utrecht NV als gevolg van uitblijven orders Nederlandse Spoorwegen, 21 maart 1967; bron: Ministerie van Verkeer en Waterstaat, Werkspoor, doss. nr. $26430 \mathrm{~F}$ deel 1, class. nr. 25.07 .352 . 
477. Verenigde Machinefabrieken NV Stork-Werkspoor, Nota in verband met een onderhoud met de directie van de Verenigde Machinefabrieken NV Stork-Werkspoor, 20 juni 1966 ; bron: Ministerie van verkeer en Waterstaat, Werkspoor, doss. nr. $26430 \mathrm{~F}$ deel 1, class. nr. 25.07.352.

Ministerie van Economische Zaken, Dreigende liquidatie van de afdeling Rollend Materieel van Werkspoor-Utrecht NV bij gebreke aan orders van de Nederlandse Spoorwegen, 19 april 1967; bron: Ministerie van Verkeer en Waterstaat, Werkspoor, doss. $\mathrm{nr} .26430 \mathrm{~F}$ deel 1, class. $\mathrm{nr} .25 .07 .352$.

478. Ministerie van Verkeer en Waterstaat, Werkspoor Utrecht, nr. D.V./045889, 's-Gravenhage, 17 januarl 1968; bron: Ministerie van verkeer en Waterstaat, Werkspoor, doss. nr. $26430 \mathrm{~F}$ deel 1, class. $\mathrm{nr} .25 .07 .352$.

479. NV Nederlandse Spoorwegen, Directie, Sct/6336-106, utrecht, 2 mei 1968; bron: Ministerie van verkeer en Waterstaat, Werkspoor, doss. nr. 26430 F deel 1 , class. nr. 25.07 .352 .

480. NV Nederlandse Spoorwegen, Sct/6336-106, Utrecht, 2 mei 1968 , p. 2; bron: Ministerie van verkeer en Waterstaat, Werkspoor, doss. nr. $26430 \mathrm{~F}$ deel 1, class. nr. 25.07.352.

481. Verslag van de $2 e$ Vergadering van de Werkgroep Wagonbouw Werkspoor, gehouden op 21 september 1967 te Utrecht, ten kantore van Werkspoor; bron: Ministerie van verkeer en Waterstaat, doss. nr. P 1, class. nr. 25.07.852.

482. Ministerie van Verkeer en Waterstaat, Nota inzake besteding 31 elektrische tweewagenstellen, 9 mei 1968, pp. 3$4 ;$ bron: Ministerie van Verkeer en waterstaat, Werkspoor, doss. $\mathrm{nr} .26430 \mathrm{~F}$ deel 1, class. nr. 25.07.352.

483. Ministerie van verkeer en Waterstaat, Bestelling 31 elektrische tweewagenstellen door NS, 's-Gravenhage, 13 mei 1968 , p. 1; bron: Ministerie van verkeer en Waterstaat, Werkspoor, doss. $\mathrm{nr} .26430 \mathrm{~F}$ deel 1, class. $\mathrm{nr} .25 .07 .352$.

484. Ministerie van Economische Zaken, DG voor Industrie en Handel, Rollend materieel NS/Werkspoor, IH/PB no. 40'69, 28 augustus 1969; bron: Ministerie van Verkeer en waterstaat, Werkspoor, doss. nr. $26430 \mathrm{~F}$ deel 2, class. nr. 25.07.352.

485. Algemeen Dagblad, Werkspoor wacht op Spoorwegen, 12 november 1969.

486. Ministerie van Verkeer en Waterstaat, Positie WerkspoorUtrecht, 6 november 1969; bron: Ministerie van verkeer en Waterstaat, Werkspoor, doss. nr. 26430 F deel 2, class. nr. 25.07 .352 . 
487. VMF/Stork-Werkspoor, Herstructurering Werkspoor Utrecht, 3 februari 1970, p. 2; bron: Ministerie van verkeer en Waterstaat, werkspoor, doss. nr. $26430 \mathrm{~F}$ deel 2, class. $\mathrm{nr}$. 25.07.352. (De directie van de NV Nederlandse Spoorwegen had kennis genomen en $z$ ich verenigd met de inhoud van deze nota).

488. VMF/Stork-Werkspoor, Herstructurering Werkspoor Utrecht, 3 februari 1970, p. 4; bron: Ministerie van verkeer en Waterstaat, Werkspoor, doss. nr. $26430 \mathrm{~F}$ deel 2, class. nr. 25.07.352. (De directie van de NV Nederlandse Spoorwegen had hiervan kennis genomen en zich verenigd met de inhoud van deze nota).

Nederlandse Spoorwegen, Fabriek Werkspoor-utrecht, deel rollend materieel, D/70/57, 15 april 1970; bron: Ministerie van Verkeer en Waterstaat, Werkspoor, doss. nr. $26430 \mathrm{~F}$ deel 3 , class. nr. 25.07.352.

489. Ministerie van Verkeer en waterstaat, Notitie voor de heer staatssecretaris, 's-Gravenhage, 14 mei 1970; bron: Ministerie van Verkeer en Waterstaat, Werkspoor, doss. $26430 \mathrm{~F}$ deel 3, class. nr. 25.07.352.

490. Nederlandse Spoorwegen, Dr. ir. Th. P. Tromp, voorzitter Raad van Commissarissen, 70/08.01-64, 13 mei 1970; bron: Ministerie van verkeer en Waterstaat, Werkspoor, doss. nr. $26430 \mathrm{~F}$ deel 3 , class. nr. 25.07.352.

NV Nederlandse Spoorwegen, Mr. M.G. de Bruin, presidentdirecteur, P/70/08.01-63, 13 mei 1970; bron: Ministerie van Verkeer en Waterstaat, Werkspoor, doss. nr. $26430 \mathrm{~F}$ deel 3, class. nr. 25.07.352.

491. Personeelsraad, Jaarverslag over 1970, pp. 175-176.

492. Ministerie van Verkeer en Waterstaat, DirectoraatGeneraal van het Verkeer, Temporisering van investeringen en terughoudendheid t.a.v. andere uitgaven, no. v-1/36630, 14 juni 1966, bron: Ministerie van Verkeer en Waterstaat, Directoraat-Generaal Verkeer 1960-1971, doss. $\mathrm{nr}$. 58277, class. nr. 25.07.352.61.

493. Arrest van het Hof van 27 november 1973, NV Nederlandse Spoorwegen tegen minister van Verkeer en Waterstaat (verzoek om een prejudiciële beslissing, ingediend door de Raad van State), zaak 36-73, p. 1302.

494. NV Nederlandse Spoorwegen, Kostensplitsing ReizigersGoederen 1967, Rapport, Utrecht, 1967, p. 2; bron: Ministerie van Verkeer en waterstaat, doss. nr. 9501, map 13, class. nr. 25.07 .352 .28 .

495. NV Nederlandse Spoorwegen, Kostensplitsing ReizigersGoederen 1967, Rapport, Utrecht, 1967, p. 4; bron: Ministerie van Verkeer en Waterstaat, doss. 9501, map 13, class. nr. 25.07 .352 .28 . 
496. NV Nederlandse Spoorwegen, Directie, P/69/11.7-187, 28 oktober 1969, p. 1; bron: Ministerie van verkeer en waterstaat, doss. nr. 26430/s (deel 1), class. nr. $25.07 .352 /$ ns.

497. Ministerie van verkeer en waterstaat, Directie Internationaal Vervoersbeleid, i-1/14, 12 februari 1970; bron: Ministerie van Verkeer en Waterstaat, Directoraat-Generaal van het Verkeer, doss. nr. 43988/I, class. nr. 25.07.352.

498. NV Nederlandse Spoorwegen, Directie, P/69/11.7-187, 28 oktober 1969, bijlage, p. 1-2; bron: Ministerie van verkeer en waterstaat, doss. nr. $26430 / \mathrm{s}$ (deel 1), class. nr. $25.07 .352 / \mathrm{ns}$.

499. NV Nederlandse Spoorwegen, Directie, P/69/11.7-187, 28 oktober 1969, bijlage, p. 3 ; bron: Ministerie van verkeer en waterstaat, doss. nr. $26430 / \mathrm{s}$ (deel 1), class. nr. $25.07 .352 /$ ns.

500. NV Nederlandse Spoorwegen tegen minister van Verkeer en Waterstaat (verzoek om een prejudiciële beslissing, ingediend door de Raad van State), arrest van het hof van 27 november 1973, zaak 36-73, p. 1308.

501. NV Nederlandse Spoorwegen, Memorandum, december 1966, p. $1_{i}$ bron: Ministerie van Verkeer en Waterstaat, doss. nr. 26430 A-3, class. nr. 25.07.352 ns.

502. Handelingen Tweede Kamer, Bijlagen, zitting 1967, 9218, nr. 3, p. 2 .

503. Handelingen Tweede Kamer, Memorie van antwoord, nr.5, zitting 1967-1968, 9218, p. 17

504. NV Nederlandse Spoorwegen, Jaarverslag 1970, Utrecht, p. 17.

505. Notitie inzake Garantiewet, Ministerie van Verkeer en Waterstaat, 10 april 1967, bron: Ministerie van verkeer en Waterstaat, doss. $\mathrm{nr} .26430 \mathrm{C}$, class. nr. 25.07.352.

506. Handelingen Tweede Kamer, 18 februari 1969, pp. 1724, 1742 .

507. NV Nederlandse Spoorwegen, Balanssanering, sct 1/4813945, 20 februari 1969, pp. 1-3; bron: Ministerie van Verkeer en Waterstaat, doss. $\mathrm{nr} .26430 / 2$ (deel 1), class. $\mathrm{nr}$. 25.07 .352 ns.

508. NV Nederlandse Spoorwegen, Jaarverslag 1970, Utrecht, p. 17.

509. Ministerie van Verkeer en Waterstaat, Nota inzake begrotingspost N.V. Nederlandse Spoorwegen 1970, DirecteurGeneraal van het verkeer, 18 februari 1969, p. 1.; bron: 
Ministerie van Verkeer en Waterstaat, doss. $\mathrm{nr} .26430 / \mathrm{s}$ (deel 1), class. nr. 25.07.352/ns.

510. Algemene Rekenkamer, Privatisering Staatsvissershavenbedrijf, Tweede Kamer, vergaderjaar 19861987, 17938, nr. 36, pp. 7-8.

511. Vuchelen en Van Impe, 1987, a.w., p. 235.

512. Huishoudelijk Reglement voor den Raad van Commissarissen der NV Nederlandsche Spoorwegen, artikel 5, 8 januari 1938.

513. NV Nederlandse Spoorwegen, Statuten, 30 augustus 1937, no. 166, artikelen 9, 10 en 11.

514. Handelingen Tweede Kamer, Zitting 1937-1938, Vaststelling begroting van het Verkeersfonds voor 1938, 2E., 13, p. 8.

515. De spoorwegovereenkomsten van 1920 tussen de overheid en de beide spoorwegondernemingen verminderde het aantal leden van de Raad van Commissarissen van 27 naar 11 leden. De overheid verwierf het recht 6 leden te benoemen.

Jonckers Nieboer, 1938, a.w., p. 282.

516. Handelingen Tweede Kamer, Bijlage A, Vaststelling begroting van het verkeersfonds voor 1938, 2E. 15, zitting 1937-1938, p. 20 .

517. Minister van Verkeer en Energie, Brief van 20 september 1945, bron: Ministerie van Verkeer en Waterstaat, DirectoraatGeneraal van het verkeer, Buitengewone Aandeelhoudersvergadering Nederlandse Spoorwegen, doss. $n$. 6526/B, class. nr. 25.07.51.

518. Ministerie van Verkeer en Waterstaat, Spoorwegpensioenen en Spoorwegpensioenfonds, 27 februari 1959, p. 3; bron: Ministerie van Verkeer en Waterstaat, doss. 898/A, class. 25.08 .743 .

519. Goudriaan, 1961, a.w., p. 24.

520. Voor een uitgebreide behandeling over dit machtsconflict wordt verwezen naar: A. van der Zwan, Goudriaan in botsing met NS, Uitgeverij Scriptum, Schiedam, 1991, pp. 234.

521. Departement van Waterstaat, Directieplaatsen N.V. Nederlandse Spoorwegen, 19 november 1945, no. 17949, pp. 1-2; bron: Ministerie van Verkeer en Waterstaat, doss. $\mathrm{nr}$. 6526A, map I, class. nr. 25.07.51.

522. Voorzitter raad van commissarissen G. van der Meulen, Notitie gericht aan de leden van de raad van commissarissen der NS, 20 december 1945, pp. 1-3; bron: Ministerie van Verkeer en Waterstaat, doss. 6526/a, map I, class. nr. 25.07 .51 . 
523. Voorzitter raad van commissarissen G. van der Meulen, Brief gericht aan de minister van verkeer en Energie betreffende directieplaatsen NV Nederlandse Spoorwegen, Utrecht, 9 januari 1946, pp. 1-2; bron: Ministerie van Verkeer en Waterstaat, doss. 6526/a, map I, class. nr. 25.07.51.

524. Statuten, NV Nederlandse Spoorwegen, Bijvoegsel Nederlandse Staatscourant, 2 april 1946, $\mathrm{nr} .65$ (nr.118).

Statuten, NV Nederlandse Spoorwegen, Bijvoegsel Nederlandse Staatscourant, 19 maart 1970, $\mathrm{nr} .55$ ( $\mathrm{nr} .2276$ ).

NV Nederlandse Spoorwegen, Jaarverslag 1970, Utrecht, 15 jun 1 1971, p. 4.

525. Notulen bespreking 8 december 1965, 's-Gravenhage, p. 4; bron: Ministerie van Verkeer en Waterstaat, doss. nr. $24630 / \mathrm{b}$, class. nr. 25.07.352.

526. Artikel 11 (c), statuten N.V. Nederlandse Staatsmijnen, in: Bijvoegsel Nederlandse staatscourant, $\mathrm{nr} .613,27$ januari nr. 20 .

527. Rapport der Commissie ingesteld bij beschikking van zijne Excellentie de Minister van onderwijs, Kunsten en Wetenschappen en Zijne Excellentie de Minister van Binnenlandse zaken en Landbouw, d.d. 30 juni 1923, Algemene Landsdrukkerij, 's-Gravenhage, 1925, p. 22 .

528. Rapport der Commissie ingesteld bij beschikking van $2 i j n e$ Excellentie de Minister van Onderwijs, Kunsten en Wetenschappen en zijne Excellentie de Minister van Binnenlandse Zaken en Landbouw, d.d. 30 juni 1923, Algemene Landsdrukkerij, 's-Gravenhage, 1925, pp. 46-54.

529. Wetenschapsbudget 1967, overzicht van alle op de rijksbegroting uitgetrokken gelden bestemd voor speur- en ontwikkelingswerk, in: Handelingen Tweede Kamer, Begroting Ministerie van Onderwijs, Kunsten en Wetenschappen, 1967, 9300, VIII, p. 22.

530. E. Breeman, Quené: TNO nu op grotere afstand van de overheid, in: Toegepaste Wetenschap TNO, augustus 1986, p. 24.

531. Wetenschapsbudget 1969, overzicht van alle op de rijksbegroting uitgetrokken gelden bestemd voor speur- en ontwikkelingswerk, in: Handelingen Tweede Kamer, Begroting Ministerie van Onderwijs, Kunsten en Wetenschappen 1969, 9800, VIII, p. 4.

532. H.W. Hartog, Gesubsidieerd versus ongesubsidieerd toegepast natuurwetenschappelijk onderzoek; in: Chemisch Weekblad, 1968, nummer 2, pp. 7-8.

533. Chemici geven strijd niet op; in: Chempress, oktober 1977, 11e jaargang $\mathrm{nr}$. 40. 
534. Handelingen Tweede Kamer, Bijlagen, Vergaderjaar 1983$1984,18393, \mathrm{nr} .3, \mathrm{p} .3$.

535. Wet van 30 oktober 1930 , tot regeling van het toegepastnatuurwetenschappelijk onderzoek, artt. 4,5, 10 en 11, staatsblad 416,1930 .

536. Artikel 16(2), Wet van 30 oktober 1930, tot regeling van het toegepast-natuurwetenschappelijk onderzoek, Staatsblad 416,1930 .

Besluit van 16 september 1931, ter uitvoering van de artikelen 5 , 11 en 13 van de wet van 30 oktober (Staatsblad 416), staatsblad $318,1951$.

537. Algemene Rekenkamer, Zitting 1946-1947, Verslag 1946, 552, no. 1, p. 4 .

538. Algemene Rekenkamer, Zitting 1955-1956, Verslag 1955, 4351, no. 2, pp. 15-16.

539. Ministerie van Financiën, Plv.-gedelegeerde, nota Subsidie aan TNO en suppletoir 1955, 1 juni 1955, p. 1; bron: Ministerie van Financiën, doss. subs. TNO 1956, map I, doos o.A. 4972, inv. nr. 1.854.2.

540. Ministerie van Financiën, Nota subsidiëring TNo, 30 november 1951; bron: Ministerie van Financiën, dossier Subsidie TNO 1953, doos 1068, inv. nr. 447.

541. Ministerie van Financiën, Nota Overmaking van f. 775.000 aan TNO, 2 april 1953; bron: Subsidie TNO 1952, doos 1068, inv. $\mathrm{nr} .447$.

542. Ministerie van Financiën, Nota subsidiebeleid TNO, 5 januari 1956, p. 2; bron: Ministerie van Financiën, Subsidie TNO 1956, map I, doos O.A. 4972, inv. nr. 1.854.2.

543. Ministerie van Financiën, Nota subsidiebeleid TNO, 6 februari 1956, p. 2; bron: Ministerie van Financiën, doss. Subsidie TNO 1956, map I, doos 0.A. 4972, inv. nr. 1.854.2.

544. Ministerie van Financiën, Nota subsidiebeleid TNo, 5 januari 1956, p. 1; bron: Ministerie van Financiën, doss. Subsidie TNO 1956, map I, doos 0.A. 4972, inv. nr. 1.854.2.

545. Plv.-gedelegeerde, Nota ter toelichting, p. 2; bron: Ministerie van Financiën, doss. Subsidie TNO 1959, inv. nr. 1.854 .2

546. Ministerie van Financiën, Nota Kapitaaluitgaven TNO, 7 juni 1951, pp. 1-2; bron: Ministerie van Financiën, Subsidie Kapitaaldienst TNO 1952, doos 1068, inv. nr. 447. 
547. TNO, Jaarverslag TNO 1966, Centrale Organisatie, Algemeen Gedeelte, 1a, p. 86; Jaarverslag TNO 1970, Centrale Organisatie, Algemeen Gedeelte, 1a, p. 98 .

548. Ministerie van Economische Zaken, Nota inzake het TNO, 28 maart 1938, pp. 21-22; Algemeen Rijksarchief, Ministerie van Financiën, Generale Thesaurie, doos 820, inv. nr. 1106-3.

549. Organisation TNO, Report of the lecture and discussions about the organisation TNo, held in The Hague on november 2 nd 1951 at the visit of OEEC-Mission No 81 to the Netherlands, p. 6.

550. Ministerie van Financiën, Nota Subsidie TNO, 27 mei 1953; bron: Ministerie van Financiën, Subsidie TNO 1954, doos 1068, inv. nr. 447.

551. Organisatie TNO, Verslag over het jaar 1954, p. 29; Organisatie TNO, Verslag over het jaar 1956, p. 40.

552. Organisatie TNO, Verslag over het jaar 1957, p. 110.

553. Ministerie van Financiën, Gedelegeerde van de minister van Financiën, Brief aan voorzitter van de centrale Organisatie TNO, onderwerp: Prestatiemeting bij TNO, A/16763, 28 november 1967; bron: Ministerie van Financiën, Algemeen Subsidiebeleid TNO 1953-1978, semi-statisch archief A 9742 , inv. $\mathrm{nr} .1 .854 .2$.

554. Voorstel inzake het rijkssubsidie voor 1970 aan de Nederlandse Centrale organisatie voor ToegepastNatuurwetenschappelijk onderzoek, bedoeld in artikel 3 van de wet van de 30 ste oktober 1930 tot regeling van het toegepastnatuurwetenschappelijk onderzoek, p. 5; bron: Ministerie van Financiën, doss. subsidie TNO 1970.

555. Voorstel inzake het rijkssubsidie voor 1953 aan de Nederlandse Centrale organisatie voor ToegepastNatuurwetenschappelijk onderzoek, bedoeld in artikel 3 van de wet van de 30 ste oktober tot regeling van het toegepastnatuurwetenschappelijk onderzoek, pp. 4-6; bron: Ministerie van Financiën, doss. Subsidie TNO 1953, doos O.A. 4972, inv. $\mathrm{nr}$. 1.854.2.

556. Ontwerp Voorstel inzake het rijkssubsidie voor 1954 aan de Nederlandse Centrale organisatie voor ToegepastNatuurwetenschappelijk onderzoek, bedoeld in artikel 3 van de wet van de 30 ste october 1930 tot regeling van het toegepastnatuurwetenschappelijk onderzoek, p. 6 ; bron: Ministerie van Financiën, doss. subsidie TNO 1954, doos O.A. 4972, inv. nr. 1.854 .2 .

557. TNO, Enige beschouwingen betreffende de toekomstige ontwikkeling van het Speurwerk in Nederland, p. 15; 13 oktober 1955; bron: Ministerie van Financiën, doss. Subsidie TNO 1956, map I, doos O.A. 4972, inv. nr. 1.854.2. 
558. Ministerie van Financiën, Nota Voorstel voor het Rijkssubsidie voor 1966 aan TNo, 22 juni 1965, p. 5; bron: Ministerie van Financiën, doss. Subsidie TNo 1966.

559. Centrale Organisatie TNO, Brief aan minister van Financiën, no. 56 A 3861, 's-Gravenhage, 12 september 1956; bron: Ministerie van Financiën, Subsidie TNO 1956, map I, doos o.A. 4972, inv. nr. 1.854.2.

560. Tweede Kamer der Staten-Generaal, vergaderjaar 1983-1984, 18393, nr. 3, p. 21 .

561. Wet van 30 oktober tot regeling van het toegepastnatuurwetenschappelijk onderzoek, artt. 8 (3) en 22 (3) staatsblad 416 .

562. Ministerie van Financiën, (handgeschreven commentaar op) Notitie, 4 december 1958; bron: Ministerie van Financiën, doss. TNO/Algemeen/map I, doos A/8978.

563. TNO, Comnissie Holtrop, Brief van 11 mei 1962; bron: Ministerie van Financiën, doos 0.A. 6019.

564. Ministerie van Financiën, Notitie Salaris voorzitter Nijverheidsorganisatie TNO, 12 februari 1965; bron: Ministerie van Financiën, doss. Salariëring voorzitter, doos 0.A. 6019.

565. Ministerie van Financiën, Nota Vergadering bestuur Centrale organisatie TNO op 12 december a.s., 7 december 1967, p. 1; bron: Ministerie van Financiën, Salariëring voorzitter, doos O.A. 6019 .

566. Artikel 1 (1), Wet van den 30sten october 1930, tot regeling van het toegepast-natuurwetenschappelijk onderzoek (s. 416), in: Organisatie TNO, Wet, Besluiten, statuten en Reglement, 's-Gravenhage, 1969, p. 3.

567. Handelingen der staten-Generaal, Tweede Kamer, Memorie van Toelichting, Bijlagen, 1928-1929, 425.3, p. 5.

568. Departement van Algemene Zaken, Samenvatting van de bespreking inzake TNO op 4 mei 1938 aan het Departement van Algemene Zaken; bron: Algemeen Rijksarchief, Generale Thesaurie, doos 818, inv. 1106-3.

569. Ministerie van Algemene Zaken, Afdeling II, Brief aan de Centrale Organisatie TNO, Toegepast-natuurwetenschappelijk onderzoek, ing. no. 39 A $61 / 258$, 13 maart 1939, p. $2 ;$ bron: Ministerie van Financiën, Generale Thesaurie, Algemeen Rijksarchief, doos 818 , inv. nr. 1106-3.

570. Centrale organisatie TNO, Brief aan minister van staat, Bericht op schrijven: Afd. II, no. 180, d.d. 13 maart 1939, onderwerp: toegepast-natuurwetenschappelijk onderzoek, 'sGravenhage, 24 april 1939, p. $1 ;$ bron: Ministerie van Financiën, Generale Thesaurie, Algemeen Rijksarchief, doos 
818, inv. nr. 1106-3.

571. Ministerie van sociale Zaken, subsidie Gezondheidsorganisatie TNO, 's-Gravenhage, 7 mei 1951; bron: doss. Subsidie TNO 1952, doos 1068, inv. nr. 447.

572. Ministerie van Financiën, Brief Subsidiebeleid, 'sGravenhage, 11 december 1953; bron: Ministerie van Financiën, doss. Algemeen Subsidiebeleid TNO, 1953-1978, A 9742 .

573. TNO, Voorstel inzake het rijkssubsidie voor $1959, \mathrm{p} .7 ;$ bron: Ministerie van Financiën, doss. Subsidie TNO 1959, doos 4972, inv. nr. i.854.2.

574. Ministerie van Financiën, Nota ter toelichting, p. 2; bron: Ministerie van Financiën, doss. Subsidie TNO 1959, doos. 4972., inv. $\mathrm{nr}$. 1.854.2.

575. Ministerie van Financiën, Salarismaatregelen 1968; bron: Ministerie van Financiën, Salarismaatregelen TNO 1967-1973, doos A 4932.

576. Centrale Organisatie, Algemeen Gedeelte, Jaarverslag TNO 1969, 1a, pp. 66-67.

577. Organisatie TNO, Jaarverslag 1934, p. 8 .

578. Organisatie TNO, Jaarverslag 1950, pp. 9-10.

579. Organisatie TNO, Verslag over het jaar 1955, p. 7 .

580. Voorstel inzake het rijkssubsidie voor 1956 aan de Nederlandse Centrale organisatie voor ToegepastNatuurwetenschappelijk onderzoek, bedoeld in artikel 3 van de wet van de 30 ste october 1930 tot regeling van het toegepastnatuurwetenschappelijk onderzoek (ontwerp), p. 5; bron: Ministerie van Financiën, doss. Subsidie TNo 1956, doos O.A. 4972, inv. nr. 1.854.2.

581. TNO, Voorstel inzake het rijkssubsidie voor 1959, p. 7; bron: Ministerie van Financiën, doss. Subsidie TNo 1959, doos 4972, inv. nr. 1.854.2.

582. Ministerie van Financiën, Subsidie TNO 1956, 19 juli 1955, p. 3; bron: Ministerie van Financiën, doss. Subsidie TNO 1956, doos 4972, inv. $\mathrm{nr} .1 .854 .2$.

583. Ministerie van Financiën, Liquiditeit; reservevorming; subsidie 1956 en 1957; 's-Gravenhage, 14 maart 1956; bron: Ministerie van Financiën, doss. Subsidie TNO 1956, map $I$, doos 0. A. 4972 , inv. nr. 1.854.2.

Voorstel inzake het Rijkssubsidie voor 1957 aan de Nederlandse Centrale organisatie voor toegepast-natuurwetenschappelijk onderzoek, bedoeld in artikel 3 van de wet van 30 oktober 1930 tot regeling van het toegepast-natuurwetenschappelijk 
onderzoek, p. 2 ; bron: Ministerie van Financiën, doss. doss. Subsidie TNO 1957, doos O.A. 4972, inv. nr. 1.854.2.

584. Chemici geven strijd niet op; in: Chempress, oktober 1977 , 11e jaargang nr. 40 .

585. Nederlandse Centrale organisatie TNO, no. A 4/174, Jaarverlag, 's-Gravenhage, 5 april 1935, p. 7; bron: Ministerie van Financiën, Generale Thesaurie, Algemeen Rijksarchief, doos 818, inv. nr. 1106-1.

586. Organisatie TNO, Jaarverslag 1950, pp. 9-10; Jaarverslag 1951 , p. 8-9.

Voorstel inzake het rijkssubsidie voor 1959 aan de Nederlandse Centrale organisatie voor Toegepast-Natuurwetenschappelijk onderzoek, bedoeld in artikel 3 van de wet van de 30 ste oktober 1930 tot regeling van het toegepastnatuurwetenschappelijk onderzoek, pp. 7-8; bron: Ministerie van Financiën, doss. subsidie TNO 1959.

587. W. Drees, Perspectieven voor ons volk; in: De Gids, De tijd waarin wij leven, Utrecht, november, 1952, p. 235.

588. Nederland moet industrieel klimaat nog scheppen, Interview met Prof. dr. Kruyt voorzitter TNO, in: Het Parool, 12 maart 1953, p. 7.

589. TNO, Enige beschouwingen betreffende de toekomstige ontwikkeling van het speurwerk in Nederland, 13 oktober 1955, p. 13; bron: Ministerie van Financiën, Subsidie 1956, map I, doos 0.A. 4972, inv. nr. 1.854.2.

590. TNO, Enige beschouwingen betreffende de toekomstige ontwikkeling van het speurwerk in Nederland, 13 oktober 1955; bron: Ministerie van Financiën, Subsidie 1956, map I, doos o.A. 4972, inv. nr. 1.854.2.

591. Voorstel inzake rijkssubsidie voor 1968 aan de Nederlandse Centrale organisatie voor ToegepastNatuurwetenschappelijk Onderzoek, bedoeld in artikel 3 van de wet van de 30 ste oktober 1930 tot regeling van het toegepastnatuurwetenschappelijk onderzoek; bron: Ministerie van Financiën, p. 2; bron: Ministerie van Financiën, doss. Subsidie TNO 1968.

592. Voorstel inzake het rijkssubsidie voor 1956 aan de Nederlandse Centrale organisatie voor ToegepastNatuurwetenschappelijk onderzoek, bedoeld in artikel 3 van de Wet van 30 oktober 1930 tot regeling van het toegepastnatuurwetenschappelijk onderzoek (ontwerp), p. 5; bron: Ministerie van Financiën, doss. Subsidie TNO 1956, doos 4972, inv. $\mathrm{nr} .1 .854 .2$. 
593. TNO, Toelichting op de kapitaalbegroting voor het jaar 1956, p. 7; bron: Ministerie van Financiën, doss. Subsidie TNO 1956, map I, doos 0.A. 4972, inv. nr. 1.854.2.

594. Artikel 3, Wet van 30 oktober tot regeling van het toegepast-natuurwetenschappelijk onderzoek, staatsblad 416 .

595. Voorstel inzake het Rijkssubsidie voor 1968 aan de Nederlandse Centrale organisatie voor ToegepastNatuurwetenschappelijk onderzoek, bedoeld in artikel 3 van de Wet van 30 oktober 1930 tot regeling van het toegepastnatuurwetenschappelijk onderzoek, p. 2; bron: Ministerie van Financiën, doss. Subsidie TNO 1968 .

596. Ministerie van Financiën, Nota subsidiebeleid TNo, 5 januari 1956, p. 4; bron: Ministerie van Financiën, doss. Subsidie TNO 1956, map I, doos 0.A. 4972, inv. nr. 1.854.2.

597. Ministerie van Sociale Zaken, Subsidie Gezondheidsorganisatie TNO, 's-Gravenhage, 7 mei 1951; bron: Ministerie van Financiën, doss. Subsidie TNO 1952, doos 1068, inv. nr. 447 .

598. Ministerie van Financiën, Nota Extra-subsidie Gezondheidsorganisatie, 30 mei 1952; bron: Ministerie van Financiën, doss. Subsidie 1953, doos 1068, inv. nr. 447.

599. Ministerie van Sociale Zaken, Brief Subsidie TNo, $\mathrm{nr}$. 11858, 26 september 1955; bron: Ministerie van Financiën, doss. Subsidie TNO 1956, map $I$, doos O.A. 4972, inv. nr. 1.854 .2 .

600. Ministerie van Financiën, Directie Financieringen en Coördinatie oorlogsschade, no. F 15697, 17 augustus 1954, p. 1; bron: Ministerie van Financiën, doss. Algemeen Subsidiebeleid 1953-1978, inv. nr. 9742.

601. Tweede Kamer, Bijlagen, Zitting 1951-1952, ontwerp van Wet tot regeling van het hoger onderwijs, artt. 9 en 24,2597 , nr. $1-2$.

Tweede Kamer, Bijlagen, Zitting 1951-1952, Memorie van Toelichting, Regeling van het hoger onderwijs, 2597, $\mathrm{nr}$. 3, p. 24.

602. Voorstel inzake rijkssubsidie voor 1968 aan de Nederlandse Centrale Organisatie voor ToegepastNatuurwetenschappelijk onderzoek, bedoeld in artikel 3 van de Wet van 30 oktober 1930 tot regeling van het toegepastnatuurwetenschappelijk onderzoek; bron: Ministerie van Financiën; bron: Ministerie van Financiën, doss. Subsidie TNO 1968.

603. TNO, Jaarverslag TNO 1966, Centrale Organisatie, Algemeen Gedeelte, $1 \mathrm{a}, \mathrm{p} .88$. 
604. TNO, Jaarverslag TNO 1969, Centrale Organisatie, Algemeen Gedeelte, 1a, pp. 66-67.

605. Ministerie van Financiën, Nota Begroting 1970; subsidie TNO, 11 juni 1969, p. 6; bron: Ministerie van Financiën, doss. Subsidie TNO 1970.

606. TNO, Jaarverslag TNO 1970, Centrale Organisatie, Algemeen Gedeelte, 1a, p. 99.

607. Ministerie van onderwijs en Wetenschappen, Brief, Inspraak bij vaststelling subsidie ingevolge artikel 3 van de Wet TNO, dgw 161.483, 's-Gravenhage, 25 september 1967; bron: Ministerie van Financiën, doss. TNO-Algemeen, map I, doos A/8978.

608. Centrale Organisatie, jaarverslag TNO 1966, algemeen gedeelte, 1a, p. 35 .

Centrale Organisatie TNO, Personeelsstop, 66 A 447, 24 augustus 1966; bron: Ministerie van Financiën, TNO Algemeen, map I, doos A 8978 .

609. Centrale organisatie TNO, Brief aan minister van Financiën, onderwerp: personeelsstop, 66 A 4447 , 'sGravenhage, 24 augustus 1966; bron: Ministerie van Financiën, Centraal oud Archief TNO, map 1, inv. nr. 8978.

610. Algemene Rekenkamer, zitting 1946-1947, 552, Verslag 1946 , no. 1, pp. 7-8.

611. Ministerie van Financiën, Nota Subsidiëring TNO, 8 januari 1952; bron: Ministerie van Financiën, doss. Subsidie 1953, doos 1068, inv. nr. 447.

612. Besluit tot wijziging en aanvulling van het Koninklijk Besluit van 16 september 1931 ter uitvoering van de artikelen 5,11 en 13 van de wet van 30 oktober 1930 tot regeling van het toegepast-natuurwetenschappelijk onderzoek, 12 juni 1934, Staatsblad nr. 308, 1934 .

613. Besluit tot wijziging en aanvulling van het Koninklijk Besluit van 16 september 1931, gewijzigd met het Koninklijk Besluit van 23 juli 1951, Staatsblad nr. 318, 1951.

614. Minister van Economische Zaken, Nota inzake het toegepast-natuurwetenschappelijk onderzoek, 28 maart 1938, pp. 17-21; bron: Ministerie van Financiën, Generale Thesaurie, doos 820, inv. nr 1106-3.

615. Ministerie van Economische Zaken, Nota no. $19 \mathrm{I}$, Voorzitter Centrale organisatie TNO, pp. 1-2; bron: Ministerie van Financiën, doss. TNO Algemeen, map I, doos A 8978 . 
616. Bestuur van de Centrale Organisatie TNO, Reglement voor de Nationale Raad voor Landbouwkundig onderzoek TNO, 16 november 1956, in: Organisatie TNO, 's-Gravenhage 1969, p. 26.

617. Ministerie van Financiën, Nota Subsidiebeleid TNO, 5 januari 1956, pp. 2-3; bron: Ministerie van Financiën, doss. Subsidie TNO 1956, map I, doos O.A. 4972.

618. U. Rosenthal en A. Reinders, Publieke ondernemingen: De schizofrenie van successen en mislukkingen, in: Beleid en Maatschappij, 1981, pp. 95-96, 99.

619. Comptabilteitswet 1976, art. 80 (1), (4) en (5); in: Nederlandse Staatswetten, Editie Schuurman en Jordens, nr. 20, Zwolle, negende druk 1977.

620. Comptabiliteitswet 1976, art. 80 (b); in: Nederlandse Staatswetten, Editie Schuurman en Jordens, $\mathrm{nr}$. 20, Zwolle, tiende druk 1991.

621. Wet openbaarheid van bestuur van 1978, in: Nederlandse Staatswetten, Editie Schuurman en Jordens, $n r .174, p .8$; Wet openbaarheid van bestuur van 1991, in: Nederlandse Staatswetten, Editie Schuurman en Jordens, $\mathrm{nr}$. 174, pp. 149151.

622. Richtlijn van 25 juni 1980 betreffende de doorzichtigheid in de financiële betrekkingen tussen lidstaten en openbare bedrijven, 80/723/EEG, Pb. nr. L 195/35.

Richtlijn tot wijziging van richtiijn $80 / 723 /$ EEG betreffende de doorzichtigheid in de financiële betrekkingen tussen lidstaten en openbare bedrijven, 85/413/EEG, Pb. nr. L 229/20.

623. EC Commission expands power over the state sector, in: The wall street Journal Europe, july 25, 1991, p.2.

624. Keyser en Windle, 1978, a.w., p. 67.

625. R.K. Yin, Case-study research: design and methods, Sage Publications Inc., sixth printing, 1990, pp. 15, 21, 44-45, 124.

626. Pestieau, in: Annals of Public and Co-operative Economy, 1989, a.w., p. 298-299.

627. Alchian en Demsetz, Production, information costs, and economic organization, in: Putterman, 1988, a.w., pp. 111-134.

628. Morrison, 1932, a.w, pp. 156-157, 171-174, 277-278.

629. R. Millward en D. Parker, Public sector economics, Longman, London, New York, first published 1983, p. 221. 
630. Ministerie van Waterstaat, Ministeriële Instructie, 12 april 1937; bron: Concern Archief DAM, Organisatie 1950-1969, in. nr. 3 .

631. Concessie NV Nederlandse Spoorwegen, art. 8, in: Nederlandse staatscourant, 30 december 1937, no. 253.

632. Statuten NV Nederlandse Spoorwegen, art. 12, in: Bijvoegsel tot de Nederlandse staatscourant van maandag 30 augustus 1937 , no. 166.

633. Besluit van 16 september 1931 ter uitvoering van de artikelen 5, 11 en 13 van de wet van 30 oktober 1930, art. 16 (1), in: organisatie TNO: Wet, besluiten, statuten en reglement, 's-Gravenhage, 1969.

634. Wet $\operatorname{van} 30$ oktober 1930 tot regeling van het toegepastnatuurwetenschappelijk onderzoek, art. 11 (1), in: organisatie TNO: Wet, besluiten en statuten, 's-Gravenhage, 1969.

635. De organisatie van een mijn, bijlage notulen 65e vergadering ondernemingsraad Staatsmijnen, 4 april 1950, pp. 1-2; bron: Concern Archief DAM, Organen van Overleg en Bedrijfsrechtspraak, 1950-1959, in. nr. 89a.

636. Personeelsraad, Rechtspositie van het personeel, De produktiviteit, Jaarverslag over 1962, p. 26.

637. Personeelsraad, Jaarverslag over 1962, p. 26.

638. Personeelsraad, Rechtspositie van het personeel, Jaarverslag over 1965, pp. 21, 26-27.

639. Ministerie van Financiën, Gedelegeerde van de minister van Financiën, Brief aan voorzitter van de Centrale Organisatie TNO, onderwerp: Prestatiemeting bij TNO, A/16763, 28 november 1967; bron: Ministerie van Financiën, Algemeen Subsidiebeleid TNO 1953-1978, semi-statisch archief doos A 9742 , inv. nr. 1.854.2.

640. Koninklijk Besluit van 25 april 1913, in: Staatsblad 1913, nr. 139.

641. Statuten NV NederIandse Staatsmijnen, Art. 11 (1)(1), in: Bijvoegsel Nederlandse staatscourant, $\mathrm{nr} .613,27$ januari $1967, \mathrm{nr} .20$.

642. Concessie Nederlandse Spoorwegen, artikel 6, in: Nederlandse Staatscourant, 30 december 1937, no. 253.

643. Ministerie van Economische Zaken, Directie Mijnwezen, Winstbestemming Staatsmijnen 1962, 7 mei 1963, bron: Ministerie van Economische Zaken, Archief Staatsmijnen, inv. nr. 384 . 
644. Uittreksel uit de notulen van de 150 e vergadering van de ondernemingsraad voor de staatsmijnen in Limburg, gehouden op 21 december 1955, pp. 1-2; bron: Nederlandse Katholieke Mijnwerkersbond, Sociaal Historisch Centrum, Maastricht, EAN 581 , H. 16.2

645. Wijziging statuten $N V$ Nederlandse Spoorwegen, art. II, Bijvoegsel Nederlandse Staatscourant, nr. 389, 13 juli 1943, nr. 133; Statuten NV Nederlandse Spoorwegen, art. 15, $\mathrm{nr}$. 1786, Bijvoegsel Nederlandse Staatscourant, 12 mei 1964, $\mathrm{nr}$. 90.

646. Personeelsraad, Jaarverslag over 1962, p. 23.

647. Veljanovski, 1988, a.w., p. 61 .

648. Staatsmijnen, Notitie Regeringsopvattingen omtrent staatsbedrijven, LA $3 / 1,21$ juli 1954; bron: Concern Archief DSM, Organisatie 1950-1969, inv. $\mathrm{nr}$. 6, map 1; Goudriaan, 1961, a.w., p. 274.

649. Staatsmijnen in Limburg, Brief aan de Minister van Waterstaat, 30 januari 1939, no. 228, pp. 1-3; bron: Concern Archief DSM, organisatie, tot en 1939, inv. nr. 4.

650. Gesprek met $\mathrm{mr}$. Wansink (Econ. Zaken) te 's-Gravenhage op 4 juni 1958; bron: Concern Archief DSM, Organisatie 1950-1969, inv. nr. 8.

651. Notulen van de bespreking, gehouden op woensdag 8 december 1965, Ministerie van Binnenlandse Zaken, tussen enerzijds de Ministers Verkeer en Waterstaat en Financiën en anderzijds een delegatie uit het bestuur van de NV Nederlandse Spoorwegen; bron: Ministerie van verkeer en Waterstaat, doss. nr. 26430b, class. nr. 25.07.352.

652. NV Nederlandse Spoorwegen tegen minister van Verkeer en Waterstaat (verzoek om een prejudiciële beslissing, ingediend door de Raad van State), arrest van het hof van 27 november 1973, zaak 36-73, p. 1308 .

653. Ministerie van Economische Zaken, Directie Mijnwezen, Nota Vaste Commissie/bedrijfseconomisch rapport staatsmijnen 1962, 30 oktober 1963, pp. 1-3; bron: Ministerie van Economische Zaken, Archief Staatsmijnen, inv. nr. 384.

654. P.S.R.F. Mathijsen, A guide to European Community Law, Sweet \& Maxwell, London, 1980, p. 170.

655. Werkgroep Wagonbouw Werkspoor, De toekomstmogelijkheden van Werkspoor-utrecht nv, 0369/68; bron: Ministerie van Verkeer en Waterstaat, doss. nr. $26430 \mathrm{~F}$ deel $I$, class. nr. 25.07 .352 .

656. Personeelsraad, Jaarverslag over 1970, pp. 175-176. 
657. D. Bös, Öffentliche Unternehmungen, in: F. Neumark (Hrsg.), Handbuch der Finanzwissenschaft, Band II, Tübingen, 1978, pp. 23-25; Blankart, 1980, a.w., pp. 24-27, 107-108.

658. Ministerie van verkeer en Waterstaat, DirectoraatGeneraal van het Verkeer, Nota betreffende publikatie investeringsgegevens N.S., 10 januari 1958; bron: Ministerie van Verkeer en Waterstaat, Samenstelling Jaarverslagen NS, 1956-1964, doss. nr. 6543/A, class. nr. 25.07.77.

659. Blankart, 1980, a.w., p. 105.

660. Simon, 1989, a.w., p. 10.

661. De kwantitatieve factoren omvatten het aantal reizigerskilometers, het aantal wagenladingen, het aantal zendingen snel- en expresgoed en rijwielen, het aantal afgegeven plaatsbewijzen en de personeelsbezetting. De kwalitatieve factoren behelsden: gebruiksintensiteit van de goederenwagens, energieverbruik, kwaliteit reizigerstreindienst (het percentage op tijd rijdende reizigerstreinen) en kwaliteit goederentreindienst (het percentage op tijd rijdende goederentreinen).

662. Personeelsraad, Rechtspositie van het personeel, Jaarverslag over 1965 , p. 25.

663. Personeelsraad, Rechtspositie van het personeel, Jaarverslag over 1965, pp. 21, 26-27.

664. Personeelsraad, Bezoldiging, vergoedingen en uitkeringen, Herziening van het algemene prestatiebeloningssysteem, Jaarverslag over 1968, pp. 91-92.

665. Blankart, 1980, a.w., pp. 83-84.

666. Boardman en Vining, 1989, a.w., p. 9.

667. Wet betreffende pensioenregeling voor de spoorwegambtenaren en hun weduwen en wezen (Spoorwegpensioenwet), 29 juni 1925, in: Staatsblad 1925, no. 294.

668. Voorstel inzake het rijkssubsidie voor 1953 aan de Nederlandse Centrale organisatie voor toegepastnatuurwetenschappelijk onderzoek, bedoeld in artikel 3 van de wet van de 30 ste oktober tot regeling van het toegepastnatuurwetenschappelijk onderzoek, pp. 4-6; bron: doss. Subsidie TNO 1953, doos o.a. 4972, inv. nr. 1.854.2.

669. Backhaus, in: Maandschrift Economie, 1989, a.w., pp. 368369 .

670. Handelingen Eerste Kamer, Vaststelling van de begroting van uitgaven van de staatsmijnen, 41ste vergadering, 27 april 1928, pp. 787-788. 
671. Handelingen Tweede Kamer, Bijlage A, staatsbegroting voor het dienstjaar 1926, 2. IX, p. 27.

672. Handelingen Tweede Kamer, Zitting 1937-1938, Vaststelling begroting van het Verkeersfonds voor 1938, 2E., 13, p. 8 .

673. De spoorwegovereenkomsten van 1920 tussen de overheid en de beide spoorwegondernemingen verminderde het aantal leden van de Raad van Commissarissen van 27 naar 11 leden. De overheid verwierf het recht 6 leden te benoemen.

Jonckers Nieboer, 1938, a.w., p. 282.

674. Ministerie van Verkeer en Waterstaat, Directoraatgeneral van het Verkeer, Bijlage bij Nota inzake mogelijke bezuinigingen bij de NS, maart 1968; Ministerie van Verkeer en Waterstaat, Bedrijfsvoering bij de NS, doss. nr. 26430/n, class. nr. 25.07.352.

675. Statuten NV Nederlandse Spoorwegen, Art. 16, Bijvoegsel Nederlandse Staatscourant, $\mathrm{nr}$. 1206, 30 augustus 1937, nr. 166; Wijziging statuten NV Nederlandse Spoorwegen, art. II, Bijvoegsel Nederlandse Staatscourant, nr. 389, 13 juli 1943, nr. 133.

676. Handelingen Tweede Kamer, Bijlagen, zitting 1954-1955, $3816, \mathrm{nr} .3, \mathrm{p} .3$.

677. Backhaus, 1989, a.w., p. 6 .

678. NV Nederlandse Spoorwegen, Exploitatiebegroting 1968, p. $3 a$.

679. TNO, Commissie Holtrop, Brief van 11 mei 1962 ; bron: Ministerie van Financiën, doos 0.A. 6019; Ministerie van Financiën, Notitie Salaris voorzitter Nijverheidsorganisatie TNO, 12 februari 1965; bron: Ministerie van Financiën, doss. Salariëring voorzitter, doos 0.A. 6019 .

680. Robson, in: Maandblad voor accountancy en bedrijfshuishoudkunde, 1962, a.w., p. 226; Slot, 1983, a.w., p. 159 .

681. Ondernemingsraad, 50e vergadering, notulen van 23 maart 1949 , p. 4; Concern Archief DSM, Organen van overleg en Bedrijfsrechtspraak 1940-1949, inv. nr. 97.

682. Verslag van de op 24 februari 1956 op het Departement van Financiën gehouden bespreking inzake het afschrijvingsvraagstuk, Heerlen, 28 februari 1956, p. 3; bron: Concern Archief DSM, Comptabele en Financiële Aangelegenheden 1940-1959, inv. nr. 29.

683. B. van den Tempel, Publieke en semi-publieke ondernemingen, Samson NV, Alphen a/d Rijn, 1935, p. 81. Voortaan aangehaald als: Van den Tempel, 1935. 
684. Van den Tempel, 1935, a.w., pp. 88-97.

685. Morrison, 1932, a.w., pp. 156-157.

686. L.P. Jones, P. Tandon en I. Vogelsang, Selling public enterprises, MIT Press, Cambridge, 1990, p. 161. In het vervolg aangehaald als: Jones, 1990.

687. Handelingen Tweede Kamer, zitting 1952-1953, 2800K, nr. 6, p. 1 .

688. Backhaus, 1989, a.w., p. 12.

689. Jones, 1990, a.w., pp. 160-162.

690. Handelingen Eerste Kamer, Wetsontwerp tot vaststelling van de begroting van de Staatsmijnen in Limburg voor het dienstjaar 1955 (3700K), deel III, zitting 1954-1955, 26ste vergadering, 1 maart 1955, pp. 3163-3165; Handelingen Tweede Kamer, Bijlagen, Nota naar aanleiding van het verslag, zitting 1960-1961, 6003, nr. 5, p.2.

691. Blankart, in: Thiemeyer (Hrsg.), 1987, a.w., pp. 59-60.

692. Algemene Rekenkamer, Privatisering staatsvissershavenbedrijf, Tweede Kamer, vergaderjaar 19861987, 17938, nx. 36, p. 7; Ministerie van Financiën, Handboek privatisering, SDU uitgeverij, 's-Gravenhage, 1990, p. 55.

693. EFA, ontwikkeling van de Staatsmijnen, 5 april 1960, p. 6; bron: Concern Archief DSM, Organisatie 1950-1969, inv. nr. 8 .

694. Jones, 1990, a.w., p. 3.

695. A. van der Zwan, J. Paauwe en B. van Dorp, Uit het dal, Uitgeverij Scriptum, Schiedam, 1991, p. 7.

696. J. Vickers en G. Yarrow, Privatization in Britain; in: P.W. MacAvoy, W.T. Stanbury, G. Yarrow en R.J. Zeckhauser, Privatization and state-owned enterprises, Boston, Dordrecht, Kluwer Academic Publishers, 1989, pp. 220-224.

697. Veljanovski, 1987, a.w., pp. 101-106.

698. Ministerie van Financiën, Persbericht, $\mathrm{nr} .91 / 221,25$ september 1991 .

699. Goudriaan, 1961, a.w., p. 24.

700. Van der Zwan, 1991, a.w., p. 150.

701. Monsen en Walters, 1983, a.w., pp. 57-58, 64 . 
702. Bestuur van de Centrale organisatie TNO, Reglement voor de Nationale Raad voor Landbouwkundig onderzoek TNO, 16 november 1956, in: Organisatie TNO, 's-Gravenhage 1969, p. 26.

703. G.E. Braun, Ziele in öffentlicher Verwaltung und privatem Betrieb, Schriften zur öffentlichen verwaltung und öffentlichen Wirtschaft, Band 76, Nomos Verlagsgesellschaft, Baden-Baden, 1988, pp. 327-328.

704. Vogelsang, 1990, a.w., pp. 44-47.

705. Notulen bespreking 8 december 1965, 's-Gravenhage, p. 4; bron: Ministerie van Verkeer en Waterstaat, doss. nr. 24630/b, class. nr. 25.07 .352 .

706. Vogelsang, 1990, a.w., p. 62 .

707. P. Eichhorn, Anforderungen an eine für die Politikberatung geeignete Theorie offentlicher Unternehmen, in: T. Thiemeyer (Hrsg.), öffentliche Unternehmen und äkonomische Theorie, Nomos, Verlagsgesellschaft, Baden-Baden, 1. Aufl. 1987, pp. 215-222.

708. Goudriaan, 1961, a.w., pp. 273-274.

709. Y. Aharoni, Comprehensive audit of management performance in u.s. state-owned enterprises, in: Annals of Public and Cooperative Economy 54, no. 1, 1983, pp. 86, 90. In het vervolg aangehaald als: Aharoni, in: Annals of Public and co-operative Economy 54, no. 1, 1983.

710. Aharoni, in: Annals of Public and Co-operative Economy 54, no. 1, 1983, a.w., pp. 90-91. 


\section{Geraadpleegde Archieven}

Algemeen Rijksarchief:

1. Centrale Organisatie TNO, $\mathrm{nr} .1106$, doos: 818, 819.

2. Notulen en Bijlagen Ministerraad en Raad voor Economische Aangelegenheden (REA).

3. Archief Mijnraad, 1902-1955, inv. nr. 50, 52 en 80

Ministerie van Economische Zaken:

1. Archief Mijnwezen, Directie Mijnwezen, Staatsmijnen: inv.nr. 147, 148, 149, 151, 156, 159; Financiën: inv. nr. 169,170, 183, 185, 187, 190; Commissariaten: inv. 386.

Ministerie van Financiën:

1. Stukken betreffende insteming met een voorstel van de minister van Sociale Zaken en Volksgezondheid inzake de uitvoering van de wet op de ondernemingsraden ten aanzien van overheid- en semi-overheidsbedrijven, Finco, inv. nr. 1099.

2. Stukken betreffende overleg met het Ministerie van Economische zaken over leningsvoorwaarden voor de Staatsmijnen, 1956-1965, Dienst Rijksbegroting, inv. nr. 2182 .

3. Stukken betreffende behandeling van de jaarrekeningen van de Staatsmijnen in Limburg over 1953-1959, Dienst Rijksbegroting, inv. nr. 1761.

4. Stukken betreffende behandeling van verslagen van de staatsmijnen in Limburg inzake investeringen en kapitaalpositie, 1951-1964, Generale Thesaurie, inv. nr. 1549.

5. Stukken betreffende toepassing van de vervangingswaarde bij de afschrijuingen op vaste activa van staatsbedrijven, 1952-1958, Generale Thesaurie, inv. nr. 1593.

6. Stukken betreffende opmerkingen naar aanleiding van een nota van de minister van Economische zaken inzake bezitsvorming door het personeel van de staatsmijnen, 1954, Finco, inv. nr. 1156.

7. Stukken betreffende behandeling van ontwerpregularisatiewetten voor de begrotingen 1952, 1953, 1955-1964, Dienst Rijksbegroting, inv. nr. 1828. 
8. Dossier Wetsontwerp Belastingheffing van overheidsbedrijven, Generale Thesaurie, 1940-1954, 19541975.

9. Dossier Algemeen Subsidiebeleid TNO, 1953-1978, inv. nr. 9742 .

10. Dossier Subsidie TNO, inv, nr. 1.854.2.

11. Dossier TNO, Gedelegeerden, benoemingen, opdrachten van Rijkswege, personeelsstop, inv. nr. 8978 .

12. Dossier Spoorwegpensioenfonds 1957-1984, map 80/4442, doos A 1.0057, inv. nr. 1.812 .5

Ministerie van Verkeer en Waterstaat:

1. Archief Nederlandse Spoorwegen, Directoraat-Generaal Verkeer, 1960-1971, dossier nrs. $26430 / \mathrm{n}, 26430 \mathrm{c}$, 26430-k4, 26430/s, 58277, 9501, classificatie nummer 25.07 .352 .

NV Nederlandse staatsmijnen:

1. Organisatie tot en met 1939.

2. Organisatie, 1950 tot en met 1969.

3. Comptabele en Financiële Aangelegenheden, 1940-1959.

4. Comptabele en Financiële Aangelegenheden, 1960-1969.

5. Sociale Zorg en Maatschappelijk Werk, 1950-1959.

6. Organen van Overleg en Bedrijfsrechtspraak, 1940-1959.

7. Gasdistributiebedrijf, tot en met 1939, 1940-1949, 19501969.

8. Centraal Laboratorium, 1936-1949.

NV Nederlandse Spoorwegen:

1. Investeringsplannen 1950-1970, Seriewerken 35, doos $\mathrm{nr}$. 96.

2. Exploitatiebegrotingen 1939-1956, doos $\mathrm{nr}$. fe 18-21.

3. Exploitatiebegrotingen, 1960-1970, Seriewerken 39, doos nr. 39.

Sociaal Historisch Centrum Limburg:

1. Archief Nederlandse Katholieke Mijnwerkersbond, EAN 581, h. 16.2 , h. 16.3 , h. 16.6 , h. 16.7, k.70.4.2. 
2. Statistiek Gezamenlijke Steenkolenmijnen, XIV-3 tot en met XIV-4.

Tweede Kamer der Staten-Generaal:

1. Archief Vaste Commissie Verkeer en Waterstaat.

\section{Gedrukte Stukken}

\section{Europese Gemeenschap:}

Verdrag tot oprichting van de Europese Economische Gemeenschap, Rome 25 maart 1957; in: Nederlandse staatswetten, editie Schuurman \& Jordens, 1982.

Verordening van de raad van 26 juni 1969 betreffende het optreden van de lidstaten ten aanzien van met het begrip openbare dienst verbonden verplichtingen op het gebied van het vervoer per spoor, over de weg en over de binnenwateren, 1191/69, Pb. תr. L $156 / 1$.

Verordening nr. 1192/69 van de raad van 26 juni 1969 betreffende de gemeenschappelijke regels voor de normalisatie van de rekeningstelsels van de spoorwegondernemingen, 1192/69, $\mathrm{Pb}$. nr. L $156 / 8$.

Richtlijn van 25 juni 1980 betreffende de doorzichtigheid in de financiële betrekkingen tussen lidstaten en openbare bedrijven, 80/723/EEG, $\mathrm{Pb}$. $\mathrm{nr}$. L 195/35.

Richtlijn tot wijziging van richtlijn 80/723/EEG betreffende de doorzichtigheid in de financiële betrekkingen tussen lidstaten en openbare bedrijven, 85/413/EEG, Pb. nr. L 229/20.

2. Staatsmijnen in Limburg:

Jaarverslagen 1902 tot en met 1970, 1991.

Bedrijfseconomische Verslagen 1950 tot en met 1970.

3. Gezamenlijke steenkolenmijnen in Limburg:

Jaarverslagen 1950 tot en met 1970 .

4. Centraal Bureau voor de Statistiek:

Maandstatistiek Financiewezen, jaargang 12, no. 8, 1964, en jaargang 13 , no. 8, 1965.

Negentig jaren statistiek in tijdreeksen, 1899-1989.

Statistisch Zakboek, 1953, p. 28; 1956, p. 35; 1961, p. 43, 1966, p. 45 en 1970, p.80. 
Maandstatistiek van de prijzen.

Veertig jaren verkeers- en vervoersstatistiek in tijdreeksen $1938-1978$

5. Nederlandse Centrale Organisatie voor Toegepast-Natuurwetenschappelijk onderzoek:

Organisatie TNO, Wet, Besluiten, Statuten en Reglement, 'sGravenhage, 1969.

Verslagen van 1950 tot en met 1970.

6. NV Nederlandse Spoorwegen:

Rail 21, Sporen naar een nieuwe eeuw, Utrecht, oktober 1988.

Rail 21 Cargo: Het tweede spoor, Utrecht, januari 1990.

7. Union Internationale des Chemins de Fer:

Statistique Internationale des Chemins de Fer, 1960-1970.

8. NV Verenigde Machinefabrieken:

Jaarverslag 1956.

\section{Wet- en regelgeving}

1. Bedrijvenwet van 1928, in: Nederlandse staatswetten, editie Schuurman en Jordens, negende druk, 1977.

2. Comptabiliteitswet van 1976, in: Nederlandse Staatswetten, editie Schuurman en Jordens, negende druk 1977.

3. Comptabiliteitswet van 1976, in: Nederlandse staatswetten, editie Schuurman en Jordens, tiende druk 1991.

4. Wet openbaarheid van bestuur van 1978, in: Nederlandse Staatswetten, editie Schuurman en Jordens, $\mathrm{nr} .174$, tweede druk, 1985.

5. Wet openbaarheid van bestuur van 1991, in: Nederlandse staatswetten, editie Schuurman en Jordens, nr. 174, derde druk, 1992.

6. Concessie N.V. Nederlandse Spoorwegen, in: Nederlandse Staatscourant, 30 december 1937, nr. 253.

7. Statuten NV Nederlandse Spoorwegen, in: Bijvoegsel Nederlandse Staatscourant, 30 augustus 1937, nr. 166 (nr. 1206). 
8. Statuten NV Nederlandse Spoorwegen, in: Bijvoegsel Nederlandse Staatscourant, 2 april 1946, nr. 65 ( $\mathrm{nr}$. 118 ).

9. Statuten NV Nederlandse Spoorwegen, in: Bijvoegsel Nederlandse staatscourant, 19 maart 1970, $\mathrm{nr} .55$ ( $\mathrm{nr}$. 2276 ).

\section{Rijksbegroting:}

1. Staatsbalansen, Miljoenennota's van 1960 tot en met 1970.

\section{Correspondentie}

1. DSM, Brief van 26 april 1989, Heerlen, CS/FP 89019.

2. Ministerie van Onderwijs en Wetenschappen, Brief van 12 januari 1990, onderwerp Archiefonderzoek, AZ/RA/CAB 89036800 .

3. NV Nederlandse Spoorwegen, Brief van 17 januari 1990, Sct $/$ B.3.3/0182A/N.

\section{Literatuur}

1. Aharoni Y., The no-risk society, Chatham House Publishers, New Yersey, 1981, pp. 113-114.

2. Aharoni $Y .$, Comprehensive audit of management performance in U.s. state-owned enterprises, in: Annals of Public and Co-operative Economy 54, no. 1, 1983, pp. 73-92.

3. Aharoni Y., The evolution and management of state-owned enterprises, Ballinger Publishing Company, Cambridge, 1986, pp. 34-35 en 39 .

4. Alchian A., Corporate management and property rights; in: Furubotn G. en S. Pejovich (ed.), The economics of property rights, Ballinger Publishing Company, Cambridge, Massachusetts, 1974, p. 147.

5. Alchian A., Demsetz H., Production, information costs, and economic organization; in: Putterman L. (ed.), The economic theory of the firm, Cambridge University Press, cambridge, 1988, p. 112, 118-119. (Oorspronkelijk gepubliceerd in: The American Economic Review, 62, 1972, pp. 777-795).

6. Aumund H., Die Aufgaben der Technik im Dienste der offentlichen Gemeinwesen; in: Technik und Wirtschaft, 1917, p. 108 . 
7. Backhaus J.G., Öffentliche Unternehmen, Haag und Herchen Verlag, Frankfurt am Main, 2. durchgesehene und erweiterte Auflage 1980, pp. 88, 102-103, 121.

8. Backhaus J.G., Assessing the performance of public enterprises: a public choice approach, Rijksuniversiteit Limburg, wp 89-007, 4 april 1989, pp. 4-8.

9. Backhaus J.G., Privatisering en nationalisering: een aanzet tot een nieuwe benadering, in: Maandschrift Economie, jaargang 53, 1989, pp. 368-369.

10. Beesley M. en S. Littlechild, Privatization: principles, problems and priorities, in: Lloyds Bank Review, july 1983, pp. 1-20.

11. Blankart C.B., ökonomie der öffentlichen Unternehmen, Verlag Franz Vahlen, München, 1980, pp. 25, 59-60, 83$84,105,129$.

12. Boardman A.E., Vining A.R., Ownership and performance in competitive environments: a comparison of the performance of private, mixed, and state-owned enterprises, Journal of Law \& Economics, vol. XXXII, April 1989, pp. 8-10.

13. Bös D., öffentliche Unternehmungen, in: F. Neumark (Hrsg.), Handbuch der Finanzwissenschaft, Band II, Tübingen, 1978, pp.23-25.

14. Bos D., Het beheer der staatsbedrijven; in: Vragen des Tijds, 1908, p. 17.

15. Bouma J.L., Leerboek der bedrijfseconomie, deel II, Delwel, Wassenaar, tweede geheel herziene druk, 1988, pp. 285-286.

16. Braun G.E., Ziele in öffentlicher Verwaltung und privatem Betrieb, Schriften zur öffentlichen verwaltung und öffentlichen Wirtschaft, Band 76, Nomos Verlagsgesellschaft, Baden-Baden, 1988, pp. 327-328.

17. Bressers J. en A. Hoogerwerf (red.), Beleidsevaluatie, Samsom, H.D. Tjeenk willink, Alphen a/d Rijn, tweede druk 1991, pp. 70-101, 102-121.

18. Chmielewicz K., Zur Problematik einzelwirtschaftlicher Effizienzkriterien bei öffentlichen Unternehmungen, in: Thiemeyer Th. (Hrsg.), öffentliche Unternehmen und ökonomische Theorie, Nomos Verlagsgesellschaft, BadenBaden, 1987, pp. 163-164.

19. Compendium voor politiek en samenleving in Nederland, Bohn, Stafleu, Van Loghum, april 1991. 
20. Curwen P., Public enterprise, Wheatsheaf Books Ltd., 1986, pp. 198-201, 216-217.

21. Davies D.G., Brucato P.F., Property rights and transaction costs: theory and evidence on privately owned and government-owned enterprises, Journal of Institutional and Theoretical Economics, 143 (1987), pp. 11-13.

22. Domar E.D., Depreciation, replacement and growth; in: The Economic Journal, vol. LXIII, no. 3, 1953, pp. 1-32.

23. Drees W., Perspectieven voor ons volk, in: De Gids, De tijd waarin wij leven, november 1952, pp. 230-236.

24. Egmond van F., wie is wie in Nederland, 1984-1988, Pragma Nederland, 's-Gravenhage.

25. Eichhorn P., Probleme der Eigenfinanzierung bei öffentlichen und gemischtwirtschaftlichen Unternehmen; in: Eichhorn P., Thiemeyer Th. (Hrsg.), Finanzierung öffentlicher Unternehmen, Nomos Verlagsgesellschaft, Baden-Baden, 1. Auflage 1979, pp. 40-42, 56-57.

26. Eichhorn P., Anforderungen an eine für die Politikberatung geeignete Theorie öffentlicher Unternehmen, in: Thiemeyer Th. (Hrsg.), öffentliche Unternehmen und ökonomische Theorie, Nomos, Verlagsgesellschaft, BadenBaden, 1. Aufl. 1987, pp 215-222.

27. Eisner R., Depreciation allowances, replacement requirements and growth; in: The American Economic Review, vol. XLII, no. 5, 1952, pp. 820-831.

28. Faber J.A. (red.), Het Spoor, 150 jaar spoorwegen in Nederland, Meulenhoff Informatief, Amsterdam, 1989, p. 107,379 .

29. Farrel M.J., The measurement of productive efficiency, in: Journal of the Royal Statistical Society, vol. 120, part III, pp. 253-281.

30. Frenken J.P.J., over kapitaalcoëfficiënten, in: Maandschrift Economie, jaargang 53, 1989, no. 5, p. 402.

31. Furubotn E.G, Pejovich S., Property rights and economic theory: a survey of recent literature; in: Journal of Economic Literature, p. 1139.

32. Geologie en Mijnbouw, maart/april 1971, pp. 313-317.

33. Goedhart $C$., Hoofdlijnen van de leer der openbare financiën, H.E. Stenfert Kroese b.v., Leiden, derde druk, 1975, 123-125, 128-136. 
34. Goldscheid R., staatskapitalismus oder Staatssozialismus, Anzengruber-Verlag, Wien/Leipzig, 2weite und dritte verbesserte Auflage, 1917, pp. 11, 15, $23-24$.

35. Goudriaan J., De toekomst der Nederlandsche spoorwegen; in: Economisch Statistische Berichten, 22 maart 1939, p. 22 .

36. Goudriaan J., Vriend en vijand, Herinneringen aan de Nederlandse Spoorwegen 1938-1948, Uitgeverij De Bezige Bij, Amsterdam, 1961, pp. 273-274.

37. Haririan M., state-owned enterprises in a mixed economy, Westview Press, Boulder, 1989, pp. 48, 53, 111-119

38. Hartog H.W., Gesubsidieerd versus ongesubsidieerd toegepast natuurwetenschappelijk onderzoek; in: Chemisch Weekblad, 1968, nummer 22, pp. 7-9.

39. Jonckers Nieboer J.H., Geschiedenis der Nederlandse Spoorwegen 1832-1938, Nijgh \& Van Ditmar n.v., Rotterdam, tweede geheel herziene druk, 1938, pp. 185$186,249-250,282,305,316-325$.

40. Jones L.P. en P. Tandon, Selling public enterprises, The MIT Press, Cambridge, Mass., 1990, pp. 160-162.

41. Jonge de H., Een overheidsbedrijf als publicke onderneming algemeen matschappelijke kanttekeningen, in: Beleid en matschappij, 1981, p. 115.

42. Kam de F., J. de Haan en C. Sterks, De kerfstok van Nederland, Academic Service, Schoonhoven, 1990, pp. 116125 .

43. Keyser $W$. en $R$. Windle, Public enterprise in the EEC, The Netherlands, Sythoff \& Noordhoff, Alphen aan den Rijn, 1978, p. 67.

44. Keyser $W$. en R. Windle, Public Enterprise in the EEC, France, part IV, Sijthoff en Noordhoff, Alphen aan den Rijn, 1978, pp. 162.

45. Keyser $W$. en R. Windle, Public Enterprise in the EEc, Italy, part $V$, Sijthoff en Noordhoff, Alphen aan den Rijn, 1978, pp. 182 .

46. Kol van H., Staatsbedrijven en staatsmonopolies, N.V. Boekhandel en Uitgeversmaatschappij "Ontwikkeling", Amsterdam, 1918, p. 3 .

47. Koutsoyiannis A., Modern microeconomics, Macmillan Education Ltd., second edition, 1987, pp. 190-191. 
48. Kreukels L., Mijnarbeid: volgzaamheid en strijdbaarheid, Van Gorcum, Assen/Maastricht, 1986, pp. 53-57.

49. Kuhne K., Der Kapazitätserweiterungseffekt der Abschreibungen (sog. Lohmann-Ruchti-Effekt) in mikround makroökonomischer sicht; in: P. Eichhorn en $T$. Thiemeyer (Hrsg.), Finanzierung öffentlicher Unternehmen, Nomos Verlagsgesellschaft, Baden-Baden, 1979, pp. 173-197.

50. Kupsch P., Friedrich P. (Hrsg.), Die Besteuerung öffentlicher Unternehmen, Nomos-Verlagsgesellschaft, 1981, Baden-Baden, p. 287.

51. Maddala G.S., Introduction to econometrics, Macmillan Publishing Company, New York, 1988, p. 132.

52. Marlow M.L., Privatization and government size, in: Public Choice, 68, 1991, pp. 273-274.

53. Mathijsen P.S., A guide to European Community Law, Sweet \& Maxwell, London, third edition, 1980, p. 170.

54. McGuire J.W., J.S.Y. Chiu en A.O. Elbing, Executive incomes, sales and profits, in: The American Economic Review, 1962, pp. 753-761.

55. Messing F.A.M., Geschiedenis van de mijnsluiting in Limburg, Martinus Nijhoff, Leiden, 1988, pp. 19, 138$143,151,185-188,290$.

56. Millward R. en D. Parker, Public sector economics, Longman, London, New York, 1983, p. 221.

57. Ministerie van Financiën, Handboek privatisering, SDUuitgeverij, 's-Gravenhage, 1990, p. 55.

58. Mishan E.J. Cost-benefit analysis, Praeger, New York, 1976, pp. 117-121.

59. Mol N.P., Bedrijfseconomie voor de collectieve sector, Samsom H.D. Tjeenk Willink, Alphen aan den Rijn, 1986, p. 68 .

60. Monsen R.J. en K.D. Walters, Nationalized companies: a threat to american business, McGraw-Hill Book Company, New York, 1983, pp. 37, 45-47, 57-58, 64.

61. Morrison H., Socialisation and Transport, London, Constable, 1932, pp. 156-157, 171-174, 277-278.

62. Niopek W., Innovationsverhalten öffentlicher Unternehmen, Nomos Verlagsgesellschaft, Baden-Baden, 1. Auflage 1986, pp. 106-110, 160. 
63. Oud P.J., Het jongste verleden, deel VI, Van Gorcum en Comp. NV, Assen, tweede druk, 1968.

64. Parris H., Pestieau P., Saynor P. (ed.), Public enterprise in Western Europe, Croom Helm, London, 1987, p. 145 .

65. Peirce W.S., Rent and technological change in the extractive industries, Paper Conference on New Issues in Industrial Economics, june 2, 1988, p. 6 .

66. Perelman S., Pestieau P., Technical performance in public enterprises, in: European Economic Review 32, 1988 , pp. $432-441$.

67. Pestieau P., Measuring the performance of public enterprises, in: Annals of public and cooperative Economy, Vol. 60, No. 3, 1989, pp. 293-305.

68. Pestieau P., Tulkens H., Assessing the performance of public sector activities some recent evidence from the productive efficiency viewpoint, June 1990, pp. 1-53. (provisional version).

69. Pieters J.M.G., Lonen en bedrijfsresultaten bij de Nederlandse steenkolenmijnondernemingen in de Gemeenschappelijke Steenkolenmarkt van de EGKS, Proefschrift, Alberts Gulpen B.V., 1981, pp. 96-97, 103, 378 .

70. Popitz J. Der künftige Finanzausgleich zwischen Reich, Ländern und Gemeinden, Verlag von otto Liebmann, Berlin, 1932 , p. 49.

71. Porter P.K., Scully G.W., slottje D.J., Industrial policy and the nature of the firm, in: Journal of Institutional and Theoretical Economics (JITE), 142, 1, 1986, pp. 89-90.

72. Püttner G., Die Finanzierungsentscheidungen und deren tberwachung; in: Eichhorn P., Thiemeyer Th. (Hrsg.), Finanzierung öffentlicher Unternehmen, Nomos Verlagsgeselischaft, Baden-Baden, 1. Auflage 1979, pp. 162-163.

73. Ramanadham V.V., Public enterprise and income distribution, Routledge, London, New York, 1988, pp. 17$18,28-29,31,83$.

74. Ramanadham V.V., The economics of public enterprise, Routledge, London and New York, first published, 1991, pp. $44-45,271,357$.

75. Rees R., Public enterprise economics, Weidenfeld and Nicolson, London, second edition, 1984, pp. 137-138. 
76. Robson T., Auditing problems in relation to hidden reserves; in: Maandblad voor accountancy en bedrijfshuishoudkunde, 36e jaargang, nr. 6, juni 1962, p. 226 .

77. Rosenthal $U$. en $A$. Reinders, Publieke ondernemingen: De schizofrenie van successen en mislukkingen, in: Beleid en Maatschappij, 1981, pp. 91-100.

78. Ru, de H.J., Staatsbedrijven en staatsdeelnemingen, Ars Aequi Libri, Nijmegen, 1981, pp. 277-303.

79. Shapiro C., Willig R.D., Economic rationales for the scope of privatization, in: Suleiman E.N, Waterbury J. (ed.), The political economy of public sector reform and privatization, Westview Press, Boulder, 1990, pp. 55-87.

80. Simon H., Organizations and markets, 4 february 1989, p. 10.

81. Slot R., Elementaire bedrijfseconomie, Stenfert Kroese bv, Leiden/Antwerpen, negende herziene druk, p. 29.

82. Smeets M.J.H., De economische betekenis van belastingen, L.J. Veen's Uitgevers Maatschappij n.v., tweede druk 1954, pp. 14 .

83. Sociaal-Democratische Arbeiderspartij (SDAP), Het socialisatievraagstuk, Rapport uitgebracht door de commissie aangewezen uit de SDAP, NV Boekhandel en uitgeversmaatschappij "Ontwikkeling", Amsterdam, 1920, pp. 35-36.

84. Telderstichting, Open ondernemerschap, Martinus Nijhoff, 's-Gravenhage, tweede druk, 1962, p. 292.

85. Tempel van den B, Publieke en semi-publieke ondernemingen, Samson NV, Alphen a/d Rijn, 1935, pp. 36$37,81,88-97$.

86. Thiemeyer Th., Die Abgeltung gemeinwirtschaftlicher Lasten als Mittel der Finanzierung öfentlicher Unternehmen, in: Eichhorn P., Thiemeyer Th. (Hrsg.), Finanzierung offentlicher Unternehmen, Nomos Verlagsgesellschaft, Baden-Baden, 1. Auflage 1979, pp. $129-130,132-134$.

87. Tulkens H., The performance approach in public enterprise economics: an introduction and an example; in: Annals of Public and Co-operative Economy 74, 1986, pp. 429-443.

88. Veljanovski C., Selling the state, Weidenfeld and Nicolson Ltd., London, 1988, pp. 61, 77, 95, 101-106. 
89. Vereniging voor de staatshuishoudkunde en de statistiek, Pre-advies, 's-Gravenhage, Martinus Nijhoff, 1918, pp. $143-144,154-155,157-158,164,168-169$.

90. Verrijn stuart C.A., De wetenschap der volkshuishoudkunde en de grondslagen der volkshuishouding, De erven F. Bohn N.V., Haarlem, vijfde herziene druk, 1943, p. 175, 250 .

91. Vickers J. en G. Yarrow, Privatization in Britain; in: P.W. MacAvoy, W.T. Stanbury, G. Yarrow en R.J. zeckhauser, Privatization and state-owned enterprises, Boston, Dordrecht, Kluwer Academic Publishers, 1989, pp. 220-224.

92. Vogelsang I., Public enterprise in monopolistic and oligopolistic industries, Harwood academic publishers, 1991, pp. 24-25.

93. Vuchelen J. en W. van Impe, Privatisering, Standaard Uitgeverij, Antwerpen, 1987, pp. 117-118, 235.

94. Windmuller J.P. en C. de Galan, Arbeidsverhoudingen in Nederland, deel 1, Uitgeverij Het Spectrum, Utrecht, derde druk 1979, pp. 67-69.

95. Yin R.K., Case-study research: design and methods, Sage Publications Inc., sixth printing, 1990, pp. 15, 21, 4445,124 .

96. Zwan van der A., Goudriaan in botsing met NS, Uitgeverij Scriptum, Schiedam, 1991, pp. 234.

97. Zwan van der A., B. van Dorp en J.P. Paauwe, Uit het dal, Uitgeverij Scriptum, Schiedam, 1991, p. 7.

\section{Dag- on opiniebladen}

1. Het Parool, Nederland moet industrieel klimaat nog scheppen, 12 maart 1953, p. 7.

2. Algemeen Dagblad, Werkspoor wacht op spoorwegen, 12 november 1969 .

3. Chempress, Chemici geven strijd niet op, oktober 1977, 11e jaargang, nr. 40 .

4. The Economist, A survey of Italy, may 26, 1990, p. 4 .

5. The Economist, Sell by 1992, Subsidising state-owned firms is incompatible with Europe's internal market, march 2nd 1991, pp. 16-17.

6. The Economist (Survey Business in Europe), The aid plague, june 8th 1991, p. 16. 
7. Europe, Agence internationale d'information pour la presse, Luxembourg-Bruxelles, no. 5166, 6-1-90, p. 15; no. 5369, 14-11-90, p. 13.

8. Financial Times, Brittan on the trail of aid to state companies, monday november 19, 1990.

9. NRC Handelsblad, $H$. Wammes, Weerstand tegen beursgang DSM, 7 juli 1988 .

10. NRC Handelsblad, Groep wil af van invloed staat in DSM, 16 april 1992, p. 21.

11. The Wall street Journal Europe, EC commission expands power over the state sector, july 25, 1991, p. 2. 


\section{Summary}

In the Netherlands the central government established the sector of public enterprise at the beginning of this century. Untransparency and absence of a consistent policy with regard to public enterprises have been the main characteristics ever since. Before 1940 a tendency existed to establish corporate bodies under private law, mainly foundations. These bodies spent public resources without adequate control by the Parliament and the General Accounting office.

From 1945 Dutch cabinets increased their number of shareholdings in limited liability companies. Parliament and the General Accounting office were not enabled to control the annual budgets of these companies. In 1951 Labour Minister of Finance $P$. Lieftinck even rejected the public parliamentary review of the policies implemented by government-owned limited liability companies. Parliament and the General Accounting office tried to obtain more information about the performance of public enterprises. The General Accounting office published some accounting data in the reports on 1950 and 1960 . Since 1966 the Government audit office has been publishing an annual survey of public enterprises.

Article 90 of the EEC Treaty enabled the European commission to adopt directives and decisions in order to increase the transparency of the relationships between governments and their public enterprises. In 1980 she obliged the member states to disclose more information about the acknowledgement and the spending of public financial resources on behalf of their public enterprises. The commission introduced some changes in this obligation in 1985. Her policy failed and for this reason a new system of information disclosure was introduced within the framework of the existing EC regulation in 1991.

The discipline of public finance distinguishes two perspectives on public revenues: the entrepreneurial state and the fiscal state. In the Netherlands the central government performs both roles. Government-owned limited liability companies contributed about 0,6 percent of the total government revenues in 1970. The entrepreneurial state was an important employer in total public employment. The state company for Post, Telex and Telephone and the Dutch state Mines (abbreviated as DSM) determined 31,6 percent of the total employment at the central government level. W. Keyser and $R$. Windle estimated that the employment by public enterprises in total employment (excluding civil servants) was about 6,6 percent in 1970 .

The untransparency facilitated political owners to use public enterprises as instruments to achieve objectives, including the objectives stated in the articles of association and the relevant legislation. Case-studies enable the identification of these objectives. This research project conducted case-studies about the Dutch state Mines, the Dutch Railroad Corporation and the organization for Applied Scientific Research (abbreviated as TNO), because they operate in the primary, secondary and tertiary sector of the Dutch 
economy. The project examined the following research question:

Which objectives, besides a sufficient achievement of the stated objectives, did the political owners of the Dutch state Mines, the Dutch Railroad Corporation and the Organization for Applied Scientific Research reveal from their establishment upto 1970 ?

The case-studies have keen conducted from the theoretical perspectives of property rights and public choice.

scientific policy evaluation emphasizes the application of combinations of quantitative and qualitative approaches. These can be applied separately to different questions, derived from the main research question. Another application consists in answering the same research question with a quantitative and a qualitative research approach.

Mainly Belgian economists contribute to the development of a quantitative analysis of the performance of public enterprises. They obtain the public enterprise objectives from general economic policy and restrict their research to measuring technical efficiency. They derive a production function with a regression analysis and construct a production possibility frontier. The expression of the production below the production possibility frontier as a percentage of the points on this frontier measures technical efficiency.

In this research project one can conduct the qualitative performance analysis in combination with the quantitative analysis. The qualitative performance analysis has its origin in the theory of property rights as developed by A. Alchian and H. Demsetz, and elaborated by J.G. Backhaus. This analysis consists of three phases, namely: a structure analysis, an analysis of the revealed objectives and an analysis of the interaction between the public enterprise explanation of its performance and the reactions of the principals to this explanation.

Structure analysis

The structure analysis examines the distribution of the public property rights. These rights constitute a governance structure of the public enterprise. The analysis focuses on the right:

(1) to control the purchases and to monitor the performance of the production factors,

(2) to control the output performance and to monitor the externalities,

(3) to monitor the production process,

(4) to monitor the composition of the team of producers, and (5) to claim profits.

The examination of the allocation of these rights results in the identification of several categories of agents, who participate in the governance structure of the public enterprise. The owners of the public property rights are able to influence the decision making process. To put it 
differently behind the identification of the agents involved exists an extended body of economic theory.

The right to control the purchases relates to the theory of bilateral monopoly, and the pricing and investment theory. Under circumstances of a bilateral monopoly the management board and the single national ancillary company negotiate about the price. Loyalty to ministerial policies or purchase obligations result in improper burdens for the public enterprise if the negotiated prices differ from the prices set by ancillary companies abroad. The relationship between the Dutch Railroad corporation and the ancillary company Werkspoor-Utrecht is an example. Purchasing results from a decision to maintain or extend the existing capacity. Economic analysis shows that the optimal pricing and investment policy requires the equality of price, short run and long run marginal costs. Empirically marginal costs are approached by the ratio of annual cost to volume differences. This approach does not deserve any recommendation, because the available data are mostly long term data.

Control of output performance concerns the presence of incentive schemes in public enterprises. Incentive schemes are only effective if the individual contributions to the production can be measured. Measurement of the wrong productivity indicators in public enterprises might cause deficits and urge the government to act as the lender of the last resort.

Externalities involve the positive and negative side effects of public enterprise activities. Considerations about the positive side effects of the public production of goods and services belong to the reasons to establish public enterprises. The positive side effects are social benefits, which are not included in the measurement of public enterprise profitability. The social benefits are difficult to measure. A public enterprise like the organization TNO contributes with technological innovations to the improvement of social welfare. The contribution of the innovations of a single public enterprise in terms of gross national product is difficult to observe. Negative externalities, for instance environmental pollution, constitute an embarrassment to a cabinet and cause social costs. These costs are not included in the pricing policies of public enterprises. In economic theory negative externalities are controlled by regulation, taxation and the transfer of property rights (the right to pollute).

The right to monitor the composition of the team of producers is affiliated with the subject of appointments. In a two-party system a change in cabinet results in an extension of personnel at the upper decision levels of public enterprises. It is a renumeration for previous political services to the newly governing party. This renumeration means a stable position and a guaranteed stream of revenues. The extension of personnel at the upper level might cause an hidden unemployment.

In the Dutch consociational democracy, characterized by a heterogeneous political culture and cartel like behaviour of elites, this phenomenon of renumeration for rendered services 
does not exist. The social democratic member of parliament G.F. Lindereijer expressed the view that election results should not play a role in the occupation of the main positions within public enterprises under public law. Hidden unemployment was not unfamiliar to Dutch public enterprise. For instance the Dutch Railroad corporation had a surplus of 106 academics in 1969 (See chapter 4: table 4.3).

The claiming of profits involves the current theories on rent seeking and public enterprise rents. Profits result from the productive allocation of the factors of production. Governments claim a part of the profits with dividends. In exceptional cases management boards obtained the right to claim bonuses/royalties, which was for instance the case for the management board of the Dutch state Mines.

Trade unions and external interest groups try to obtain a share in the profits by wasting their factors of production. They will waste their factors of production until the revenues forgone exceed the benefits to be had from the public enterprise. This behaviour is known as rent seeking. The existence of rent seeking deprives a public enterprise of its profits. The profits forgone constitute the public enterprise rents. These can be estimated by using the rate of return of government perpetuities as an indicator of profitability. The transfer of rents from the public enterprise to the rent seekers is untransparent, because of the negative value to society.

The structure analysis in the case studies shows no ministerial interference with the daily routine of the management board. In this respect the governance structure does not differ with the British model of public enterprise, mentioned after $H$. Morrison, the Labour minister of Transport from 1929 up to 1931. He developed a governance structure of public enterprise at $\operatorname{arm}^{r}$ s-length distance of the cabinet.

\section{Analyzing the revealed objectives}

Research on the objectives of public enterprises is still in an initial phase. $Y$. Aharoni, M. Haririan and V.V. Ramanadham made important contributions to the research on public enterprise objectives. These leading authors in the discipline agree that the efforts of public enterprises to achieve noncommercial objectives entail costs.

Aharoni proposes a contingency approach to study public enterprise. This approach emphasizes the influence of external variables on the performance of a public enterprise, for instance external coalitions and market structure. The objectives of these enterprises are the result of a conflict among stakeholders. The revealed objectives are rarely identical with the formal objectives.

According to Haririan performance evaluations of public enterprises should be based on their failure or success in achieving predetermined objectives. For this purpose a Goal Attainment Model should be developed, which determines the variation between target objectives and attained objectives. The objectives have to be ranked and assigned weights in accordance with the priorities. An adjustment factor is used 
to reflect the negative impact of conflicting objectives.

Ramanadham combines analysis with illustrative references in his approach to public enterprise performance. He distinguishes official and non-commercial objectives. The latter contain economic and non-economic objectives, which have their origin outside the enterprise. If a cabinet wants to pursue non-commercial objectives it has to specify these objectives in managerially clear terms and to quantify the financial impacts on the enterprise.

Although these authors have their own approaches and taxonomies, they neither attempt to derive objectives from archival documents or behaviour nor measure the related opportunity costs. The qualitative performance analysis clearly distinguishes itself from these authors by collecting revealed objectives from archival documents and parliamentary proceedings. Ministers reveal their objectives to the boards of public enterprises amongst others in policy papers. The revealed objectives belong to the discretionary leeway of the ministers. In contrary management boards of public enterprises try to achieve autonomy in order to protect the profitability and to be able to achieve their own objectives. They also reveal their objectives in policy documents and financial. reports. In this research project the revealed objectives are compared with the objectives obtalned by the structure analysis. The objectives stated in the articies of association and the relevant legislation belong to the conditions to be fulflled sufficiently before any other objective can be achieved.

The documents from the examined public enterprises and the relevant proceedings reveal a limited number of ninisterial objectives. The managenent board revealed wore objectives than the inisters (See chapter 6: table 6.1). These objectives do not have any indicators to measure the degree of performance and do not contain a time dimension.

public enterprises are public investments, which need a profitability at least equal to the rate of return on government perpetuities. otherwise the government should not invest in this type of enterprise. The pubilo enterprise rents, the profits forgone, are the difference between the rate of return on government perpetulties and the profitability of the enterprise. This rent indicates the existence of discretionary leevay or autonomy. Discretionary leeway means that the dinister reveals his objectives to the public enterprise, while autonomy enables the management board to pursue its own objectives. A public enterprise with profitability exceding the rate of return on government perpetuities performs a fiscal role. The Dutch state Mines performed a fiscal role frow 1965 up to 1970 . The profitability of the Dutch state Hines was the result of cross subsidizations within this enterprise. The Dutch Railroad corporation and the organization Two suffered public enterprise rents from 1965 upto 1970 (See chapter 6: table 6.21 .

The market structure of the Dutch state Mines and the Netherlands Rallroad Corporation offers the possibility to conduct a comparative quantitative performance analysis. 
The quantitative performance analysis of the Dutch state Mines shows a technical efficiency for private mining companies, which exceeds the technical efficiency of the Dutch state Mines from 1951 upto 1960. They achieved the highest degree of technical efficiency from 1961 upto 1965 (See chapter 3: table 3.3). The international comparative analysis of fourteen European railroad companies demonstrates that the Dutch Railroad Corporation attained the highest degree of technical efficiency in 1965 and 1970 (See chapter 4: table 4.5). This degree of technical efficiency occurred with public enterprise rents.

A quantitative analysis of the organization TNO was not possible because of the limited availability of relevant data and the absence of comparable Dutch research organizations. A solution would be an international comparative performance analysis, which is beyond the possibilities of this research project.

Public enterprises can be confronted with combinations of profits forgone and technical inefficiency. The public enterprise rents result from the revealed objectives, which cause externalities. It is only possible to determine the public production function of private goods. Some of these factors of production are involved in the production externalities. A production function of externalities can not be measured, because of the characteristics of nonexcludability and nonrivalry. Under these circumstances two options exist. The first option concerns the reduction of the number of factors of production (improvement of technical efficiency). The second option entails the elimination of rents by abolishing for instance wages exceeding wages in comparable industries, social prerogatives, expensive purchases and subsidization of charities.

The co-existence of a high degree of technical efficiency and public enterprise rents within the Dutch Railroad Corporation seems to conflict with the theoretical expectation of public enterprise rents and technical inefficiency. A technical efficiency close to the production possibility frontier indicates a sufficient attempt to achieve the objectives stated in the articles of association. A reorganization of the allocation of the factors of production might be hardly possible. The only possibility to reduce public enterprise rents in this company is the elimination of rent seeking.

\section{Privatization.}

In the fifties and sixties privatization was interwoven with a debate about asset formation in the Netherlands. One of the objectives of the policy of asset formation was the distribution of shares among the population, particularly the employees in the companies involved. Privatization terminated the ministerial discretionary leeway and the autonomy of the management board.

The intention of the policy of asset formation shows a similarity with the privatization policies of the Thatcher cabinets in Great Britain. These cabinets also wanted to 
distribute shares among small investors. The distribution of shares meant a transfer from the taxpayers to the small shareholders. This policy was quite successful in Great Britain, because the number of shareholders doubled (17) percent) from 1983 upto 1986. The Dutch policy of asset formation did not increase the number of small investors by privatizing public enterprises. The Dutch government even increased her number of shareholdings in companies with limited liability from 24 in 1950 upto 45 in 1990.

The current policy of privatization intends to improve public administration, to strengthen market competition and to raise revenues for the government. To implement this policy cabinets need a clear criterion to identify public enterprises, which should be considered for privatization. The rate of return on government perpetuities is such a criterion. Public enterprises failing to achieve a profitability above this rate of return should be considered for privatization. In 1983 the German Sachverständigenrat zur Begutachtung der Gesamtwirtschaftichen Lage proposed a similar criterion. According to this principle the Dutch Railroad corporation and the Organization TNO should be considered for privatization. These public enterprises can only be sold if investors expect to be able to obtain future profits by a management turnaround. The Dutch State Mines should not be privatized but continue to raise revenues for the government. In 1988 Parliament allowed the Christian Liberal cabinet Lubbers II to privatize this enterprise. The Labour Party doubted whether the advantages of selling the shares would exceed the loss of dividend and the future increase in the value of the firm.

Performance and the reactions of the principals.

The importance of the objectives appears from the analysis of the interaction between the explanation given by the public enterprise of its performance and the reactions of the principals to this explanation. This analysis comprises the appointments in the supervisory and management boards, the explicit policy changes and shifts in objectives between different institutions, the implicit policy changes, the discrepancies between language and behaviour, and the activities not at all discussed but continued.

Walters and Monsen dispute that the inefficient performance of public enterprise means incompetent management. Successful managers like E. Mattei (ENI), P. Dreyfus (Renault) and D. Ezra (National coal Board) had pragmatic and effective working relationships with the government. In their opinion members of management boards of public enterprises have to distinguish between lobbying the government and criticizing the government. Managers who did not appreciate this distinction lost their jobs.

Loyalty to cabinet policies is a condition for appointments in the boards of public enterprises and the monitoring bodies. External appointments and loyalty might result in conflicts with the other members of the board. This type of conflict happened after the external appointment of professor $\mathrm{J}$. Goudriaan (a former Philips manager and an outspoken member of 
the Labour Party from 1912 upto 1933) as a member of the management board of the Dutch Railroad Corporation by the Christian-Democratic cabinet-colijn IV in 1938. His loyalty to the ministerial policies caused a confrontation with a coalition of board members, supervisory directors and civil servants. He voluntarily resigned in 1945.

Explicit policy changes and shifts between different organizations reflect ministerial discontent with the performance of the public enterprise. For this purpose new organizations are even established. This was the case with the establishment of the National Council of Agricultural Research, which replaced the Agricultural organization TNo in 1957. Implicit policy changes can be discovered by examining financial administrations. Changes in expenditures might reveal implicit policy changes.

The activities, not discussed at all but continued, encompass advertising, publicity expenditures, and guarantees. These activities are instruments to achieve either revealed or stated public enterprise objectives.

Empirical research hardly exists about advertising and publicity expenditures by public enterprises. These enterprises can direct their advertising and publicity policies toward their clientele. Advertising emphasizes the meritory aspects of their consumption goods and services. Public enterprise advertising and publicity expenditures influence the consumers' preferences and demands. From a public choice perspective advertising and publicity expenditures belong to the instruments of cabinets to convince the electorate about the performance of public enterprises in order to reassure their re-election. The case-study about the Dutch Railroad corporation shows a significant relationship between publicity expenditures and sales, and publicity expenditures and revenues from passenger travel (See chapter 4: table 4.21).

Governments apply guarantees as a policy instrument to achieve economic or political objectives. However guarantees can be used as off-budget expenditures to be financed with private loans. Guarantees are given to private industries or public enterprises to continue their production and to decrease the cost of capital.

The reduction of the cost of capital provides a gain for the receiver. This guarantee becomes an economic rent if the entrepreneurial precaution is reduced. Guarantees have the character of an indirect subsidy and might stimulate high risk activities. The costs of rent seeking are at the expense of the public budget or at the expense of the customers, because of an increase of the interest rate as a result of crowding out.

An alternative method to central government guarantees is the use of public enterprise guarantees. Governmental guarantees to public enterprises and public enterprise guarantees to private enterprises results in a system of twotier monitoring of rent seeking. It is efficient for a cabinet to have the guarantees distributed by public enterprises, because the monitoring costs for these enterprises are lower than for the government. The civil service lacks the 
specialized knowledge and can not monitor every guarantee, so the danger exists that more guarantees are requested than necessary. The managers of public enterprises are able to monitor the guarantees by participating in the boards of subsidiaries and private enterprises. Managers of public enterprises have an incentive to monitor guarantees and to minimize rent seeking behaviour, because these might endanger the liquidity position of the public enterprise. The liquidity position is an important measure to determine whether a public enterprise can meet its guarantee-obligations, in case of deficits or prohibitions to borrow from the capital market.

The liquidity position of the Dutch state Mines enabled this company to meet its guarantee-obligations if necessary, with the exception of 1965 and 1966. The Dutch Railroad corporation faced a negative liquidity position from 1960 up to 1970. This railroad company was not able to meet the guarantee-obligations in case of a financial failure of a guarantee receiving company (See chapter 4: figures 4.4 and 4.5).

Public enterprise guarantees for certain sectors of the economy have the character of a subsidization and might cause positive externalities, which have to be determined. The benefits of the positive externalities have to be weighted with the necessary costs, related with the obligation to meet the guarantees. The liquidity deficit affects either the pricing policies or the fiscal burden for the taxpayer.

\section{Scientific policy advise}

Scientific policy advise contributes to a re-appraisal of the fiscal role of the public enterprise, if an empirical theory about this type of enterprise is available. conducting quantitative and qualitative performance analyses results in the collection of information about the daily management of public enterprises in mixed economies, which extends the existing economic literature.

Scientific policy advise enables the development of a new governance structure for public enterprises in the Netherlands. The main elements of this governance structure are monitoring and accountability in order to reduce public enterprise rents.

The case-studies showed the existence of public enterprise rents with the Dutch Railroad Corporation and the organization TNO. Both operated at arm's-length distance of the cabinet and had bodies for special interest representation. The Dutch State Mines operated at an equal distance from the cabinet, but did not suffer public enterprise rents. One of the possible explanations for this fact is the application of personnel and management incentive schemes related to profitability.

In 1961 the above mentioned Goudriaan described the characteristics of an alternative governance structure for public enterprises. His proposed governance structure broke with the Morrisonian element of arm's-length control in Dutch public enterprise. He proposed centralized monitoring, because the existing governance structure (a three layer-structure: 
minister-ministry-board of supervisory directors) entailed the danger of a coalition between members of the management board, supervisory directors and civil servants. This coalition endangers the loyalty to cabinet policies, which is irreconcilable with parliamentary democracy.

Goudriaan advocated centralization within the supervisory or monitoring boards. The minister should become the chairman of the board. His top senior civil servant participates officially as a secretary. Now conflicting points of view are solved within one single body. The minister is accountable about the performance of the public enterprise to Parliament.

The performance analysis conducted in this research project about Dutch public enterprises shows similarities with Aharoni's proposal for a comprehensive audit system. This type of audit pays attention to objectives and the costs related with their achievement. According to Aharoni the objectives of public enterprises could be derived from the decisions taken by the board of managers. The public accountant evaluates the performance and calculates the costs of the alternatives to achieve the objectives. The traditional audit departs from verifying compliance with certain accounting principles.

A centralized governance structure with a comprehensive audit system abolishes the existing untransparency of the sector of public enterprise. Further research about the distribution and application of public property rights in public enterprise is conducive to the development of an efficient governance structure. Management boards of public enterprises should admit the importance and the results of quantitative and qualitative performance analyses. 


\section{Curriculum Vitae}

Robert Willem Jacob Jansen is geboren op 20 oktober 1960 te Nijmegen. Na een gedeelte van zijn middelbare school te hebben gevolgd in de Bondsrepubliek Duitsland, slaagde hij in 1979 voor zijn examen VWO-A aan het Fioretti-college te Lisse. Van 1979 tot en met 1986 studeerde hij Politicologie aan de Katholieke Universiteit Nijmegen. Hij behaalde "met lof" zijn doctoraal examen Politicologie. Na vervulling van zijn militaire dienstplicht trad hij in 1988 in dienst van de Rijksuniversiteit Limburg. Hier verrichtte hij bij de Vakgroep Algemene Economie van de Faculteit der Economische Wetenschappen promotie-onderzoek naar de prestaties van Nederlandse overheidsbedrijven. 
